UNIVERSIDADE DE SÃo PAULO

FACULDAdE DE FILOSOFIA LETRAS E CIÊNCIAS HUMANAS

DEPARTAMENTO DE LETRAS CLÁSSICAS E VERNÁCULAS

Programa de Pós-GRAdUAÇÃo EM LETRAS ClÁSSICAS

ROBERT BROSE PIRES

\title{
Epikomios Hymnos
}

VERSÃo CORRIGIDA

SÃo PAULO 


\section{ROBERT BROSE PIRES}

\section{Epikōmios Hymnos}

Investigações sobre a performance dos epinícios pindáricos

Tese apresentada ao Programa de Letras Clássicas do Departamento de Letras Clássicas e Vernáculas da Faculdade de Filosofia, Letras e Ciências Humanas da Universidade de São Paulo, para a obtenção do título de Doutor em Letras.

Área de Concentração: Letras Clássicas

Orientador: Prof. Dr. Christian Werner

VERSÃo CORRIGIDA

São Paulo 


\section{Epikōmios Hymnos}

Investigações sobre a performance dos epinícios pindáricos

Tese apresentada ao Programa de Letras Clássicas do Departamento de Letras Clássicas e Vernáculas da Faculdade de Filosofia, Letras e Ciências Humanas da Universidade de São Paulo, para a obtenção do título de Doutor em Letras.

Área de Concentração: Letras Clássicas

Orientador: Prof. Dr. Christian Werner

\section{EXEMPLAR CORRIGIDO}
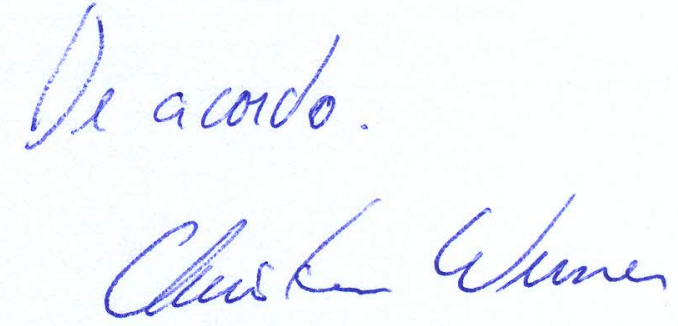

São Paulo 
Autorizo a reprodução e divulgação total ou parcial deste trabalho, por qualquer meio convencional ou eletrônico, para fins de estudo e pesquisa, desde que citada a fonte.

Catalogação na publicação

Serviço de Biblioteca e Documentação

Faculdade de Filosofia Letras e Ciências Humanas 
Nome: Pires, Robert Brose

Título: Epikōmios Hymnos: investigações sobre a performance dos epinícios pindáricos.

Tese apresentada ao Programa de Letras Clássicas do Departamento de Letras Clássicas e Vernáculas da Faculdade de Filosofia, Letras e Ciências Humanas da Universidade de São Paulo, para a obtenção do título de Doutor em Letras.

Aprovado em:

BANCA EXAMINADORA

Prof. Dr.

Instituição:

Assinatura:

Prof. Dr.

Instituição: Assinatura:

Prof. Dr.

Instituição: Assinatura:

Prof. Dr.

Instituição:

Assinatura:

Prof. Dr.

Instituição: Assinatura: 
para os meus pais,

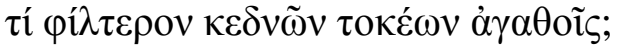

para o Nélson,

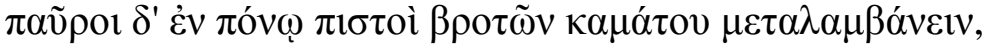

e para o Christian,

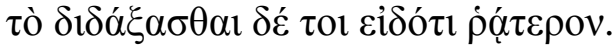




\section{AGRADECIMENTOS}

EM PRIMEIRO lugar, gostaria de expressar minha gratidão e dívida para com o meu amigo, orientador e colega Christian Werner, que me acompanhou numa longa jornada desde o meu mestrado, a partir de 2005, até a conclusão deste doutorado, sem jamais duvidar de minhas capacidades, deixando-me livre para perseguir minhas convicções teóricas e estando ao meu lado sempre como melhor amigo e orientador exemplar. Seu auxílio logo no início desta tese, em 2009, ao me oferecer abrigo em seu apartamento em Berlin - durante um longo e enregelante mês de inverno do qual eu guardo, porém, ternas lembranças -, foi essencial para que eu pudesse coletar material bibliográfico inexistente no país junto à Freie Universität Berlin e a Staatsbibliothek zu Berlin. Durante todos os momentos e, literalmente, até os últimos instantes da redação desta, pude contar com a sua disponibilidade em me ajudar a obter todas as fontes bibliográficas de que necessitei. Sua erudição, crítica sincera e o seu acume como revisor salvaram-me de inúmeros e embaraçosos equívocos até onde eu permiti. $\mathrm{O}$ que ainda permanece deve-se inteiramente à minha teimosia ou descuido.

Minha gratidão estende-se também à Dra. Erika Werner, sua esposa, pela hospitalidade e gentileza em me hospedar por um mês inteiro durante uma fase crítica para a finalização de sua própria tese.

Gostaria de agradecer, ainda, a algumas pessoas que contribuíram em maior ou menor grau durante esses quase cinco anos.

À querida amiga Lucia Sano, por dividir comigo as angústias de ser um doutorandoprofessor, por nossas conversas diárias por e-mail e pelos raros, porém inesquecíveis, momentos de bebedeira e comilança em São Paulo.

Aos meus alunos na Universidade Federal do Ceará, pelo incentivo constante e pelo que me ajudaram a crescer como profissional e pessoa e à minha amiga, Prof. Dr. Emília Maria Peixoto Farias, colega na mesma instituição, que tão gentilmente me forneceu material bibliográfico inestimável sobre as Ciências Cognitivas, uma parte importante do enquadramento teórico desta tese.

Ainda, a Richard Rawles (University of Nottingham), não só pelas inúmeras discussões via Facebook acerca de vários aspectos relacionados (ou não) à poesia lírica grega 
em geral mas também por me adiantar seu capítulo sobre "Early epinicians" publicado no volume editado por ele e P. Agócs. À Lucia Prauscelo (University of Oxford) pela idêntica gentileza com relação ao seu capítulo sobre a inovação musical na época de Píndaro, publicado naquele volume e, finalmente, ao Prof. Giambattista D'Alessio, por me permitir acesso à sua palestra (inédita) Dancing with the Dogs, acerca do fr. 107ab S-M de Píndaro. Finalmente, pelas conversas informais que tive a oportunidade de ter com os professores Jim Marks (University da Flórida), William Allan (University College) e Laura Swift (Open University) acerca de minhas ideias pouco ortodoxas que redundaram nos resultados da pesquisa ora apresentada. Sou especialmente grato ao Prof. William Allan pela franca conversa, o encorajamento e os conselhos recebidos durante sua visita à Fortaleza.

Aos gatos, Filó, Penélope, Toshiro, Basílio, Olívia, Pedro, Cástor e Odisseu e à cadela Nina por terem escolhido caminhar comigo nesta vida. Eles me são, nela, uma fonte de luz e

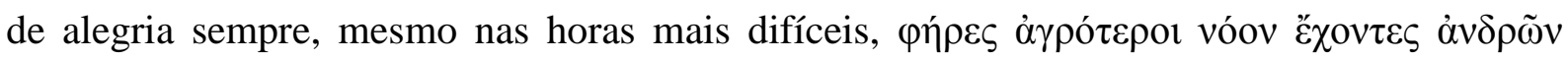
pínov.

Ao meu esposo, companheiro e amigo Nelson Conrado Vasel Jr., minha gratidão e o meu amor. Ainda que último nesta lista, você é sempre o primeiro em meus pensamentos. Um refúgio e um abrigo nesta vida contra as coisas do mundo. Sem a sua paciência, dedicação, companheirismo e apoio irrestrito, esta tese não teria sido escrita. Na verdade, sem você, nada teria sido possível. 


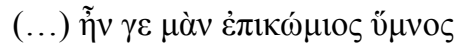

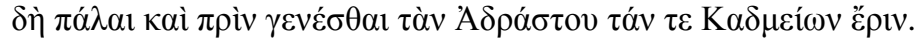

(...) o hino celebratório vem de épocas

mui distantes; antes, inclusive, da discórdia entre Adrasto e os Cadmeus.

N. $8.50-1$ 


\section{RESUMO}

PIRES, R. B. (2013) Epikōmios Hymnos - investigações sobre a performance dos epinícios pindáricos. Tese de Doutorado, Faculdade de Filosofia, Letras e Ciências Humanas, Universidade de São Paulo, São Paulo.

Nesta tese, irei investigar as implicações que o uso consistente que Píndaro e Baquílides fazem do termo $\kappa \tilde{\omega} \mu \mathrm{s}$ têm para a ocasião de performance dos epinícios. Irei argumentar, do ponto de vista da Linguística e da Poética Cognitivas, que, através de uma análise das passagens relevantes da literatura grega, de Homero ao drama do século V, o termo sempre implica algum tipo de celebração, seja móvel ou não, e que ele nunca é usado para denotar

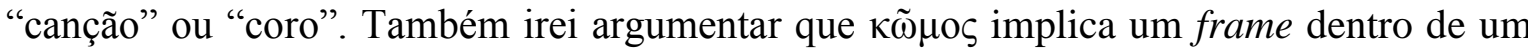
Modelo Cognitivo Idealizado para CELEBRAÇÃO DE VITÓRIA, dentro do qual referências às odes devem ser entendidas. Baseando-me nesta análise irei discutir as implicações dos resultados e reexaminar a pressuposição, atualmente tida como não problemática, segundo a qual as odes eram sempre executadas por um coro em sua première. Além disso, irei discutir também o problema da identificação da persona loquens nos poemas e irei propor que, na maioria dos casos, ela nunca parece se referir a um coro. Finalmente, discutirei alguns cenários de transmissão das odes, propondo que a escrita não precisa ser proposta para a transmissão do texto até uma data bem tardia e que uma tradição de reperformances orais dos poemas deve ter tido um papel essencial na preservação do texto.

Palavras-chave: Píndaro; epinícios; performance; $\kappa \tilde{\omega} \mu о \varsigma ;$ teoria coral; teoria solo.

\section{ABSTRACT}

PIRES, R. B. (2013) Epikōmios Hymnos - investigations on the performance of Pindaric epinikia. Doctoral thesis, Faculdade de Filosofia, Letras e Ciências Humanas, Universidade de São Paulo, São Paulo.

In this thesis I shall investigate the implications of the consistent use Pindar and Bacchylides make of the term $\kappa \tilde{\omega} \mu о \varsigma$ to the occasion of the performance of the epinikia. I shall argue, from the perspective of Cognitive Linguistics and Poetics, that, through the 
analysis of the relevant passages in Greek literature from Homer to the V century drama, the term always implies some sort celebration, either mobile or not, and that it is never used to denote either 'song' or 'chorus'. Most importantly I shall argue that $\kappa \tilde{\omega} \mu \circ \varsigma_{\text {implies }}$ a frame in an Idealized Cognitive Model for VICTORY CELEBRATION within which references to the victory ode must be understood. Based on this, I shall discuss the implications of these results and try to reexamine the assumption, held as unproblematic by the majority of critics, that the victory odes were always performed chorally on its premiere. Additionally I shall also discuss the problems of identifying the persona loquens in the poems and I shall propose that in most cases it never seems to refer to a chorus. Finally, I shall discuss some scenarios of transmission of the odes, proposing that writing needs not be assumed for the transmission of the text until a fairly late date and that a continuous tradition of oral reperformances must have played an essential role in the preservation of the text.

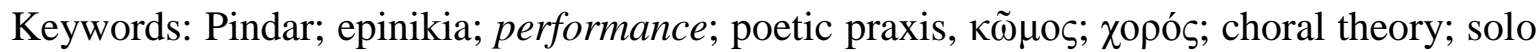
theory. 


\section{ABREVIAÇÕES DAS OBRAS MAIS CITADAS ${ }^{1}$}

B.

$\mathrm{CAH}$

CAMPBELL

CONSBRUCH

DENNISTON

DAGM

DELG

EDG

EDL
Bacchylides, ed. H. Maehler. 11ª ed. Leipzig, Sauer, 2003.

Cambridge Ancient History, ed. F. W. Walbank et alii, 12 vols. Cambridge: CUP, 2008, $2^{\mathrm{a}}$ ed.

Greek Lyric, vol 1: Sappho and Alcaeus; vol. 2: Anacreon, Anacreontea, early choral lyric; vol. 3: Stesichorus, Ibycus, Simonides and others; vol. 4: Bacchylides, Corinna, and others; vol. 5: The new school of poetry and anonynous songs and fragments. Loeb Classical Library. Harvard: Harvard University Press:

Enchiridion de Metris, ed. M. Consbruch, Hephaestionis Enchiridion cum commentariis veteribus. Leipzig: Teubner, 1906 (repr. Stuttgart: 1971): 1-58.

The Greek Particles. $2^{\circ}$ ed. rev. by J. K. Dover. London: Duckworth, 1950.

E. Pöhlmann/M.L. West (ed.), Documents of Ancient Greek Music. Oxford 2001.

Dictionaire Étymologique de la langue grecque: Histoire des mots. Ed. P. Chantraine, 4 vols. Paris: Édiotions Klincksieck, 1968-80. Etymological Dictionary of Greek. Ed. R. Beekes. Leiden IndoEuropean Etymological Dictionary Series, vol. 10/1-2. Leiden/ Boston: Brill, 2010.

Etymological Dictionary of Latin and the other Italic languages. Ed. Michiel de Vaan. Leiden Indo-European Etymological Dictionary Series, vol. 7. Leiden/ Boston: Brill, 2008.

EM

Etymologicum Magnum.

${ }^{1} \mathrm{O}$ leitor deve notar que, para os autores antigos não citados acima, foram utilizadas as edições dos discos do TLG e do PHI 
ERBSE

DRACHMANN

Epigr. Gr.

FGH

$\mathrm{IEG}^{2}$

$\mathrm{W}^{2}$

KAIBEL

Histoire

LSJ

TrGF

OED

PHI

PMG

RACE

RUMPEL

RV
Scholia Graeca in Homeric Iliadem (Scholia Vetera). Berlin: Walter de Gruyter, 1971.

Scholia in Pindarum (scholia vetera), ed. A.B. Drachmann, Scholia vetera in Pindari carmina, 3 vols. Leipzig: Teubner, 1:1903; 2:1910; 3:1927 (repr. Amsterdam: Hakkert, 1:1969; 2:1967; 3:1966): 1:12-395.

G. Kaibel, Epigrammata Graeca ex lapidibus conlecta, Berlin 1878.

Die Fragmente der griechischen Historiker, ed. F. Jacoby (Leiden, 1923-58)

Iambi et Elegi Graeci ante Alexandrum Cantati. Editio Altera. Ed.

M. L. West. Oxford: Oxford University Press, 1998.

$=\mathrm{IEG}^{2}$.

Athenaei Naucratitae Deipnosophistarum, ed. G. Kaibel, 3 vols. Berlin: Teubner, 1935.

Irigoin, J., Historie du Texte de Pindare, Paris: Klincksieck, 1952.

A Greek-English lexicon. "With a revised supplement, 1996." (Rev. and augm. throughout). Oxford; New York: Clarendon Press; Oxford University Press.

Tragicorum Graecorum Fragmenta. Ed. Augustus Nauck e Bruno Snell. Georg Olms: Hildesheim, 1964.

Oxford English Dictionary. $2^{\text {nd }}$ edition. Oxford: Oxford University Press, 2009.

Latin Library, Packard Humanities Institute, PHI v. 5.3 CD-ROM, 1991.

Poetae Melici Graeci, ed. D. L. Page, Oxford: Oxford UNiversity Press, 1962

Pindar, vol. 1: Olympian odes, Pythian odes; vol.2: Nemean odes, Isthmian odes, fragments. Loeb Classical Library. Harvard: Harvard University Press.

Lexicon Pindaricum, ed. J. Rumpel. Leipzig: Teubner, 1883.

Rig Veda Samhita - Complete text in Devanagari. $2^{\text {nd }}$ ed. Ed. Prof.

R.L. Kashyap \& Prof. S. Sadagopan. Bagalore, 2005. 
SLATER

S-M

TESSIER

TLG
Lexicon to Pindar. Ed. W. J. Slater. Berlin. Walter de Gruyter, 1969.

Pindarus, ed. B. Snell, H. Maehler, 2 vols. Berlin: Walter de Guyter, 1969.

Scholia Metrica Vetera in Pindari Carmina, ed. A. Tessier, Bibliotheca Scriptorum Graecorum et Romanorum Teubneriana. Leipzig: Teubner, 1969.

Thesaurus Linguae Graecae (TLG-E). Irvine, [Calif.]: University of California, Irvine, 2000. 


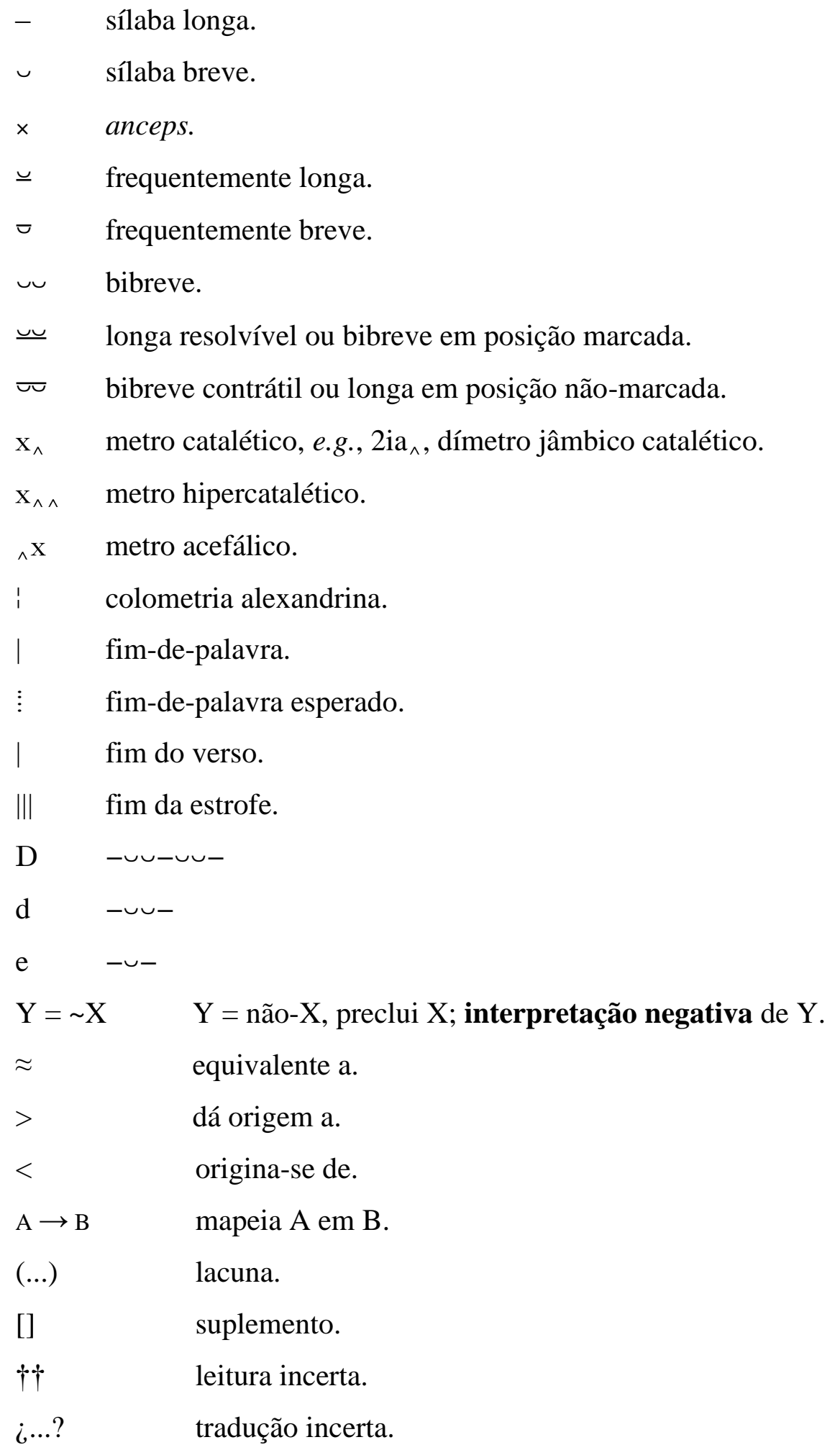




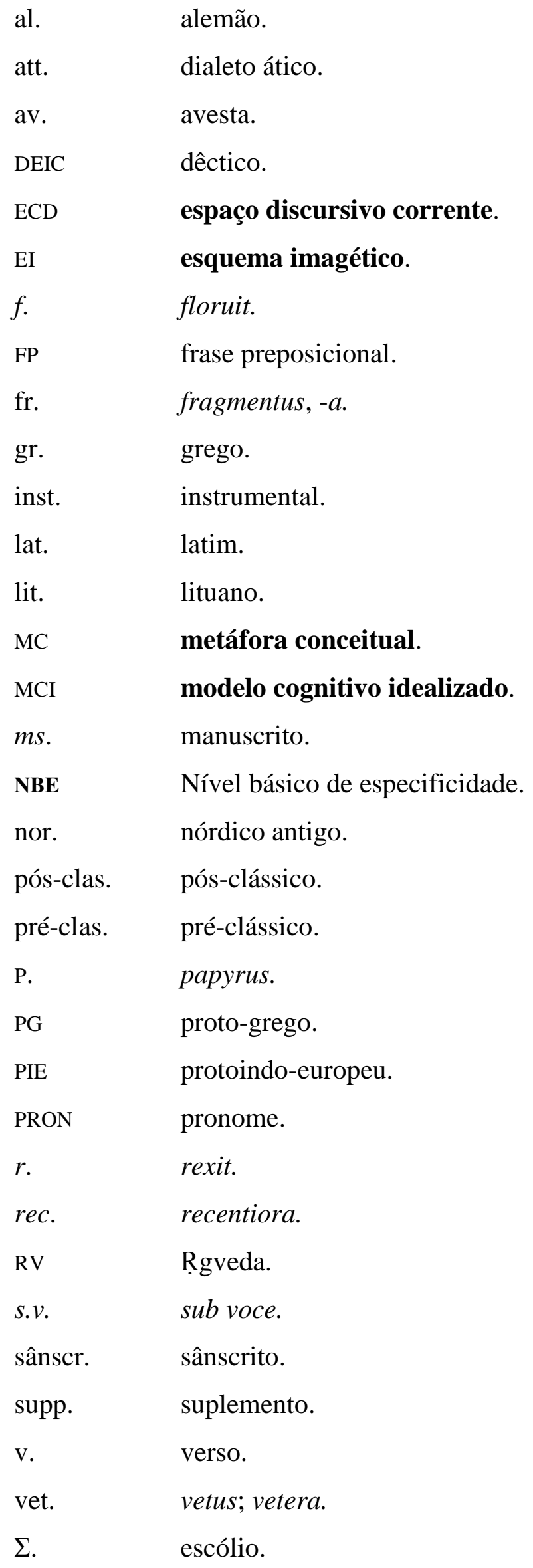


Em todo o texto, as seguintes convenções foram adotadas:

(a) O plural é indicado pela repetição da última consoante da abreviatura, e.g., v. Quer dizer "verso", mas vv., "versos"; p., "página”, pp. "páginas” e assim por diante;

(b) A menos que seja indicado em contrário, todos os textos gregos foram retirados do disco do TLG-E e os latinos, do disco do PHI, v. 5.3, utilizando-se a plataforma Diógenes, v. 3.1 (http://www.dur.ac.uk/p.j.heslin/Software/Diogenes/index.php), respeitandose a ordem de entrada das divisões das obras adotadas por essa plataforma a fim de facilitar possíveis consultas. Essas divisões podem, eventualmente, diferir daquelas de outras edições impressas;

(c) Ainda, nos autores antigos, o estilo adotado para a citação das divisões referidas no item b foi: separar a divisão principal (canto, livro, coleção, etc.) de suas subdivisões por pontos simples (e.g. Il. 12.23, leia-se, canto 12, verso 23; ou Paus. 3.2.23, leia-se Pausânias, livro 3, capítulo 2, seção 23; S. fr. 548.3, Sófocles, fragmento 548, linha 3, etc.). O hífen serve para marcar um intervalo contínuo inclusivo (e.g. S. fr. 548.3-4, leia-se, da linha 3 até a 4), enquanto o ponto-e-vírgula marca intervalos discretos (e.g. S. fr. 548.3;4, leia-se, na linha 3 e na 4). Para os autores antigos dos quais temos uma única obra, utilizou-se apenas nome do autor, assim Heródoto (ou Hdt.), 3.2.5, refere-se, obviamente, às suas Histórias;

(d) Para os nomes das obras de autores gregos e latinos, preferiu-se as abreviaturas já padronizadas pela $9^{a}$ edição eletrônica do LSJ, sem se seguir, necessariamente, as mesmas edições lá apontadas;

(e) No que tange ao uso do vernáculo, preferi as lições do Dicionário Eletrônico Houaiss da Língua Portuguesa (2009, v. 3.0) e, para a padronização de acordo com o novo acordo ortográfico, foi usado o guia Escrevendo pela Nova Ortografia: como usar as regras do novo acordo ortográfico da língua portuguesa, Instituto Antônio Houaiss, com a coordenação e assistência de José Carlos de Azevedo. $2^{a}$ ed. São Paulo: Publifolha-Houaiss, 2008. Quanto a estrangeirismos e nos casos em que a palavra não conste no Houaiss, procurei seguir o banco de dados online do Vocabulário Ortográfico da Língua Portuguesa, $5^{\mathbf{a}}$ ed, 2009$^{1}$ (abreviado VOLP), grifando-se com o itálico os estrangeirismos lá listados. No que tange a questões da norma culta, a obra de referência é a de Celso Cunha e Lindley Cintra,

\footnotetext{
${ }^{1}$ http://www.academia.org.br/abl/cgi/cgilua.exe/sys/start.htm?sid=23.
} 
Nova Gramática do Português Contemporâneo, $4^{\mathrm{a}}$ ed., revista e ampliada. Rio de Janeiro: Lexicon, 2007;

(f) Em todas as citações do grego, bem como nas suas respectivas traduções, os destaques negrito e sublinhado são meus. Com o primeiro, eu chamo a atenção para o uso do item lexical; como segundo, para a construção;

(g) Em toda tese foi adotado o sistema "APA Author-Date" para as referências bibliográficas, de acordo com as recomendações do Serviço de Bibliotecas da Universidade de São Paulo. 


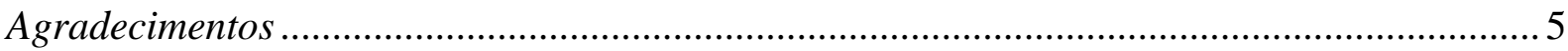

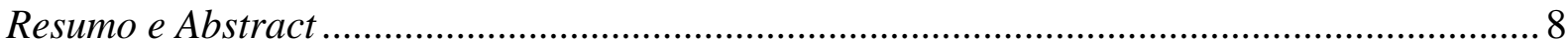

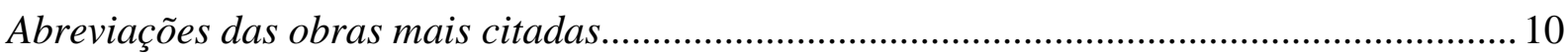

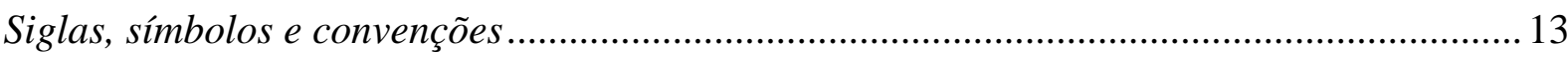

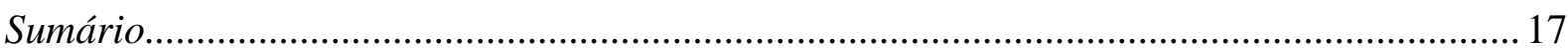

INTRODUÇÃ

CAPÍTULO 1 - Considerações sobre a práxis poética em Píndaro ..........................................43

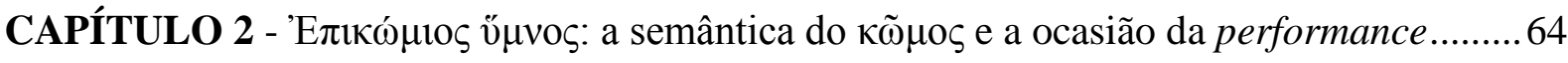

2.1. O $\kappa \tilde{\omega} \mu о \varsigma$ grego a partir de um Modelo Cognitivo Idealizado....................................... 77

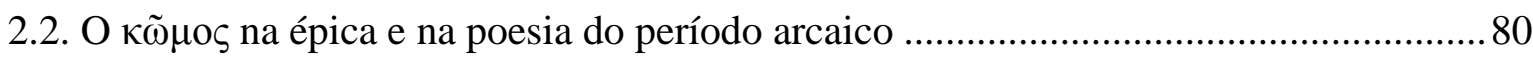

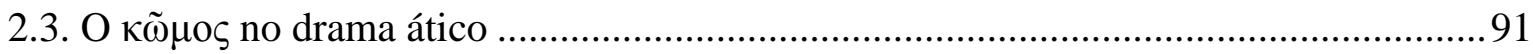

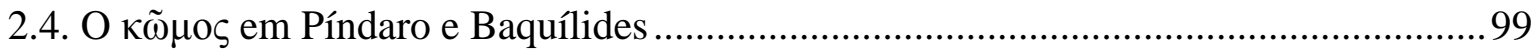

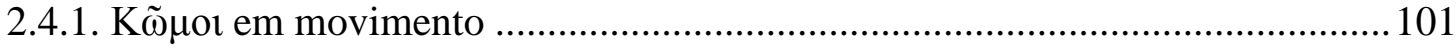

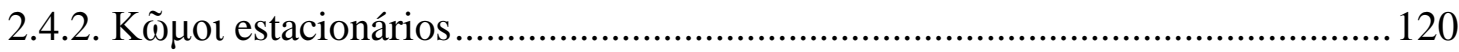

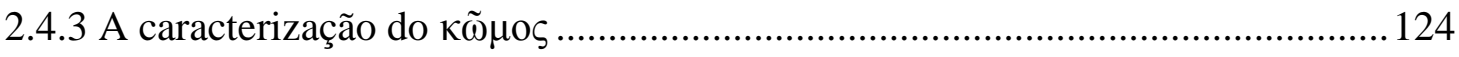

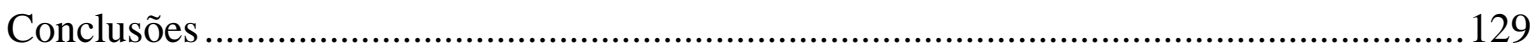

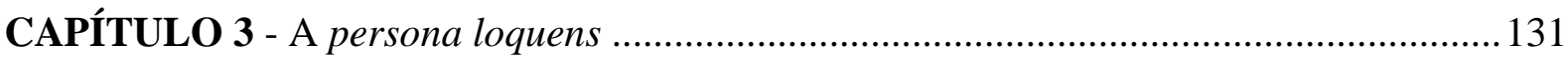

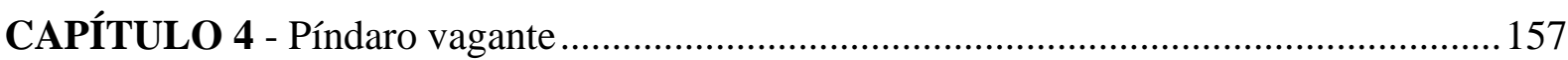

CAPÍTULO 5 - O modo da performance I: a controvérsia............................................... 176

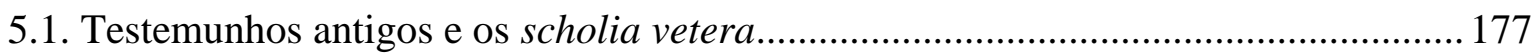

CAPÍTULO 6 - O modo da performance II: os epinícios .................................................. 194

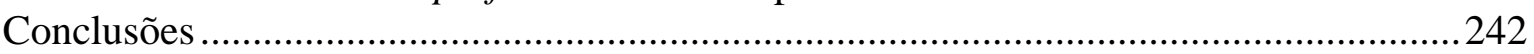

CAPÍTULO 7 - Ao infinito e além: cenários de transmissão e reperformance ....................246

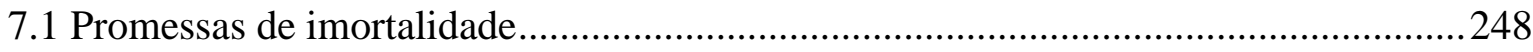

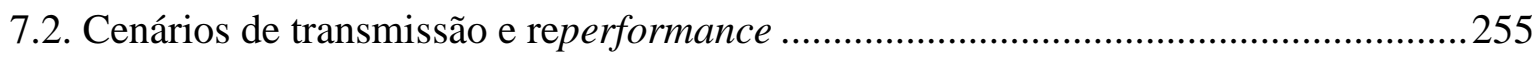

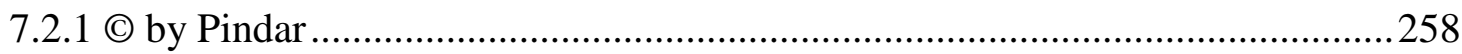




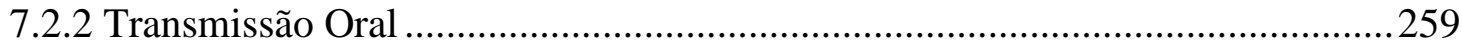

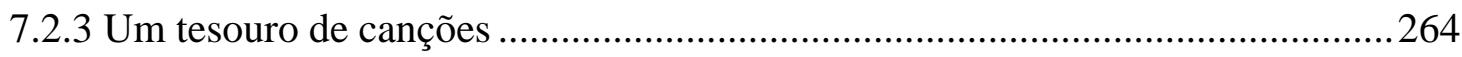

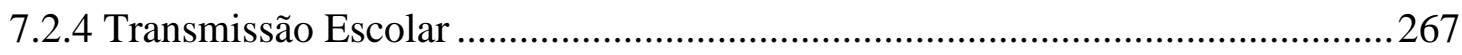

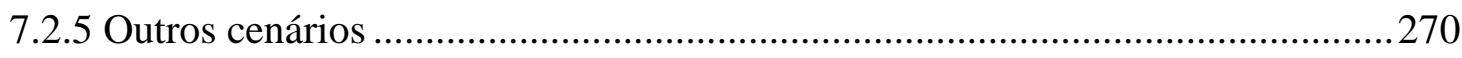

7.2.6 Fixação e Transmissão na Antiguidade ..........................................................2 274

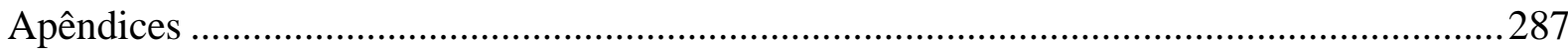

Apêndice 1 - Tabela sinóptica dos epinícios pindáricos .................................................28

Apêndice 2 - Ocorrência de palavras em - $\kappa \omega \mu$ - em Píndaro e Baquílides.......................... 290

Apêndice 3 - Glossário de termos técnicos ……...........................................................295

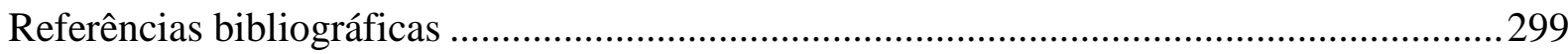




\section{INTRODUÇÃO}

PínDARO é o único dos nove líricos canônicos cuja produção poética nos foi legada praticamente intacta, ao menos no que diz respeito a um dos gêneros a que se dedicou, os غ̇ंıvíkıo, ou canções de celebração de uma vitória atlética, agrupados em quatro, dos dezessete livros catalogados pelos bibliotecários de Alexandria. Essa fortuna, comparada a de seus contemporâneos Simônides e Baquílides ${ }^{1}$, deve nos dizer alguma coisa sobre sua apreciação já no período helenístico, mas, principalmente, bizantino e romano, particularmente do livro de epinícios, uma vez que o restante de sua obra não parece ter tido a mesma atenção. Seja como for, Píndaro ocupa um papel central dentro do cânon literário grego e, por ser, tanto cronológica quanto tematicamente, o ponto de inflexão entre duas eras aquela da idade arcaica, baseada nos ideais aristocráticos do modelo homérico, e a da idade clássica, cujo ponto focal deve ser procurado na pólis -, seu estudo e compreensão são indispensáveis para se entender tanto uma quanto outra.

O que me leva imediatamente a uma das pressuposições desta tese, a saber, o de que Píndaro, ainda que opere em uma época que muitos manuais classificam como "clássica", representa uma tradição de fazer poético firmemente ancorada no período arcaico e que, portanto, dentro dos objetivos deste estudo, e levando-se em consideração quais características de sua poesia serão relevantes para o seu escopo, considerá-lo-ei como um poeta arcaico. Essa ressalva é importante porque ela é admitidamente arbitrária e não pretende negar ou ignorar que certos elementos importantes da poesia pindárica possam, ou talvez mesmo devam, ser estudados do ponto de vista de um poeta operante em zonas descontínuas com relação ao que classificaríamos como arcaico ou clássico que, apesar disso, muitas vezes se imbricam.

Seja como for, a passagem do período arcaico para o clássico não é discreta, nem pode ser fixada no tempo ou, mais importante ainda, no espaço, o que fica claro se tomarmos apenas duas áreas importantes para o programa poético pindárico: a Magna Grécia, com ponto focal em Siracusa, e a Ática, centrada sobretudo em Egina e, em menor medida no caso de

\footnotetext{
${ }^{1}$ Aquele sobrevive em apenas esparsos fragmentos, ao passo que Baquílides, não fosse pela descoberta do magnífico papiro de Londres ( $P$. Lond. inv. 733), teria sido partícipe de um destino semelhante ao do tio.
} 
Píndaro, Atenas. Dessa forma, ao longo desta discussão irei trabalhar com uma definição um pouco estendida do período arcaico, aproximadamente o período que vai de 650 a 450 a. C., não muito antes da morte de Píndaro, que deve ter se dado um pouco depois de sua última ode que pode ser datada, a Pítica 8 , de 446 a.C. ${ }^{2}$

Qualquer um que se disponha a estudar Píndaro, no entanto, enfrenta um problema que parece, a princípio, intransponível: o tamanho da bibliografia que the é dedicada desde sua primeira edição "moderna”, aquela de Manúcio, ainda na Idade Média. De lá pra cá, outras dezenove se seguiram ${ }^{3}$, cada uma engendrando uma nova onda de comentários, estudos, artigos e pequenas revoluções em uma área da literatura grega que, em termos de aporte de material bibliográfico e controvérsias ${ }^{4}$, só perde para Homero, se formos pensar, é claro, em um único poeta e não em um gênero, como a tragédia, com uma fortuna certamente maior. Desnecessário dizer da dificuldade enfrentada pelo estudioso ou comentador em potencial que se disponha não só a ler, mas antes, a coletar todo esse material, especialmente no Brasil, carente de bibliotecas de tradição filológica. Situação ainda mais grave quanto mais nos afastemos do eixo sul-sudeste.

Dessa forma, não deveria ser surpreendente que os estudos pindáricos ainda se encontrem em uma fase incipiente no Brasil, mesmo no âmbito acadêmico ${ }^{5}$. Uma parte dessa carência e do pouco interesse despertado por Píndaro entre nós poderá ser explicada, talvez, pelo fato de que, como disse Voltaire, de modo muito perspicaz, o poeta teria o talento de "parler beaucoup sans rien dire/ (...) [e de modular de um modo erudito] Des vers que personne n'entendel Et qu'il faut toujours qu'on admire"6; ou, de um modo ainda mais burlesco, no verbete do Bluffer's Guide to Classics? , "Pindar: Almost untranslatable, usually

${ }^{2}$ Utilizo-me, portanto, de critérios semelhantes aos de KIRKWOOD (1974, p. 3) e NAGY (1990, p. 2). A partir daqui irei abandonar a abreviação a.C. e o leitor deve presumir, a menos que especificamente dito em contrário, que todas as datas se referem a esse período.

${ }^{3}$ D.E. GERBER (1969).

${ }^{4}$ Sobre essas, $c f$. especialmente Young (1970). Na verdade, a edição de Manúcio representa apenas o renascimento de uma tradição filológica que remonta aos bibliotecários de Alexandria, especialmente a Zenódoto e a Aristófanes de Bizâncio, que prepararam as primeiras edições do poeta. Sobre isso, $c f$. a Histoire.

${ }^{5}$ Situação que admite algumas exceções. Trabalhos publicados que conheço são MALHADAS, D. (1976) Píndaro: odes aos príncipes da Sicília; ARAúJo, A. A de (2006), VII Ode Olímpica de Píndaro: tradução e notas, (Diss. Mestrado, pub. Biblioteca de Teses e Dissertações/ USP - online) e ANTUNES, C. L. B. (2012) Métrica e Rítmica nas Odes Píticas de Píndaro, (Tese Dout. USP). No ultramar a situação não é muito diversa, embora tenhamos notícia de algumas traduções, como p. ex., CAEIRO, A. C. (trad.) Todas as Odes de Píndaro. Quetzal: 2010 e, especialmente, a tradução das odes Olímpicas realizadas por F. LourENÇO, Poesia Grega: de Álcmã a Teócrito, 2006, Cotovia.

${ }^{6}$ Voltaire, Gallimathias Pindarique, citado em diversas obras, aqui apud HUMMEL (1993, p. 24, n. 1), "falar muito sem dizer nada/ [e de modular de um modo erudito] Versos que ninguém entende/ mas que é necessário sempre admirar".

${ }^{7}$ LECKIE (2005). 
unintelligible and always inexplicable, he is unfortunately the greatest of Greek lyric poets"8. Humorismo à parte, a opinião de Voltaire ou de Leckie não destoa muito da real apreciação do poeta na fase final de seu estudo renascentista ${ }^{9}$, antes da publicação do magnificente comentário e tradução latina de Boeckh (1811), com o qual é inaugurada a fase moderna da crítica pindárica e por meio do qual o poeta veio a ser mais apreciado e traduzido ${ }^{10}$, especialmente para as línguas vernáculas.

Numa primeira leitura, uma ode de Píndaro pode ser desestimulante mesmo para um leitor acostumado a ler autores clássicos no original, sobretudo por conta da linguagem altamente convencional, do uso de símiles por vezes aparentemente abstrusos, de narrativas míticas que parecem pouco integradas ao contexto (afinal de contas a "unidade" das odes sempre foi a crux para a crítica especializada) e, do nosso ponto de vista, pela sensação de vã grandiloquência de seu estilo, aumentada ainda mais quando se junta a isso a irrelevância, para o leitor moderno, das digressões pessoais presentes no texto, do contexto histórico muitas vezes paroquial, das dúvidas (ou total ignorância) relativas à ocasião e ao modo da performance, todos esses essenciais para o entendimento de uma ode ${ }^{11}$, que, como argumentaremos mais adiante, não é apenas o produto da soma de todos os seus elementos textuais, como quer, atualmente, uma corrente de "ultra-unitaristas", mas sim a relação de seus elementos textuais com a ocasião de performance, o momento histórico da mesma, e as instituições sociais e culturais em meio às quais a canção foi produzida. Muito embora essas últimas peças do quebra-cabeça estejam faltando ou sejam de difícil compreensão, isso não nos autoriza a promover o texto da ode a um objeto semiótico independente de qualquer contexto, com "leis" internas próprias que deveriam ser mínimas, evidentes, claras e precisas o suficiente para que, apenas por meio delas, fossemos capazes de explicar todos os aspectos dos epinícios.

Uma corrente teórica que tem ganhado momento nas últimas décadas (embora não seja necessariamente nova ${ }^{12}$ ), é a que retira o foco do texto para centrá-lo na recepção das odes por uma hipotética "protoaudiência"13. Um dos bem-vindos benefícios dessa abordagem é que ela traz para o primeiro plano o caráter não-literário dos poemas, preferindo vê-los como canções, ou, antes, como objetos polissêmicos, no qual palavra, música e dança convergem para criar

\footnotetext{
8 "Píndaro: quase intraduzível, normalmente ininteligível e sempre inexplicável, ele é, infelizmente, o maior dos poetas líricos gregos". Para uma opinião diversa sobre o assunto, $c f$. MosT (1985).

${ }^{9}$ Sobre essa fase da crítica, não coberta por Young (1970), $c f$. HEATH (1986).

10 YOUNG (1970).

${ }^{11}$ Bundy (1962, p. 2 et seq.). Vide também SchadeWALDT (1928) e THumMER (1968/1969).

${ }^{12}$ Cf. e.g., Boeckh, (1821), 2.2,6

${ }^{13}$ Cf. esp. YOUNG (1968); RÖSLER (1980); PFEIJFFER (1999b); KRUMMEN (1990), entre outros.
} 
um significado integrado. No entanto, em suas versões mais severas, ela, entre outras coisas, limita a relevância de Píndaro às comunidades de seus laudandi, relegando sua importância pan-helênica a um subproduto de suas odes ${ }^{14}$. Neste tipo de análise, todas as referências devem ser entendidas de acordo com as expectativas e o contexto histórico-cultural de uma "primeira audiência" e de acordo com a dinâmica de uma "primeira performance", embora esses termos normalmente sejam empregados sem qualquer definição prévia e nos deixem, muitas vezes, a imaginar quem, de fato, seria essa "primeira audiência" e como poderíamos ter a pretensão de conhecê-la sem arriscar incorrer, na melhor das hipóteses, em um sério anacronismo $^{15}$.

Uma segunda via, ainda dentro dessa mesma perspectiva, parece ser aquela inaugurada por Rösler ${ }^{16}$ e aplicada a Píndaro por $\operatorname{Krummen}^{17}$, que admite a fragilidade de qualquer argumento centrado nas idiossincrasias de uma "protoaudiência" tão remota, ao mesmo tempo em que coloca em suas devidas proporções a importância do contexto histórico para uma compreensão profunda da ode. Essa abordagem propõe, basicamente, que a interação entre o poeta e sua audiência dar-se-ia em um contexto idêntico ao de qualquer comunicação verbal, ou seja, que emissor e receptor estariam imersos num mesmo ambiente sociocultural e que partilhariam de uma mesma disposição mental que permitiria que algumas partes da mensagem (nesse caso a ode) permanecessem subentendidas. A tarefa do intérprete moderno, dessa forma, mais do que conjeturar sobre como uma audiência antiga reagiria à determinada mensagem, seria a de entender como o poeta controlava a interpretação de seu texto por meio do público-alvo, como aquele poderia saber o que deixar implícito e o que explicitar, ou seja, como codificava sua mensagem de modo a adequá-la às possíveis expectativas de seus ouvintes (“Erwartungshorizont”)"18, algo factível, na medida em que essas canções, ao contrário da poesia moderna, estavam profundamente relacionadas à comunidade para a qual eram produzidas e que, pelo menos em parte, deveriam refletir e ser refletidas por ela.

Essas abordagens são eminentemente sincrônicas e intraculturais e há, naturalmente, um limite até onde elas podem ser úteis antes que tenhamos de lançar mão de uma visão mais ampla, diacrônica e intercultural ${ }^{19}$, e não poderia ser de outra forma uma vez que se considere

\footnotetext{
${ }^{14}$ Assim PFEIJFFER (1999b, pp. 9-11).

${ }^{15}$ FINNEGAN (2008, pp. 37-8).

${ }^{16}$ RÖSLER (1980).

${ }^{17}$ KRUMMEN (1990). Resenhas em D. E. GERBER (1991) e InSTONE (1993).

18 "Es ist dieses 'Wissens", das der Leser Pindars teilen muss, um die Gedichte zu verstehen", KRUMMEN (1990, p.4).

${ }^{19}$ Por outro lado, no que tange a uma abordagem intercultural, ainda que importantíssima e um campo fértil para novos insights não só sobre Píndaro, mas sobre a poesia grega em geral ( $c f$. WEST, 2007), ela não será considerada nessa tese, uma vez que naturalmente extrapolaria seu escopo.
} 
que as odes de Píndaro não surgiram ex nihilo ${ }^{20}$. É bom que se diga desde já que minha interpretação dos dois termos saussurianos, diacronia e sincronia, ecoa aquela de Jakobson e $\mathrm{Nagy}^{21}$, ou seja, de que um determinado sistema pode ser analisado em termos diacrônicos e/ou sincrônicos tanto a partir de fora, quanto a partir de dentro desse mesmo sistema. De um modo inverso, no entanto, proposições diacrônicas externas (a partir daqui, simplesmente diacrônicas) podem ser válidas para um determinado sistema, sem o serem do ponto de vista sincrônico, algo que Nagy ${ }^{22}$ chama "diachronic skewing", e que eu traduzi por "distorção diacrônica".

Outro termo que será usado, espero que consistentemente, ao longo da discussão sobre as odes pindáricas, é aquele de tradição, diretamente dedutível dos conceitos de diacronia/ sincronia como expostos acima. Se pensarmos em tradição como aquilo que se escolhe passar de uma geração à outra, então tradição poderia ser entendida como a tendência que uma determinada comunidade exibe, ao longo de uma série temporal (o que não equivale a dizer diacronicamente), de passar alguns conteúdos adiante, ao passo que relega outros à marginalização, ao esquecimento ou, no caso extremo, à extinção ${ }^{23}$. O termo chave nessa definição é o verbo "escolher", que não só explicita o papel ativo da comunidade sobre o sistema, sendo assim capaz de moldar sua própria tradição (ainda que, sincronicamente, os mecanismos ativos nesse processo possam lhe escapar ao entendimento), mas também reconhece o caráter canônico do que foi passado como algo digno de ter sido passado e que, portanto, deve ser repassado e preservado, em um processo de retroalimentação que admite mudanças apenas infinitesimais ao longo de grandes períodos de tempo, a menos que um processo catastrófico intervenha. Um sistema tradicional que segue à risca essa definição, como se sabe, é aquele que regula mudança e inovação na linguagem humana.

Da definição de "tradição" pode-se passar então à definição de "tradição oral" e também aqui minha abordagem segue a escola inaugurada por Milman Parry (1971) e desenvolvida de diferentes maneiras por outros pesquisadores. Especialmente importante, no entanto, em minha interpretação de "tradição oral”, é a formalização dada por Nagy ${ }^{24}$, mas já apontada por Svenbro ${ }^{25}$ e Thomas $^{26}$, segundo a qual a "literatura" é definida por meio da

${ }^{20}$ É minha intenção, ao longo do desenvolvimento da tese, limitar as análises diacrônicas a um mínimo possível (principalmente por uma questão de tempo e espaço: seria impossível tratar do assunto ad libitum).

${ }^{21}$ JAKOBSON (1987), NAGY (1990, p. 21).

${ }^{22}$ NAGY (1990, p. 21).

${ }^{23} \mathrm{O}$ modo como esse processo opera, pode ser visto de diferentes maneiras; particularmente, eu acho a exposição de NAGY (1990, p. 52 et set.), para a cultura grega, convincente.

${ }^{24}$ NAGY (1990, p. 17 et set.).

${ }^{25}$ SVENBRO $(1976,1993)$.

26 THOMAS $(1989,1992)$. 
“oralidade”, e não o contrário. Operando dentro do sistema jakobsoniano, e em contradição com o nosso ponto de vista e os nossos preconceitos, "literatura" seria o termo marcado; ao passo que "oralidade", o não-marcado ${ }^{27}$, algo que pode ser facilmente entendido se considerarmos que, mesmo em textos escritos hoje em dia, o uso de verba dicendi é mais comum que o de verba scribendi ${ }^{28}$, lançando-se mão dos últimos somente quando se sente a necessidade de se enfatizar o caráter permanente dado à mensagem pela escrita e/ou o caráter tradicional, canônico, da mesma ${ }^{29}$. Esse conceito de tradição oral servirá de base para definir uma série de outras abordagens em nosso tratamento das odes pindáricas, entre elas, o de poesia oral, composição poética e principalmente o de performance.

Obviamente a teoria de Parry precisa ser adaptada à realidade da tradição na qual Píndaro se insere, algo que já foi de certa forma iniciado pelo trabalho de Nagy ${ }^{30}$. É preciso que se entenda que o conceito de tradição oral desenvolvido por Parry adequava-se muito bem à realidade da épica homérica, mas não (ao menos sem que haja um alargamento da definição) à lírica. Para Parry ${ }^{31}$, por exemplo, Píndaro teria "escrito" seus poemas e não faria mais parte de uma tradição oral como aquela a que pertenciam os bardos homéricos. Ele chega a essa conclusão analisando a ausência de estruturas formulares na poesia pindárica e a partir do fato de que Píndaro já pertenceria a uma era dominada pela escrita.

Essa era uma conclusão natural da teoria de Parry e deriva justamente da acepção que ele dá à tradição: é justamente por causa do estilo formular dos poemas homéricos que a poesia homérica é tradicional, no sentido de que ela não pode ter sido a invenção de um único indivíduo $^{32}$. No entanto, o conceito de "fórmula", em primeiro lugar, sofreu grandes modificações desde a sua definição inicial por aquele pesquisador. Um grande avanço no entendimento da motivação formular advém do trabalho de $\operatorname{Lord}^{33}$, mais especificamente do conceito desenvolvido por ele de "tema". Ora, a partir dos trabalhos de Lord e Nagy começa a ficar mais claro que a fórmula está submetida ao tema e às restrições impostas pela natureza métrica da poesia épica e que, portanto, uma variação em um ou outro implica, a fortiori, uma

\footnotetext{
${ }^{27}$ Sobre o conceito de marcação JAKOBSON (1987);NAGY (1990); BATTISTELLA (1996)

${ }^{28}$ Como, e.g., em frases do tipo "(o autor) disse que...", "nessa passagem, (o autor) fala/ reporta/ menciona que..." etc.

${ }^{29}$ Um exemplo de "interpretação positiva" ("plus interpretation" NAGY (1990, pp. Intro., §14), intro.§14). Considere-se, por exemplo, a diferença entre duas frases do tipo: "A lei fala que todos os homens são livres para emitir uma opinião" e "Está escrito na lei que todos os homens são livres para emitir uma opinião", onde a primeira pressupõe um princípio geral; enquanto a outra dá um direito como líquido e certo, delimitado e passível de ser verificado a qualquer momento e por qualquer um.

${ }^{30}$ NAGY (1990).

${ }^{31}$ PARRY (1987, p. 266 et set.). Para uma revisão da teoria de Parry, $c f$. MALTA (2013) .

${ }^{32}$ Cf. BAKKER (1997, p. 10 et seq.)

${ }^{33}$ LORD (2000).
} 
variação na expressão formular e/ou na sua frequência/uso. Na medida em que Píndaro pertence a uma outra tradição de composição poética, não podemos esperar que o conceito (ou a ausência de) "fórmula" possa ser usado para definir o caráter oral e tradicional de sua poesia. Outra questão que Parry ignorava é que essa tradição a que Píndaro pertencia era tão ou mais antiga que a épica, ainda que Píndaro, como um representante individual dessa tradição, não o fosse, e é a tradição, obviamente, que determina o fazer poético e não o poeta, que nela apenas navega com um barco na corrente de um largo rio $^{34}$.

O conceito de "fórmula" (além de apresentar uma grande "movência", para usar o termo zumthoriano), ou, mais especificamente, a sua absoluta necessidade para a existência de uma poesia oral tradicional tem sido extremamente exagerado por diversos estudiosos, seja em virtude de uma interpretação por demais estrita dos escritos de Parry, seja por causa da atitude etnocêntrica a que aludimos anteriormente ${ }^{35}$. Como nota Finnegan ${ }^{36}$, nem toda poesia formular é oral (p. ex., o Beowulf) assim como nem toda poesia oral é formular (p. ex., os izibongo zulus).

Dentro dessa definição de tradição oral que é mais inclusiva, uma outra premissa importante para o trabalho à frente é a de que não se pressupõe a escrita como necessária nem para a composição, nem para a (re)performance, nem para a transmissão imediata dos epinícios pindáricos. Aqui, no entanto, algumas salvaguardas e esclarecimentos se impõem. Em primeiro lugar, como é possível provar que Píndaro não tenha usado a escrita na composição de seus epinícios? Ou, então, que ele não tenha se valido dessa importante inovação tecnológica para enviar seus epinícios para os seus laudandi, a fim de que fossem executados por cantores/ coros locais (se quisermos pensar que não era o próprio Píndaro que o fazia, algo que discutiremos no Capítulo 4) ou, de outra feita, para treinar o coro que, supostamente, estaria encarregado da performance? A resposta mais simples a essa pergunta é que simplesmente não é possível apresentar uma prova conclusiva acerca de qualquer uma dessas hipóteses. Além disso, nós temos um texto transmitido, o que implica que, em algum momento, as odes devem ter sido transferidas para alguma mídia, restando apenas saber quando, como e porquê.

Quando eu digo, no entanto, que não precisamos pressupor a escrita como necessária para explicar a composição, performance e transmissão das odes pindáricas, eu não estou afirmando que a mesma não pudesse ter um caráter acessório no processo criativo (em que

\footnotetext{
34 “As fórmulas existem em uma tradição, e não podem dela se dissociar”, ZUMTHOR (2010, p. 129).

35 THOMAS (1992).

${ }^{36}$ FinNEGAN (1980, p. 69 et set.).
} 
grau, é difícil saber), nem que ela não tenha tido um papel importante na história de transmissão pós-performance dos mesmos, pois está claro que ela teve. O que eu quero dizer é que a lógica textual do texto pindárico se insere dentro de uma práxis poética e se manifesta, tanto no nível da forma quanto no do conteúdo, a partir de estratégias claramente pertencentes a uma tradição oral de fazer poético; ou que, em outras palavras, as odes apontam para um poeta cuja mentalidade ainda funcionava por meio de processos de pensamento e de conceitualização que parecem ter sido eminentemente orais. Isso implica dizer que, ainda que fosse possível que Píndaro conhecesse e fosse capaz de utilizar a escrita para fins de composição poética, o que eu duvido, ele estava completamente imerso em uma tradição oral de comunicação e de fazer poético, de tal forma que um possível uso da escrita serviria apenas para reproduzir, no papel, uma poética da oralidade. Ainda, essa poética da oralidade está preservada nos textos que chegaram até nós e ela é, portanto, passível de ser explicitada e demonstrada. Isto, obviamente, torna a questão de se saber se Píndaro usou ou não a escrita para compor seus epinícios irrelevante. Nesse sentido, é de extrema importância para as considerações feitas nesta tese, a diferença apontada por Bakker ${ }^{37}$ entre oralidade conceitual e midiática:

\begin{abstract}
No sentido conceitual, "oral" pode designar os hábitos mentais de pessoas que não participam, ou não participam integralmente, numa cultura letrada como a conhecemos, um fenômeno que associamos ou com outras sociedades ou com sociedades mais primitivas que a nossa. Quando aplicado para um "texto", "oral", neste sentido, implica que uma determinada escritura não demonstra características que são normais e esperadas em uma cultura da escrita: ela veio a existir sem a premeditação que está normalmente envolvida na produção de textos escritos. Um tal discurso foi escrito e é "gráfico" com relação ao seu meio, mas pode ser chamado de "oral" com relação à sua concepção. No sentido conceitual, portanto, "oral" pode denotar a ausência de características da língua escrita, seja um discurso falado ou escrito. Assim, ainda que os dois sentidos de "oral" tenham uma certa afinidade um com o outro, é importante não confundi-los. Um discurso que é conceitualmente oral (como uma narrativa em uma conversa) também é normalmente oral midiaticamente, porém é possível também que esse discurso seja escrito. E um discurso midiaticamente oral (fônico) é, com frequência, conceitualmente oral, mas, ao contrário, ele pode ser totalmente literário no que diz respeito à sua concepção (como no caso de um artigo acadêmico lido em voz alta)..$^{38}$
\end{abstract}

Um aspecto importante para que possamos entender os epinícios enquanto roteiros de uma performance diz respeito ao próprio modo como se aborda a práxis poética, uma vez que ela deve ser orientada pelas expectativas do texto enquanto um ato da fala.

De uma maneira geral, eu vejo todo o ato da comunicação como a articulação de dois planos de significação, o plano da forma e o do conteúdo. Obviamente, forma e conteúdo nem

\footnotetext{
${ }^{37}$ BAKKER (1997).

${ }^{38}$ Idem, p. 8.
} 
sempre cooperam da mesma maneira e o modo como o fazem depende essencialmente da natureza do texto, que, por sua vez, é o resultado da operação de uma função linguística sobre a mensagem. No texto poético, como deve estar claro, é a função poética, centrada na própria mensagem, que domina a orientação e estruturação dos conteúdos semânticos. Nas palavras de Jakobson ${ }^{39}$, ela "projeta o princípio da equivalência do eixo da seleção sobre o eixo da combinação" ${ }^{40}$, o que implica dizer que o meio de transmissão da mensagem assume o controle na criação de significados através de diversos processos que privilegiam a equivalência e o paralelismo, o que é apenas um outro modo, mais acurado, de expressar o caráter especial, marcado, do discurso poético em relação ao não-poético, como discutido anteriormente.

Essa marcação, que é o resultado da translação do eixo paradigmático sobre o sintagmático, privilegia a construção da sentença a partir de uma gramática poética (que não é uma entidade à parte, autônoma dentro da gramática convencional, mas está espalhada sobre ela), que pode variar de sociedade à sociedade e de tradição poética à tradição poética, mas cujo denominador comum é o parâmetro mensurador que dispõe os elementos da sentença de acordo com um determinado contraste entre eles, a fim de salientar diferenças ou semelhanças. Entre os gregos, por exemplo (mas também em várias outras sociedades, indoeuropeias ou não), "poesia" distinguia-se de "fala" pela presença de ritmo e melodia (Aris. Poet. 1409a35-1447a20) e, em sua métrica quantitativa, as sílabas eram ordenadas de acordo com padrões sequenciais que exploravam o contraste entre sílabas curtas e longas.

Para Nagy ${ }^{41}$, aliás, a estilização dos ritmos e melodias inerentes ao discurso nãopoético foi o que, diacronicamente, produziu os ritmos e melodias regulares da canção, algo reconhecido já por Aristoxeno (Harm. 1.8-10), segundo o qual "canto" diferenciava-se de "fala" justamente através do modo de execução dos intervalos melódicos: nesta, contínuos

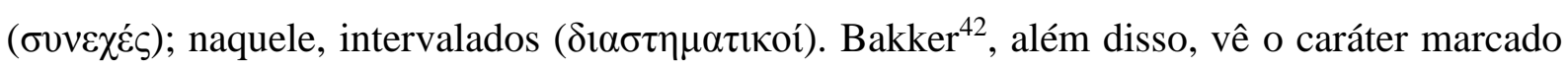
da poesia, a que aludimos, não como um sistema que, surgindo do nada, é sobreposto ao discurso para torná-lo distinto da fala cotidiana. Na verdade, para ele, a linguagem da poesia surge a partir da linguagem cotidiana e por meio da extrapolação de características que já existem na fala coloquial, por isso, no parágrafo anterior, disse que a gramática da poesia está imbricada na gramática da fala (não da escrita). Poesia, a partir deste ponto de vista, ao qual

\footnotetext{
${ }^{39}$ JAKOBSON (1987, p. 62 et set.).

40 Respectivamente, do "eixo paradigmático" sobre o "eixo sintagmático", para usar os termos da glossemática de Hjelmeslev, que prefiro por ser mais clara.

${ }^{41}$ NAGY (1990, pp. §39-40).

42 BAKKER (1997, p. 125 et seq.).
} 
eu me associo, é apenas uma forma especial da fala (special speech) na qual certas características (ritmo, assonância, metro, tonalidade etc.) são perfiladas contra o pano-defundo da linguagem cotidiana e assumem maior proeminência ${ }^{43}$. Na verdade, a abordagem de Bakker à poesia homérica é, em certa medida, semelhante a que eu proponho para Píndaro. Ao menos metodologicamente, ambos trabalhamos com esses textos (que obviamente são muito diferentes) do ponto de vista das Ciências Cognitivas, ainda que possam existir divergências no uso de alguns conceitos devido aos interesses específicos de Bakker no que diz respeito às técnicas típicas da narrativa épica. Mas o que são as Ciências Cognitivas e em que aspectos disciplinas como a Linguística e a Poética cognitivas são importantes para o trabalho à frente?

Em primeiro lugar é preciso entender que a Linguística Cognitiva (grafada assim, em maiúsculas e, a partir daqui, invocada sob a abreviação de LC) é apenas uma abordagem dentro de um campo maior de estudos, do qual ela se originou, e que, até hoje, também leva o nome de linguística cognitiva (neste trabalho sempre grafada com minúsculas). Por sua vez, a linguística cognitiva e a LC se inserem dentro de um programa maior, interdisciplinar, de estudos da cognição que inclui a psicologia, a antropologia, a sociologia, os estudos sobre inteligência artificial etc. A diferença mais marcante entre a linguística cognitiva e a LC está no modo como as duas teorias veem a linguagem humana e os processos comunicativos.

O modelo padrão da linguística cognitiva vê na linguagem um processo computacional, modular e, principalmente, autônomo, no qual a sintaxe, independente dos módulos fonológico e semântico, tem primazia no processamento e na construção de enunciados bem ordenados. Sua principal e mais difundida, embora não única, expressão é o Gerativismo desenvolvido por Noam Chomsky ${ }^{44}$, que, aliás, pode ser visto como o fundador da abordagem cognitiva na Linguística na medida em que foi o seu trabalho na década de sessenta que serviu para remodelar os estudos nessa área, até então fortemente centrados na teoria estruturalista de F. de Saussure como definida no Cours.

Por outro lado, a LC adota uma abordagem não-modular, não computacional e não localizada em seu estudo da linguagem, o que equivale a dizer, em primeiro lugar, que ela não é concebida como um "programa de computador" pré-instalado em nossos cérebros, o qual, alimentado com os dados oriundos da experiência empírica, seja capaz de reproduzir, por meio da linguagem, uma imagem exata desse mundo, de tal forma que o valor dos enunciados

\footnotetext{
43 "We are concerned, then, not with oral as the special case of poetry, but with poetry as the special case of oral, in other words, with poetry in speech", BAKKER (1997, p. 14).

${ }^{44}$ Sobretudo CHOMSKY (2002, p. 13 et seq.).
} 
possa ser avaliado contra um conjunto definido de regras sintáticas, num primeiro momento, e, então, contra a realidade, numa escala binária do tipo falso x verdadeiro ${ }^{45}$. Ao contrário, por levar em conta que os órgãos de cognição mediam o processo de apreensão da realidade, a LC propõe que sejam eles os responsáveis por moldar a linguagem, que surge justamente para fazer sentido dessa interação e organizá-la. É nesse sentido que o adjetivo “cognitivo" deve ser entendido no contexto da LC, isto é, essa é uma abordagem na qual a cognição, como mediada pelos sentidos, ou, se quisermos ser mais precisos, pelo corpo em geral (uma vez que, como seres humanos, experienciamos a realidade em que vivemos com o corpo todo), tem o papel central na construção e organização dos significados.

A linguagem obviamente é a expressão do pensamento e este, por sua vez, é um produto da mente. Esta última, na tradição filosófica ocidental, sobretudo aquela da Filosofia Analítica, representada pelo trabalho de Descartes, Kant e Frege, é vista como uma faculdade autônoma e independente do corpo ${ }^{46}$. Obviamente, desde o princípio, o objetivo da filosofia frequentemente foi o de nos separar dos animais em virtude do nosso uso da razão, vista como transcendente. No entanto, com o advento das ciências neurológicas, começou a ficar cada vez mais claro que a mente não é indissociável do cérebro, uma vez que lesões neste órgão causam, muitas vezes, deficiências graves no funcionamento daquela. Além disso, várias pesquisas começaram a demonstrar que, embora existam áreas especializadas no cérebro que podem ser associadas com determinadas funções, como o córtex cerebral, responsável pelo pensamento racional e a empatia, o funcionamento dentro dessas zonas, e entre elas, tende a se organizar na forma de redes neurais, cujo processamento de informações ocorre de maneira paralela e não serial ou, sem abuso algum do termo, sintática.

A partir daí um modelo de redes neurais pôde se desenvolver para dar conta do funcionamento do cérebro e, consequentemente, da mente. O princípio de funcionamento das redes neurais é o de que um determinado estímulo, mediado pelo sistema sensório-motor do corpo, irá ativar grupos de neurônios distintos que, por sua vez, irão se organizar para fornecer uma resposta a esse estímulo. A reiteração de um mesmo estímulo é, assim, capaz de gerar uma associação permanente entre grupos diferentes de neurônios, formando redes. Esse é um modelo que foi confirmado por evidências obtidas empiricamente, como, por exemplo, no tratamento de pessoas com lesões em áreas específicas do cérebro, as quais, através de

\footnotetext{
${ }^{45}$ Nesse sentido, a linguagem não pode ser "um conjunto [set - em sua acepção matemática] (...) de sentenças construídas a partir de um conjunto finito de elementos”, grifo meu, СHOMSKY (2002, p. 13 et seq.).

${ }^{46}$ Essas teorias, aliás, surgiram antes do advento dos trabalhos de Charles Darwin, que demonstra, por meio de sua teoria da evolução das espécies, como os animais em geral se adaptam às circunstâncias de seu ambiente.
} 
fisioterapia, que envolve principalmente movimentos de repetição, foram capazes de induzir a formação de novas redes neurais em áreas não afetadas de seus cérebros.

Dessa forma, a perspectiva das ciências cognitivas é a de que a mente e os seus produtos, i.e., a razão, o pensamento e a linguagem, evoluem e aprimoram suas capacidades à medida que o nosso corpo, peculiar de várias maneiras, interage com o espaço-tempo em que vivemos. Em outras palavras, esta visão evolucionária e darwiniana da mente, propõe que esta última use e surja das nossas capacidades (e limitações) corporais. A mente, desta forma, não está separada do corpo, mas é um produto dele, e, consequentemente, assim também a razão, o pensamento e a linguagem. Este é o "princípio da corporificação" (embodiment principle) ${ }^{47}$ da mente.

As implicações dessas descobertas para o estudo das Humanidades são imensas. Em primeiro lugar, elas nos dizem que nós humanos, como outros animais, somos seres que, para codificar e organizar as experiências que temos ao interagirmos com o mundo, usam neurônios que funcionam em redes de processamento paralelo, e que nossos processos de categorização do conhecimento assim obtido devem ser uma função dessa arquitetura neural. Dado que o número de neurônios em qualquer sistema neural é finito (cerca de 100 bilhões no caso dos humanos, o que produziria em torno de 100 trilhões de conexões sinápticas), há apenas um número limitado de conexões possíveis entre grupos de redes para mapear todo o infinitamente diverso conjunto de experiências possíveis entre nós e o mundo. Logo, uma relação unívoca entre a realidade e a configuração de nossas redes neurais não é possível. Dessa forma, várias experiências, ou inputs, precisarão passar pelas mesmas, ou por quase todas as mesmas, conexões neurais e, consequentemente, serão armazenadas na memória na forma de um perfil característico de seu trajeto por essa rede. A memória então irá organizar esses perfis em grupos de parecença familiar e isso irá gerar categorias mais ou menos relacionadas umas com as outras.

O processo de categorização é, de fato, inescapável do ponto de vista evolucionário, e dada a arquitetura de nossos sistemas nervosos, mesmo os seres mais simples como as bactérias categorizam os objetos que encontram em seu caminho como "comida" ou "nãocomida". Além do mais, nós não podemos escolher "não categorizar", nós simplesmente o fazemos e esta capacidade, bem como o modo como a usamos, foi uma consequência natural

47 Cf. sobretudo LAKOFF e JOHNSON (1999), "These findings of cognitive science are profoundly disquieting in two respects. First, they tell us that human reason is a form of animal reason, a reason inextricably tied to our bodies and the peculiarity of our brains. Second, these results tell us that our bodies, brains, and interactions with our environment provide the mostly unconscious basis for our everyday metaphysics, that is, our sense of what is real." 
da nossa evolução como seres neurais. Em um nível de funcionamento mais elementar, nós não podemos sequer escolher o modo como categorizamos, nem podemos mudar as categorias mais básicas com as quais operamos (em cima x em baixo; direita x esquerda; presente $\mathrm{x}$ passado x futuro, etc.), ainda que outras, mais complexas, sejam passíveis de recategorização ${ }^{48}$. Finalmente, a maior parte dos processos de categorização ocorre inconscientemente, sem que sequer entendamos o seu funcionamento. Na verdade, um outro princípio importante para a LC é o de que a maior parte do pensamento é inconsciente ${ }^{49}$.

Os processos pelos quais os seres humanos categorizam suas experiências sempre foram entendidos como uma associação entre objetos que têm características comuns, essa é a abordagem da Semântica tradicional. Por exemplo, todo animal que têm asas, bico, penas e voa é uma ave. No entanto, como avaliaríamos a pertinência da galinha ou do avestruz dentro dessa categoria? afinal de contas, apesar desses animais terem asas, bico e penas, eles não voam. Essa deficiência da semântica estruturalista, desenvolvida principalmente por Katz e Fodor $^{50}$, mas que, de fato, remonta ao tratado de Aristóteles nomeado, justamente,

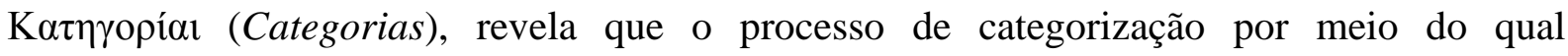
organizamos o nosso conhecimento do mundo é mais complexo e sofisticado do que poderíamos imaginar.

Em uma série de artigos, Eleanor Rosch pôde demonstrar que (a) o processo de categorização não se baseia unicamente nas características partilhadas por diferentes objetos; (b) o processo de categorização não depende apenas dos objetos e suas características, mas principalmente do indivíduo que executa a caracterização ${ }^{51}$ e (c) os objetos dentro de uma categoria não têm uma existência discreta, mas estão distribuídos em um espectro que vai da total pertinência à total impertinência a uma determinada categoria. Os objetos com total ou alta pertinência a uma categoria, ou seja, que têm todos ou quase todos os requisitos exigidos para a pertinência àquela categoria - no nosso caso, ter asas, bico, penas e voar -, são vistos como "bons exemplos" ou representantes típicos da mesma, ao passo que aqueles que têm alguns atributos, são classificados como "maus exemplos" ou exemplares atípicos. No vocabulário técnico da LC, os membros típicos de uma categoria são ditos prototípicos ${ }^{52}$, e,

\footnotetext{
${ }^{48}$ Por exemplo na maioria das sociedade ocidentais a categoria "sexo" divide-se em duas subcategorias apenas, "masculino" e "feminino", mas algumas sociedades preveem a existência de um terceiro, ou mesmo quarto, sexo.

${ }^{49}$ LAKOFF e JOHNSON (1999, pp. 19-19).

${ }^{50}$ KATZ, J. J.; FODOR, J.A. "The Structure of Semantic Theory", Language, 1963.

${ }^{51} \mathrm{O}$ que está de acordo com o princípio cognitivo da corporificação, como discutido acima.

52 Termos pertencentes ao nome-de-espaços da LC serão grafados, ao longo da tese, em negrito em sua primeira instanciação ou quando for necessário desambiguá-los. Todos os termos em negrito aparecem explicados em um glossário ao final desta tese. Um dos problemas inerentes às diversas abordagens que se
} 
em nosso exemplo, o sabiá, o pardal, e outros passarinhos, seriam exemplos prototípicos dentro da categoria $\mathrm{AVE}^{53}$, ao passo que a galinha e o avestruz, seriam membros nãoprototípicos $^{54}$.

As categorias nas quais organizamos os objetos do nosso conhecimento, ademais, estruturam-se de uma forma semelhante às bonecas russas. Assim, "galinha" é um item subordinado à categoria AVE, mas, ao mesmo tempo, superordenado do ponto de vista do item "galinha de angola". Da mesma forma, AVE pode ser colocada dentro da categoria ANIMAL e esta, por sua vez, dentro da categoria SER VIVO. O que nos interessa porém é que, dentro de uma hierarquia complexa de categorias, haverá sempre um nível básico de especificidade (a partir daqui NBE) de que os falantes normalmente farão uso ou não de acordo com os seus propósitos comunicativos. Nenhum falante nativo do português irá dizer, sem soar estranho, que "comeu ave no almoço", mas sim que comeu "galinha" (ou pato, ou codorna), isto é, dentro da categoria AVES COMESTÍVEIS, o NBE pertence ao nome comum, qualquer que seja, do animal dessa categoria ${ }^{55}$.

As categorias superordenadas, à medida que se afastam do NBE, tendem a ter um menor número de pré-requisitos de pertinência, uma menor semelhança entre membros do mesmo nível e, muitas vezes, são descritas por meio de nomes não-contáveis, como é o caso da categoria LOUÇA, que inclui como seus membros as subcategorias TRAVESSA, COPO, PRATO, XÍCARA, entre outros utensílios. O inverso é verdadeiro para as categorias subordinadas. É comum que se fale, então, em esquematicidade: do ponto de vista do NBE as categorias superordenadas são mais esquemáticas, ao passo que as subordinadas são menos esquemáticas. Tomemos por exemplo a categoria PESSOA, com relação a ela as categorias subordinadas HOMEM, MULHER, JOÃO, são menos esquemáticas ${ }^{56}$. O uso de uma e não de outra categoria (ou item de uma categoria) normalmente é motivada pelas intenções do falante. Se eu digo, por exemplo, que "Maria está se relacionando com uma pessoa" posso estar

utilizam da LC é a proliferação de vocabulário técnico. Os interessados podem encontrar um bom guia no livro de EVANS (2007).

${ }_{53}^{53}$ Conceitos, categorias e metáforas conceituais são, por convenção, sempre grafados em caixa alta.

${ }^{54}$ Dois experimentos clássicos sobre o modo como os humanos organizam objetos dentro de uma mesma categoria é aquele de B. BERLIN e P. KAY, Basic color terms: their universality and evolution. Berkeley: University of California Press, 1969, sobre as cores e o de W. LABOV (The boundaries of words and their meaning. In: BAILEY, C. e SHUY, R. New ways of analyzing variation in English. Washington DC: Georgetown University Press, 1973. pp. 340-73) sobre xícaras e objetos similares.

${ }^{55}$ Note que isto não acontece, por exemplo, em inglês, onde é comum frases do tipo "I had fowl for dinner yesterday", onde a categoria FOWL funciona como nível básico de especificidade, ao contrário, por exemplo, de "chicken". Compare com o uso de POULTRY, que é uma categoria que exclui todos os galináceos e "waterfowl" (pato, ganso, marreco) em geral.

${ }^{56}$ É uma convenção da LC que se represente a esquematicidade diminuindo da esquerda para a direita e aumentando no sentido contrário. 
querendo inferir que Maria o está fazendo dentro de uma relação não-prototípica do ponto de vista da categoria RELACIONAMENTOS ROMÂNTICOS, que normalmente define como prototípico o par HOMEM-MULHER. Dessa maneira, posso estar insinuando que Maria está se relacionando com outra mulher ou, então, que não desejo revelar o nome de seu parceiro, ou, ainda, ambos, se se tratar de uma parceira.

Dentro de uma mesma categoria, a prototipicidade de que falamos acima pode ser vista de uma maneira relativa e se organizar de diferentes maneiras. Podemos pensar, por exemplo, na categoria superordenada MAMÍFERO, cujos pré-requisitos de pertinência incluem, como principal característica, a existência, nas fêmeas, de mamas produtoras de leite, pelos, termorregulação, a presença de três ossos no ouvido interno, um neocórtex cerebral, esmalte nos dentes etc. Tomemos agora os seguintes membros dessa categoria: uma cadela, uma baleia e uma ornitorrinco. Fica evidente que, dos três, a cadela, por ter o maior número de requisitos de pertinência é o exemplar mais prototípico e, portanto, ocuparia o círculo mais interno da categoria; a baleia, o intermediário e o ornitorrinco estaria bem na fronteira da mesma, podendo até mesmo ser excluído dela por alguns falantes. O que fica evidente é que a categorização dos itens de MAMÍFERO obedece uma distribuição radial na qual seus membros mais prototípicos aproximam-se do centro, ao passo que os outros são relegados a diferentes regiões da periferia. Essa, no entanto, é apenas uma forma de organização categorial; outras categorias podem se organizar por meio de um critério de ponto focal, como no caso das cores, ou de modelos culturais, como no caso da categoria "boa forma", ou então por motivos religiosos, como no caso das dietas kosher ou halal.

Um outro conceito importante que emerge da categoria MAMÍFERO é aquele de centralidade. Como vimos, a presença de glândulas mamárias nas fêmeas de alguns animais é uma condição sine qua non para que os chamemos de "mamíferos" e, em certa medida, também o é a presença de pelos. Ter três ossos em seu ouvido interno, no entanto, tem pouca influência em nossa experiência cotidiana em separar, por exemplo, mamíferos de peixes. Esses pré-requisitos, então, têm pesos diferentes na concessão ou preclusão de pertinência a itens da categoria em questão e o grau com que têm importância ou não para a nossa categorização é expressa por meio do conceito de centralidade. Dessa forma, o requisito "ter glândula mamária" tem centralidade absoluta na definição do conceito MAMÍFERO, ao passo que o requisito, "ter pelos", ainda que bastante central, não pode, por si só, defini-lo. Já o requisito "ter três ossos no ouvido interno" só é relevante em um contexto científico ou especializado da Taxonomia. 
Aliás, seria importante definir com mais propriedade o que entendemos por contexto. Num primeiro nível, "contexto" pode ser entendido de duas maneiras: (a) um contexto linguístico e (b) um contexto sociocultural. Por contexto linguístico entende-se (i) o discurso precedente, (ii) o ambiente linguístico imediato e (iii) o tipo de discurso, que se define por meio do gênero textual, do registro e do campo discursivo (legal, religioso, discursivo, dialógico etc. $)^{57}$. O contexto sociocultural diz respeito não apenas a todo um sistema de práticas, atitudes, crenças, convenções, instituições, estados mentais etc. partilhados por toda uma comunidade mas também implica na consciência, em cada um de seus membros, de que esse conhecimento é partilhado por todos, o que permite que apenas contextos significativos para ambas as partes possam ser invocados com a máxima economia de metalinguagem ou elaboração ${ }^{58}$. Uma vez que o modo como categorizamos o mundo depende, em grande medida, do modo como interagimos com ele (e dado o fato de que essa interação é mediada também por fatores sociais e culturais), é de se esperar que o contexto sociocultural tenha uma grande influência no modo como construímos nossas categorias mentais. Numa aplicação mais local, podemos falar de um espaço discursivo corrente (EDC), que nada mais é do que o frame (definido a seguir) no qual falante e ouvinte interagem e que tomam como base para um discurso em um determinado momento. O EDC é estável e pressupõe um imenso conhecimento como pano-de-fundo, mas à medida que o discurso prossegue, ele é continuamente atualizado. Em qualquer momento, o EDC fornece a base para interpretar a próxima sentença, que modifica tanto o seu conteúdo quanto o seu foco

Uma outra forma, aliás, de entender contexto, e com a qual, talvez, seja mais fácil de se lidar objetivamente, é defini-lo em termos do enquadramento do evento da fala em uma situação bastante específica e determinada, ou seja, em um frame ${ }^{59}$. O uso deste conceito ao longo da tese segue a teoria da Semântica de Frames, desenvolvida por Charles Fillmore ${ }^{60}$ no início da década de setenta. De acordo com Fillmore, um frame é

(...) qualquer sistema de conceitos relacionados de tal maneira que, para entender qualquer um deles, você tem que entender toda a estrutura na qual ele se enquadra; quando um desses itens em tal estrutura é introduzido em um texto, ou em uma conversa, todos os outros tornam-se automaticamente disponíveis. ${ }^{61}$

${ }^{57}$ Como definido por CLARK (1996), apud L. FERRARI (2011, p. 44).

${ }^{58}$ Para uma abordagem cognitiva da pragmática, $c f$. especialmente BARA (2010).

${ }^{59}$ Para evitar uma superposição de estilos, frame, embora pertença ao espaço-de-nomes da LC, não será grafado em negrito.

${ }^{60} C f$. Fillmore (2006) e, também, LANGACKer (2008, p. 27 et seq.)

${ }^{61}$ FillMore (2006, p. 373). 


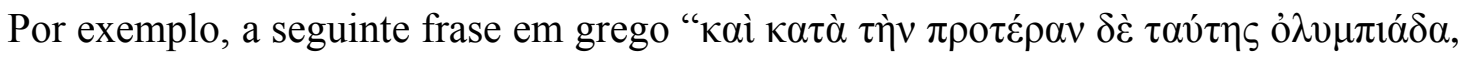

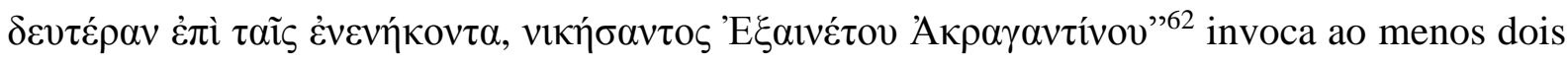
frames sem os quais é impossível compreender a sentença. O primeiro deles é o frame CALENDÁRIO CÍCLICO, o outro é OLIMPÍADA. Por meio do primeiro frame, é instanciada a base conceitual grega segundo a qual a passagem do tempo é contada por meio das séries olímpicas, que se repetiam a cada cinco anos do ponto de vista grego, o qual incluía o intervalo inicial ${ }^{63}$. O segundo frame, que é subordinado ao primeiro, invoca o costume de se nomear todo o período de uma olimpíada por meio do nome do vencedor na corrida de estádio, que para este caso fora Exeneto de Agrigento. Note que, sem a invocação do frame OLIMPÍADA, seria preciso explicitar a prova na qual o atleta fora vencedor. Para alguém cujo calendário esteja organizado de uma outra maneira, seria extremamente difícil entender a dimensão temporal envolvida na datação. Mesmo nós, que temos um certo conhecimento dos frames envolvidos no entendimento da sentença, precisamos invocar o nosso próprio frame de CALENDÁRIO CÍCLICO, organizado em anos, para que, por meio de uma correlação entre os dois, possamos compreender adequadamente o significado temporal implicado pela sentença. Obviamente, Diodoro da Sicília ficaria confuso na mesma proporção que um leigo moderno se lhe disséssemos que Exeneto fora vencedor no ano de 412 a.C. uma vez que nem o conceito de ANO, nem de ANTES DE CRISTO fariam qualquer sentido dentro do seu frame de CALENDÁRIO CÍCLICO ${ }^{64}$.

Uma outra característica importante da teoria da semântica de frames desenvolvida por Fillmore é que ela nos permite entender melhor do que a semântica tradicional, baseada em tabelas-verdade do tipo falso x verdadeiro, os mapeamentos de significado entre duas línguas diferentes. Tomemos, por exemplo, um conceito essencial para os epinícios pindáricos (e para a cultura grega em geral), aquele de ARETE, que mapeia significados diversos em português. Uma forma tradicional de tentar entender o que cada instanciação dessa palavra significa em Píndaro, ou em qualquer outro texto, seria consultar o LSJ ou dicionários especializados, como RUMPEL e SLATER, para tentar "encaixar" uma dessas definições na passagem em questão. Ao fazer isso, no entanto, o que descobriremos é que, na maioria das vezes, o significado geral da passagem fica pouco claro ou nos parece insatisfatório ${ }^{65}$. Isto, de fato, acontece (abstraindo-se os problemas inerentes à transmissão textual) em virtude da nossa

62 "Na primeira olimpíada anterior a esta, a nonagésima segunda [412 a. C.], quando Exeneto de Agrigento foi vencedor [na corrida de estádio]", D.S. 13.82.7, citado na íntegra à p. 67.

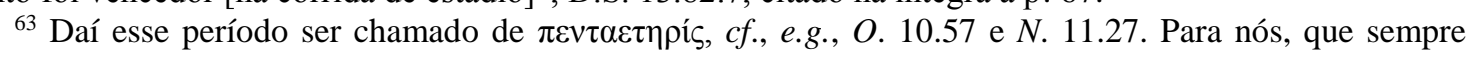
excluímos o intervalo inicial, o período compreendido é de quatro anos.

${ }^{64} \mathrm{O}$ exemplo clássico tomado por Fillmore dizia respeito ao conceito de WEEKEND.

${ }^{65}$ Sobre isso, $c f$. excelente capítulo de CLARKE (2010) in BAKKER (2010). 
compreensão bastante pobre dos frames passíveis de ser invocados em uma audiência para a qual o conceito de ARETĒ tivesse representado uma categoria conceitual operante em suas vidas diárias. Ainda assim, podemos deduzir, mesmo que de maneira bastante esquemática através dos textos em nossas edições, alguma coisa do escopo de alguns frames identificáveis nos epinícios.

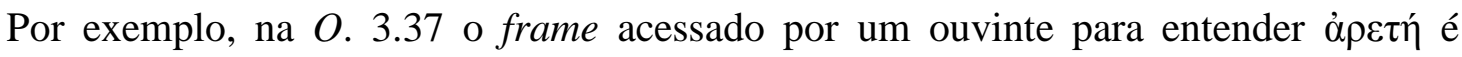
JOGOS OLÍMPICOS e, dessa forma, "virtude", o termo guarda-chuva para a tradução daquela palavra, seria totalmente inadequado, pois os Tindaridas não seriam juízes das "virtudes" dos

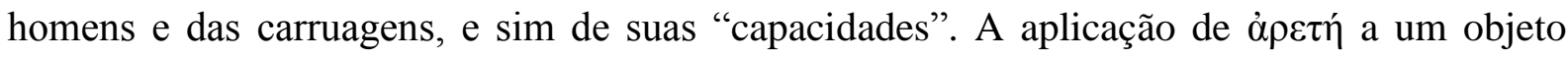
inanimado é, ademais, um claro índice de seu uso metafórico. Na $O .9 .100-2$, um outro frame, TREINO, é invocado e nos permite entender o sentido de ả $\rho \varepsilon \tau$ como "habilidade", "talento".

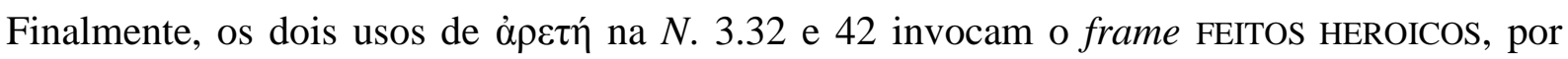

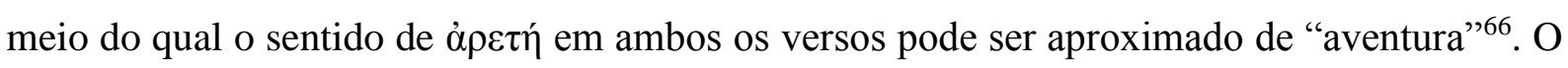
importante não é decidir se estamos de acordo ou não com os significados propostos para

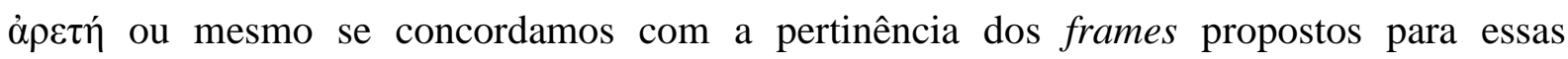
passagens. O fato linguístico para o qual eu estou chamando atenção é que, em grego, uma

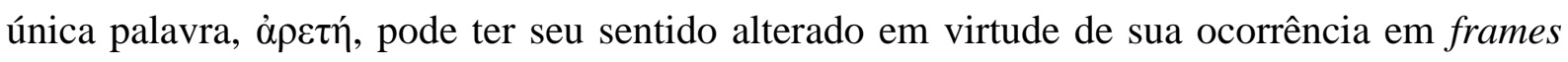
específicos que, ademais, invocam associações externas, não intrínsecas, ao item lexical. O conhecimento desses frames, portanto, e de que atividades e relações eles predicam, é mais importante para se compreender uma palavra do que a sua definição dicionarizada, que apenas lista suas principais, porém finitas e de modo algum exaustivas, características ou acepções. É preciso salientar, ainda, que a semântica de frames de Fillmore não nos ajuda a entender a definição de uma palavra, mas sim seu significado, dedutível a partir das associações que evoca na mente do ouvinte ${ }^{67}$.

A semântica de frames de Fillmore permitiu a Lakoff ${ }^{68}$ desenvolver a sua ideia de Modelo Cognitivo Idealizado (MCI), que nada mais seria que um conjunto complexo de frames distintos que se estruturam a partir de três princípios básicos: (a) estrutura proposicional, (b) esquemas imagéticos e (c) projeções metafóricas e metonímicas. Um exemplo clássico da estrutura proposicional dos MCI's é aquele que construímos para

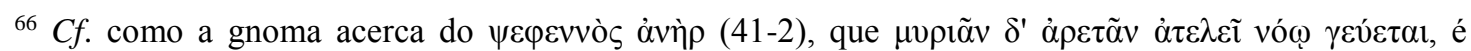
colocada entre a narrativa dos feitos impressionantes ( $\mu \varepsilon \gamma \alpha \dot{\lambda} \alpha \alpha$ है $\rho \gamma \alpha)$ de Peleu e Aquiles.

${ }^{67}$ CROFT e CRUSE (2004, p. 8), "Fillmore describes his frame semantic model as a model of the semantics of understanding, in contrast to a truth-conditional semantics: the full, rich understanding that a speaker intends to convey in a text and that a hearer constructs for that text. Fillmore argues that in the analysis of linguistic meaning, understanding is the primary data; truth-value judgments and judgments of semantic relations such as synonymy and implication are derivative and theory-driven", grifo meu.

${ }^{68}$ LAKOFF e JOHNSON (1987). 
organizar o nosso tempo em unidades discretas: anos, meses, semanas, dias, horas etc. Se tomarmos por exemplo o conceito de SEMANA veremos que nele os dias estão dispostos em uma ordem que vai de segunda-feira a domingo, sendo que a semana sempre começa na segunda-feira. Em português essa estrutura é ainda mais explícita por usarmos numerais ordinários (segunda, terça, quarta, quinta e sexta) para os cinco dias da semana de trabalho ou dias úteis. É apenas dentro dessa estrutura proposicional que FIM-DE-SEMANA faz sentido. O modelo é obviamente idealizado porque ele não existe na "realidade", mas é um construto cultural dedutível a partir de uma divisão do tempo que tem como base o ano solar ${ }^{69}$.

A segunda característica dos MCI's é que eles se estruturam por meio de esquemas imagéticos (EI) que nada mais são do que as conceitualizações abstratas construídas a partir de nossa experiência corporal com o mundo. Eles podem ser muito simples, mas, por meio do processo de entrincheiramento, tornarem-se bastante complexos. Um exemplo relativamente fácil de entender é o EI "FRENTE-ATRÁS", a partir do qual relacionamos nossa experiência com o tempo, projetando qualquer sequência de eventos sobre esse eixo, onde PASSADO ESTÁ ATRÁS e o FUTURO ESTÁ À FRENTE, de modo a tornar possíveis e inteligíveis expressões do tipo "minha infância ficou para trás" ou “daqui para frente, tudo será melhor". Relacionado a isso está o terceiro princípio, da projeção metafórica ou metonímica, a partir do qual tendemos a projetar o MCI de TEMPO sobre aquele de ESPAÇO, entendo o primeiro em termos do segundo, como vimos nas frases acima, ou então, quando dizemos, por exemplo, que "os anos passam voando". O que nos leva a um dos conceitos mais centrais na LC e que nos servirá já no primeiro capítulo dessa tese, o de Metáfora Conceitual.

De acordo com o modelo tradicional de Lakoff-Johnson ${ }^{70}$, as metáforas mais primárias surgem da nossa experiência muito peculiar com o nosso corpo e no modo como ele interage com o mundo. Um exemplo clássico dessa interação é a maneira como relacionamos "afeição" com "calor" em virtude da relação corporal de afeição que temos, desde muito cedo, com nossos pais. Essa relação nos leva a conceitualização da metáfora primária AFEIÇÃo É CALOR, dedutível, por exemplo, de expressões como "João é uma pessoa fria" (isto é, não demonstra afeição). É preciso, no entanto, entender que o conceito AFEIÇÃo É CALOR normalmente não é pensado conscientemente, ainda que muitos modos de expressão possam dele derivar, o que nos leva a um segundo princípio muito importante da LC segundo o qual

${ }^{69}$ Os Igbo da Nigéria, por exemplo, têm "semanas" baseadas em ciclos de 4 dias, ao passo que os nativos de Java se organizam em ciclos de 5 dias. Os cristão primitivos concebiam uma semana de 8 dias em que o oitavo dia, o domingo, era também o primeiro dia da semana seguinte, ou seja, sua semana era distribuída sobre um intervalo inclusivo no que diz respeito ao último/ primeiro dia da semana.

${ }^{70}$ LAKOFF E JOHNSON (1980). 
não podemos pensar como quisermos ou da maneira que quisermos, isto é, independentemente das categorias conceituais que nos são impostas pelo corpo e pelo mundo desde o nascimento. Um corolário de (2) é que não podemos escolher as metáforas conceituais que usamos, já que muitas delas nos são impostas ou transmitidas culturalmente.

O que me leva a um segundo ponto que também merece destaque. Embora haja uma grande quantidade de metáforas aparentemente universais, sobretudo aquelas construídas sobre conceitos mais básicos, oriundos das relações que os seres humanos têm com o seu corpo (que pode ser definido como uma constante na medida em que todos temos corpos com uma mesma morfologia física), há também uma série de metáforas não universais, culturalmente determinadas.

Em seu livro sobre variação e universalismo metafórico, Kövecses ${ }^{71}$ nos dá alguns exemplos interessantes: embora na maioria das sociedades ocidentais o amor seja conceitualizado em termos de JORNADA ("Nosso amor não está indo a lugar algum”), CAÇA ("Hoje é dia de ir à caça”), CALOR (“O amor de João e Maria esfriou”) etc., em algumas partes da China o amor é conceitualizado como VOAR NUM PAPAGAIO-DE-PAPEL. Ao passo que entre nós a RAIVA é conceitualizada em termos de um FLUIDO ou GÁS EM EBULIÇÃO ("Ele estava fervendo de raiva", "Ele estava soltando fumaça pelas ventas"), entre os zulus, a RAIVA é entendida como OBJETOS DENTRO DO CORAÇÃO.

Finalmente, um exemplo mais familiar, com o qual todo estudante de grego se depara, não sem certa admiração, ao aprender a língua, é o modo como os antigos falantes da língua conceitualizavam a orientação do tempo a partir da metáfora TEMPO É UM OBJETO EM

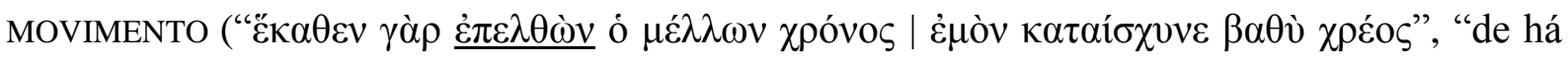
muito tendo chegado o tempo futuro, | envergonhou-me o débito profundo", O. 10.7-8), isto é, a partir de um sentido contrário ao que estamos acostumados, com o futuro às costas, a aproximar-se, e o passado, à frente, a distanciar-se do observador. Na verdade, em grego antigo, o futuro pode ser conceitualizado através de uma dimensão espacial a partir da metáfora FUTURO É O QUE VEM DE TRÁS, dedutível da palavra mais comumente usada para

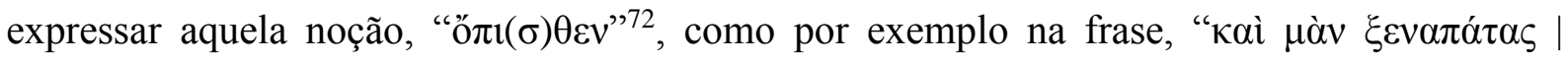

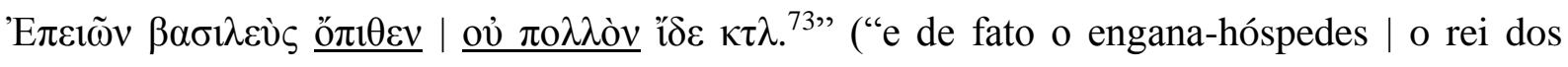
Epeus [do que veio] de trás | muito não viu etc.”, $O$. 10.34). Essa orientação é fácil de

${ }^{71}$ KÖVECSES (2005).

${ }^{72}$ Como na língua Aymara, aliás, em que a palavra para passado é "nayra" equivalente a "olho", visão", "frente", ao passo que futuro é "qhipa", equivalente à "atrás", "às costas", PISHWA (2009, p. 463).

${ }^{73}$ Que indica ainda que, como nós, os gregos conceitualizavam "tempo" em termos de quantidade (muito tempo x pouco tempo) ao invés de duração (longo tempo x curto tempo), como em inglês (long time $\mathrm{x}$ short time), por exemplo. 
entender se considerarmos que a experiência de futuro para os gregos está intimamente ligada à orientação corporal segundo a qual FRENTE É AQUILO PARA O QUE SE OLHA, ATRÁS sendo definido, consequentemente, como aquilo que não se vê. Por meio de um processo de entrincheiramento entre as duas metáforas TEMPO É UM OBJETO EM MOVIMENTO e FRENTE É AQUILO PARA O QUE SE OLHA, pode se chegar às metáforas secundárias de que FUTURO É O QUE VEM DE TRÁS (porque não se vê) e PASSADO É O QUE ESTÁ À FRENTE, posto que conhecido.

Com isso espero ter fornecido ao leitor os princípios básicos que orientam a abordagem metodológica desta tese. É preciso que se ressalte que essa abordagem emergiu naturalmente de minha leitura de Píndaro e, de uma maneira geral, da oratura $^{74}$ grega arcaica. Não se trata, portanto, de uma imposição da teoria sobre os fatos, muito embora, em qualquer abordagem que se queira científica, o teste de modelos teóricos capazes de descrever os fenômenos sob estudo constitua, ou deva constituir, uma das primeiras fases da investigação desse mesmo problema. A teoria, qualquer que seja, não muda a realidade, ela nos ajuda a vêla melhor ou de um ponto de vista melhor e, nesse sentido, ela é como uma caixa de ferramentas que permite que manipulemos determinados aspectos de um problema de uma maneira mais eficiente.

Dessa forma, um aspecto e uma vantagem da LC que eu acredito que devam ser ressaltados é a sua capacidade de colocar o texto em função daquele que o produziu e não como um produto daquele que deverá interpretá-lo. De outra maneira, isso equivale a dizer que pessoas de sociedades distantes da nossa, seja no tempo, seja no espaço, vivem (ou viveram) em uma realidade que deve nos ser estranha em vários aspectos e em diferentes graus e que, portanto, seria inadequado abordar sua produção cultural de acordo com as nossas próprias categorias e os nossos próprios modos de conceitualização. Obviamente que, como todos temos a mesma morfologia corporal e partilhamos de um mundo objetivo comum, haverá certamente uma base conceitual intercultural idêntica para todos nós. A parte desse pano-de-fundo comum, no entanto, o mundo é apreendido, conceitualizado e representado (por meio da linguagem, das artes, da filosofia) de uma maneira tão diversa, quanto diversas são as sociedades que nele existem ou existiram. Como a mente não é uma faculdade

\footnotetext{
${ }^{74}$ A partir daqui irei usar o termo "oratura" (uma vez que "oratória" já se encontra empregado para outro uso) e "oracia" para classificar a produção literária da Grécia arcaica vista como primordialmente produzida oralmente ou com vistas à uma performance oral. $\mathrm{O}$ termo é creditado ao linguista e crítico literário Pio Zirimu que o teria cunhado em 1977, em conjunto com Austin Bukenya, em um artigo intitulado "Oralcy as a Tool for African Development", lido na Festac de 1977 em Lagos THIONG'O (1998, p. 111). O termo "oratura", de fato, parece ter uma frequência maior nos países anglófonos e está especialmente ligado aos estudos póscolonialistas da literatura africana, FINNEGAN (1980, p. 15) nota que "It avoids the etymological problems of 'oral literature' and is also a positive term in its own right (the parallel to écriture) in the context of 'decolonising the mind"'.
} 
autônoma, mas que depende e se forma a partir do corpo e da interação deste com o mundo e os outros, isto implica que a mente e os seus processos, o pensamento, a razão, a linguagem, estão ulteriormente e inextrincavelmente ligados ao corpo e ao contexto no qual ele se desenvolveu. Desta feita, é lícito dizermos que a linguagem, em seus mais variados níveis de expressão, retrata ou espelha não apenas as categorias e os hábitos mentais de um único indivíduo, mas de toda uma sociedade. Abordar, então, uma determinada cultura a partir das nossas próprias categorias mentais é incorrer no sério risco de não ser capaz de entende-la, ou, o que é pior, entende-la de uma maneira completamente distorcida.

$* * *$

A tese está dividida em sete capítulos. No primeiro, eu explico, de uma maneira mais detalhada, as pressuposições que fundamentam meu trabalho com a obra de Píndaro e, de fato, minhas inclinações teóricas com relação à lírica grega arcaica em geral como o produto de uma sociedade oral, isto é, uma oratura, da qual o próprio Píndaro fazia parte. Este é o panode-fundo dentro do qual todo o restante da tese está enquadrado.

No Capítulo 2, procuro entender a semântica do termo $\kappa \tilde{\omega} \mu \mathrm{s} \varsigma$ por meio de uma investigação que leva em conta a conceitualização do termo dedutível a partir dos textos da oratura arcaica e, em menor medida, clássica, já que incluí também exemplos oriundos do drama ático. Minha tese central apoia-se no fato de que Píndaro e Baquílides sempre se referem ao frame da performance das odes como um $\kappa \tilde{\omega} \mu \mathrm{s}$ e que, portanto, se quisermos entender alguma coisa sobre a natureza da performance, devemos ser capazes de compreender, ao menos minimamente, o que este frame implica, já que é em função dele que

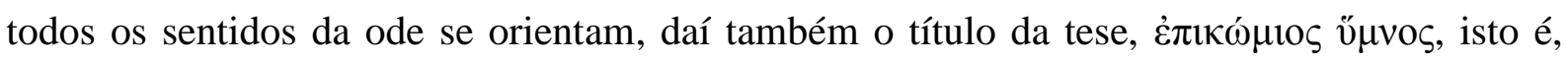
hino cantado por ocasião de um $\kappa \tilde{\omega} \mu$ os. Como não acredito que o uso do termo em Píndaro e Baquílides seja uma idiossincrasia atribuída ao estilo ou gênero do epinício, mas que, ao contrário, remeta à uma tradição indo-europeia de louvor, no contexto mais amplo, que foi herdada pela poética grega, é essencial investigar quais as práticas, expectativas e usos prototípicos e não-prototípicos estão associados com o conceito. Por razões óbvias de espaço, limitei-me a explorar a dimensão indo-europeia apenas tangencialmente, dedicando-me a investigar o uso do termo a partir de sua conceitualização dentro da cultura grega. Meu objetivo principal é demonstrar que $\kappa \tilde{\mu} \mu$ o pressupõe um modelo cognitivo idealizado de práticas celebratórias das quais a performance da ode era apenas uma parte. 
No Capítulo 3, eu abordo a questão da persona loquens nos epinícios, o que compreende uma investigação para saber se é possível determinar ou não quem está por trás

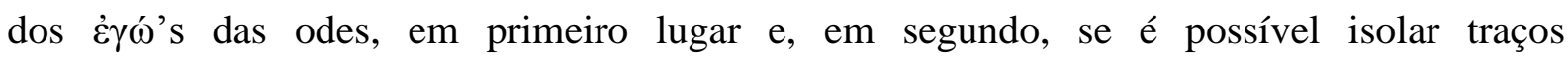
característicos dessa persona loquens que sejam passíveis de ser associados com o modo da performance, isto é, se a voz que fala na canção apresenta características de um eu-lírico individual ou se pode ser associada a um grupo que seria responsável por executá-la. Isto será importante, posteriormente, para a discussão nos capítulos 5 e 6 .

No Capítulo 4, eu questiono a presunção tácita de que não era o próprio Píndaro que executava suas odes, dentro de um cenário solo, ou de que ele não estava presente durante as performances das mesmas, num cenário que pressuponha uma execução coral. Neste, eu tento mostrar que essa hipótese baseia-se, em última análise, em argumentos apriorísticos acerca da composição poética (a maior parte das abordagens pressupõe que Píndaro escrevia e enviava seus poemas para seus laudandi), não considera questões culturais e testemunhos que apontam para o fato de que os laudandi derivavam prestígio também da presença física de grandes poetas em suas celebrações de vitória, e, finalmente, não se baseia em dados históricos ou geográficos que apontam para uma grande mobilidade de indivíduos, poetas ou não, no Mediterrâneo antigo.

Nos capítulos 5 e 6, eu reavalio a controvérsia acerca do modo da performance dos epinícios em sua première ${ }^{75}$. Na primeira parte, eu me dedico a rever as principais posições teóricas e, trabalhando com as conclusões obtidas nos capítulos anteriores, procuro demonstrar que a teoria coral, ainda que tenha se tornado a posição dominante nos últimos trinta anos, está longe de ter sido provada e que, além disso, alguns pressupostos teóricos envolvidos em sua formulação merecem ser reavaliados. Minha tese é a de que há mais motivos para postularmos uma performance solo do que coral, embora reconheça que, dado o estado atual da pesquisa, é impossível provar tanto um quanto outro cenário. Chamo a atenção, no entanto, para o fato de que considerar acriticamente a performance coral como tendo sido, de alguma maneira, provada ou mesmo mais provável e, a partir daí, embasar outras conclusões acerca das odes pode nos conduzir a sérios problemas. No Capítulo 6, eu analiso algumas das passagens mais controversas e que são apresentadas como evidência de um ou outro cenário, acrescentando minhas próprias conclusões oriundas, sobretudo, da minha abordagem metodológica e dos resultados obtidos nos capítulos precedentes.

\footnotetext{
${ }^{75}$ Como eu chamarei a "primeira” performance, seguindo MORRISON (2012, p. 111), que ainda faz uma distinção entre esta e as performances secundária, próxima no espaço-tempo da première, e terciária, referindose a audiências mais amplas ao longo do mundo grego ou executadas muito tempo depois da première.
} 
Finalmente, no Capítulo 7, eu me dedico a analisar alguns cenários de reperformance que poderiam ter sido conducentes à fixação de um texto escrito e termino com um cenário, admitidamente especulativo, acerca de uma possível via de transmissão de uma primeira coleção dos poemas de Píndaro em Alexandria.

Como o leitor irá notar, portanto, minha abordagem das canções parte do pressuposto de que é a performance que determinou, em última análise, não apenas o próprio texto, entendido como a forma entextualizada das odes, mas, inclusive, a própria materialização desse registro, uma vez que foi o prestígio das canções que garantiu, ao longo do tempo, que as mesmas fossem preservadas oralmente, por muitos e diversos meios, até o momento em que, no limiar da oracia para a literacia, essas obras vocais fossem registradas pela escrita. Essa transição de canção a texto, portanto, aparece refletida no esqueleto a partir do qual eu decidi organizar a discussão. 


\title{
CAPÍTULO 1
}

\section{CONSIDERAÇÕES SOBRE A PRÁXIS POÉTICA \\ EM PÍNDARO}

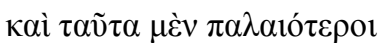

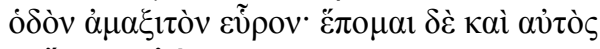 \\ $\varepsilon ้ \chi \omega \nu \mu \varepsilon \lambda \varepsilon ́ \tau \alpha \nu$. \\ E se tais coisas já os mais antigos \\ acharam, uma via a se trilhar, também eu por ela seguirei \\ tendo-a em meu cuidado.
}

N. 6.53-4.

EM UM ARTIGO ${ }^{1}$ de 2002, publicado no Journal of the American Oriental Society, intitulado Pindar's Rigveda, Calvert Watkins conta-nos uma anedota ao mesmo tempo em que nos apresenta uma hipótese acerca da práxis poética de Píndaro que, pode-se presumir, também seja aplicável aos seus colegas de ofício, Íbico, Simônides e Baquílides², para ficarmos apenas naqueles de que temos fragmentos identificáveis como epinícios, ou mesmo a todos os poetas da lírica arcaica.

A anedota diz respeito ao fato de que a coeditora do volume teria lhe dito que nunca compreendera Píndaro até o dia em que lera o Rgveda, uma coleção de hinos escritos em uma forma arcaica do sânscrito conhecida como védico ${ }^{3}$, que pode ser datado de entre os séculos XVIII e XII a.C., mas que exibe paralelos fonéticos e temáticos com o Avesta iraniano, o que nos remeteria a uma protoforma datável do período anterior à separação dos dois ramos da família indo-irânica, por volta do ano 2000 a. C. A hipótese de Watkins, por outro lado, diz respeito ao fato de que tanto em Píndaro quanto no védico (ele toma exemplos do Rgveda, daí o título do artigo) um nome pode ser instanciado tanto explícita quanto implicitamente, por meio de hipérbato e anagrama, a fim de lhe conferir uma maior saliência.

\footnotetext{
${ }^{1}$ WATKInS (2002).

${ }^{2}$ Para uma pré-história do gênero, $c f$. RAWLES (2012).

${ }^{3}$ O Rc ("verso de louvor") é apenas um parte, ainda que a mais conhecida no ocidente, de uma coleção de 4 śrutayah, conhecidas como Vedas: o Yajur-, o Sama- e o Atharvaveda. Os três primeiros Vedas tinham uma clara função ritualística e eram recitados por sacerdotes distintos, respectivamente o hotr, o adhvaryu e o udgātr, ao passo que o Atharvaveda é uma coleção de hinos, encantamentos e mitologias.
} 
Por meio do hipérbato, tanto o grego quanto o védico usam a seguinte estrutura: PRON. DEIC. $+F_{1}, F_{2} \ldots F_{N}+$ NOME, onde $F$ pode ser desde um predicado simples até uma série de frases que intervenham entre o pronome e o nome. No védico, o dêictico usado é o pronome demonstrativo स (sá), equivalente e cognato do grego ó. Assim, no RV 1.132 घा विद् अन्विन्द्रो गवेषणो बन्धुक्षिम्यो गवेषणः (sá ghā vide anvindro gaveșaṇo bandhukșidbhyo ghaveșanah, "Este, de fato, é conhecido por seu ardor [pelo combate], Indra, um combatente para os seus aliados"), a distância entre स (sá) e इन्द्र (Indra) serve para pôr o nome do deus em evidência. Em Píndaro,

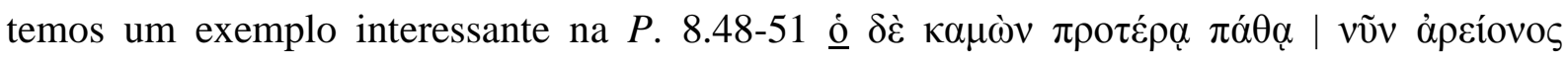

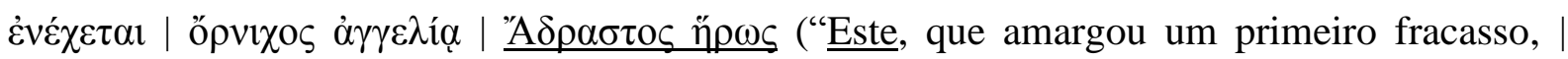
agora encontra-se com um anúncio | de melhor presságio, | o herói Adrasto”). A mesma técnica aparece inclusive no caso de relativos, como por exemplo, no RV 2.12.7b यः सूर्यं य उषसं जजान यो अपां नेता स जनास इन्द्र: (yah sūryam ya uṣasam jajāna yo apām netā sá janāsa Indraha, “quem ao Sol e à Aurora gerou e as Águas guia, este, ó homens, é Indra") e na P. 1.95-6-9

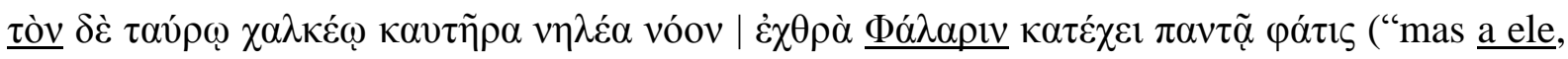
a odiosa fama obtida pelo touro de bronze, ao de incendiário, ao de destrutivo pensamento, $\mid \underline{a}$ $\underline{\text { Faláris, }}$ ela silencia em todo canto"5).

A forma como o védico e, por extensão, muitas tradições poéticas do indo-europeu, pode codificar um determinado nome, instanciado explicitamente em sua primeira aparição e

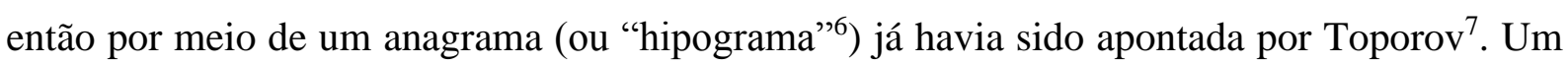
exemplo citado por Watkins ${ }^{8}$ seria o nome do poeta Vimada, a que se atribuem os hinos 2026, da décima mandala do Rgveda, que aparece explicitamente em RV 10.20.10:

\section{एवा ते अग्ने विमदो मनीषामूर्जो नपादक्तेभिःसजोषाः । \\ गिर आ वक्षत सुमतीरियान इषमूर्जंसुक्षितिं विश्वमाभाः ।।}

\footnotetext{
${ }^{4} \mathrm{Na}$ verdade, todo esse hino é construído sobre essa forma “ele que/ por meio de quem (...) este é Indra".

${ }^{5}$ A catacrese é proposital, para mostrar mais graficamente a disposição dos elementos da frase. A ordem direta seria: "Mas a odiosa fama [obtida] pelo touro de bronze silencia, em todo canto, Faláris de pensamento destrutivo e incendiário".

${ }^{6}$ Isto é, parte de um nome instanciado em uma outra palavra, por exemplo, "João sofre com seus joanetes", onde joan- é um hipograma para João.

${ }^{7}$ TOPOROV (1981).

${ }^{8}$ WATKINS (1995, pp. 188-9).
} 
evā te agne vimado manīṣāmūrjo napādamṛtebhihsajoșāh $\mid$

gira à vakșat sumatīiryāna ișamūrjamsukșitịn viśvamābhāh \|

Assim, Ó Agni, Filho da Força, Vimada com o auxílio de sua mente e dos imortais ofertou-te hinos, pedindo teu favor. Deste toda comida, força e próspera morada.

E, subsequentemente, de maneira implícita por meio de anagramas: RV $10.25 .1 \mathrm{~b}$ वि वो मदे (...) विवक्षसे ( $\underline{\text { i }}$ vo made... vivakșase, "Em êxtase... quero dizer-te"); 10.23.6a विमद़ा (vimadā, “os Vimadas”, isto é, sua família); 7a विमद़स्य चर्शो: (vimadasya caṛseh, "teu e do ṛsi Vimada”),

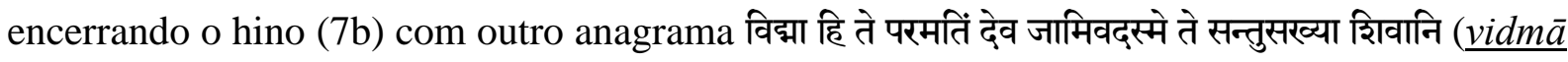
hi te pramatim deva jāmivadasme te santusakhyā śivāni, "sabemos que cuidas de nós como um irmão, ó deus. Que tua amizade seja auspiciosa”).

Já em Píndaro, esta técnica pode ser vista empregada de maneira semelhante no priamel expresso por meio de uma aporia no prelúdio da $O .2 .1-6$, exceto que aqui os hipogramas aparecem antes do nome, de modo a dar a maior saliência possível a este quando ele aparecer no verso 5 em acavalamento:

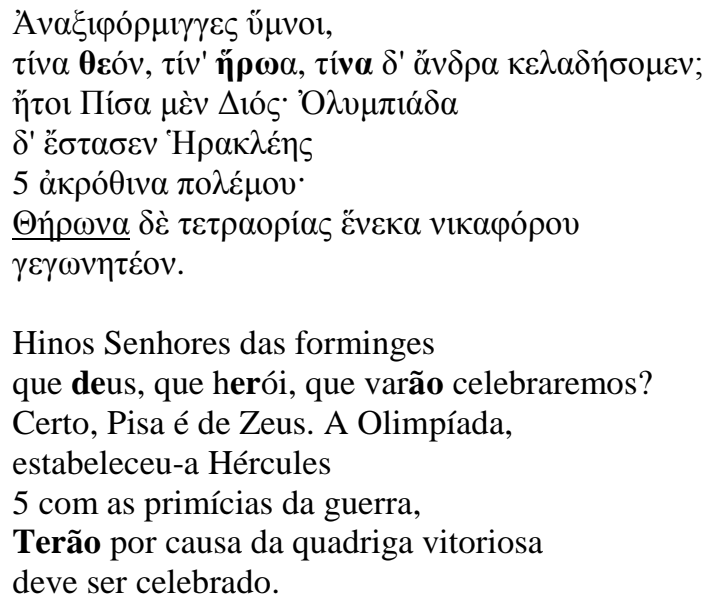

Esse tipo de artifício ${ }^{9}$, que pode nos parecer tanto inacreditável quanto pueril - e que frequentemente pode ser rejeitado em nome de uma ideia de "Hochpoesie" que, não raro, é imposta sobre Píndaro a partir de nossas próprias concepções acerca do que é ou não é "poético" -, pode ser, de fato, uma das marcas mais características da poética indo-europeia em geral e da grega em particular. No caso dos epinícios, ela já havia sido notada por

\footnotetext{
${ }^{9}$ Outros exemplos em WATKINS (1995, p. 189 et seq.).
} 
Mezger $^{10}$, muito embora tenha sido descartada pela crítica pindárica, até mesmo por Gildersleeve, um dos maiores admiradores do pindarista alemão, que avalia que "se isso fosse verdade [i.e., a teoria da palavra recorrente], dificilmente serviria para aumentar nossa admiração da antiga arte $(. . .)^{11}$.

Não é, no entanto, meu objetivo nesse capítulo fazer uma análise comparatista nos termos esboçados acima. Eu apenas cito o artigo e o trabalho seminal de Watkins para chegar às duas primeiras pressuposições que guiam meu trabalho com a poesia de Píndaro e, naturalmente, também esta tese.

A primeira delas é a de que Píndaro insere-se dentro de uma tradição de fazer poético que é de origem indo-europeia e, portanto, tão antiga quanto, se não mais antiga que, a épica. Essa afirmação necessita de pouca elaboração já que minhas conclusões, neste sentido, ecoam aquelas de $\mathrm{Nagy}^{12}$, isto é, eu acredito que uma estilização progressiva dos metros e da dicção da lírica levou ao metro e à dicção da épica. A segunda pressuposição, que é de certa forma dependente e derivada da primeira, é a de que a poesia de Píndaro revela uma natureza altamente intricada de fazer poético, tanto no nível da forma quanto no do conteúdo, e que, além disso, essa característica é típica de tradições de poesia oral. Nessas tradições, a estilização progressiva dos elementos da fala cotidiana é levada a um nível máximo, de modo a produzir uma canção que é na verdade, um objeto, uma joia, e de fato, como veremos a seguir, ela é normalmente conceitualizada dessa maneira.

Para denotar esse processo de "objectificação" da canção, eu me utilizo do termo "entextualização"13, cunhado por Bauman e Briggs. Segundo eles, a entextualização,

é o processo de tornar um discurso extraível, de transformar uma certa extensão de
produção linguística em um unidade - um texto - que pode ser extraída de seu
cenário interacional. Um texto, então, desse ponto de vantagem, é um discurso que
pode ser descontextualizado. A entextualização pode muito bem incorporar aspectos
do contexto, de modo que o texto resultante carregue elementos da história de seu
uso dentro dele. ${ }^{14}$

Em uma sociedade oral, o processo de entextualização envolve a promoção progressiva da saliência de características da fala em torno de padrões que possam ser mais

${ }^{10}$ MeZGer (1880, p. 26 e 28), "In den Fällen, wo nicht die Form der Rede selbst schon den Uebergang kenntlich macht, liebt es der Dichter (...) durch Wiederholung eines bestimmten, gewöhnlich bedeutsamen Wortes in gleichen Vers und Fuß der Strophe, das dann natürlich auch durch Melodie, Musikbegleitung und Tantzbewegung ausgezeichnet gewesen sein wird, die Stele der Uebergangs anzuzeigen".

11 GiLDERSLEEVE (1886, pp. 1-li).

12 NAGY (1990).

${ }^{13}$ Por se tratar de um termo-chave e técnico, utilizá-lo-ei, a partir daqui, sem aspas nem itálico.

${ }^{14}$ BAUMAN e BRIGGS (1990, p. 73). 
facilmente lembrados, o que normalmente acontece por meio da promoção de características que são raras ou sentidas como estilizadas na linguagem coloquial. Como argumentamos na Introdução, a forma mais eficiente que o cérebro humano tem de armazenar informações é através de redes de processamento paralelo. Essas redes desempenham um papel crucial na memorização do conhecimento porque permitem que as experiências que temos com o mundo sejam organizadas em categorias que têm o mesmo padrão de processamento e armazenamento na memória. A estilização, dessa forma, contribuiria para a imposição de padrões sobre a linguagem cotidiana que tornariam a memorização da mesma mais fácil. Por outro lado, ela serviria para "amarrar" a mensagem em um rede de cada vez mais estilizada nos níveis fônicos, sintáticos ou outros (melódicos, por exemplo) que transformariam uma determinada produção vocal ordinária em um produto extraordinário no qual a mensagem poderia ser aprisionada ou codificada. Esse produto final seria, no sentido mais adequado do termo, um texto (< lat. textus, tecido, padrão) e o processo que o originaria seria então a entextualização.

Cada tradição poética em todo o mundo desenvolveu técnicas diferentes de entextualização que facilitassem a memorização ao se aproveitar dessa faculdade da memória de otimizar o armazenamento e o acesso a informações recuperáveis através de um padrão associativo. Aparentemente os poetas gregos também tinham os seus próprios métodos, pelo que sabemos das anedotas acerca de Simônides ${ }^{15}$, alegadamente o "primeiro" a inventar uma técnica de mnemônica que, infelizmente, se perdeu. Se, contudo, nos voltarmos outra vez aos hinos do Rgveda, que vêm sendo transmitidos oralmente há milênios até os dias de hoje, veremos que uma técnica muito eficiente foi desenvolvida para entextualizar seu conteúdo. Ela se baseia na iteração alternada de diferentes palavras de um mesmo hino por meio de vários padrões de recitação (पाठ, pātha $)^{16}$. Assim, por exemplo, se $\mathrm{P}_{1}, \mathrm{P}_{2}$ e $\mathrm{P}_{3}$ forem três palavras consecutivas de um hino, uma das formas mais simples de iteração seria a जटापाठ (jațāpațha, "recitação trançada"), na qual o aprendiz recitaria $\mathrm{P}_{1} \mathrm{P}_{2}, \mathrm{P}_{2} \mathrm{P}_{1}, \mathrm{P}_{2} \mathrm{P}_{3}, \mathrm{P}_{3} \mathrm{P}_{2} \mathrm{e}$ assim por diante até o fim do sukta. A forma mais complicada, dominada apenas pelos mestres, seria a

15 Plin. N. H. 7.24.89; Cic. de Fin. 2.32.104; Longin. Rhet. 718. Reunidos em CAMPBELL como testimonia $\mathrm{n}^{\text {os. }} 24,25,26$, p. 350-1.

16 Onze, na verdade, em ordem crescente de dificuldade: Saṃhita, Pada, Krama, Jațā, Mālā, Sikha, Rekha, Dhvaja, Danda, Rathā, Ghana. Um mestre na recitação dos Vedas é conhecido como Ganaphațin, por ter dominado o último estágio na arte de recitar os Vedas. Esse aprendizado normalmente começava (e começa, pois ainda existe na Índia) por volta dos 5 ou 6 anos em escolas mantidas pelo governo. Para uma descrição fascinante de todo o processo, $c f$. SCHARFE (2002, p. 270 et seq.) 
घनपाठ (ghanapātha, "recitação compacta"), na qual o aprendiz aprenderia a recitar $\mathrm{P}_{1} \mathrm{P}_{2}, \mathrm{P}_{2} \mathrm{P}_{1}$, $\mathrm{P}_{1} \mathrm{P}_{2} \mathrm{P}_{3}, \mathrm{P}_{3} \mathrm{P}_{2} \mathrm{P}_{1}, \mathrm{P}_{1} \mathrm{P}_{2} \mathrm{P}_{3}, \mathrm{P}_{2} \mathrm{P}_{3}, \mathrm{P}_{3} \mathrm{P}_{2}, \mathrm{P}_{2} \mathrm{P}_{3} \mathrm{P}_{4}$ e assim por diante. É preciso ressaltar que essas não são apenas técnicas para memorizar os vedas, embora elas tenham provavelmente se desenvolvido com esse propósito, mas constituem uma forma artística independente e podem ser recitadas e apreciadas pela beleza intrínseca de suas permutações.

Além, evidentemente, da estrutura métrica dos epinícios, que teve um papel importantíssimo na sua entextualização, um padrão que aponta para um outro desenho composicional para o qual eu gostaria de chamar a atenção - e que foi notado por mim durante uma leitura habitual, em voz alta, das odes de Píndaro ${ }^{17}$-, é o da disposição dos acentos melódicos na $N$. 11: dos 45 versos dessa ode ${ }^{18}$, apenas 17 não terminam em paroxítona, sendo que, destes, 9 ou são perispômenas ou oxítonas sobre vogal longa. Ambas poderiam, portanto, ser resolvidas musicalmente por meio de melisma, isto é, $\theta \varepsilon \tilde{\omega} v$ no $v .6$, por exemplo, poderia ser executado na forma $\theta \varepsilon$ óòv, e o mesmo valeria para દ̇́́v, no v. 32, छ̇óòv. Essa prática pode ser vista, por exemplo, no P. Vienna G. 2315 (E. Or. 338-44) ${ }^{19}$,

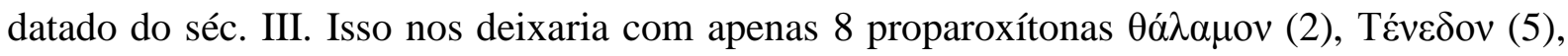

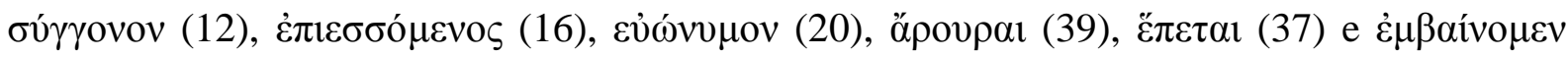
(44).

Entre essas, é possível perceber um padrão mesmo numa rápida análise como a presente: sempre que o elemento D da coda coincidir com fim-de-palavra, como, por exemplo

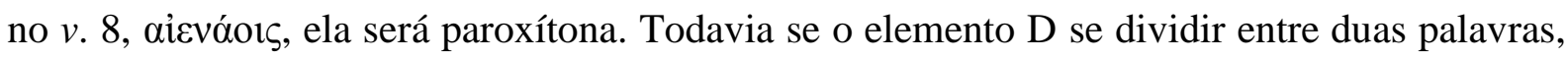
a coda será paroxítona apenas se a primeira longa receber um circunflexo, como por exemplo no $v .35, \delta \varepsilon \tilde{\rho} \rho ’ \alpha \dot{\alpha} \alpha \dot{\gamma} \omega v$; do contrário, será proparoxítona, como nos $v v .3,5$ e 43 . Sempre que o elemento -e ou xe coincidir, na coda, com uma palavra, ela será paroxítona, como no $v$. 28, $\pi о \rho \varphi v \rho \varepsilon ́ o 1 \varsigma^{20}$. Se, contudo, houver fim-de-palavra após $\times$ ou -, ou seja, sempre que tivermos

${ }^{17}$ Ignoro se este mesmo padrão já foi notado por algum outro comentador para esta ode. Um trabalho nesse sentido, mas para a $N$. 7 foi realizado por STEINRUECK (2012). Infelizmente a disposição gráfica escolhida pelo autor para tabular as posições acentuais torna a leitura e, portanto, a avaliação dos resultados, muito difícil. Apesar disso, sua conclusão acerca dos sândis acentuais nas perispômenas adequa-se às minhas próprias observações no que tange à $N$. 11. Como ele, eu não levei em consideração, senão apenas marginalmente, o impacto que esses sândis poderiam ter sobre a estrutura métrica.

${ }^{18}$ Utilizei como padrão o período boechkiano, como as odes foram colometrizadas a partir da edição de 1821 de Boechk. Seria interessante investigar que tipo de padrão emerge se dividíssemos os períodos na forma dos pés prototypa em que os alexandrinos dividiram as odes e que vigeram até a edição de HEYNE (1817).

${ }^{19}$ DAGM, no 3, p. 12.

${ }^{20}$ Note que a sinizese aqui parece ser uma evidência da resolução, por meio de melisma, para as oxítonas em posição final. 
×|e ou -|e, então a coda será proparoxítona, como em 12, 20 e 44 ${ }^{21}$. As únicas proparoxítonas para as quais não pude deduzir um padrão foram as dos $v v .16$ e 39, o que provavelmente se deve a uma rápida análise ad hoc dessa ode. Talvez uma investigação mais aprofundada pudesse mesmo chegar a uma explicação de valor topológico para a acentuação das codas em todas as odes.

Ainda assim, mesmo a partir desses resultados limitados, a melodia da ode, como denotada apenas pelos acentos é muito característica, o que qualquer um poderá verificar lendo-a em voz alta e tomando cuidado de pronunciar os acentos corretamente. Essa peculiar regularidade da $N .11$ é, ademais, ainda mais intrigante quando se considera que este tipo de resposta acentual não é esperada em uma composição estrófica, já que seria muito difícil manter uma relação entre a melodia e os acentos e ainda manter a resposta rítmica entre os diferentes períodos da ode. Talvez esse princípio valha apenas para a coda e seja um resquício de um tempo em que apenas essa parte do verso era marcada em relação ao ritmo, como acontece com os versos do Rgveda e, numa medida bem menor, na lírica eólica, em que uma certa liberdade métrica é aceitável na cabeça do verso. Seja como for, devemos nos contentar, por hora, com um non liquet a esse respeito.

O que eu pretendo enfatizar com essas observações são dois pontos principais.

O primeiro é o de que o ofício do aedo era um processo que envolvia um longo aprendizado que provavelmente se iniciava na infância para a maioria dos casos, ao mesmo tempo em que era visto como um "dom dos deuses". O segundo é o de que essa instrução deveria ser de caráter eminentemente, se não completamente, oral, isto é, o aprendiz de poeta deveria estudar com um mestre que lhe passaria, desde muito cedo, toda uma dicção e técnicas tradicionais de fazer poético que ele usaria para o resto de sua vida. Há algumas evidências de que esse tenha sido o cenário ao menos para o caso de Píndaro ${ }^{22}$, ao passo que estudos etnográficos desde os tempos de Parry demonstram que este $e ́$ o caso na maioria, se não em todas, as sociedades que ainda cultivam algum tipo de poesia oral. Campanile resumiu isso muito bem ao dizer que

O que nós chamamos de poesia indo-europeia era, na verdade, a soma do conhecimento de uma sociedade, o qual era transmitido oralmente. As características que a nossa tradição ocidental atribui à poesia (sentimentalismo, inspiração, individualismo, participação etc.), as quais foram particularmente salientadas pela estética do Romantismo, eram, para a poesia indo-europeia, apenas uma questão

${ }^{21}$ Note que em 44, o elemento $\dot{\varepsilon} \mu$ - pode ser sentido como fim de palavra, devido ao seu valor preposicional.

${ }^{22}$ Ao menos se houver alguma verdade nas anedotas contadas pelo Suda de que ele fora aluno de Mirtis e, talvez, colega de Corina. 
subsidiária, ainda que estivessem presentes. O principal era preservar e aumentar os elementos culturais que representavam algo de essencial para o bem-estar, a coesão e a estabilidade da sociedade. Estamos falando de encantamentos que curam os doentes, fórmulas legais que resolvem disputas, as preces que pedem por bens materiais dos deuses, as genealogias que dão às pessoas uma consciência de seu passado e que as fazem ter orgulho dele, os poemas de louvor que legitimam os reis através da celebração de sua grandeza. Aquele que cumpria uma tal função mantinha a primeira posição no ranque dessa sociedade, mas o seu comércio com as Musas não era nem especialmente frequente ou necessário. Para esse tipo de poesia, uma pessoa só poderia se preparar ao longo de anos de estudo. O que a métrica dos textos do irlandês do período médio nos diz sobre o treinamento do poeta irlandês arcaico é basicamente válido para o indo-europeu também. ${ }^{23}$

Acerca do primeiro ponto e em sintonia com o que diz Campanile, eu vejo como paradigmática a dupla motivação apresentada por Hesíodo na famosa cena de sua iniciação, na Teogonia, vv. 22-34:

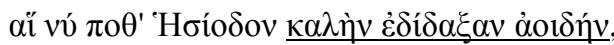

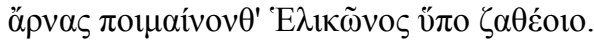

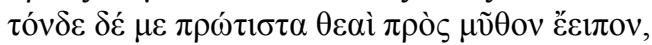

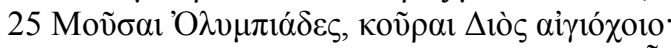

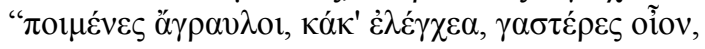

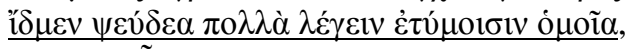

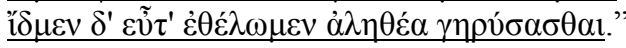

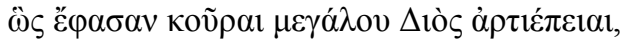

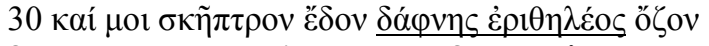

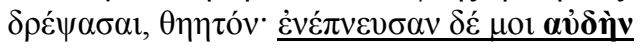

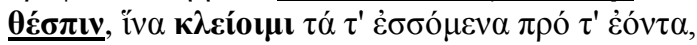

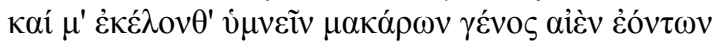

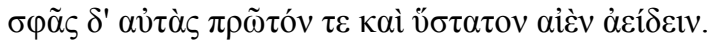

Elas ${ }^{24}$ um dia a Hesíodo ensinaram bela canção, ao pastorear cordeiros no sopé do sacratíssimo Hélicão. E esta fala imediatamente dirigiram-me as deusas, Musas filhas do Olimpo, meninas de Zeus Porta-égide: "Pastores do campo, infâmias vis, ventres apenas, sabemos muitas mentiras contar símeis aos fatos, e sabemos, quando queremos, cantar a verdade ${ }^{25}$ ". Assim disseram as maviosas meninas do Grande Zeus, 30 e um cetro me deram, de um ramo de loureiro florido tendo-o colhido, esplêndido, e insuflaram-me uma voz

divina, a fim de que pudesse dar fama ao que será e ao que foi antes, e exortaram-me a hinear a geração dos Beatos sempre vivos, e elas mesmas, primeiro e por último, sempre cantar.

É interessante notar que, na passagem acima, vemos a inter-relação, mencionada por Campanile, entre uma transmissão tradicional da arte poética como ofício capaz de ser

${ }^{23}$ CAMPANILE, E. Indogermanische Dichtersprache. Studiem zum indogermanischen Wortschatz, ed. por W. Meid, 21-28. Innsbruck: Innsbruck Beiträge zur Sprachenwissenchaft, apud, WATKINS (1995, p. 69).

${ }^{24}$ Isto é, as Musas.

${ }^{25}$ É muito provável que, em grego, o verbo poético $\gamma \alpha \rho v ́ \omega ~(<* \hat{g} \bar{a} r$, donde o inglês care, lat. garriō e português, garrir) já não tivesse mais o sentido de "clamar", "gritar", mas sim "cantar", como no ossético zarum. Cf. também, armênio, cicarn e cicarnuk, respectivamente, "andorinha" e "rouxinol", MALLORY e ADAMS (2006, p. 354). 
ensinado e a natureza eminentemente divina do dom concedido ao poeta. Não é à toa que, segundo Pausânias, antigamente havia apenas três Musas que recebiam culto no Hélicão:

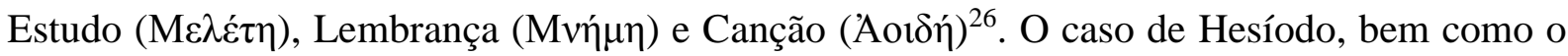
de outros poetas legendários ${ }^{27}$, é excepcional apenas na medida em que ele aprende sua

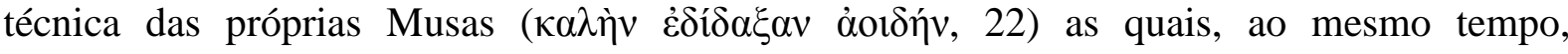
insuflaram-lhe uma "voz divina", $\theta \varepsilon \dot{\sigma} \sigma \pi \varsigma \varsigma$ $\alpha \hat{\delta} \delta$ (31-2). Dessa forma, e a um só tempo, Hesíodo afirma sua natureza dupla de artesão, treinado no ofício que deverá executar, e de figura de autoridade capaz de derivar seu conhecimento de uma fonte divina, cujo símbolo material de um poder imaterial é um ramo de loureiro, árvore sagrada para $\mathrm{Apolo}^{28}$.

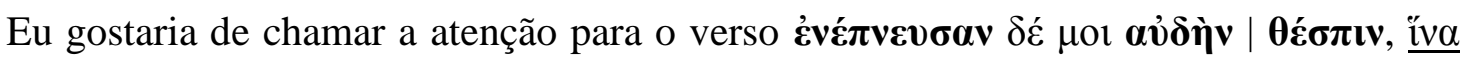

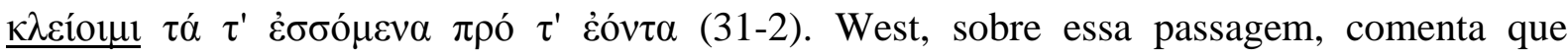

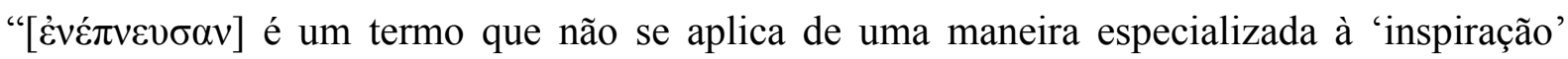
artística, mas à concessão, por um deus, de uma nova disposição mental ou física" ${ }^{29}$. No

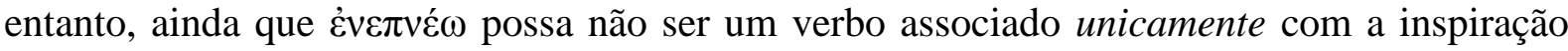
poética, o fato de normalmente termos um deus ou, neste caso, as deusas como responsáveis por incutir o conhecimento no ânimo do poeta, torna a expressão funcionalmente equivalente à fraseologia poética atestada nas línguas indo-europeias segundo a qual a canção é algo colocado no poeta (no seu coração, na sua mente etc.). Um paralelo interessante é a injunção inicial do Rgveda, 10.20.1 em que o poeta pede भद्रं नो अपि वातय मनः (bhadram no api vātaya manaḥ, "feliz pensamento insufla em nós"), onde अपि वातय (api vātaya) literalmente significa “sopra sobre ${ }^{30 "}$. No próprio grego, a famosa apologia de Fêmio à Odisseu (22.347-8), fornece

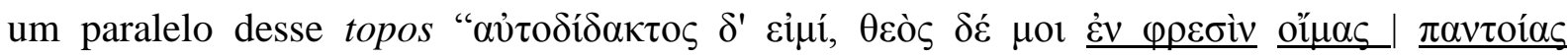

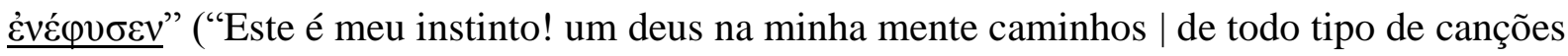
plantou" $)^{31}$.

26 29.2.5-3.

${ }^{27}$ Como Demódoco e Fêmio.

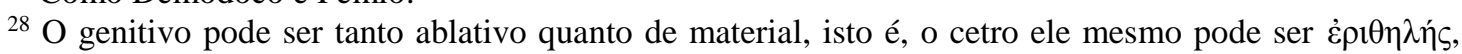
contendo as folhas e as flores do loureiro, quanto pode ter sido retirado de um loureiro em floração. No primeiro caso ele seria um $\kappa \lambda \alpha ́ \delta o \zeta$; no segundo, poderia ser um cetro propriamente dito, como os vistos com os rapsodos nas representações vasculares. $C f$. as observações de M.L. WEST (1966, pp. 163-4).

${ }^{29}$ M.L. WEST (1966, p. 165).

${ }^{30}$ De वात, vāt, "soprar" e अपि, api, como o grego, غ̇ंí. $C f$. GAMKRELIDZE e IVANOV (1995, p. 734).

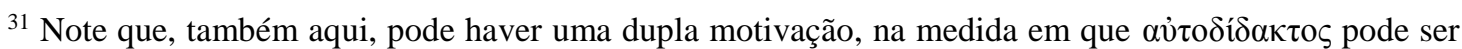
interpretado tanto como "instintivo, um conhecimento que nasce com a pessoa" quanto como "auto-ensinado", como preferem muitas traduções. $C f$. a passagem da $O d .1 .89$, na qual Atena "incute" $\mu \varepsilon ́ v o \varsigma(>* ~ m n-)$ no ânimo

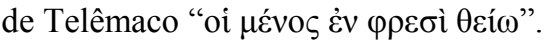




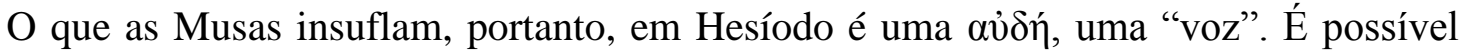
que $\alpha \hat{\delta} \delta$, cuja etimologia é controversa, esteja associada a um termo técnico ligado ao

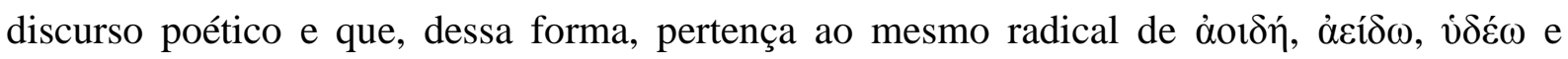

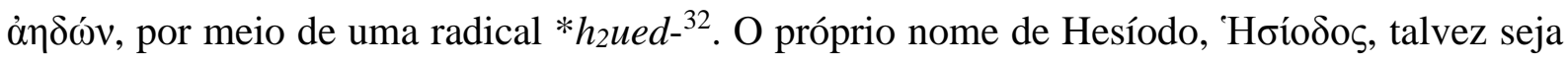

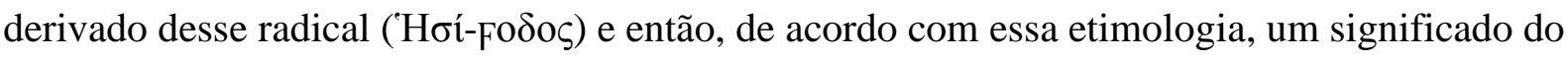
tipo "emissor da canção" foi proposto por Schultz ${ }^{33}$. O que me interessa mais, no entanto, é que, provavelmente porque a noção de "voz inspirada por um deus" já estava começando a se perder em grego - que, aliás, para expressar esse mesmo conceito dispunha do termo ỏ $\mu \varphi \eta ́$-, Hesíodo sente a necessidade de qualificar a voz que as Musas lhe incutem como $\theta \varepsilon \dot{\varepsilon} \sigma \pi \varsigma^{34}$ e, a fim de sublinhar oralmente essa característica, a coloca em acavalamento. É essa qualidade da

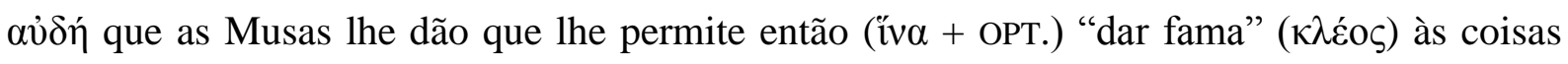

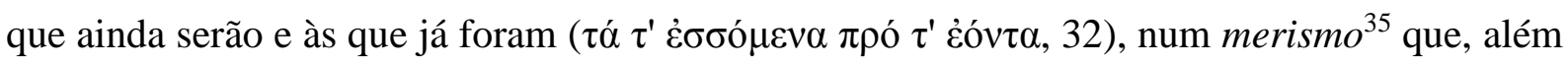
de servir para resumir a ideia de que o poeta é o único capaz de acessar todo o conhecimento humano, passado e futuro, é capaz de assim fazê-lo perfilando áreas distintas de atuação, a de

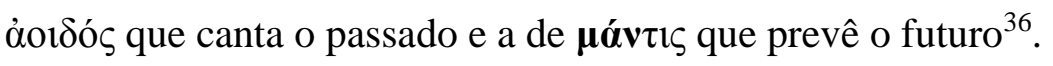

Esse conhecimento, porém, não vem do exercício ou do aprendizado da arte poética ( $\mu \varepsilon \lambda \dot{\varepsilon} \tau \eta)$, mas é conferido por um poder maior. Tanto o poeta da Ilíada deixa isto claro em

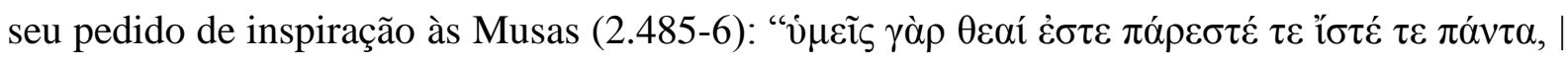

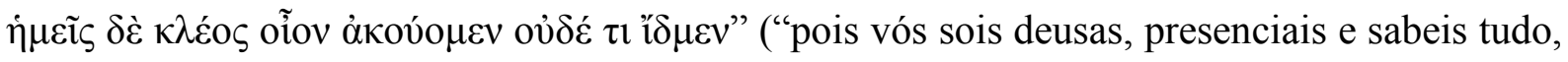
| ao passo que nós apenas ouvimos a fama e nada sabemos") quanto Píndaro, dois ou três séculos mais tarde, no mínimo, ao dizer no Peã 6 (fr. 52f/ D6 R ${ }^{37}$ ) que “ ‘ $\lambda \lambda \lambda \grave{\alpha} \pi \alpha \rho \theta \varepsilon ́ v o r ~ \gamma \alpha ́ \rho$,

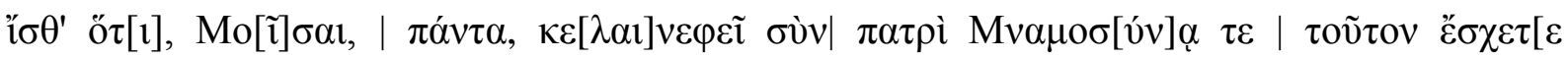
$\tau \varepsilon \theta] \mu o ́ v, \mid \kappa \lambda \tilde{v} \tau \varepsilon v \tilde{v}$ ” ("Mas Vós Moças, posto que sabeis, ó Musas, | tudo, auxiliadas pelo negrinubiloso | Pai e a Memória, | tal detendes este poder. Ouvi agora!”).

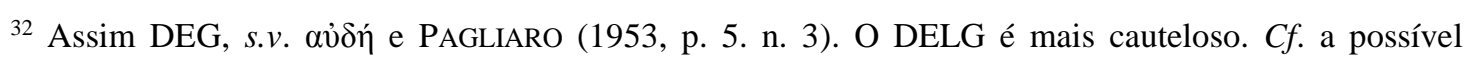
associação com a raiz वद ( $v a d)$, do sânscr. cuja polissemia vai desde "falar" até, e especialmente, "louvar".

33 Apud M.L. WeST (1966, p. 161), que acha "teoricamente" possível, ainda que veja como mais plausível um composto com ódó $\varsigma$ e, aqui, devemos notar que este também seria apropriado do ponto de vista da poética do indo-europeu, onde normalmente o poeta é descrito como o que "descobre o caminho das palavras", cf.e.g., O. 1.110 .

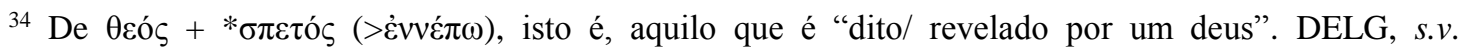

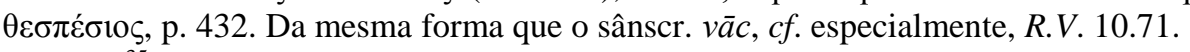

35 Adoto a definição de WATKINS (1995, p. 9) segundo a qual um merismo é "uma figura de duas partes que faz referência à totalidade de um único conceito". Como exemplo, ele cita $O d .2 .75 \kappa \varepsilon 1 \mu \varepsilon ́ \lambda$ í $\tau \varepsilon \pi \rho o ́ \beta \alpha \sigma i ́ v \tau \varepsilon$, "riquezas imóveis e móveis", isto é, todo o seu reino.

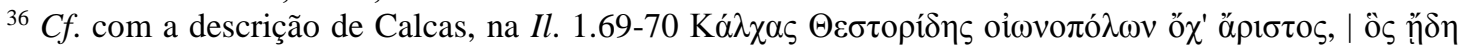

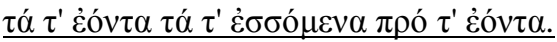

${ }^{37} \mathrm{R}$ refere-se à numeração na edição de RUTHERFORD (2001). 
Isto nos permite supor que Píndaro, operando em uma tradição de poesia oral, deveria, ele também, compor os seus poemas a partir de uma lógica da oralidade, o que, para todos os fins práticos, significa dizer que Píndaro é um poeta oral do ponto de vista da concepção de suas canções. É preciso ser cuidadoso aqui, no entanto. Dizer isso não implica afirmar que Píndaro não pôde (ou não deve) ter se utilizado da escrita para compor seus poemas, até mesmo porque qualquer afirmação nesse sentido, ou em sentido contrário, não seria passível de ser falseada ou provada e, portanto, seria apenas uma opinião, mais ou menos plausível, dependendo das evidências que forem usadas. Propor que Píndaro é um poeta oral do ponto de vista da concepção de sua poesia tira, por outro lado, a escrita da equação, uma vez que, tenha ele escrito os seus poemas ou não, a forma entextualizada das odes que chegaram até nós exibe marcas de um estilo que não é típico da poesia produzida por uma mente literata e, portanto, mesmo que Píndaro tivesse de fato escrito suas odes, ele estaria apenas registrando no papel uma forma de composição e uma estrutura de discurso que são orais ${ }^{38}$. Esta é uma das dimensões por meio da qual "oral" deve ser entendido quando aplicado a Píndaro, a outra diz respeito à performance e dela falaremos mais adiante.

A hipótese de que Píndaro seria um poeta oral não é nova, contudo. Em um trabalho já fundamental, J. B. Wells ${ }^{39}$, partindo dos pressupostos da etnografia da fala, chegou às seguintes conclusões:

Sempre que a metalinguagem de Píndaro, tanto em comunicação representada quanto representante ${ }^{40}$, evidencia índices de status e vocalização do texto dos epinícios, essa metalinguagem regularmente descreve o modo de comunicação como sendo a fala e nunca o descreve como sendo a escrita. No que diz respeito ao status do texto dos epinícios, a metalinguagem usada na representação da linguagem indica que a performance da canção epinicial implica em uma produção oral e em uma recepção aural na comunicação, ao passo que nunca indica comunicação escrita. Em termos da vocalização no texto dos epinícios, a metalinguagem usada para representar a comunicação indica uma interação face a face e nunca indica uma interação texto-leitor. O mesmo acontece na comunicação representada: a metalinguagem de Píndaro indica comunicação falada de acordo com o status do texto e interação face a face de acordo com a vocalização do texto, mas nunca indica comunicação escrita ou uma interação texto-leitor. Podemos concluir então que os textos de Píndaro têm o status de registros de uma comunicação falada e que a

38 ThOMAS (1992, p. 10 et set.) nos conta como, ainda no séc. XIX, quando a literacia, que é um fenômeno bastante recente, ainda era incipiente e sobretudo rara nas áreas rurais da Inglaterra, as pessoas escreviam como falavam ou, ainda, falavam para si mesmas o que estavam escrevendo, de forma que o produto final da escrita é apenas um registro de um evento oral.

${ }^{39}$ WELLS (2009).

${ }^{40}$ WELLS (2009, p. 23) define comunicação representada e representante "in terms of how they relate to each other. For present purposes, the frame is the individual epinician song, a communicative event that embraces other communicative acts, the frameworks, that constitute the frame. The frame is representing communication - for example, in mythological narrative, the addresser's communicative stance characterized by the third-person voice. The framework is represented communication - for example, in mythological narrative, indirect or direct discourse". 
vocalização nos textos epiniciais indica que o contexto intencionado para a recepção é o da interação face-a-face na performance da canção epinicial. (...) Disso se segue que a linguagem epinicial pode ser apropriadamente descrita em seus próprios termos como uma mídia oral. Eu saliento um ponto final: mesmo se textos materiais ou se a escrita teve algum papel em alguma fase no processo de composição e transmissão dos epinícios de Píndaro, o evento da fala da performance - não da escrita - é constitutivo da linguagem dos epinícios [grifo meu].

Dessa forma, ele critica análises como as de Carey $^{41}$ e Miller ${ }^{42}$ que fazem uso da teoria do "subterfúgio oral" - desenvolvida pelo primeiro para explicar as intrusões metapoéticas da persona loquens -, por serem baseadas em uma concepção etnocêntrica e anacronística que vê na escrita o termo não-marcado a partir do qual a fala, que seria o termo marcado, poderia ser definido $^{43}$. O que está, de fato, de acordo com o que Nagy ${ }^{44}$ e outros pesquisadores, como Ruth Finnegan e Rosalind Thomas ${ }^{45}$ já apontaram, isto é, nosso impulso é sempre o de, nas palavras de Nagy, "definir oral em termos do que é escrito" e daí a necessidade de falarmos de uma poesia oral, como se assumíssemos que poesia sempre implica no uso da escrita ${ }^{46}$.

É interessante que, apesar de a escrita ser tomada, tácita ou conscientemente, como a forma mais provável para a composição das odes, em todo o corpus pindárico, o verbo “escrever", $\gamma \rho \alpha ́ \varphi \omega$, é empregado apenas três vezes ${ }^{47}$ e o verbo associado com "ler",

41 CAREY (1981). A teoria do "subterfúgio oral" de Carey é funcional no frame da performance, contudo, porque, de fato, deveria servir para dar a impressão, na audiência, de uma composição extemporânea da ode, o que não implica, como ele pressupõe, que a composição prévia tenha que ter se dado por meio da escrita.

42 A. M. MiLler (1993).

${ }^{43} \mathrm{Na}$ verdade essa é a posição dominante dentro da filologia clássica, sobretudo europeia, muitas vezes incapaz de dialogar com outras disciplinas das Humanidades, como a antropologia, a etnografia, a linguística etc. Felizmente este quadro vem mudando nas últimas décadas. Em meio aos estudos pindáricos, a posição, tácita ou assumida, é a de que a escrita era fundamental para a composição de odes tão "complicadas" como as de Píndaro. Cf., e.g., Irigoin, Histoire, p. 5-6 [grifo meu em todas as passagens], "Une ode chorale, écrite dans des conditions déterminées (...)" ou, logo em seguida, "Avant le manuscrit original, autographe du poète ou copie de ses notes établie par un homme de métier, comment s'élabore le poème? Ces vers lyriques inégaux, souvent fort longs, qui reviennent régulièrement dans les éléments strophiques de l'ode, comment le poète les compose-til? A-t-il un schéma directeur sous les yeux, ou se fie-t-il uniquement à sa mémoire? Voilà déjà une question qui reste sans réponse" e, finalmente, "Une fois le poème mis au net, paroles et musique, Pindare devait en écrire ou en faire écrire plusieurs copies (...).”. Sobre a questão da difusão do texto, cf. o Capítulo 7. Sobre a problemática de manuscritos acompanhados de notação musical, $c f$. FlEMING e KoPFF (1992). Há posições mais ou menos radicais no que concerne à crença do uso da escrita por Píndaro, para a primeira $c f$., e.g., T. K. HUBBARD (1985, p. 67) "For Pindar, writing is intimately bound up with the very process of thought" $\mathrm{e}$ MORRISON (2007, p. 117) citada na p. 260, para a crítica desse último, $c f$. VERDENIUS (1988a, p. 55; 1988b).

${ }^{44}$ NAGY (1990, p. 8).

${ }^{45}$ FinNEGAN (1980) e THOMAS (1992).

${ }^{46}$ Mesmo um comentador tão brilhante de Píndaro como D.E. GERBER (1982, p. 32), pode se deixar levar pela premissa de que a composição das odes deva pressupor a escrita. Comentando sobre a forma como Píndaro poderia compor suas odes, ele se pergunta (percebe-se que quase inconscientemente): “As Pindar composed a verse, did he tend to look back at what he had written in a corresponding verse and, if so, did the vocabulary or collocation of sounds of the earlier verse exercise a conscious or unconscious influence on his choice of words, even though the repetition might serve no particular purpose? Are some correspondences a mnemonic device to assist the chorus? grifo meu".

${ }^{47}$ O. $10.3,3.30 ;$ N. 7.10 . 


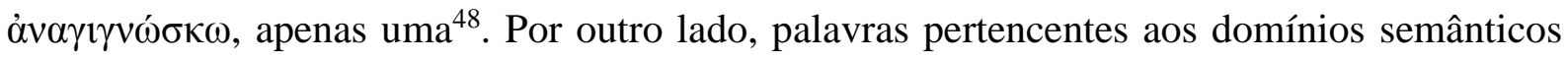
do falar, cantar, entoar etc. abundam. Além disso, os termos usados para se referir aos epinícios propriamente ditos são sempre alusivos de formas orais pertencentes ao domínio

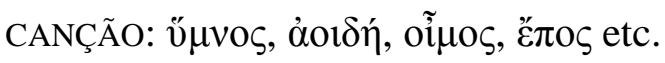

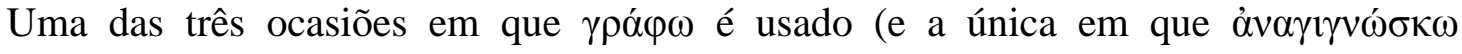

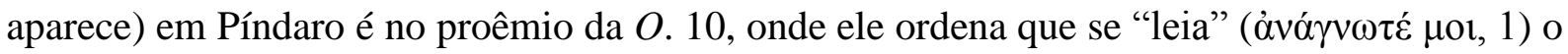

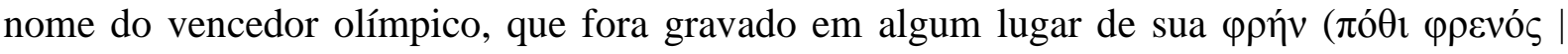
$\dot{\varepsilon} \mu \tilde{\alpha} \varsigma \gamma \dot{\varepsilon} \gamma \rho \alpha \pi \tau \alpha 1,2-3)$. Gildersleeve, comentando essa passagem ${ }^{49}$, vê um certo humor no comando do poeta para que se busque em seu livro de contabilidade ("the poet's ledger") o nome do requerente da ode. De fato, toda essa canção é construída a partir de uma série de metáforas cujo domínio principal é FINANÇAS. Como alerta Verdenius ${ }^{50}$, no entanto, a expressão não implica num débito real, financeiro, para com o vencedor, mas é motivada pela ideia de que a ode pode ter sido (ou é projetada para a audiência como sendo) uma promessa que se cumpriu tardiamente, daí a menção ao "juro" ( sabemos desde Bundy ${ }^{51}$, a vitória atlética enseja a obrigação nos poetas e na comunidade, de uma maneira em geral, de louvar o vencedor ${ }^{52}$, sendo que o fracasso em fazer isso implicaria em algum tipo de censura ou reparação.

Por outro lado, o uso do imperativo pela persona loquens implica na existência de uma personae adloquenti que deve executar a ordem e que dificilmente poderia ser a audiência ou o poeta. Poderíamos nos perguntar, então, por que o próprio Píndaro não dirige a si mesmo o comando expresso pelo imperativo, uma vez que auto-apóstrofes não são estranhas ao seu estilo $^{53}$. Segundo Verdenius, o imperativo estaria sendo usado absolutamente com uma mera força retórica ${ }^{54}$, o que me parece uma explicação plausível, mas insatisfatória. É preciso lembrar que durante os primeiros anos do séc. V temos muitas notícias de atenienses ricos que, não obstante soubessem ler, possuíam escravos letrados cujo objetivo principal era o de ler em voz alta todo tipo de texto, sobretudo registros comerciais e financeiros ${ }^{55}$ e é possível que, dentro do domínio proposto para a metáfora, fosse exatamente esse cenário que Píndaro e sua audiência poderiam ter em mente.

\footnotetext{
${ }^{48}$ O. 10.1 .

${ }^{49}$ GILDERSLEEVE (1886, p. 214).

${ }^{50}$ VERDENIUS (1988a, p. 55).

${ }^{51}$ BUNDY (1962, p. 33).

${ }^{52} C f$. KURKE (1991, p. 112 et seq.).

${ }^{53}$ Cf., e.g., O. 1. 4, P. 3. 61, etc.

54 VERDENIUS (1988a, p. 57).

${ }^{55}$ HARRIS (1991, p. 100).
} 
De qualquer maneira, propor, como faz $\operatorname{Hubbard}^{56}$, que o que estaria escrito na $\varphi \rho \eta ́ v$ do poeta fosse a própria canção ou que o verbo se refira ao meio de composição da mesma, é certamente um exagero. Isto porque - à parte do contexto da própria ode, que implica a simples inscrição do nome do vencedor olímpico (como era costume se fazer em uma estela ou em uma estátua) - o verbo $\gamma \rho \alpha ́(\varphi \omega$, sobretudo nesta época, era empregado principalmente no sentido de "gravar" ou "dedicar". No primeiro caso, normalmente em algum material, por meio de uma inscrição bastante simples. É exatamente nessa acepção que o vemos empregado em sua outra aparição em Píndaro, na $O$. 3.30, onde se diz que a ninfa Taugeta dedicara o

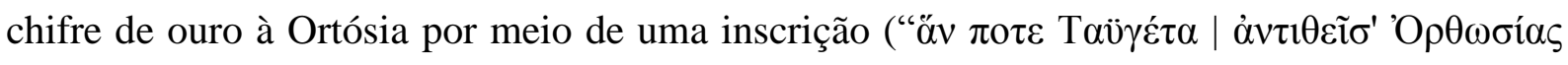

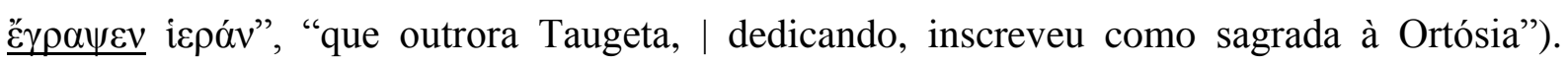
Finalmente, a última instância em que o verbo aparece é na $N$. 6.7, onde o sentido é claramente o de traçar uma linha no chão ${ }^{57}$, em alusão à $\gamma \rho \alpha ́ \mu \mu \alpha$ com que se demarcava a linha de chegada nas competições de corrida ou salto ${ }^{58}$.

$\mathrm{Na}$ verdade, ao descrever sua arte poética por meio de metalinguagem, Píndaro usa metáforas oriundas de diversos domínios de atividades humanas como a agricultura, a navegação, a condução de carruagens, o lançamento com arco e flecha e com o dardo, a luta, a construção, a escultura, a tecelagem e negócios ${ }^{59}$, sem nunca, contudo, se referir ao ofício do escriba, ao ato de escrever ou à escrita, seja explícita ou alusivamente. Uma análise dessas metáforas, acredito, pode nos ajudar a compreender melhor que o processo de composição em Píndaro é conceitualizado como uma experiência completamente corporificada, prática, ao invés de um processo dominado por categorias abstratas que poderíamos associar com a escrita. Uma investigação detalhada de todas as metáforas conceituais oriundas dos domínios listados por Race, acima, no entanto, extrapolaria os limites deste capítulo ${ }^{60}$, mas eu gostaria de chamar a atenção para algumas metáforas conceituais que, segundo acredito, descrevem alguns processos de entextualização da canção, principalmente aquelas metáforas em que a canção é descrita como se fosse um objeto precioso, um edifício ou o fruto de algum tipo de trabalho manual.

\footnotetext{
${ }^{56}$ T. K. HUBBARD (1985, p. 68). $\sigma \tau \dot{\alpha} \theta \mu \alpha v^{\prime \prime}$.

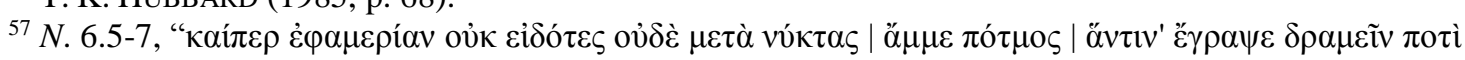

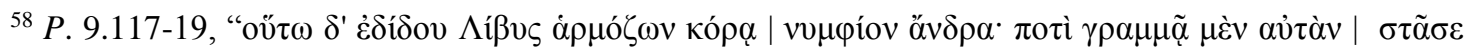

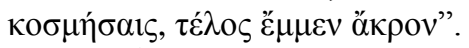

${ }^{59}$ RACE (1997b).

${ }^{60}$ Sobre esse assunto, ainda que utilizando uma metodologia completamente difetente, o livro de NÜNLIST (1998), que não se limita apenas a Píndaro, é essencial. Uma das monografias mais importantes sobre a imagética da CANÇÃO É UM CAMINHO é BECKER, O. (1937) Das Bild des Weges um verwandte Vorstellungen in frühgriechischen Denken. Berlin, 1937, não consultado por mim.
} 
A metáfora segundo a qual CANÇÃO É UM OBJETO PRECIOSO pode ser expressa de muitas maneiras e o seu relacionamento com outros domínios (joalheria, tapeçaria, coroas etc.) é complexo. Um exemplo que imediatamente poderia vir à cabeça de qualquer um que tenha lido os epinícios é o caso da N. 7.77-9:

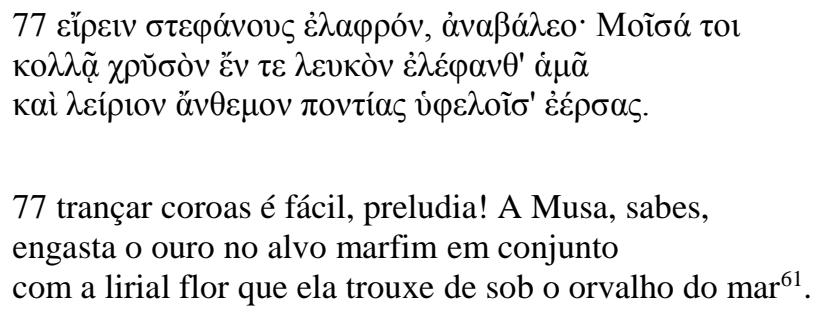

Essa passagem é interessante porque, além de ser um bom exemplo da concepção de que uma CANÇÃO É UMA JOIA, ela também parece sugerir que tocar o prelúdio com a forminge ${ }^{62}$ é como tecer, neste caso, uma coroa. De fato, o sentido mais prototípico do verbo Elp $\omega$ é "encadear" um elo em outro (como o latim serō), o que pode nos remeter à ideia de juntar uma nota à outra, mas de uma maneira intricada, como sugerido no proêmio da $P .1$, em que se fala da forminge como tocando as òv $\alpha \beta$ o $\alpha$ í dos "proêmios que guiam a dança"

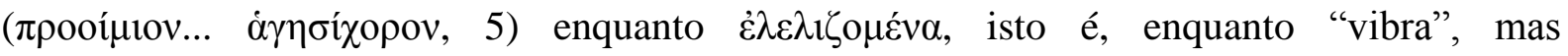
possivelmente também "percute" de uma maneira virtuosa, o que pode ser sugerido pelo movimento das mãos, indo e vindo sobre as cordas, como o das mulheres ao tear ${ }^{63}$. Aqui, contudo, quase ao fim da N.7, dificilmente poderíamos falar de um "proêmio" no sentido da P. 1 e, por isso mesmo, parece-me difícil conciliar o uso do imperativo $\alpha \dot{v} \alpha \beta \alpha ́ \lambda \varepsilon o$ (77) com a ideia mais ou menos consensual de que o sentido principal do verbo seria o de "preludiar" ${ }^{64}$. Aqui esse sentido só seria possível na acepção, mais ou menos semelhante, de "tocar um interlúdio", ou seja, uma seção instrumental entre uma parte do canto e a outra.

O que nos interessa, no entanto, é que a canção é conceitualizada como esse objeto precioso tão esquisito (na acepção positiva da palavra!) na medida em que é algo que, fosse material, requereria do artesão uma habilidade incrível para misturar os três elementos que o compõe, ouro, marfim e coral, em um todo harmonioso. É face a essa dificuldade em construir

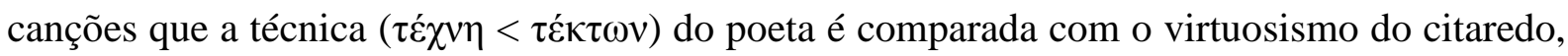

\footnotetext{
${ }^{61}$ Um kenning para "coral".

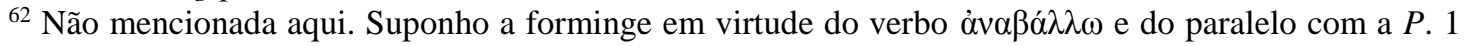

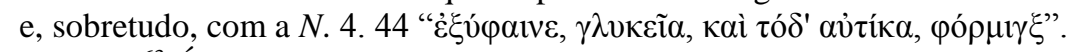

${ }^{63}$ É preciso notar que o tear grego, ao invés do anglo-saxão, era vertical, o que obrigava a mulher a cruzar de um lado para o outro do mesmo ao tecer a trama. Sobre essa relação entre cantar, tocar e tecer, $c f$. sobretudo, SNYDER (1981).

${ }^{64} C f .$, e.g., LSJ s.v. $\alpha v \alpha \beta \alpha ́ \alpha \lambda \omega$, B.
} 
em si mesma uma atividade que demandava anos de estudo e prática e que nada teria de

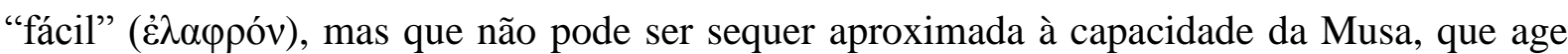
através do poeta, em fabricar arranjos complicados de palavras como aquelas que formam um epinício ou, de fato, qualquer outra canção inspirada.

Na $O .7 .10$, a canção é comparada com um taça toda de ouro, a joia da coroa no tesouro de uma família, que é trazida para comemorar uma ocasião especial. Logo em seguida ela é novamente conceitualizada como o mel, sumo produto do trabalho elaborado das abelhas que, neste caso, são as Musas, as quais, através da mente do poeta, vertem a canção sobre o vencedor olímpico a fim de "apaziguá-lo"65:

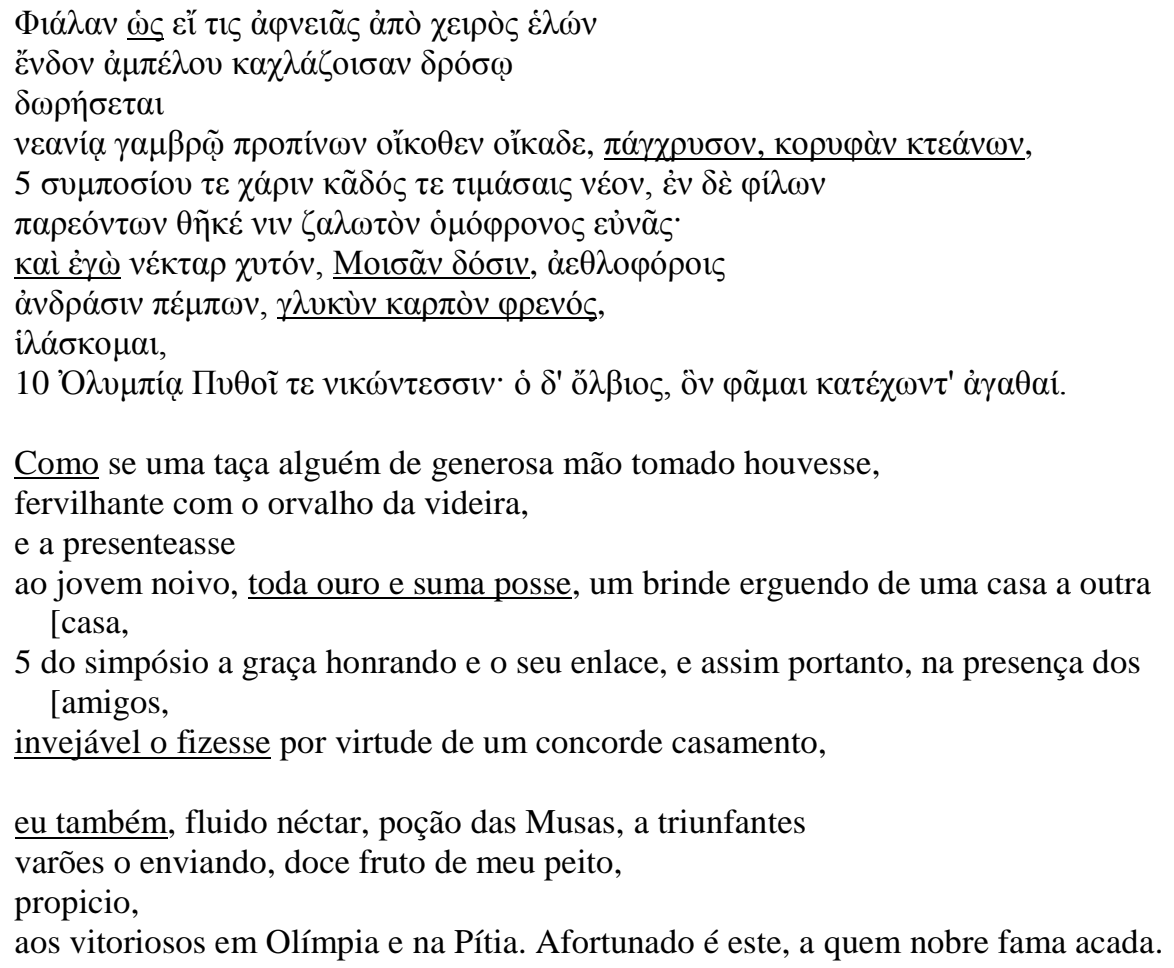

Note que nos $v v$. 7-8 há a dupla motivação da canção que já havíamos encontrado em Hesíodo: ao mesmo tempo em que a canção é o néctar das Musas, ela também é o fruto da $\varphi \rho \eta ́ v$ do poeta, onde, presumivelmente, as Musas o colocaram ou por onde ele deverá "escorrer" 66 sobre o vencedor e a audiência.

É notável, nesse sentido, que a canção seja frequentemente conceitualizada como um "fluxo", mais do que como composta de partes discretas, isto é, palavras ou frases. Quando, no entanto, a canção é descrita em termos de seus elementos discretos, as "palavras" ("̌́ $\pi$ s,

${ }^{65}$ Não teríamos tempo para explorar as ressonâncias rituais presentes na volta do herói e o processo de reintegração à sua comunidade. Sobre isso $c f$. CROTTY (1982) e KURKE $(1991,1998,2005)$.

${ }^{66} C f$. minha discussão acerca da $N$. 3.1-12 no qual o poeta é conceitualizado como uma fonte, p. 224 et seq. 


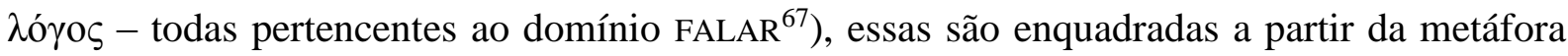
segundo a qual a CANÇÃO É UMA CONSTRUÇÃO ou A CANÇÃO É UM ARRANJO, no qual os elementos fônicos (não há jamais menção à palavra escrita em Píndaro, exceto nas passagens já analisadas) são tratados como blocos de construção.

Um dos exemplos mais apropriados dessa forma de ver o processo composicional parece-me ser o modo como Píndaro refere-se explicitamente à construção das canções que perpetuam a fama de Nestor e Sarpédão, na $P$. 3.112-13:

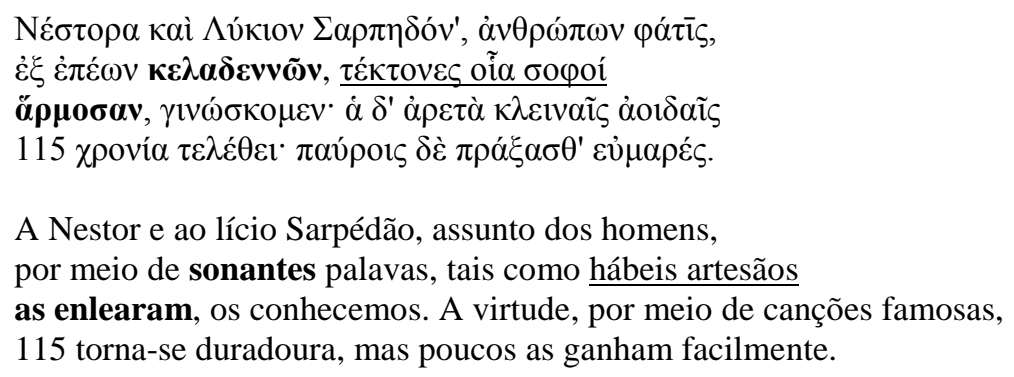

Outro exemplo semelhante é o modo como Píndaro descreve o discurso construído por Jasão na $P$. 4.136-8, quando o herói “ $\beta \alpha ́ \alpha \lambda \lambda \varepsilon \tau o ~ \kappa \rho \eta \pi \tilde{\imath} \delta \alpha \sigma o \varphi \tilde{\omega} v \dot{\varepsilon} \pi \varepsilon \dot{\varepsilon} \omega v$ ”, isto é, "lançou o fulcro de hábeis palavras". Uma metáfora utilizada também pelo próprio poeta para descrever a “construção" de uma canção, como no fr. 194 S-M:

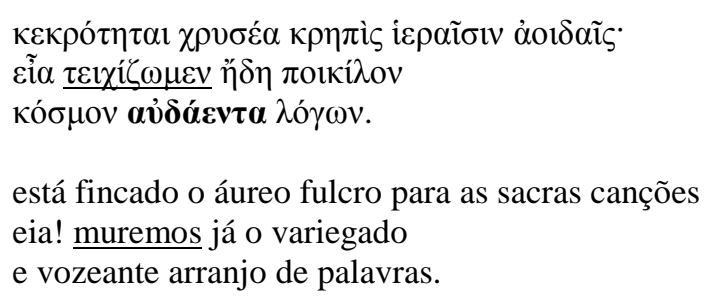

Do mesmo modo que as palavras eram "sonantes" na $P$. 3, aqui elas são "vozeantes". A ideia de "murar" um arranjo de "vozeantes palavras" pode parecer estranha, mas ela encontra ressonância no fato de que a canção é frequentemente conceitualizada como uma fortaleza contra o tempo, onde os grandes feitos dos homens podem ser preservados, como, por exemplo, na $P$. 6.5-17

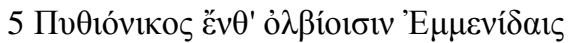

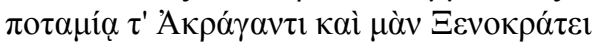

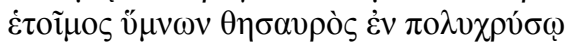

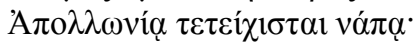

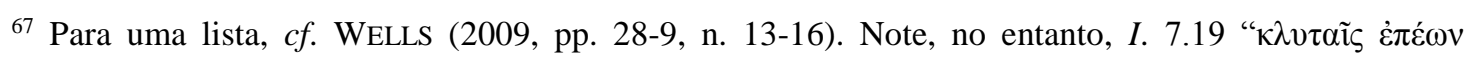

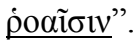




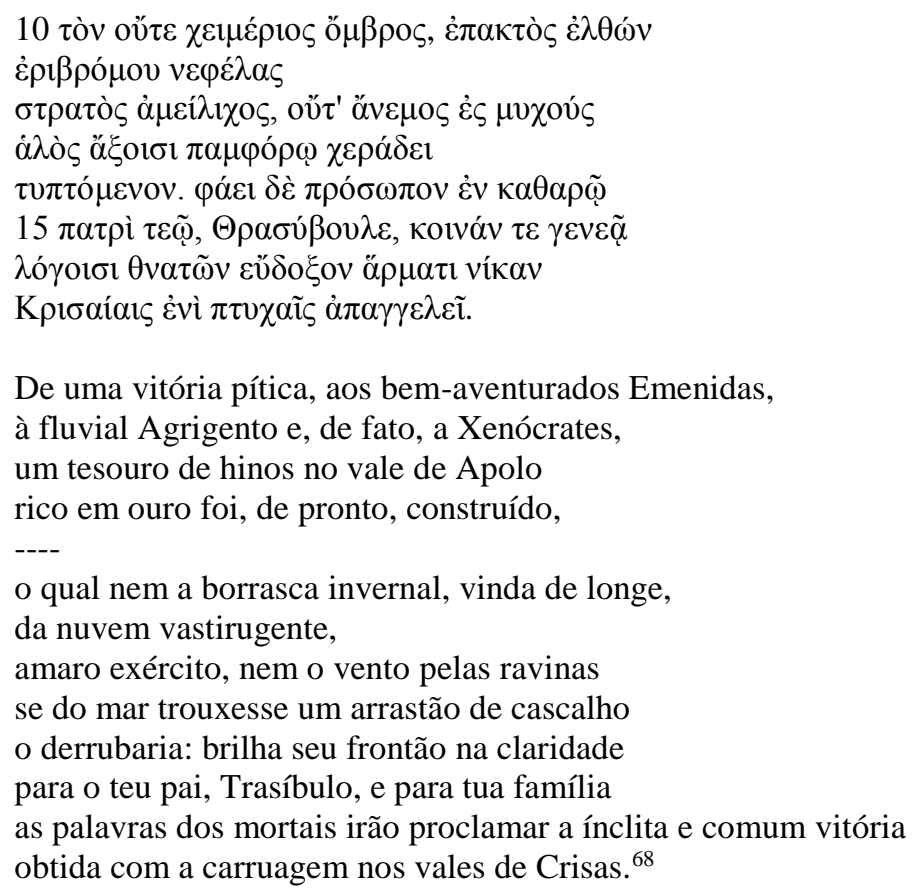

A mesma ideia subjaz ao início da $O$. 6.1-4; seria, no entanto, desnecessário e impossível citar ou comentar todos os exemplos. O padrão que notamos em todas essas passagens é o de que a metalinguagem dos epinícios aponta para uma entextualização progressiva da canção, ou seja, para a transformação de um ato da fala epifenomenal e, portanto, destinado a desaparecer juntamente com o evento que o enquadrou, em um textus, isto é, uma estrutura criada por meio do uso de diversos aspectos não-triviais da fala: o metro, as assonâncias, a paronomásia, as alusões, a obscuridade, a sintaxe convoluta, o mito, etc. Todas essas características servem para marcar a canção contra o pano-de-fundo da linguagem cotidiana e lhe dar saliência, tornando esse "texto" passível de ser desconectado do hic et nunc da première ao transformá-la em algo precioso, que todos desejam ter.

Nesse sentido, a própria complexidade dos epinícios, que engendraria uma série de obscuridades - por si só um tema à parte dentro da crítica pindárica e que já foi muito deplorada ou elogiada dependendo da sua recepção crítica ${ }^{69}$-, é frequentemente citada como um empecilho para a transmissão oral dos mesmos ${ }^{70}$. Essa complexidade pode, porém, ter sido um dos fatores que garantiram a sua difusão, como nota Thomas ${ }^{71}$ em um trabalho recente, em que, baseando-se no trabalho etnográfico de vários especialistas em culturas em que uma tradição de poesia oral ainda é viva, argumenta que poemas compostos com vistas a uma performance, como é certamente o caso dos epinícios, não precisam ter como uma de

\footnotetext{
${ }^{68}$ Compare com o fr. 531 CAMPBELl de Simônides.

${ }^{69} C f$. Most (1985, p. 22 et set.) e J. T. HAMILTON (2003).

${ }^{70}$ MORRISON (2012), $c f$. citação p. 260.

71 THOMAS (2012).
} 
suas principais características a clareza de enunciação, que é tipicamente associada com as nossas concepções modernas e ocidentais de como um texto em performance deva ser. Segundo ela,

\begin{abstract}
Peritos na poesia somali, na literatura de corte persa ou na poesia de louvor africana poderiam retrucar que a complexidade [de um poema] durante a performance é precisamente o objetivo. É muito bem sabido, entre aqueles que estudam literaturas modernas dependentes da performance, que essas podem ser extremamente densas, alusivas e complexas, mas que nenhuma dessas características diminui seu efeito potencial durante a performance. Na verdade, elas contribuem para ele (...). A poesia oral somali do tipo tradicional, conhecida como maanso, composta e transmitida completamente sem o auxílio da escrita, é tão densa, cuidadosamente composta ('tecida", na verdade) e ornamentada com uma linguagem e imagética especiais que Martin Orwin prefere falar de um poema desse tipo como um "texto definitivo". (...) Muitos tipos de poesia de louvor em culturas da África subsaariana também valorizam a obscuridade e a alusão de maneiras que mostram uma certa similaridade básica com Píndaro. Vail e White, em seu estudo das tradições de poesia laudatória africanas, analisam vários tipos que são abundantes em linguagem figurativa e metafórica. A 'dificuldade' da poesia, que se expressa em termos de densidade de alusões, metáforas, imagética, dificuldade, gramática pouco convencional e uma dicção inusitadamente elevada, longe de tornarem a performance mais difícil, a tornam mais especial e distinta. Nessas mais variadas literaturas modernas - ou, de fato, medievais -, o quanto mais elaborada for a letra, ou a performance, mais ela cumprirá a função de marcar e salientar o evento, capturando a atenção da audiência, elevando os sentimentos a um nível especialmente refinado, mais sofisticado ou exaltado do que seria possível ao se ouvir um discurso comum. Resumindo, a dificuldade ajuda a fazer da performance, uma performance [grifo meu].
\end{abstract}

$\operatorname{Most}^{72}$, falando da obscuridade em Píndaro já havia argumentado que é precisamente a natureza enigmática de sua poesia que pode agir como uma força centrípeta que serviria, ao mesmo tempo, para dirigir a atenção do público para a performance, bem como promover um sentimento de integração entre os mais variados strata da audiência, na medida em que todos

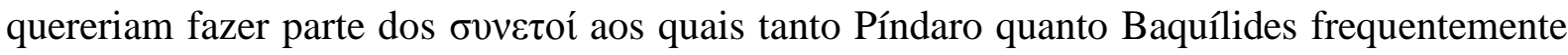
se dirigem ${ }^{73}$. A partir desse sentido, podemos entender porque $\mathrm{Nagy}^{74}$ vê na linguagem do

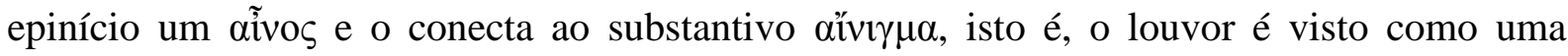
mensagem codificada que é inteligível a um determinado círculo de pessoas e incompreensível para outro, a partir de uma compreensão idealizada da performance. Dentro

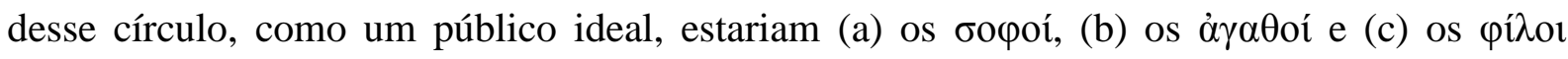
capazes de decodificar a mensagem. Fora dele, os кaкoí. Esse contraste, no entanto (e ao contrário do que poderíamos pensar), opera para aumentar a coesão do grupo social na medida em que a soma das expectativas de todos os membros da comunidade, para os quais é sempre

${ }^{72} \operatorname{Most}(1985$, p. 23).

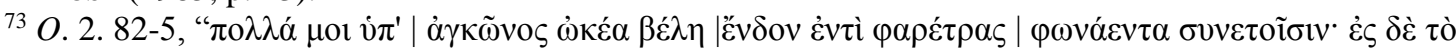

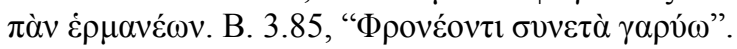

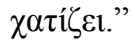

${ }^{74}$ NAGY (1990, p. 148). 
o outro que pertence aos какoí e nunca o "eu”, faz do público da performance um grupo formado apenas por aqueles capazes de entender e se fazerem entendidos, dessa forma excluindo, automaticamente, os какоí. A performance, consequentemente, é capaz de criar as próprias condições ideais para as quais, em primeiro lugar, ela foi criada e a própria linguagem e ideologia do epinício agem nesse sentido.

Por essa mesma razão, o público que se reúne para assistir uma performance, qualquer que seja, espera que algo especial aconteça. Nesse sentido, da mesma maneira que a poesia é marcada em relação à fala cotidiana, a performance é marcada em relação aos atos da vida cotidiana e é também por meio disso que ela pode, inclusive, assumir um caráter de ritual ou mesmo sagrado, no sentido etimológico do termo, isto é, de ser um evento "separado" do mundo como algo especial a ser posto à parte para ser vivenciado. Dentro deste frame, portanto, a linguagem altamente estilizada, enigmática do epinício encontra um sentido e uma função. Como notam Baumann e Briggs:

Algo básico para o processo de entextualização é a capacidade reflexiva do discurso, a capacidade que ele compartilha com todos os sistemas de significação de "torcer-se ou virar sobre si mesmo, de tornar-se um objeto para si mesmo, de referirse a si mesmo" $(15,16)$. Em termos jakobsonianos $(151)$, no que diz respeito à linguagem, essa capacidade reflexiva manifesta-se mais diretamente por meio das funções metalinguísticas e poéticas (174). A função metalinguística (ou metadiscursiva) objectifica o discurso ao fazer dele o seu próprio tópico; a função poética manipula as características formais do discurso para chamar atenção para as estruturas formais por meio das quais o discurso é organizado.

Performance, a execução da função poética, é um modo altamente reflexivo de comunicação. Na medida em que o conceito de performance evoluiu na antropologia linguística, ela é vista como uma forma especialmente marcada, artificiosa de falar, que conjura ou representa um frame interpretativo especial dentro do qual o ato de falar deve ser entendido. A performance põe o ato de falar em exibição - objetifica-o, eleva-o em certo grau de seu cenário interacional e o abre ao escrutínio por uma audiência. A performance amplifica a consciência do ato de falar e dá licença à audiência para que esta avalie a habilidade e a efetividade do sucesso do executante. Por sua própria natureza, então, a performance potencializa a descontextualização.

Com base nessas considerações preliminares, espero que tenha sido possível desenhar um panorama esquemático através do qual possamos entender que a concepção da canção como um artefato, mais do que uma abstração literária, não é nem mesmo pindárica, mas faz parte, como já demonstrou Nünlist ${ }^{75}$ de uma práxis que forma o cerne e a razão de ser da poética grega. Uma poética voltada para a performance pública e oral que vê no fazer poético um tipo de técnica de construção de textos cujo objetivo é transformá-los em algo especial, portável e de valor, um $\kappa \tau \tilde{\eta} \mu \alpha$ passível de ser entesourado.

\footnotetext{
${ }^{75}$ NÜNLIST (1998).
} 
Indo mais longe ainda, há muitos estudos ${ }^{76}$ que mostram que muitas das metáforas que encontramos em Píndaro e que dizem respeito a domínios de atividades humanas relacionados à fabricação de coisas ou a atividades práticas como as que listamos anteriormente, são de origem indo-europeia e representam uma linguagem herdada desde há muito por gerações de poetas que trilharam o mesmo, ou quase o mesmo, caminho de seus antepassados, ainda que as sociedades a que pertenciam, em algum momento da pré-história, tenham se separado de um tronco principal, se subdividido, migrado e se transformado. Ao menos é esta consciência de pertencer a um passado imemorial de fazer poético a que Píndaro, na epígrafe deste capítulo, e Baquílides, neste fragmento de peã (fr. 5 CAMPBELL), parecem estar aludindo:

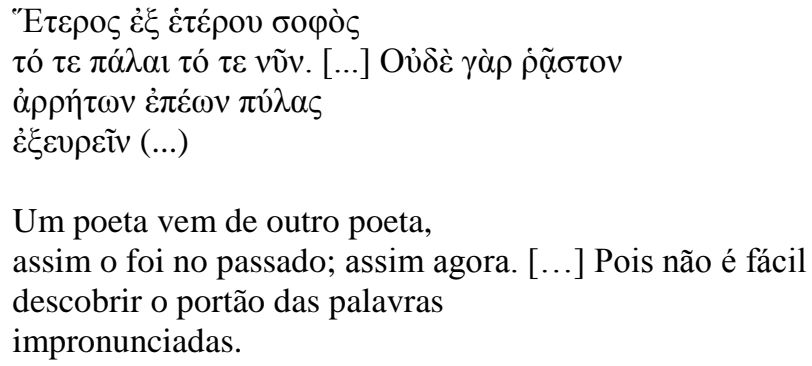

A dicção poética, porém, foi resiliente a todas as vicissitudes e pôde ser passada de poeta para poeta, oralmente e face a face. Parece-me, portanto, que seja a partir desta dinâmica da oralidade que devamos ver essas canções aprisionadas em texto. Assim, ao menos, é como $e u$ as vejo: como um inseto aprisionado em âmbar, uma leve e alada criatura

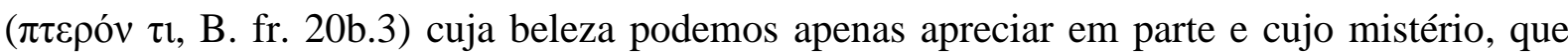
um dia já se fez em voo, nos será, para sempre, indecifrável.

É, no entanto, a esse voo e como ele poderia ter se dado, e em quais condições, que o restante desta tese será dedicado.

\footnotetext{
${ }^{76}$ WATKINS (1995) e M.L. WEST (2007) para ficar apenas nos mais extensos.
} 


\title{
CAPÍTULO 2
}

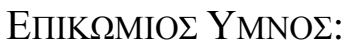 \\ A SEMÂNTICA DO K $\Omega M O \Sigma$ E A OCASIÃO DA PERFORMANCE
}

\section{इदं जना उप श्रुत नरारांस स्तविष्यते।}

Isto ouvi, homens: uma celebração de varões será cantada.

Atharvaveda, 20.127.

$\mu \alpha ́ \kappa \alpha \rho \delta \varepsilon \dot{\varepsilon} \kappa \alpha i ̀ ~ v \tilde{v},(\ldots)$

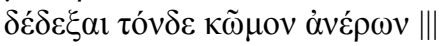

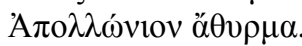

\begin{abstract}
Abençoado também agora, porque (...) recebeste esta celebração de varões: $\| \mid$ brinquedo de Apolo.
\end{abstract}

É IMPOSSÍVEL precisar com algum grau de certeza o local ou a locação da performance de qualquer um dos epinícios ${ }^{1}$ a partir apenas das evidências internas das odes, sobretudo porque essas, quando existentes, são amiúde imprecisas ou ambíguas, quando não simplesmente contraditórias ${ }^{2}$ em suas referências ao contexto físico da première. É provável que essa tendência à generalização - evidente não apenas no que diz respeito a este problema, mas, de um modo geral ao Sitz im Leben das canções ${ }^{3}$-, seja uma característica própria dos epinícios, cujo objetivo principal, dedutível a partir de sua dicção tradicional, era o de

${ }^{1}$ Por "local" eu entendo a localização geográfica do evento no qual o epinício seria executado (a cidade ou o sítio dos jogos) e, por "locação", a estrutura física ou arquitetônica (templo, casa do laudandus, precinto de um deus etc.). Para uma lista de prováveis locais e locações, baseadas em evidências internas das odes, sobretudo suas referências cultuais, e os achados da arqueologia, $c f$. KRUMMEN (1990, p. 275 et seq.).

${ }^{2}$ Como, por exemplo, a $O .8$, em que, a partir da invocação para que Olímpia, sede dos jogos, aceite ( $\delta \varepsilon \dot{\xi} \xi \alpha \mathrm{l}$ ) o $\kappa \tilde{\omega} \mu \mathrm{o}$ de Alcimédão, poderíamos supor uma performance in situ, o que, no entanto, é contradito por

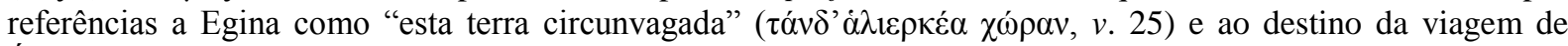
Éaco por meio do advérbio "para aqui" ( $\delta \varepsilon \tilde{\rho} \rho o, v .51)$

\footnotetext{
${ }^{3}$ Cf. CAREY (2007, p. 199).
} 


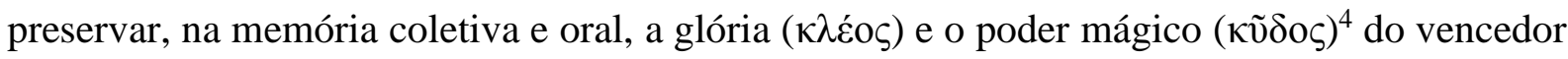
através da difusão da canção em inúmeras (idealmente, infinitas) reperformances separadas, tanto no tempo quanto no espaço, da première. É possível detectar nos próprios epinícios uma consciência do poeta, certamente partilhada com o laudandus e a audiência, desse papel imortalizador da canção, mesmo nos primeiros registros que temos do gênero ${ }^{5}$.

Apesar desse cenário obscuro em que se situa o primeiro momento no qual uma ode era executada, algumas considerações mais gerais podem ser feitas. A crítica é unânime em supor ao menos três cenários prováveis para a première: (a) in situ no momento da vitória - o que explicaria a existência de odes bastante curtas como, por exemplo, as $O .3,4$ e 11 e a $P .7$. Isto pressuporia, no entanto, uma composição ex tempore ou, então, prévia da ode ${ }^{6}$; (b) $\mathrm{Na}$ cidade e/ou na casa do laudandus ou ainda, para esse último caso, na de seu patrono (e.g., $O$. 1, O. 7, P. 6); (c) Em um templo ou santuário, de um deus ou herói, tanto no local da vitória quanto na cidade do vencedor, como, possivelmente, as $O .9, P .8, P$. 11. Nesses três casos, é possível postular uma procissão para um templo ou vindo daí. Essa situação adequar-se-ia, segundo alguns comentadores, sobretudo às odes monóstrofas, como a $O$. 14, a $P$. 6 e, particularmente, a $N$. 2, com a sua impressionante estrutura cíclica, sugestiva de uma execução da capo, ou, ainda àquelas que fazem referências explícitas a um culto, e.g., O. 3, I. $4, P .5^{7}$. Não há, no entanto, qualquer tipo de evidência interna explícita ou testemunho externo que nos assegure da realidade de qualquer um desses cenários ${ }^{8}$ e a opinião dos escólios deve ser tomada com precaução ${ }^{9}$. A situação, além do mais, é complicada pelo fato de que algumas odes do corpus podem não ser epinícios ${ }^{10}$.

Algumas práticas celebratórias relacionadas à vitória nos jogos atléticos nos são conhecidas. Sabemos, por exemplo, que, no momento da vitória, o nome do vencedor era imediatamente anunciado e um filete ( $\tau$ aıvía) de lã vermelha (ou vermelha e branca) era então atado em volta de sua cabeça ${ }^{11}$, ao passo que, na mão, ele recebia um ramo de palmeira.

\footnotetext{
${ }^{4} C f$. KURKE (1998).

${ }^{5}$ Como, por exemplo, o fr. 282 (CAMPBELL) de Íbico e 581 PMG de Simônides. Sobre os fragmentos dos possíveis epinícios anteriores à segunda metade do séc. V, $c f$. a excelente discussão de RAWLES (2012).

${ }^{6}$ Como parece ser o caso da $O .8, C f$. GiLdersleEve (1886), Farnell $(1961$, p. 59) e, mais recentemente, ATHANASSAKI (2004), que propõe uma reperformance em Siracusa. Contra, WILAMOWITZMOELLENDORFF (1966, p. 403) e RACE (1997a, pp. vol.1, p. 134).

${ }^{7} C f$. as análises de KRUMMEN (1990).

${ }^{8}$ CAREY (2007, p. 199) e HORNBLOWER e MORGAN (2007)

${ }^{9} C f$. mais abaixo, seção 5.1 , pp. 177 et seq. a discussão sobre a problemática representada pelo conhecimento transmitido pelos escólios.

${ }^{10}$ Uma situação já corrente na antiguidade, $c f$. n. 47, abaixo.

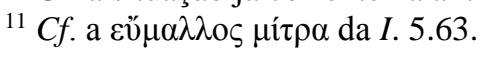


Depois disso havia a famosa "volta olímpica" ( $\pi \varepsilon \rho 1 \alpha \gamma \varepsilon \rho \mu o ́ s))^{12}$, durante a qual a plateia costumava saudar e jogar sobre o vencedor uma chuva de folhas, frutos (secos, provavelmente), coroas e filetes, numa prática conhecida como $\varphi v \lambda \lambda \circ \beta \circ \lambda i ́ \alpha$, e mencionada por Píndaro, por exemplo, na $O \cdot 9.123-5^{13}$. O atleta vencedor era então, em alguns casos, cercado por seus amigos e espectadores que lhe amarravam ainda mais filetes de lã na cabeleira e em seu corpo ou, então, os penduravam em sua coroa ( $\lambda \eta \mu v i ́ \sigma \kappa o l)$, daí algumas vezes Píndaro chamar as coroas de $\pi \tau \varepsilon \rho \varepsilon_{\varepsilon ı \varsigma^{14}}$. Além disso, em várias passagens das odes ele faz menção a essa prática, colocando-se, metaforicamente, no papel de celebrante que irá coroar, aspergir, derramar, atar, etc. coroas e filetes sobre (a cabeça de) o vencedor ou sua cidade.

Após o $\pi \varepsilon \rho 1 \alpha \gamma \varepsilon \rho \mu o ́ \varsigma$ e a $\varphi v \lambda \lambda o \beta o \lambda i ́ \alpha$, seguia-se algum tipo de celebração informal, impromptu, que incluía uma espécie de "viva o vencedor" um bordão tradicional na forma da

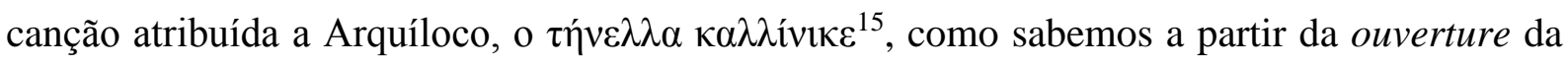
O. 9.1-5. A esta primeira celebração mencionada na ode, que deveria ser bastante simples, provavelmente sem nenhum tipo de acompanhamento musical ${ }^{16}$, é contraposta uma outra, mais sofisticada ( $\dot{\alpha} \lambda \lambda \grave{\alpha} v \tilde{v} v, 5)$ que pressupõe uma cerimônia organizada provavelmente na própria cidade de Opus em um contexto dedicatório ou cultual ${ }^{17}$. Ainda a esse respeito, e no caso dos jogos olímpicos pelo menos, somos informados de que, ao final de um dia de competição, o vencedor, sua família e amigos podiam organizar uma festa ( $\tau \grave{\alpha}$ غ̇ंıvíkı $)$ para comemorar a vitória do competidor, como aquela dada por Alcibíades em 416 , por ocasião de sua vitória na corrida de quadriga ${ }^{18}$, para a qual Eurípides compusera um epinício, o último,

${ }^{12} C f$. p. ex., a volta olímpica dada por Acusilau e Damageto, filhos de Diágoras de Rodes, para quem Píndaro compusera a $O$. 7, carregando o pai por entre a multidão de espectadores sob uma chuva de flores, Pausânias, 6.7.3.

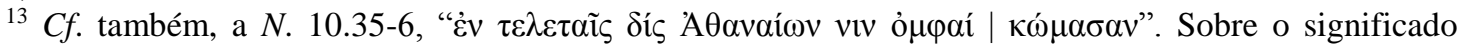
religioso dessas práticas, $c f$. KEFALIDOU (1999). Para uma reconstrução da cerimônia dos jogos Olímpicos do ano 300, $c f$. o excelente livro de S. G. MiLLER (2006), bem como a reunião, feita pelo mesmo autor, das fontes históricas que descrevem os jogos e suas provas, em S. G. MiLLER (2012).

${ }^{14}$ Como na $O .14 .24$.

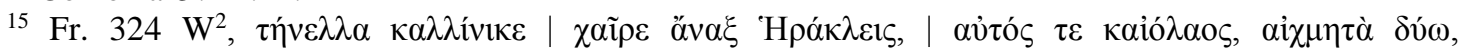
provavelmente a ser executada da capo. Uma tradução livre seria "Viva o Senhor Hércules, o campeão, viva ele e Iolau, os dois lanceiros | taram tam! | Viva ao Senhor Hércules, o campeão!”. A palavra $\tau \eta ́ v \varepsilon \lambda \lambda \alpha$ teria sido inventada para imitar o som da lira (ou do aulos) na ausência de acompanhamento musical. Os comentários antigos diferem sobre se o bordão era "triplóos" (ou seja, "triplo") porque se repetia o "viva ao vencedor" três vezes, entoando-se a canção uma segunda vez (mais provável), ou se era porque, enquanto o líder da procissão

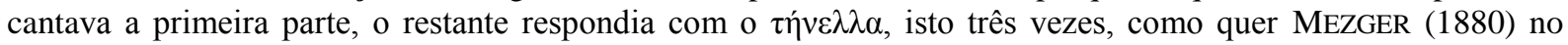
comentário aos versos de Píndaro. $C f$. ainda o aparato crítico de West no IEG ${ }^{2}$.

${ }^{16} C f$. nota 15 , acima.

${ }^{17}$ Pelo que se deduz dos versos finais, 108-112.

18 Andocides, 4.29. Note que Andocides, nesta passagem, denuncia o comportamento violento de Alcibíades ao se apropriar das bacias e dos incensórios de ouro dos atenienses para a sua própria procissão particular, alegando serem suas. 
aliás, de que temos uma parte do texto ${ }^{19}$. No caso dos Jogos Olímpicos, para os quais temos mais informações, as coroas de oliveira selvagem eram distribuídas aos vencedores no último dia das competições, e, ao final desse, os 'E $\lambda \lambda \alpha v o \delta i ́ \kappa \alpha$ organizavam um jantar comum no pritaneu $^{20}$.

Todas essas ocasiões poderiam ser apropriadas, em maior ou menor medida, à execução de um epinício, mas é importante salientar que não temos nenhuma evidência que, de fato, corrobore esses cenários.

Uma outra oportunidade, de que temos mais detalhes, seria a recepção dada ao vencedor em sua cidade natal, com grande pompa, em uma cerimônia chamada de "Entrada" $(\varepsilon i \sigma \varepsilon ́ \lambda \alpha \sigma i \varsigma)^{21}$ durante a qual aquele, vestido com uma túnica púrpura (ou cor de açafrão), a $\xi v ́ \sigma \tau \iota^{22}$, era conduzido em uma carruagem para dentro da cidade através de uma brecha feita nos muros com este único propósito, como nos informa Plutarco nesta passagem das Questões Conviviais $^{23}$ em que os jogos e as provas atléticas são explicados como um "treino" para a guerra:

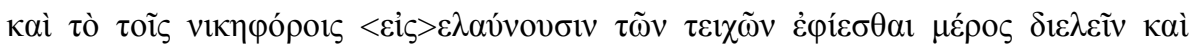

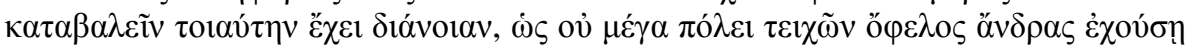

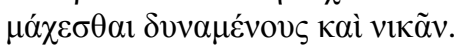

e a ordem de se derrubar uma parte dos muros a fim de abrir uma brecha para a entrada dos vencedores [nas competições atléticas] segue o mesmo raciocínio, segundo o qual não há maior utilidade para uma cidade do que ter homens capazes de lutar e vencer.

Trata-se de uma prática também atestada por Diodoro da Sicília ${ }^{24}$ na Agrigento da segunda metade do século V:

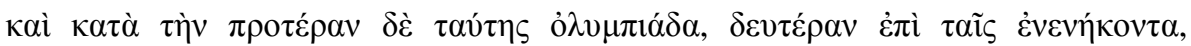

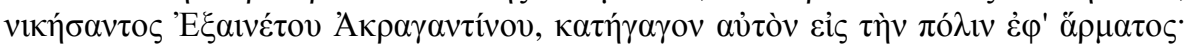

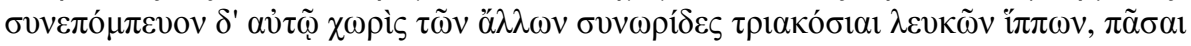

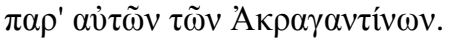

$\mathrm{Na}$ Olimpíada anterior a esta, a nonagésima segunda [412 a. C.], quando Exeneto de Agrigento foi vencedor [na corrida de estádio], trouxeram-no para a cidade sobre uma carruagem: fizeram-lhe acompanhar em procissão, além de outras coisas, trinta parelhas de éguas brancas, todas financiadas pelos próprios agrigentinos.

${ }^{19}$ Fr. 755 PMG.

${ }^{20}$ Cf. Pausânias 5.15.12.

${ }^{21}$ Sobre a $\varepsilon i \sigma \varepsilon ́ \lambda \alpha \sigma i \varsigma$ e as demais honras conferidas aos atletas vencedores, $c f$. o excelente trabalho realizado por CURRIE (2005, p. 139 et seq.) e, em especial, as fontes citadas por ele à n. 114 .

${ }^{22}$ Vista, por exemplo, na escultura do Auriga de Delfos (Bronze, 1,80 de altura. Museu de Delfos, Grécia), dedicada por Polizelo, irmão de Hierão e tirano de Gela, em comemoração à sua vitória na corrida de quadriga $c .478$ ou 474 a. C.

${ }^{23} 639 \mathrm{e} 4-7$.

${ }^{24} 13.82 .7$. 
Esses testemunhos só podem ser tomados por exagerados se não os compararmos com o triunfo de Nero (o emulador paradigmático dos costumes gregos), após sua escandalosa campanha atlética pela Grécia, como descrita por Suetônio, onde podemos ter uma ideia das “outras coisas" acerca das quais Diodoro silencia, na passagem acima, e de uma série de outras práticas, como, por exemplo, a $\varphi v \lambda \lambda \circ \beta$ o $\lambda i ́ \alpha$ e a derrubada dos muros ${ }^{25}$ :

\begin{abstract}
Reuersus e Graecia Neapolim (...) albis equis introiit disiecta parte Nero muri, ut mos hieronicarum est; simili modo Antium, inde Albanum, inde Romam; sed et Romam eo curru, quo Augustus olim triumphauerat, et in ueste purpurea distinctaque stellis aureis chlamyde coronamque capite gerens Olympiacam, dextra manu Pythiam, prae eunte pompa ceterarum cum titulis, ubi et quos quo cantionum quоuе fabularum argumento uicisset; sequentibus currum ouantium ritu plausoribus, Augustianos militesque se triumphi eius clamitantibus. Dehinc diruto circi maximi arcu per Velabrum forumque Palatium et Apollinem petit. Incedenti passim uictimae caesae sparso per uias identidem croco ingestaeque aues ac lemnisci et bellaria. sacras coronas in cubiculis circum lectos posuit, item statuas suas citharoedico habitu, qua nota etiam nummum percussit.
\end{abstract}

Retornando da Grécia para Nápoles, Nero adentrou [a cidade] com cavalos brancos por uma parte demolida dos muros, como é o costume dos [vencedores nos] jogos sagrados $^{26}$. Da mesma maneira entrou em Âncio, em Alba e em Roma. Mas, em Roma, entrou com aquela carruagem na qual Augusto outrora fizera seu triunfo, com uma túnica púrpura e um xale ricamente decorado com estrelas de ouro, carregando em sua cabeça a coroa olímpica e, na mão direita, a pítica; à sua frente, uma pompa com inscrições de seus outros prêmios, onde e quais vencera por meio de que cantos e de que estórias. Sua carruagem era seguida por aplaudidores que, segundo o rito, o ovacionavam, clamando serem Augustanos e guardas do triunfo. Daí, demolido o arco do Circo Máximo, desfilou pelo Velabro, pelo Fórum, pelo templo de Palas e o de Apolo. Por onde quer que passasse, vítimas eram-lhe sacrificadas e as ruas eram cobertas com açafrão, aves, filetes e frutas secas. As sagradas coroas, ele as suspendeu todas em volta de seu quarto. Ainda [mandou erigir] estátuas suas vestido com o hábito dos citaredos, com cuja imagem também mandou cunhar moedas de prata. $^{27}$

Esses tipos de reações a uma vitória atlética, tanto in situ, quanto durante o retorno do atleta e, possivelmente, a cada aniversário de sua vitória, podem nos ajudar a entender melhor um fato que emerge claramente de uma leitura do corpus das odes, ou seja, que, de diferentes formas, os epinícios estão sempre enquadrados por um contexto festivo ${ }^{28}$, ao qual fazem

${ }^{25} \mathrm{O}$ fato de Nero ter usado de todos os meios, na Grécia, para se sagrar campeão em todos os jogos que visitou não diminui o valor da evidência relativa ao seu acolhimento na Itália. Em primeiro lugar porque dificilmente uma grande parcela da população dessas cidades teria ciência dos fatos e, em segundo, porque o relato de Suetônio, além de se configurar em uma análise ex posto facto e de não ser representativo da coletividade, não deixa de ser ideologicamente motivado.

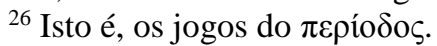

${ }^{27}$ Suetônio, Nero, 25.1-2.

${ }^{28}$ Uma análise a partir dessa perspectiva foi levada a cabo por KRUMMEN (1990, p. 9) para a $O .1$ e $3, P$. 5 e $I$. 4, com resultados variáveis para cada uma das odes. Naquele estudo, ela se dispôs a "[sich beschäftigen] mit der Rekonstruktion dieses kultisch-festlichen Erwartungshorizontes. Im Grundsätzlichen ist dabei auch der Nachweis zu erbringen, dass Pindars Aussagen zum Kontextrealitätsbezogen und historisch richtig sind. Das primäre Ziel dieser Untersuchung besteht also darin, die jeweils relevanten Textpassagen und die Kommunikationsbedingungen in der aktuelle Situation der Siegesfeier zu erläutern, und zwar sowohl 
menção. Independentemente de quais contornos mais precisos queiramos (ou possamos) dar a esse contexto, referências a ele são facilmente mapeáveis no vocabulário pindárico, onde

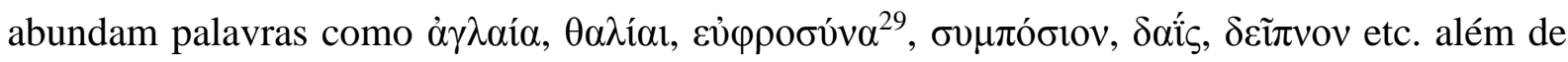
inúmeros merismos que, como veremos mais adiante, perfilam diversos aspectos de uma celebração, como a música, a dança, os sacrifícios, a comida, a bebida etc. Infelizmente os detalhes desse contexto permanecem ocultos e uma razão bastante óbvia para isso é que, para a audiência de uma ode, eles deveriam ser claros o suficiente para dispensar uma maior

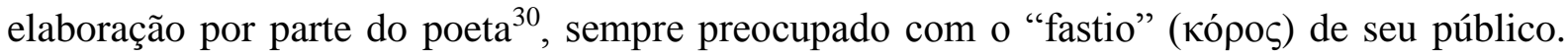
Outra razão é aquela já mencionada, e a que retornaremos, de que os epinícios tendem a evitar descrições detalhadas do hic et nunc da performance porque isso naturalmente poderia significar uma maior dificuldade na transmissão e disseminação da canção em outras situações e para outros públicos, separados tanto no tempo quando no espaço da primeira performance $e^{31}$.

Uma outra constatação importante dedutível a partir dos testemunhos arrolados acima é que o retorno de um vencedor, mesmo daquelas competições que não tinham o prestígio dos

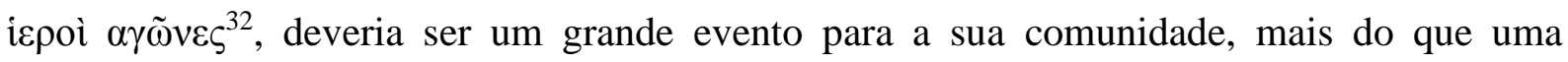
ocasião que dissesse respeito apenas aos círculos mais próximos do atleta, e isso independente do fato de ele ser um grande tirano, como Hierão ou Arcesilau, ou um cidadão privado como Psaumide ou Agésias ${ }^{33}$. Na verdade, a distinção entre público e privado é, em grande parte, uma invenção moderna pouco útil para a compreensão das atitudes gregas em relação à figura

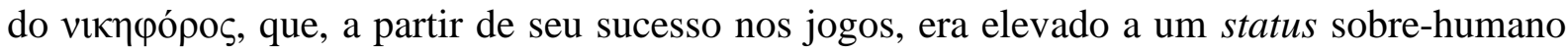
que o punha em uma situação no mínimo ambígua em relação à comunidade para a qual retornava e na qual precisava ser reintegrado, mormente por meio de algum tipo de celebração que, muito provavelmente, incorporava também aspectos religiosos. Leslie Kurke ${ }^{34}$, aliás, vê na prática da derrubada dos muros, mencionada acima, e no fato de que, na guerra e em momentos de crise, tanto o próprio vencedor quanto as coroas conquistadas nos jogos

hinsichtlich der Rahmenbedingungen, als auch (...) der mythisch-kulturellen ,Erwartung ‘." Para uma crítica de seus resultados, $c f$. D. E. GERBER (1991) e INSTONE (1993).

${ }^{29}$ Inclusive personificadas, como, e.g., na $O .14$.

${ }^{30}$ JENNY STRAUSS CLAY (1999, p. 32).

${ }^{31}$ Sobre isso $c f$., especialmente, G. NAGY (1994).

32 Como, e.g., no caso das vitórias obtidas por Aristágoras em sua minúscula ilha de Tênedos, listadas na $N .11$.

33 Cf. Jenny Strauss Clay (1999) e CARey (2007, p. 200 et seq.), que aventa, inclusive, a possibilidade, bastante plausível, segundo ele, de patrocínio estatal para a celebração da volta do vitorioso em alguns casos.

${ }^{34}$ KURKE (1998). Cf. também CURRIE (2005), especialmente, a esse respeito, as pp. 139 et seq. Mais recentemente, um estudo interessante que traça um paralelo entre o retorno de Hércules, nas Traquínias, e o do vencedor atlético é aquele de KRATZER (2013). 
poderem ser usados como amuletos de sorte e poder contra o inimigo, um indício desse poder mágico que precisava ser transferido do indivíduo para a cidade.

Essa relação tão íntima dos epinícios com a comunidade do laudandus foi explorada por dois trabalhos que, embora separados no tempo, complementam-se. O primeiro é o livro de K. Crotty ${ }^{35}$, da década de 80 , que pôde relacionar o gênero epinicial com outros tipos de poesia celebratória como a poesia erótica, encomiástica e, sobretudo, simposial, salientando

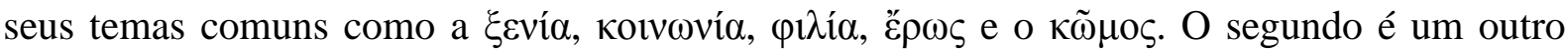
trabalho de Leslie Kurke, The Traffic in Praise, ${ }^{36}$, bastante influenciado pelo de Crotty e que, de certa forma, expande suas ideias. Neste livro, Kurke, rejeitando a análise centrada no atleta como um ser humano extraordinário, cujas ações revelariam o ápice de uma excelência

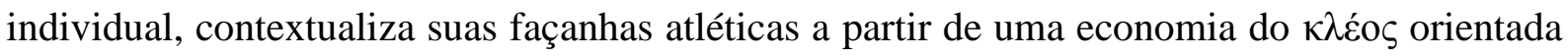
pelas necessidades do oĩkoৎ arcaico de angariar e distribuir este valor (que é visto como propriedade imaterial de sua casa e estirpe) entre os membros de sua família e os da própria comunidade.

Segundo sua análise, o oĩ אos é a força por trás do movimento do atleta para fora de sua comunidade e, outra vez, após o sucesso atlético, é o que o impulsiona de volta a ela e, dessa forma, essas forças centrífuga e centrípeta exercidas sobre o indivíduo o levam a completar o que ela chama, muito adequadamente, de "ciclo do nostos". Este ciclo completa-se, num primeiro momento, com a celebração da vitória, que inclui a execução do epinício, mas não deveria se restringir apenas a ele. Este serve para mediar, por meio do poeta, a reintegração do "ingente homem"37 ao seu círculo comunitário numa relação de relativa igualdade dentro do estatuto social que opõe homens, de um lado, e heróis e deuses, de outro. Daí as constantes admoestações do poeta acerca do perigo do excesso e da insolência (üßpıৎ) que ameaçaria os vencedores. A festa da vitória pelo retorno do atleta à sua comunidade original pode ser vista, dessa forma, como a expressão de um ritual que efetua a transição do mundo exterior para aquele do oĩkos. Esse ritual reflete-se tanto na linguagem quanto na imagética dos epinícios ${ }^{38}$.

J. S. Clay $^{39}$, por outro lado, seguindo também nos passos de Crotty, foi a primeira a propor que a ocasião da performance dos epinícios, qualquer que fosse a locação em que os

\footnotetext{
${ }^{35}$ CROTTY (1982).

${ }^{36}$ KURKE (1991).

${ }^{37}$ O. 7.15 .

${ }^{38}$ Cf. KURKE (1991, p. 120 et seq.).

${ }^{39}$ JENNY STRAUSS CLAY (1999).
} 
mesmos pudessem ser executados, seria o simpósio ${ }^{40}$. Ela salienta, com razão, que a ideia de "simpósio" precisa ser repensada de uma forma mais inclusiva, não limitada apenas por nossas concepções acerca do que sabemos das práticas áticas do séc. V, que criam uma tensão, quiçá inexistente em algumas sociedades do período arcaico (sobretudo nas tiranias), entre público e privado, opondo, dessa forma, as grandes festas cívicas das póleis aos banquetes da aristocracia. Baseando-se no trabalho de Schmitt-Pantel ${ }^{41}$ e aduzindo exemplos da literatura grega antiga, Clay consegue construir um cenário bastante convincente para algumas odes de Píndaro as quais se propõe a analisar e que são denominadas por ela, muito acertadamente, como “epinícios simpóticos"42.

Felix Budelmann ${ }^{43}$, por seu turno, prestou um serviço inestimável ao retomar o tratamento anterior dado por Clay, expandindo as possibilidades de performance do epinício para além dos limites do simpósio strictu sensu, que, como ele nos lembra - muito embora não fosse uma atividade monolítica, cujas práticas poderiam variar de cidade para cidade -, ainda assim preservava uma série de características e uma ideologia que o distinguia, por reduzi-lo a uma espécie de agrupamento festivo, de outras atividades também aludidas nos

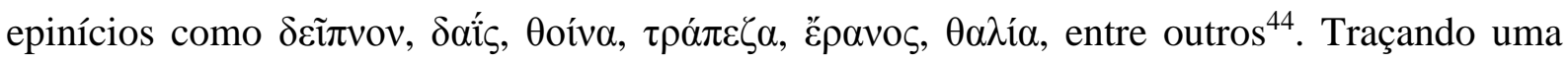
comparação com os encômios ${ }^{45}$ pindáricos, seu objetivo principal foi o de avaliar de que maneira ambos os gêneros se relacionariam - entre si e com o simpósio -, e como aludiriam ao contexto festivo no qual estão inseridos, salientando que a linha que os delimita como gêneros independentes parece ser, ao contrário do que acreditava Van Groningen ${ }^{46}$, bastante tênue, tendo gerado na verdade uma celeuma, ademais já existente na recepção helenística de Píndaro, que põe em dúvida se algumas odes deveriam ser classificadas como epinícios ou encômios $^{47}$.

40 JENNY STRAUSS CLAY (1999), "But, whatever the venue, the immediate context for epinician performance is, as I shall argue, the symposium, whether in a large panegyris, (...) or a more intimate occasion", p. 26.

${ }^{41}$ P. Schmitt-Pantel, 'Sacrificial Meal and Symposium: Two models of Civic Instititions in the Archaic City?', in Sympotica: A Symposium on the Symposion. Ed. por O. Murray, Oxford, 1990, p. 20-25.

${ }^{42}$ O. 7; I. 6; P. 4 e N. 9.

${ }^{43}$ BUDELMANN (2012).

${ }^{44}$ Segundo a contabilidade de BudELmanN (2012, pp. 181, sub n. 25), a frequência de alguns desses

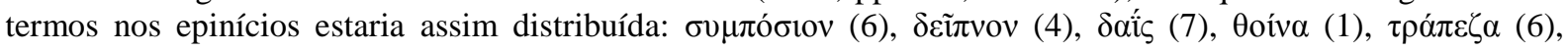
ह́pavos (3), $\theta \alpha \lambda i \alpha$, , (4).

${ }^{45}$ Já comentados por B.A. VAN GRONINGEN (1960) em sua edição ainda bastante útil, mas que, porém, começa a dar sinais de sua idade, $c f$. CINGANO (2003).

${ }^{46}$ B.A. VAN GRONINGEN (1960).

${ }^{47} C f$., p. ex., o $\Sigma N$. 11, inscr. a, 1 et seq. (DRACHMANN, vol. III, p. 185), que preserva a opinião de Dídimo, baseada em evidências internas apenas, de que a ode em questão não deveria ter sido incluída entre os epinícios. Para os modernos, $c f$. as referências citadas em BudELMANN (2012, p. 179): Vetta, M. (ed.) (1983) Poesia e simposio nella grecia antica. Rome, que sugere (pace Budelmann) que as O. 2, P. 5 e I. 2 são encômios, e Ucciardello, G. (2001) 'P.Oxy xxxii 2636: commentario a Pindaro o a Ibico?' in D'Alessio, G. B. 
Budelmann, por meio de sua análise, pôde, então, apontar para o que parece ser uma complementaridade entre os dois tipos de canções ao lembrar, ainda, que alguns patronos comissionavam um encômio e um epinício possivelmente para a mesma ocasião ${ }^{48}$. Obviamente, se pudermos supor que os dois tipos de canções eram executadas num mesmo momento e se, pelo que sabemos, a performance típica de um encômio era au banquet, poderíamos inferir que, ao menos para os epinícios que lhes faziam $\operatorname{par}^{49}$, a performance dessas e talvez de outras odes deveria se dar igualmente em um simpósio ou imediatamente após o mesmo. Indo mais longe ainda, poderíamos imaginar algum tipo de celebração na qual diversas canções (e cantores) suceder-se-iam numa dinâmica que podemos apenas começar a intuir $^{50}$. Infelizmente, não há nenhuma evidência que comprove ou ateste que um encômio e um epinício, ainda que comissionados para o mesmo laudandus, tenham sido executados na mesma ocasião e, portanto, essa possibilidade deve permanecer apenas uma especulação, ainda que intrigante.

Há outra dificuldade, já apontada por Budelmann: ainda que tanto os encômios quanto os epinícios aludam ao simpósio, eles o fazem de maneira muito diferente. Ao passo que os encômios são sempre explícitos em suas referências ao momento da performance, isso jamais acontece com os epinícios. Esses, para tanto, sempre utilizam o termo $\kappa \tilde{\omega} \mu \mathrm{s}$, não raro acompanhada de um dêictico, ou o verbo denominativo $\kappa \omega \mu \alpha ́ \zeta \zeta$, ou, então, adjetivos formados sobre $-\kappa \omega \mu-$. A discussão sobre o significado desse termo e de seus derivados nos epinícios $e$ em outros gêneros é pontuada pela controvérsia.

A solução mais antiga, aquela dos escólios exegéticos, seguida pela imensa maioria da

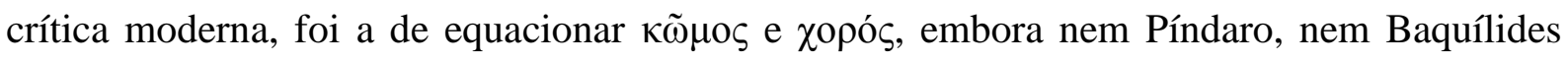

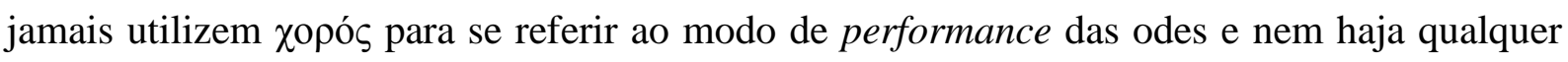
autoridade externa que nos permita fazê-lo ${ }^{51}$. Na verdade, a evidência dos textos antigos aponta justamente para uma distinção bastante clara entre os termos tanto no nível semântico,

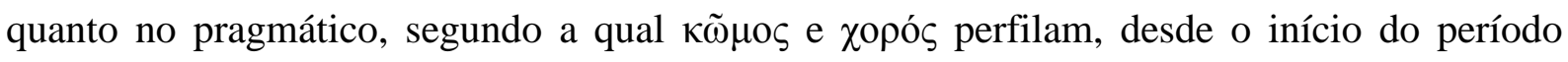
arcaico, atividades completamente distintas. Este paradoxo entre o uso que Píndaro faz de

and M. Cannatà Fera (eds.) (2001) I lirici greci: Forme della comunicazione e storia del testo, Atti dell'incontro di studi, Messina 5-6 novembre, 1999. Messina. Nenhum desses dois trabalhos foi consultado por mim.

${ }^{48}$ Por exemplo, Terão de Agrigento: epinícios, $O .2$ e 3; encômios, fr. 118-19. Xenofonte de Corinto, epinícios, O. 13; encômios, fr. 122. Trasíbulo de Agrigento, epinício, I. 2 (Possivelmente. S-M preserva a atribuição, dada pelos escólios, à Xenócrates), encômio, fr. 124. Hierão de Siracusa e Etna, epinícios, $O .1, P .1$, 2 e 3; fr. 124d-126. Apenas Alexandre I da Macedônia e Teoxeno de Tênedos não tem epinícios correspondentes aos seus encômios, respectivamente, os fr. 120-1 e fr. 123, BUDELMANN (2012, p. 177).

${ }^{49} \mathrm{Cf}$. n. 48 , acima.

${ }^{50}$ BUDELMANN (2012, p. 179).

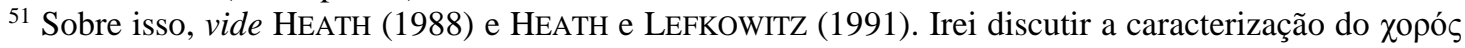
em mais detalhes a partir da p. 188. 


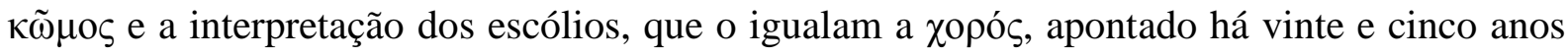
atrás por Malcolm Heath ${ }^{52}$ é, contudo, e infelizmente, sistematicamente ignorado, conscientemente ou não, por uma considerável parcela da crítica pindárica, porém com consequências catastróficas para muitas análises das odes, que se baseiam neste a priori. É interessante notar, ademais, que é apenas dentro do círculo dos estudos pindáricos que se pode assumir, sem maiores problemas, uma tal equivalência.

Agócs $^{53}$, mais recentemente, tentou retomar o tema, partindo de uma definição de $\kappa \tilde{\omega} \mu \mathrm{s}$ como

\begin{abstract}
um grupo (os $\kappa \omega \mu \alpha \sigma \tau \alpha$ í), um tipo de composição musical e uma ação. De um modo menos tangível, ele marca uma atmosfera ${ }^{54}$. Ele funciona como um termo para a materialidade da ode e para o grupo que a canta. Ele também aponta para o contexto mais amplo da performance. Finalmente, ele também pode se referir a certas normas e expectativas associadas com aquele contexto, cujo caráter preciso é difícil de estabelecer. Devoção religiosa (dedicatórias, sacrifícios e procissões) formavam uma parte dele, da mesma forma que o banquete e a bebedeira, e, finalmente, a canção: o

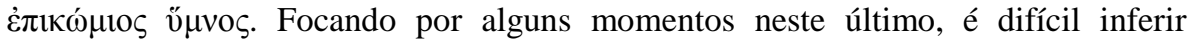
qualquer coisa sobre o grupo que executava a performance ou sua produção. $\mathrm{O}$ tamanho dos coros epiniciais é desconhecido ${ }^{55}$, e os poetas não falam sobre sua seleção ou treinamento. O vitorioso é, algumas vezes, um dos participantes; outras, não. Algumas vezes ele lidera sua própria celebração. A persona loquens pode, também, apresentar-se como um comasta, ou mesmo como um cantor solo, ou então ela pode, simplesmente, permanecer isolada. Os próprios comastas quase nunca são caracterizados e eles são sempre homens [grifo meu]. ${ }^{56}$
\end{abstract}

Essa definição, ainda que bastante precisa, tropeça, contudo, ao adotar de antemão a visão ortodoxa da classificação dos epinícios como canções corais. Ao fazer isso, Agócs não só impõe esse frame à leitura que faz do $\kappa \tilde{\omega} \mu \mathrm{s}$, isto é, como se ele pudesse ser entendido como subespécie ou sinônimo de $\chi 0 \rho o ́ \varsigma^{57}$, mas embasa toda a sua discussão a partir de uma lógica que depende desse enquadramento, cuja validade, ademais, nunca foi provada para o período arcaico, mas, ao contrário, foi seriamente posta em dúvida por Heath ${ }^{58}$. Ao proceder dessa forma ele limita grandemente os resultados que poderia obter. Adicionalmente, ao restringir sua análise apenas às odes de Píndaro e, eventualmente, de Baquílides, como se elas existissem desconectadas de uma tradição e de uma dicção poética, que ele mesmo

${ }^{52}$ HEATH (1988). A controvérsia entre coralistas e solistas, no entanto, deverá nos ocupar mais adiante.

${ }^{53}$ AGÓCS (2012).

${ }^{54}$ Em nota (48, p. 198), ele diz, "adaptando um termo da linguística, poder-se-ia chama-lo de "registro".

${ }^{55} \mathrm{Em}$ nenhum momento lhe ocorre que isso possa se dar porque a ideia de um "coro epinicial" seja uma criação moderna. Para uma teoria sobre como seria a produção de um coro epinicial, vide, por exemplo, CURRIE (2011).

${ }^{56}$ BUDELMANN (2012, p. 198).

${ }^{57}$ AGÓCS, CAREY e RAWLES (2012, pp. 195-6). Cf. mais abaixo minha crítica a essa definição.

${ }^{58}$ Op. cit. n. 52. 
reconhece $^{59}$, mas com a qual se revela incapaz de dialogar, os resultados a que chega são inconclusivos e não nos ajudam a entender melhor os usos que aqueles dois poetas fazem de $\kappa \tilde{\omega} \mu$ os. Sua conclusão principal, portanto, e inevitável dado o seu método, é a de que "o panode-fundo do komos permanece indistinto. Se sabemos pouco sobre a performance do epinício, sabemos ainda menos sobre os komoi de vitória gregos" ${ }^{60}$, e, mais adiante:

\footnotetext{
A linguagem comástica de Píndaro e Baquílides não narra ou descreve: ela alude ao contexto da enunciação, mas de uma maneira que a audiência possa reconhecer o komos através das circunstâncias variáveis da performance e da reperformance. Qualquer que seja o contexto real da performance, o contexto descritivo continua o

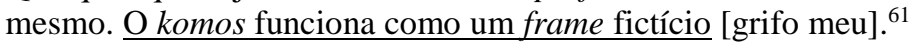

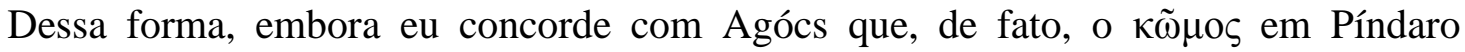
evoque sempre um determinado frame - no sentido, porém, que a LC dá a este termo ${ }^{62}$ - ele está longe de ser "fíctício". Ao contrário, o epinício, em seu diálogo com uma dicção tradicional e a história cultural, deveria ser capaz de invocar uma série de associações importantes entre categorias e conceitos relativos à performance que fossem pertinentes dentro de um MCI representado por todo o rico conjunto de conhecimentos, partilhados pela comunidade, relativos à tradição, à práxis poética e à performance (pública) de diversos tipos de obras vocais, o que limitaria bastante a possibilidade de que qualquer palavra pudesse ter um significado "supragenérico" ou "fictício". O significado de qualquer palavra não reside nem no item lexical apenas, neste caso em $\mathbf{\kappa} \tilde{\boldsymbol{\omega}} \boldsymbol{\mu} \mathbf{s} \varsigma$, nem é negociado inteiramente a partir do contexto do evento da fala. O significado de qualquer palavra surge por meio de sua conceitualização em um frame específico invocado durante o ato da fala, e é esse frame que permite a associação do item lexical a todo um conhecimento enciclopédico existente na comunidade de falantes, mas instanciado em diferentes graus em cada um dos indivíduos.

Infelizmente, essas conclusões negativas, longe de ser inevitáveis, muitas vezes são resultado de uma leitura das odes que eu denomino "ultra-unitária" que é, em última análise, autolimitativa, por não admitir que a relação entre elementos textuais e extratextuais da canção também seja uma parte importante no entendimento de sua unidade. Certamente, do ponto de vista do Nachleben dos epinícios, sobretudo após a entextualização das canções, ela pode fazer algum sentido, já que a programática do gênero, que vê além do hic et nunc da primeira performance, como salientamos no início deste capítulo, tende a evitar expressões

\footnotetext{
${ }^{59}$ AgÓCS (2012, p. 213).

${ }^{60}$ AGÓCS (2012, p. 218).

61 Agócs et al. (2012, p. 219).

${ }^{62}$ Cf. pp. 34 et seq.
} 


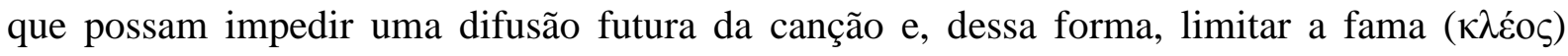
prometida ao laudandus quando da desestabilização da ocasião original. Ao absolutizar a ocasião de performance em uma dicção genérica que, pode-se argumentar, é capaz de compensar pela eventual perda da ocasião original, Píndaro estava, na verdade, assegurando a sobrevivência do louvor em outros contextos ${ }^{63}$. Isto não implica, contudo, que $\kappa \tilde{\omega} \mu$ o̧ seja, ou tenha sido, um termo completamente esvaziado de conteúdo semântico que pudesse servir como substituto para toda e qualquer ocasião de performance ou reperformance futura.

Ainda que concordássemos que $\kappa \tilde{\omega} \mu$ os pudesse representar um "frame" fíctício, não poderíamos nos eximir de tentar entender que tipo de ficção poderia estar por trás desse termo, quais seriam mais e quais seriam menos prováveis. Dizer que o $\kappa \tilde{\omega} \mu$ o $̧$ é uma "ficção" não é o mesmo que dizer que ele é uma variável plurivalente, intencionalmente pensada por um único poeta a fim de que suas canções pudessem ser readaptadas a qualquer cenário posterior possível. Se este fosse o caso, ademais, não nos sentiríamos tão incomodados por

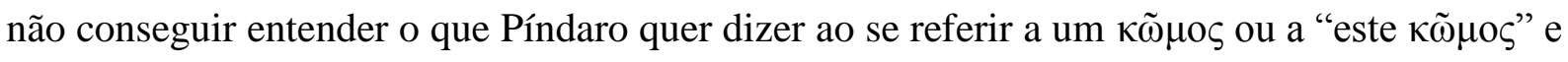
uma grande parte de nossa apreciação de sua poesia não seria prejudicada justamente por

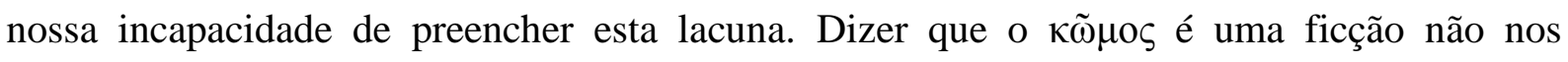
desobriga, mesmo se quisermos acreditar nisso, de tentar entendê-la, suas motivações e o que jaz por trás dela.

Possivelmente pode haver, como quer $\mathrm{Nagy}^{64}$, um uso deliberado de uma forma "supragenérica" nos epinícios que olha para além de sua première; no entanto o epinício não é, e não se reduz, apenas a esta forma, readaptável ad infinitum em uma perspectiva diacrônica, uma hipótese que a própria história do gênero contraria: quando aquela cultura, com a qual o epinício mantinha um diálogo capaz de preencher as lacunas oriundas da perda da ocasião original, entrou em declínio, ela levou consigo também a própria canção. $\mathrm{O}$ simples fato de, já na segunda metade do séc. V, epinícios não serem mais compostos ou executados atesta o fato de que o gênero não era imune às mudanças culturais e não podia se adaptar a qualquer tipo de realidade por parte de suas audiências futuras. Isso explica também, ao menos em parte, a perplexidade dos comentadores antigos em tentar interpretar referências

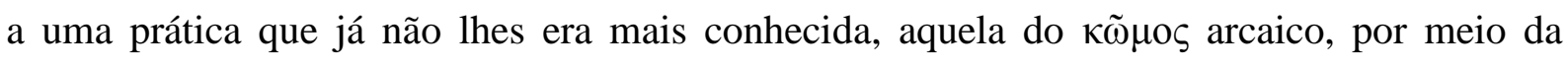

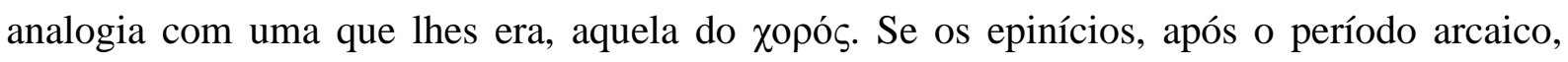
sobreviveram através da tradição literária helenística e, posteriormente, romana e bizantina, na forma entextualizada das canções, isto se deu por razões que pouco têm a ver com uma

${ }^{63}$ G. NAGY (1994, p. 19 et seq.), CAREY (2007, p. 199).

${ }^{64}$ G. NAGY (1994). 
eventual apreciação do valor das mesmas como obras vocais, já que no ambiente escolar, onde Píndaro provavelmente deve ter sobrevivido na forma de livro-texto ${ }^{65}$, a precisa ocasião de performance das odes em pouco ou nada importava.

É assim, portanto, apenas no nível entextualizado das odes e de uma perspectiva diacrônica que $\kappa \tilde{\omega} \mu$ o adquire essa espécie de "indeterminação quântica" que nos impede de isolar seu significado preciso, e Nagy ${ }^{66}$ pode estar certo ao dizer que a forma da ode epinicial serve para absolutizar a performance que, assim, libera o conteúdo dêictico das canções para se referir a todos os seus possíveis contextos, futuros e passados. No entanto, essa polivalência dos referentes internos do texto implica automaticamente que, fora da performance; ou seja no nível da canção entextualizada, eles não se referem a nada, algo que é verdade apenas trivialmente, na medida em que qualquer palavra não significa nada se não for conceitualizada. Nagy ${ }^{67}$ vê no uso que Píndaro faz de $\kappa \tilde{\omega} \mu \varsigma_{\zeta}$ a prova mais contundente dessa natureza supragenérica do epinício. Entretanto, ainda que válida diacronicamente, essa análise não pode ser verdadeira na sincronia, seja para o momento da première, seja para o das reperformances, uma vez que, vocalizada pelo aedo (ou mesmo pelo coro, se se quiser) e apresentada a uma audiência, as características supragenéricas deveriam se estabilizar pela evocação de frames específicos através dos quais o significado da ode e de suas partes pudessem ser resolvidos. O que a avaliação de $\mathrm{Nagy}^{68}$ tem de importante, apesar de tudo, é que ela nos alerta para o fato de que, do ponto de vista das odes apenas, ou seja de seu texto, é impossível definir o significado de $\kappa \tilde{\omega} \mu \varsigma^{69}$ e que qualquer análise nesse sentido só poderá chegar a conclusões negativas como as de Agócs, já expostas.

Deduz-se, portanto, que seria possível, pelo que vimos, investigar, ao menos hipoteticamente, as diferentes interpretações das odes em contextos outros que aqueles da première, não fosse a carência de evidências para muitos períodos ${ }^{70}$. Não é isso que me interessa, no entanto, neste capítulo, onde meu objetivo principal é tentar definir, ainda que de

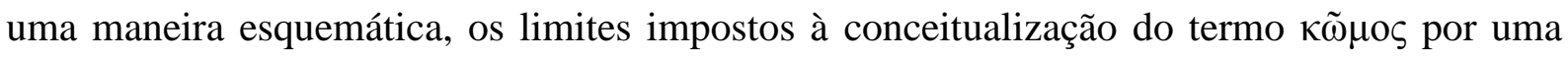
audiência do período arcaico, não necessariamente pela audiência da première ou por outras, imediatamente anteriores ou posteriores à Píndaro, mas uma audiência para a qual a

\footnotetext{
${ }^{65}$ Sobre isso confira o Capítulo 7.

${ }^{66}$ G. NAGY (1994).

${ }^{67}$ Idem.

${ }^{68}$ Idem.

${ }^{69}$ MORRISON (2012, p. 116).

${ }^{70} \mathrm{Cf}$. sobretudo MORRISON $(2007,2012)$.
} 
linguagem tradicional e alusiva do epinício ainda representasse o pano-de-fundo principal $^{71}$ a partir do qual um entendimento minimamente comum das odes pudesse ser alcançado. Ou seja, interessa-me entender, pelo menos de uma maneira preliminar, o (ou uma parte do) Modelo Cognitivo Idealizado implicado nas práticas performáticas gregas que envolvem a palavra $\kappa \tilde{\omega} \mu \mathrm{o}$ e, a partir desse, o que podemos deduzir dos conceitos e categorias associados ao frame delimitado pela própria palavra e seus derivados.

Uma vez que estamos lidando com uma língua e uma cultura não mais "vivas"72, o único modo de acesso a essa cultura é por meio de uma abordagem filológica que pressupõe o uso dos textos ou em muitos casos, das formas entextualizadas dos registros vocais e dos hábitos mentais dessa cultura. Evidentemente, em virtude da natureza da amostra que escolhi, e por óbvios motivos de tempo e espaço impostos por essa tese, devem ficar de fora dessa análise toda a literatura pós-clássica, ainda que essa deva certamente preservar uma dicção tradicional que poderia ser útil na elucidação da conceitualização arcaica de $\kappa \tilde{o} \mu$ os.

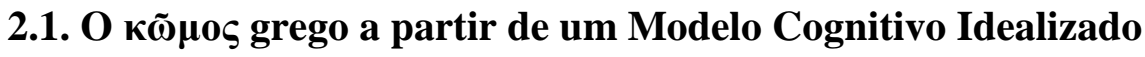

A interpretação tradicional, dicionarizada, de $\kappa \tilde{\omega} \mu$ ○ é aquela sumariada do LSJ como (a) "folia, bando de bêbados, festejo", (b) "em sentido concreto: bando de bagunceiros" e (c) "a ode cantada em algumas dessas procissões festivas" ". Trata-se de uma opinião ecoada por outros autores $^{74}$ e, sobretudo, utilizada por tradutores. Neste último caso, não sem implicações problemáticas ${ }^{75}$. No caso específico de Píndaro, as opiniões de RUMPEL e SLATER não se afastam muito da ideia de "bagunça" ou "procissão"76.

${ }^{71} \mathrm{Ou}$ o "common ground" na acepção da pragmática cognitiva. Ou seja, a audiência em questão, para a qual eu proponho um modelo, define-se melhor por meio de suas características do que por meio de um corte temporal. Para uma explicação sobre o que eu entendo por "período arcaico", $c f$. Introdução, p. 19.

${ }^{72}$ Apenas no sentido de que nenhum falante nativo desta língua e que tenha vivido nesta cultura existe.

${ }^{73}$ LSJ, s.v. $\kappa \tilde{\omega} \mu \mathrm{s}$, "revel, carousal, merry-making"; "concrete, band of revellers"; "the ode sung at one of these festive processions".

${ }^{74}$ PÜTZ (2007) e HEATH (1988, p. 182), a quem devo muitos dos exemplos aqui aduzidos. Compare com a definição dada por AGócS et al. (2012, p. 198).

${ }^{75}$ Cf. ECKERMAN (2010, p. 307).

${ }^{76}$ RUMPEL, s.v. $\kappa \tilde{\omega} \mu \mathrm{s}$, “comissatio epinicial, pompa ludicra cum cantu et intrumentis musicis”, grifo

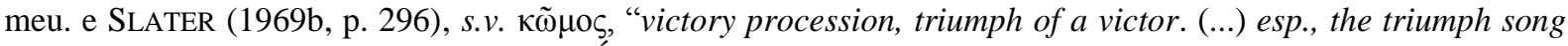
sung in conjunction with the procession". É preciso que se acrescente que ambos os dicionários estão já datados e, mesmo na qualidade de dicionários, não oferecem muita ajuda a um leitor de Píndaro que não a praticidade da concordância de passagens semelhantes. A ausência de um contexto mais amplo, fornecido por um dicionário como o LSJ pode ser, na verdade, prejudicial a uma leitura mais aberta das odes. 
Uma outra interpretação, a meu ver mais razoável, para o $\kappa \tilde{\omega} \mu о \varsigma$, foi proposta por Chris Eckerman ${ }^{77}$ em um brilhante, porém ainda pouco difundido, artigo em que, segundo ele, aquele termo,

significa 'celebração' e refere-se, amplamente, à primeira celebração na qual uma

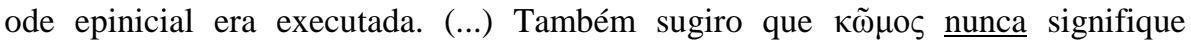
primariamente 'coro', 'ode', 'procissão' ou 'grupo de foliões' nas odes epiniciais de Píndaro e Baquílides que sobreviveram (...). Pelo contrário, irei sugerir que o substantivo polissêmico $\kappa \tilde{\omega} \mu о \varsigma$ despertou essas diversas denotações porque a celebração pode ser interpretada de diversas maneiras: uma celebração é composta por vários atos e falas que são partes da celebração como um todo. (...) Ainda, $\kappa \tilde{\omega} \mu \circ \zeta$ refere-se aos aspectos 'estáticos' da celebração além de se referir aos seus possíveis aspectos 'móveis'. Dessa forma, eu expando a afirmação de Heath de que

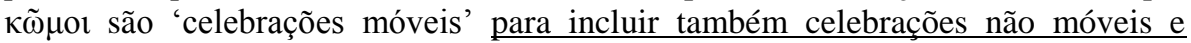
aspectos não móveis das celebrações; isto é, mesmo que as celebrações da vitória possam ter regularmente incluído procissões, não precisamos delimitar o $\kappa \tilde{\omega} \mu \mathrm{s} \varsigma$ epinicial a uma procissão [grifo meu].

Obviamente a definição de Eckerman é mais inclusiva que aquela de Agócs que, como já dissemos, precisa fazer concessões ao caráter do $\kappa \tilde{o} \mu \mathrm{s}$, por interpretá-lo como um

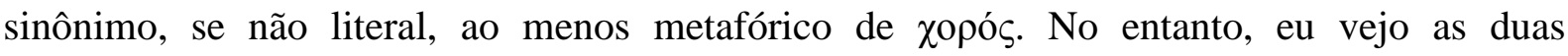
definições como complementares.

Duas coisas, ademais, devem nos interessar na definição de Agócs, a primeira é a sua afirmação de que o $\kappa \tilde{\omega} \mu$ o denota uma "atmosfera", mais do que uma situação específica e a segunda é a de que o termo sempre subentende um conjunto de pessoas do sexo masculino.

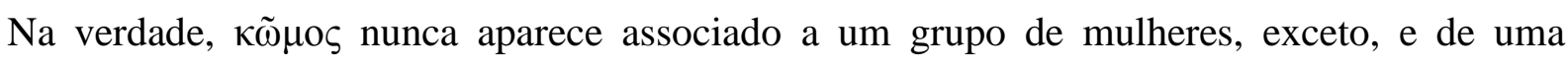
maneira muito interessante, quando esse grupo assume características notadamente não compatíveis com o comportamento prototípico associado ao sexo feminino, como no caso do $\kappa \tilde{\omega} \mu \mathrm{s}$ das bacantes ou das Erínias ${ }^{78}$, isto porque o elemento festivo do $\kappa \tilde{\omega} \mu$ o está delimitado pelas fronteiras do universo masculino, o que o aproxima do simpósio, uma conexão que exploraremos mais adiante. De fato, a ideia de uma "atmosfera" performática se aproxima bastante da própria definição de Eckerman e da minha tentativa de identificar as predicações impostas pelo frame evocado por $\kappa \tilde{\omega} \mu \mathrm{os}$.

Eckerman embasa, ainda, uma parte de sua argumentação sobre a etimologia do termo $\kappa \tilde{\omega} \mu$ os. Há, no entanto, duas possibilidades principais que, talvez, estejam interconectadas.

Por um lado, uma hipótese enfatiza o agrupamento comunal e a reunião de pessoas por

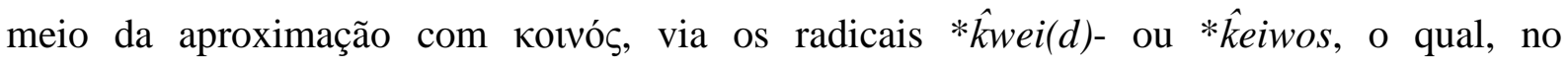

\footnotetext{
${ }^{77}$ ECKERMAN (2010, pp. 302-3), grifo meu.

${ }^{78}$ Respectivamente, E. Ba., 1167 e 1172 e A., Ag., 1186-9.
} 
protogrego, poderia ter resultado em ${ }^{*} \kappa o \mu j o \varsigma^{79}$.A outra, que me parece mais plausível, como também a Eckerman, aproxima o termo $\kappa \tilde{\omega} \mu \varsigma_{\varsigma}$ de um ancestral do PIE do tipo *ke $(n)_{s-}$, dedutível, por exemplo, a partir do radical sânscr. शंस् (śaṃs-), "recitação", "invocação", "louvor", "elogio", “celebração", usado, por exemplo, em relação à recitação dos Vedas. Um paralelo muito interessante é aquele da epígrafe que abre este capítulo, em que temos um poema de louvor ao rei Kaurama, no qual o composto bahuvrihi नराइांस (naraśamsa), formado pelos nomes नर (nara), "varão" 80 e शंस (śamsa), "celebração", está em perfeita equivalência

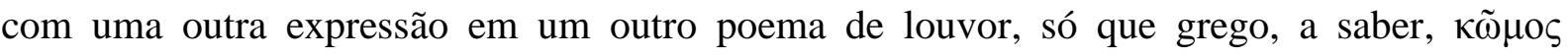
$\grave{\alpha} v \delta \rho \tilde{\omega} v^{81}$ da $P$. 5.20-3. Talvez estejamos, aqui, frente a uma expressão formular indoeuropeia fossilizada na linguagem tradicional de Píndaro. Da fato, este hino do Atharvaveda apresenta ainda uma série de outros palalelismos que não teríamos tempo de discutir, mas que já foram, em certa medida, explorados por Durante, inclusive com relação às suas ressonâncias com expressões formulares semelhantes no avesta ${ }^{82}$. Não poderíamos salientar suficientemente, porém, a importância desse paralelo para se estabelecer, em primeiro lugar, uma relação diacrônica entre os epinícios pindáricos e toda uma tradição de poesia de louvor indo-europeia e, em segundo, para fortalecer o indício de que, já nesse substrato comum, a celebração e o louvor dos grandes feitos (políticos, marciais, atléticos etc.) dos homens eram designados por

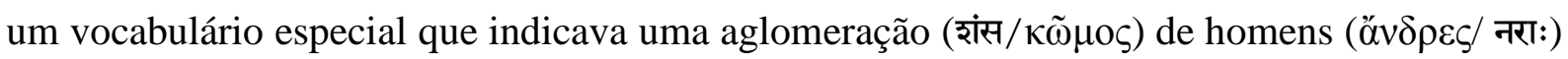
e que, possivelmente, servia para distinguir essa atividade, mais mundana, de outros tipos de

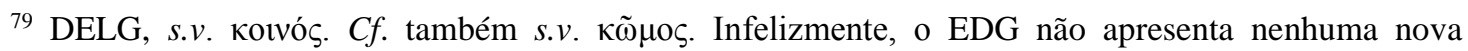
sugestão e é, de fato, para este item, bastante incompleto.

${ }^{80}$ Distinto, portanto, do vocativo जना (jana), que seria equivalente ao grego $\varphi \tilde{\omega} \varsigma$.

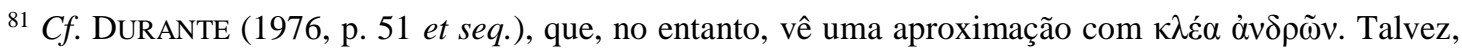
ainda, relacionado com o lat. cēnsēo, $c f$. MALLORY e ADAMS (2006, p. 356), ECKERMAN (2010) e M. DURANTE, 'Greco K $\Omega \mathrm{MO}$, ANT. IND. ŚANSA-, in Studi linguistici in onore di Tristano Bolelli (não consultado por mim). É

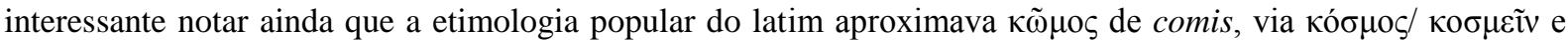

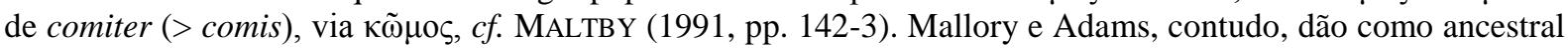
de $\kappa \tilde{\omega} \mu \mathrm{s}$, o radical IE *kem-, com um sentido aproximado de "comprimir" (em um monte, em uma bola, p. ex.) e, daí, interpretam o termo grego como "crowd", "multidão", i.e., um grupo de pessoas "comprimidas", ou seja, "reunidas". Notável também é a relação desses radicais com o termo grego normalmente traduzido por "glória",

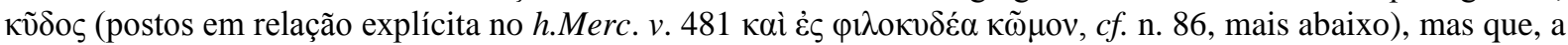
bem da verdade, é melhor traduzido por "proeminência", "vantagem”, "poder" etc. o que se adequa ao sentido do sânscr. शून (śūna), "inchado", “crescido", “aumentado”, por meio do radical श्वि (śvi-) ou श्वा (śvā-), como p. ex. em श्वयस् (śvayas), "poder", possivelmente via um radical do PIE tipo *k̂kwei(d)-, que está na origem, também, do

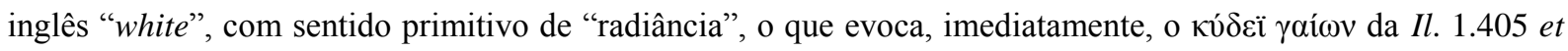
alibi.

\footnotetext{
${ }^{82}$ DuRANTE (1976, p. 51 et seq.) e $c f$. também a bibliografia acima.
} 
festividades relacionadas com o culto e as festas dedicadas aos deuses ${ }^{83}$. Importantíssima, a esse respeito, torna-se então a conclusão a que Durante chega, sobretudo porque ela resume uma grande parte do argumento que desenvolveremos a seguir. Segundo ele,

\begin{abstract}
O substantivo śámssa- continua uma forma pré-histórica *kómso-, a qual corresponde

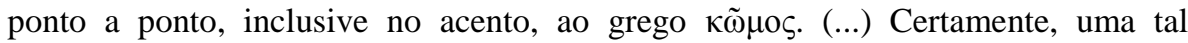
correspondência, até hoje não proposta por ninguém, poderá ser tida por

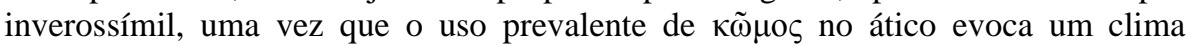
diferente da celebração dos heróis: [o termo] evoca aquele cortejo festivo e desenfreado que sai do simpósio, mas que, outrossim, deveria fazer parte daquela obscura liturgia popular que constituiu o primeiro embrião da $\kappa \omega \mu \omega \delta i ́ \alpha . ~ \underline{\mathrm{Na}}$ realidade, seria uma verdadeira e real mistificação dos dados documentais, se se tomar como significado primário da palavra o conceito de procissão ou de cortejo festivo. Ao contrário, o valor mais antigo dedutível dos textos é aquele de uma celebração dos feitos ou pessoas egrégias. Isso se deduz de uma série conspícua de testemunhos, sem se excluir a atestação mais antiga, onde $\kappa \tilde{o} \mu о \varsigma$ é qualificado

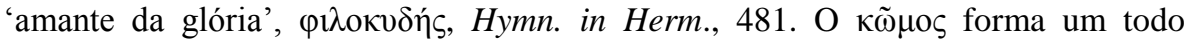
integral com o epinício pindárico $(O$. IV, 9 , etc.) e, em Píndaro, o verbo derivado $\kappa \omega \mu \alpha ́ \zeta \omega$ não significa outra coisa se não 'celebrar', seja o vencedor (N. II, 24) ou o seu triunfo $(P$. IX, 89). Significados afins encontram-se no discurso ático elevado;

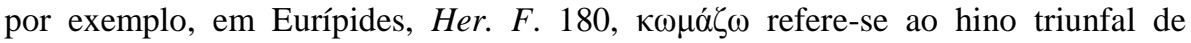

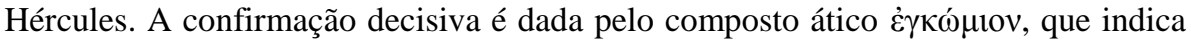
um elogio em prosa ou verso e, mais especificamente, como o $\kappa \tilde{\omega} \mu \mathrm{s}$ pindárico, a celebração da vitória de um atleta (Plat., Leg., p. 822b. Athen., p. 537f). A passagem de 'celebração festiva' a 'festa, cortejo triunfal', é comum ao quase sinônimo

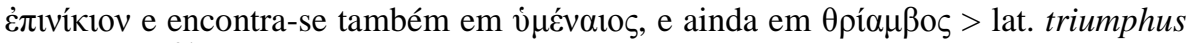
[grifo meu]..$^{84}$
\end{abstract}

Com base, então, neste panorama geral e mais amplo, poderemos tentar olhar para as formas entextualizadas das obras vocais gregas em busca de um modelo que nos permita entender melhor que tipo de frame o uso do termo $\kappa \tilde{\omega} \mu \mathrm{o} \varsigma$ seria capaz de invocar ao ser empregado de diversas formas desde a épica homérica até o tempo de Píndaro.

\title{
2.2. $\mathrm{O} \kappa \tilde{\omega} \mu \mathrm{s}$ na épica e na poesia do período arcaico
}

Com base nas balizas preliminares estabelecidas na seção anterior, seria apropriado que começássemos nossa análise pela aparição mais antiga do termo no Hino Homérico a Hermes $^{85}$ :

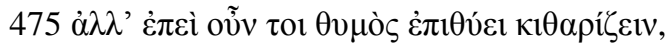

${ }^{83}$ Assim BREMER (1990, p. 55) e DURANTE (1976, p. 51 et seq.).

${ }^{84}$ DURANTE (1976, p. 53).

${ }^{85}$ A datação mais tardia do hino é aquela proposta por M.L. WEST (2003), c. 523 Para uma discussão completa e atualizada do problema, $c f$. VERGADOS (2012, p. 130 et seq.), que propõe uma data em torno do final do séc. VI É importante que se atente para o fato de que datar a composição do hino não significa datar a tradição que ele representa, certamente, por meio de sua dicção, assim, e.g., CÀssola (2006, p. 173) em sua excelente edição. 


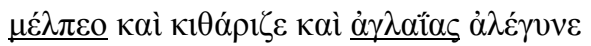

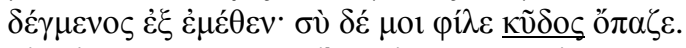

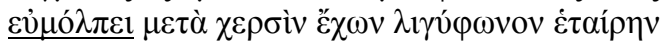

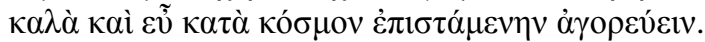

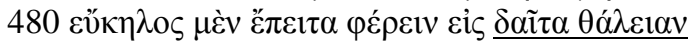

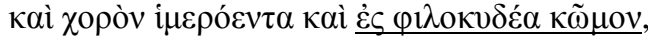

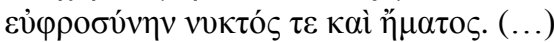

475 Agora, já que teu coração almeja com ardor citarizar,

canta-dança e citariza e das festas sê o patrono,

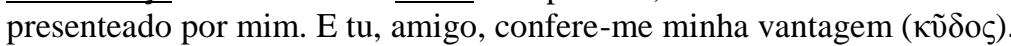

Canta-dança com graça ( $\varepsilon v j \mu o ́ \lambda \pi \varepsilon \imath$ ) tendo nas mãos estrídula consorte

que sabe falar belamente e de maneira bem decorosa.

480 De agora em diante, confiante [a] leves ao banquete festivo,

à dança que excita o desejo e ao kōmos que ama o kudos ${ }^{86}$,

um divertimento noite e dia.

Um dos aspectos mais interessantes dessa passagem é que, já no período de composição deste hino, a atividade do $\kappa \tilde{\omega} \mu$ os é conceitualizada como independente daquela

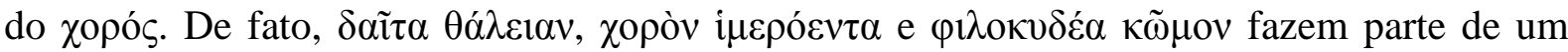
merismo que perfila diferentes aspectos de $\alpha \gamma \lambda \alpha \hat{i} \alpha$, "festa", e, embora aqueles não precisem, necessariamente, ser interpretados como atividades desconectadas umas das outras ${ }^{87}$, nada impede que assim também se leia essa passagem. Na verdade, qualquer uma das leituras convém à discussão, uma vez que a cena representada no hino, como sói ocorrer, apresentanos um cenário que é uma generalização acerca de todo tipo de celebração humana ${ }^{88}$. Dessa forma, o perfilhamento de diversas características salientes de $\dot{\alpha} \gamma \lambda \alpha \hat{i} \alpha$ pelos versos subsequentes nos oferece uma visão privilegiada das características mais prototípicas da atividade denotada pelo conceito "FESTA" no pensamento arcaico, ao menos de acordo com o

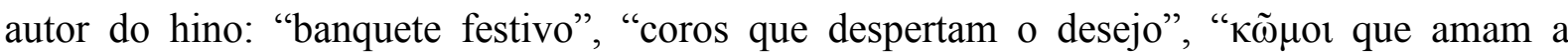

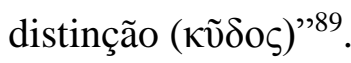

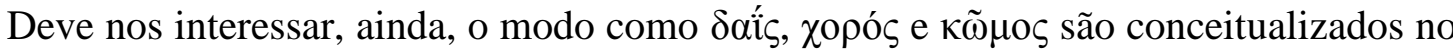

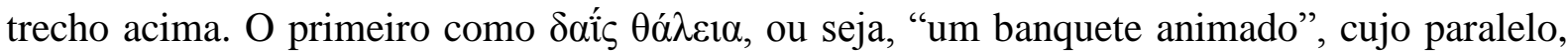

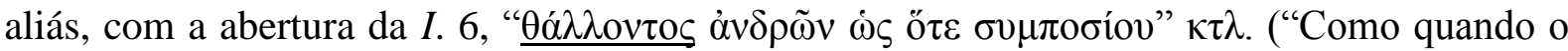

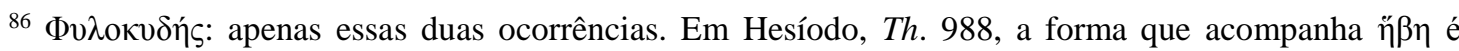

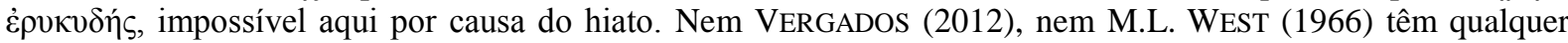
coisa a dizer sobre ambos epítetos. 'E $\rho$

${ }^{87} \mathrm{Cf}$., por exemplo, as diferentes fases do banquete no trabalho homônimo de Xenofonte.

${ }^{88}$ MULLEN (1982, p. 9 e 11), "The gods after all can be trusted not to make a poor show of it because of lack of skill or resources (...). These early hexameter epiphanies of immortal choreia have a peculiar authority about them which is to be respected". Assim também RICHARDSON (2011, p. 31), "Although Hermes is a soloist, the double comparison to a sequence of songs by young men at feasts points toward a communal activity on the plane of contemporary human society, although this is of a more personal and spontaneous kind than choral song".

${ }^{89}$ Como eu não pressuponho de antemão que possamos ter uma ideia do conceito implicado pelo item lexical $\kappa \tilde{\omega} \mu$ o e seus derivados, deixarei estas palavras sem tradução, apenas transliteradas nos trechos traduzidos. 


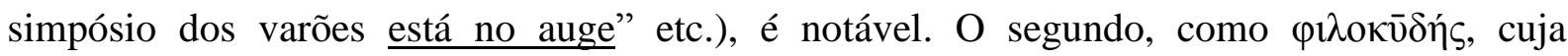
colocação ${ }^{90}$ no $v$. 375, como epíteto de $\eta \Uparrow \beta \eta$, autoriza-nos a entender o adjetivo em seu sentido

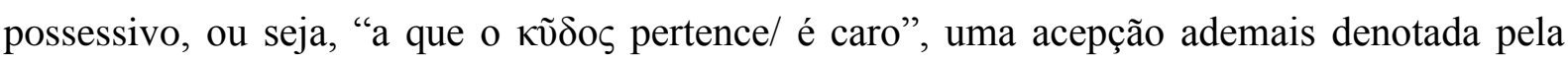
relação de entrincheiramento ${ }^{91}$ entre o uso homérico de $\varphi$ íno ${ }^{\prime}$ na qualidade de possessivo ${ }^{92}$ e vários adjetivos, e a qual, a bem da verdade, me parece salientada pela colocação de $\varphi$ í̉ $\varepsilon$

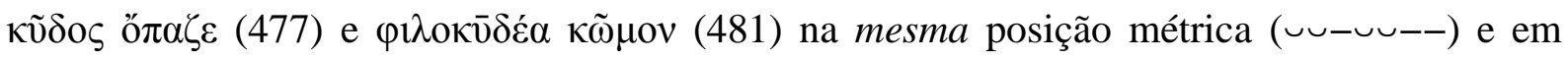

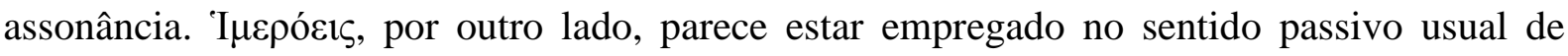

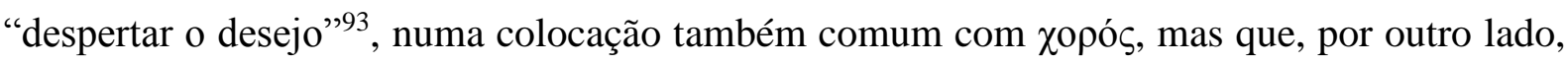

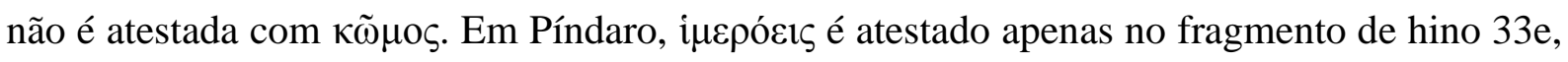
referindo-se à progênie de Leto, porém nunca aparece nos epinícios, onde se prefere o

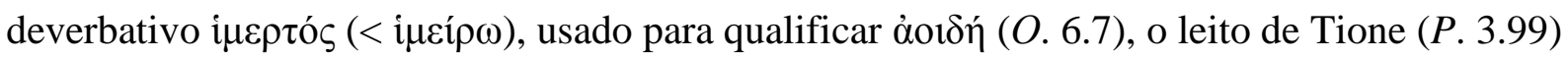

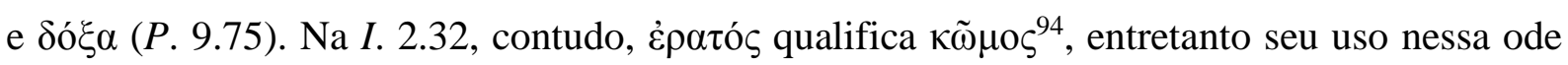
provavelmente deve ser um indício para que a entendamos a partir do frame SIMPÓsIO, o que estaria em consonância com a atmosfera claramente pederástica da mesma.

É muito difícil - certamente, porque se trata de uma generalização -, entender

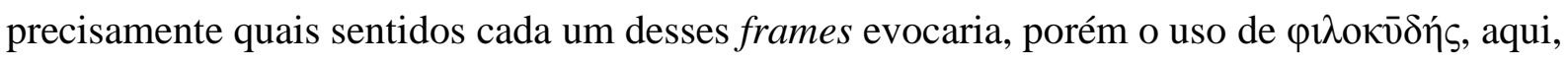
pode nos fornecer uma pista crucial para entender o uso de $\kappa \tilde{\omega} \mu \varsigma_{\varsigma}$ em outras passagens da literatura grega e, sobretudo, nas odes pindáricas. Por hora, seria importante notar que, em Píndaro, $\kappa \tilde{\delta} \delta o \varsigma^{95}$ conta quase o mesmo número de ocorrências de $\kappa \lambda \dot{\varepsilon}$ o $\varsigma^{96} \mathrm{e}$, ao menos em

${ }^{90}$ Defino colocação, nos termos da LC, como a formação de uma expressão complexa por meio do entrincheiramente de dois itens lexicais que formam uma combinação prototípica em uma determinada língua. Por exemplo, em português, o substantivo "louça" é usado na expressão fixa como "lavar a louça", mas nunca * “dar banho na louça" (ao contrário da possibilidade de se dizer, "eu vou me lavar" e "eu vou me banhar"), dessa forma dizemos que "louça" aparece em português em colocação com o verbo "lavar". Colocações podem ser únicas ou mais ou menos prototípicas.

${ }^{91}$ Vide o glossário. Para mais detalhes sobre o entrincheiramento semântico, $c f$. LANGACKER (2008, pp.

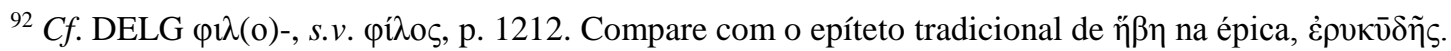

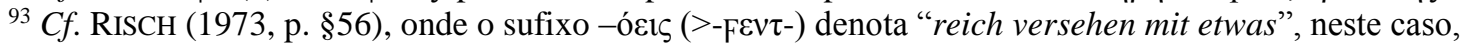

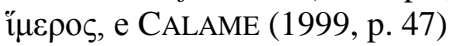

${ }^{94}$ E apenas aqui, até onde pude avaliar. THUMMER (1968/1969), embora discuta o adjetivo $\mu \varepsilon \lambda \imath \kappa o ́ \mu \pi \omega v$, em colocação com ảoı $\delta$, parece ignorar a raridade da colocação.

95 Note que o sentido primitivo de $\kappa \tilde{\delta} \delta$ s, sistematicamente traduzido por "glória", é, de fato, "poder mágico que emana ou é conferido a alguém" e que, portanto, atrai a vista; daí, "vantagem", "proeminência" que "salta aos olhos" ou "distingue" (nesse caso, a vantagem/ privilégio/ poder pedido por Hermes é o dom da profecia); pertence, frequentemente, ao campo da visão, ao passo que $\kappa \lambda \dot{\varepsilon}$ $\varsigma$, "glória" propriamente dita, pertence ao campo da audição. $C f$. n. 96.

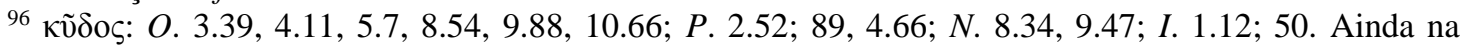

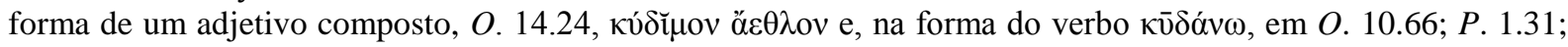

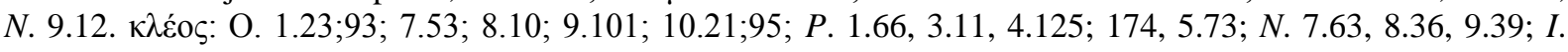

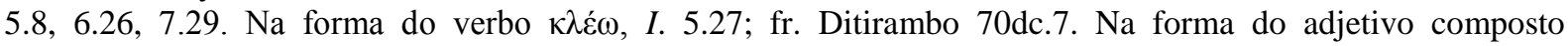

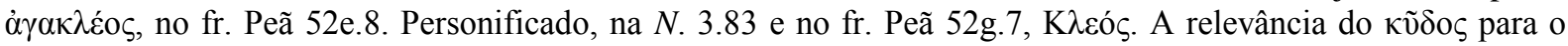
epinício pindárico foi discutida com muita propriedade, e dentro da sua metodologia da poética cultural, por 
duas passagens, na $O .4 .8-12$ e 5.1-8, aquele termo aparece diretamente associado ao $\kappa \tilde{\omega} \mu о \varsigma$ na qualidade de uma oferta preciosa à cidade:

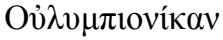

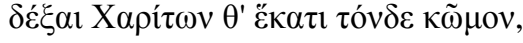

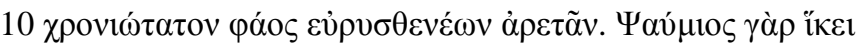

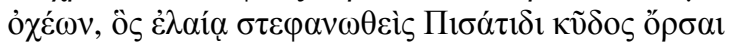

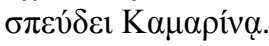 \\ próprio de um vencedor olímpico ${ }^{97}$ \\ recebe, em nome das Graças, este kōmos, \\ 10 oportuníssima ${ }^{98}$ luz de sobrepujantes virtudes, pois ele vem da quadriga \\ de Psaumis, que, coroado com a pisana oliveira, kudos anseia \\ por soerguer a Camarina.
}

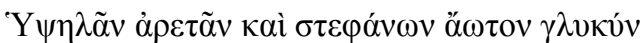

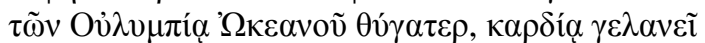

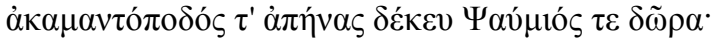

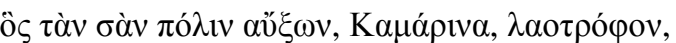

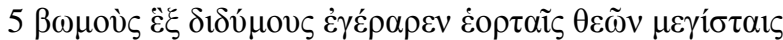

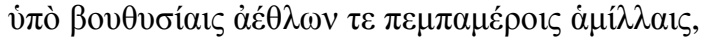

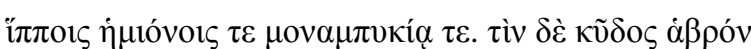

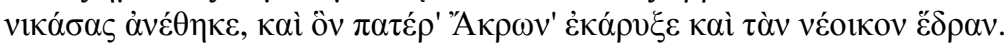

Das supinas virtudes e das guirlandas esta doce e fina-flor, dentre todas em Olímpia, ó Filha do Oceano, com alegre coração, recebe e, do carro de pés infatigáveis de Psaumide, as ofertas; $---$

5 ele que, tua cidade, nutriz do povo, exaltando, ó Camarina, os seis gêmeos altares honrou nas grandes festas dos deuses com bovinos sacrifícios e, nos quinquídios jogos e corridas, com cavalos, com mulas e uníjugos carros. Para ti precioso kudos, após vencer, dedicou, e Ácrão, seu pai, fez proclamar, e o recém fundado assento.

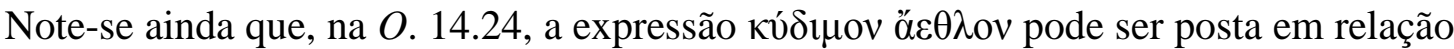

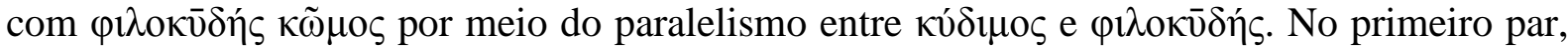

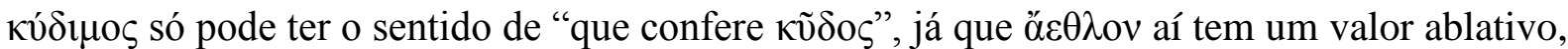
isto é, ele é a fonte da "distinção" obtida com a vitória nos jogos. No segundo par, no entanto,

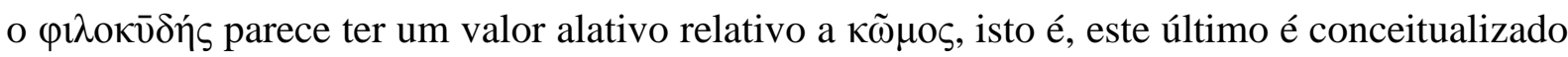

KURKE (1998), que recupera o sentido por mim aludido aqui e o relaciona a uma economia do poder talismânico conferido pelo atleta vitorioso à sua cidade.

${ }^{97}$ Cf. n. 160.

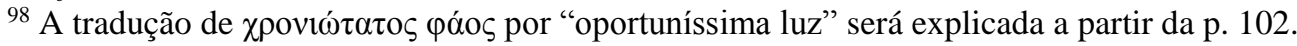




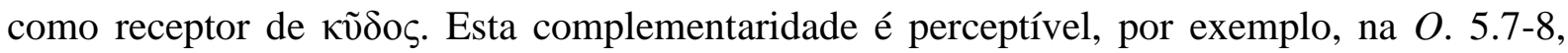

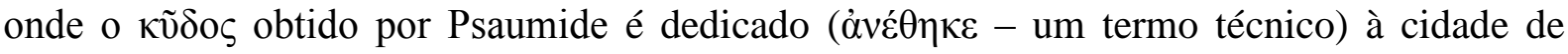

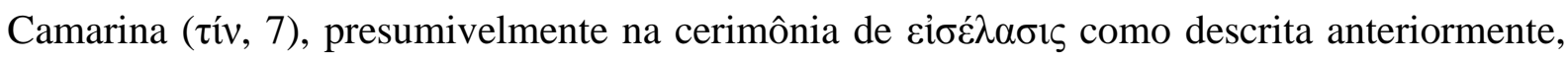

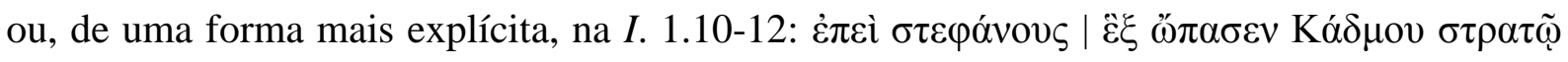

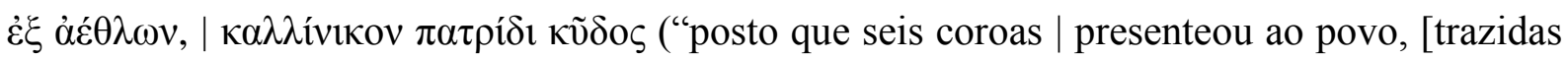
dos jogos de Cadmo: | um kudos vitorioso à pátria]). Nessa e em outras passagens, fica claro

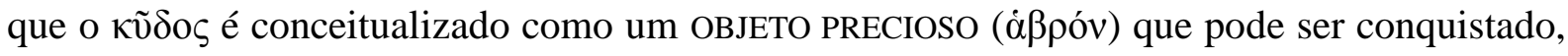
mantido ou obtido de várias maneiras ${ }^{99}$ e que pode, por isso mesmo, ser entesourado e

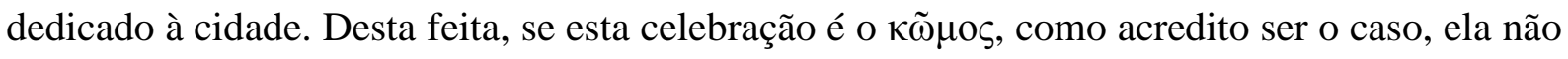

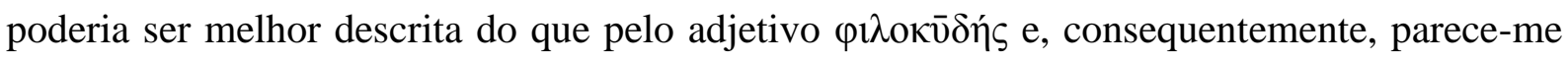
atraente considerar o fato de que este epíteto possa, já na época do Hino Homérico a Hermes, ter sido usado como uma dica (cue) para evocar o frame CELEBRAÇÃo DE VITÓRIA no qual o sentido de $\kappa \tilde{\omega} \mu \mathrm{s} \varsigma$ poderia ser determinado.

Um outro testemunho importante é aquele da cena da "cidade em festa", no Escudo de Hércules, atribuído a Hesíodo:

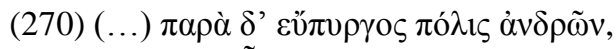

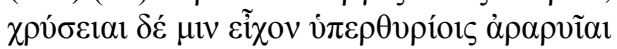

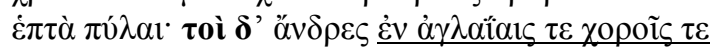

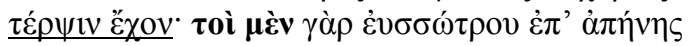

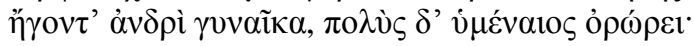

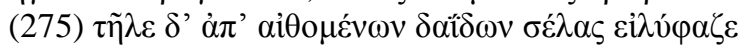

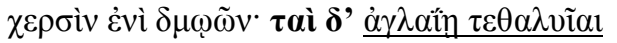

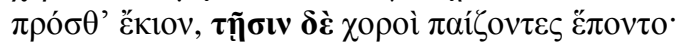

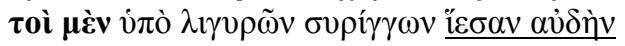

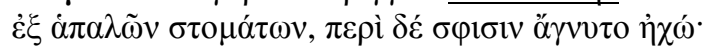

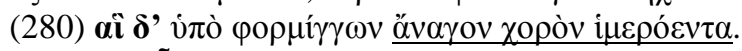

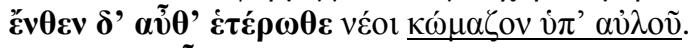

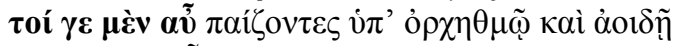

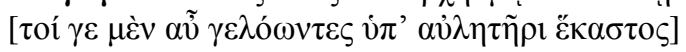

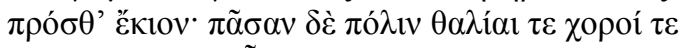

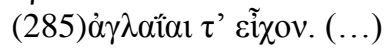

(270) (...) e logo ao lado, uma cidade de homens, de altas torres: protegiam-na, afixados aos lintéis, sete dourados portões: deste lado varões em pompa e em danças folgavam; acolá, sobre um carro de mulas de boas rodas, a esposa era levada ao marido; muito o himeneu fremia, (275) e alta rolava a chama das tochas acesas nas mãos das cativas. Estas, embevecidas sob seu brilho, iam à frente; seguiam-lhes coros dançando.

Esses, sob estrídulas siringes, soltavam a voz de suas bocas macias e a sua volta reverberava o eco. (280) Essas outras, ao som da cítara, puxavam amável dança. E aí, mas doutro lado, jovens faziam o komos ao som do aulos: e alguns dançavam acompanhados pelo coro e a canção,

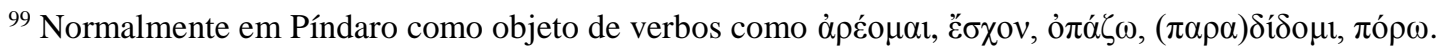


[e alguns rindo, acompanhados de um auleta] ${ }^{100}$

à frente iam. E por toda a cidade festas e danças

(285) e espetáculos havia.

Nessa écfrase, é possível distinguir a cena de um casamento, enfocada de diferentes

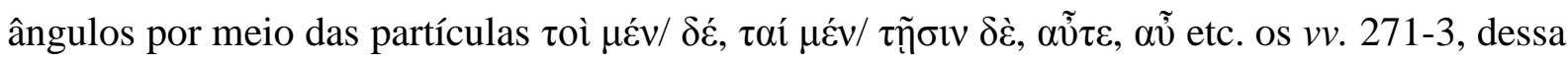
forma, servem como um "orienting preview" do que se seguirá101. Em primeiro lugar, a cidade é colocada em perspectiva e, em seguida ( $\tau$ oì $\delta, v .272$ ), a festa como um todo,

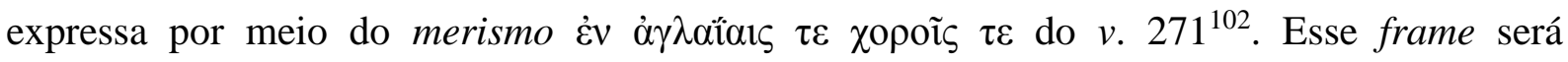

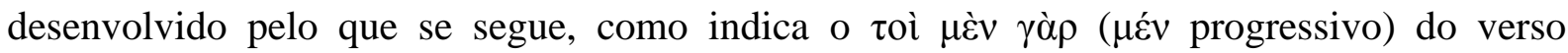
seguinte. A atenção da audiência é atraída para a cena do varão puxando o carro, onde vai a noiva, e para os cantos de himeneu que a circundam. A cerimônia dá-se ao cair da noite, como usual, e mais detalhes tradicionais são acrescentados à cena, como o brilho da chama nas mãos das cativas, que abrem caminho, indo à frente, embevecidas pelo luxo da festa ( $\alpha \gamma \lambda \alpha i \tilde{\alpha} \alpha$, v. 276). Entre elas e o carro da noiva vão dois coros, um masculino ( $\tau$ oì $\mu \grave{\varepsilon} v, 278$ ), provavelmente de meninos, como se deduz pelo tom de voz, adequado às siringes, e pela menção às "bocas macias" (278-9); o outro feminino, provavelmente de meninas, ou de moças, companheiras da noiva, que dançam ao som da cítara. Como no Hino a Hermes, a

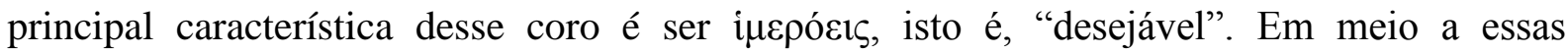
festividades ('้̌ $\left.v \varepsilon v \delta^{\prime}, 281\right)$, mas dessa vez num outro lugar que não o cortejo nupcial ( $\alpha \tilde{\tilde{u}} \theta^{\prime}$

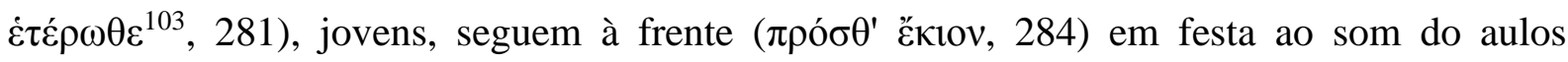

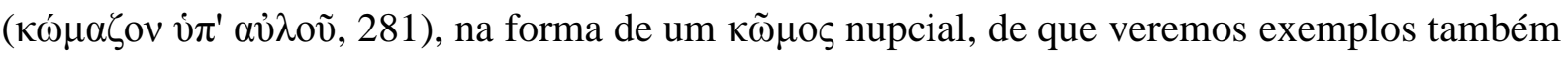
na tragédia e na comédia. Finalmente, numa estrutura circular, o preview dos $v v$. 271-3 é

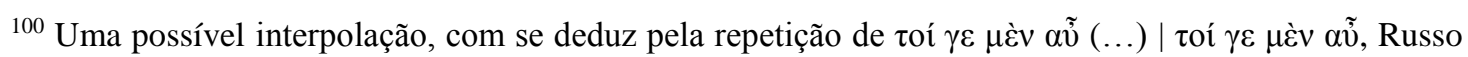
1950, p. 149)

${ }^{101}$ Para usar o termo de BAKKER (1997, p. 87et seq.)

102 'A $v \delta \rho \varepsilon \varsigma$ aqui apenas enfoca a cena ou do ponto de vista dos que nela têm interesse, supondo-se uma audiência provavelmente masculina, ou, se preferirmos, o faz a partir de uma visão masculina da cena, já que a cidade é descrita, como de costume, como $\pi$ ó $\lambda \iota \varsigma \grave{\alpha} v \delta \rho \tilde{\omega} v$ (v. 270). São os homens que derivam prazer da festa

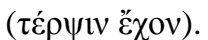

${ }^{103}$ RUSSO (1950, p. 148) não tem razão ao dizer que "Unire, comme di solito si fa, questa scenetta del

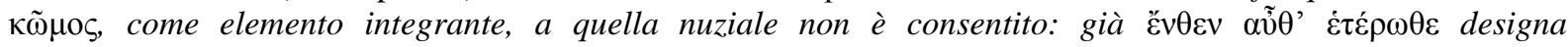
stilisticamente um buon stacco", porque "้̌v $\theta \varepsilon v \delta$ ' claramente alude ao mesmo quadro, isto é, o da cidade em festa pelo casamento e, nesse sentido, tem a função progressiva de "e também aí". A imagem do casamento, além do mais, contrabalança aquela da guerra nos $v v$. anteriores: isto é, toda a cidade está em festa por causa do casamento, que representa vida e renovação, e, dessa forma, todos os seus habitantes o celebram. A cidade, além do mais, deve ser Tebas e o casamento alude, muito provavelmente, às bodas de Cadmo e Harmonia. Por isso mesmo $\alpha \tilde{v} \theta^{\prime} \dot{\varepsilon} \tau \dot{\varepsilon} \rho \omega \theta \varepsilon$ não pode se referir a uma cena externa à da cidade (como a que virá a seguir, a partir dos $v$. 285, do lado de fora), o que, ademais, seria uma transição muito brusca da narrativa, sobretudo em virtude da estrutura circular do trecho. Obviamente a interpretação de Russo é influenciada pela sua noção de $\kappa \tilde{\omega} \mu$ o $\varsigma$ como "una allegra sfilata de beoni" que, presumivelmente, não estaria de acordo com a dignidade de um casamento. 
recapitulado pelos $v v$. 284-5, o que demarca o limite dessa narração e indica a transição para um outro frame.

Quando esta cena é comparada com aquela do Hino a Hermes, ela é capaz de nos

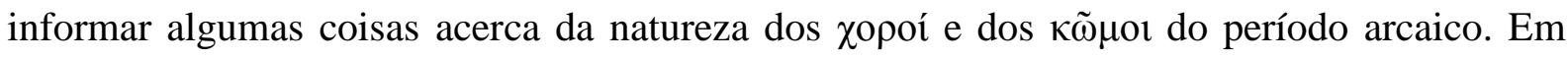
primeiro lugar, é preciso notar que, dos dois coros, o de meninos dança sob o som da siringe, que descreve um instrumento de sopro, o qual podia ser uma flauta simples, como um pífaro, até um tipo conhecido como "flauta de Pã" ( $\pi 0 \lambda v \kappa \alpha ́ \lambda \alpha \mu \circ \varsigma \sigma \tilde{\rho} \iota \gamma \xi)$. Uma identificação precisa não é necessária, uma vez que a siringe esteve sempre associada a performances musicais amadoras, folclóricas ou, então, ao mundo rústico dos pastores ${ }^{104}$. Seu registro agudo, aqui

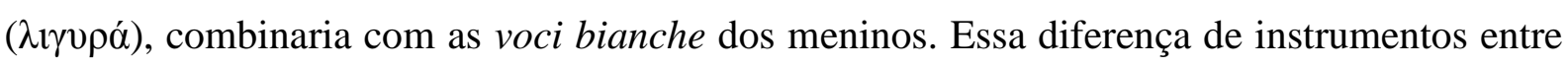

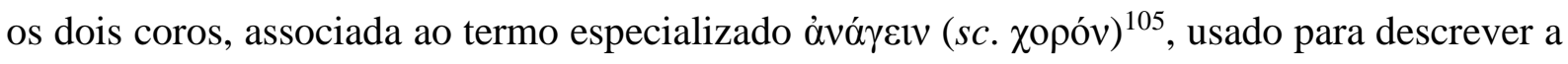
atividade das moças, é importante e nos faz pensar em uma performance mais técnica por parte delas, muito provavelmente ensaiada.

A atividade da dança de ambos os coros, a despeito da evidente diferença de nível técnico entre eles, bem como do $\kappa \tilde{\omega} \mu \mathrm{o}$, no v. 282, é sumariada pelo mesmo verbo, $\pi \alpha i \zeta \zeta \omega$, cujo sentido mais prototípico é "brincar", mas que também pode ser conceitualizado de maneira diferente dentro dos frames TOCAR UM INSTRUMENTO (como, aliás, no inglês "to play"), e DANÇAR, como no português de algumas regiões do Brasil. Em grego, no entanto, não está subentendida qualquer ideia de "informalidade" que contraste o uso desse verbo com

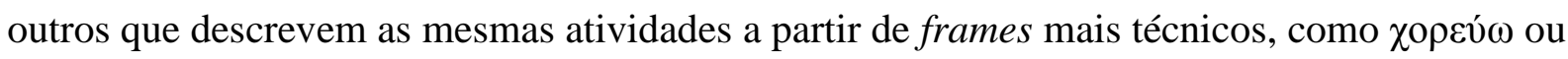
$\mu \varepsilon ́ \lambda \pi \omega$, o que desautoriza a tradução desse verbo por "foliar", ou semelhantes, quando apareça empregado junto a $\kappa \tilde{\omega} \mu \mathrm{s}$, uma prática bastante difundida por tradutores e comentadores que

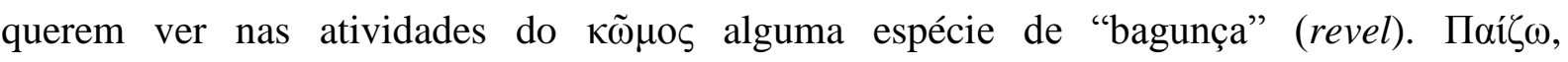
conceitualizado dentro do frame DANÇAR, salienta apenas a sensação de alegria e divertimento oriundos de atividades como a dança e a música.

No outro quadro da mesma cena, vemos o $\kappa \tilde{\mu} \mu \varsigma_{\zeta}$ de jovens (véoı) ${ }^{106}$. Mas por que a atividade desse grupo é descrita separadamente? Possivelmente porque, em primeiro lugar, deve haver uma diferença no tipo de performance denotada pelo que os jovens estão fazendo quando comparado aos dois coros, isto é, há um corte duplo aqui, claramente delimitado,

${ }^{104}$ MATHIESEN (1999, pp. 222-5).

${ }^{105}$ Como, também num contexto de himeneu muito instrutivo para essa passagem do Escudo, na fala de

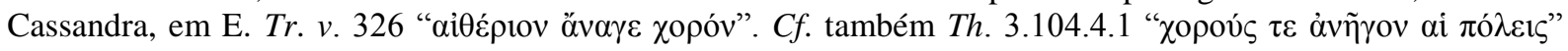
acerca dos coros em Delos.

${ }^{106} C f$. a semelhança com os versos iniciais da $N$. 5 que, segundo os coralistas, seria uma evidência

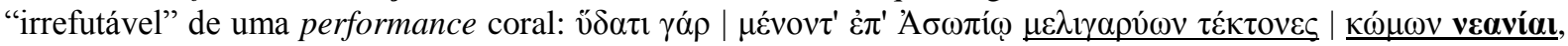

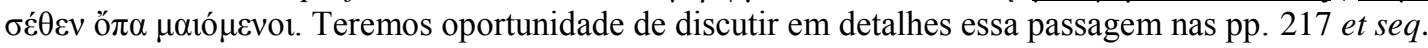


entre atividade coral, profissional (moças) e amadora (meninos), de um lado, e performance comástica, como quer que a queiramos interpretar, de outro. Em segundo lugar, há claramente uma divisão entre os que acompanham o cortejo da noiva e aqueles que festejam em volta, e esta divisão diz respeito também ao modo como nele participam. Acredito que se pode dizer

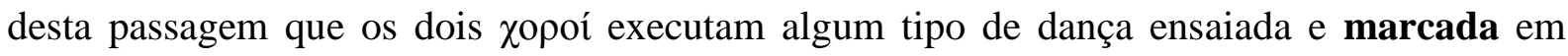
relação à dança executada pelos jovens, esses últimos, provavelmente amigos e familiares do noivo. Uma outra diferença importante diz respeito ao acompanhamento musical: enquanto no cortejo tínhamos siringe para as crianças e forminge para as moças, aqui temos o aulos para os rapazes. O uso de diferentes instrumentos pode perfilar e servir de indício acerca dos diferentes níveis de especialização da dança executada e, consequentemente o que sabemos sobre esses instrumentos e a que ocasiões eles eram prototipicamente associados deve importar, porém não necessariamente o seu uso em situações mais reais, uma vez que nosso objetivo é definir práticas idealizadas de performance a partir das quais as práticas reais possam ser conceitualizadas; por isso mesmo, falamos de um MCI, ou seja, um Modelo Cognitivo Idealizado. Por fim, é interessante que aqui a siringe, a forminge e o aulos pareçam bem integrados ao $\kappa \tilde{\omega} \mu \mathrm{s}$, como, aliás, nos epinícios pindáricos, onde os dois últimos aparecem mormente juntos ${ }^{107}$.

Consequentemente, havendo rejeitado o uso de $\pi \alpha i \zeta \omega$ como "foliar" dentro do frame

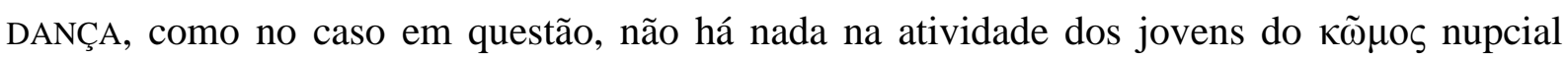
visto nesta passagem do Escudo que denote "bagunça", "procissão de bêbados" ou "folia" e mesmo o " $\gamma \varepsilon \lambda$ ó $\omega \nu \tau \varepsilon \varsigma$ " do verso (possivelmente interpolado) indica apenas a atmosfera de alegria comum aos casamentos e às celebrações de uma cidade em festa. Na verdade, o $\kappa \omega ́ \mu \alpha \zeta o v$ do $v .281$ recebe, de fato, uma definição na linha seguinte, por meio de uma técnica

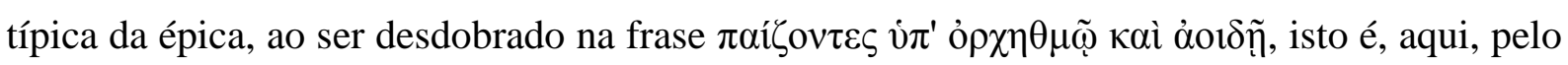
menos, $\kappa \omega \mu \alpha ́ \zeta \omega$ quer dizer exatamente isto, "divertir-se com o acompanhamento da dança e da música" 108 , o que está em harmonia com os resultados a que Eckerman chegou, de que os sentidos primários e secundários do termo e de seus derivados estão organizados sob o conceito de "CELEBRAÇÃO" a partir do qual diferentes aspectos podem ser perfilados de

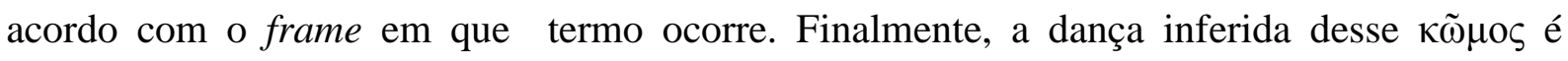
certamente de um caráter informal e espontâneo e nada tem a ver com a atividade

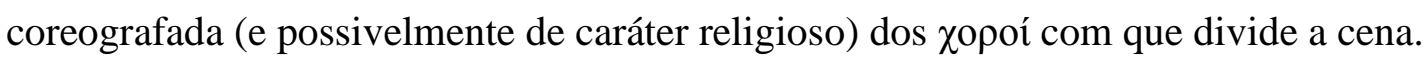

${ }^{107}$ Cf., e.g., O. 2.50-1.

${ }^{108}$ Não "em meio a", o dativo aqui é claramente comitativo, $C f$. LSJ, s.v. vंđó, 4. 
Posto que veremos Píndaro e Baquílides um pouco mais adiante, os exemplos de $\kappa \tilde{\omega} \mu \mathrm{o} \varsigma$ e seus derivados na lírica arcaica não são abundantes. Para ser mais preciso, eles contam apenas três, todos sem contexto suficiente para que deles possamos tirar informações muito úteis. O primeiro é o fragmento 374 CAMPBELL de Alceu, de apenas uma linha:

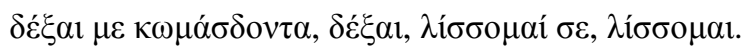

recebe-me enquanto kōmazō, recebe-me, eu te imploro, eu te imploro.

O segundo é o fr. 373 PMG de Anacreonte,

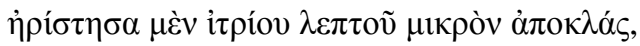

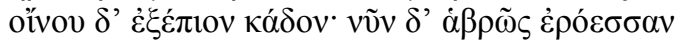

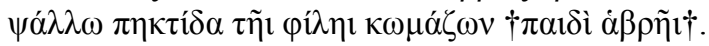

lanchei um pedacinho de fina bolacha de gergelim mas de vinho bebi um jarro. Já agora delicadamente uma linda harpa dedilho, enquanto kōmazō com a minha ¿tenra menina?.

E, por último, temos outro fragmento de Anacreonte, o 442 PMG, dado pelo escoliasta em seu

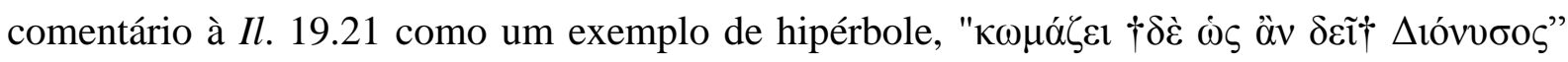
(“e faz o kōmos ¿como se fosse Dioniso?”. Em todas essa passagens é possível, mais uma vez,

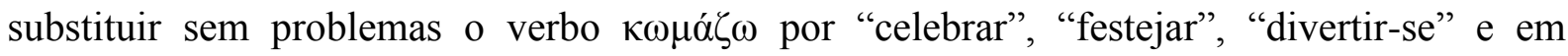
nenhuma delas há a noção de baderna ou comportamento violento.

O fragmento de Alceu, aliás, nos fornece, pela primeira vez, um exemplo do $\delta \dot{\varepsilon} \xi \alpha 1-$ $M_{o t i v}{ }^{109}$ no contexto simpótico da hetairia lésbia do séc. VII ${ }^{110}$, e típico das cenas do simpósio ateniense do séc. $\mathrm{V}$, e que também figura de maneira proeminente nas odes pindáricas. Infelizmente, é impossível suprir-lhe um contexto ${ }^{111}$. De qualquer maneira, poderíamos inferir, pelo aspecto do particípio, que a persona loquens implora pelo acesso à

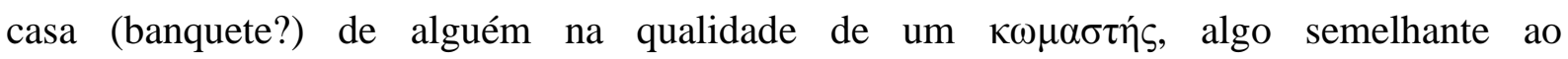
$\pi \alpha \rho \alpha \kappa \lambda \alpha v \sigma i ́ \theta v \rho o v$ como descrito, por exemplo, por Platão e Xenofonte ${ }^{112}$.

109 SCHADEWALDT (1966, p. 274). Vide também BUNDY (1962, p. 30 et seq.). Para uma interpretação mais em linha com argumentação desenvolvida aqui, vide HEATH (1988, p. 180 et seq.).

${ }^{110}$ Sobre esse fr. e a sua associação com o simpósio, RÖSLER (1980, p. 244 et seq.)

111 Tanto Hefestião (7, p. 268 CONSBRUCH) quando o $\Sigma$ a Aristófanes (v. 302, p. 342 Dübner) o citam apenas como o exemplo de um tetrâmetro jâmbico acatalético, sem fornecer quaisquer outros detalhes.

112 Platão, Banquete, 176a et seq. Note a semelhança da fala do eu-lírico em Alceu com o pedido de

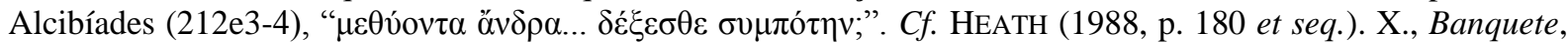
2.1 et seq. Por questão te tempo e espaço, preferi não comentar essa passagens, muito embora elas corroborem o argumento desenvolvido aqui. 
O fragmento de Anacreonte, por outro lado, parece descrever uma espécie de "simpósio particular" do ponto de vista dos celebrantes ${ }^{113}$, e não há qualquer alusão à procissão ou folia; ao contrário, a cena é calma e relaxada $(\dot{\alpha} \beta \rho \tilde{\omega} \varsigma \ldots \psi \alpha \alpha ́ \lambda \lambda \omega)^{114}$, ainda que a

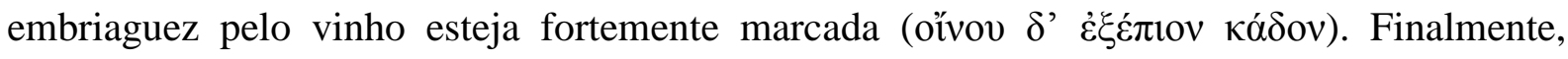

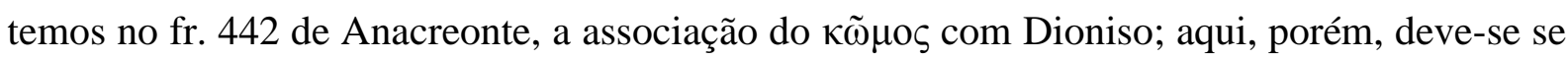
salientar que, como em outras passagens, não há qualquer evidência que nos permita

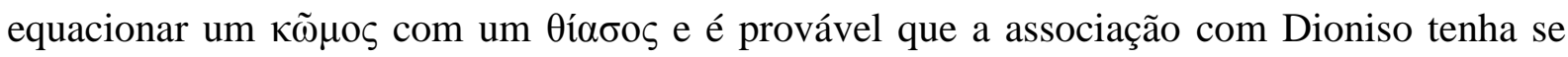
desenvolvido não só pela presença do vinho em contextos festivos, mas também pela qualidade liminar do comasta em sua qualidade de "candidato" à festa na casa de outrem. $\mathrm{Na}$

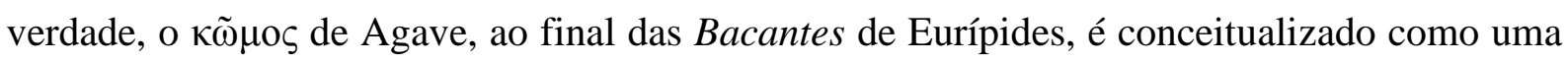
procissão de vitória, o que torna a cena ainda mais pungente ${ }^{115}$. Além do mais, se retornarmos à cena do Hino Homérico a Hermes, veremos que lá é Apolo, e não Dioniso, que está caracterizado como patrono dos $\kappa \tilde{\omega} \mu \mathrm{o}$, o qual é convidado a comparecer com a sua forminge, talvez na mesma qualidade de citaredo que lhe é atribuída na cena do Hino Homérico a Apolo, que, além de um coro, parece incluir também um $\kappa \tilde{\omega} \mu$ o formado por Ares e Hermes ${ }^{116}$. A esse respeito, me parece intrigante que Píndaro, na $P$. 5.20-3, refira-se ao $\kappa \tilde{\omega} \mu$ o como "brinquedo de Apolo" em uma posição enfática, em acavalamento no início do epodo.

Na elegia, o uso de $\kappa \tilde{\omega} \mu$ os restringe-se à Teognideia ${ }^{117}$, mas aí todos os exemplos parecem confirmar o modelo que propormos para aquele substantivo, ou seja, um que se aproxima muito do nosso próprio conceito de FESTA, algo evidente já na primeira aparição da palavra (1.829-30), onde $\kappa \tilde{\omega} \mu$ os é usado numa clara oposição a "lamento" em primeiro $\operatorname{lugar}^{118}$,

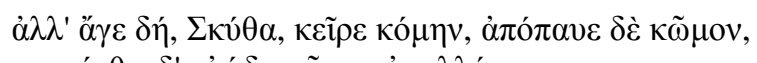

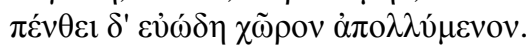

mas chega vai, Cita, corta tua cabeleira, vai parando com o kōmos

113 Ou do celebrante, já que a tenra menina pode ser apenas uma metáfora para a harpa. Cf. h. Hom.

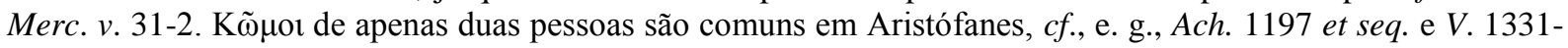
90, aí, no entanto, são facilmente explicáveis ou pelo enredo ou pela paucidade de atores disponíveis quando o coro ainda está ocupado, em meio à peça, com a performance das partes líricas.

114 Como acontece com os simposiastas na casa de Agatão, antes da chegada de Alcibíades, na passagem do Banquete mencionada na n. 112.

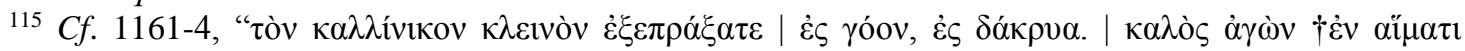

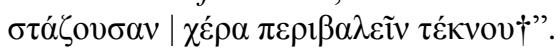

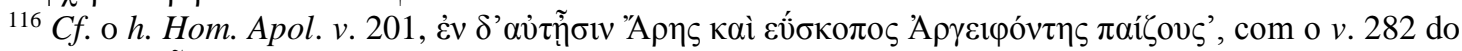

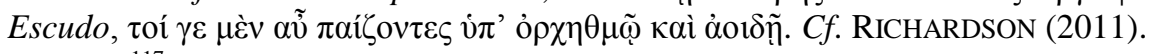

117 Não me interessam, obviamente, os exemplos helenísticos, como o fr. 348 Pfeiffer de Calímaco ou do Idílio III, de Teócrito por já estarem bem distantes das práticas arcaicas.

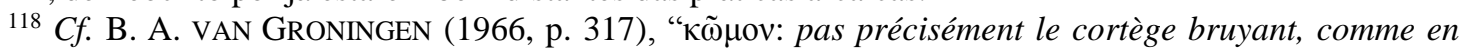
940 et 1046, mais la fête en général", grifo meu. 
e lamenta a fragrante terra que se está perdendo.

E à "guerra", em segundo (1.886-7), numa oposição que nos remete à cena do Escudo:

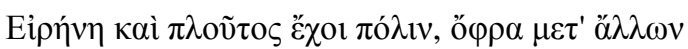

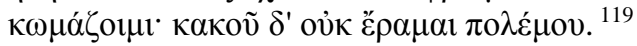

Que a paz e a riqueza reinem na cidade, para que com os outros eu possa kōmazeîn. Não gosto da guerra má.

Como veremos ao analisar o uso do termo por Aristófanes, o frame invocado por $\kappa \tilde{\omega} \mu$ o quase sempre está associado à presença da paz na cidade e à vida tranquila da juventude, sem as preocupações trazidas pelas responsabilidades do casamento e da

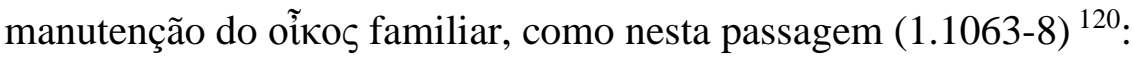

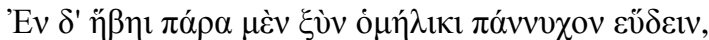

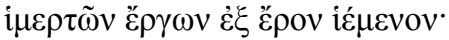

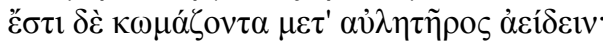

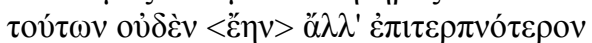

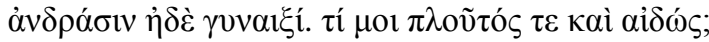

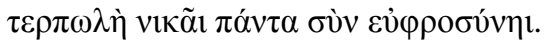

Na juventude dá para dormir com um camarada a noite toda saciando todo desejo de lúbricas refregas;

e dá para cantar com um auleta, festejando:

nada se compara a tais prazeres, mas sobremaneira gozosos o são para homens ou mulheres. Que me importam riqueza e respeito?

O Prazer a tudo vence aliado ao Divertimento.

Neste outro fragmento (1.939-40), porém, fica claro que o poeta emprega o termo $\kappa \tilde{\omega} \mu$ o provavelmente no sentido de $\pi \alpha \rho \alpha \kappa \lambda \alpha v \sigma i ́ \theta v \rho o v$, ao passo que o contexto do hic et nunc da ode parece ser o próprio simpósio, o que aponta para uma diferenciação entre

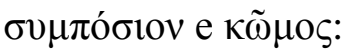

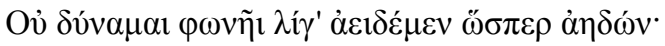

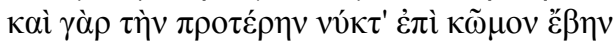

Não consigo cantar com a límpida voz de um rouxinol porque na noite de ontem fui à um kōmos.

O trânsito de uma festa à outra, tão enfatizada pelos textos do séc. V, e que, de certa forma, acabou por assumir uma maior centralidade na definição de $\kappa \tilde{\omega} \mu о \varsigma$, está bem definida

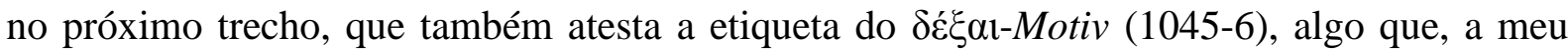

119 "Malgré le nombre relativement considérable de morceaux symposiaques, le verbe ne se retrouve ici qu'en deux endroits du premier livre, 1067 et 1207', VAN GRONINGEN, idem, p. 337.

120 “Ici le poète passe aux plaisirs symposiaques", B. A. VAN GRONINGEN (1966, p. 394). 
ver, desautorizaria uma leitura dessas linhas como irônicas, a qual atribuiria à persona loquens a intenção de forçar uma admissão, se preciso fosse ${ }^{121}$ :

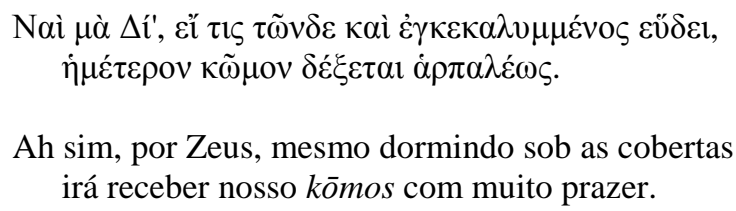

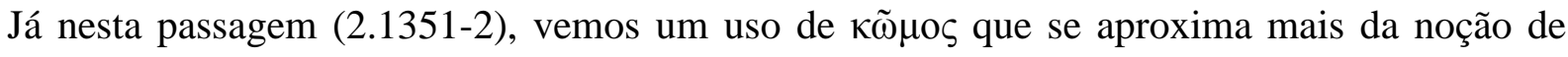
"festança", "folia", "bagunça", ("bebedeira"?). No entanto, é preciso que ela seja lida dentro da convenção, que agora já deve estar clara, de que a participação em $\kappa \tilde{o} \mu o ı$ era típica dos jovens ( $c f$. véoı no Escudo, mais acima), compondo uma atitude fácil e tradicionalmente alvo de ataque e reprimenda por parte dos mais velhos:

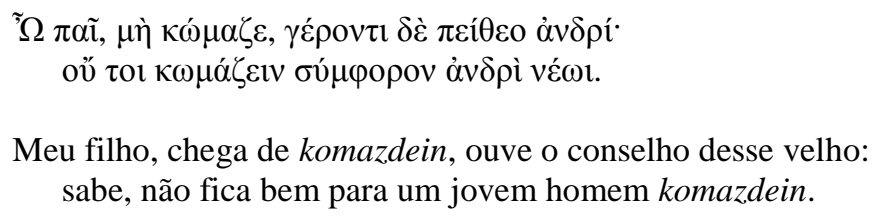

Ademais, o conselho do velho, aqui, talvez aluda ao risco de abuso sexual a que o jovem rapaz, possivelmente um membro da aristocracia megariana, deveria estar sujeito ao frequentar o simpósio, uma prática aludida em várias outras passagens da Teognideia ${ }^{122}$.

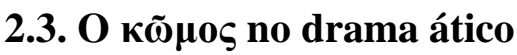

Não seria possível discutir em detalhes todos as acepções de $\kappa \tilde{\omega} \mu$ o na tragédia e na comédia do período clássico (o que por si só mereceria um estudo em separado ${ }^{123}$ ), no entanto, algumas observações são inevitáveis. Talvez a mais importante de todas é a de que se nota muito claramente uma tendência, no drama, em conceitualizar $\kappa \tilde{\omega} \mu \mathrm{s}$ a partir do frame SIMPÓSIO, que pode ser definido mais esquematicamente a partir daquilo que A. M. Bowie chama de "complexo do deipnon-simpósio-komos"124. Seja como for, em algumas passagens, o sentido de $\kappa \tilde{\omega} \mu$ o em sua acepção mais esquemática de CELEBRAÇão é o que ainda norteia e,

121 Como faz HeAth (1988, p. 181), ao relacioná-las às linhas 1041-2. Não há qualquer evidência que nos permita ler os fragmentos da Teognideia como se fossem contínuos ou como se se relacionassem a partir de um contexto comum.

${ }^{122} C f$., e.g., Eur. $C y c ., v v .577-84$

${ }^{123}$ Sobre a comédia, o estudo mais completo de que tenho conhecimento é aquele de PÜTZ (2007).

${ }^{124}$ BOWIE (1997, p. 2). 
de certa forma, chancela esse uso, na medida em que SIMPÓsIO poder ser visto como uma categoria subordinada de CELEBRAÇÃO. Uma outra observação crucial para o argumento que desenvolveremos quando falarmos do modo da performance epinicial, é a constatação de que,

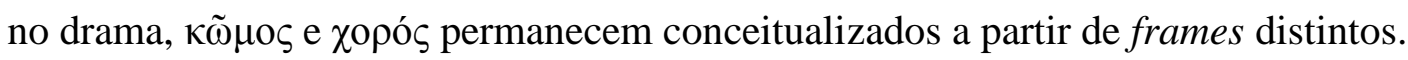

A esse respeito, é muito interessante notar que para Eurípides, escrevendo na segunda

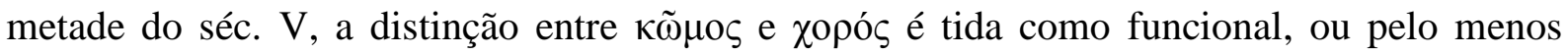
assim a vemos explicitamente formulada por uma passagem coral de Cresfontes $^{125}$ na qual o coro, em uma prece dirigida à Paz, manifesta seu temor de que a guerra civil os impeça, antes

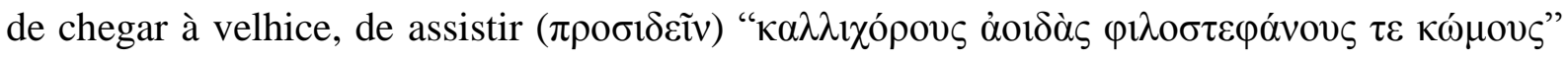
(“as canções dos belos coros e os kōmos a que as guirlandas são caras", vv. 7-8), um merismo

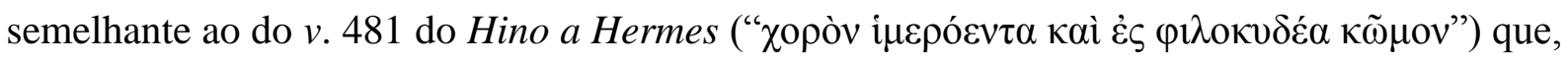
como já discutimos, perfila aspectos diferentes dentro da categoria CELEBRAÇÃO. Como já salientamos anteriormente ${ }^{126}$, em $\varphi \imath \lambda o \sigma \tau \varepsilon ́ \varphi \alpha v o \varsigma \kappa \tilde{\mu} \mu \varsigma_{\varsigma}$ o elemento $\varphi \imath \lambda_{0}-$ perfila uma característica específica de $\kappa \tilde{\omega} \mu \mathrm{s}$, isto é, aquela que o associa a guirlandas ou coroas (presumivelmente ostentadas por seus membros). Note que aqui CELEBRAÇão e os conceitos subordinados a ela, KHOROS e KŌMOS, estão definidos a partir do frame PAZ. Finalmente, temos na $O$. 8. 9-10 um paralelo interessante com o $\varphi \imath \lambda \sigma \sigma \tau \dot{\varepsilon} \varphi \alpha v o \varsigma$ $\kappa \tilde{\omega} \mu \circ \varsigma$ usado por

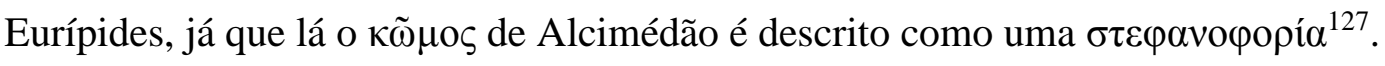

No drama satírico do mesmo autor, O Ciclope, encontramos, compreensivelmente, o maior número de alusões a $\kappa \tilde{\mu} \mu \rho \zeta$, oito, no total, que desvelam uma série de características associadas ao termo dentro do frame SIMPÓsIO ${ }^{128}$. Assim, logo nos versos iniciais (37 et seq.), $\kappa \tilde{\omega} \mu$ o $\varsigma$ é empregado para descrever a alegre procissão dos filhos de Sileno indo a uma festa na casa de Alteia. É digna de atenção a associação traçada pelo Sileno entre os passos da dança do $\kappa \tilde{\omega} \mu о \varsigma$ de outrora com o movimento dos seus filhos, agora pastores, ao tentar reunir um

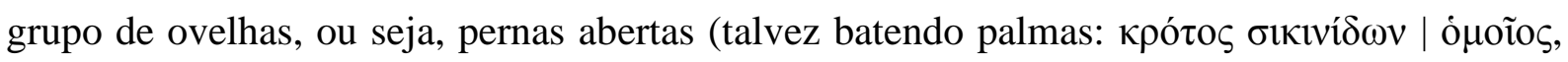

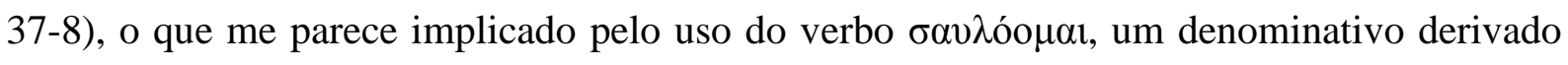
de $\sigma \alpha \tilde{\nu} \lambda o \varsigma$, usado para descrever, por exemplo a ginga da tartaruga no Hino Homérico a Hermes $^{129}$ ou, ainda, o trote característico dos cavalos, como em Semônides ${ }^{130}$. O grupo, além disso prossegue, na companhia de Baco, do qual são companheiros tradicionais, ao som de

${ }^{125}$ Cresfontes, fr. 453 TrGF, é datado $c .424, c f$. HARDER (1985).

${ }^{126} \mathrm{Cf}$. pp. 82.

${ }^{127} C f$. ainda $O .13 .29 ; P .3 .73,12.5$. Essas passagens serão discutidas Capítulo 6.

${ }^{128}$ Para uma análise sob essa ótica, $c f$. especialmente R. HAMILTON (1979).

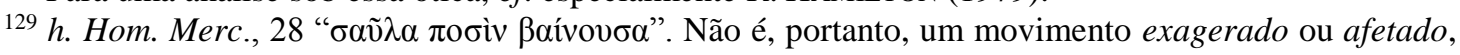

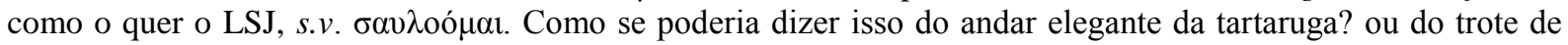
uma égua? $C f$. a discussão sobre a passagem da $O$. 14.16-17, no Capítulo 6, pp. 128 et seq.

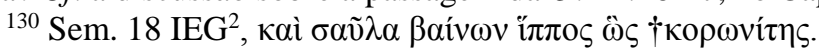


canções cantadas sob o acompanhamento do bárbito e não do aulos, como poderíamos esperar. O que deve nos interessar nesta passagem é que os movimentos executados pelos

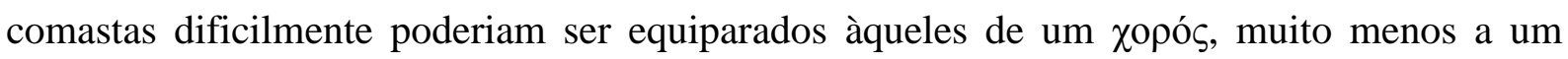
grupo de bêbados sem controle, ainda que, no plano da performance do drama, os filhos de Sileno provavelmente deveriam dançar como um coro.

Uma outra característica interessante d'O Ciclope é que a violência, muitas vezes associada ao $\kappa \tilde{\omega} \mu \mathrm{\zeta}_{\text {em }}$ virtude do consumo excessivo de vinho, é sugerida em algumas passagens ${ }^{131}$, mas permanece sempre no pano-de-fundo. É interessante notar que a mais violenta e bárbara das criaturas, o ciclope Polifemo, tem a sua violência transformada em docilidade justamente pela ação do vinho e de sua integração a uma instituição tipicamente associada com a civilização, de acordo com a "mundivisão" grega, o simpósio. É somente por meio desse raciocínio, portanto, que o coro pode dizer que irá educar o ciclope sem educação

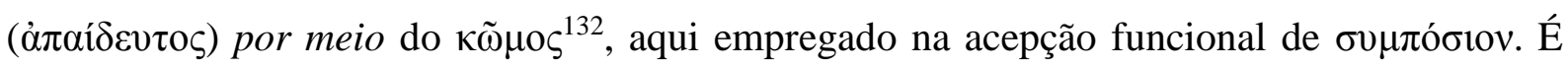
através do $\kappa \tilde{\omega} \mu \mathrm{s}$, ainda, que a detestável criatura, conhecida do Livro 9 da Odisseia, é transformada no gigante quase gentil dos $v v .576-84^{133}$ com quem podemos nos identificar e que é mesmo capaz de ganhar a simpatia da audiência.

Em suma, este drama satírico de Eurípides, ainda que nos aponte para significados não-prototípicos do $\kappa \tilde{\omega} \mu \mathrm{s}$, como por exemplo, ao sugerir uma degeneração da ordem natural do simpósio em possíveis brigas e confusões causadas pelo consumo excessivo de vinho ${ }^{134}$, também não permite uma identificação do conceito exclusivamente com as ideias de "bagunça”, "folia", "revel”, “comissatio" ou "pompa ludicra".

Algo semelhante acontece em outra peça de Eurípides, dessa vez a tragédia Alceste, onde $\kappa \tilde{\omega} \mu о \varsigma$ também é empregado a partir do ponto de vista das práticas simposiais do séc. V.

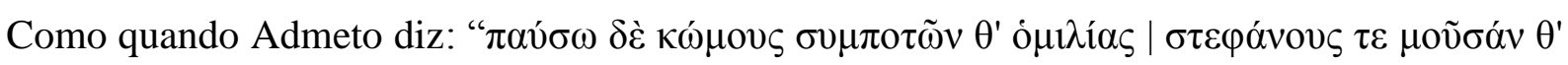

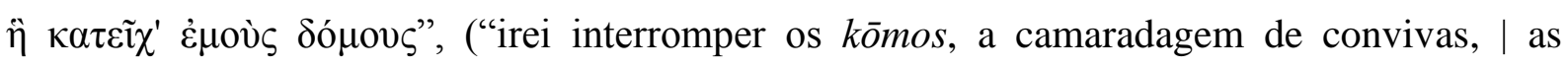
guirlandas e a música que um dia encheu minha casa”, 343-4), usando $\kappa \tilde{\omega} \mu$ o em uma de suas acepções móveis, como um grupo de convivas que procura ser acolhido em um simpósio, em

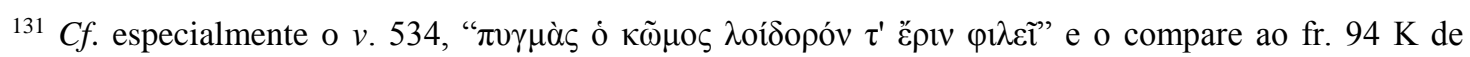

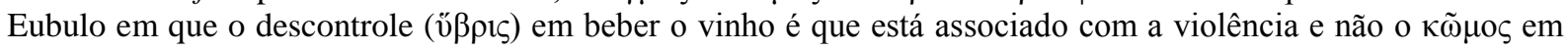
si. De um modo geral, estamos aqui diante da relação semelhante àquela entre os Centauros e o vinho, ou seja, da ideia de que os seres não civilizados, que vivem à margem da sociedade, são ultrassensíveis aos efeitos mais negativos do vinho. Sobre isso, $c f$. também Od. 21.293-8.

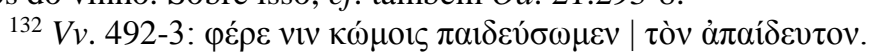

${ }^{133}$ De claro cunho homoerótico, aliás. $C f$., nos versos citados, a referência à prática da pederastia a partir do mito de Ganimedes, o que nos faz pensar imediatamente na $O .1$ e na teoria de KRUMMEN (1990) e outros de que a ocasião de performance da ode teria sido, provavelmente, o simpósio.

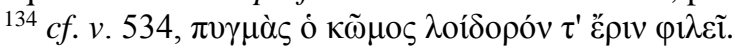




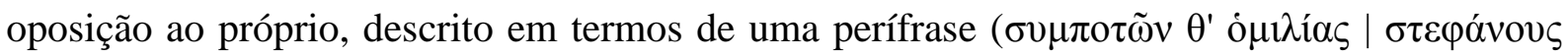

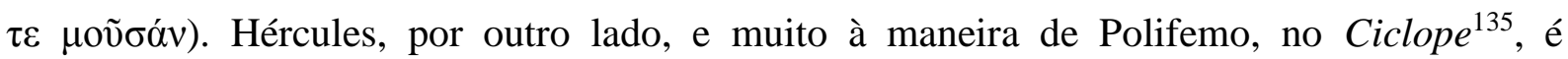
retratado como o conviva inconveniente. É notável que tanto ele quanto o criado que deve servir-lhe usam uma linguagem e descrevem práticas claramente associadas com o vocabulário técnico do simpósio: o uso do verbo $\delta \varepsilon ́ \chi 0 \mu \alpha$, a prática da $\sigma \tau \varepsilon ́ \psi 1 \varsigma$, a menção à ó $\mu \imath \lambda i^{1} \alpha^{136}$, o canto, o vinho etc. ${ }^{137}$ No entanto, nos $v v$. 803-4, o uso de $\kappa \tilde{\omega} \mu \sigma_{\zeta}$ em seu sentido mais geral de "celebração" parece vir à superfície outra vez, quando a presente situação de lamento é posta em contraste com o comportamento festivo e inadequado de Hércules:

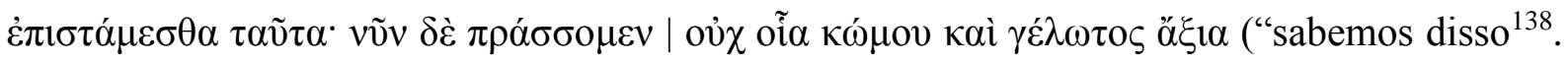
Agora, porém, não faremos coisas apropriadas ao kōmos e ao riso"), onde a acepção móvel de $\kappa \tilde{\omega} \mu$ o s seria inadequada e o termo parece ser usado no sentido mais geral de "festa" na medida em que se opõe ao "luto" dos moradores.

Finalmente, temos no monólogo de Admeto nos $v v$. 912-25, um exemplo de $\kappa \tilde{\omega} \mu \mathrm{s}$ nupcial semelhante àquele do Escudo e que será um dos tipos bem discerníveis nas comédias de Aristófanes. Essa passagem é importante também por ressaltar a oposição entre a festa do casamento - e a alegria denotada por ela -, e o encerramento dos ritos fúnebres com o consequente período de luto:

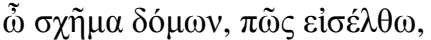 \\ $\pi \tilde{\omega} \zeta \delta$ ' oikń $\sigma \omega, \mu \varepsilon \tau \alpha \pi i ́ \pi \tau o v \tau o \varsigma$

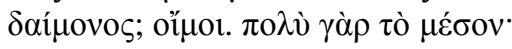

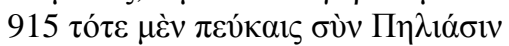

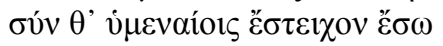

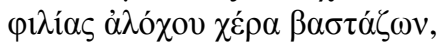

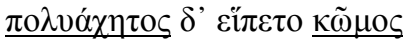

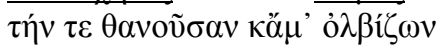

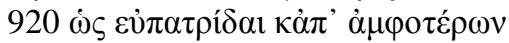

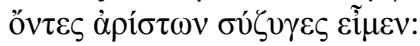

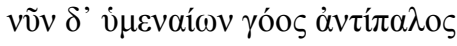 \\ $\lambda \varepsilon v \kappa \tilde{\omega} \nu \tau \varepsilon \pi \varepsilon \dot{\pi} \lambda \omega \omega \nu \mu \varepsilon \dot{\lambda} \alpha v \varepsilon \varsigma \sigma \tau \mathrm{\sigma} \lambda \mu \mathrm{ò̀}$ \\ $\pi \varepsilon \dot{\varepsilon} \mu \pi$ ov бí $\mu$ ' है $\sigma \omega$

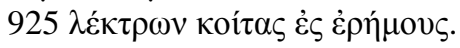 \\ 912 Ai a aparência da casa! Como adentrá-la? \\ Como viver aí, virado de ponta cabeça \\ meu destino? Que tristeza, quanta diferença! \\ 915 Outrora com tochas do Monte Pélio, \\ junto com himeneus eu a adentrei, \\ em minha mão, a mão pegando da amada esposa, \\ e seguia-nos um kōmos de altas vozes,
}

${ }^{135}$ Como Polifemo, Hércules não consegue cantar de modo afinado, vv. 760 et seq.

${ }^{136}$ Compare como fim da $O .1 .115,115$ (b)-116, $P .6 .52-3$ e $P .2 .96$. Sobre a significância do uso do termo técnico ó $\mu \imath \lambda \varepsilon \dot{\varepsilon} \omega$ nessas odes e em Píndaro em geral, $c f$. ATHANASSAKI (2004, pp. 322-3).

${ }^{137} \mathrm{Cf} . v v .747$ et seq.

${ }^{138}$ Em resposta a uma exortação do tipo carpe diem de Hércules. 


\begin{abstract}
à morta e a mim chamando de afortunados, 920 como descendentes, ambos, de nobres famílias aristocráticas que se uniram em casamento. Agora o lamento, adversário dos himeneus, e [adversárias] dos alvos péplos, as vestes negras, conduzem-me para 925 a cama vazia de meus aposentos.
\end{abstract}

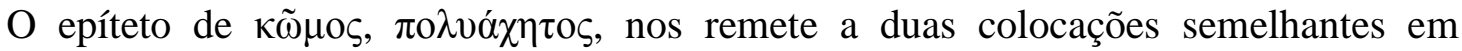

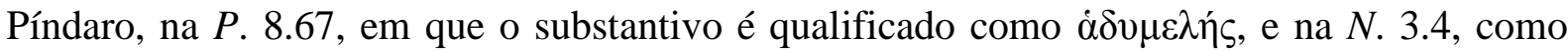

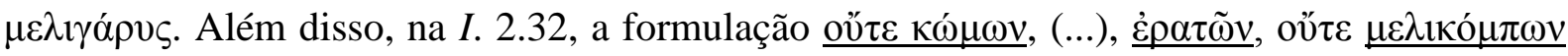
$\underline{\alpha o t \delta \tilde{\alpha} v}$ ("nem de amáveis kōmoi, (...), nem de melífluas e retumbantes canções”) parece-me

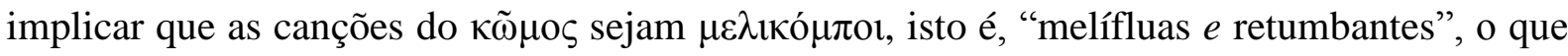

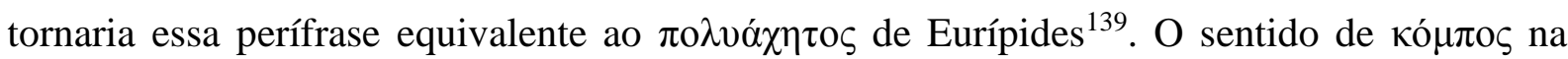
acepção de "som alto" é, ademais, confirmado pela canção da sirena no parteneio fr. 94b.13

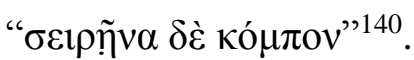

Uma outra e última passagem que tem relevância para a nossa discussão é a famosa

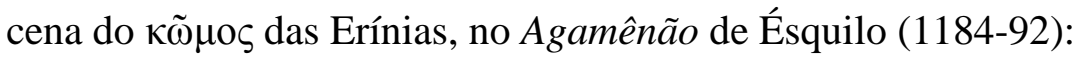

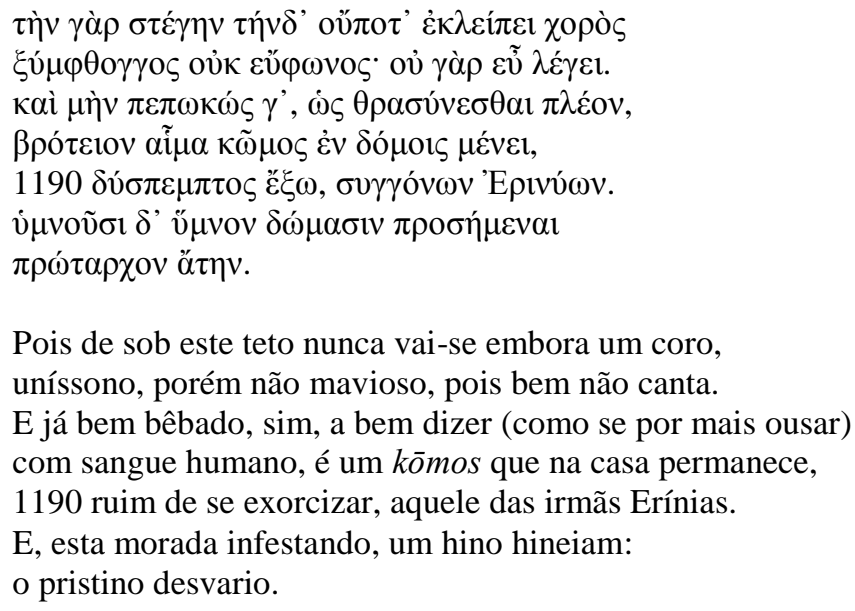

Pois de sob este teto nunca vai-se embora um coro, uníssono, porém não mavioso, pois bem não canta.

E já bem bêbado, sim, a bem dizer (como se por mais ousar) com sangue humano, é um kōmos que na casa permanece, 1190 ruim de se exorcizar, aquele das irmãs Erínias.

E, esta morada infestando, um hino hineiam: o pristino desvario.

Como Heath já argumentou ${ }^{141}$, há uma clara mudança de imagética, entre o coro que

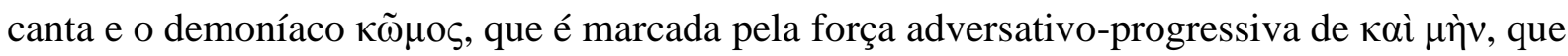
elabora e detalha progressivamente o ponto deixado subentendido nos dois primeiros versos $^{142}$, a saber, de que isto que a casa habita e que desta forma canta não pode, na verdade,

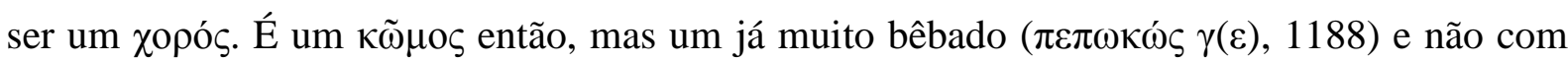

\footnotetext{
${ }^{139}$ Face aos paralelos acima, não há porque negar o valor semântico do segundo termo como "som alto, retumbo", vendo nele um uso metafórico com o sentido de "jactância”, como quer THUMMER (1968/1969, p. 46).

${ }^{140} \mathrm{Cf}$. texto e tradução na p. 144.

${ }^{141}$ HEATH (1988, p. 186).

${ }^{142} C f$. Denniston, p. 353.
} 
qualquer bebida, este intoxica-se com sangue humano (1189). Ao contrário de um $\kappa \tilde{\omega} \mu \mathrm{\varsigma} \varsigma$ humano, do qual se poderia esperar que partisse um dia, este jamais vai embora. É, na verdade, impossível de exorcizar. O que vemos é que, à medida que Cassandra vai descrevendo a cena, sua visão, antes indefinida, começa a se tornar cada vez mais precisa, como se ela afinasse cada vez mais o foco de seu olhar. Esse processo continua até o momento em que vemos surgir, frente aos olhos da nossa imaginação, uma imagem muito distinta daquela com que sua descrição se iniciara, e assim somos levados da imagem de

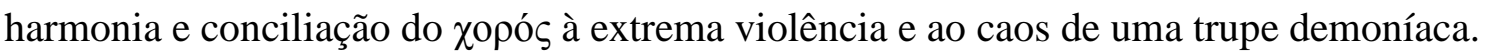

A conceitualização do termo $\kappa \tilde{\omega} \mu \mathrm{s}$, nesta passagem do Agamênão, dá-se a partir do frame SIMPÓSIO, como o contexto nos permite deduzir por meio da menção à bebida e porque

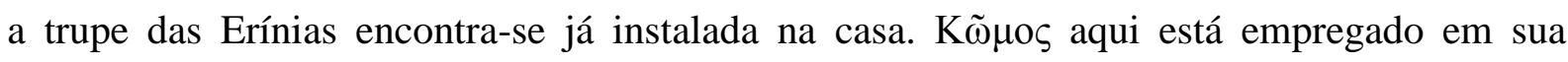
acepção estática. No entanto, este enquadramento implica no perfilhamento das características negativas associadas ao $\kappa \tilde{\omega} \mu о \varsigma$ : excesso, bebedeira, discórdia etc. Consequentemente, o uso do termo é motivado pelo fato de que este $\kappa \tilde{\omega} \mu \mathrm{s}$ das Erínias é atípico inclusive porque nunca deixa a casa, como seria de se esperar dentro do script denotado pelo frame SIMPÓSIO de acordo com as suas fases prototípicas $\delta \varepsilon i \tilde{\pi v o v} \rightarrow \sigma v \mu \pi$ ó informados de que ele não pode ser expulso ( $\delta$ $\sigma \pi \varepsilon \mu \pi \tau o \varsigma$ ๕̌ $\xi \omega, 1190)$.

Acredito que essas considerações sejam suficientes para que possamos descartar uma

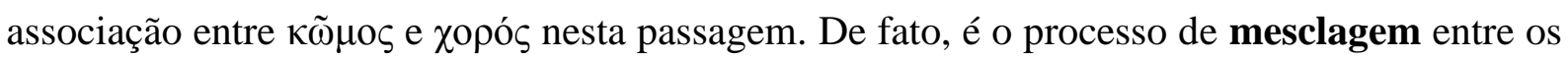
frames desses dois últimos conceitos com a imagem destoante das Erínias como irmãs e deusas do sexo feminino, ou seja, aptas para participar de um coro, como aquele das Musas, mas que, ao invés disso, comportam-se de uma maneira inadmissível até mesmo para os mais

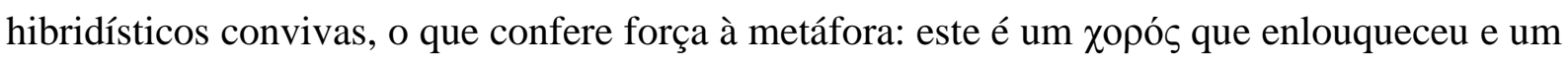
$\kappa \tilde{\omega} \mu о \varsigma$ que não compartilha da alegria trazida pelo vinho, nem pelas regras da comunhão, mas ultrapassa todos os limites impostos pela ordem e a decência.

Agora, a comédia. Vemos que, nela, o $\kappa \tilde{\omega} \mu о \varsigma$ tem um papel importantíssimo, sobretudo nas exuberantes cenas finais das peças, para marcar a vitória de um protagonista sobre seus inimigos, como no caso de Diceópolis, nos Acarnenses (1227 et seq.), em que o mesmo saúda-se e é saudado, após sua vitória sobre Lamaco, com o bordão reservado aos

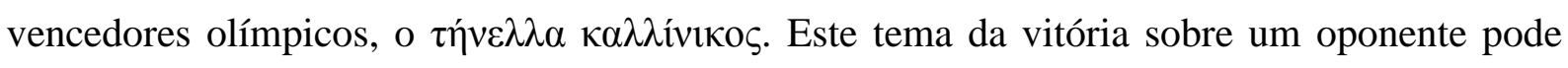
mesmo motivar, como em Nuvens (1204 et seq.), a paródia de um epinício que, como em Píndaro, inicia-se com um $\mu \alpha \kappa \alpha \rho ı \mu{ }^{\prime} \varsigma^{143}$. Algumas peças, ao invés de se encerrarem com um

${ }^{143} C f$., e.g., P. 10.1-2 e 5.5. 
$\kappa \tilde{\omega} \mu$ o de vitória, fazem-no por meio de um $\kappa \tilde{\omega} \mu$ o nupcial e, embora a própria palavra $\kappa \tilde{\omega} \mu о \varsigma$ não seja usada em nenhuma dessas passagens, não há porque duvidar, pelas associações que vimos anteriormente entre o termo e a cerimônia de casamento, da identificação entre as duas ocasiões $^{144}$. Além disso, como destaca Pütz ${ }^{145}$, há alguns exemplos de $\kappa \tilde{\omega} \mu$ o religiosos em Aristófanes. É preciso, no entanto, distinguir com cuidado entre $\kappa \tilde{\omega} \mu \mathrm{or}$ propriamente ditos,

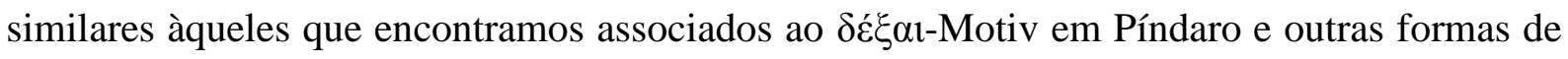

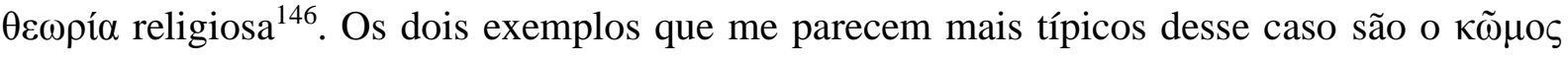
de Diceópolis, nos Acarnenses, vv. 243-60, e o de Agatão, ao comemorar sua vitória nas competições poéticas, em Tesmoforiantes, vv. 104 et seq., através de uma menção explícita à procissão como uma forma de $\kappa \tilde{\omega} \mu \mathrm{o}$, como ficamos sabendo por meio da pergunta do coro,

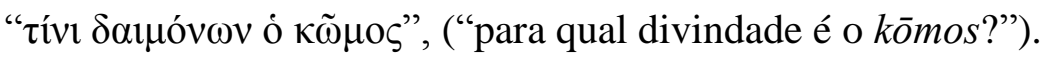

Apesar de sua ligação com o bas-fond do mundo da Comédia Antiga, é surpreendente que a maioria dos $\kappa \tilde{\omega} \mu o$ em Aristófanes seja do tipo "pacífico", isto é, celebratório e, embora certamente haja muitos exemplos de $\kappa \tilde{\omega} \mu$ or violentos ou satíricos, inclusive em resposta aos do tipo religioso, sua função principal seria, segundo Pütz ${ }^{147}$, a de "salientar os problemas e as diferenças entre os personagens nas peças”. Segundo esta mesma autora:

\begin{abstract}
Nas peças mais antigas de Aristófanes, os komoi frequentemente fazem parte das celebrações de paz de uma das partes vencedoras. Isto está de acordo com o fato de que a comédia em geral explora uma associação entre festividade e paz (como a segunda parte de Paz demonstra claramente). (...) Portanto, nessas passagens, as festas (revels) representam uma vida de prazer contínuo, livre de preocupações.

(...)

Esse aspecto do komos como uma das bênçãos da paz, também é empregado em outras partes da literatura grega. (...) Consequentemente, pode-se ver que este conceito já existia muito antes do tempo de Aristófanes. Contudo, as comédias são amiúde ambíguas acerca do que se está celebrando. Frequentemente, uma celebração nupcial ou de vitória são combinadas, ou mesmo elementos exteriores ao argumento da comédia podem ter um papel, como a esperança do autor em vencer uma determinada disputa cômica. A perversão cômica das festas (revels) na forma de komoi violentos enfatiza que algo está errado, p. ex., relações de gênero e política masculina, como em Lisístrata, 730 et seq. Isto fica muito evidente quando komoi pacíficos são interrompidos [grifo meu]. ${ }^{148}$
\end{abstract}

${ }^{144}$ Para uma análise detalhada dessas cenas, $c f$. PÜTZ (2007, p. 134 et seq.).

145 PÜTZ (2007, p. 139 et seq.)

146 Por exemplo, a procissão das canéforas durante a Panateneia (Ec.732 et seq.) dificilmente poderia ser descrita como um $\kappa \tilde{\omega} \mu \mathrm{s}$.

${ }^{147}$ PÜTZ (2007, p. 148).

148 PÜTZ (2007, pp. 128 e 49-50). 
Apesar de sua proeminência nas comédias aristofânicas, a própria palavra $\kappa \tilde{\omega} \mu \mathrm{o}$ (e derivados) aparece apenas oito vezes no $\operatorname{corpus}^{149}$, sendo que em todas elas o substantivo alude a algum tipo de procissão religiosa ou de comastas. Além disso, não há, em nenhuma dessas passagens, nenhum tipo de referência a uma dança coral. Com duas notáveis exceções, a primeira delas é a seguinte passagem das Tesmoforiantes (985-88b):

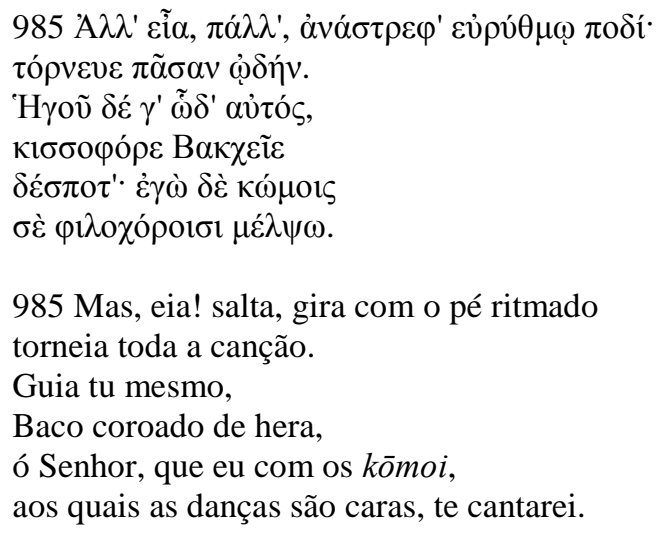

E a segunda é o fr. $491 \mathrm{~K}$ (Tagenistae),

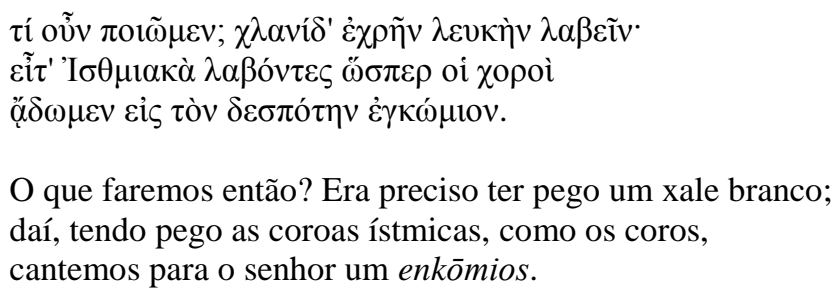

Na primeira passagem, contudo, a dança, que é evidentemente coral, é descrita como

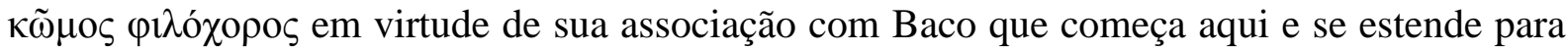
a estrofe e a antístrofe seguintes. Como a dança das mulheres só pode tomar a forma de um coro cíclico, tanto no nível da performance dramática quanto no do ritual fictício, é preciso que a dança báquica seja descrita em termos corais. Ou seja, o coro de mulheres improvisa, da melhor forma que pode, um $\kappa \tilde{\omega} \mu$ o a Dioniso. Trata-se, aqui sim, da ficção de um $\kappa \tilde{\omega} \mu$ o que, $^{-}$ ademais como já vimos, nunca é associado às mulheres no período arcaico e, portanto, não poderia estar sendo executado nesta cena senão numa acepção metafórica ou, evidentemente, cômica. De qualquer maneira, seria desaconselhável dar muita importância ao segundo

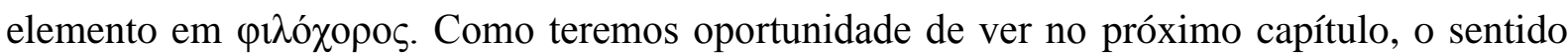

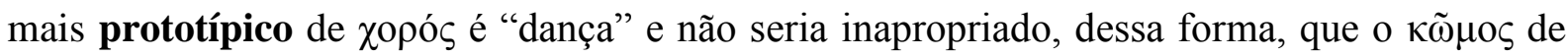

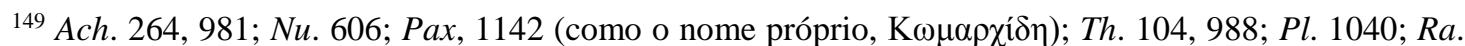

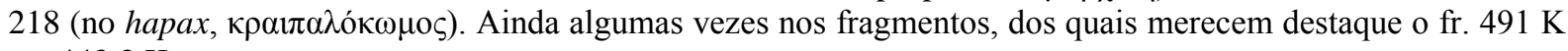
e o $443.3 \mathrm{~K}$. 
Dioniso fosse descrito como "amante de danças". Não se deduz daí, contudo, que a dança de um $\kappa \tilde{\omega} \mu$ o possa ser do tipo descrita pelo início da ode coral, ou seja cíclica, nem a caracterização implica em um generalização acerca do modo de performance comástica.

Quanto à segunda passagem, apesar da falta de contexto, é possível entender que aqueles que se propõem a cantar o $\dot{\varepsilon} \gamma \kappa \omega ́ \mu 10 v$ veem a sua própria performance de modo

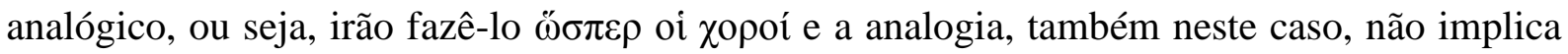
em uma identificação.

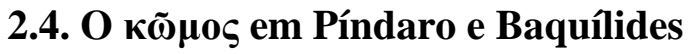

O termo $\kappa \tilde{\omega} \mu о \varsigma$ e derivados aparecem trinta e cinco vezes em Píndaro, distribuídos ao longo de vinte nove das quarenta e seis odes, ou $63 \%$ do corpus total. Em Baquílides, a forma nominal aparece apenas cinco vezes, das quais três em um suplemento, e a forma verbal pode ter sido usada uma única vez, se a leitura do editor estiver correta ${ }^{150}$. Não creio que seja adequado, no entanto, falar de uma preferência de Píndaro pelo termo, dado o estado do corpus de epinícios baquilidiano, composto por apenas 14 odes, muitas das quais em estado bastante fragmentário. É bem possível que, se tivéssemos um maior número de epinícios do poeta de Ceos, os números tenderiam a convergir. Um claro indício disso surge quando comparamos a frequência do termo no menor livro de Píndaro, aquele das odes ístmicas, com o único livro de seu colega: em ambos, o número de ocorrências é o mesmo, cinco.

Seja como for, é plausível supor que o uso que Píndaro faz de termos derivados do

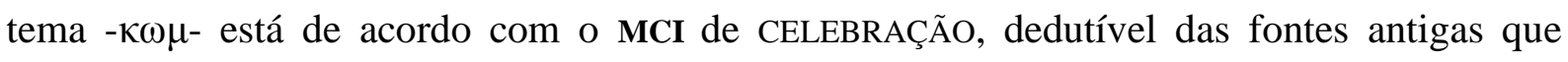
analisamos. É a partir desse MCI e dos diferentes frames invocados pelos elementos construídos sobre $-\kappa \omega \mu$ - que uma ideia da ocasião de performance de cada uma das odes em que esses itens lexicais aparecem pode ser proposta. Na medida em que, dentro do escopo lexical, a forma nominal parece ser a mais esquemática, tendo a forma verbal e a adjetival se desenvolvido através do entrincheiramento com outros prefixos e sufixos, parece-me adequado fundar a minha análise principalmente sobre esta, derivando daí outros usos perceptíveis nas formas derivadas.

${ }^{150} C f$. o Apêndice 2 para uma tabela sinóptica de todas as ocorrências do termo nos dois poetas acompanhados do contexto. Cf. também a relação de AGócs (2012, p. 221), que contém dois erros, no entanto: em (1) o verso dado é 0.4 .19 , quando, na verdade, o termo aparece em 4.9 e, em (4), ao invés de Baquílides 13.74, deve-se ler 13.4. 
Dentro do domínio delimitado por $\kappa \tilde{\omega} \mu о \varsigma$, várias características associadas ao conceito podem ser perfiladas por meio dos elementos dêicticos do discurso, como o tempo verbal e demonstrativos, com o objetivo de salientar um aspecto que defina de maneira mais apropriada as condições do evento da fala representadas pela ode. Esse perfilamento pode promover, então, duas conceitualizações por meio das quais $\kappa \tilde{\omega} \mu$ $\varsigma$ pode ser construído: como PROCESSO ou como PRODUTO. Esses dois aspectos de $\kappa \tilde{\omega} \mu \mathrm{s}$, capazes de evocar subframes dentro do domínio, relacionam-se hierarquicamente dentro dele, na medida em que a construção de $\kappa \tilde{\omega} \mu \mathrm{s}$ como PRODUTO é menos esquemática e, portanto, subordinada, à construção como PROCESSO, o que se torna evidente quando comparamos esta passagem da $O$. 4.8 ,

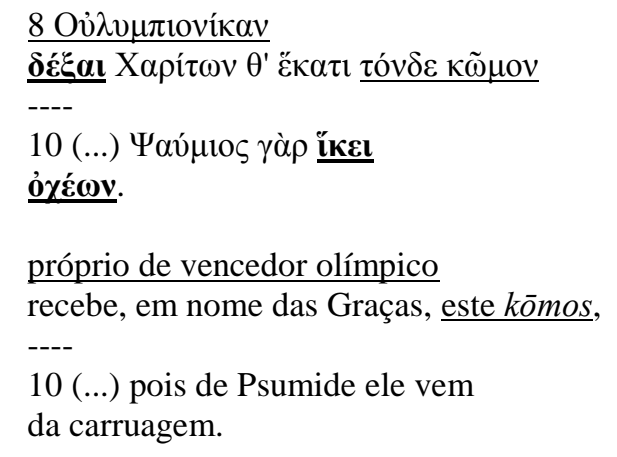

Com esta outra da $P$. 5.20-1,

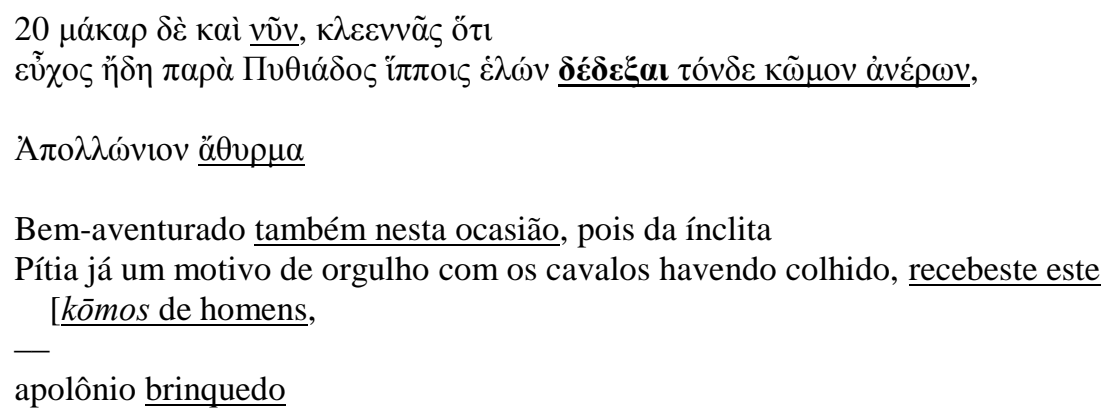

Ao passo que na $O .4$ o trajetor, $\kappa \tilde{\omega} \mu$ os, é perfilado como se afastando do marco,

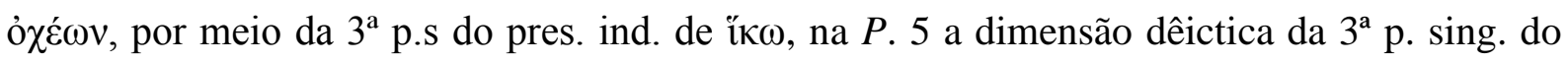
perf. de $\delta \varepsilon ́ \chi \chi \mu \alpha \iota$ seleciona um momento, coincidente com o evento da fala ( $v \tilde{v} v)$, que perfila a ação do verbo como completa a partir do ponto de vantagem da persona loquens. Isso

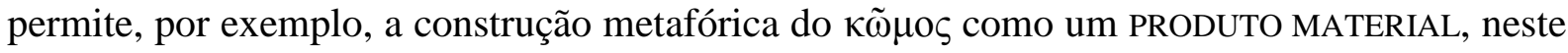
caso, mais especificamente, como um "brinquedo", ä $\theta v \rho \mu \alpha$. Adicionalmente, na $O .4$, a ação

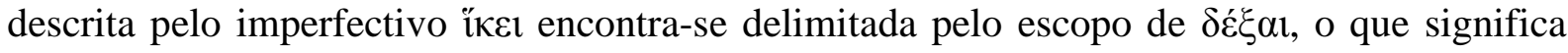
que a ação do verbo, modificada pelo modo verbal, se realizada, implica na imediata 
finalização da sub-rotina delimitada pelo frame evocado por ǐkєı; ou seja, o imperativo aoristo solicita a transição do estado-de-coisas de $\kappa \tilde{\omega} \mu \mathrm{s}$ de PROCESSO para PRODUTO. A comparação, portanto, dessas duas cenas nos permite deduzir que $\delta \varepsilon \dot{\varepsilon} \xi \alpha$ predica $\delta \varepsilon \delta \varepsilon \xi \alpha$ e que, consequentemente, do ponto de vista do conceito simbolizado por $\kappa \tilde{\omega} \mu \circ \varsigma$, a construção como PROCESSO é sempre mais esquemática do que aquela como PRODUTO ${ }^{151}$.

Com base nisso, eu proponho que $\kappa \tilde{\omega} \mu о \varsigma$ seja sempre conceitualizado como PROCESSO ao ser construído como sujeito de verbos de movimento ou, então, como o objeto do verbo

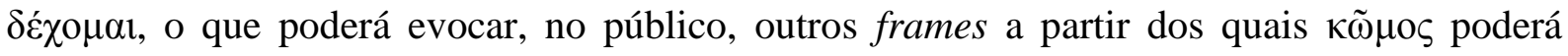
sofrer, ou não, uma nova conceitualização. Nos outros casos, a conceitualização prototípica de $\kappa \tilde{\omega} \mu$ os será sempre a de PRODUTO, entendido, no entanto, como um perfilamento sobre a base PROCESSO. Isto é importante, em primeiro lugar, porque nos permite ver cada instanciação de $\kappa \tilde{\omega} \mu \mathrm{S}_{\text {n }}$ nas odes a partir de um espaço discursivo corrente (EDC) em que essa estrutura categorial esteja pressuposta, ou seja, em que mesmo na ausência de gatilhos que permitam a construção do conceito como PROCESSO, essa informação possa ser tomada como informação de pano-de-fundo da audiência; em segundo lugar, porque irá fundamentar, mais adiante,

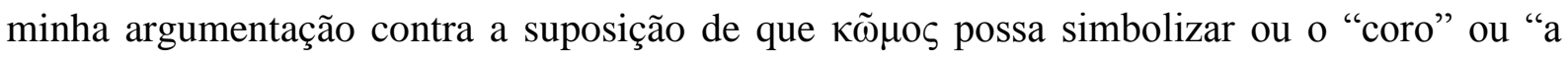
ode", na mesma medida em que irá me permitir discutir possíveis cenários de performance da première das odes.

No que se segue, irei analisar alguns exemplos que me parecem mais paradigmáticos dessa interpretação e, embora seja impossível, dados os limites impostos por este trabalho, analisar todas as ocorrências, uma tabela sinóptica dos usos que Píndaro e Baquílides fazem dos termos construídos sobre - $\omega \mu$ - pode ser encontrada no Apêndice 2, onde procurei fornecer cada instância dentro de um contexto mínimo, organizadas de acordo com os grupos celebratórios que proponho para cada uma delas e o possível local de performance.

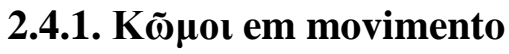

Três odes em Píndaro caracterizam o $\kappa \tilde{\mu} \mu \mathrm{s}$ de uma maneira que sugere fortemente a sua conceitualização como PROCISSÃO. São elas as $O .4,8$ e 14, algo normalmente admitido pela maioria dos críticos, havendo apenas algumas dissenções quanto ao local da performance. Como estes são os únicos exemplos para os quais temos informações suficientes

151 Utilizando os termos do estruturalismo jakobsoniano, poderíamos dizer que $\kappa \tilde{\omega} \mu \mathrm{s} \varsigma$ enquanto PROCESSO é não marcado, ao passo que $\kappa \tilde{\mu} \mu \varsigma_{\varsigma}$ como PRODUTO é marcado. 
que nos permitam lê-los a partir do frame mencionado, irei discutir essas três odes em maiores detalhes.

No caso da $O .4$, a passagem relevante à nossa discussão é a seguinte:

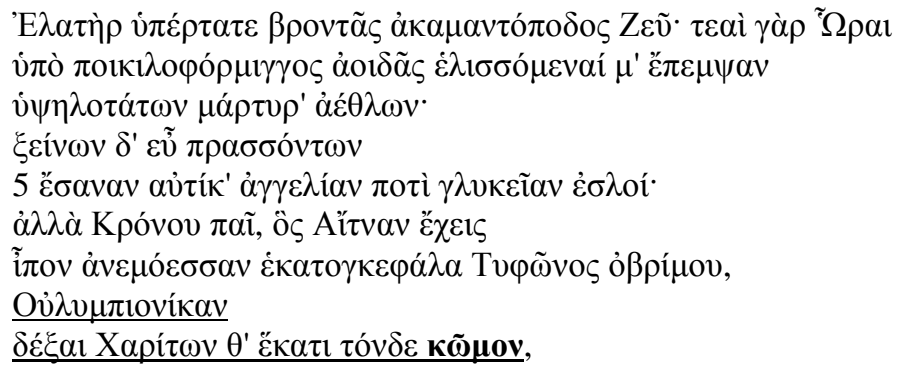

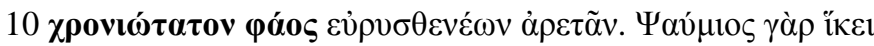

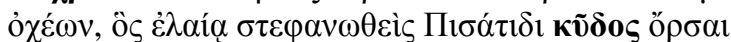

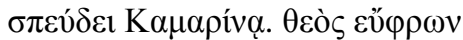

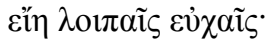

Sumo Auriga do trovão de pés infatigáveis, ó Zeus, tuas Horas pois, desenrolando-se, sob a canção da lira multimelodiosa, enviaram-me como testemunha dos jogos supremos.

Quando os amigos (kseînos) são bem sucedidos 5 exultam logo os homens de bem face ao doce anúncio. Mas, ó Filho de Crono, que o Etna habitas, nebuloso gravame do Cem-cabeças, violento Tufão, próprio de um vencedor olímpico recebe, em nome das Graças, este $\boldsymbol{k} \overline{\boldsymbol{o}} \boldsymbol{m o s}$,

10 oportuníssima luz ${ }^{152}$ de sobrepujantes virtudes, pois ela vem da carruagem de Psaumide, que, coroado com a pisana oliveira, uma distinção por soerguer anseia a Camarina. Benfazejo um deus lhe seja às futuras preces.

Boeckh pressupunha uma performance em Olímpia em virtude, principalmente, de a persona loquens dizer-se enviada como testemunha dos jogos pelas Horas $(2-3)^{153}$. Nesse sentido, ele via os $v v$. 4-5, como um indício da composição imediatamente ( $\alpha$ $\tau i ́ \kappa \alpha)$ após a

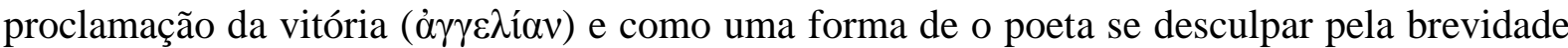
da mesma, lendo os $v v$. 11-12 na acepção literal de que Psaumide teria pressa em retornar para

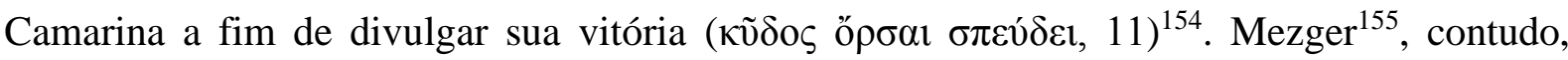

${ }^{152}$ No que se segue irei explicar minha opção por essa tradução.

153 BOECKH (1821, p. 143), "Iam horum carminum prius Olympiae et scriptum et cantatum esse poeta ipse docet". Ele contrapunha essa ode, executada em Olímpia, à $O .5$, para a qual pressupunha uma performance em Camarina. Assim também Wilamowitz-MoELlendorfF (1966, p. 418) e KRUMMEN (1990).

${ }^{154}$ Ou Estações, "das ist einerlei”, como diria WILAMOWITZ-MOELlENDORFF (1966, p. 418). BOECKH (1821, p. 143), "statimque post victoriam compositum carmen demonstrant haec [ i.e., os vv. 4-5]: unde odae brevitas excusator". E, sobre os vv. 11-12: "Hinc quod nondum divulgata nec Camarinam delata victoriae fama est (...) de Psaumidi dicitur [vv. 11-12].”

${ }^{155}$ MEZGER (1880, p. 136 et seq.). 
seguindo a sensível análise de L. Schmidt ${ }^{156}$, que também propusera Camarina como o local da première, parece-me ter resumido de maneira bastante convincente os problemas da análise de Boeckh.

Segundo Mezger, os vv. 1-3 referem-se apenas ao almejado sucesso que coroa o fim de um longo trabalho de preparação e treino para os jogos aliado às qualidades naturais do laudandus, ao que se alude, de fato, nos vv. 14-16. Daí a importância das Horas como filhas

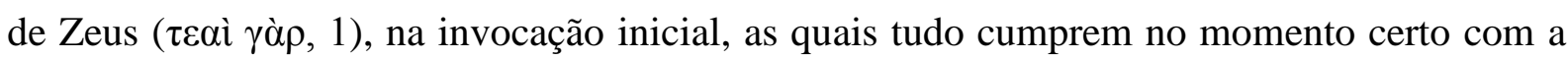
sua dança, que representaria a passagem do tempo ${ }^{157}$. Em segundo lugar, os $v v$. 4-5, de claro

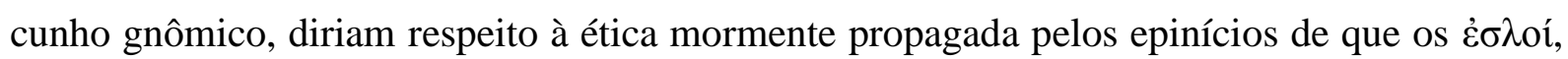
entre os quais Píndaro obviamente se incluía, alegram-se imediatamente ao saber do sucesso

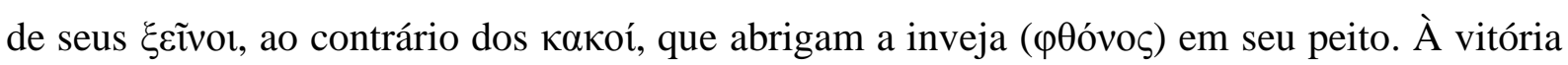
deve-se seguir o imediato louvor, daí o uso de $\alpha$ $\tau \tau^{\prime} \kappa \alpha^{158}$. Por outro lado, $\sigma \pi \varepsilon v ́ \delta \varepsilon ı$ (13) referese ao fato de que esta vitória conquistada por Psaumide dera-se apenas poucos anos após a fundação de sua cidade, na qual o mesmo tivera um papel decisivo, como sabemos pela $O$. 5.9-14. Finalmente, tanto a invocação de Zeus como padroeiro do Etna, distante apenas cerca de $150 \mathrm{~km}$ a oeste de Camarina, donde suas erupções poderiam ser facilmente observadas ${ }^{159}$

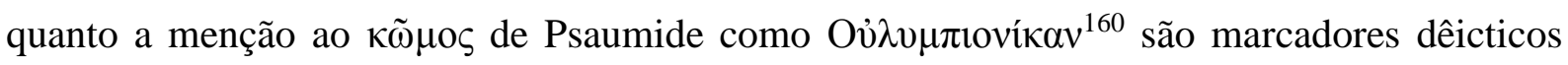
que me parecem apontar, por proximidade, no primeiro caso, e por distanciamento ${ }^{161}$, no segundo, para aquela cidade. Muito embora os $v v$. 4-5 sejam expressos de uma maneira gnômica, a aplicação parece ser ao contexto imediato da ode e, dessa forma, a identificação da persona loquens como um dos $\xi$ cĩvo pode ser um indício de que essa se via (de maneira real ou fictícia) sob a esfera de influência de seu laudandus, neste caso, Psaumide; isso, a meu ver,

${ }^{156}$ SCHMIDT (1862, p. 382 et seq.).

${ }^{157}$ Idem, p. 383, "Doch jene lieblichen Gestalten, die Pindar einführt, haben eine tiefere Bedeutung. Wer der Auseinandersetzung des erwähnten Gelehrten mit Aufmerksamkeit gefolgt ist, wird sich erinnern, dass sie die Göttingen der Zeitung sind, die Spenderinnen alles dessen, was nicht in jäher Hast vom Schicksal erzwungen werden kann, sondern erst eintritt, wenn die Zeit erfüllet ist. Ihre Wirkung sah man also auch an dem Erfolge des Psaumide". Assim também FracCAROLI (1894, p. 220), "Il tempo dunque, che tutto apporta, ha recato anche a Psaumidi la vittoria". GILDERSLEEVE (1886), "It has taken time for Psaumide's success to ripen".

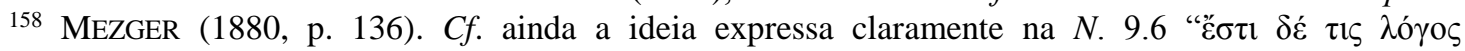

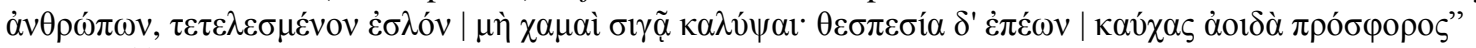

159 Aliás, a menção à Tufão e ao Etna como gravame do maior inimigo de Zeus sugere uma erupção recente ou mesmo coincidente com a ocasião de performance da ode.

160 Alguns comentadores e tradutores tratam como um substantivo. No, entanto, como observa WILAMOWITZ-MOELLENDORFF (1966, p. 418 n. 3), "Die inkongruente Verbindung eines prädikativen Adjektivs und eines adverbiellen Gliedes ist echt pindarisch".

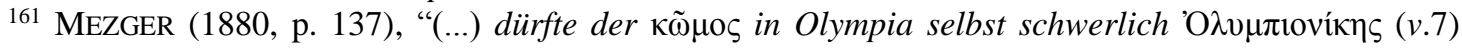
genannt worden sein (...).” 
faria mais sentido se a ode fosse executada em Camarina ${ }^{162}$. Finalmente, o fato de a persona

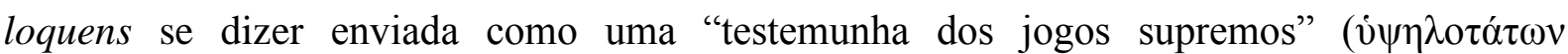
$\mu \alpha ́ \rho \tau v ' \grave{\alpha} \varepsilon \dot{\theta} \theta \lambda \omega v, 3)$, aponta, necessariamente, para um evento situado no passado, do qual ela poderia dar testemunho por tê-lo presenciado. 'Е $\mathrm{\varepsilon} \varepsilon \mu \alpha \alpha \nu$, dessa forma, parece apontar para um tempo em que este testemunho já poderia ter se dado e para um local onde o relato deste testemunho era necessário, isto é, em Camarina, uma vez que, em Olímpia, nenhum testemunho seria necessário já que a vitória de Psaumide teria sido presenciada por todos.

Apesar da confiança dos comentadores, precisamos admitir que é impossível precisar

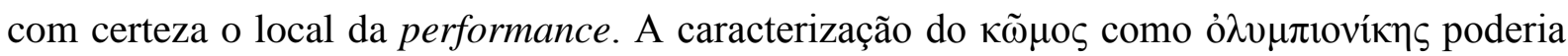
ser possível por meio de uma deixis am phantasma ${ }^{163}$. E, embora os $v v$. 4-5 pareçam-me estranhos se enquadrados em uma performance em Olímpia, este não seria um cenário improvável. Do ponto de vista da identificação do $\kappa \tilde{\omega} \mu o \zeta$, no entanto, esta questão tem pouca relevância porque, se não em Camarina, poderíamos pensar em uma procissão ao templo de Zeus em Olímpia, em cujo trono, como sabemos por meio do testemunho de Pausânias (5.11.7), as Graças tinham sido esculpidas com grande destaque ${ }^{164}$. Caso contrário, se postularmos a performance em Camarina, o $\kappa \tilde{\omega} \mu \mathrm{o} \varsigma$ da ode estaria associado à procissão que

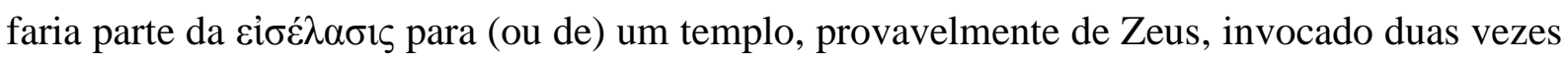

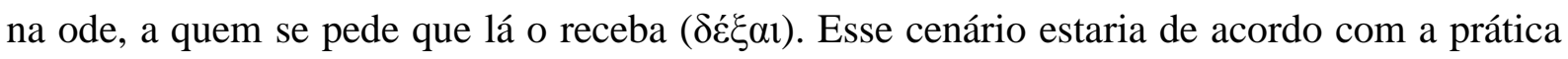
atestada para o caso de Exeneto, citado anteriormente na passagem de Diodoro da Sicília ${ }^{165}$.

A ideia, no entanto, de que $\kappa \tilde{\omega} \mu$ o aqui deva ser entendido como se referindo à própria ode, como quis Fraccaroli, Fogelmark, Gelzer, Gerber ${ }^{166}$ e, mais recentemente, Chris Carey ${ }^{167}$

\footnotetext{
162 Note que na $O .9$ os comastas que celebram junto com Efarmosto em Olímpia são descritos como

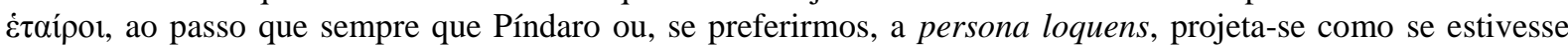
(se, de fato, não estava) na presença de seu laudandus, ele se descreve como um $\xi$ cĩvo, , $f f . ~ N .7 .61$.

${ }^{163}$ Possibilidade para a qual Christian Werner me chamou à atenção.

164 Ainda segundo o $\Sigma$ 10a-b à $O .5 .6$ (DRACHMANN, p. 141), Hércules por ocasião da fundação dos duplos altares aos deuses em Olímpia, teria dedicado um deles às Graças e a Dioniso, $c f$. Paus. 5.14.10.

165 Cf. p. 67.

${ }^{166}$ FRACCAROLI (1894, p. 220), “Questo $\kappa \tilde{\omega} \mu \mathrm{o} \varsigma$ è lo stesso inno trionfale, che, come fosse una persona,

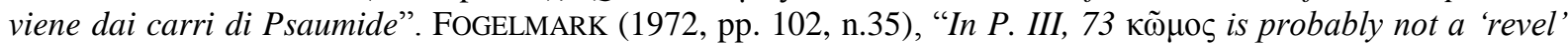
but means song and should be compared with O.XI, 13 (...) where [it] presents the same idea of the Epinician ode as the crowning glory of a victory as in P. III, 73 (...). The verb $\kappa \omega \mu \alpha \dot{\zeta} \varepsilon \mathrm{v}$ can also be understood in two ways, 'to revel' or 'to sing”. Em sua nota ele justifica sua opinião da seguinte maneira: "The vulgar aspect of $\kappa \tilde{\omega} \mu \mathrm{s}, \kappa \omega \mu \alpha \dot{\zeta} \varepsilon \mathrm{iv}$ may be the reason why neither verb nor the noun occurs in Epinicians to the most powerful and dignified rulers, Hieron of Syracuse and Theron, of Acragas", grifo meu, certamente para esse autor, Arcesilau, a quem Píndaro dedica o maior de seus epinícios, a $P$. 4, bem como a impressionante e solene $P$. 5,

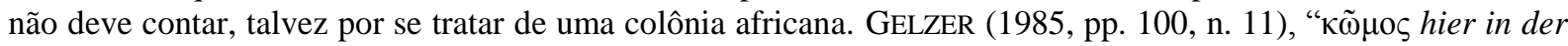
Bedeutung 'Siegeslied'; das Lied dauert lange und erhält den Ruhm (10), nicht ein 'Festzug". Note a semelhança com a afirmação de Carey, abaixo. D.E. GERBER (1987), "It is only song that could be described as a 'most enduring light of mighty achievements ". Cf. também MuLLEN (1982, p. 24 et seq.).

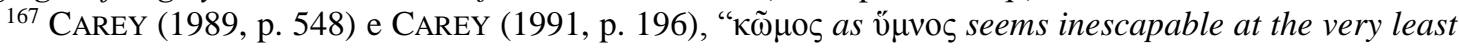
in O. 4.9, where the phrase 'the most lasting illumination of mighty achievements' describes song (...), not the
} 
(que, aliás, não cita nenhum desses críticos) parece-me, pelo que já vimos, insustentável. Segundo Carey, com uma certeza que lhe é característica, essa passagem da $O .4$ seria um

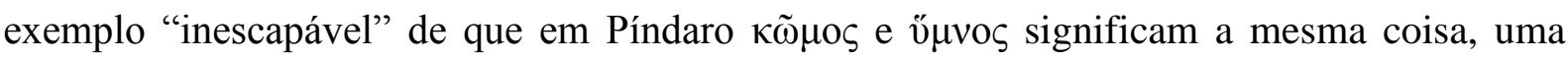
acepção, ademais, jamais atestada na literatura supérstite. A impressão que se tem, contudo, é a de que a hipótese de que $\kappa \tilde{\omega} \mu$ o significaria a própria canção parece ser uma proposição $a d$ hoc válida somente para Píndaro justamente naquelas passagens em que uma identificação

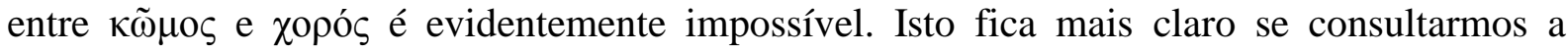
palavra no LSJ, pois iremos notar que, em sua definição, aquele dicionário define o termo como "a ode cantada numa dessas procissões festivas, Pi.P. 8.20, 70, O. 4.10, B. 8.103 [sic,

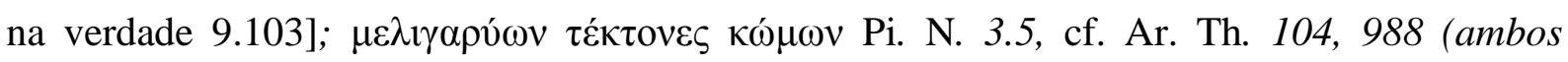
lyr.)" $)^{\prime 68}$.

Note que, com exceção da passagem das Tesmoforiantes, todos os outros exemplos provêm da poesia epinicial, sendo quatro de Píndaro, todos os quais, aliás, teremos a

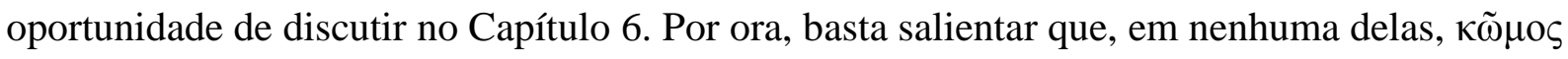
precisa ser interpretado de uma maneira diferente daquela em que o vimos conceitualizado nos exemplos citados da literatura relevante, isto é, sobretudo como CELEBRAÇÃO, FESTA ou PROCISSÃO. Nesse sentido, é esclarecedor o comentário de Austin e Olson ${ }^{169}$ à passagem das

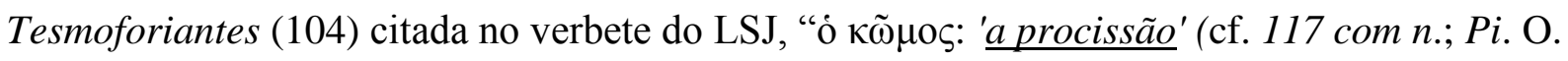
4. 11; 8. 10; Bacch. n. 12; E. Hipp. 55; Tr. 1184; Hel. 1469) e assim, por meio de uma extensão natural do sentido, o hino que os participantes da procissão cantam; cf. $988 \mathrm{~b}-9$ com n.; Braswell sobre Pi. P. 4. 2"170. É notável que Austin e Olson, mesmo claramente convencidos de que o único sentido possível e necessário para ambas as passagens em questão das Tesmoforiantes seja "procissão"171 - claríssimo, aliás, no contexto da fala de Agatão e na do coro -, vejam-se compelidos a listar um sentido apenas aceito e proposto pela crítica pindárica, sem qualquer relevância, aliás, com o verso comentado. Isto aponta fortemente, a

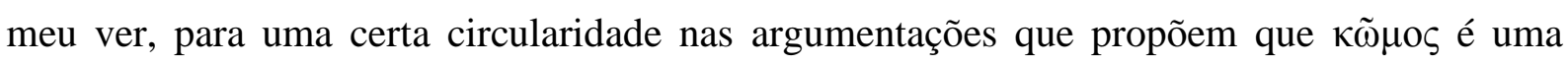
metonímia para "canção" e talvez seja um indício de que o debate possa ter sido

ephemeral victory celebration". Para uma crítica dessa posição e uma interpretação que leve em conta uma outra leitura, por parte da audiência, na qual $\chi \rho o v i \omega ́ \tau \alpha \tau o v$, poderia ser lida também como "duradoura" em referência à ode sem conflitar com o que se está propondo nesta tese, $c f$. ECKERMAN (2010, p. 310).

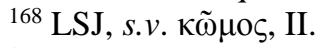

${ }^{169}$ Para o v. $988, c f$. p. 98.

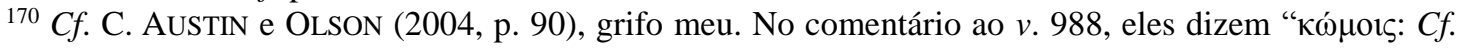
104 n.; but in context a reference to Dionysiac 'revels' (e.g. Nu. 606; Eub. fr. 93. 8; E. Cyc. 492; Ale. 343; cf. 1176 ) is heard as well". Cf. o comentário ao v. 1176. Em nenhuma dessa passagens parece aos comentadores que

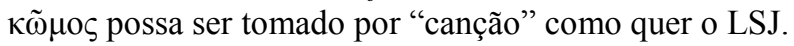

171 Note que DUARTE (2005, p. 112 e 66) traduz o v. 104 "Para quem dentre as divindades esse cortejo?", e o 988 como “cortejos amantes da dança”, grifo meu. 
inevitavelmente contaminado por dogmatismos. No comentário de Braswell, a que nos remete, este diz, ademais, que "aqui [i.e., na $P$. 4.2] o verbo é usado intransitivamente e (diferentemente da Ol. 9.4 e Ne. 9.1, onde o contexto implica uma procissão), sem a implicação de movimento; $c f$. Py. 9.89, Is. 3/4.8, 7.20-21"172, o que é condizente com a ideia de "celebração".

Retornando então ao ponto em questão, todos os comentadores da $O .4$ que veem no

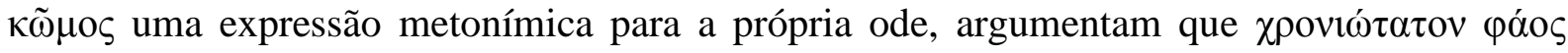
(10), aposto daquele termo, significaria "a mais duradoura luz", algo que, segundo eles, só poderia ser dito da ode e não de uma celebração epifenomenal. Essa leitura, no entanto, revela uma intepretação que não leva em conta nem o contexto da ode, nem o valor acordado por

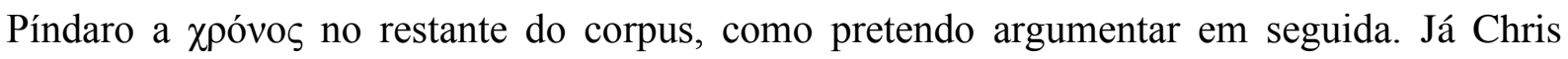
Eckerman, acerca dessa passagem, notava que:

\begin{abstract}
Finalmente, a confusão no que diz respeito ao significado de $\kappa \tilde{\omega} \mu о \zeta$ levou alguns eruditos a mesclar interpretações disparatadas na esperança de dar algum sentido a elas. Essas interpretações atacam apropriadamente a dificuldade interpretativa que $\kappa \tilde{\omega} \mu \mathrm{o \zeta} \mathrm{apresenta} \mathrm{na} \mathrm{poesia} \mathrm{epinicial;} \mathrm{contudo,} \mathrm{esses} \mathrm{eruditos} \mathrm{não} \mathrm{forneceram} \mathrm{uma}$ explicação que suportasse as muitas acepções que $\kappa \tilde{\omega} \mu o \zeta$ supostamente teria. Como mencionado acima [p. 302], é o sentido primário de celebração que permite que sentidos metonímicos como, 'ode', 'coro' e 'foliões' pareçam plausíveis. Carey sugere $^{173}$ que $\kappa \tilde{\omega} \mu о \varsigma$ possa se referir, ocasionalmente, ao hymnos, à própria canção. (...) Carey usa este exemplo [i.e. O. 4.6-10] para 'provar' que Píndaro algumas vezes

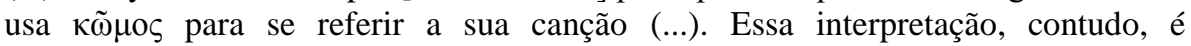

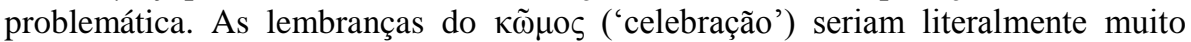
duradouras para o vencedor, uma vez que era uma festa da qual o vencedor poderia se lembrar com ternura; a própria ode poderia ser guardada como uma memória particularmente vívida da ocasião e cada reperformance dela traria, em alguma medida, a primeira vitória de volta à vida para o patrono. Se, como eu sugeri, o

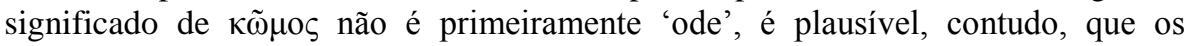
membros da audiência pudessem interpretar a frase 'a mais duradoura luz para sucessos de grande esforço' em relação à ode de Píndaro. Esse é um ponto importante que deve ser salientado no que tange à interpretação de Carey. Não é que 'este $\kappa \tilde{\omega} \mu \mathrm{s}$, a mais duradoura luz para sucessos de grande força' 'prova' que

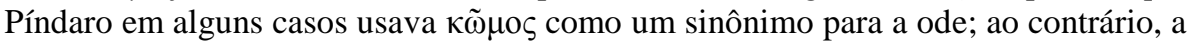
linguagem de Píndaro permite que os membros da audiência expandam a semântica

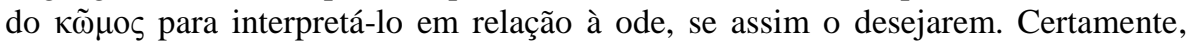

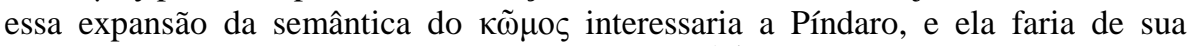
própria ode a parte central da celebração de vitória ${ }^{174}$.
\end{abstract}

Muito embora eu concorde com a leitura perspicaz de Eckerman, não posso partilhar

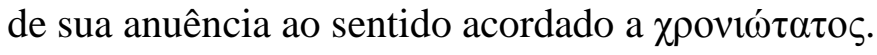

\footnotetext{
172 BRASWELL (1988, p. 61), grifo meu.

${ }^{173}$ CAREY (1989, p. 549) e CAREY (1991, p. 196).

${ }^{174}$ ECKERMAN (2010, p. 310), grifo meu.
} 
Já L. Schmidt, Mezger e Gildersleeve ${ }^{175}$ haviam proposto que o sentido do adjetivo deveria ser entendido como subordinado ao yó $\rho$ do $v .1$ e que, portanto, deveria significar algo como "tardio", em virtude da vitória de Psaumide ter sido obtida após muitas tentativas e

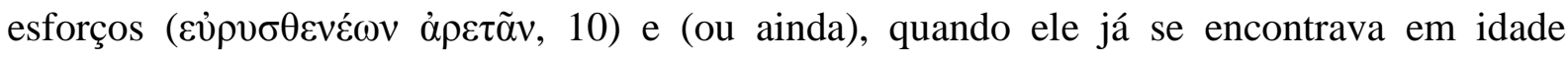
avançada, ao que aludiria a gnoma do verso final. Essa é uma interpretação possível, sobretudo se enquadrada dentro da gnoma expressa ao final da ode. Entretanto, a ideia de tempo expressa por $\chi \rho \operatorname{lovi\omega ́} \tau \alpha \tau o \varsigma$ não pode ser dissociada nem da figura de Zeus ${ }^{176}$, nem das Horas, muito embora a ênfase maior seja nessas deusas, que representam não apenas a ideia arcaica de que o tempo desenrola-se por meio de um ciclo que, aqui, é a própria dança dessas deusas mas também de que cada evento, dentro deste ciclo, tem lugar definido numa sucessão, um conceito que os gregos expressavam por meio da palavra каıрós.

Homero, pela primeira vez no Canto 5.749 (8.393), nos fala das Horas como guardiãs

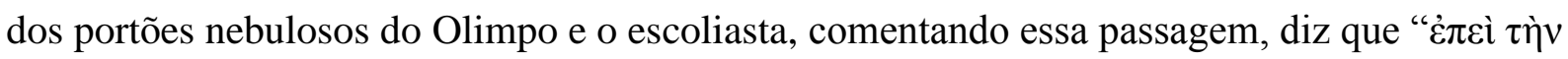

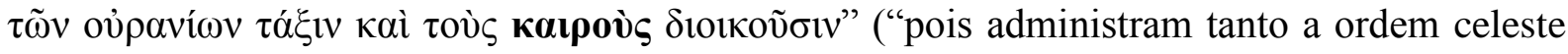
[i.e., o movimento dos planetas] como [o tempo certo d]as estações") ${ }^{177}$. Na Odisseia, uma canção marcada por ciclos em seus mais diversos níveis ${ }^{178}$, a passagem de um determinado período de tempo até a chegada de um momento específico na narrativa costuma ser descrita

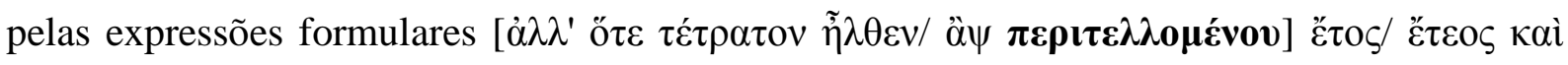

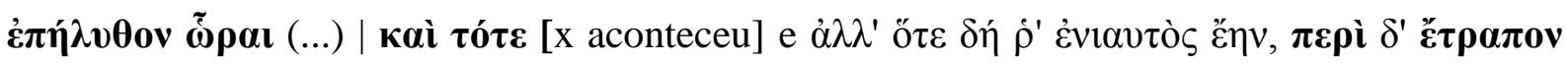

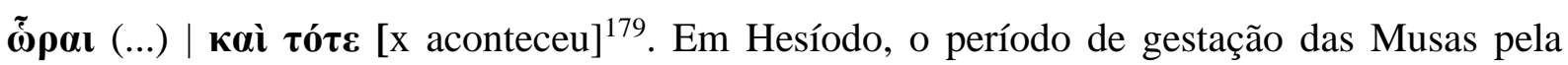

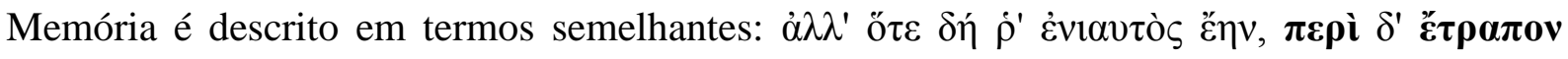

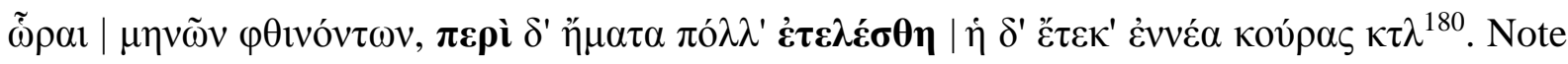

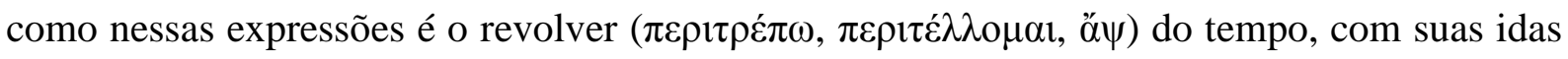
e vindas, que marca um determinado momento no qual algo deve acontecer ${ }^{181}$. De fato, as

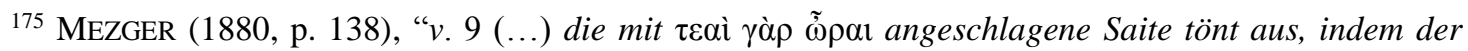
Sieg als eine spät gezeitigte Frucht ächter Tüchtigkeit erscheint". SCHMIDT (1862), "Die gewöhnliche Erklärung, wonach dies Wort hier 'dauernd' bedeuten soll, würde nur passen, wenn von dem Gedichte die Rede

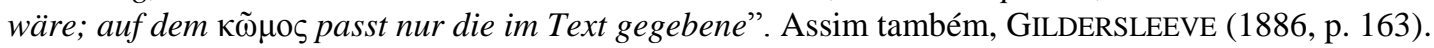

${ }^{176}$ Que é $\pi \alpha ́ v \tau \omega \nu ~ \alpha ̉ \rho \chi \alpha ́, ~ \pi \alpha ́ v \tau \omega v ~ \dot{\alpha} \gamma \eta ́ \tau \omega \rho$, segundo Terpandro, 698 PMG.

$177 \Sigma 5.749$ b.1 (Erbse, p. 102). Cf. também KIRK et al. (1993, p. 136)

178 Já no início da canção somos introduzidos a essa noção, ao saber que o tempo chegara de o herói

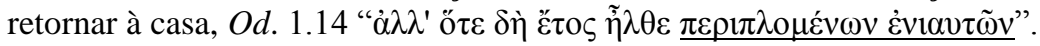

179 Tradução: "[mas quando o quarto ano chegou/ e outra vez, com o revolver do ano completando-se] também as horai voltaram | então [x aconteceu]" e "mas então quando um ano se passara e revolveram-se as horai | então [x aconteceu]" Hom. Od. 2.107, 10.469, 11.295, 14.294, 24.142. Nem HeUBECK, WEST e HAINSWORTH (1998) nem DE JONG (2001) comentam essas expressões.

${ }^{180}$ Hes. Th. 58-60.

${ }^{181}$ Cf. M. FinKELBERG (2011, p. 785), s.v. Seasons. 


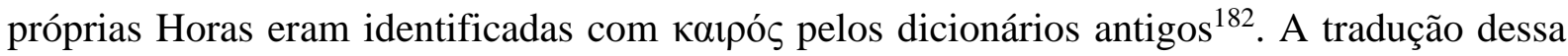
palavra pelo português "estação" obscurece o sentido mais primitivo do substantivo - que, além do mais, nunca perdeu sua força em grego - que parece ser aquele de "momento crítico que marca a passagem de um estado de coisas a outro" ${ }^{183}$, um sentido a partir do qual o

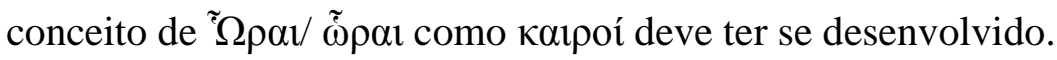

Dessa feita, o movimento do tempo cósmico das Estações é contrastado com a pressa

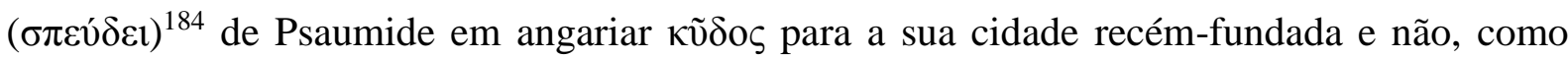
quis Boeckh, em voltar o mais rapidamente possível à Camarina para que sua vitória fosse divulgada pela execução da ode. Ainda num outro nível, a dança das Estações (غ̇ $\lambda \imath \sigma \sigma o ́ \mu \varepsilon v \alpha \imath)$ é

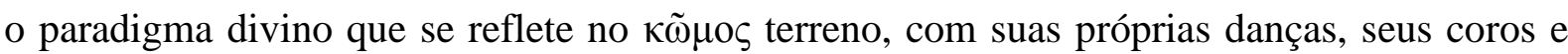
sua alegria ${ }^{185}$. A imagem da luz, outrossim, como sinalizadora do fim de um período de dificuldades, representa, desde Homero, o momento de resolução de uma crise $^{186}$ e aqui também ela pode ter sido empregada nesse sentido, isto é, de "último raio de luz" para uma vida que, de outra forma, teria passado à história sem qualquer outra memória, já que nada, além do que Píndaro aqui nos conta e na $O .5$, foi transmitido acerca de Psaumide.

A ideia, portanto, de que é o tempo ${ }^{187}$ que, em seu revolver, tudo consuma no momento certo, é central nesta ode, que fala de um sucesso aparentemente tardio ${ }^{188}$.

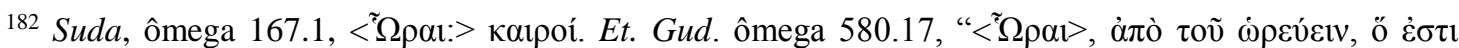

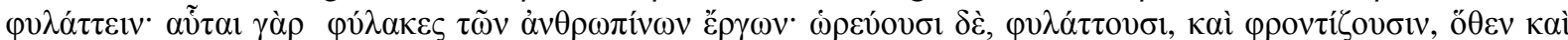

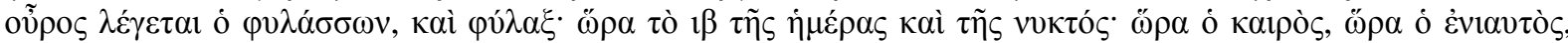

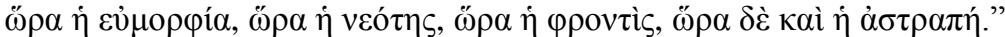

${ }^{183}$ Cf. DELG, s.v. кaıрós. WILAMOWITZ-MÖLLENDORFF (1880, p. 506) parece ter compreendido tão bem a ideia subjacente ao conceito quando diz que "Offenbar ist es [i.e., кaıó $\varsigma$ ] die Schneide, die scharfe Trennungslinie, welche das richtige vom verkehrten, das genug von zuviel und zu wenig, scheidet, die fines, quos

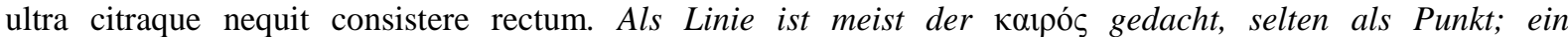
entsprechendes Wort stellt mir keine Sprache, von der ich etwas wüsste, zur Verfügung. Doch ist die Entwickelung von momentum einerseits, von discrimen andererseits wohl geeignet (...). Ich zweifle nicht, dass

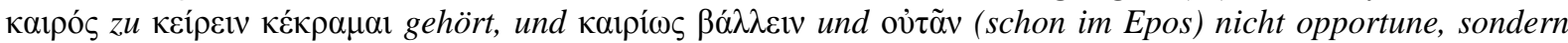
wirklich 'treffend, schneidend' bedeutet', grifo meu.

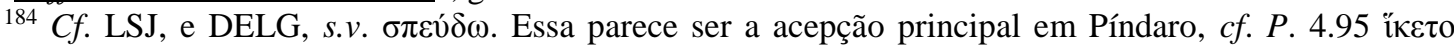
$\sigma \pi \varepsilon v ́ \delta \omega v$. RUMPEL, festino, propero; SLATER, be in haste e, particularmente acerca desta passagem, be eager for.

${ }^{185}$ FrACCAROLI (1894, p. 220), que relaciona essa passagem ao h. Hom. Apol. 194-7.

${ }^{186} C f$. O. 5.14, para o mesmo vencedor. KIRK et al. (1993, pp. 322, vol. 2). Cf. ainda minha discussão relativa ao uso de $\varphi$ ó $\varsigma_{\varsigma}$ no fr. Sim. I FGE e Homero, em BROSE (2007, p. 50 et seq.), onde eu dizia que "De fato,

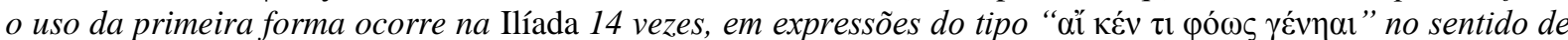
luz como 'saida', 'escape', 'esperança'. Nas duas vezes em que aparece na Odisseia, é empregado apenas conotativamente, exatamente na única acepção em que páos aparece nos dois poemas, o que nos permite

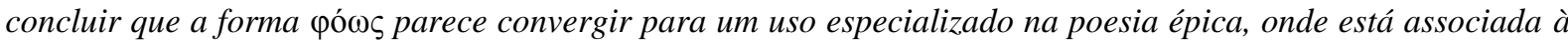
aparição do herói e à resolução de conflitos gerados pela batalha". O uso de $\varphi \tilde{\omega} \varsigma$, nessa acepção épica, pareceme atestado em Píndaro, além do mais, na passagem da $P$. 3.75.

187 Sobre a noção de tempo em Píndaro, $c f$. sobretudo KOMORNICKA (1976) e, de uma maneira mais geral, para o restante da lírica arcaica a importantíssima análise de FRÄNKEL (1993), passim.

188 Aqui representado pela dança cíclica das Estações, filhas de Zeus, de quem, por sua vez, depende a realização (ou não) de todas as coisas. Uma noção cuja expressão mais paradigmática é desenvolvida na $I$. 3. $C f$. também a O. 8.1-8; P. 5.122-3 e I. 5.52. 
Aparentemente porque a dança das Horas com que a ode se abre já nos prepara um frame através do qual poderemos conceitualizar o superlativo, isto é, a partir da ideia que Psaumide obteve sua vitória no último momento possível, porém não menos oportuno. Essa ideia, ademais, é uma característica típica do pensamento pindárico, isto é, o de que o esforço sempre é coroado, ainda que tardiamente, com o sucesso se aquele que se aplica a uma determinada tarefa tem em si uma qualidade inata que, mais cedo ou mais tarde, será revelada. O tempo, nas odes, é uma força, mais do que apenas um fenômeno, que tudo revela e põe à prova, e, assim, é capaz de separar o revelar a verdadeira natureza das coisas. É exatamente

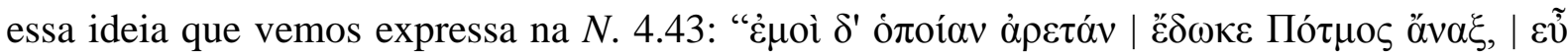

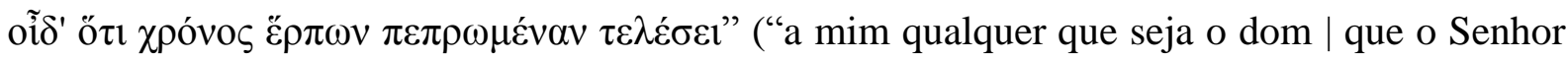
Destino concedeu | bem o sei que o tempo vindouro irá cumprir o que está fadado") ${ }^{189}$ e, numa passagem alusiva de uma imagética semelhante à $O .4$, neste fragmento ${ }^{190}$ :

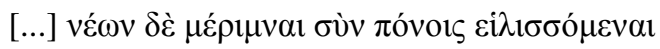

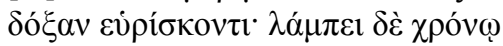

है $\rho \gamma \alpha \mu \varepsilon \tau^{\prime} \alpha i \theta \dot{\varepsilon} \rho^{\prime}<\dot{\alpha} \varepsilon \rho>\theta \dot{\varepsilon} v \tau \alpha$.

[...] as ambições dos jovens, aliadas ao treino, em seu desenrolar-se, a fama encontram. Brilha, com o tempo ${ }^{191}$, o resultado elevado ao céu.

Como nota Komornicka, "em Píndaro, o tempo "atesta”, "prova” ( $\dot{\varepsilon} \xi \varepsilon \lambda \varepsilon \dot{\varepsilon} \gamma \omega)$, em Baquílides ele "faz crer", "exalta" ( $\alpha$ $\xi \omega)$ os feitos que a Verdade faz resplandecer contra o

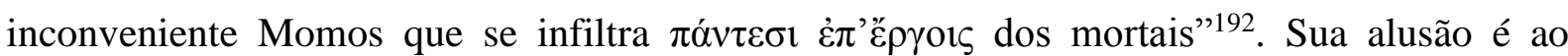
epinício 13.204-205 de Baquílides:

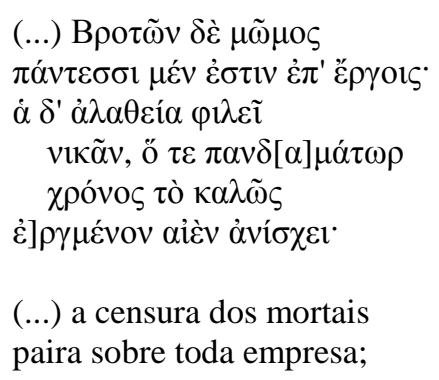

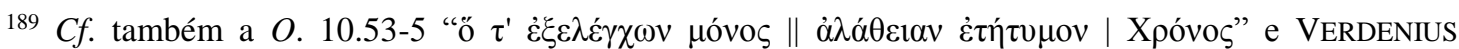
(1988a, p. 58) que, comentando essa passagem diz: "In contradiction to Homer, where time is a kind of void, time in Pindar is an active power (...). Time brings everything to fulfilment (...) in the present case the poet's premise. Since fulfilment constitutes the true reality, time is called $\pi \alpha \dot{v} \tau \omega \nu \pi \alpha \tau \eta \dot{\rho}(O .2,17)$ and even a power 'superior to all the gods (...)."

${ }^{190}$ Fr. 227 S-M. Citado por Clemente de Alexandria, Stromata, 4.7.49.1, logo após o fr. Sim. 579 PMG sobre a virtude (baseado ulteriormente em Hes. Op. 289 et seq.), a qual, morando no alto de uma pedra de difícil acesso, exige esforço e persistência para ser alcançada.

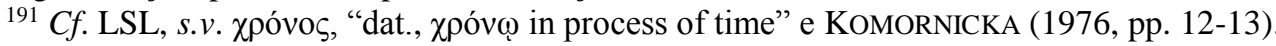

192 KOMORNICKA (1976, p. 8). 


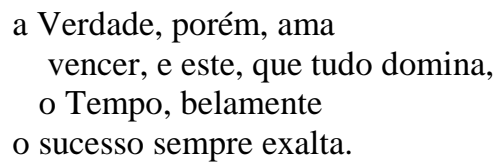

Quando Píndaro nos conta, ao final da $O .4$, como Ergino, um dos argonautas, livrou-

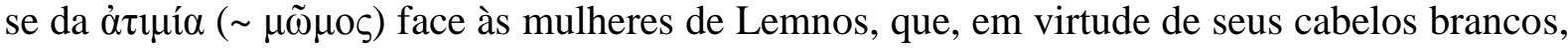
haviam desdenhado de suas chances de sucesso, parece-me que ele está concluindo com um

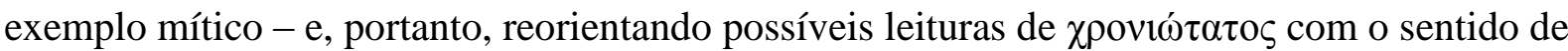
"a mais duradoura luz" que uma audiência poderia ter feito no início da ode, como quer Eckerman ${ }^{193}$-, a partir da noção do tempo e, portanto, das Horas e de Zeus, a que aludimos, isto é, como aqueles responsáveis por cumprir e revelar as virtudes inatas de todas as coisas.

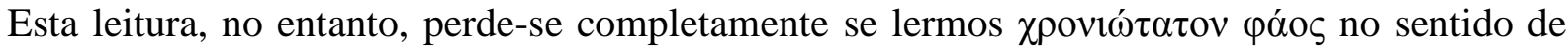
"a mais duradoura luz", referindo a expressão à ode, e não à vitória de Psaumide, cujo $\kappa \tilde{\omega} \mu \circ \varsigma$ é a sua manifestação material:

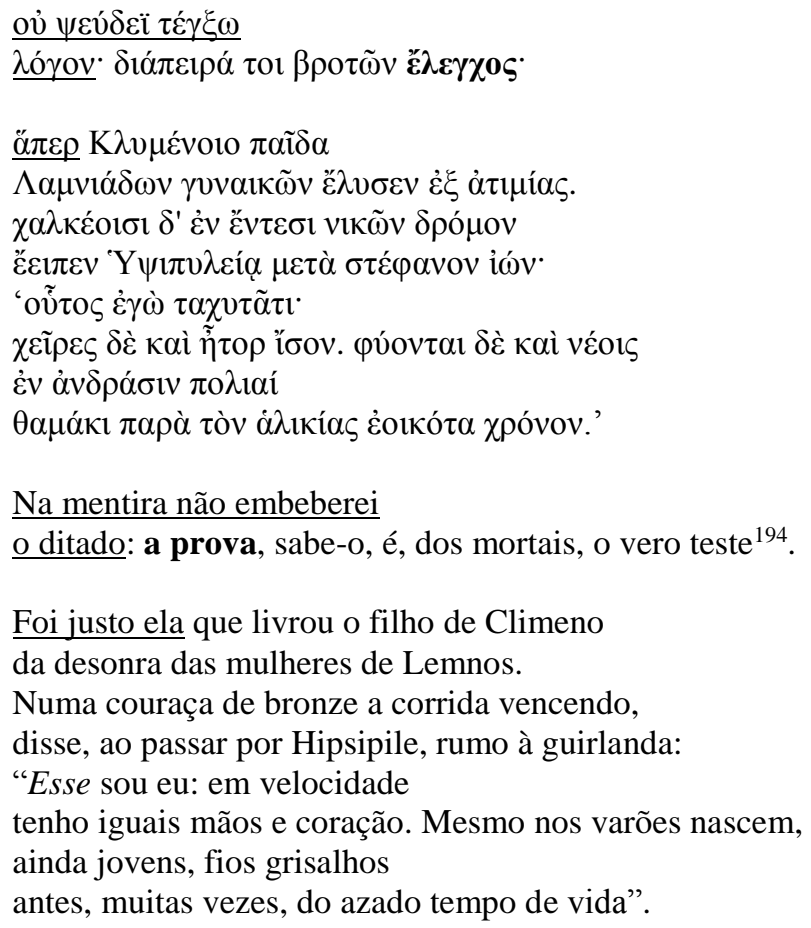

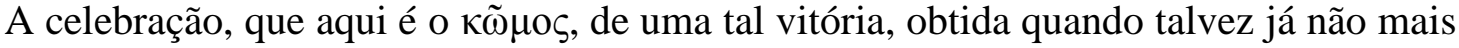
esperada, e possivelmente desacreditada por todos ${ }^{195}$, pode, portanto, e justificadamente, ser descrita como "a luz mais tardia/ oportuna oriunda de incansáveis/ inabaláveis ( $\varepsilon u ̉ \rho v \sigma \theta \varepsilon v \varepsilon ́ \omega v)$

${ }^{193} C f$. citação do autor, mais acima.

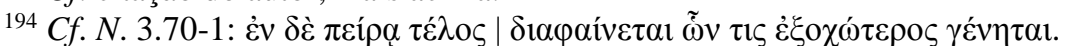

195 Assim WilamowiTZ-MOELlENDORFF (1966, p. 419), cujo acume crítico, tão raro atualmente, nos pergunta "Ist die Epode nicht ein prächtiger Abschluß? Und sagt die schichte Kürze nicht, wir können andere beiseite lassen: der Erfolg entscheidet"." 
qualidades"196, e ela "vem" (ǐkel, 10) da carruagem de Psaumide tanto metaforicamente, no sentido de que é o pagamento devido (ä́rovv $\alpha)^{197}$ pela vitória obtida com aquela carruagem, quanto, possivelmente, num sentido também concreto, se quisermos pensar que o $\kappa \tilde{\omega} \mu$ o toma

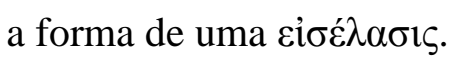

Já na $O .8$, para Alcimédão de Egina, vencedor na luta juvenil, inicia o seu proêmio com uma invocação à Olímpia, em cujo bosque sagrado pede que essa receba o $\kappa \tilde{\omega} \mu \mathrm{s}$ coroado de guirlandas:

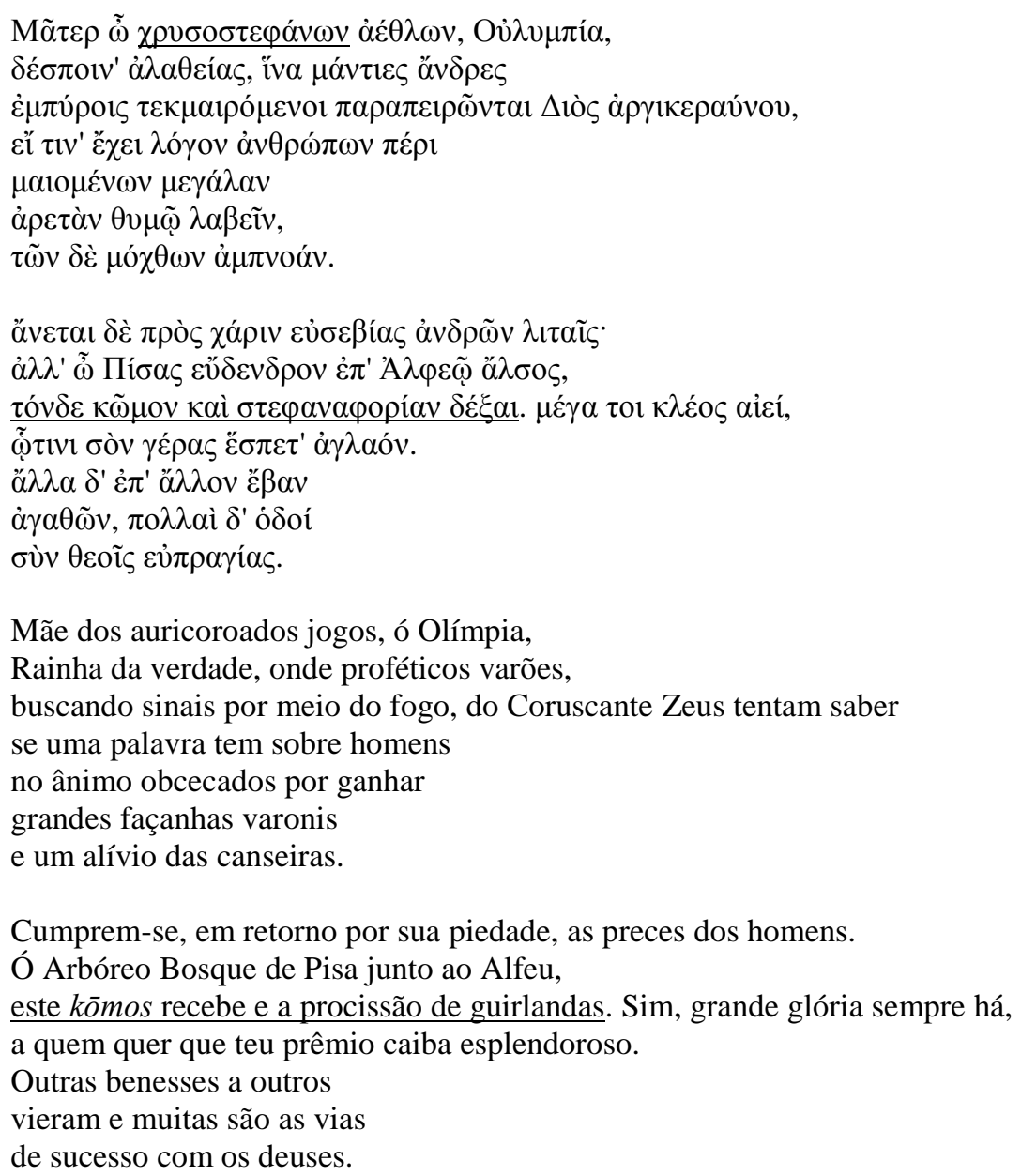

Muito embora Wilamowitz e outros acreditem ${ }^{198}$ que essa ode só poderia ter sido

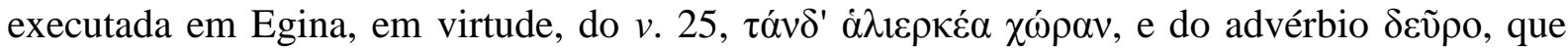
parecem apontar, por meio de uma dêixis proximal, para aquela ilha, essa avaliação é

196 O genitivo é ablativo. Cf. a bela interpretação de MEZGER (1880, p. 138), “den so spät erschienenen

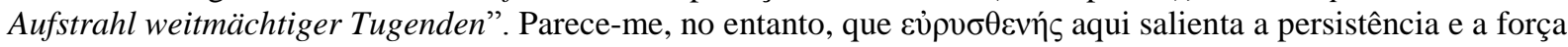
de caráter inabaláveis que, mesmo em face da adversidade, são capazes de produzir resultados.

197 Cf.KURKE (1991, p. 110).

198 Wilamowitz-MoEllendorfF (1966, p. 403), “Olymp. 8 ist auf Aigina gesungen, V. 25”. Assim também RACE (1997a, pp. vol.1, p.134). 
disputada por muitos comentadores, como Mezger ${ }^{199}$ e Gildersleeve ${ }^{200}$. De fato, Schmidt nos dá uma boa razão para que a première da canção ocorresse em Olímpia, junto ao altar de Zeus, e não em Egina, em um Olimpeio, como queria Wilamowitz: Tucídides ${ }^{201}$ relata que, no verão anterior à vitória de Alcimédão, Atenas e Egina haviam entrado em guerra e a liga do Peloponeso havia destacado trezentos hoplitas para a ilha, a fim de defender a cidade de uma possível invasão ateniense. Dessa forma, segundo Schmidt, "o ruído das tropas teria abafado completamente o som do hino de vitória"202. Seja como for, os sinais ambíguos de dêixis nessa ode são problemáticos e podem apontar para uma reperformance em Egina ${ }^{203}$, em cujo contexto, no entanto, deveria ter soado algo estranho, a uma audiência local, a invocação ao Bosque de Pisa como destino de um $\kappa \tilde{\omega} \mu о \varsigma$ de vitória executado na ilha, num outro templo, mesmo se supormos que este fosse também um templo de Zeus.

A menção à $\sigma \tau \varepsilon \varphi \alpha v \eta \varphi o \rho i ́ \alpha$, ademais, quando lida em conjunto com a invocação à Olímpia, de que se diz $\chi \rho v \sigma o \sigma \tau \varepsilon \varphi \alpha ́ v o \varsigma$, parece complicar a hipótese de uma première em Egina ao mesmo tempo em que reforça a ocasião de celebração da ode em um procissão, a que se referiria o $\tau$ òv $\delta \varepsilon \kappa \tilde{\omega} \mu \mathrm{ov}$ do $v .10$ segundo a explicação de Triclínio a essa passagem,

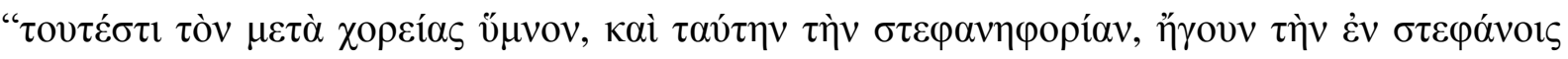

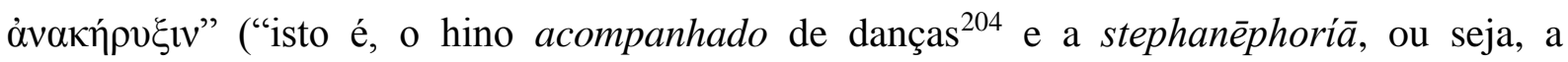
proclamação [acompanhada de celebrantes] portando coroas”). O escoliasta de Élio Aristides $^{205}$ nos informa que o termo $\alpha \dot{v} \alpha \kappa \eta ́ \rho v \xi ı$ ı referia-se à proclamação dos vencedores, do

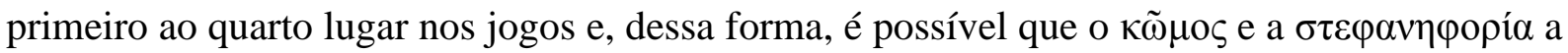
que Píndaro faz menção poderiam se referir a uma procissão ao altar de Zeus imediatamente após a cerimônia de coroação do vencedor, o que acontecia no último dia de competições em Olímpia. Uma vez que as provas de luta na categoria juvenil aconteciam no primeiro dia da lua cheia ( $\pi \alpha v \sigma \varepsilon ́ \lambda \eta v o \zeta)$ após o início dos jogos, isto é, dois dias antes do encerramento ${ }^{206}$, haveria tempo suficiente para que Píndaro compusesse o epinício. Nada impede, no entanto,

${ }^{199}$ MEZGER (1880), "Dagegen [i.e., contra a performance em Olímpia] spricht weder v. 25 noch v. 51;

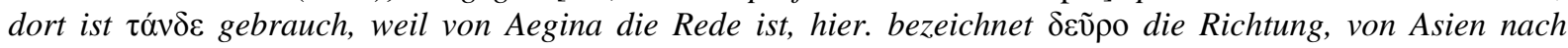
Griechenland (...)".

${ }^{200}$ GILDERSLEEVE (1886, p. 192).

2011.105.

${ }^{202}$ SCHMIDT (1862, p. 343).

$203 C f$. AtHANASAKI (2009) e, de uma maneira mais geral, sobre dêixis em Píndaro, também AthanASSAKI (2004) e D'Alessio (2004).

${ }^{204}$ Note que, para Triclínio, o hino não seria cantado por um coro, mas "entre danças". Para o valor de $\mu \varepsilon \tau \alpha$ com dativo, $c f$. LURAGHI (2003, p. 244 et seq.).

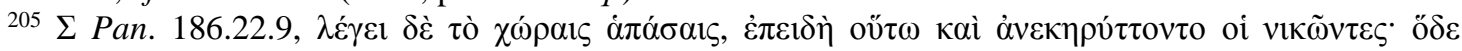

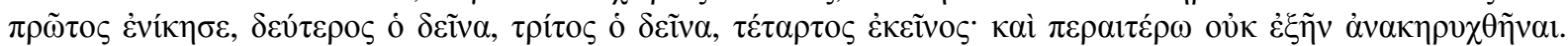

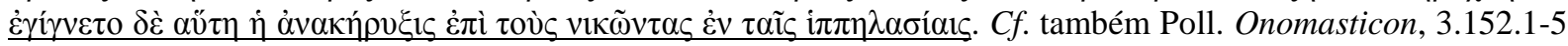
e os $\Sigma$ recentiora $O$. 13.136-148.10-12.

${ }^{206} C f$. S. G. MiLLER (2006) e 2012). 
que postulemos uma celebração impromptu, imediatamente após a vitória de Alcimédão pois, segundo Mezger ${ }^{207}$, Píndaro poderia ter composto a ode de antemão, prevendo a vitória do menino, ao que a menção ao oráculo de Zeus no proêmio aludiria. Quer concordemos ou não com Mezger, é difícil pensar que uma composição extemporânea ou num período bastante curto de tempo estivesse além das capacidades de um poeta oral como Píndaro, certamente treinado para improvisar em ocasiões como a descrita ${ }^{208}$.

No caso da $O .14$, uma ode monóstrofa para Asópico de Orcomenos, que começa com uma invocação às Graças, deusas tutelares daquela cidade, os elementos processionais estão bem demarcados, tanto no metro, quanto no texto da antístrofe. Como a ode é bem pequena, vale a pena citá-la por completo ${ }^{209}$ :

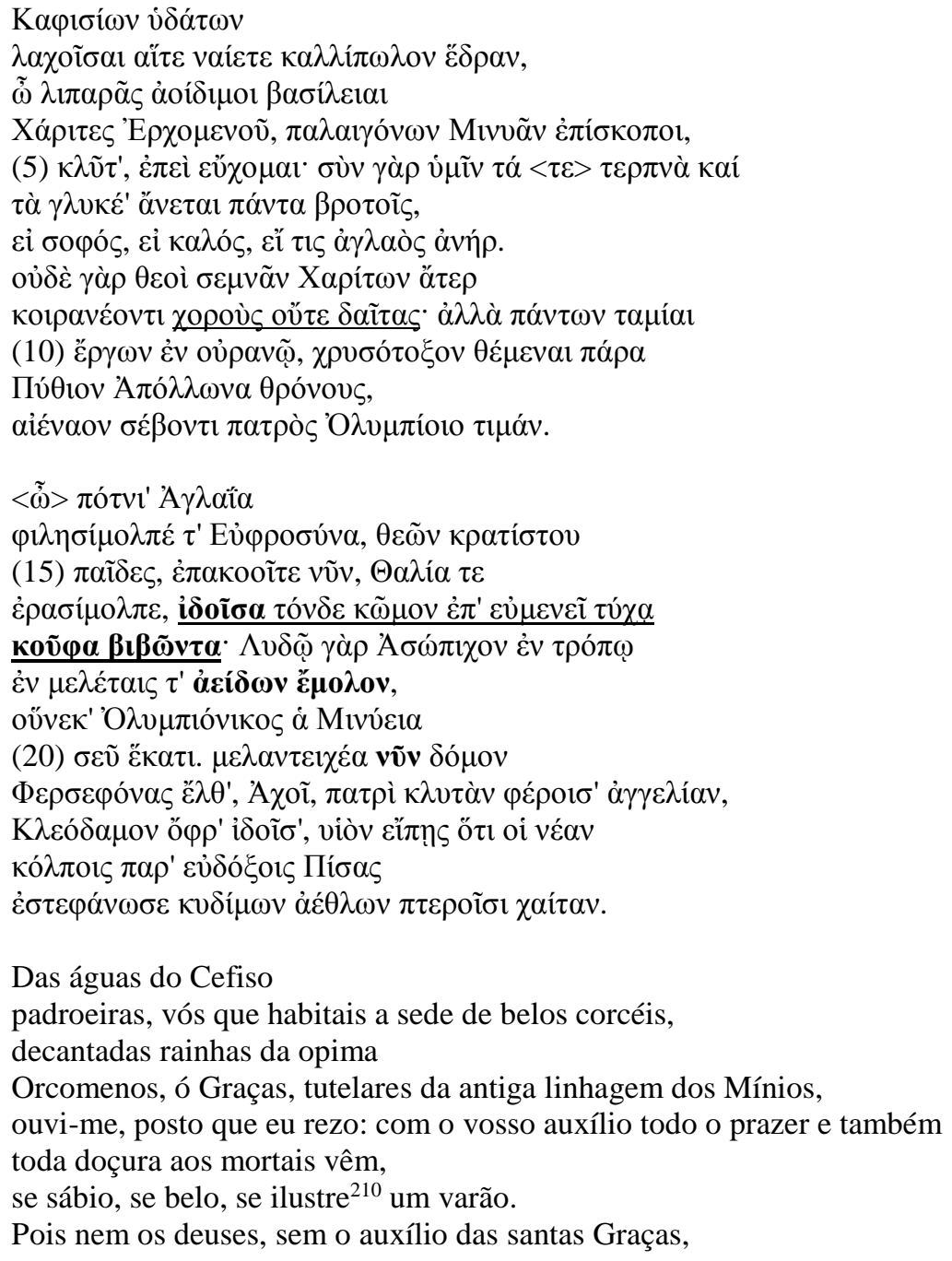

${ }^{207}$ MEZGER (1880, p. 375).

${ }^{208}$ Aristóteles, Rhet. 3.2.1405b, parece se referir a algum tipo de improvisação, por exemplo, por parte de Simônides (fr. 515 PMG) ao compor o epinício das mulas de Anaxilas de Régio, tão logo recebeu uma soma que lhe parecia adequada.

${ }^{209} C f$. o estudo da tradução dessa ode por ASSUNÇÃo (1999).

${ }^{210}$ VERDENIUS (1987, p. 111), “Illustrious', not on account of corporeal beauty”. 
organizam danças ou banquetes. Mas guardiãs de todas

as atividades no céu, ao do arco d'ouro tendes

tronos, junto ao Pítio Apolo,

e sempiterna reverenciais, do Olímpio Pai, a honra.

Ó Senhora Radiância,

e tu, Alegria amiga da canção, do mais poderoso dos deuses

filhas, possais me ouvir com atenção, e especialmente tu, Festa,

que amas a canção, após veres este kōmos numa auspiciosa ocasião,

com graça a avançar. Numa lídia harmonia a Esópico,

em bem pensados versos ${ }^{211}$, vim cantando,

porque vitoriosa em Olímpia é a terra mínia,

graças a ti. E agora às atras muralhas

de Perséfone vai, Eco, ao pai portando a ínclita mensagem,

a fim de que, ao veres Cleodamo, possas lhe dizer que o filho,

nos bem-afamados vales da Pítia,

coroou sua jovem cabeleira com as aladas guirlandas dos ilustres jogos.

Mezger, Boeckh e Gildersleeve ${ }^{212}$ situam a performance durante a procissão que, na ode, seria o $\kappa \tilde{\omega} \mu \varsigma$, muito embora para Schmidt e, mais recentemente, Verdenius ${ }^{213}$, a canção

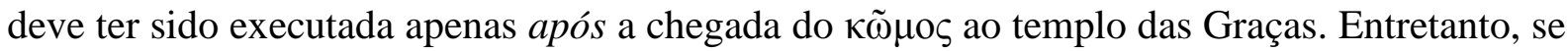

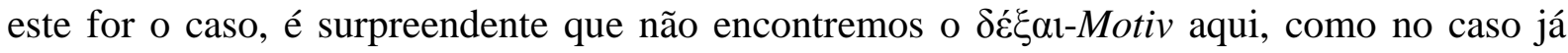
visto da $O .4$. Talvez, no entanto, porque o aoristo i̊oĩ $\sigma \alpha$ tenha uma função semelhante neste poema, na medida em que, do ponto de vantagem da persona loquens, ele constrói a procissão de uma maneira retrospectiva ${ }^{214}$ e indica o ponto de passagem de um estado-de-coisas (a procissão) a outro, que jaz fora do escopo da ode e do qual não somos informados provavelmente porque estaria claro para a audiência original. Consequentemente, o aoristo sinaliza a passagem ao frame delimitado pela invocação à Eco (ṽ̃v, 20) e, também, por meio dela, para o final da canção, que se encerra como uma prece ao pai morto, numa passagem alusiva da ideia, já mencionada por Píndaro na $P$. 5.98-103 e na O.8.77-80, de que os mortos também partilham da glória conferida pelo epinício.

De fato, esta ode, como os comentadores acima já apontaram, toma claramente a forma de uma prece, encaixando-se apenas de uma maneira muito esquemática em nosso conceito - bastante incompleto, é verdade - sobre o que é um epinício ou sobre o que

211 VERDENIUS (1987, p. 122), "Does not refer to the training of the chorus (Fenn.) but to the careful composition of the text (Nis. 's 'in chosen phrases' is better than Slater's 'among my (poetic) preocupations'): cf. N. 6, 54 (..), I. 5, 28-9."

${ }^{212}$ MEZGER (1880, p. 313) aposta em uma performance coral de um Knabenchor; GILDERSLEEVE (1886, p. 237). BOECKH $(1821$, p. 221), acha plausível, dada a brevidade da ode, propor uma performance em Olímpia, no moldes da $O .8$, sobretudo porque Pausânias e o $\Sigma$ a $O .5 .10$, atestam um templo das Graças em Olímpia.

213 Respectivamente, SCHMIDT (1862, p. 209) e VERDENIUS (1988b, p. 119.16). O argumento de Verdenius - que cita o trabalho de R. von Scheliha, Interpretation der XVI Olympische Ode von Pindar in Freiheit und Freundschaft in Hellas. Amsterdam, 1968 (não consultado por mim) -, no entanto, é apriorístico na medida em que pressupõe uma performance estática (e coral) porque "in that case [i.e., durante a procissão] it could hardly have been understood and appreciated by the public".

${ }^{214} \mathrm{O}$ assim chamado aoristo complexivo. Cf. SMYTH e MESSING (1956, p. §1927). 
podemos deduzir de suas características formais por meio do corpus. Consequentemente, o

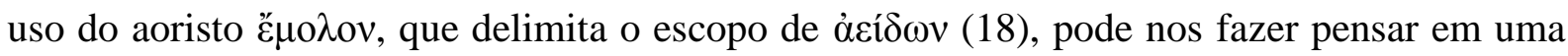
ocasião pretérita em que um epinício propriamente dito, ou seja, um que apresentasse características mais prototípicas do gênero, pudesse ter sido executado e com o qual a presente situação, cantada nesta ode, estaria conectada ( $\gamma$ à $\rho, 17$; ṽ̃v, 20). Seria possível, por

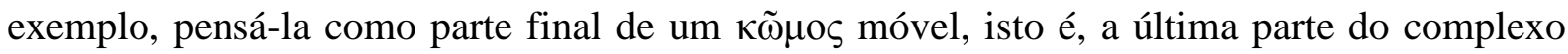

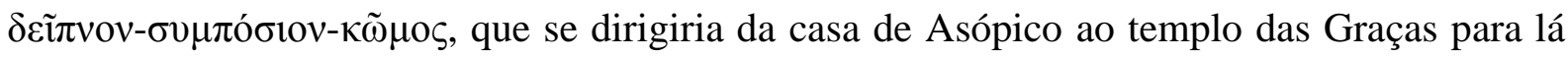
dedicar sua coroa, além de prestar homenagem ao pai morto do atleta ${ }^{215}$.

De qualquer maneira, como quer que interpretemos um possível cenário da performance e a sua dinâmica, alusões ao movimento dos celebrantes são claros e apontam, novamente, para um acompanhamento espontâneo que, possivelmente, poderia incorporar

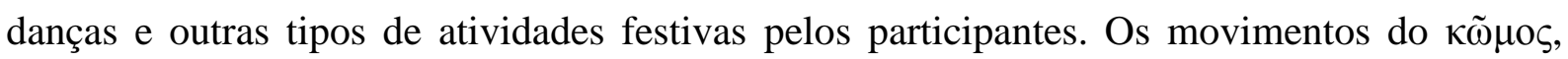
aqui, não podem ser interpretados do ponto de vista de uma performance coral, ou seja, não pressupõem uma dança ensaiada. Na verdade, eles são reminiscentes dos passos que Apolo, enquanto citaredo, executa em meio ao coro das Musas ${ }^{216}$,

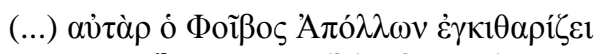

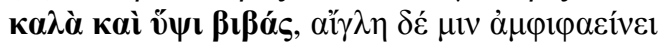

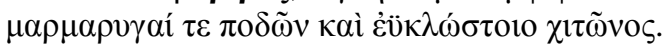

(..) De seu turno, Apolo acompanha na lira

com belas e altas passadas, um fulgor o envolve

e faíscas saltam de seus pés e de sua bem tecida túnica.

e, sobretudo, da dança extemporânea que o coro da Electra de Eurípides (859-65) pede que a personagem-título execute, ao saber da morte de Egisto, numa linguagem bastante alusiva ao gênero epinicial ${ }^{217}$

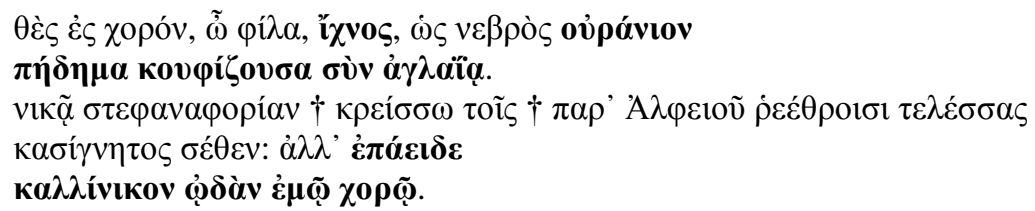

Finca na dança, ó amiga, o pé, como uma corça, ao céu um salto ligeiro erguendo em festa.

Tendo obtido uma vitória maior que aquelas ao largo do Alfeu, é vencedor o teu irmão: anda então, canta uma ode de vitória para a minha dança.

\footnotetext{
${ }^{215}$ Para um paralelo, $c f$. O. 8.77.

216 h. Hom. Apol. v. 202.

${ }^{217}$ Sobre alusões do gênero epinicial nas tragédias, sobretudo na Electra, cf. SWIFT (2010).
} 
Uma comparação entre as três passagens permite-nos entender que a dança descrita por elas é do mesmo tipo: alegre, informal e improvisada. Note a relação entre os versos غ̇ं

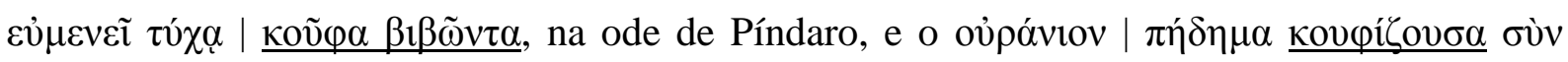

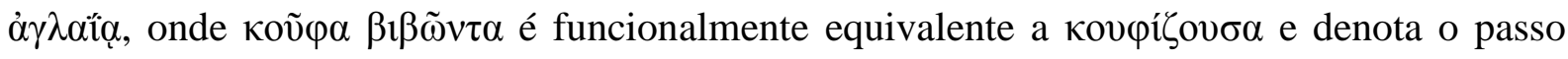
despreocupado, destro e alegre dos celebrantes de um lado, e o salto de alívio que Electra deve dar, de outro, ao saber da vitória do irmão. Ou seja, em ambos os casos os movimentos

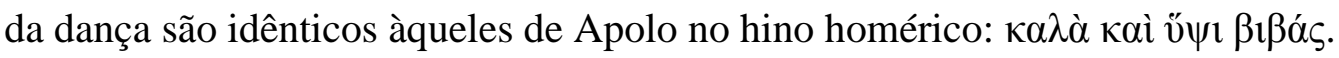

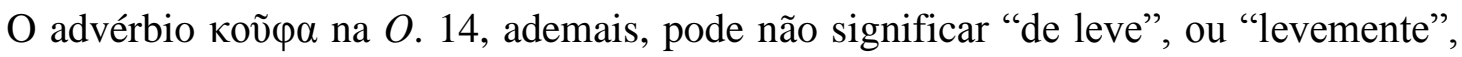
numa acepção que indique qualquer tipo de movimento majestoso como os associados com a dança coreografada de um coro. De fato, essa acepção só é possível se a palavra for contextualizada, aprioristicamente, a partir de uma hipótese de performance coral, como de fato o é, pelo que se vê na solução dada pela maioria dos tradutores para esse verso ${ }^{218}$. Essa contextualização, no entanto, é arbitrária e está em contradição com as evidências que analisamos até aqui, que apontam para uma diferenciação, mais do que uma identificação entre $\kappa \tilde{\omega} \mu \mathrm{o} \varsigma$ e $\chi 0 \rho \rho^{\prime 219} \varsigma^{2}$. Consequentemente, uma comparação entre as três passagens permite deduzir que o uso deste termo deve ser entendido mais no sentido de "aliviado" (> lat. alleviatus), isto é, "sem preocupação", “com alegria" 220 , e, daí, por extensão de sentido, “confiante", como na Il. 13.155-8, quando, após a admoestação de Heitor, Deífobo avança

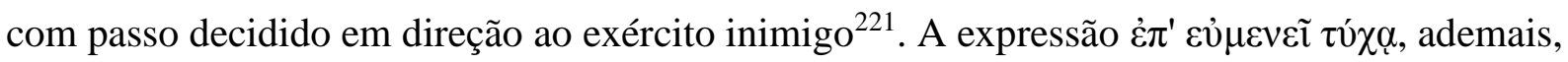

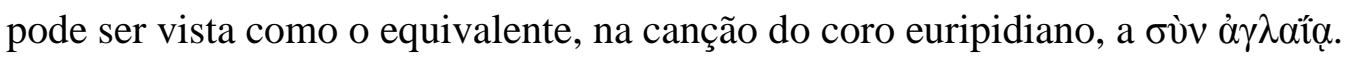

218 Verity2007), RACE (1997b), Svarlien 1990), “stepping lightly"; Lourenço 2006), "de leves passos”. Mas note a interpretação de BOECKH (1821, p. 222), "V. 17 (...) est incedentem levi pede, alacri motu, qualis est

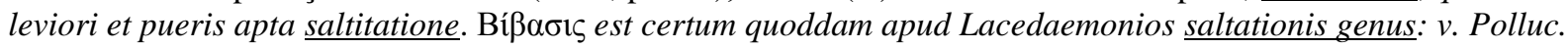
$I V^{\prime \prime}$, grifo meu.

${ }^{219}$ A controvérsia foi vista em detalhes no Capítulo 5. De uma maneira geral, $c f$. HEATH (1988)

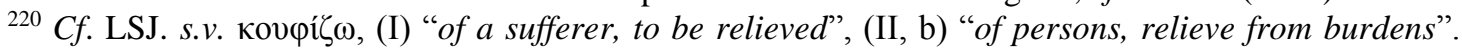

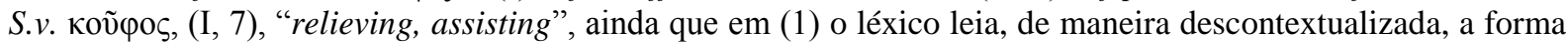
adverbial no sentido de "lightly", o que é evidentemente incompatível com a passagem da Electra em questão, uma vez que a mesma salta de alegria por se ver aliviada do peso que a morte não vingada do pai lhe causava,

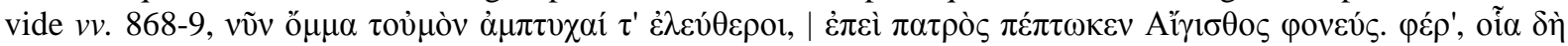

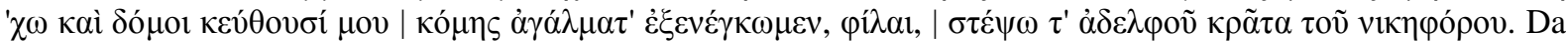

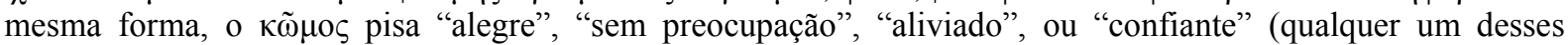
sentidos é possível) porque o vencedor deixou para trás o đóvo $\varsigma$ da fática atlética, um topos dos epinícios, $c f$., p.

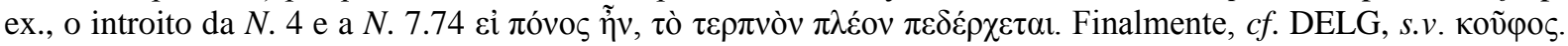
VERDENIUS (1987, p. 120.17), parece se aproximar dessa interpretação, embora não perceba que a interpretação de Leaf da passagem homérica citada, revela justamente que Défobo "salta" para frente, de maneira destemida

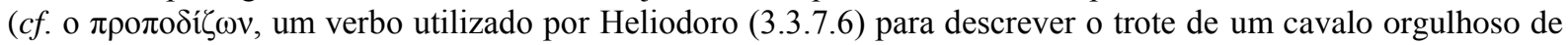

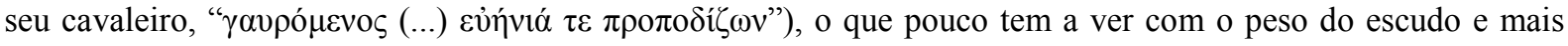
com o alívio representado pelo "peso" antes imposto pelo medo.

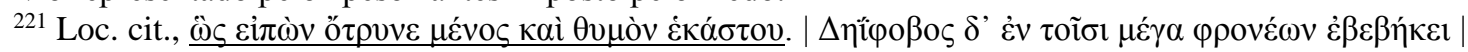

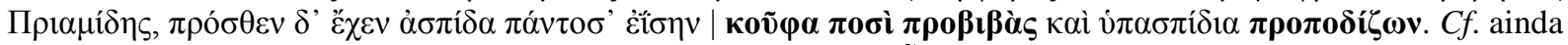

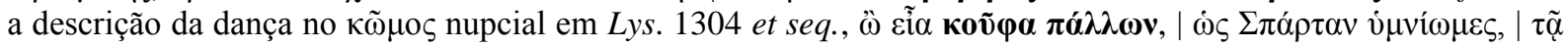

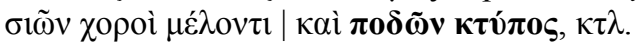


Tratam-se, consequentemente, de ocasiões semelhantes que requerem um tipo de dança semelhante, mesmo se pensarmos que, para o caso da Electra, a dança, obedecendo às regras da performance trágica, deve ser, no nível de sua execução no palco, face à audiência, uma coreografia que, no entanto, reproduz, no nível da narrativa e por meio de suas autorreferências e metalinguagem, uma dança não coreografada, mas espontânea e do tipo que um vencedor olímpico, com o qual Electra é comparada, executaria ${ }^{222}$. Esta passagem, portanto, dificilmente poderia ser tomada como evidência de uma performance coral para um epinício. Na verdade, o contrário deve ser verdade. Note, finalmente, que é Electra, e não o

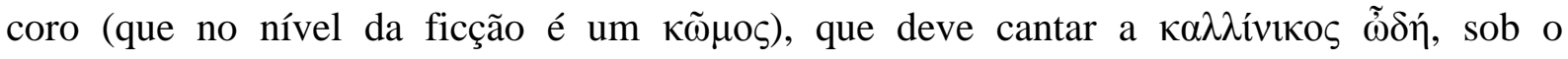
acompanhamento da qual aquele irá dançar ${ }^{223}$, ou seja, ao menos no nível cênico da peça, o "epinício" de Electra é conceitualizado como uma performance monódica. Essas observações preliminares serão importantes para nossa discussão acerca da forma da performance nos Capítulos 5 e 6.

As $O .6$, a $P .5$ e 8 , por seu turno, permitem-nos visualizar o movimento do $\kappa \tilde{\omega} \mu$ o $\varsigma$ em diferentes momentos e pontos de vista.

Na O. 6, composta para Agésias de Siracusa ${ }^{224}$, temos uma prece (92-100) da persona loquens para que o $\kappa \tilde{\mu} \mu \mathrm{s}$, partindo de Estínfalo, onde provavelmente se dá a première, fosse bem recebido por Hierão em seu retorno à Sicília:

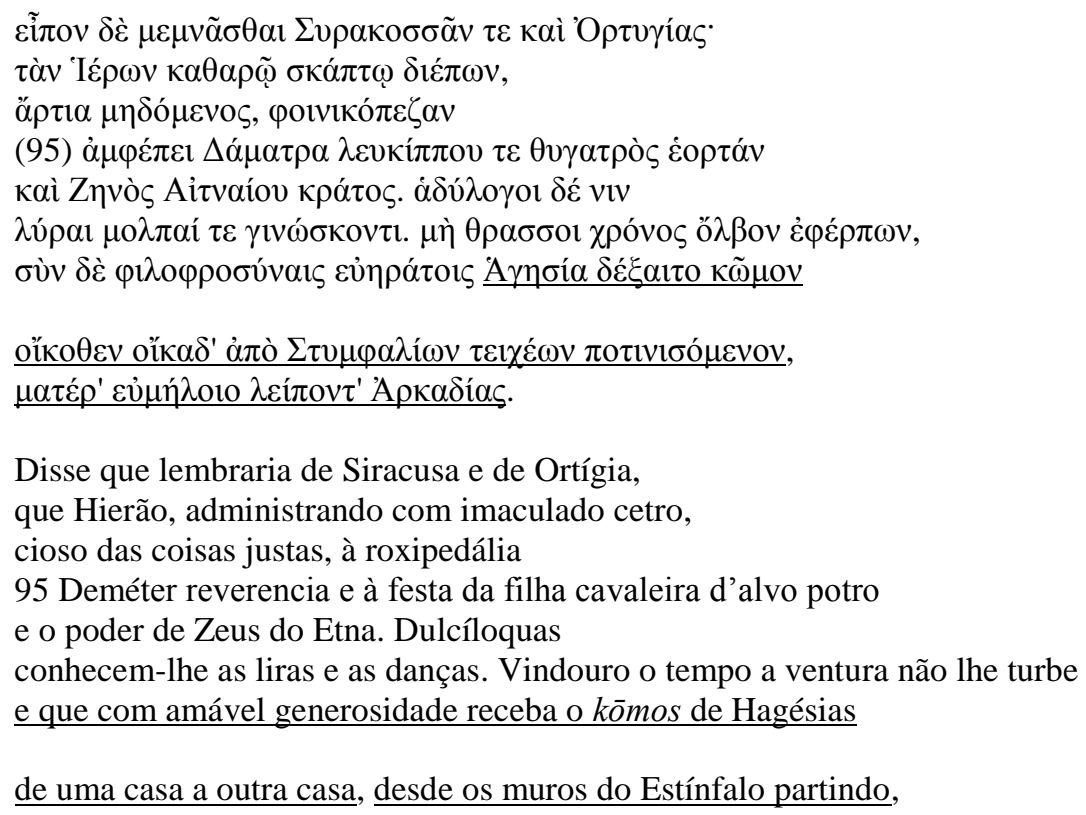

222 Assim HeATH (1988, pp. 185-6).

${ }^{223}$ A importância dessa passagem será rediscutida nos próximos capítulos.

${ }^{224}$ Possivelmente um general de Hierão ou, doutra forma, certamente uma figura de poder naquela

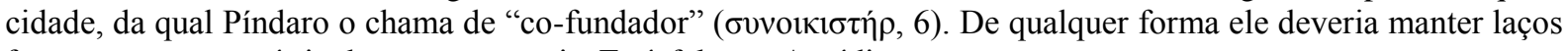
fortes com com a pátria de seus ancestrais, Estínfalo, na Arcádia. 
deixando a mãe da Arcádia de belos rebanhos.

A volta de Agésias é, portanto, conceitualizada como um $\kappa \tilde{\omega} \mu о \varsigma$ que se afasta de seu marco, neste caso Estínfalo, em direção a um alvo, Siracusa. Ele procede como um $\kappa \tilde{\omega} \mu о \varsigma$ típico, tal qual vimos, por exemplo, na elegia e em Aristófanes, "de uma casa a outra casa" (99). Trata-se evidentemente de uma metáfora para a feliz viagem de retorno do vencedor, mas ela funciona em diversos níveis.

Em primeiro lugar, porque a ode faz uma referência explícita a um $\kappa \tilde{\omega} \mu$ o $\varsigma$ estacionário, do qual Agésias é o "senhor" ( em meio ao qual a ode está sendo executada. Este $\kappa \tilde{\omega} \mu \mathrm{o}$, que delimita o frame da ode e que não é móvel, provavelmente acontece na própria casa de Agésias, ou de um parente, em Estínfalo ${ }^{225}$, e o cenário mais provável seria o de um simpósio, como a referência a غ̇ंaípoı no v. 87 sugere, já que não me parece minimamente plausível que Píndaro pudesse se referir aos membros de um suposto coro de meninos por meio desse substantivo. O hino a Hera Parteneia do mesmo verso deve dizer respeito a uma canção que não a própria ode e poderíamos pensar em uma procissão até um tempo local da deusa nos termos sugeridos para a performance da $O .14$, ao final desta celebração.

É possível, ainda, postular que a própria chegada de Agésias na sua cidade, na

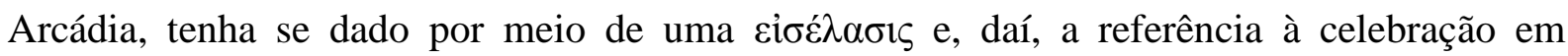

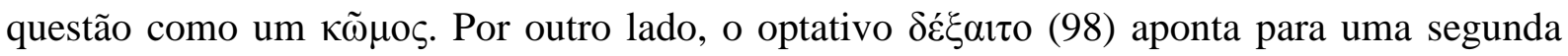
performance em Siracusa e não se pode descartar a ideia, fortemente sugerida pela ode, de

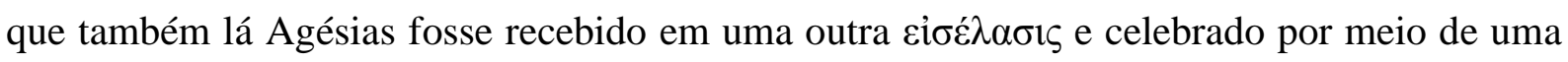
grande festa tanto em virtude de seu status junto a Hierão quanto por ser um descendente dos iamidas e $\tau \alpha \mu$ íaৎ do mantéu de Zeus em Olímpia. Isso seria, ademais, apenas o esperado de

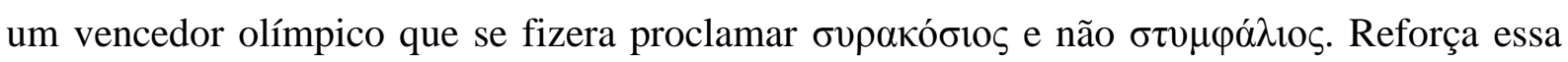

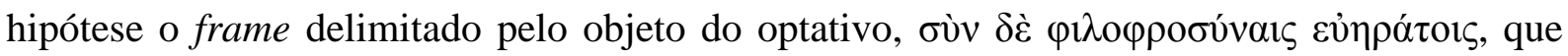
sugere um contexto festivo em meio ao qual o $\kappa \tilde{\omega} \mu$ os será recebido. Não podemos deixar de notar que, nos versos anteriores, a generosidade de Hierão e a sua intimidade com a lira e as canções é salientada e certamente não se esperaria dele que contrariasse o ideal de $\alpha \dot{\varphi} \theta$ ovía expresso no proêmio da ode (4-7):

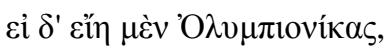

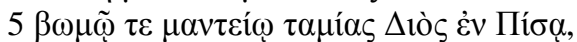

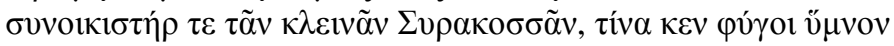

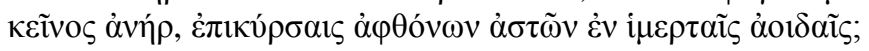

${ }^{225}$ Assim, MEZGER (1880, p. 121), seguido pela maioria dos comentadores. 
Houvesse acaso um vencedor Olímpico,

5 um guardião do altar profético de Zeus ${ }^{226}$ em Pisa

e um co-fundador da célebre Siracusa, como de um hino furtar-se-ia

um tal homem, convivendo com cidadãos generosos com as canções?

Toda a imagética dessa canção depende de entendermos a sua dinâmica a partir do complexo de um simpósio, onde $\kappa \tilde{\omega} \mu$ or chegam e instalam-se, e donde partem em busca de

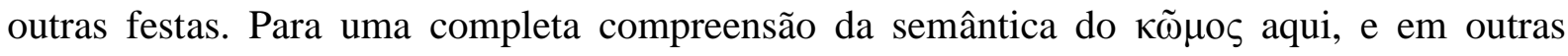
canções, precisamos tentar imaginar o que precedeu e o que se sucederá ao hic et nunc do canto. Obviamente, a compreensão de um e de outro estão interligadas, uma vez que, se imaginarmos que este $\kappa \tilde{\omega} \mu$ o, que agora vemos instalado em algum lugar em Estínfalo, é descrito em termos de movimento para outro lugar, Siracusa, onde uma outra celebração irá ocorrer, não há porque pensar que o mesmo não se aplique para a situação anterior que jaz aquém do escopo da ode, ou seja, uma possível procissão até a locação atual. O que eu quero dizer com isso é que esta passagem da $O .6$ nos permite ter uma visão mais compreensiva da

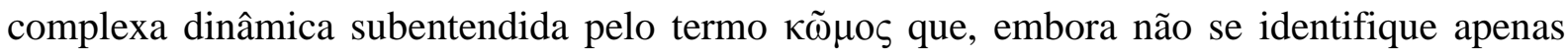

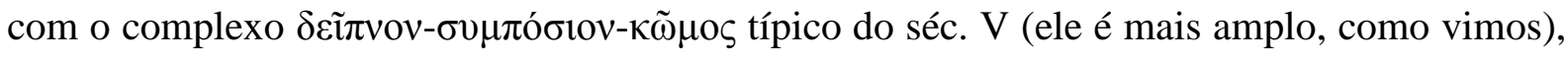
também o implica e é nesta acepção que ele está claramente delimitado aqui e em outras odes ditas simpóticas ${ }^{227}$.

Se, portanto, na $O .6$ temos uma projeção de um $\kappa \tilde{\omega} \mu$ o $\varsigma$ em um frame futuro, nas $P .5$ e

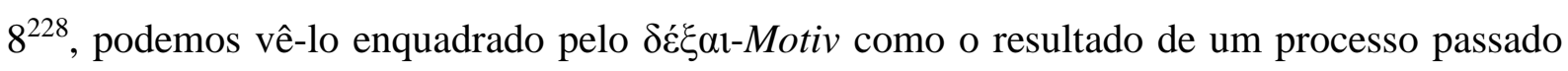
que redunda, no caso da $P$. 5, na própria ocasião de performance da ode, como o demonstrativo $\tau o ́ v \delta \varepsilon$ (22) pode indicar. De sua vez, na $P$. 8, a primeira referência ao $\kappa \tilde{\omega} \mu$ o $\varsigma$ (20) diz respeito possivelmente à celebração in loco, imediatamente após a vitória, por meio de uma passagem abrupta do mito à ocasião, na qual a persona loquens afirma que, se Apolo dominara $(\delta \mu \tilde{\alpha} \theta \varepsilon v, 17)$ o rei dos Gigantes com uma chuva de flechas, recebera (๕̌ $\delta \varepsilon \kappa \tau o, 19)$,

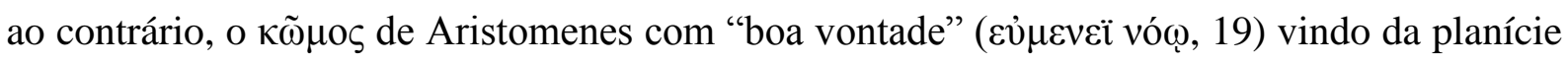

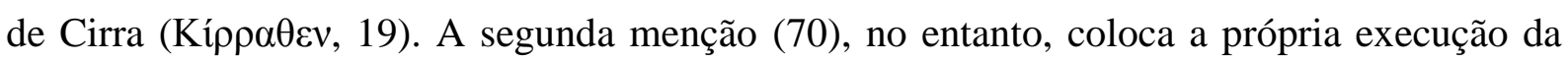
ode dentro do frame delimitado por $\kappa \tilde{\omega} \mu о \varsigma$, aí descrito como $\alpha \delta v \mu \varepsilon \lambda \eta ́ s . ~ A p o l o$, talvez por ser o patrono dos jogos, aparece, como já vimos no Hino Homérico a Hermes, proeminentemente

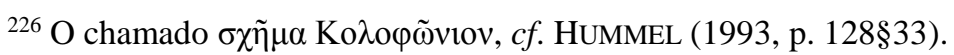

${ }^{227} C f$. JeNNY STRAUSS ClAY (1999); KRUMMEN (1990), sobretudo a segunda parte, p. 155 et seq.

${ }^{228}$ A $P .8$ foi composta para comemorar a vitória do rei Arcesilau de Cirene na quadriga, para quem Píndaro já compusera a enorme e magnificente $P$. 4. Sua première pode ter se dado durante o festival de Apolo Carneio, naquela cidade. A P. 5, para Aristomenes de Egina, um menino vencedor na categoria juvenil da luta nos jogos píticos. 
associado com ambos os $\kappa \tilde{\omega} \mu$ or. Na P. 5, inclusive, o $\kappa \tilde{\omega} \mu$ o de Arcesilau é descrito como o "brinquedo" (ou "deleite", $\alpha \theta v \rho \mu \alpha, v .23$ ) do deus.

Nessas três últimas odes que analisamos há claros indícios de que o $\kappa \tilde{\omega} \mu$ o s a que a persona loquens faz referência está inserido dentro de um frame que constrói o seu sentido a partir de um espaço discursivo corrente que pressupõe algum tipo de convergência para o local da performance, ou, algumas vezes, daí para outro lugar, como demonstram os marcadores dêicticos de tempo verbal e a partícula adverbial $-\theta \varepsilon v$, citados acima. Uma comparação com as formas verbais construídas sobre - $\kappa \omega \mu$ - pode ser, nesse sentido, ilustrativa. Na $O .9 .4$, por exemplo, Efarmosto é descrito como $\kappa \omega \mu \alpha ́ \zeta \omega v$ em meio aos seus

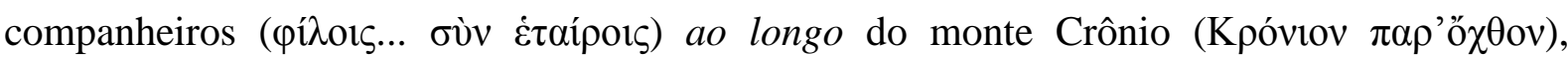
provavelmente em direção ao templo de Zeus. Na $N$. 9.1-2, é a própria persona loquens que conclama as Musas a irem em festa da casa de Apolo, em Sicião, à casa de Crômio no Etna

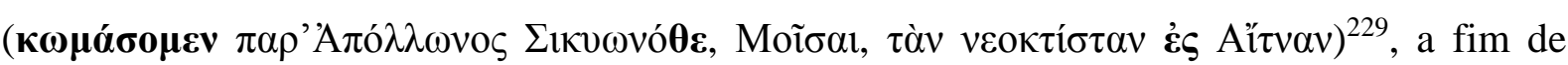
celebrarem sua vitória na corrida de quadriga, onde lhes esperam de portas abertas.

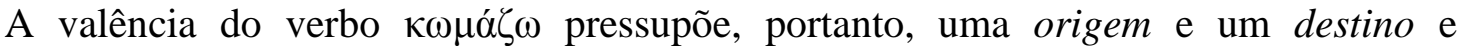
descreve, normalmente, o deslocamento através de uma paisagem. Muito embora qualquer um dos elementos possa permanecer não perfilado em todas as ocorrências de termos derivados de $-\kappa \omega \mu-$, o próprio substantivo bem como o seu verbo poderiam ser capazes de evocar um frame capaz de contextualizar a celebração ora em andamento a partir de um EDC no qual essas informações fizessem parte do conhecimento partilhado pela audiência.

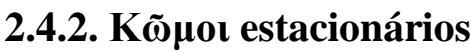

J. S. Clay, como vimos, já argumentou, há algum tempo atrás, que "qualquer que seja a locação, o contexto imediato da performance (...) é o simpósio"230. De fato, em alguns epinícios de Píndaro enquadrados pelo termo $\kappa \tilde{\omega} \mu о \varsigma$, a linguagem utilizada é muito sugestiva do vocabulário técnico do simpósio. Nos exemplos acima, vimos o uso do termo marcado

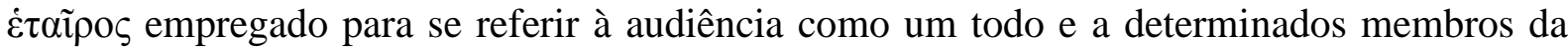
mesma $^{231}$, como a Carroto, o auriga de Arcesilau, na P. 5.26. Da mesma forma, o próprio $\kappa \tilde{\omega} \mu \mathrm{s}$ é descrito como sendo formado por ä $\delta \delta \rho \varepsilon \varsigma$, tanto de uma maneira explícita, como no caso da $P$. 5.22, quanto de uma forma mais genérica, na $O$. 1.17, em que a persona loquens se

${ }^{229} C f$. o oǘo $\theta \varepsilon v$ oǐk $\alpha \delta(\varepsilon)$, da $O .6 .99$, acima.

${ }^{230}$ JENNY STRAUSS CLAY (1999, pp. 25-6).

${ }^{231} C f$. ainda $N$. 11.4. 
inclui entre os "varões" que frequentam a mesa de Hierão em Siracusa ${ }^{232}$. Ao passo que não me interessa estabelecer se o simpósio de fato era, ou não, a principal ocasião de performance dos epinícios, irei analisar algumas passagens em que o termo $\kappa \tilde{\omega} \mu$ os é, ao menos metaforicamente, assim conceitualizado. Um bom lugar para começarmos, portanto, seria a $N$. 9.48-53:

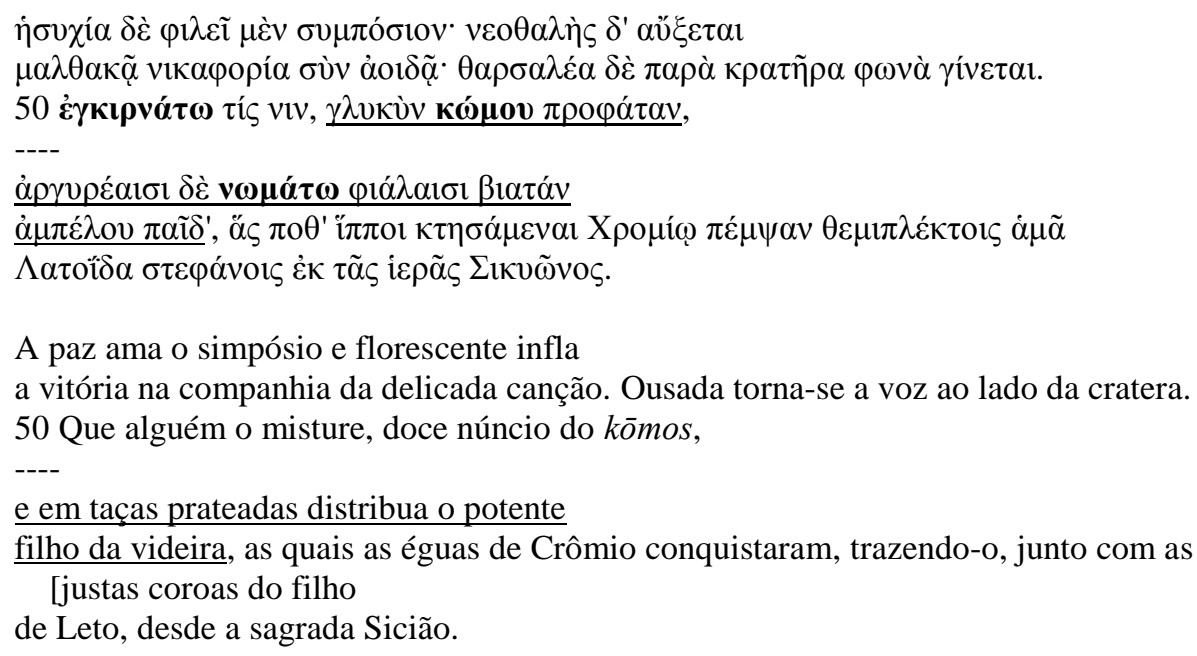

O vinho é o "núncio" do $\kappa \tilde{\omega} \mu$ os não porque ele sinaliza para um subsequente $\pi \alpha \rho \alpha \kappa \lambda \alpha v \sigma i ́ \theta v \rho i o v$ ou um "revel"233, que teria lugar ao final da festa. Ao contrário, como

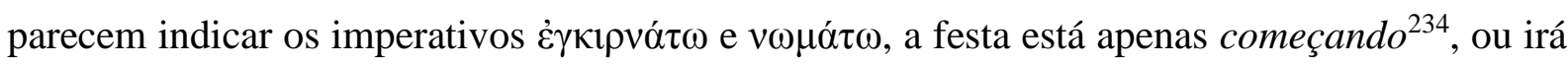
começar após a execução da ode, o que faz mais sentido, uma vez que esta passagem ocorre justamente na última estrofe, seguida de uma breve prece às Graças na qual o poeta pede que lhe seja possível, ao celebrar os feitos de Crômio, superar outros eulogistas ${ }^{235}$. Desta forma, o $\kappa \tilde{\omega} \mu \varsigma_{\varsigma}$ a que se alude aqui é a própria festa, que toma a forma de um simpósio ou é com ele comparada $^{236}$. Esta festa é, além do mais, aquela já prenunciada pelo futuro $\kappa \omega \mu \alpha ́ \sigma o \mu \varepsilon v(1)$ do proêmio. Relembrando brevemente a $O .6$, veremos que os $v v \cdot 17-8^{237}$ daquela ode também

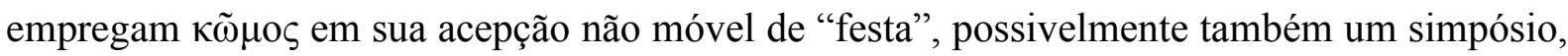
ao apontar Agésias como o "senhor do kōmos".

${ }^{232} C f$. ainda a $I .6 .1$.

${ }^{233}$ Assim, RACE (1997a, pp. 94, vol. 2).

${ }^{234}$ MEZGER (1880, p. 120).

${ }^{235}$ É tentador pensar, à luz desta e de outras passagens em que Píndaro se torna extremamente competitivo e descreve sua arte nesses termos, que mais de um epinício pudesse ser executado na mesma ocasião por poetas diferentes em uma espécie de competição poética. Disso, no entanto, não temos nenhuma evidência.

${ }^{236}$ SCHMIDT (1862, p. 244), "Um das Lied ganz zu würdigen, muss man seine Bestimmung für den Vortrag bei einem Gastmahle beachten. Diese geht aus dem letzten Theile unverkennbar hervor (...)”. Contra, THUMMER (1968/1969, p. 100).

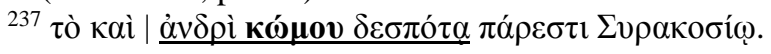


Uma situação muito semelhante dá-se na $I$. 6.1-9, que se abre com o famoso símile entre as três vitórias atléticas, duas obtidas e uma almejada, e as três libações em um simpósio ${ }^{238}$ :

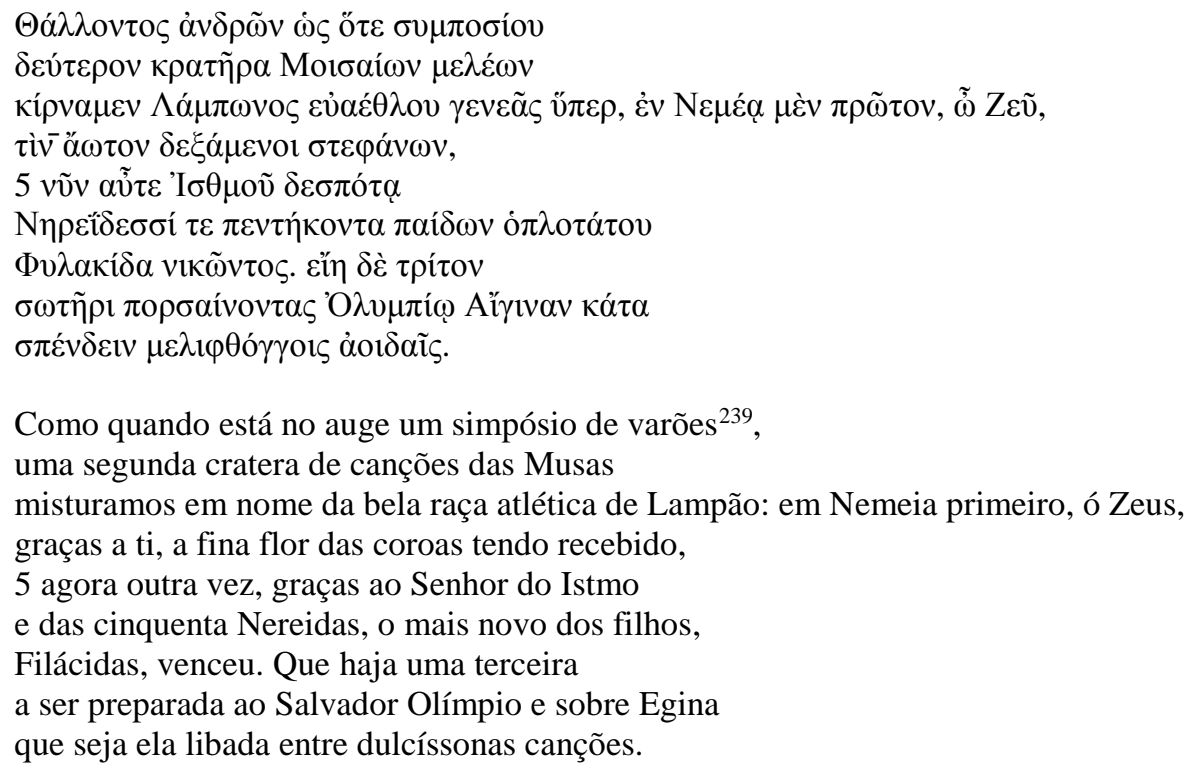

Mesmo que a performance da ode não se dê em um simpósio stricto sensu, é praticamente inconcebível pensarmos que alguma celebração similar não estivesse em andamento durante a execução da ode. Como dissemos anteriormente, é preciso que se suponha algum tipo de relação entre a metáfora empregada no proêmio da ode e o espaço discursivo corrente compartilhado pelo executante e o público. Parece-me, portanto, bastante óbvio que o contexto de performance dessa ode deva ser o de algum tipo de festa, à qual a persona loquens comparece na qualidade de $\tau \alpha \mu i_{\alpha}$, como somos informados pelo seguinte Abbruchsformel de retorno do longo mito à ocasião:

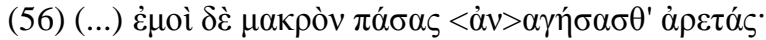

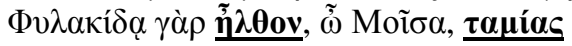

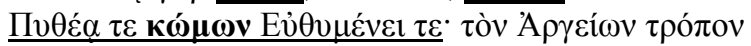

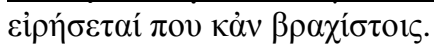

Levar-me-ia muito tempo para contar em detalhes todas suas qualidades.

Pois eu vim, ó Musa, como um organizador dos kōmos de Piteas, Filácidas e Eutimenes: à moda argiva, tudo será dito, creio, brevissimamente.
}

238 A primeira por Piteas, para quem Píndaro compusera a $N .5$, e a celebrada na presente ode, por Filácida. As três libações seriam a Zeus Olímpio; a segunda, à Terra e aos Heróis e a terceira, à Zeus Salvador.

${ }^{239}$ MeZGER (1880, p. 341), talvez com razão, relaciona o genitivo absoluto com o homérico $\delta \alpha \tilde{\tau} \tau \alpha$ $\theta \alpha \dot{\lambda} \varepsilon 1 \alpha \nu$. 
Aqui $\kappa \tilde{\omega} \mu \mathrm{o}$ está muito provavelmente empregado no sentido de "celebrações", "festas", sobretudo se compararmos o uso de $\tau \alpha \mu$ ía (57) com aquele da $O$. 14, onde se diz o

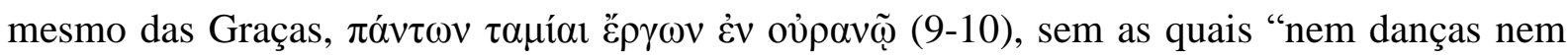

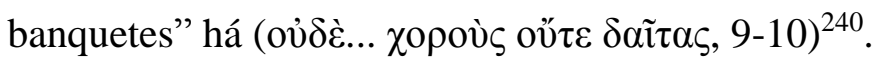

Além disso, em outras odes, Píndaro também compara a celebração epinicial à uma festa, sobretudo de casamento ${ }^{241}$, como na célebre cena do brinde que abre a $O .7$, ou, então, de uma maneira, ao menos para nós, não tão evidente, na $O$. 11.11-19, em que a persona loquens despacha as Musas para que celebrem na companhia dos lócrios ocidentais

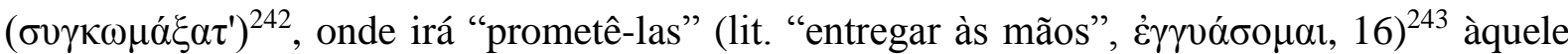
povo como um pai que "promete" a noiva ao noivo. Os comentadores não parecem se

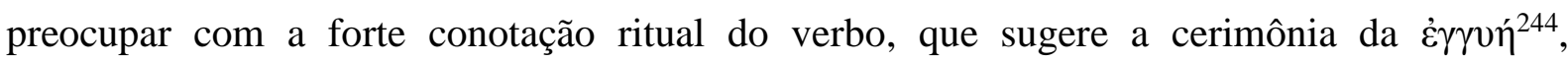
preferindo ver na voz média, que aqui indica o interesse e/ou a participação do poeta no "contrato", a acepção dicionarizada de "dar como garantia", que, embora também esteja implicada, oculta a metáfora mais importante, que é aquela de "casar" as Musas com os Lócrios, cujas qualidades são ressaltadas pelo poeta justamente como um pai ressaltaria, para as filhas, as qualidades do noivo.

O sentido mais prototípico do verbo $\kappa \omega \mu \alpha ́ \zeta \zeta \omega$ parece ser, portanto, aquele associado à celebração. É esta acepção, ao menos, que emerge da maioria de seus empregos nas odes, dentre os quais, eu gostaria de chamar a atenção para $P$. 9.87-90 em que a persona loquens expressa seu desejo de celebrar com Hércules e Íficles por sua prece ter sido atendida, " $\tau$ oĩ

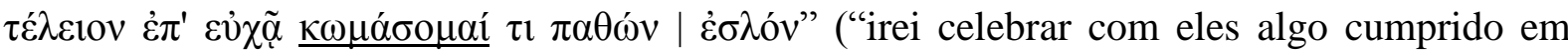
resposta a uma prece, tendo recebido uma graça" $)^{245}$ e para a $N$. 2.23-4 em que em uma

240 THUMMER (1968/1969, p. 108), que não relaciona esta passagem da $O$. 14, diz que "Der Dichter

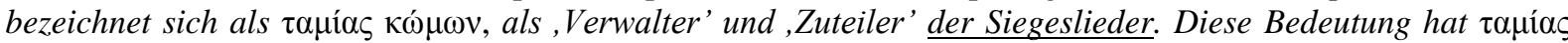
in O. VI 5 (...) und O. XIII 7 (...). Vielleicht klingen hier auch die Bedeutungen ,Herrscher', ,Besitzer ' mit, die in P. V 62 (...) und N. VI 25f. (...) belegt sind", grifo meu.

${ }^{241}$ Para a relação entre o epinício e o casamento, $c f$. o Capítulo 5 de KURKE (1991).

${ }^{242}$ Note a confusão de de VERDENIUS (1988a, p. 93) ao ler neste verbo o sentido de "ir foliando até": "It seems bizarre to sugest that the $\kappa \tilde{\omega} \mu \mathrm{\varsigma}$ goes all the way from Olympia to Locri, but cf. N. 9, 1-2. Similarly the victory ode is said to 'come from' Olympia O. 1, 8, O. 3, 9-10.

243 MEZGER (1880, p. 423) lê o verbo no sentido convencional, verbürgen. Outros comentadores simplesmente não o veem como digno de nota. VERDENIUS (1988a, p. 93), e.g., não tem nada a acrescentar sobre

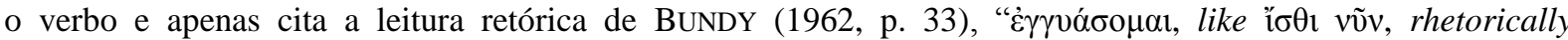
heightens the laudator's praise by setting itself firmly and confidently against imaginary objections. From these

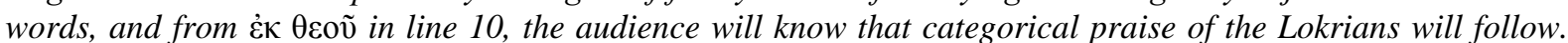
The eulogy itself is cast in an entirely conventional form", grifo meu.

${ }^{244}$ Sobre esta e suas implicações rituais, $c f$. o capítulo sobre o "Casamento" emJ.-P. VERNANT (1990, p. 55 et seq.).

${ }^{245}$ Uma passagem muito disputada, na minha opinião em virtude de uma compreensão equivocada de $\kappa \tilde{\mu} \mu \varsigma_{/} / \kappa \omega \mu \alpha ́ \zeta \omega$ como "folia"/ "foliar", que aqui é claramente descabida. Note que RACE (1997a, pp. vol. 1, 351), traduz o fututo de $\kappa \omega \mu \alpha ́ \zeta \omega$ apenas nesta passagem como "celebrar" e prefira, em todas as outras ocasiões, "foliar" (revel): "I shall celebrate them for the great good I enjoyed | when my wish was fulfilled", grifo meu. 


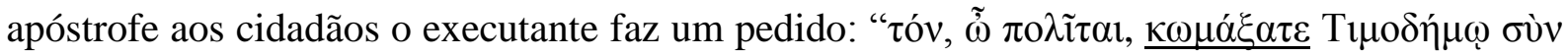

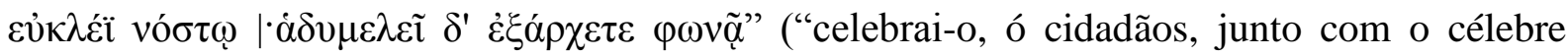
retorno de Timodemo: e com a doce voz puxai o canto") ${ }^{246}$.

\subsubsection{A caracterização do $\kappa \tilde{\omega} \mu \circ \varsigma$}

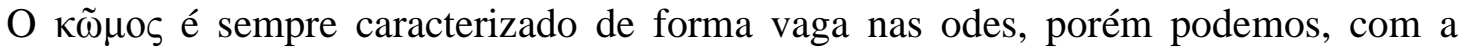
ajuda dos textos já analisados, entender alguns de seus predicados. Uma de suas principais características é a de ser composto apenas por membros do sexo masculino, que, na maior

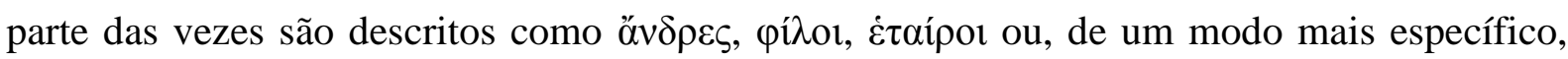
como véoı e veavíaı, o que salienta a juventude típica do atleta ideal grego e, de uma maneira geral, do homem no auge de sua vida ${ }^{247}$. Esta caracterização de $\kappa \tilde{\omega} \mu$ o s está de acordo com a conceitualização do termo no restante da literatura, sobretudo, na épica e na elegia, como já tivemos oportunidade de ver.

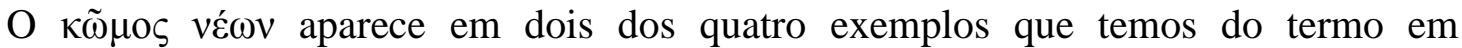
Baquílides e em colocação com este no Peã 1.64-8. Em Píndaro, na N. 3.1-5, ele é formado

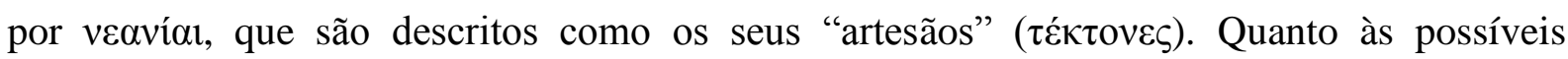
características vocais dos $\kappa \tilde{\omega} \mu o$, Píndaro as explicita em apenas duas instâncias e de um

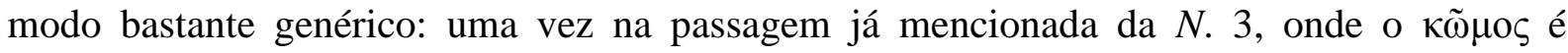

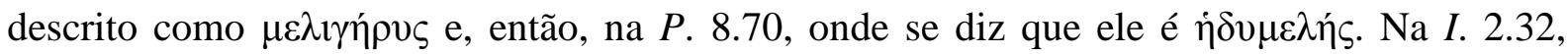
provavelmente em virtude de sua clara atmosfera pederástica, ele é qualificado como épatós.

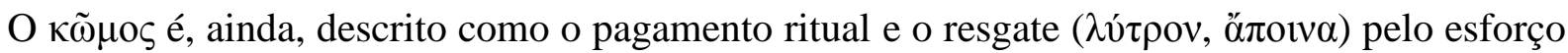
e pela vitória do atleta na $I$. 3.7-8 e, de uma maneira impressionante, no início da $I$. 8.1-8 ${ }^{248}$.

GENTILI et al. (1995) diz que o verbo tem o sentido de "cantare um canto in onore" por causa do uso com dativo e cita como paralelo I. 7.20 e a entrada do LSJ s.v. $\kappa \omega \mu \alpha ́ \zeta \omega$, II.2 que, por sua vez cita apenas estas duas passagens. Nem THUMMER (1968/1969), nem PRIVITERA (1998) e nem mesmo HuMMEL (1993) preocupam-se

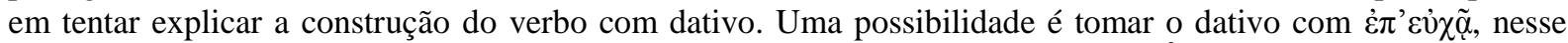
caso, viz., "irei celebrar algo obtido por um prece feita a eles [ i.e., Hércules e Íficles]", muito embora essa solução não explique a construção para a $I$. 7.20. Uma outra opção, que adotei, seria pensar no dativo como

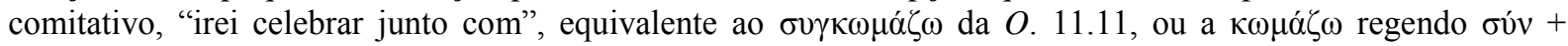
dativo, como na $P .4 .3, I$. 4.90-91 e no exemplo citado acima da $N$. 2.23-4, o que seria apropriado para todas as passagens e estaria de acordo com o sentido do verbo. Minha tradução de $\pi \alpha \theta \omega ́ v \varepsilon \dot{\varepsilon} \lambda$ óv, segue o sentido que este verbo me parece ter na $N .1 .32$ e na $I .2 .24$, $c f$. LSJ s.v. $\pi \alpha ́ \sigma \chi \omega$, III.b. Segundo o $\Sigma 156$ a (p. 235 DRACHMANN) a essa passagem, o ex-voto seria a vitória do laudandus na Ioleia, ou jogos em honra a Iolau. De modo similar, também BOECKH (1821, p. 327), MEZGER (1880, p. 246) e GILDERSLEEVE (1886, p. 345), entre outros, mas referindo o ex-voto à presente vitória.

${ }^{246}$ Outros usos do verbo em que o sentido de celebrar fica bastante claro ocorrem na N. 10.31-6, 11.24-

9; I. 3.7-8, I. 4.90 etc. para maiores detalhes, $c f$. o Apêndice 2.

${ }^{247}$ Cf. LSJ s.v. $\alpha \dot{v} \rho$, III.

${ }^{248}$ Para uma discussão mais detalhada, $c f$. KURKE (1991), sobretudo o Capítulo 5. 
Essa noção de que a celebração da vitória é capaz de restituir a vida e a força ao atleta que retorna dos jogos é, na verdade, predicada do poder dispensado pelo próprio poeta, como sacerdote das Musas, que, em meio aos celebrantes, canta o hino dito, com toda razão, "غ̇ंt-

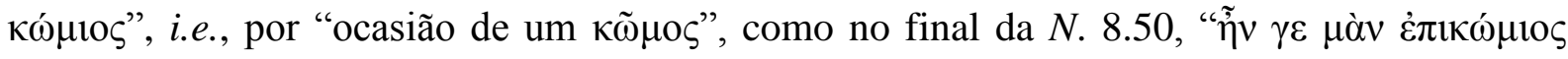

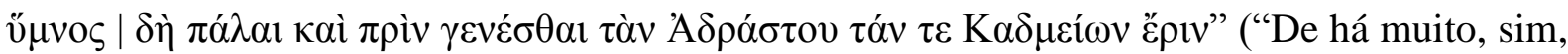
vêm o hino epikốmios, | de priscas eras e mesmo antes da discórdia ter surgido entre Adrasto e

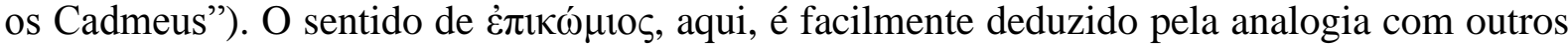

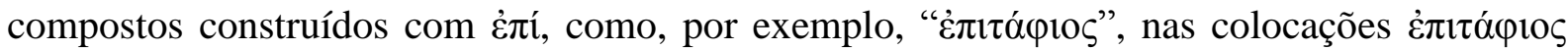

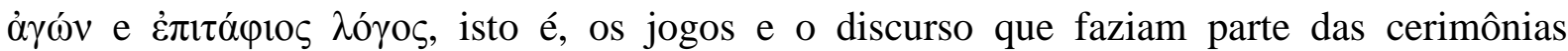

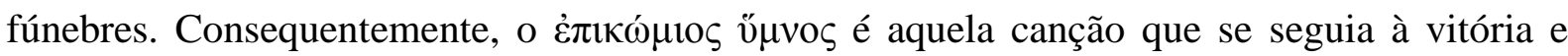
fazia parte da sua celebração ( $\kappa \tilde{\omega} \mu о \varsigma)$ e, dessa forma, o adjetivo perfila um tipo específico de canção dentro do frame evocado pelo conceito CELEBRAÇÃO, como CANÇÃO POR OCASIÃO DE UMA VITÓRIA, donde se pode deduzir: غ̇ंıvíkıos. É somente por essa mesma razão que a voz dos homens (ő $\psi \dot{\alpha} v \delta \rho \tilde{\omega} v)$ que participam do $\kappa \tilde{\omega} \mu$ os pode ser descrita, dentro desse mesmo frame, como غ̇лıкஸ́ $\mu 1 \alpha$ na $P$. 10.4-7.

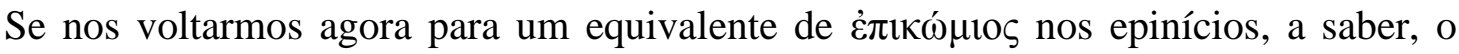

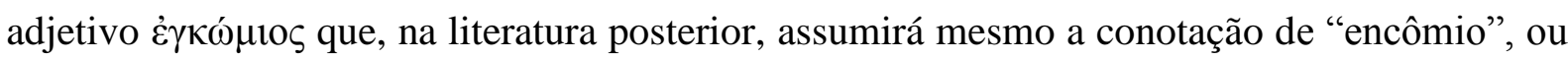
seja, "de poema em louvor a alguém", mas que, sincronicamente, era usado na acepção mais

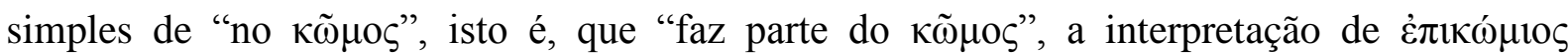
proposta acima torna-se mais evidente. Na verdade, o elemento preposicional $\dot{\varepsilon} v$ - induz a construção do adjetivo como um contêiner dentro do qual outro objeto pode ser mapeado, o que consequentemente induz a sua conceitualização como OBJETO $^{249}$. É a partir dessa

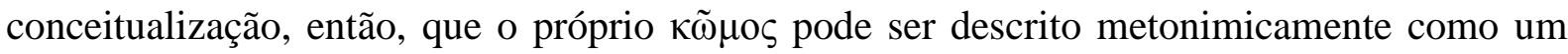

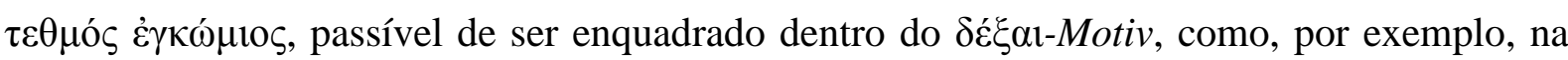

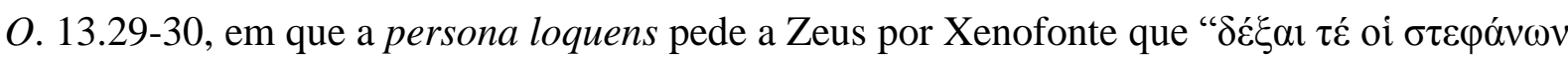

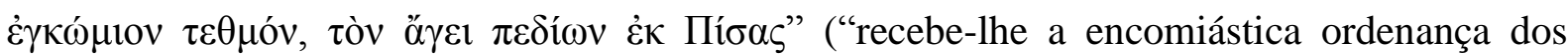
lauréis que ele traz da planície de Pisa"), onde a "encomiástica ordenança" nada mais é do que

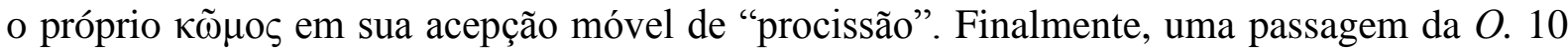
parece esclarecer o sentido que $\dot{\varepsilon} \gamma \kappa \omega ́ \mu ı \varsigma$ deveria ter para Píndaro e sua audiência. Após descrever as provas e os vencedores no primeiro dos jogos olímpicos, o poeta nos fala da celebração do $\pi \alpha v \sigma \varepsilon ́ \lambda \eta v o \zeta$ nos seguintes termos:

\section{(...) $\varepsilon^{\prime} v \delta^{\prime} \varepsilon \tilde{\sigma} \sigma \tau \varepsilon \rho \circ$}

\footnotetext{
${ }^{249}$ Cf. LURAGHI (2003, p. 82 et seq.).
} 


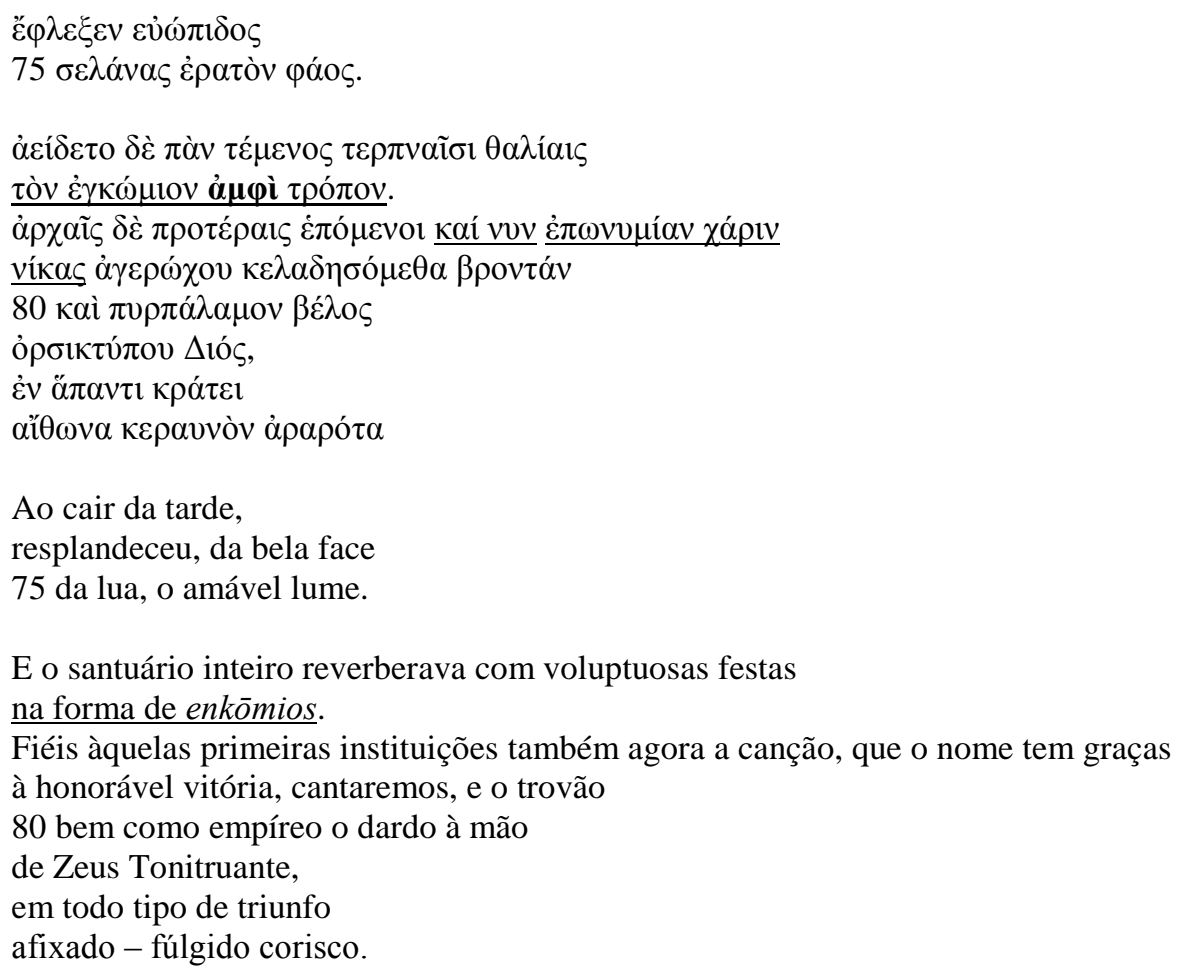

Como Bossler já notara ${ }^{250}$, antecipando os resultados sumariados por Luraghi através de uma perspectiva da $L^{251}$, o uso de $\dot{\alpha} \mu \varphi$, aqui e em outras passagens, é derivado de sua dimensão adverbial que perfila, primeiramente, ambos os lados de um objeto e então, por derivação (na medida em que a maioria dos objetos pode ser conceitualizada como tendo apenas dois lados), todos os lados. Fennel, em seu comentário a essa passagem diz que "aqui claramente $=$ 'de acordo com', embora a noção de 'em todos os lados' possa ainda ser mantida. $\mathrm{O}$ canto era de caráter variado, mas todos se aproximando, de um lado e de outro, do estilo do enkômion [grifo meu]"252, do que Verdenius ${ }^{253}$ discorda, sem oferecer, no entanto, uma solução muito diferente ou melhor, já que sua opinião de que aqui $\tau \rho o ́ \pi o \varsigma$ significa um “modo" musical, como na $O .14 .17(\Lambda v \delta \tilde{\omega} . . . \dot{\varepsilon} \vee \tau \rho o ́ \pi \omega)$, não é suportada nem pela evidência linguística (casos/preposições diferentes), nem pelas evidências internas da ode e nem pelo seu contexto.

Consequentemente, o uso de $\alpha \mu \varphi$ í aqui mapeia, acredito, todas as características do

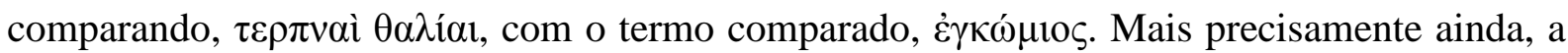
preposição é empregada como um trajetor multiplex, já que se refere a cada uma das $\tau \varepsilon \rho \pi v \alpha i ̀$

${ }^{250}$ BOSSLER (1862, p. 46), "Saepius rursus àupí acusativo juncta est. Primariam circundandi notionem et inde notionem vicinitatis vides non apud transitiva solum sed etiam apud intransitiva verba. Ex hoc usu [i. e., locativo] opinor ortum esse, quid legitur Ol. XI, [sic] 77 (...), nam carmen intra modum encomii versari

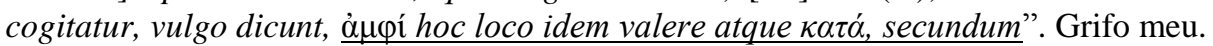

${ }^{251}$ LURAGHI (2003, p. 256 et seq.).

${ }^{252}$ FENNELL (1893, p. 116.77).

${ }^{253}$ VERDENIUS (1988a, p. 79). 
$\theta \alpha \lambda i ́ \alpha$ separadamente. O precinto de Zeus ressoava, portanto, com festas que eram como a festa na qual a persona loquens agora toma parte, uma vez que cada um dos primeiros vencedores listados na ode deveria ter tido a sua própria canção de vitória e o seu próprio $\kappa \tilde{\omega} \mu \mathrm{s}$, os quais, executados ao mesmo tempo, faziam o santuário reverberar. Cada uma

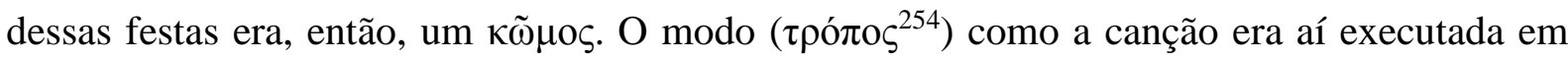
cada um desses $\kappa \tilde{\omega} \mu \mathrm{o}$ era, portanto, típico dos mesmos, ou seja, era um modo executado $\dot{\varepsilon} v$

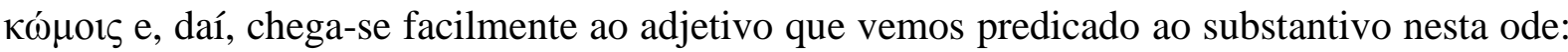

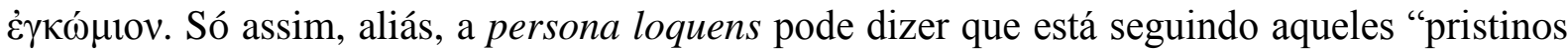

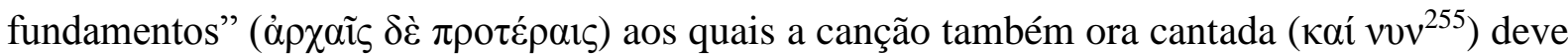

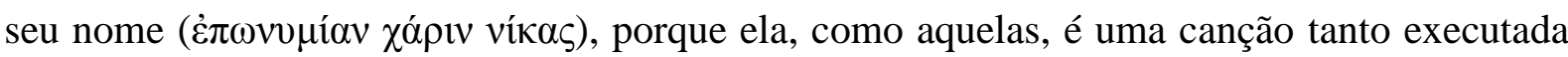

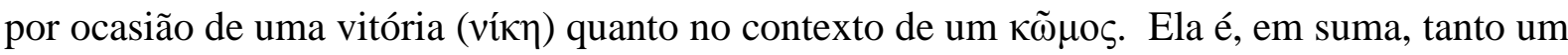

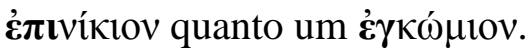

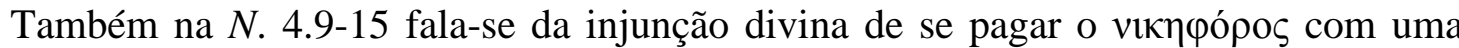
celebração e, consequentemente, um hino, mas aí este último é caracterizado como

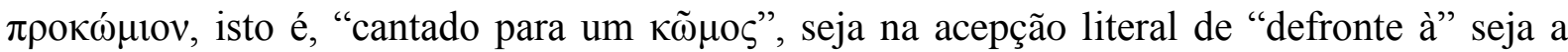
partir do perfilamento do $\kappa \tilde{\omega} \mu \varsigma_{\varsigma}$ como beneficiário/ destinatário da canção ${ }^{256}$. É possível ainda ver na construção um valor temporal, no sentido de "cantado por primeiro em um $\kappa \tilde{\omega} \mu о \varsigma "$, como, por exemplo, em $\pi \rho o ́ \lambda o \gamma o \varsigma$. A acepção temporal, aliás, parece estar explícita

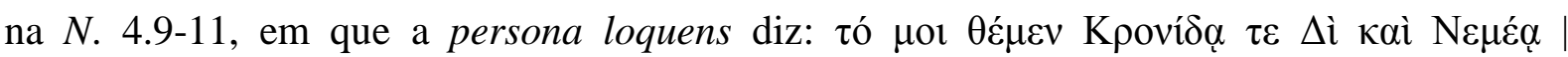

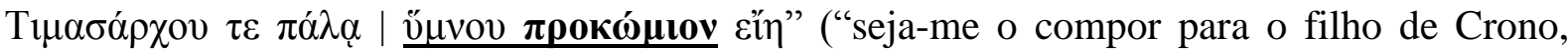

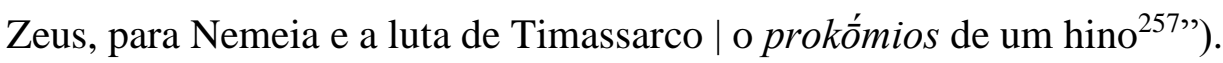

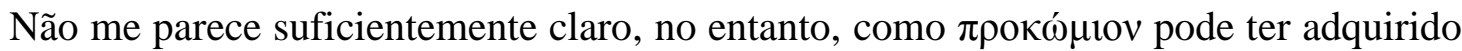
a acepção de "primeira parte" ou "prelúdio", muito embora seja possível traçar essa interpretação à ideia de Boeckh, ainda defendida por muitos comentadores modernos, de que,

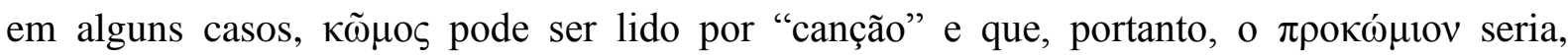
naturalmente, o "prelúdio" da canção ${ }^{258}$. Entretanto, como espero já ter deixado claro, $\kappa \tilde{\omega} \mu$ o nunca é empregado como sinônimo de canção, nem em Píndaro, nem em qualquer outro autor.

${ }^{254}$ Mas não em sua acepção musical, como o quer Verdenius.

${ }^{255}$ Note o valor final de $v 0 v$.

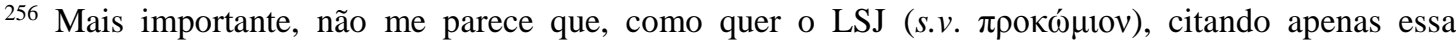

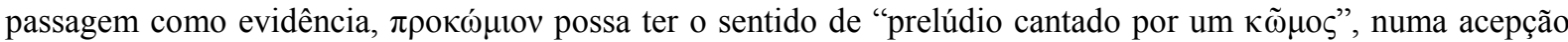
instrumental jamais atestada em qualquer língua do IE para o prevérbio $\pi \rho 0-$. $C f$. sobre isso, especialmente, DELG e EDG, s.v. $\pi \rho$ ó e LURAGHI (2003, p. 155 et seq.).

${ }^{257}$ Minha tradução literal pretende ressaltar a estranheza da construção.

${ }^{258}$ BOECKH (1821, p. 381). 
Até onde pude verificar, Fennel ${ }^{259}$ parece ter sido o único a estranhar a construção, propondo, então, uma explicação que me parece bem mais satisfatória, ao ver em ư $\mu v o v$ um

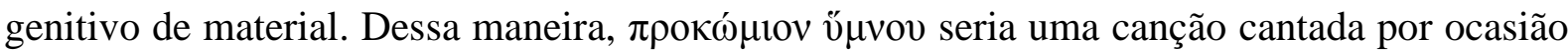
de um $\kappa \tilde{\omega} \mu о \zeta$ na forma de um hino, e a expressão referir-se-ia à toda ode e não apenas a um "prelúdio". Os escólios atribuem a Dídimo uma hipótese semelhante

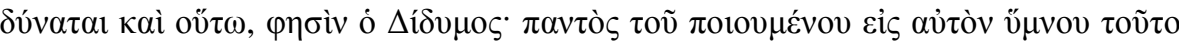

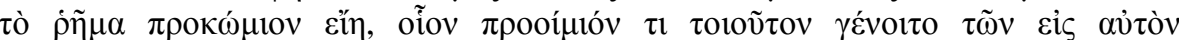

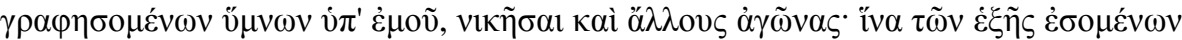

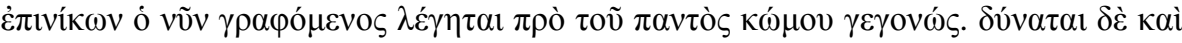

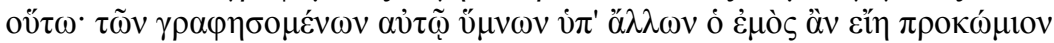

Também pode ser que, como disse Dídimo, a palavra $\pi \rho \kappa^{\prime} \omega ́ \mu$ เov referir-se-ia à todo o hino composto para o mesmo [i.e., Timasarco], de modo que ele possa se tornar uma espécie de proêmio para todos os hinos que ainda serão escritos para o mesmo por mim, quando vencer outros jogos, a fim de que o [hino] agora escrito como o primeiro dos epinícios que virão seja dito antes de [ou "à frente de"] todo $\kappa \tilde{\omega} \mu \mathrm{s}$ que vier a existir. Outra possibilidade seria esta: dentre os hinos que serão escritos para

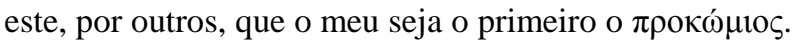

Pelo que se vê da passagem acima, ao menos para Dídimo, a ideia de que uma parte da ode pudesse ser tida como um "prelúdio", nunca ocorreu e, quando ele fala de uma "espécie de proêmio", ele está pensando em toda a canção, não apenas em parte dela. O sentido que ele dá à "proêmio" nos faz pensar que, para Dídimo, Píndaro poderia ter em mente possíveis cenários de reperformance e, dessa forma, expressa o desejo de que sua ode pudesse sempre ser a primeira a ser executada em futuros $\kappa \tilde{\omega} \mu \mathrm{o}$, o que implicaria também futuras vitórias, ligando a sobrevivência de sua canção ao sucesso futuro de seu laudandus: mesmo se outras vitórias fossem celebradas por outros poetas, ainda assim seria a sua canção sempre a primeira a ser executada, posto que composta para a primeira vitória. Sem dúvida essa leitura faz sentido com os versos que se seguem, no qual o poeta diz que seu hino seria cantado frequentemente pelo pai do vencedor, caso ele ainda estivesse vivo:

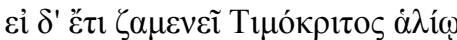

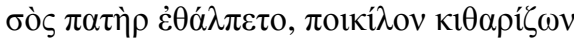

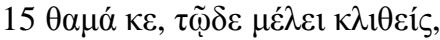

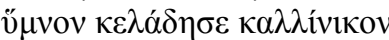

se ainda abrasante, Timócrito, com o sol, o teu pai, se aquecesse, tocando a cítara 15 frequentemente, inclinado nesta melodia, variegado o hino cantaria de vitória.

${ }^{259}$ FENNELL (1893, pp. vol. 2, 24). 


\section{Conclusões}

Trabalhando a partir destes dados, eu proponho, portanto, que, em sua acepção mais prototípica, $\kappa \tilde{\omega} \mu \mathrm{\varsigma} \varsigma$ designe um agrupamento de pessoas do sexo masculino com o objetivo de exercer uma atividade celebratória, normalmente em comum ${ }^{260}$, seja no plano cívico, religioso ou político da cidade ${ }^{261}$, seja no contexto de uma reunião particular, com especial ênfase no simpósio. É importante salientar tanto o substantivo "agrupamento" quanto o adjetivo "celebratório". O primeiro porque subentende uma convergência, frequentemente na forma de uma procissão, para o local da celebração, um movimento que ${ }^{262}$, como vimos, é a característica mais esquemática de $\kappa \tilde{\omega} \mu \mathrm{s}$, e, portanto, sempre capaz de ser salientada a partir da informação dedutível do espaço discursivo comum, mesmo quando este é descrito em sua

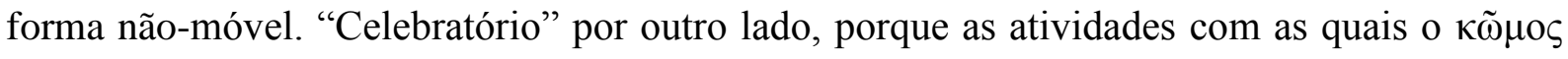
está associado podem ser tanto seculares quanto, possivelmente, religiosas ${ }^{263}$. Neste sentido, aliás, é possível delimitar a sua acepção móvel, como conceitualizada a partir do frame SIMPÓSIO, isto é, a partir do que A. M. Bowie 264 chama de "complexo deîpnon-simpósionkồmos", como subordinada à categoria superordenada CELEBRAÇÃO.

As atividades do $\kappa \tilde{\omega} \mu \circ \zeta$, como já havia sido apontado por M. Heath ${ }^{265}$, incluem dança e canto, mas a dança é sempre de um tipo informal, não coreografado e o canto, que não é um elemento prototipicamente associado com o termo, nunca é associado com qualquer tipo de performance ensaiada ou uníssona, exceto num nível muito básico, como no bordão aludido no início da $O$. 9. Apesar disso, como vimos sobretudo quando falamos da comédia, as atividades do $\kappa \tilde{\omega} \mu \mathrm{o}$, embora possam ser descritas como festivas, nunca são, prototipicamente, associadas à desordem ou à bebedeira. Como demonstra Pütz de maneira bastante convincente, as atividades violentas, a bebedeira e a bagunça, de um modo geral, são sempre caracterizadas como comportamentos desviantes das atividades normais do $\kappa \tilde{\omega} \mu о \zeta$.

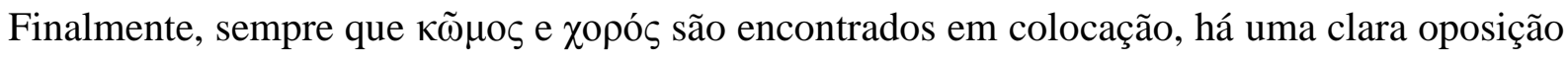

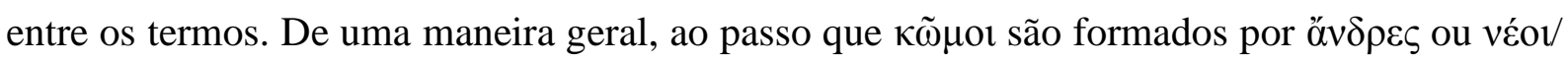

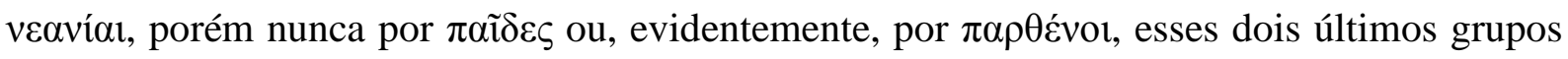

\footnotetext{
${ }^{260}$ Mas $c f$. fr. 373 PMG de Anacreonte, acima, onde, presumivelmente há apenas o poeta e sua hetaira que, além disso, pode simplesmente ser uma metáfora para a lira.

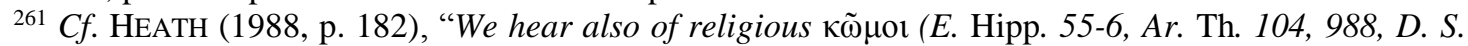

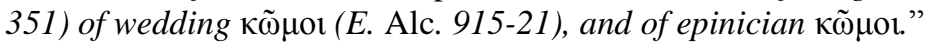

${ }^{262}$ Assim Vergados (2012, p. 539) comentando a referida passagem do h. Merc.

263 As evidências de $\kappa \tilde{\omega} \mu \mathrm{or}$ religiosos restringem-se, como vimos, às comédias de Aristófanes. Precisamos, portanto, ter cuidado com um possível abuso do termo naqueles textos.

${ }^{264}$ BOWIE (1997).

${ }^{265}$ HEATH (1988).
} 


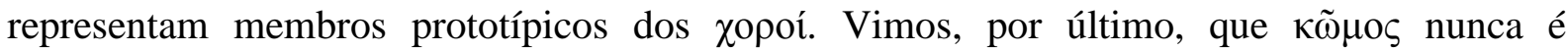
empregado com o sentido de "canção" na literatura arcaica até, e inclusive em, Píndaro e Baquílides. 


\section{CAPÍTULO 3}

\section{A PERSONA LOQUENS}

One voice will not do either. All the voices are present; but changed out of themselves into an intensified common voice, as individual speaking voices can become one in song or incantantion. Whether the lines are spoken in unison or in alternation this single lyrical voice is the one that will be heard. Deeply personal, but without individuality.

A. David Moody, Thomas Stearns Eliot: Poet.

A DISCUSSÃO DA persona loquens dos epinícios é, como tudo o mais que tenha a ver com a intricada problemática da performance das canções da lírica grega arcaica, extremamente complexa e requereria muito mais espaço do que o disponível neste capítulo. Inevitavelmente, portanto, meu tratamento da questão irá tocar no ponto mais nevrálgico, o "problema da identificação", como o batizou D’Alessio ${ }^{1}$. Esse problema, por sua vez, envolve dois subproblemas: o primeiro deles é o de avaliar se é possível saber quem está por trás dos

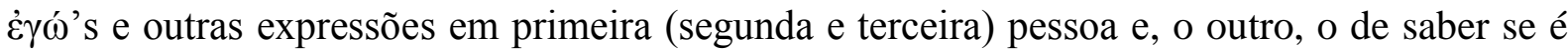
possível, por meio de uma análise dessas referências número-pessoais, deduzir alguma coisa sobre o modo de performance das odes ${ }^{2}$.

A primeira questão envolve o uso da primeira pessoa como a encontramos nos enunciados da lírica grega arcaica, o chamado "eu-lírico"3. Até o início do século XX, a

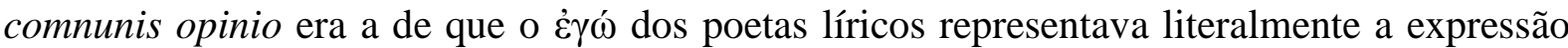
das suas ideias, sentimentos e opiniões, e que estariam começando a demonstrar uma consciência maior de si mesmos como indivíduos destacados do seu meio social, quando não em franca rebeldia contra esse. Pensa-se imediatamente em um Arquíloco, soldado e poeta, que um dia, desafiando todas as normas de bravura homérica, não só abandonara seu escudo para salvar sua vida, como ainda vangloriava-se de seu feito $\left(1\right.$ e $\left.5 \mathrm{~W}^{2}\right)$ ou, então, em uma Safo, que, em outra inversão dos valores marciais, colocava de maneira enfática sua opinião

\footnotetext{
${ }^{1}$ D'Alessio (1994).

${ }^{2}$ Cf. GoldHiLl (1991, p. 129).

${ }^{3}$ Minha discussão desta parte é baseada principalmente em SLINGS (1990).
} 
de que aquele a quem se ama valeria mais do que uma frota de navios, do que exércitos ou do que toda a riqueza da Lídia (fr. $16 \mathrm{~V}$ ). Análises nesse sentido não eram raras e podem, na verdade, ser encontradas até hoje. Elas são, ademais, produtos do Romantismo do séc. XIX, que continua bem vivo e, de certa forma, tem seu papel na difusão dos Clássicos ${ }^{4}$. De um modo mais geral, via-se nesse "acordar" do eu na poesia grega uma "descoberta do espírito" 5 e um ponto de ruptura com a narrativa épica, a qual não deixava qualquer espaço para manifestações de uma subjetividade pessoal.

A maré das ideias contudo, não tardou a mudar e, como sempre, com o avançar do século XX, foi de uma posição moderada - a qual já aceitava que muitas vezes o "eu-lírico" assumia apenas uma posição representativa das opiniões, ideias e sentimentos do seu grupo social, ou nas palavras de H. Fränkel, um "urteilende ich (...) immer repräsentativ gemeint" para um total agnosticismo, se não um ceticismo total, segundo o qual nenhuma das declarações feitas na primeira pessoa, singular ou plural, poderia ser atribuída ao poeta. $\mathrm{O}$ representante inaugural desta última posição é Dover em seu estudo comparatista acerca da poesia de Arquíloco e outras tradições líricas ao redor do mundo, nas quais, segundo ele, fica bastante claro que a separação entre o poeta e a sua persona poética é mais uma regra do que exceção. Com base em seus estudos, ele conclui que:

(...) minha abordagem dos fragmentos é mais do que cautelosa; ela é agnóstica ao ponto do niilismo e, se ela for válida, isto implica que já não sabemos sobre Arquíloco muitas coisas que (...) sempre acreditamos saber ${ }^{7}$.

West, por outro lado, tratando da poesia de Arquíloco em seus Studies $^{8}$, via a primeira pessoa como completamente ficcional e tratava os eventos contados no ciclo de Licambes e Neobule como derivados de histórias populares envolvendo personagens folclóricos que Arquíloco teria usado para compor suas canções tendo em vista, provavelmente, alguma função ou ocasião ritual.

Essa posição foi combatida duramente por Rösler em sua discussão do Epodo de Colônia $\left(196 \mathrm{a} \mathrm{W}^{2}\right)^{9}$, na qual ele argumentava que West não levava em consideração a audiência. Um poema que falasse sobre as aventuras sexuais de seu narrador deveria ser lido a partir da pressuposição de uma hetaireia de amigos e não de um contexto ritual. O segundo

${ }^{4}$ Mas isso já seria outro assunto.

${ }^{5}$ Cuja expressão maior é o trabalho de SNELL (1946).

${ }^{6}$ FRÄNKEL (1993, pp. 169, n. 50), “eu avaliativo (...) sempre tido como representativo".

7 DOVER, K. J. (1964) 'The poetry of Archilochus' in Archiloque, ed. O. Reverdin. Entretiens sur l'antiquité classique 10. Geneva: 183-222. Apud SLINGS (1990, p. 5).

${ }^{8}$ M.L. WEST (1974, p. 27).

${ }^{9}$ RÖSLER, W., "Die Entdeckung der Fiktionalität in der Antike”, Poetica 12, 1980, 283-319. 
problema de Rösler com a abordagem de West era o fato de que ela ignoraria o caráter eminentemente oral da comunicação poética na Grécia arcaica. Numa tal sociedade, segundo ele, os poetas seriam os portadores da verdade na qualidade de bardos inspirados pela Musa, o que tornaria inconcebível que pudessem cantar histórias reconhecidamente inventadas ou que assim fossem vistas pela audiência ${ }^{10}$. Mesmo que algum tempo depois Rösler tenha, sob a influência da Nova Crítica, alterado um pouco a sua argumentação, ainda assim ele não pôde aceitar a teoria de West, por alegar, sobretudo, que a divisão entre um "eu fictício" e um "eu biográfico" seria rígida demais para dar conta de todas as complexas situações performáticas de uma sociedade arcaica e oral como a dos séc. VII-IV. Essa seria precisamente a posição desenvolvida por Bremer, que propunha que o "eu-lírico" tratava-se, na verdade, de uma máscara social vestida pelo artista e que ou não deveríamos ou não teríamos como separar um do outro. De fato, para Bremer, colocar a questão do "eu-lírico" do ponto de vista de uma dicotomia "biográfico x fictício" era, já de início, compreender mal a natureza da lírica $\operatorname{arcaica}^{11}$.

No entanto, e em uma versão mais madura de suas ideias, ao salientar a natureza oral de toda poesia arcaica e a sua relação com o grupo social para o qual fora produzida, Rösler, em Dichter und Gruppe ${ }^{12}$, parece ter enquadrado a questão de um ponto de vista bastante promissor porque, mesmo que queiramos rejeitar uma oralidade mais estrita, que diga respeito tanto à produção quanto à disseminação da poesia no período arcaico, resta ainda a certeza de que ao menos a performance dessa poesia era de caráter público e oral e que, consequentemente, a composição dessa canções deveria ser pensada, necessariamente, a partir da finalidade que elas teriam no ato comunicativo. Esperar que o engajamento dessa poesia com um público pudesse ser da mesma natureza que a experiência de um leitor (ou crítico) com um texto deve nos conduzir a vários equívocos ${ }^{13}$. Para Slings ${ }^{14}$, então, não é totalmente absurdo supor que a poesia grega, por seu caráter performativo e público, implique em uma certa despersonalização do poeta. No caso da lírica, ele vê nessa despersonalização um processo de reação contra o "eu-lírico" das carmina popularia, onde situa uma das possíveis origens do gênero ${ }^{15}$ : à medida em que as audiências da poesia lírica transitam de um círculo restrito a um determinado grupo social para adquirir um caráter cada vez mais público, o “eu-

${ }^{10}$ Talvez Rösler tenha se esquecido da fala das Musas, na Teogonia, quando dizem nos $v v$. 27-8: ’ $\delta \mu \varepsilon v$

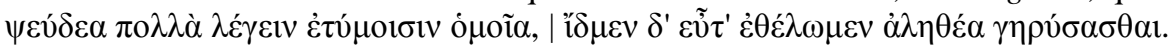

${ }^{11}$ BREMER, J.M., "Het gemaskerd”, IK. Amsterdam, 1978, apud SLINGS (1990).

12 (1980).

13 Sobre isso, $c f$., de um modo geral, o seminal trabalho de Gentile recolhido em GENTILI (1990), especialmente o Cap.1, Orality and Archaic Culture.

${ }^{14}$ SLINGS (1990).

${ }^{15}$ Uma questão rica de controvérsia. Aqui não seria o local para entrar em detalhes. 
lírico" se expande para se adequar à polifonia de vozes dele requerida por essas mesmas audiências.

Essa "despersonalização", não obstante, não seria absoluta e não implicaria em um total aniquilamento da personalidade do autor, mas em uma extensão dela, liberando-a para assumir novos papeis que ele mesmo não poderia tomar ou que não lhe seriam permitidos. Pensa-se imediatamente na persona poética criada por Sólon para aconselhar seus concidadãos atenienses ${ }^{16}$. Essa não impediria, por exemplo, que em muitas de suas elegias ele se referisse a si mesmo como o indivíduo Sólon, pretérito arconte e vo $\mu$ o $\theta \dot{\varepsilon} \tau\rceil \varsigma$ de Atenas, que fizera isto e aquilo pela cidade ${ }^{17}$. Deve haver, dessa forma, um espalhamento contínuo, mais do que uma dicotomia, entre as duas posições extremas que o "eu-lírico" pode assumir, a totalmente biográfica e a completamente fictícia ${ }^{18}$. O problema reside, justamente, em se analisar cada nuance desse espectro, sobretudo em virtude da carência de informações históricas sobre a vida dos poetas ${ }^{19}$ e da ausência de um contexto a partir do qual pudéssemos resolver algumas das ambiguidades dos textos da oratura lírica arcaica.

Slings, em sua análise, divide os tipos de enunciados possíveis ao "eu-lírico" em quatro grandes categorias: aquela na qual o "eu-lírico" se manifesta como um representante das Musas e assume o papel de cantor, que ele identifica primeiramente com a lírica coral ${ }^{20}$; uma outra, que poderíamos classificar de "erótica", na qual o "eu-lírico" fala de suas experiências amorosas e sobre a qual é praticamente impossível, segundo ele, dizer qualquer coisa. Poríamos aí a poesia de Safo e Anacreonte, por exemplo. Na terceira categoria, o "eulírico" assume a persona de um urteilende ich, na expressão de Fränkel, típica da elegia. Finalmente, a quarta categoria diria respeito àqueles poemas nos quais o "eu-lírico" relata suas experiências, o que fez e disse, com quem ou contra quem. Seria apenas para esta última categoria que Slings estaria disposto a admitir a possibilidade de se propor um "eubiográfico" e um "eu-fictício", mesmo assim, são poucos os exemplos em que o ator no poema é identificado com o próprio poeta ${ }^{21}$. Para todos os outros casos é preciso supor, por meio de uma série de argumentos, qual seria a possiblidade mais plausível.

${ }^{16} C f$. Sol. fr. $1 \mathrm{~W}^{2}$ cum testimonia.

${ }^{17}$ Sol. fr. $5 \mathrm{~W}^{2}$. Sobre isso, $c f$. também JARCHO (1990, p. 32 et seq.).

${ }^{18}$ SLINGS (1990, p. 12 et seq.).

${ }^{19}$ Cujo trabalho mais importante, ainda que extremamente pessimista e que teve uma recepção bastante controversa, é o livro de LefKOwITZ (2012). Cf. também PODLECKI (2011) e KIVILO (2010), sobretudo o Cap. 5, sobre a formação da tradição biográfica.

${ }^{20}$ Porque para Slings não parece haver dúvida quanto à natureza coral dos poemas pindáricos. Sobre a utilidade e possível anacronismo de uma divisão da lírica arcaica em "monódica" e "coral", $c f$. DAVIES (1988) e CINGANO (2003).

${ }^{21}$ Por exemplo, em Safo, fr. 1 V ou Hipônax, fr. 32 W². 
Eu menciono esta classificação de Slings não por ver nela uma divisão adequada ou suficiente dos modos de expressão do "eu-lírico"22, mas apenas para salientar o fato de que os epinícios pindáricos, a que devemos nos voltar a partir de agora, colapsam-na completamente. De fato, das quatro categorias mencionadas por Slings, apenas a erótica não está representada e, mesmo assim, apenas do ponto de vista dos enunciados em primeira pessoa, no sentido de que não vemos jamais a persona loquens dos epinícios se gabando de suas experiências sexuais, manifestando sua paixão ou alardeando sua competência como amante ${ }^{23}$. Quanto ao resto, como veremos, o "eu-lírico" é, frequentemente e ao mesmo tempo, tanto um aedo inspirado, capaz até mesmo de se colocar no papel de reformular a tradição; um "urteilende ich", que dá conselhos e dispensa a censura ou o louvor; quanto, ainda, um "erlebende ich" que manifesta experiências em primeira pessoa que, se não reais, ao menos assim são projetadas para a audiência. Nesse sentido, o continuum que Slings propõe parece ser um modo mais adequado no qual enquadrar o uso da persona loquens nos epinícios.

Obviamente, no caso de Píndaro, a questão é complicada justamente por não sabermos se estamos lidando com um "eu-lírico" que se identifica com a pessoa, real ou ficcionalística, do poeta ou, doutra forma, com uma voz polifônica que expressa, por meio de um coro, a persona de uma comunidade, ou, ainda, se esses dois papeis se confundem e se complementam, o que me parece mais provável. Precisamos pensar, ainda, que algumas odes apresentam narrativas em que outras vozes emergem e o epinício adquire características quase épicas, como é o caso da $P .4$ mas também em menor medida da $O .1$, da $P .5$ etc.

Consequentemente, na medida em que o "eu-lírico" em Píndaro apresenta esse tipo de ambiguidade com relação ao seu conteúdo dêictico, acredito que seria mais apropriado, como tem sido o costume já há algum tempo, falar de uma persona loquens, isto é, de uma voz que não precisa necessariamente remeter a um "eu". Essa distinção faz ainda mais sentido se pensarmos que nem sempre o "eu-lírico" é explicitado diretamente: muitas vezes a referência é oblíqua, já que um "tu”, um "vós" ou um "nós" pode pressupor indiretamente um "eu” ou um "nós", assim como imperativos em terceira pessoa, que muitas vezes podem denotar de um modo geral aquilo que o laudandus, a comunidade ou qualquer pessoa sensível deveria reconhecer como sendo o caso $^{24}$.

\footnotetext{
${ }^{22}$ De fato, o próprio Slings nos alerta que sua subdivisão pretende fornecer uma visão esquemática de um fenômeno complexo.

${ }^{23}$ Uma função, em certa medida, preenchida pelos encômios. Sobre a relação entre os dois e a natureza erótica subjacente à linguagem dos epinícios, $c f$. CROTTY (1982) e BUDELMANN (2012).

${ }^{24}$ BREMER (1990, p. 45).
} 
Bremer, em seu estudo sobre os દ̇yó's de Píndaro $^{25}$, vê um paradoxo no uso de uma forma tipicamente associada com a voz da comunidade, isto é, a lírica coral, para expressar o louvor de um indivíduo, o laudandus, por outro, o poeta, em razão de um sucesso igualmente individual, a vitória em uma competição atlética. Após o trabalho de Leslie Kurke ${ }^{26}$, que

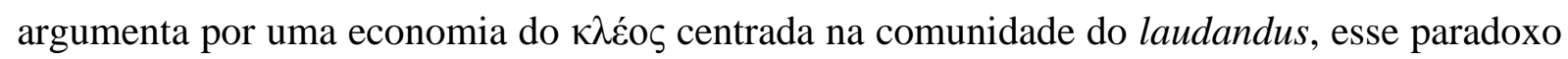
parece ter perdido muito de sua força, se ainda for relevante nesses termos. Os غ̇үó's continuam, não obstante, paradoxais, em um outro sentido, também notado por Bremer, o de que, para um poema tido como coral, eles se associam predominantemente com a voz do próprio poeta e raramente com a voz de um grupo ou do vencedor. Isso deve nos interessar a partir de agora.

Segundo a análise de Bremer, 90\% de todos os enunciados em primeira pessoa se

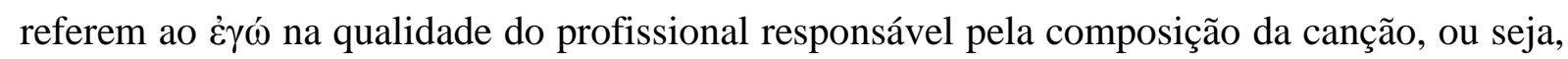
ele pertenceria à primeira categoria na classificação de Slings, a qual eu, seguindo a nomenclatura de Lefkowitz, irei chamar de "eu-bárdico"27. Ainda, em todas as vezes em que ele usa a primeira pessoa do plural, em cerca de $10 \%$ dos casos, essa também parece se referir ao próprio poeta: "Seria de se esperar que Píndaro usasse a primeira pessoa do plural muito mais para se referir ao coro como executante do epinício e portador da mensagem poética. Mas ele nunca usa a primeira pessoa do singular $[\text { sic }]^{28}$ para esse propósito. Uma característica impressionante (...)". Os exemplos citados por Bremer restringem-se, quase que totalmente, ao chamado "futuro encomiástico" como veio a ser conhecido a partir de Bundy 29 :

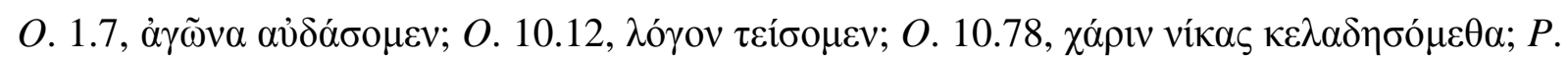

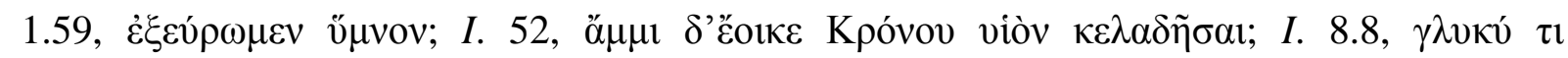
$\delta \alpha \mu \omega \sigma o ́ \mu \varepsilon \theta \alpha^{30}$.

Obviamente verbos no futuro, como esses, implicam duas dimensões dêicticas importantes: a do tempo e a da voz. Sobre o tempo, é importante salientar que em Píndaro, como em toda a história do grego até a língua moderna, o futuro sempre tem um valor desiderativo, do qual se originou ${ }^{31}$, e ao qual, muitas vezes, não se dá a devida ênfase. Sobre a voz, parece-me que se deve ver na maioria dos casos da primeira pessoa do plural, se não em

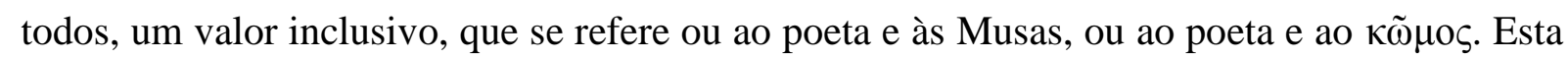

\footnotetext{
25 Idem.

${ }^{26}$ KURKE (1991).

${ }^{27}$ LEFKOWITZ (1991, p. 3 et seq.).

${ }^{28}$ Provavelmente ele quis dizer "plural".

${ }^{29}$ BUNDY (1962, p. 28(20/21)) e, sobretudo, PFEIJFFER (1999a).

${ }^{30}$ BREMER (1990, pp. 46-7).

${ }^{31}$ Via sufixos $\mathrm{s}^{\mathrm{e} / \mathrm{o}}, \mathrm{s}^{\mathrm{y} / \mathrm{o}}$.
} 
é uma proposição que, para ser demonstrada, requereria uma análise de todas as ocorrências da primeira pessoa do plural, algo para o que não teremos nem tempo, nem espaço aqui. Espero, contudo, que essa ideia faça mais sentido a partir do que veremos no restante desta discussão.

Retornando, então, ao nosso ponto principal, a segunda categoria, que Bremer, seguindo D. Young ${ }^{32}$, chama de "primeira pessoa indefinida", é, na verdade, correspondente ao urteilende ich de Fränkel, na qual o poeta, normalmente por meio de uma gnoma ou de uma exortação direta ao laudandus, usa a primeira pessoa para dar um conselho ( $\pi \alpha \rho \alpha i ́ v \varepsilon \sigma ı \varsigma)$ ou manifestar uma opinião que reflete mais uma ética comum do que uma ideia particular, como por exemplo na $N .1 .31-5$

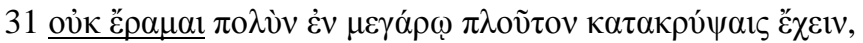

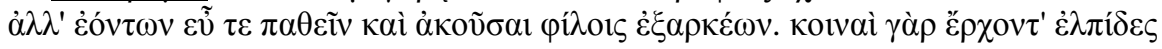

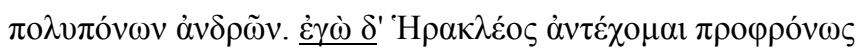

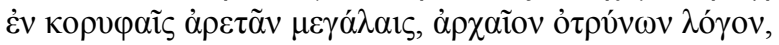 \\ $35 \dot{\omega} \varsigma, \varepsilon \dot{\varepsilon} \varepsilon \varepsilon \dot{~} \sigma \pi \lambda \dot{\alpha} \gamma \chi v \omega v \kappa \tau \lambda$. \\ 31 Não desejo muita riqueza econdida em um cômodo ter, \\ mas, tendo-a, ser bem sucedido e, socorrendo os amigos, ouvir falar bem de mim. \\ [Pois juntas caminham as expectativas \\ de azafamados varões. Quanto a mim, de bom grado Hércules contraponho \\ como exemplo supremo de virtude, acordando a antiga lenda \\ 35 que conta como, após recém-nascido etc.
}

A recusatio v. 31 irá lembrar qualquer um (quiçá poderia ter lembrado mesmo uma

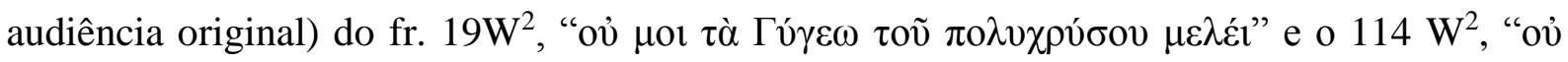
$\varphi \imath \lambda \varepsilon ́ \omega \mu \varepsilon^{\prime} \gamma \alpha \nu \sigma \tau \rho \alpha \tau \eta \gamma o ́ v \kappa \tau \lambda . ”$ de Arquíloco bem como diversas outras opiniões emitidas, por exemplo, pela persona loquens na Teognideia. Nesse sentido, os vv. 31-3 adequam-se bem a ideia de um urteilende ich que usa a primeira pessoa do singular para exprimir algo que deveria ser a opinião do próprio laudandus e do próprio público. Na tradição de poesia didática, entretanto, esse tipo de injunção normalmente seria expressa por meio de

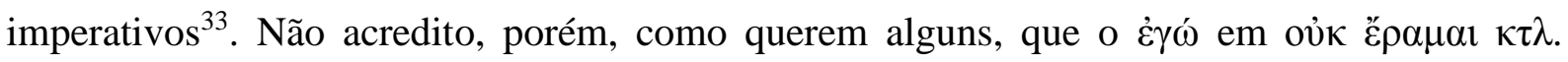
possa se confundir com a própria voz do laudandus, como emitida por um coro, por exemplo, na pressuposição de que apenas este, por representar a voz da comunidade, teria mais autoridade para fazê-lo. Não são poucos os epinícios em que a voz autoritária da persona

\footnotetext{
${ }^{32}$ Young (1968, p. 23 et seq.).

33 BREMER (1990, p. 47).
} 
loquens se põe acima daquela dos oi $\pi 0 \lambda \lambda$ ó , inclusive para corrigi-la ${ }^{34}$. Parece-me mais

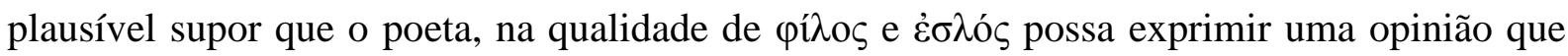
tanto ele quanto a audiência ou laudandus veem como implicitamente compartilhada por todos. Essa leitura parece-me, aliás, mais coerente à luz dos $v v$. 34-5 em que a persona loquens, na qualidade do poeta que controla a tradição, contrapõe um aĩvo $\varsigma^{35}$, na forma de um mito, que serve como possível defesa contra aqueles que poderiam discordar da proposição anteriormente emitida na forma de uma gnoma e, portanto, já demonstra, num primeiro momento, que qualquer compartimentação da voz da persona loquens em categorias muito rígidas pode nos fazer perder de vista a rica complexidade que lhe subjaz ${ }^{36}$. Por outro lado, a sujestão de Bremer de que o uso idiossincrático que Píndaro faz da primeira pessoa revelaria seu desejo de chamar o máximo de atenção para si mesmo não parece em sintonia com a sua ideia de que as odes devam ter sido executadas coralmente. A persona loquens dos poemas corais, como veremos a seguir, aparenta ter objetivos diversos.

A terceira categoria de Bremer, aquela em que o غ̇ $\gamma \omega ́$ referir-se-ia ao próprio vencedor também pode ser colocada junto da discutida no parágrafo anterior e, como aquela, ela pode

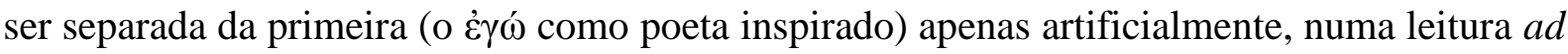
$h o c$ da passagem. Bremer cita como exemplo quase literal de sua terceira subdivisão os $v v$.

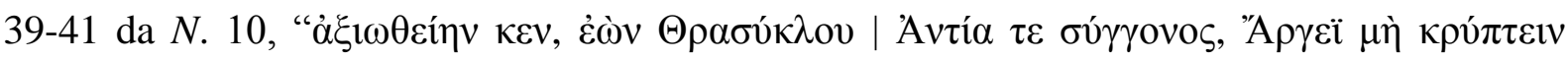

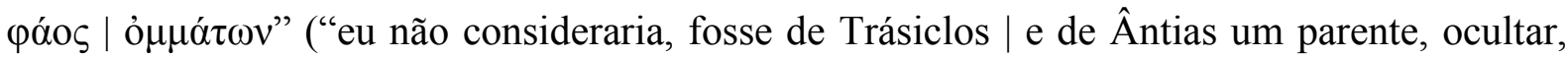
dos olhos, a luz em Argos") e a vê como equivalente a "'Se eu fosse você, meu caro Teaios, eu estaria orgulhoso dos feitos dos meus antepassados' (e não hesitaria em tentar a sorte nos jogos Olímpicos, algo já aludido pelo poeta nos $v v$. 28-33)"37. Se voltarmos um pouco na ode,

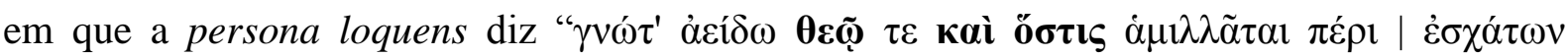

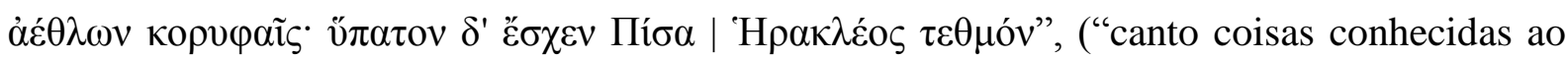
deus e a qualquer um que compita pelo ápice nos jogos supremos: sublime, Pisa detém o

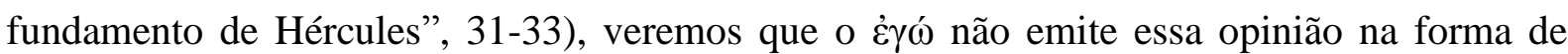
uma possibilidade, mas como alguém que não só tem acesso ao que o deus sabe ( $\gamma v \omega ́ \tau \tau^{\prime} \alpha \dot{\varepsilon} \delta \omega$

${ }^{34}$ Por exemplo, $O .1 .26$ et seq. e $9.35-40$.

${ }^{35}$ Meu entendimento deste termo-chave para a poesia pindárica ecoa a definição trabalhada por NAGY (1990, pp. 215-49), sobretudo em sua conclusão de que "On the surface the ainos is predicated on the reality of the uncertainties in interaction between performance and audience; underneath the surface, however, it is predicated on the ideology of an ideal audience, listening to an ideal performance of an ideal composition, the message of which applies to all humanity."

${ }^{36}$ Nesse sentido, é quase divertido notar o espanto de BREMER (1990, p. 46), que não deixa de ser reminiscente do espanto dos críticos do séc. XVIII e dos escólios, com a destreza com que Píndaro "manages to start with a first person singular, then to slalom via imperative (2nd person singular) into a first person plural, only to switch back into a first person singular finally, all of it within the compass of a few lines!"

${ }^{37}$ BREMER (1990, p. 48). 


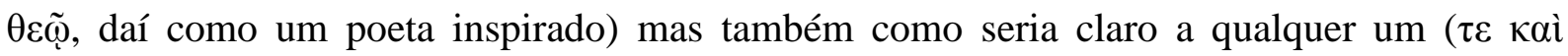
ő $\tau \imath \varsigma)$ que costumasse competir nos jogos ou até mesmo apenas assisti-los, torcendo por este

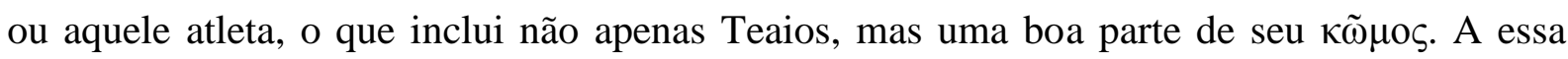
passagem eu acrescentaria ainda a pungente passagem da $N$. 11. 22-29 que, apesar de não ser um epinício (e talvez por isso mesmo seja um indício interessante), é um paradigma perfeito do mesmo tipo de enunciado, exceto que aqui trata-se não mais do que certamente será, mas do que poderia ter sido e não foi, mas que, fossem outras as circunstâncias, o poeta daria o resultado como certo:

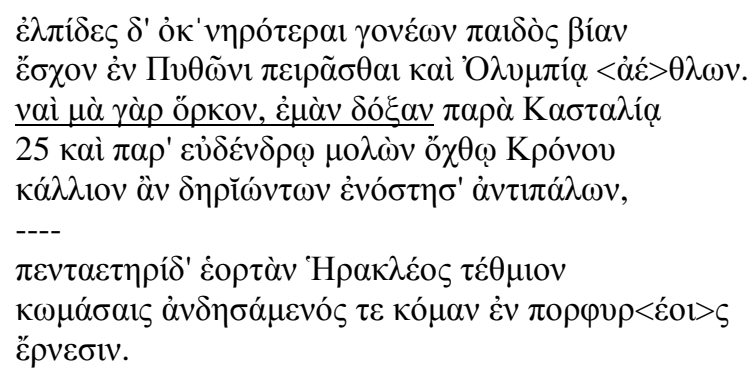

Mas as temerosas apreensões dos pais à determinação do filho refrearam, impedindo-o de ser testado nos jogos na Pítia e em Olímpia. Oh sim, eu juro que, em minha opinião, à Castália

25 e à arboral montanha de Crono tivesse ido, o mais belo entre os combatentes teria retornado após lutar

no quinquenal e tradicional festival de Hércules, celebrando com a cabeça entretecida com vermelhos fios de lã.

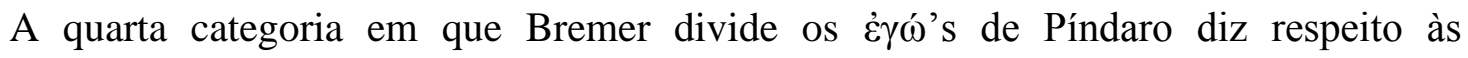
passagens que, como ele mesmo admite, são poucas e não isentas de controvérsia, em que a primeira pessoa do plural poderia se referir a um coro: $N$. 7.85, a P. 5.75, a P. 8.98 e B. 2.7-9. A passagen relevante da $P .5$ será discutida no próximo capítulo ${ }^{38}$. No que diz respeito às $N$. 7.85, P. 8.98 e a B. 2.7-9, os exemplos dificilmente são pertinentes à proposição em questão.

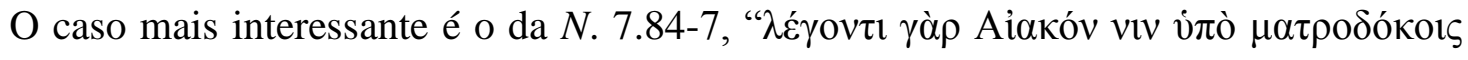

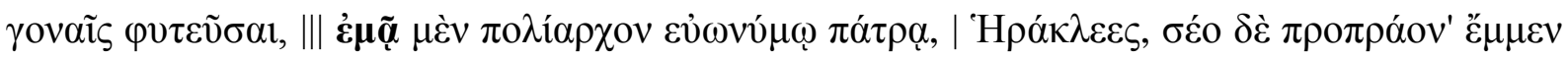
$\xi \varepsilon i ̃ v o v ~ \alpha ̊ \delta \varepsilon \lambda \varphi \varepsilon o ́ v ~ \tau(\varepsilon)$ ”, ("pois conta-se que ele [Zeus] teria gerado Éaco por meio das sementes recebidas pela mãe [Egina], ||| tanto para ser regente para minha pátria | quanto, ó Hércules, teu hóspede aliado e irmão"), que está longe de ser "o mais claro exemplo de um

${ }^{38}$ Cf. p. 209 et seq. 
eu-coral" 39 . Ele prova apenas que ou (1) Píndaro chama Egina de "minha pátria" por assumir a persona de um conterrâneo do vencedor e, assim, estreitar os laços de $\xi \varepsilon v i ́ \alpha$ entre os dois, como quer Lefkowitz ${ }^{40}$, ou, então, que a ode fora executada por um bardo eginense cantando no lugar de Píndaro. A hipótese de uma performance coral seria indiscutível se, e apenas se,

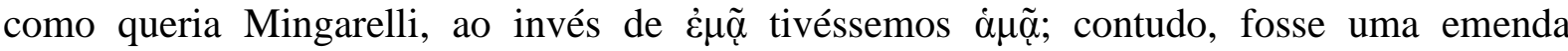
necessária, faria mais sentido adotar a hipótese de Hermann, $\dot{\varepsilon} \tilde{\alpha}^{41}$. Nenhuma correção do texto

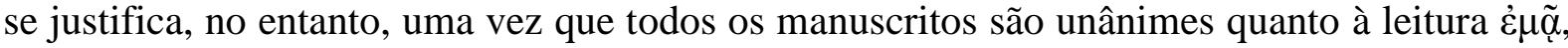
que motiva, inclusive, os comentários dos escólios a essa passagem.

O caso da $P .8 .98$ é semelhante, uma vez que a apóstrofe a Egina como $\varphi \hat{i} \lambda \alpha \mu \tilde{\alpha} \tau \varepsilon \rho$, ainda que a consideremos como unicamente apropriada a um eginense, o que por si só já é duvidoso $^{42}$, não implica que a evocação tenha que ser feita por um coro, pelas mesmas razões

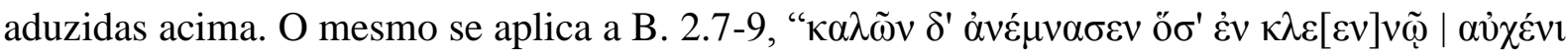

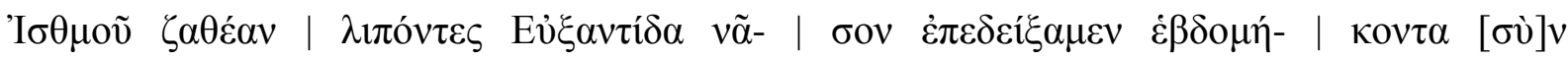

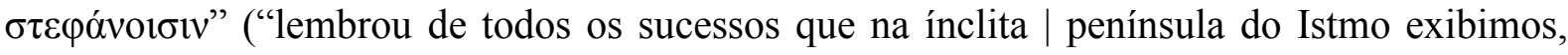
sagrada | após deixarmos e ilha de Euxântios ${ }^{43}$ | na companhia de setenta coroas”), onde é natural que esperemos um sujeito plural quando a ode é pela vitória de um compatriota do poeta, Argeio de Ceos. Podemos ter aqui um bom exemplo em que a $1^{\mathrm{a}}$ p. do pl. é empregada em seu sentido inclusivo.

Finalmente, a última categoria que Bremer distingue é aquela em que a persona loquens parece se referir ao indivíduo Píndaro, poeta nascido em Tebas. Esta, como era de se esperar, é a menos atestada de todas, apenas algumas referências aqui e acolá que não nos permitem deduzir praticamente nada de sua vida ${ }^{44}$. Apesar de isso ser má notícia para aqueles que ainda têm esperanças de encontrar nos poemas pindáricos alguma informação pessoal sobre a vida do poeta, o fato está de acordo com a economia do epinício segundo a qual aquele deve falar o menos possível de si mesmo e, quando o fizer, apenas se for relevante, de algum modo, para o louvor do laudandus. Um caso em questão, por exemplo, é quando vemos Píndaro gabar-se de seu talento poético, ou, então, de sua afiliação com as Musas, de sua descencência aristocrática etc. disposições que, por sua relação pessoal (fictícia ou não, pouco importa) com o seu patrono, apenas servem para aumentar o prestígio de ambos.

${ }^{39}$ CAREY (1981) "Fränkel (...) argues for a choral first person. He is surely right. Not only is ćũ̃ the only mss. reading but it clearly troubled the ancients (schol. 123a). It cannot be rejected out of prejudice, and remains the clearest example in Pindar of a choral first person" , grifo meu.

${ }^{40}$ LEFKOWITZ (1991, p. 8).

${ }^{41}$ Outras emendas propostas à leitura dos mss.: $\tau \varepsilon \tilde{\alpha}$, de Paw., vi $\mu \tilde{\alpha}$, Heyne, $c f$. D. GERBER (1976, p. 115).

${ }^{42} C f$. minha discussão na p. 213 e a bibliografia relevante lá listada.

${ }^{43}$ Isto é, Ceos.

${ }^{44}$ BREMER (1990, p. 50). 
Uma outra característica interessante do "eu-bárdico" de Píndaro apontada por Lefkowitz $^{45}$, mas que já havia sido antecipada por Schadewaldt ${ }^{46}$, é que ele aparece em posições específicas nos epinícios: nas introduções a um tema, nas transições do mito à ocasião (ou vice-versa) e na conclusão de um tema ou poema. Nesses locais ele teria tanto essa função, que ela chama de "estrutural", quanto uma outra, "descritiva", mais comum nas $\sigma \varphi \rho \alpha \gamma i ́ \delta \varepsilon \varsigma$ das odes e que serviria para identificar o poeta como o compositor da canção e listar suas obrigações, ligando, além disso, a sua fama com a de seu laudandus.

Ela deduz, a partir desses fatos, que estas incursões da persona loquens no fluxo da canção devam ser, provavelmente, uma característica herdada pelo gênero. Lefkowitz acredita em uma continuidade a partir do modelo épico ${ }^{47}$ :

\begin{abstract}
Ao usar a primeira pessoa como uma transição e um meio de auto-identificação profissional, Píndaro parece estar se utilizando de uma tradição estabelecida, uma vez que os enunciados do "eu" nos epinikia de seu rival contemporâneo, Baquílides, têm a mesma função dupla. A prática pode ter se originado com os bardos que, quase sempre de modo invariável, iniciavam seus prelúdios aos deuses com a frase em primeira pessoa 'eu irei cantar Hércules, filho de Zeus (h. Hom. 15.1); 'lembrarei e não me esquecerei de Apolo longiflecheiro (h. Hom. 3.1). Essas linhas iniciais introduzem o tema do prelúdio e indicam que o 'eu' é um aoidos, cuja profissão é lembrar os grandes feitos do passado. Da mesma forma, a canção normalmente é concluída com um enunciado em primeira pessoa, onde o bardo novamente irá chamar a atenção para suas habilidades profissionais: 'Adeus, mas eu lembrarei de ti em uma outra canção também' ( $h$. Hom. 2 .495, 6.21); 'adeus... dá-me a vitória nesta competição, torna agradável minha canção' (h. Hom. 6.19-20). Portanto, tradicionalmente, uma referência à presença controladora do poeta indica uma mudança de assunto, o começo ou o fim de um tema. ${ }^{48}$
\end{abstract}

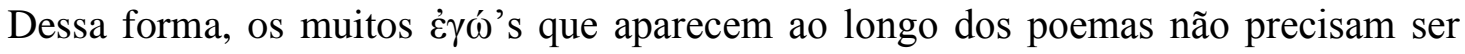

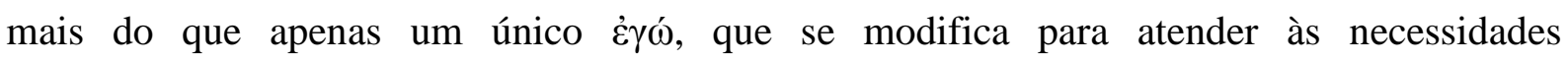
encomiásticas de cada passagem e eles não se referem ao Píndaro, indivíduo histórico, mas à sua persona retórica: ao seu papel como bardo inspirado, ao seu ofício como poeta e aos seus deveres como panegirista. Apesar disso, eles são pessoais o suficiente para serem identificados com a voz de um bardo, um mensageiro e profeta das Musas, que celebra um

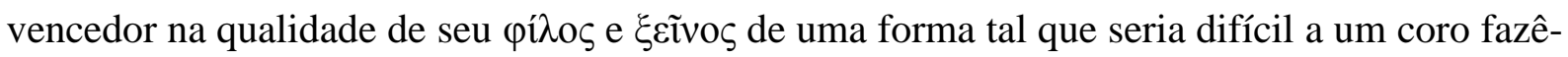
lo, como veremos a seguir.

Seria desnecessário e redundante analisar novamente todas passagens relevantes, o que já foi feito pela própria Lefkowitz e outros pesquisadores ${ }^{49}$, sob diferentes pontos de vista. Ao

\footnotetext{
${ }^{45}$ LEFKOWITZ (1991).

${ }^{46}$ SCHADEWALDT (1966, p. 265 et seq. e 334).

${ }^{47}$ Como Slings, $c f$. SLINGS (1990, p. 26 et seq.).

${ }^{48}$ LEFKOWITZ (1991, pp. 6-7).

${ }^{49}$ D'Alessio (1994), CAREY (1989, 1991), CAlAME (2011).
} 
contrário, eu gostaria de centrar a questão em apenas um tipo de غ̇үó que ainda causa bastante controvérsia, a saber, aquele que parece descrever as atividades de um coro e que não poderia,

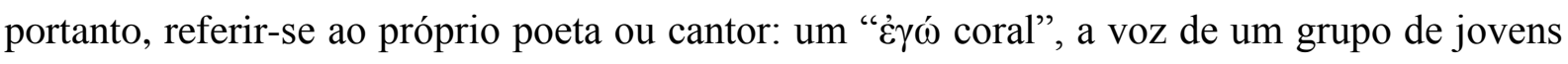
locais responsáveis pela execução da ode. Essa análise também foi feita por Lefkowitz, mas seus resultados foram questionados por vários outros especialistas, e, especialmente, por G. B. $\mathrm{D}^{\prime} \mathrm{Alessio}^{50}$, que se propôs a refutar passo a passo a argumentação de que a persona loquens dos epinícios é de uma natureza completamente diferente daquela dos outros poemas da lírica coral que conhecemos, inclusive do próprio Píndaro. É preciso que se revise os resultados a que ambos chegaram.

Lefkowitz, ao comparar os غ̇үó's da N. 9 com aqueles dos Peãs 4 e 2, por exemplo, conclui que, nesses últimos, a primeira pessoa coral é caracterizada por autodescrição e pela sua identificação explícita com a localidade a que pertence, seu temas são locais e nunca há considerações sobre a composição poética. Os epinícios, ao contrário, lidariam com temas mais universais e seriam conspícuos pelo seu conteúdo metapoético, ainda que em ambos a primeira pessoa possa servir às mesmas funções, estrutural e descritiva. Nos peãs, além disso, há descrições geográficas bastante precisas, muito embora nos parteneios a ênfase esteja na descrição física do coro de meninas. É apena natural que seja assim porque, ao contrário do

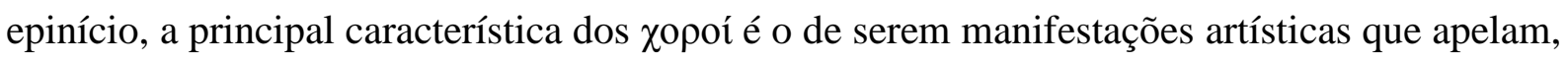

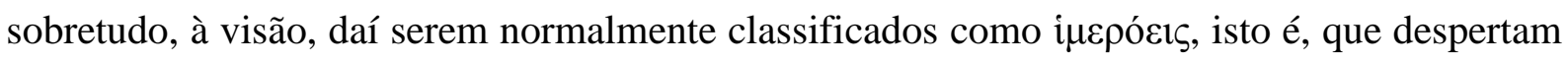
o desejo naquele que os vê, já que o adjetivo tem uma conotação principalmente passiva ${ }^{51}$.

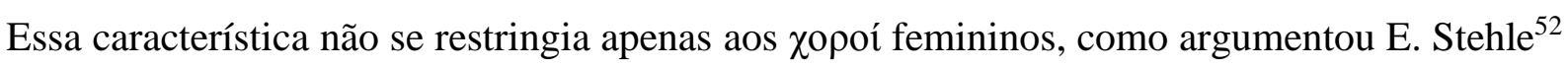
em um trabalho importantíssimo sobre a relação entre a identidade de gênero e a performance da poesia coral: coros masculinos também eram caracterizados pela autodescrição, mas sobretudo por meio de referências altamente eróticas acerca da masculinidade de seu próprio corpo, como no caso do fr. 870 PMG citado por ela como ilustrativo desse fato. Neste, o coro é formado por velhos, jovens e meninos, que se alternam em cantar os seguintes versos:

\footnotetext{
$\dot{\alpha} \mu \varepsilon \varepsilon_{\zeta} \pi \mathrm{o} \kappa^{\prime} \hat{\eta} \mu \varepsilon \zeta \alpha^{\alpha} \lambda \kappa 1 \mu \mathrm{ol} v \varepsilon \alpha v^{\prime} \alpha 1$.

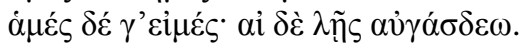

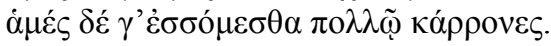

Nós já fomos valorosos rapazes, e nós ainda somos, acaso olhes. Vê! e nós seremos em muito superiores.
}

\footnotetext{
${ }^{50}$ D'Alessio (1994).

${ }^{51} C f$. a minha discussão na p. 82.

${ }^{52}$ STEHLE (1997, p. 119 et seq.).
} 
Algumas características típicas da persona loquens dos poemas corais apontadas por Lefkowitz e que estariam em oposição àquela dos epinícios podem ser facilmente identificadas nestas passagens dos Peãs 2 (fr. 52b S-M/ D2 $\mathrm{R}^{53}$ ), para os abderitas, 4 (fr. 52d/ DIV R), para os habitantes de Ceos, e, sobretudo, do Parteneio 2 (fr. 94b), um dafnefórico para Agasiclês de Tebas:

Peã 2

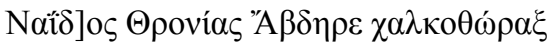

Пo丂] $\varepsilon i \delta \tilde{\nu} v o ́ \varsigma \tau \varepsilon \pi \alpha \tilde{i}$,

$\sigma \varepsilon ́ \theta] \varepsilon v$ 'Iáovı $\tau o ́ v \delta \varepsilon \lambda \alpha \tilde{\omega}$ $\pi \alpha 1] \tilde{\alpha} v \alpha[\delta 1] \omega ́ \xi \omega$

$\Delta \eta_{\jmath} \rho \eta v o ̀ v ~ ' A \pi o ́ \lambda \lambda \omega v \alpha \pi \alpha ́ \rho ~ \tau ' ~ ' A \varphi \rho o[\delta i ́ \tau \alpha \nu \cup-$

(lines $6-22=$ str. A $5 b+7+$ ant. A missing)

(...)

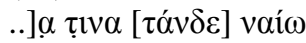

$25 \Theta[\rho] \alpha \ddot{\kappa} \kappa i ́ \alpha v \gamma[\alpha \tilde{l}] \alpha \nu \dot{\alpha} \mu \pi \varepsilon \lambda o ́[\varepsilon \sigma] \sigma \alpha ́ v \tau \varepsilon \kappa \alpha i ́$

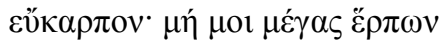

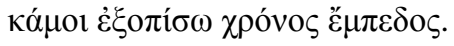

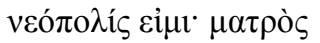

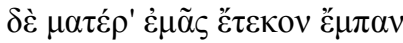

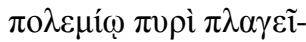

$\sigma \alpha \nu$.

Abdero do peitoral de bronze, da náiade Trônia

e de Posidão, ó filho,

desde ti ao povo jônio este

peã perseguirei

4 à casa de Apolo Derenos e de Afrodite (...)

(linhas 6-22 = strofe A 5b+7 + antístrofe A estão faltando)

(...) moro nesta

25 terra trácia repleta de videiras e também

boa de frutos: em seu arrastar-se o grande tempo, no futuro, não se canse de me ser firme.

Venho de uma jovem cidade $^{54}$ : de minha mãe

a mãe gerei, contudo,

ao ser pelo fogo da guerra

fustigada.

\section{Peã 4}

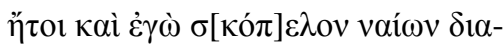

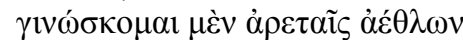

'E $\lambda \lambda \alpha v i ́ \sigma v v, \gamma i v \omega ́ \sigma \kappa[o] \mu \alpha[1] \delta \grave{\varepsilon} \kappa \alpha \grave{~}$

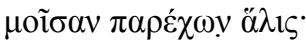

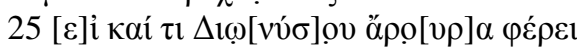

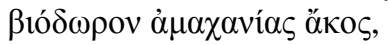

${ }^{53}$ Os números precedidos de "R" referem-se à edição e comentário dos peãs editados por RUTHERFORD (2001). O texto também reproduz (com exceção de algumas marcas paleográficas desnecessárias aos nossos propósitos aqui) o da daquela edição.

${ }^{54}$ Assim RUTHERFORD (2001, p. 266). Outros ( $c f$. bibliografia na n. 20, em Rutherford) interpretam

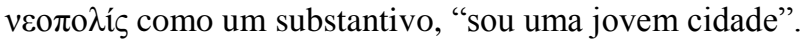




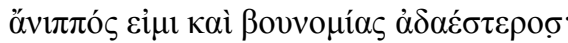

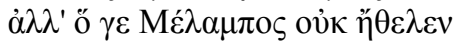

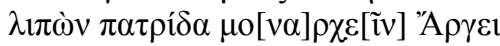

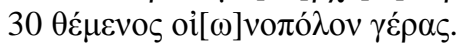

ì̀ iท́,

(...)

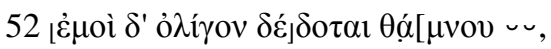

¡ov̉ $\left.\pi \varepsilon v \theta \dot{\varepsilon} \omega v \delta^{\prime} \dot{\varepsilon} \lambda \alpha \chi \circ v,<0 u ̉>\sigma \tau \alpha \sigma i ́ \omega v\right]$

E ainda que eu viva numa rocha alcantilada ${ }^{55}$, sou conhecida por minhas virtudes tanto nos jogos

entre os helenos, quanto o sou também por fornecer música farta.

E ainda que algum fruto de Dioniso produzam os campos, dom vital e remédio contra as misérias,

cavalos, porém, não tenho e nada sei de criar gado.

E apesar disso, Melânipos, ao menos, não quis,

tendo deixado a terra-mãe, ser monarca em Argos,

pondo de lado seu dom do augúrio.

iè ié, ò iè Paián.

\section{Parteneio 2}

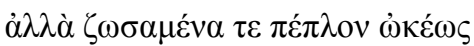

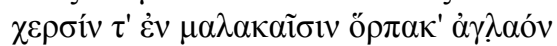

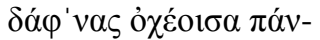

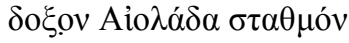

10 vioṽ $\tau \varepsilon$ П $\alpha \gamma \omega \dot{v \delta \alpha}$

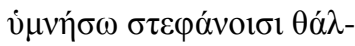

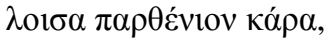

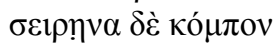

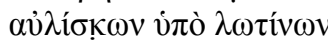

$15 \mu \mu \eta ́ \sigma o \mu^{\prime} \dot{\alpha} \mathrm{o} \delta \alpha \tilde{\varsigma}$

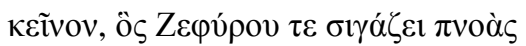

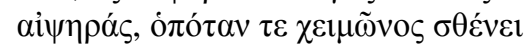

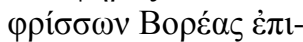

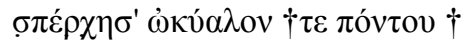

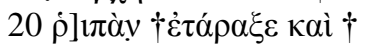

(desunt vv. aut 8 aut 23)

$$
\text { (..) }
$$

$\pi \mathrm{o}] \lambda \lambda \grave{\alpha} \mu \grave{\varepsilon} v[\tau] \grave{\alpha} \pi \dot{\alpha} \rho 01 \theta[--x-v-$

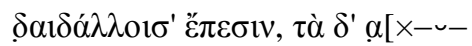

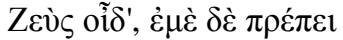

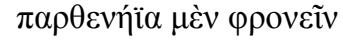

$35 \gamma \lambda \omega ́ \sigma \sigma \alpha \alpha \tau \varepsilon \lambda \dot{\varepsilon} \gamma \varepsilon \sigma \theta \alpha l^{\circ}$

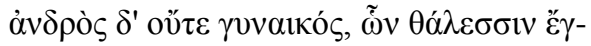

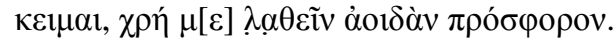

$\pi \imath \sigma \tau \dot{\alpha} \delta^{\prime}$ 'А $\gamma \alpha \sigma \iota \kappa^{\prime} \lambda \varepsilon ́ \varepsilon 1$

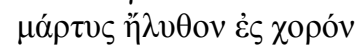

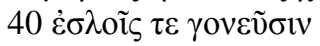

${ }^{55}$ A persona loquens diz que não abandonaria sua terra nem mesmo pelas planícies da Babilônia. É o tema do "there is no place like home". 


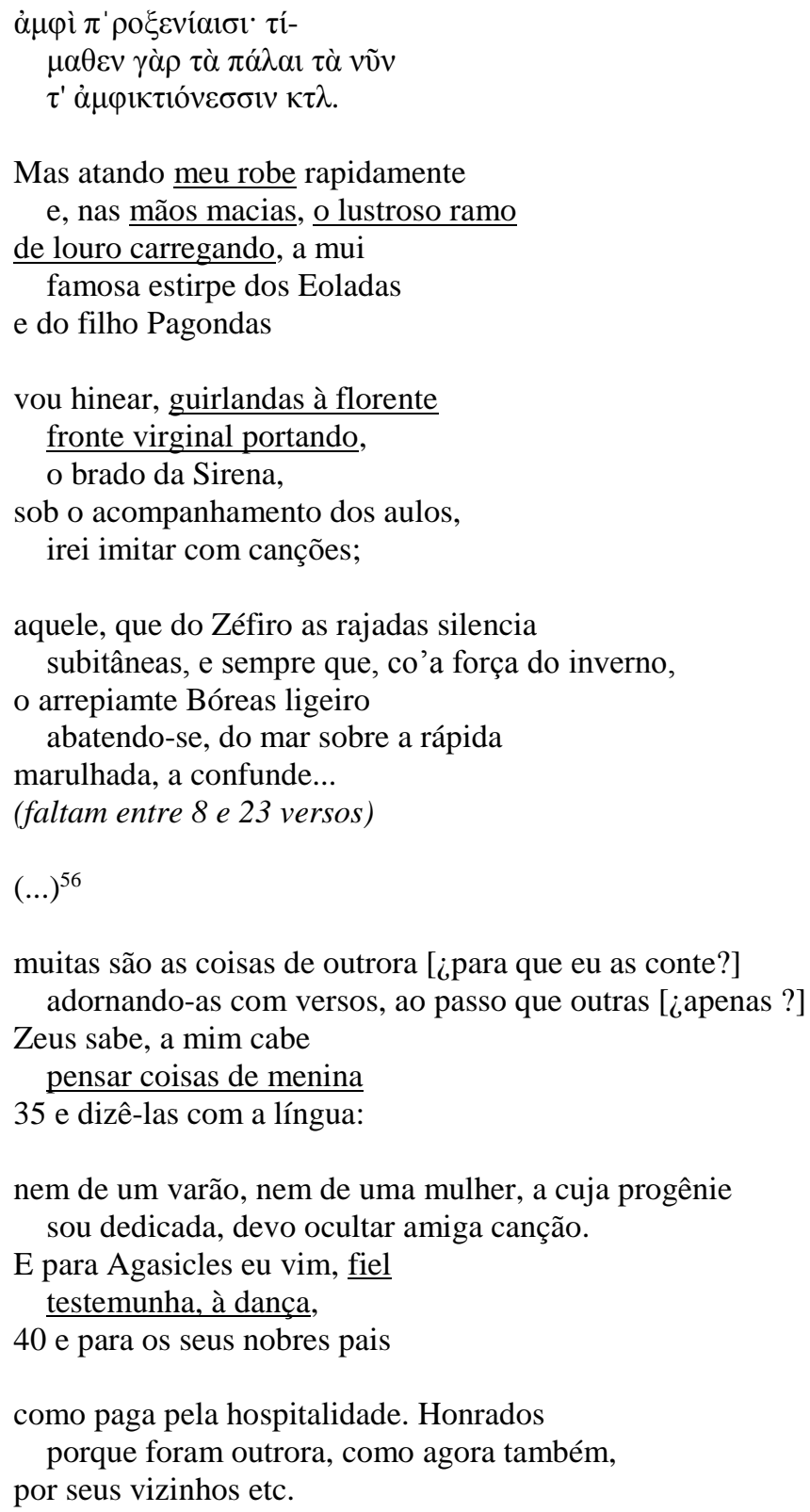

Qualquer um que tenha lido os epinícios não pode deixar de se surpreender com a diferença nos enunciados da persona loquens nesses poemas corais e com as estratégias utilizadas pela mesma para situar a performance no hic et nunc sobretudo se pensarmos que essa assim o faz face a uma audiência que assistia ao coro no momento mesmo em que este cantava e dançava. Há, nos peãs, por outro lado, uma descrição muito cuidadosa, que procura explicitar quem são os componentes do coro, de que cidade vêm, quais as características de suas terras etc. No caso do Peã 2 há mesmo o cuidado de descrever o caminho que a procissão irá tomar (3-4). Já no Parteneio 2, a autodescrição dos membros do coro é ainda mais

${ }^{56}$ Os vv. 29 e 30 estão muito fragmentados. 
impressionante e, como nota Lefkowitz ${ }^{57}$, pouco é deixado à imaginação da audiência. A identificação precisa da persona loquens, mesmo que essas descrições tão detalhadas estivessem ausentes, é precisada pelo uso dos particípios femininos (37). A semelhança com o Parteneio de Álcmã (1 PMG) ${ }^{58}$ é inegável: na lacuna após o v. 47 há o que parece o início da seção mítica da canção e, quando o texto retorna, vemos o que só pode ser a interação das meninas do coro, nomeadas como Damaina, possivelmente a líder-do-coro, e Andaisistrota, aparentemente sua mãe, o que sugere uma canção estreitamente ligada à pequena comunidade de famílias para a qual foi composta.

Uma outra característica dessas canções corais, e por meio da qual elas também diferem dos epinícios, é que nunca há uma mudança de referencial dêictico da persona loquens: é sempre a voz do grupo que fala do início ao fim do poema. Não há jamais, e até onde podemos estar seguros em se tratando de poemas tão fragmentados, a intrusão da voz do poeta nessas canções. Quando, no Parteneio 2.33-5, o coro de meninas fala sobre o que lhes convém cantar, elas não estão confabulando sobre que caminho dar à canção, como falar, sobre o que falar ou silenciar, como nos epinícios; ao contrário, elas estão apenas emitindo uma opinião, que, ademais, é a opinião da comunidade como um todo acerca do papel que lhes cabe no ritual ${ }^{59}$.

Nada disso parece impressionar D’Alessio que, com sua erudição característica, nos oferece um tour de force em favor de uma persona loquens coral nos epinícios ${ }^{60}$ ao tentar refutar, um a um, os argumentos de Lefkowitz. Seu próprio argumento, porém, está longe de ser tão convincente no que tange às evidências que aduz dos parteneios. Sua argumentação no que diz respeito aos peãs, no entanto, merece mais atenção. Apesar de alguns problemas esses mesmos incontornáveis devido à própria natureza da questão -, o artigo de D’Alessio é um dos mais equilibrados em toda a controvérsia "solo x coral" e, ainda que não seja decisivo a ponto de encerrá-la, representa uma contribuição de alto nível em um momento em que o debate, mais do que filologia, já havia se convertido em um cabo de guerra. O problema mais sério com as refutações propostas por D’Alessio diz respeito à quantidade e à extensão das

${ }^{57}$ LEFKOWITZ (1991, p. 18 et set.).

${ }^{58}$ Para uma análise detalhada das semelhanças entre os dois poemas, $c f$. LEFKOWITZ (1991, p. 18 et seq.). Certamente como salienta a autora, "These similarities in style and content are surely great enough to suggest that there was a formal stylistic tradition in maiden-songs to which both Alcman and Pindar intentionally adhered."

${ }^{59}$ Assim CALAME (2001), passim.

${ }^{60}$ É salutar, no entanto, que sua posição seja bem menos dogmática que a de Chris Carey. Por exemplo, à nota 2, de seu capítulo citado, ele diz "I assume that, as a rule, victory odes were composed for choral performance. (...) Nevertheless I would not be reluctant to concede that the actual practice might have been somewhat flexible and that some poem, e.g., Ol. 1, might have been composed for solo performance." 
evidências que usa, a maioria delas em um estado muito fragmentário. Isto, como veremos a seguir, reduz muito o valor de seu argumento.

Logo no início de seu artigo, ele propõe que as atividades possivelmente atribuídas às meninas do coro nos parteneios seriam da mesma natureza daquelas que Lefkowitz admitiria apenas à persona loquens dos epinícios, a saber:

1) elas são inspiradas pelas Musas: as evidências apresentadas por D’Alessio são os fr. Alcm. 3. 1-9, 14, 27, 29 e 59(b) $\mathrm{PMG}^{61}$. Antes de mais nada é preciso que se ressalte que todos os fragmentos estão muito mutilados. No fr. 3. 1-9 (P. Oxy. 2387), a identificação das

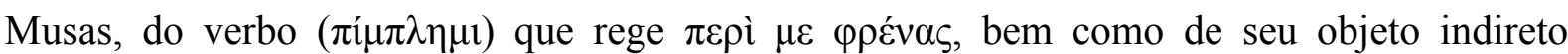
(i $\mu \varepsilon ́ p \omega)$, dependem de suplementos, sem os quais o trecho é praticamente ilegível. Ainda que estejamos dispostos a aceitá-los, há 51 versos faltando entre o que seria a primeira e a segunda parte do poema, que se encontra em uma outra coluna do papiro e, muito embora a continuidade entre as duas partes seja provável, não há como garanti-la, sobretudo porque há uma grande diferença temática entre elas: é apenas na segunda parte que o poema torna-se evidentemente coral, o que levou Campbell a postular que "as linhas de abertura [isto é, toda a primeira parte] podem ter sido cantadas por um cantor solo, que faria a introdução para o resto do coro" ${ }^{\text {"2 }}$. Comentarei essa possibilidade mais abaixo, ao falar do Peã 6.

Em 14(a) dificilmente poderíamos falar de "inspiração" no sentido que vemos, por exemplo, na $O$. 3. 4-6 ou na $N$. 9. 1-5, nas quais a Musa é invocada para assistir diretamente na composição do epinício. Aqui trata-se apenas de uma invocação na qual se pede a Musa, como seria natural a uma padroeira do canto e da dança, que dê início à performance. $\mathrm{O}$ mesmo se aplica ao fr. 27, que já comentamos brevemente no capítulo anterior em virtude da aparente divisão que a persona loquens parece estabelecer entre dança e canto. Novamente aqui, como no fr. 3 , não podemos excluir a possibilidade de o poeta estar assumindo o papel

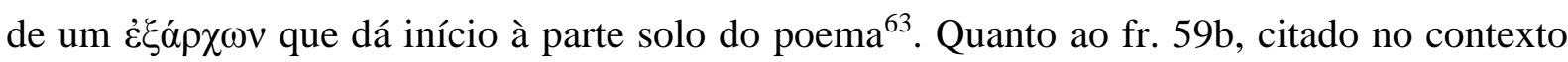
de uma discussão dos Sábios ao Jantar (13.75 et seq.) que envolve, principalmente, lírica monódica de caráter erótico, é opinião do comentador que o referido fragmento teria sido composto por Álcmã em virtude de seu amor por uma outra poetisa, Megalóstrata. Não há sequer o menor indício, no contexto da citação, que permita deduzir que o fragmento possa ter sido executado por um coro e, de fato, ele lembra a poesia erótica anacreôntica com que divide a mesma passagem. O fr. 29 é muito curto para permitir que qualquer dedução possa

\footnotetext{
${ }^{61}$ A edição usada por D’Alessio é a de Calame. A numeração, no entanto, é a mesma.

${ }^{62}$ CAMPBell (1988, pp. 379, n.1).

${ }^{63}$ Sobre isso, $c f$. mais abaixo.
} 
ser feita no que tange à sua possível forma de performance, ou mesmo sobre qualquer outro aspecto.

2) elas poderiam, como o "eu-bárdico”, operar uma seleção na narrativa: D’Alessio

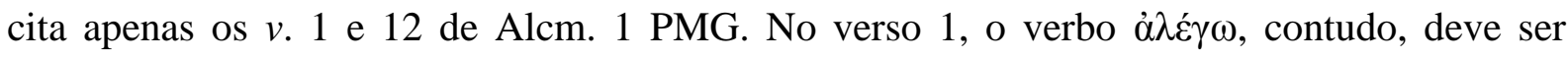
tomado provavelmente no sentido dado pelo fr. $\Sigma$ A a essa passagem, isto é, "ov̉

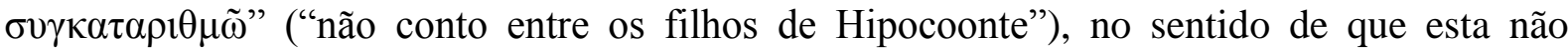
deveria ser a versão do mito corrente em Esparta ou, então, aceita pela audiência. Dificilmente comparável às passagens dos epinícios em que Píndaro seleciona, descarta ou silencia sobre aquilo que irá contar, como no caso mais paradigmático do mito de Tântalo. O futuro $\pi \alpha \rho \eta ́ \sigma o \mu \varepsilon \varsigma$ (12) tampouco pode representar uma seleção de material mítico. Se quisermos lêlo com o suplemento ele apenas nos informa que a glória de Álcão era tamanha que seria impossível a qualquer um não mencioná-la. Na verdade, ele revela uma imposição do material mítico sobre a teórica liberdade do coro em poder alterá-lo e, nesse sentido, é uma evidência contra esta mesma liberdade. Todo o argumento, portanto, parece-me pouco convincente.

3) Elas podem emitir gnomas em suas canções: muito embora Lefkowitz nunca tenha dito que elas não poderiam - e seja mesmo difícil entender porque as meninas de um coro não o fariam -, sua gnomas são completamente diferentes daquelas dos epinícios: mais limitadas em escopo, mais específicas. No caso do Parteneio de Álcmã (1 PMG), dos trechos citados ( $v v .15-9 ; 36-8 ; 83-4)$, nenhum deles está na primeira pessoa. No caso dos trechos citados de Píndaro, as quais D'Alessio faz referência apenas como "passim", é preciso que se esclareça que o Parteneio 1 (94a) provavelmente não seja, na verdade, um parteneio, uma vez que a

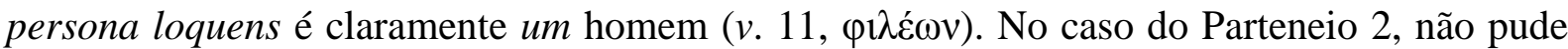
identificar nenhuma passagem que pudesse ser classificada como uma gnoma.

4) Elas podem louvar a qualidade de sua própria canção: novamente, não entendo porque elas não poderiam. D’Alessio parece ignorar que a diferença entre os enunciados dos epinícios e os de outros poemas corais não reside primariamente na existência ou não deste ou daquele tipo de enunciado, mas em como ele é caracterizado. Mesmo que ele pudesse citar diversos exemplos de outros poemas corais - e ele não pode - não vejo como eles poderiam decidir a questão se não fossem comparáveis em conteúdo e escopo aos enunciados em primeira pessoa encontrados nos epinícios. Dito isto, como evidência desta quarta característica, ele cita os muito mutilados vv. 76-8 do Parteneio 2 de Píndaro " $\mu \eta ̀$ vṽv

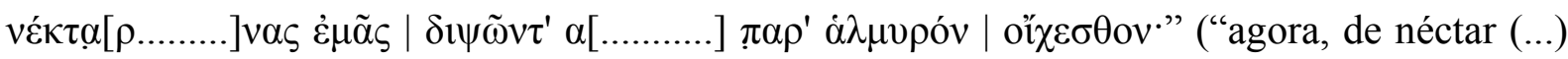
do meu $\mid$ sedentos, (...) para o salgado, não partais vós dois"). Não me parece que se possa 
falar qualquer coisa desses versos ${ }^{64}$ : dado o estado fragmentário, as possibilidades seriam infinitas. Gostaria apenas de salientar que alguns versos acima vemos algum tipo de interação entre as meninas, Damaina e Andaisistrota, acontecendo, da qual os vv. 76-8 poderiam representar apenas um diálogo como em Alcm. 1 PMG, vv. 70 et seq.

5 e 6) Elas podem louvar tanto suas companheiras quanto seus concidadãos da mesma forma que Píndaro faz com seus laudandi nos epinícios; elas tem ciência das normas que regem suas canções e fazem referências a essas normas da mesma forma que Píndaro, nos epinícios: As evidências que apresenta são novamente tênues e se restrigem ao Parteneio 2 de Píndaro, respectivamente $v v$. 50-65 e 34;37.

No caso dos peãs, a situação é mais complexa e a posição de Lefkowitz, tida como a mais ortodoxa, isto é, de que neste tipo de poema coral não há jamais uma mudança de referencial da persona loquens, que sempre se referiria aos membros do coro, parece não estar de acordo com as evidências dos próprios fragmentos. A solução proposta por D’Alessio, contudo, não é menos insatisfatória, na medida em que ele, ao mesmo tempo em que propõe uma mudança na voz da persona loquens, ainda se apega à ideia de que ela reflete uma polifonia vocal típica dos poemas corais, inclusive dos epinícios, o que também não parece ser suportado pelo texto dos poemas. Não é possível, numa discussão que já se torna muito longa, comentar detalhadamente as evidências aduzidas por D’Alessio. Uma vez, porém, que seu argumento depende principalmente do Peã 6, poderemos discutir brevemente esse caso.

A passagem relevante do Peã 6 (fr. 52f/ D6 R) é a seguinte:

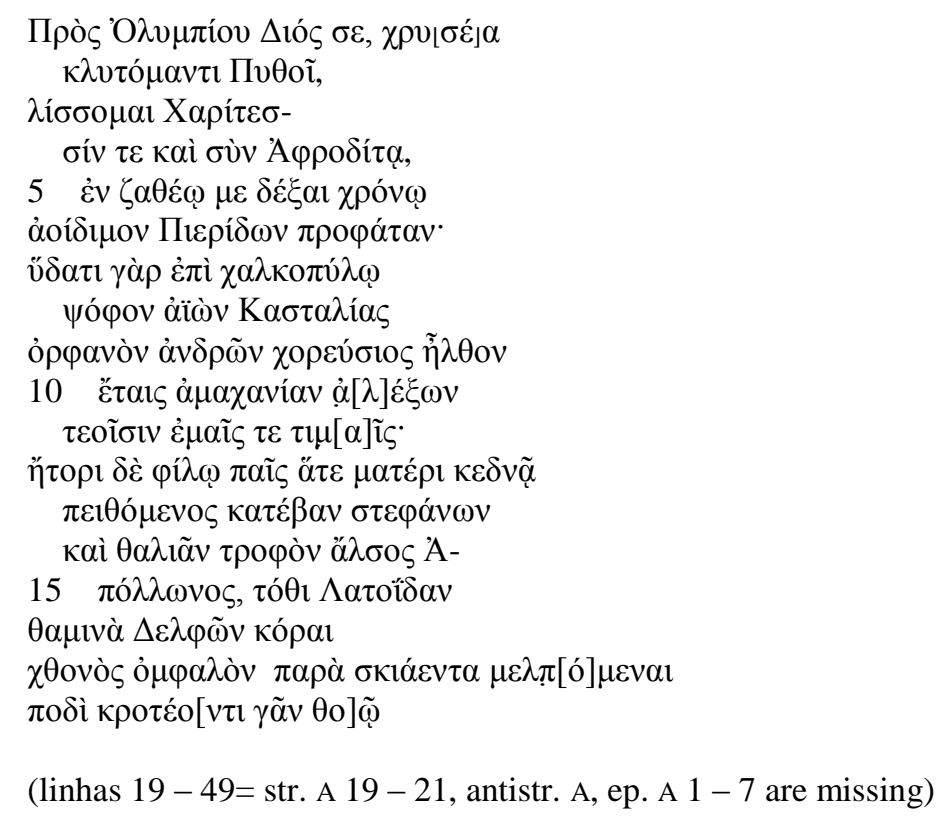

${ }^{64}$ A intepretação de L. Lehnus que D’Alessio cita como se fosse uma autoridade baseia-se em pura especulação. 


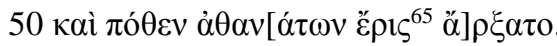

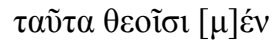

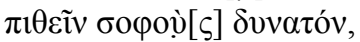

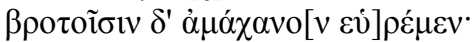

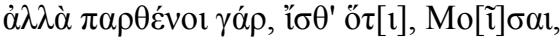

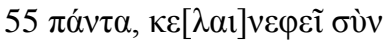

$\pi \alpha \tau \rho \grave{~ M v} \alpha \mu \circ \sigma[v ́ v] \alpha \tau \varepsilon$

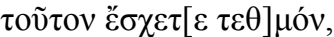

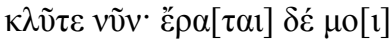

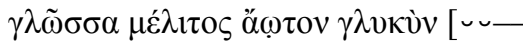

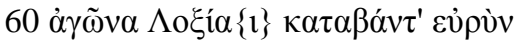

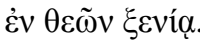

(...)

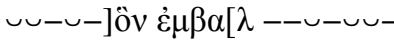

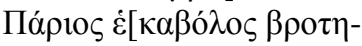

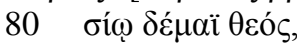

'I $\lambda$ íov $\delta \dot{\varepsilon} \theta \tilde{\eta} \kappa \varepsilon v$ ă $\varphi \alpha \rho$

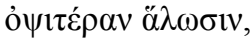

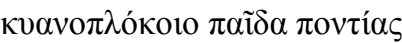

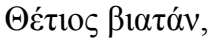

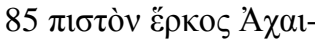

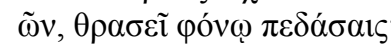

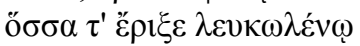

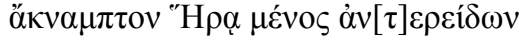

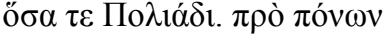

$90 \delta \varepsilon \dot{\varepsilon} \kappa \varepsilon \mu \gamma \gamma \alpha \dot{\lambda} \omega v \Delta \alpha \rho \delta \alpha v i ́ \alpha v$

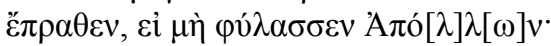

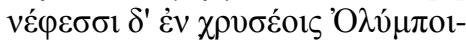

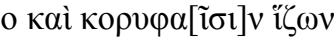

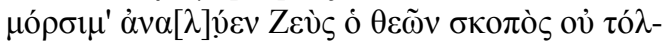

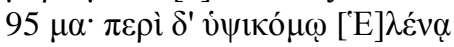

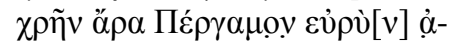

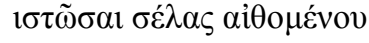

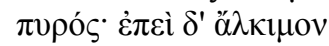

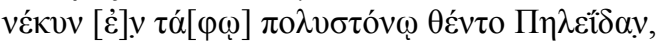

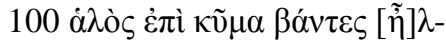

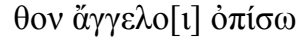

$\Sigma \kappa \nu \rho o ́ \theta \varepsilon v$ N $[\varepsilon]$ o $\pi \tau o ́ \lambda \varepsilon \mu \mathrm{o}[\mathrm{v}$

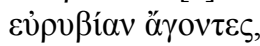

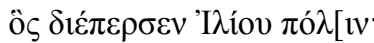

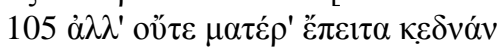

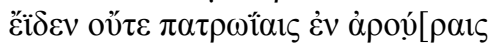

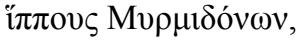

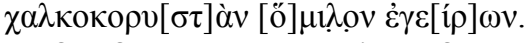

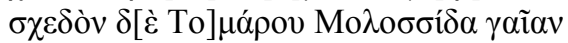

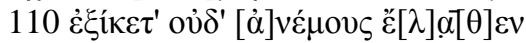

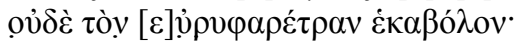

$\dddot{\omega}[\mu o] \sigma \varepsilon[\gamma \grave{\alpha} \rho \theta] \varepsilon o ́ \varsigma$,

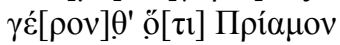

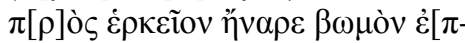

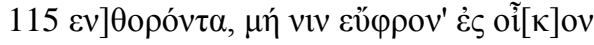

$\mu \eta \dot{\tau} \tau^{\prime} \dot{\varepsilon} \pi \mathrm{i} \gamma \tilde{\eta} \rho \alpha \varsigma \mathrm{i} \xi \varepsilon^{-}$

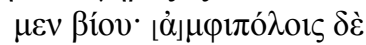

$\kappa] v \rho\left[\imath \tilde{\alpha} v_{]} \pi \varepsilon \rho \grave{i} \tau 1 \mu \tilde{\alpha} v\right.$

65 Permaneço com o suplemento de S-M contra đóvos de R (RUTHERFORD (2001, p. 309)), cujo argumento não me parece convincente. 
]Aír[เví $\tau] \alpha 15$

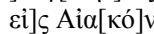
] $\pi \rho \circ \sigma[0 ́] \delta$ เov

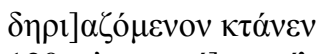

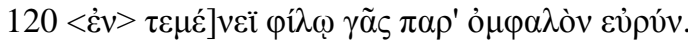

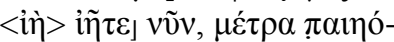

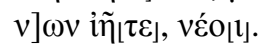

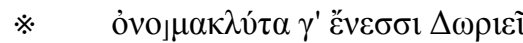

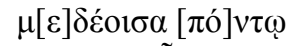

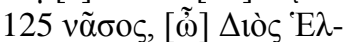

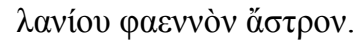

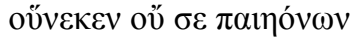

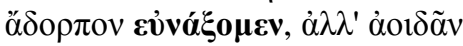

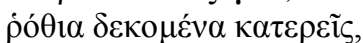

$130 \pi$ ó $\theta \varepsilon v$ č̀ $\lambda \beta \varepsilon \varsigma$ v $\alpha v \pi \rho v ́ \tau \alpha v i v$

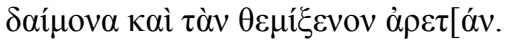

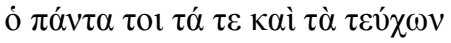

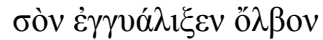

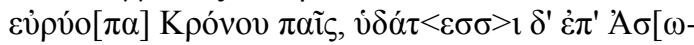

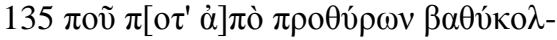

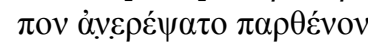

Aǐrivav'

(...)

Por Zeus Olímpio, a ti, áureo e ínclito mantéu Pítio,

eu imploro que, na companhia das Graças e também de Afrodite,

5 sagrada nesta época me recebas, o famoso intérprete das filhas da Piéria:

junto, pois, às águas dos portais de bronze ao ouvir da Castália o murmulho

orfanado das danças dos varões, eu vim

10 para defender da dificuldade os membros de teu clã e as minhas honrarias.

$\underline{\text { Ao meu coração, }}, \underline{\text { tal um filho à mae querida }}$,

obedecendo, eu vim ao precinto

de Apolo, nutriz de festas e guirlandas, onde amiúde ao filho de Leto

as moças de Delfos no frondoso,

umbigo da terra, cantando e dançando,

com rápido pé o chão percutem.

(linhas 19-49 estão faltando)

e donde dos imortais a luta começou, tais coisas aos deuses sim

é possível comunicar aos poetas;

aos mortais, contudo, é impossível descobrir.

Mas Vós Virgens, posto que sabeis, ó Musas, tudo, auxiliadas pelo negrinubiloso

Pai e a Memória,

tal deténs este poder.

Ouvi-me então! Deseja a minha

língua a doce essência do mel (¿cantar?)

tendo vindo à assembleia de Lóxias

à epoca da teoxenia dos deuses.

$(\ldots)^{66}$

${ }^{66}$ Os $v v$. 62-78, muito fragmentados, não são relevantes à nossa discussão. Eles lidam principalmente com a parte mítica, que se encerra logo em seguida. 


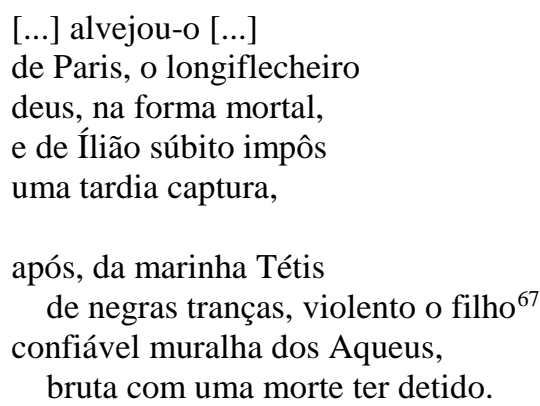

Qual não foi a luta que travou com Hera

de alvos braços à sua inflexível fúria se antepondo, qual não foi contra Pólias ${ }^{68}$ ! E após esforços

enormes a cidade de Dárdano

teria saqueado, não a guardasse Apolo.

Nas douradas nuvens do Olimpo e em seus picos assentando-se,

Zeus, o Vigia dos deuses, ao fadado não ousou desfazer. Por Helena de alta coma era preciso, enfim, que a grande Pérgamo fosse consumida pela chama do ardente fogo. E depois que o valoroso

cadáver do filho de Peleu na multiplangente tumba deitaram, do mar sobre a onda navegando retornaram mensageiros de Esquiro, Neoptolemo vastipotente conduzindo,

que arrasou a cidade de Ílião.

Mas no porvir nem sua cara mãe reviu, nem, nos pátrios campos, os cavalos dos Mirmidões, reunindo a multidão de brônzea crista. Perto de Tomaros, à molossia terra chegou, mas nem dos ventos escapou

à vista nem do Longiflecheiro da larga aljava, pois o deus jurara que, por ter ao velho Príamo, matado, quando este se refugiara no altar de Herkeios, nunca o doce lar ou a velhice na vida alcançaria. E com os atendentes, por míriades de honrarias quando brigava, o matou em seu precinto, no largo umbigo da terra. Ié bradai ${ }^{69}$ agora os metros do peã, bradai, jovens.

[Prosódio para Eginenses dedicado a Éaco]

De mui famoso nome, que no Dório ponto o domínio tens,

Ó ilha de Zeus Helânio, luzente astro.

${ }^{67}$ Aquiles, que permanece o tópico de toda esta passagem até a introdução de Neoptolemo.

${ }^{68}$ Atena Pólias, guardiã de Ílião.

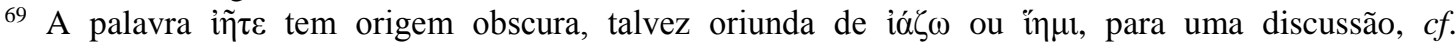
RUTHERFORD (2001, p. 315 et seq.). 


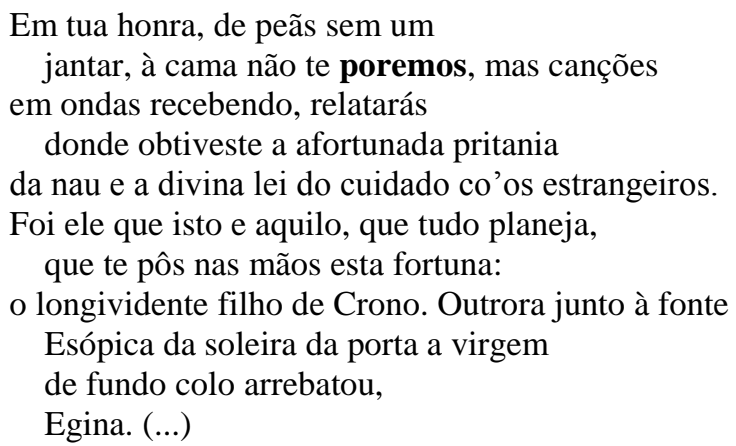

D’Alessio apoia-se nesta passagem para mostrar que, ao contrário do que diz Lefkowitz, a persona loquens nos peãs pode falar de um modo idêntico àquela dos epinícios e que, ademais, a mudança de referencial dêictico entre a primeira parte do peã, onde apenas a $1^{\mathrm{a}}$ p. do sing. fala, e a segunda parte, onde temos verbos na $2^{\mathrm{a}}$ p. do plural, contradiria o princípio de que seria possível diferenciar, por essas marcas, um غ̇үó monódico de um coral e que, finalmente, toda a hipótese baseada nesta distinção seria inválida bem como o próprio "problema da identificação", que resultaria apenas em um dogmatismo que pretenderia atribuir tudo que é sublime e genial ao poeta e tudo o que é lugar-comum às vozes do coro ${ }^{70}$. Ele diz:

\begin{abstract}
A fama do poeta das Musas naturalmente depende das canções que ele mesmo produz e irão durar o tempo em que forem cantadas. $\mathrm{O}$ narrador aqui formou a sua própria imagem apropriando-se de características que pertencem ao objeto divino de sua canção. Seria uma petitio principii dizer que aqui o coro está falando como se fosse o poeta. $\mathrm{O}$ fato importante é que todas as marcas distintivas convergem para a construção de uma figura coerente, um narrador pessoalmente impressionante, cujas marcas distintivas são a produção poética e a inspiração divina, ao passo que não há nenhum elemento formal que caracterize os executantes como tais.

(...)

Está claro, eu espero, que a teoria coro/poeta no mínimo simplifica em muito o problema. Não é possível separar o nobre (e 'metafísico'?) sujeito das odes de vitória da preocupação paroquial e autodescritiva dos poemas cultuais, nem 'identificar' o narrador das odes de acordo com distinções genéricas, às vezes arbitrárias, que podem conduzir a equívocos [grifo meu]. ${ }^{71}$
\end{abstract}

Todas essas considerações de D’Alessio podem estar corretas, uma vez que sabemos muito pouco sobre a forma de execução dos poemas corais e ele tem razão quando diz que Lefkowitz tende a estabelecer fronteiras muito rígidas na sua tentativa de identificar as distintas personae loquentes dos poemas. Abandonando-se, no entanto, essa tipologia fixa de vozes, há uma série de indícios que apontam para uma distinção no nível da dicção entre a

${ }^{70}$ D'Alessio (1994, p. 124). Assim também, utilizando-se de exemplos semelhantes, CingANO (p. 31). Cf. também a excelente discussão de STEHLE (1997, p. 139 et seq.).

${ }^{71}$ D'Alessio (1994, pp. 125-6). 
persona loquens do "eu-bárdico" e a coral. Paradoxalmente, o Peã 6 parece-me ser a prova mais contundente.

Em sua edição e comentário dos peãs de Píndaro, Rutherford faz a seguinte observação acerca do possível modo de performance desses poemas:

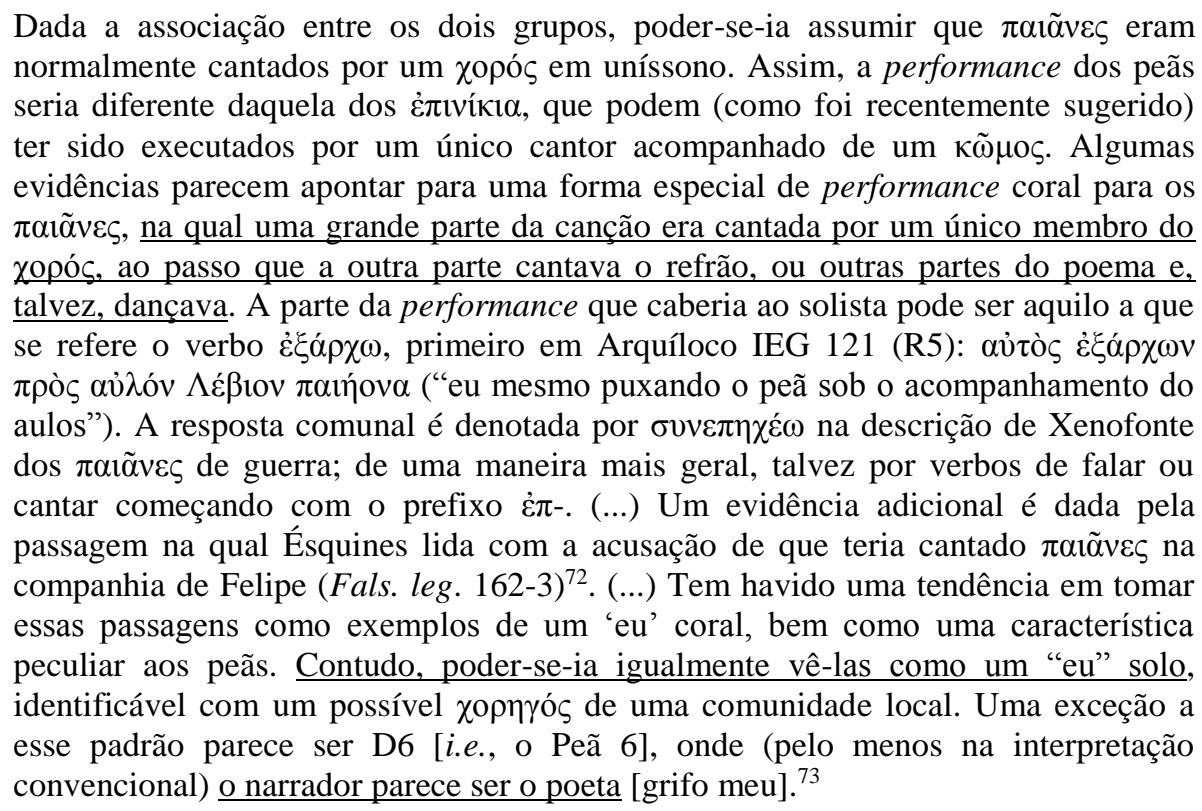

Essas observações de Rutherford parecem estar em bastante sintonia com os fragmentos que vimos até aqui, muitos dos quais, no caso de Álcmã, restringem-se, provavelmente, às linhas iniciais dos poemas, justamente no local em que esperaríamos pelo incipit da parte solo do cantor. Parece-me que o Peã 6 seja, neste sentido, um exemplo interessante da tendência, dedutível a partir daqueles fragmentos, em que a persona loquens assumiria uma voz identificada com a de um $\dot{\varepsilon} \xi \alpha ́ \alpha \chi \chi \omega v$, e este poderia ser o próprio poeta, ao menos para a première. Nele a parte solo cobriria os $v v$. 1-120, onde vemos uma fraseologia e estilo bastante similares aos epinícios (pensa-se logo na $P$. 5), onde a persona loquens, como previra Lefkowitz, jamais muda e onde prevalecem considerações sobre a autoridade do "eubárdico", a inspiração poética, os deveres do aedo etc. Mais importante ainda, esta primeira parte encerra-se com uma coda (121) que tem causado dor de cabeça à maioria dos críticos,

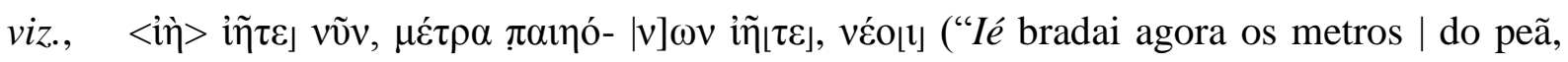
bradai, jovens.”). Rutherford sugere, e eu proponho, que essa coda marque o fim da parte solo e sirva de cue para que o coro comece a cantar.

72 A passagem é importante e Rutherford a cita em contexto, o que não seria possível aqui. A fala

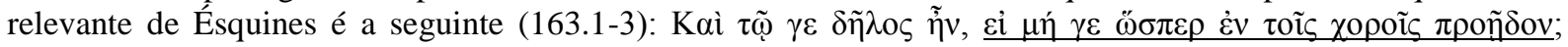

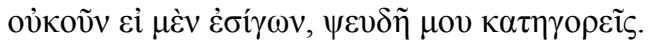

${ }^{73}$ RUTHERFORD (2001, pp. 67-8). 
Surpreendentemente (ou não), os versos que se seguem são tão completamente distintos em tom que, em algum momento de sua transmissão, foram separados da canção original e transmitidos como um prosódio, o que é atestado por uma anotação marginal encontrada no papiro. Rutherford, com razão, argumenta contra a teoria de que se tratariam de dois poemas distintos, sobretudo porque há continuidade temática e métrica entre as duas partes. Dificilmente poderá ser coincidência, no entanto, que é apenas nesta segunda parte do peã que vemos emergir as características associadas por Lefkowitz com os poemas corais: a

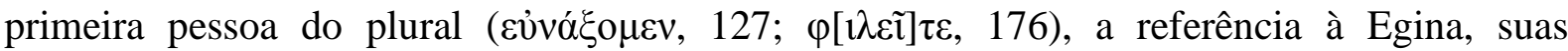
qualidades como uma ilha distinta por seu poder naval e entreposto para viajantes, seu mito fundador etc. Infelizmente uma grande extensão desta última parte está irremediavelmente danificada. Acredito, porém, que poderíamos encontrar outras características associadas à canções corais, acaso dispuséssemos de mais texto.

Não se trata, por fim, de ver na persona loquens dos epinícios enunciados de caráter eminentemente pessoal ou de alguma maneira biográficos, ainda que, na minha opinião, mesmo esses últimos deveriam ser considerados como possíveis, se, em alguma medida, servissem para salientar a glória do laudandus ${ }^{74}$ e, assim, fazer avançar o propósito encomiástico do poema (é de se perguntar se uma audiência original teria se preocupado em separar o fictício do biográfico, em primeiro lugar), mas sim uma voz de autoridade que, na figura de um poeta inspirado pelas Musas, pudesse estender o seu poder e o seu prestígio como um $\tau \alpha \mu i ́ \alpha \varsigma \kappa \tilde{\omega} \mu \mathrm{ov}^{75}$ ao laudandus.

Dessa forma, se pensarmos em uma performance monódica para os epinícios, a persona loquens deve ter no aedo a sua ancoragem dêictica ${ }^{76}$, na première, e, nas reperformances seguintes, em quem quer que se tornasse responsável por executá-la. Como os epinícios parecem ter sido compostos com vistas a uma reperformance, parece-me de certa forma evidente que a persona loquens raramente seja mais do que isto: uma persona. Consequentemente, intrusões biográficas no poema tendem, naturalmente, a ser raras, já que isto, de certa forma impediria a apropriação da persona loquens por futuros executantes. $\mathrm{O}$ epinício, no entanto, como veremos mais adiante, pode utilizar a persona histórica do poeta para estabelecer sua própria autoridade e, nesses casos, declarações de alto cunho biográfico,

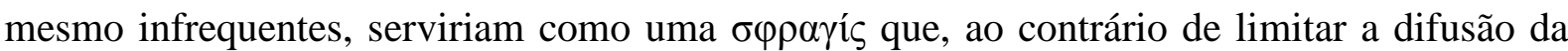

${ }^{74}$ Cf., e.g., O. 10.99-105, N. 1.19-20.

${ }^{75}$ I. 6. 57-8.

${ }^{76}$ No próximo capítulo, eu argumento que a performance da première deveria pressupor, via de regra, a presença do poeta. No entanto, mesmo que este não estivesse presente (e em alguns casos ele poderia não estar), a ancoragem dêictica centrar-se-ia em seu sub-rogado que, dentro do frame da performance, poderia incorporar a persona do poeta. 
canção, seria capaz, na verdade, de estimulá-la. Finalmente, quando a persona loquens expressa-se por meio da $2^{\mathrm{a}}$ p. do plural, não é difícil vermos neste uso uma acepção inclusiva ${ }^{77}$, que pretende envolver todos os membros do $\kappa \tilde{\omega} \mu о \varsigma$ não apenas na celebração, mas no próprio ato de composição da ode e de louvor ao laudandus.

77 Assim SLATER (1969a, p. 90), "I suggest that first-person plural verbs, specially those that occur at

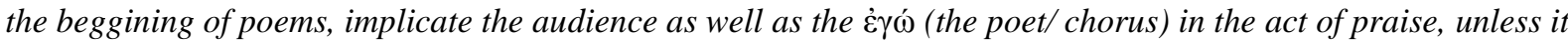

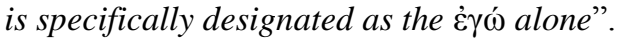




\title{
CAPÍTULO 4
}

\section{PÍNDARO VAGANTE}

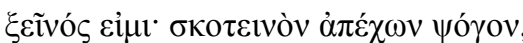

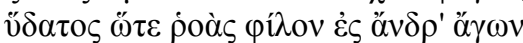

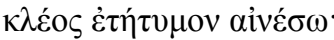

Sou um hóspede: da túrbida injúria me abstendo, como um regato d'água a um amigo venho para louvar uma glória genuína.

A PARTIR da discussão acerca da natureza da persona loquens nos epinícios, eu gostaria de abordar brevemente um cenário muitas vezes tido, tacitamente ou não, como normal para a première das odes, segundo o qual Píndaro não precisava (não podia ou não queria) estar presente durante a première de suas odes e que, por conseguinte, não era necessariamente ele (ou não era sempre ele) que as cantava ou que treinava o coro local como quer que se veja o modo de performance das odes, esta distinção realmente não é relevante aqui -, tarefas que poderiam ser deixadas a um bardo profissional ou a um mestrede-coro local. Uma implicação de se admitir esse tipo de cenário é que, não se fazendo presente no local da performance, ele deveria enviar, de alguma maneira, sua ode aos responsáveis por executá-la, uma ideia que me pareceu apropriado chamar de "hipótese da

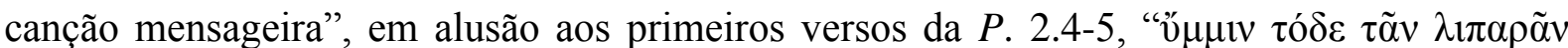

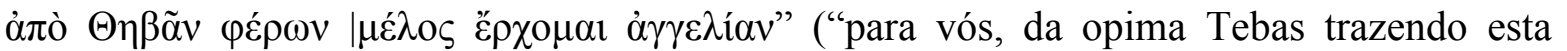
canção mensageira, chego").

Segundo a argumentação desenvolvida no Capítulo 1, parece-me bastante claro que, por trás dessa pressuposição, esconda-se uma certa atitude com relação à poesia pindárica, qua "grande poesia", que tende a projetar na práxis arcaica as nossas próprias experiências, expectativas e preconceitos relativos à gênese de formas poéticas complexas, tipicamente (as vezes, inconscientemente) associadas ao contexto de um literacia desenvolvida. Dessa forma, a partir de dados concretos acerca da atividade dos poetas da idade arcaica, e mesmo tardia, eu tentarei mostrar que não há nada de excepcional em se postular um "Píndaro vagante"1, ocupado em viagens a fim de atender, se não a todos, pelos menos a alguns dos seus clientes

\footnotetext{
${ }^{1}$ Em alusão ao trabalho de Guarducci, $c f$. n. 36.
} 
mais importantes, como os tiranos que celebrou. Ainda que este tipo de cenário não possa ser proposto para todas as odes, para as quais a limitação da idade, mais do que a distância, poderia ter impedido Píndaro de executar suas próprias obras, acredito que não deveríamos pressupor a ausência do poeta como a situação mais prototípica a partir da qual poderíamos imaginar a première de uma ode ${ }^{2}$. Não é minha intenção, contudo, reconstruir um itinerário hipotético das prováveis viagens que Píndaro poderia, ou não, ter feito, nem, em absoluto, tentar apontar quais odes poderiam ter sido executadas por ele ou não. Tudo isso seria impossível de determinar e extrapolaria o limite saudável de especulação que se espera de qualquer estudo filológico. O que eu pretendo argumentar é que não podemos descartar automaticamente que Píndaro nunca fosse o próprio executante de suas odes, no caso de admitirmos uma hipótese de performance solo, ou, de outra maneira, que não estivesse presente quando da execução das mesmas, seja para prestigiar seu patrono, seja para treinar o coro local, ainda que isso implicasse em longas e frequentes viagens por parte do poeta.

Parece-me que, além dos preconceitos associados com a "grande poesia" de que acabávamos de falar, um outro fator pode ter sido o principal responsável pela presunção quase automática de que (1) Píndaro escrevia suas odes e então (2) as despachava para que fossem executadas por outras pessoas: a anedotas contida em suas Vitae.

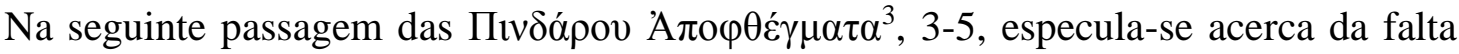
de conhecimento musical do poeta:

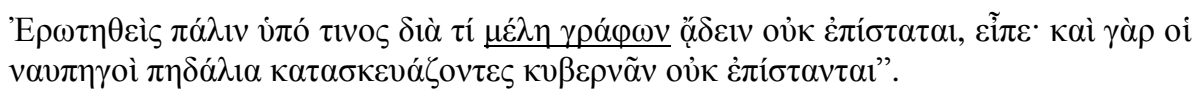

Quando alguém lhe perguntara porque, sendo um escritor de canções, não sabia cantar, respondeu que também os construtores de navios, construindo lemes, não sabiam pilotar.

Outra possibilidade aventada por seus "biógrafos" seria algum distúrbio da fonação ${ }^{4}$, o que naturalmente o impediria de cantar. Note que a passagem seguinte é uma tentativa de explicar a invocação a um tal de Eneias na $O .6 .87$ :

${ }^{2}$ Mesmo a idade não me parece ser, em princípio, um argumento muito forte, basta que pensemos que Ésquilo deve ter partido para a Sicília, onde continuou ativo como tragediógrafo, já com mais de cinquenta anos, uma idade bastante avançada para a época, $c f$. Vita $9=$ TrGF vol. 3. Mais singular ainda é o caso de Simônides, que teria viajado para a Sicília com mais de 80 anos, c. 470 a.C.

${ }^{3}$ Todas as passagens biográficas se referem aos testimonia da edição de DRACHMANN.

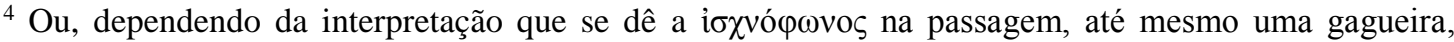
embora o contraste com $\mu \varepsilon \gamma \alpha \lambda$ ó $\varphi \omega v o \zeta$, na minha opinião, desautorize essa interpretação. Para uma revisão do termo, WOLLOCK (1997, p. 159 et seq.). 


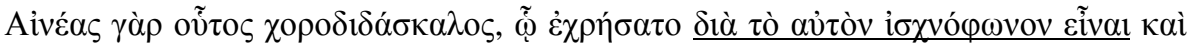

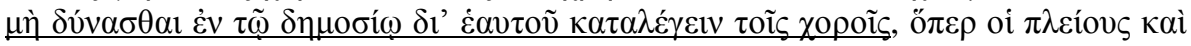

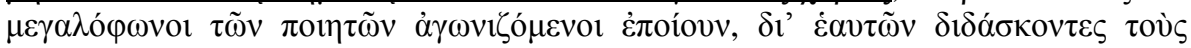

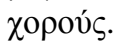

Esse Enéas é o professor do coro que Píndaro usou em virtude de ter uma voz débil, o que o impedia de recitar para o coro em público, exatamente como fazia a maior parte dos poetas de voz magnificente quando competiam nos festivais, eles mesmos ensaiando com os coros. ${ }^{5}$

Essas duas notícias, no entanto, estão em franca contradição tanto com esta outra lição da Vita Pindari:

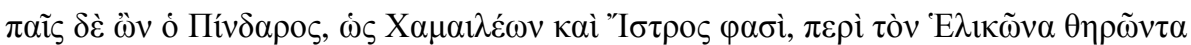

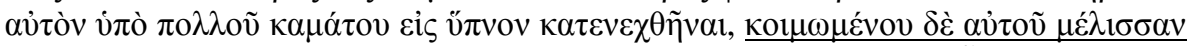

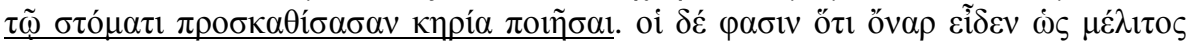

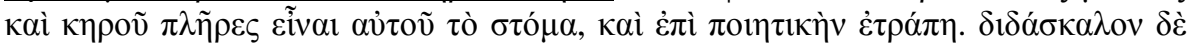

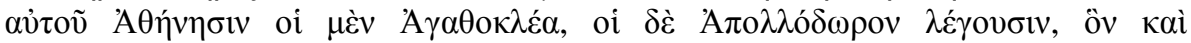

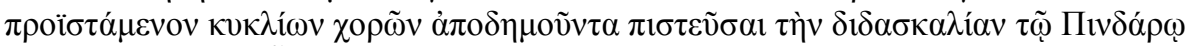

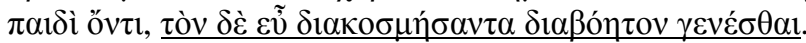

Quando Píndaro ainda era uma criança, como contam Camaleão e Istro, e estava caçando ao sopé do Hélicão, acabou caindo no sono em virtude do cansaço. Enquanto dormia profundamente, uma abelha, pousou sobre sua boca e construiu um favo de mel. Contam ainda que teve um sonho no qual sua boca estava repleta de mel e de cera, e [por causa disso] dedicou-se à poesia. Alguns dizem que o seu professor de música em Atenas foi Agatoclés, outros, porém, Apolodoro. [Qualquer um que tenha sido], no meio do processo de montar um coro cíclico, foi viajar e deixou a produção (didaskalía) do coro sob a responsabilidade de Píndaro, que ainda era uma criança, mas ele, por se sair tão bem no arranjo [da coreografia], tornou-se seu ajudante ${ }^{6}$.

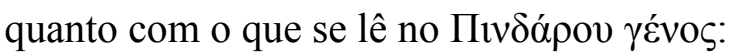

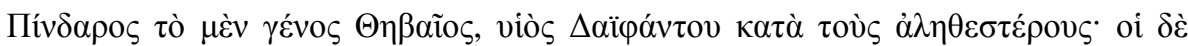

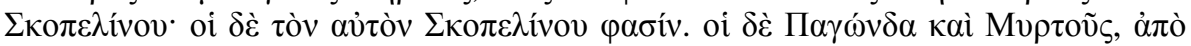

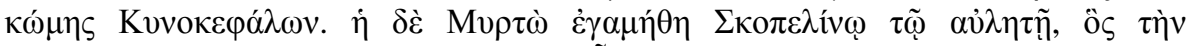

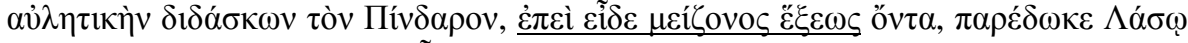

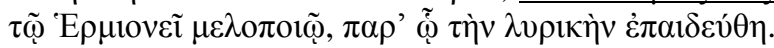

Píndaro, no tocante à sua naturalidade, é tebano e filho de Daifanto, segundo as fontes mais precisas. Mas segundo outros, é filho de Escopelino, outros ainda dizem a mesma coisa. Outros ainda, de Pagonda e Mirto, da vila de Cinocéfala. Essa Mirto casou-se com Escopelino, o auleta, que começou a lhe ensinar a tocar o aulos, mas quando viu que se lhe tornara superior, o passou ao compositor Lasso de Hermione, sob a tutela do qual ele foi educado na arte da lírica.

${ }^{5} \Sigma$ O. VI, $148^{\mathrm{a}}$ (DRACHMANN, p. 188), Minha tradução é uma tentativa de interpretar dois termos importantes nessa passagem: $\kappa \alpha \tau \alpha \lambda \varepsilon \dot{\gamma \varepsilon \iota v}$ e $\delta i \delta \alpha ́ \sigma \kappa o v \tau \varepsilon \varsigma$. O primeiro pode ser tanto "recitar para" como "ditar para", isto é, "ensinar oralmente parte por parte", para mais detalhes, MARGALIT FINKELBERG (1987). O segundo pode ser entendido como um termo técnico usado na tragédia para denotar desde o "ensaio" à "produção" de uma peça e, dessa forma, poderia incluir também as direções de dança e movimentos, ensinadas pelo poeta, além da letra e da música.

${ }^{6}$ Esta passagem provavelmente se refere à montagem de um ditirambo. 
Eu cito essas passagens das Vitae de Píndaro apenas para ilustrar como as ficções criadas por elas, mesmo que em franca contradição umas com as outras, foram e ainda são usadas para ilustrar tanto "fatos" da vida do poeta, quanto para fundamentar hipóteses de que ele seria incapaz de cantar suas próprias odes e que, portanto, algum outro aedo ou o coro deveria fazê-lo. Não deveríamos perder muito mais tempo com elas; de qualquer maneira, Mary Lefkowitz construiu um caso bastante forte ao demonstrar que nenhuma dessas notícias sobre a vida de Píndaro tem qualquer credibilidade e eu remeto, portanto, o leitor interessado ao seu trabalho ${ }^{7}$.

Se as informações nas Vitae poderiam ser descartadas, em que se baseariam então as suposições, muitas vezes feitas sem qualquer explicação, de que Píndaro não poderia estar em tal ou tal lugar e que, portanto, enviara a canção para ser executada por outrem, seja um coro seja um aedo local? Um motivo plausível seria que, dado o grande número de cidades para as quais o poeta compunha e considerando-se a extensão geográfica coberta por elas, seria praticamente impossível que Píndaro estivesse em todos os lugares e ainda fosse capaz de encontrar tempo para trabalhar (leia-se, “escrever") em outras composições ${ }^{8}$. Porém, o que sabemos, de fato, sobre a dinâmica das viagens no mediterrâneo durante os séc. V e IV em que Píndaro era ativo como poeta? Praticamente nada. Muitas premissas sobre a possibilidade ou a impossibilidade de viagens no mundo antigo estão baseadas no que Geus e Thiering ${ }^{9}$ chamam de "common sense geography", isto é, concepções ingênuas totalmente desconectadas de uma investigação real acerca da arqueologia prática da movimentação marítima no Mediterrâneo da Antiguidade.

Finalmente como deveríamos explicar algumas declarações da persona loquens na sua capacidade de erlebende ich, como mencionei anteriormente, se não pudermos pressupor que, ao menos para uma audiência, elas poderiam ser tidas como plausíveis? Certamente é impossível provar que as experiências narradas por um tal erlebende ich nas odes não sejam mais do que ficções, entretanto mesmo as ficções precisam partilhar das expectativas da audiência acerca do que seria possível ou costumeiro e do que não o seria, do contrário elas correriam o sério risco de parecerem apenas ridículas. A persona loquens, na $O$. 1, por exemplo, fala como alguém que tenha assistido a vitória de Ferênico em Olímpia, donde teria tirado a inspiração para compor o próprio epinício (17-22). Além do mais, descreve a convergência dos poetas ao palácio de Hierão na Sicília como frequente $(\theta \alpha \mu \alpha$, 16). Seria tão

\footnotetext{
${ }^{7}$ LEFKOWITZ (1977, 1978, 1980), reunidos em LEFKOWITZ (1991), e LEFKOWITZ (2012).

${ }^{8}$ HeringtON (1985, p. 26 et seq.).

${ }^{9}$ Geus e ThIERING (2012). Meus agradecimentos a Elizabeth Irwin por dirigir minha atenção a este
} trabalho importantíssimo. 
absurdo pensar que, ao invés de ficarem em suas casas esperando por um convite dos seus laudandi para que compusessem um epinício, os poetas, ao contrário, convergissem para os locais das competições em busca de possíveis clientes? Dio Crisóstomo ${ }^{10}$ nos dá uma ideia da atmosfera dos Jogos Ístmicos na primeira metade do séc. I d.C.:

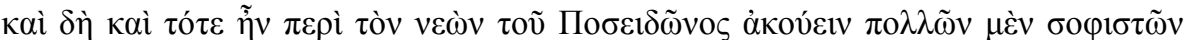

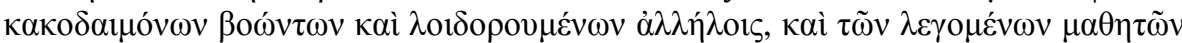

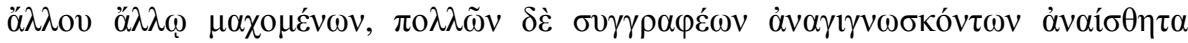

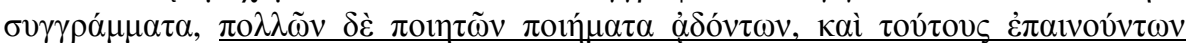

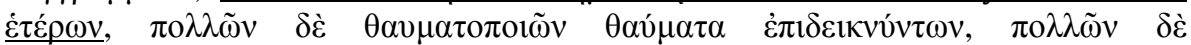

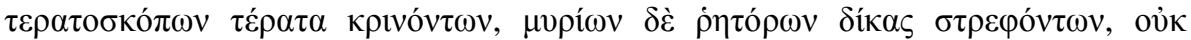

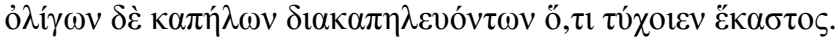

Além do mais, em torno ao templo de Posídão, podiam-se ouvir muitos desses malditos sofistas gritando e se insultando uns aos outros e os seus alunos, de que já falamos, que competiam uns com os outros, e muitos escritores lendo suas obras estúpidas, e muitos poetas cantando seus poemas, enquanto eram louvados por outros. Muitos magos demonstrando suas magias, e muitos praticantes da teratoscopia interpretando prodígios, e milhares de advogados revirando seus processos e, em não menor quantidade, camelôs vendendo todo tipo de coisas.

Percebe-se $\operatorname{logo}$ que essa, novamente, não é uma situação que a maioria dos admiradores de Píndaro estaria disposta a associar com a "águia tebana". Acredito, no entanto, que ela possa ser bastante plausível, afinal, como diz Bernardini, "sabemos de historiadores (basta pensar em Heródoto), de filósofos (de Tales a Górgias, de Platão a Hípias), de rapsodos, de escultores, de pintores e até de um famoso matemático e astrônomo que foram a Olímpia com o objetivo de angariarem um público mais vasto"11. É difícil, afinal de contas, interpretar como pura ficção ${ }^{12}$ passagens como as da Olímpica 10. 97-105, em que a persona loquens diz:

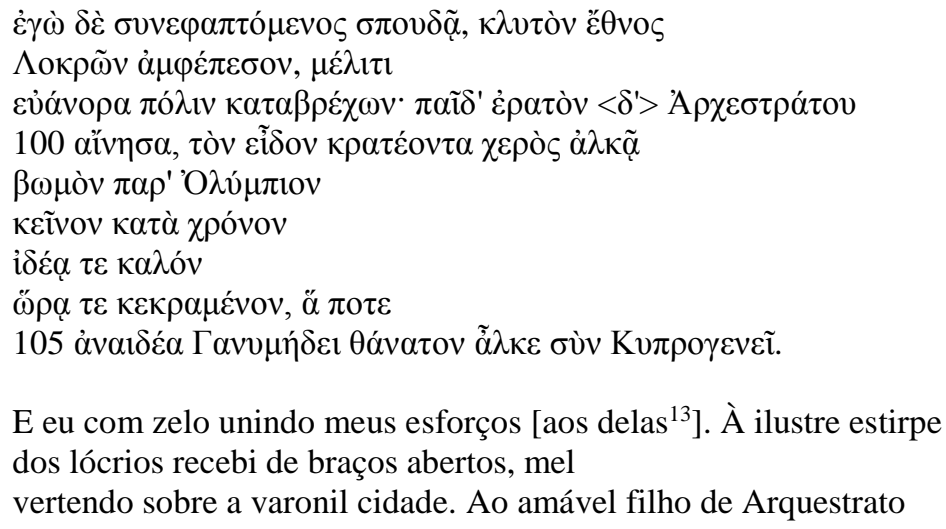

10 8.9-10.

${ }^{11}$ P. BERNARDINI (1997, p. 187).

${ }^{12}$ Sobre essa passagem, até mesmo VerdeniUs (1988a, p. 85) diz que "Pindar simply says that he was present during the contest".

${ }^{13}$ As Musas, mencionadas ao final da antístrofe. 


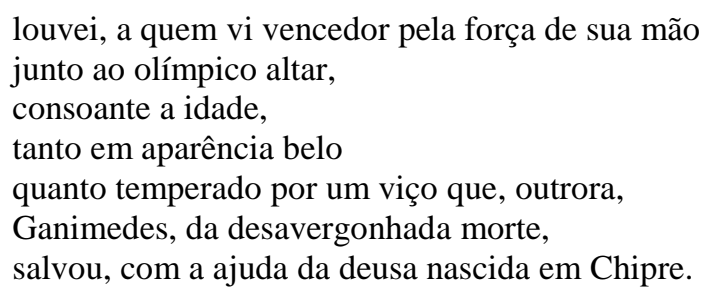

Onde o sujeito de عĩôv não poderia ser outro que não o próprio poeta devido à identificação entre os dois por meio do $v v$. 97, o que seria verdade mesmo se estas palavras pudessem ter sido ditas por um coro, que então funcionaria apenas como um ventríloquo do compositor. É importante contrapor, a essa passagem, aquela da P. 2.54-6:

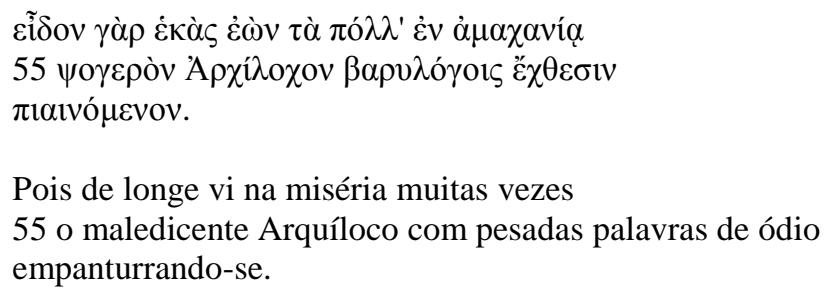

Segundo Gentili et al. ${ }^{14}$, o verbo عĩov é usado aqui numa acepção metafórica, uma vez que Píndaro não poderia ter visto, literalmente, Arquíloco em dificuldade. Essa afirmação seria, então, explicável por meio do uso do advérbio غ́кás, que denotaria uma distância temporal (pertenciam a gerações diferentes) ou a distância que separa os dois gêneros antagônicos do louvor e da invectiva, algo já ressaltado nos vv. 52-3. No entanto, não há porque postular qualquer metáfora nesse caso, já que me parece bastante plausível que o poeta possa assumir, sempre que necessário, a posição de um $\mu$ óv $\tau \iota \varsigma^{15}$, na qual seria capaz de "ver", através dos olhos das Musas, e de um modo que pareceria muito literal a uma audiência

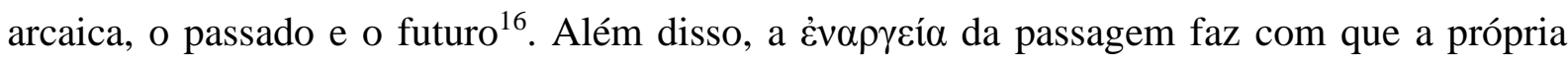
audiência (e mesmo nós, meros leitores!) projete-se para dentro deste quadro e veja com os olhos do poeta a cena que está sendo descrita (ante oculos ponendi), compartilhando, desta feita, de uma experiência transcendental que colapsa as divisões entre passado, presente e

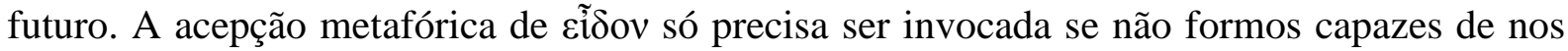
colocar na posição de um público que via no poeta não só um artista mas também um profeta

\footnotetext{
${ }^{14}$ GeNTILI et al. (1995, p. 386).

${ }^{15}$ Sobre isso $c f$. o Capítulo 1.

16 Sobre isso, $c f$. o trabalho de DUCHEMIN (1956) e o artigo mais recente de SuÁrEZ DE LA TORRE
} (1990). 
das Musas ${ }^{17}$ e se formos igualmente incapazes de entender que o texto que agora lemos já se fez performance (e ritual) em algum momento.

Um outro ponto a se ressaltar é que se Píndaro, precisamente em virtude de sua qualidade de poète et prophète, para usar a já célebre alcunha que lhe foi dada por Duchemin $^{18}$, poderia ser capaz de conferir prestígio aos seus laudandi por meio de sua simples presença, o quanto mais não o faria comparecendo em pessoa para executar a ode que lhe fora comissionada! Além do mais, se como vimos, essa mesma ode pode ser conceitualizada como um objeto precioso passível de ser entesourado e, portanto, capaz de ser ofertado em uma troca de presentes entre $\xi$ cívol, seria mais adequado que aquele que a oferta o fizesse pessoalmente.

Kurke $^{19}$, de fato, vê na $\xi \varepsilon v i ́ \alpha$ um dos aspectos mais importantes dos epinícios pindáricos. Por meio dessa instituição social, o louvor trazido pelo poeta é conceitualizado a partir de uma relação de troca de presentes entre hóspede e hospedeiro, no qual a parte do poeta é representada pela canção. Como fica claro pela epígrafe da $N .7$ que abre esse capítulo, a qualidade de ser um $\xi \dot{\varepsilon} v o \varsigma$ de seus laudandi confere a Píndaro a capacidade de

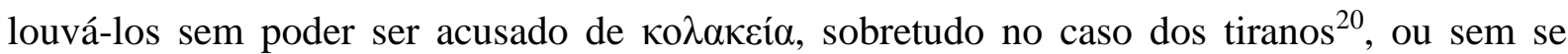

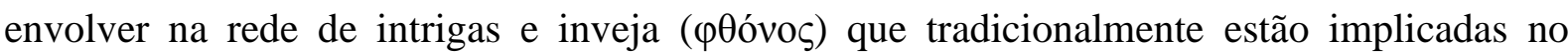
louvor de um indivíduo. Comentando a passagem da Nemeia citada, o escoliasta cita um outro verso (fr. 181 S-M) que provavelmente deve ser atribuído a Píndaro, em que essa noção de

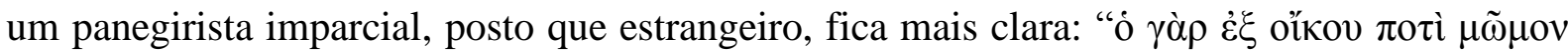

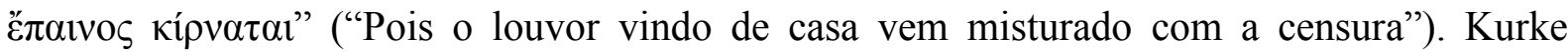
comenta:

O louvor é parte de um sistema de troca, pois a mesma casa que produz sucessos não pode também fabricar a sua própria glorificação. O louvor deve vir de fora, de maneira que a comunidade em volta não seja alienada; ou, colocado de uma maneira positiva, o valor do sucesso é o prestígio que ele tem aos olhos daquela comunidade, de maneira que o louvor deve vir de um grupo maior. ${ }^{21}$

${ }^{17}$ Cf. Peã 6.6, p. 149 .

18 DUCHEMIN (1956).

${ }^{19}$ KURKE (1991).

${ }^{20}$ Essa é uma questão central no diálogo de Xenofonte intitulado Hierão, em que o tirano homônimo de Siracusa, acossado pela infelicidade trazida pelo poder, tenta se aconselhar com o poeta Simônides de Ceos, sobre como recuperar a felicidade que tinha quando era um cidadão privado. Este tema e a sua relação com o epinício é tratado por mim em um artigo que será publicado em breve.

${ }^{21}$ KURKE (1991, p. 135), muito embora a teoria de Kurke não dependa, nem pressuponha a presença física do poeta, "More important than the reality of Pindar's visits in particular cases in the fact that he conceptualizes the relationship of poet and victor in general as one of xenia, of reciprocal hospitality and giftexchange". 
Some-se a isso o fato de que uma das principais prerrogativas do aedo é a sua

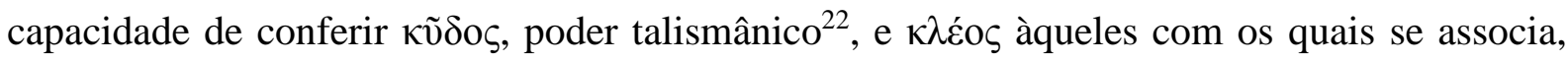
em uma espécie de simbiose cuja contraparte se traduz em algum tipo de recompensa que não

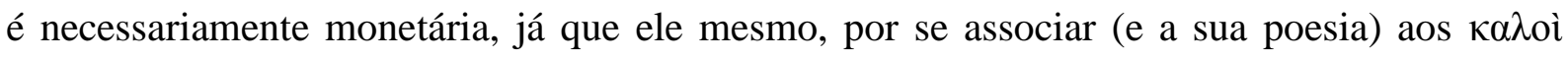
$\kappa a ̉ \gamma \alpha \theta$ oí, cresce ainda mais em prestígio, estabelecendo com esses últimos um jogo de favor e contra-favor ( $\chi \alpha ́ \rho ı \varsigma)$ do qual as duas partes sempre saem ganhando ${ }^{23}$. A expressão dessa capacidade do poeta parece mesmo fazer parte da dicção tradicional da poesia laudatória, cujo exemplo mais antigo é o fr. 282 (CAMPBELL) de Íbico (segunda metade do séc. VI), a $O$. 1.115-17 de Píndaro (entre outras) e a ode de Baquílides, 3.95-8 ${ }^{24}$. Se, no entanto, supormos que a presença do poeta na celebração mesma para a qual o epinício fora composto não era importante, como ficaria a relação, ainda que simbólica, da troca de presentes a que Kurke alude em seu trabalho? Na medida em que não é raro vermos Píndaro colocar-se tanto na

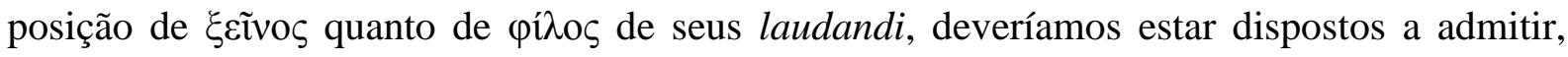
portanto, que ele poderia cumprir (ou mesmo esperava-se que ele cumprisse) esses papeis de uma maneira mais literal e menos simbólica, ou seja, de que ele realmente deveria se fazer presente na maioria das vezes em que uma ode sua era executada pela primeira vez, sobretudo no caso de celebrações patrocinadas por tiranos, sempre tão sensíveis à menor ofensa, e que, ao contrário, a sua ausência fosse a situação menos prototípica.

A partir desse cenário, ao menos, não soa surpreendente que tiranos e ricos cidadãos capazes de competir nos grandes jogos buscassem o prestígio que a companhia dos poetas mais famosos poderia lhes conferir e, segundo $\mathrm{Nagy}^{25}$, é mais provável que um poeta adquirisse sua fama justamente ao ser comissionado por um tirano influente, como aqueles das famílias importantes da Tessália e da Sicília, do que, primeiro, construísse uma carreira entre círculos aristocráticos de cidadãos privados. Sabemos, por exemplo, que Íbico foi atraído desde Régio, sua cidade natal, por Polícrates de Samos (r. 533-22), a cuja corte foi ter também o poeta Anacreonte ${ }^{26}$. E esses não são exemplos isolados, mas se inserem, na verdade, dentro da realidade que deve ter sido a vida dos poetas da Idade do Ferro $^{27}$, na qual a

${ }^{22}$ Sobre isso, KURKE (1998).

${ }^{23}$ GENTILI (1990, p. 155 et seq.). KURKE (1991, p. 155), "Charis appears as a central concept of gift exchange ideology: it organizes the cosmos within the epinikia in accordance with an aristocratic world view. Within the syntax of aristocratic exchange, charis acts as social glue, and its workings can be charted along what we may call syntagmatic and paradigmatic axes".

${ }^{24} \mathrm{Eu}$ comento e dou uma tradução dessas passagens no Capítulo 6, p. 249 et seq.

${ }^{25}$ NAGY (1990, p. 382 et seq.), mas $c f$. especialmente suas conclusões a partir da p. 410.

${ }^{26}$ Ael. V. H. 9.4; CAMPBELL, vol.2, p. 26 (test. 4), que descreve Polícrates como um patrono das artes,

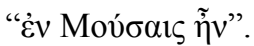

27 Ao contrário, por exemplo, dos aedos da Idade do Bronze, como retratados pela épica homérica, quando na vigência dos grandes complexos palacianos, deveria ser muito mais vantajoso, se não uma absoluta 
necessidade de correr o mundo em busca de patronos deveria ser a forma mais eficiente de enriquecer e ter a sua fama espalhada e promovida pela maior extensão geográfica possível ${ }^{28}$, estabelecendo assim laços de amizade ( $\varphi$ ı ía) e hospitalidade ( $\xi \varepsilon v i ́ \alpha)$ com um número cada vez maior de clientes.

A esse respeito, a história mais paradigmática, ainda que fantástica em seus detalhes, é aquela que Heródoto (1.23-4) nos conta sobre o semilegendário citaredo lésbio Árião de

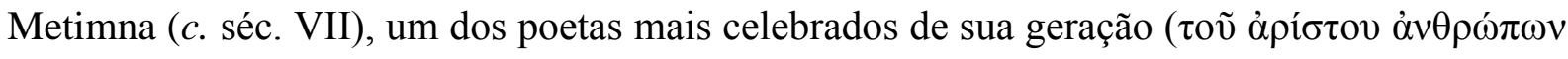
àoıঠoṽ, 4.16-7). Ele teria sido comissionado pelo tirano de Corinto, Periandro (r. 627-585), em cuja corte passara um longo tempo, tendo, em seguida, empreendido uma longa viagem

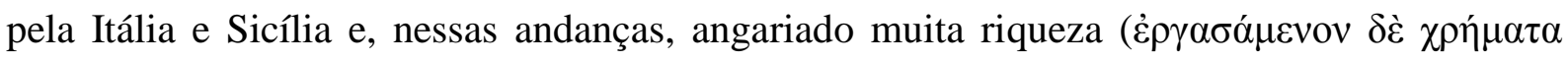

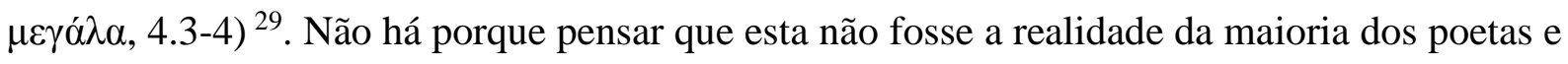
o discurso de Heródoto, que toma a forma de um aĩvos, revela as expectativas que sua audiência deveria ter com relação à figura de um grande músico, não muito diferente, aliás, das grandes estrelas do "showbiz" moderno, erudito ou popular.

Devemos lembrar também do cosmopolitismo de Esparta no período anterior à segunda metade do séc. VII, onde um ambiente de mecenato propício a aedos em busca de fama e riqueza parece ter atraído muitos, vindos de diversos lugares da Grécia para o Peloponeso. Uma evidência indireta disso é o testemunho de Plutarco, segundo o qual

A primeira escola de música, então, foi fundada por Terpandro em Esparta. Quanto à segunda escola, Taletas de Gortina, Xenódamo de Citera, Xenócrito de Locres, Polimnesto de Cólofon e Sácadas de Argos, sobretudo, têm reputação de terem sido os chefes. ${ }^{30}$

Para aí veio também Álcmã, um lídio de Sárdis destinado a se tornar uma espécie de poeta laureado entre os espartanos.

Nenhum tirano, no entanto, parece ter passado à história como maior amante das artes e da música das grandes celebridades do que o filho de Pisístrato, Hiparco (r. 528/7-514). Segundo somos informados por Platão no diálogo de mesmo nome ${ }^{31}$, ele teria despachado

necessidade para um poeta, fixar residência na corte de um rei, como Fêmio e como Demódoco, por exemplo. Cf. HUNTER e RUTHERFORD (2011, p. 10 et seq.); GENTILI (1990, pp. 155-6).

${ }^{28}$ Sobre o tema dos poeti vaganti, $c f$. o espetacular volume editado por HUNTER e RUTHERFORD (2011), a que toda a minha argumentação nesta seção deve muito.

${ }^{29}$ Não sabemos ao certo que forma o $\mu \iota \sigma \theta$ ó (lat. merces), aparentemente devido aos poetas, tomava forma, nem como se davam as relações financeiras entre laudator e laudandus. $\chi \rho \tilde{\eta} \mu \alpha$, nesse exemplo, não precisa, e provavelmente não significava, "dinheiro", como às vezes se vê traduzido, mas posses e presentes, i.e., "riqueza" em geral.

${ }^{30}$ De Musica, 1134b-c, trad. de Rocha JR. (2007, p. 89); HUNTER e RUTHERFORD (2011, p. 11)

${ }^{31} 228 \mathrm{~b} 5$ et seq. 
uma penteconter para buscar Anacreonte de volta à Atenas ${ }^{32}$ e teria convencido, por enorme

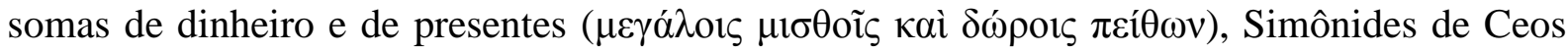
(c. 556-477-6) a fixar residência na cidade, de modo a tê-lo sempre ao seu lado (à

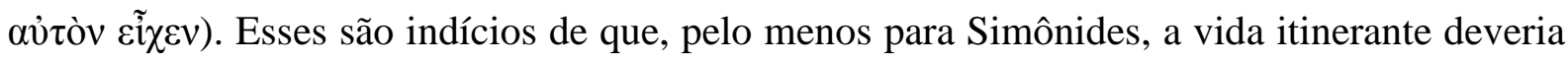
ser uma realidade, já que ele, provavelmente ainda aquém dos trinta anos, deveria ser uma jovem estrela em ascensão para quem a estrada poderia ser mais vantajosa que a vida na corte.

Após a morte de Hiparco, somos informados que Simônides deve ter continuado a viajar frequentemente. Primeiro para o norte da Grécia onde passou algum tempo entre as famílias reais dos Alevadas e Escopadas, para os quais compôs vários epinícios. Tendo retornado para Atenas após as Guerras Médicas, compôs, no ápice de seu estrelato, epitáfios e elegias celebrando tantos os heróis mortos quanto as vitórias gregas durante as batalhas daquela guerra. Passou ainda algum tempo na corte de Hierão, em Siracusa, para quem provavelmente deve ter composto epinícios e outras canções, tendo falecido provavelmente em Agrigento $c .468 / 7^{33}$. É possível que Hiparco tenha atraído também outros cantores, a crerse no testemunho de Aristóteles ${ }^{34}$. Entre esses, certamente devemos contar o alegado professor de música de Píndaro, Lasso de Hermione ${ }^{35}$.

Mesmo para um período bem tardio, quando supostamente uma literacia mais desenvolvida deveria ter alterado a dinâmica das comunicações, cedendo maior espaço a modos de comunicação escrita (assim promovendo aquela imobilidade proposta para Píndaro já no período arcaico), o que vemos é que as andanças dos poetas não parecem ter diminuído, algo que reforça a ideia de uma realidade inerente à profissão e resiliente à passagem do tempo e à introdução de novas tecnologias. Há indícios de que uma grande parte da renda desses poetas itinerantes poderia advir das honras que lhe eram conferidas durante suas visitas

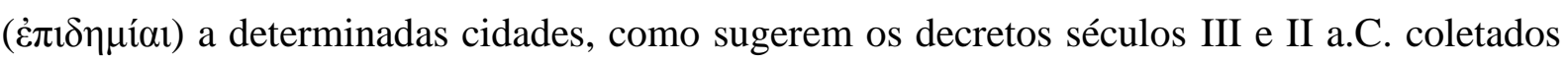
por Guarducci ${ }^{36}$ em sua obra seminal, na qual ela lista

cerca de vinte e cinco 'poeti vaganti' que foram honrados por sua 'presença' (epidèmia) e comportamento (anastrophē) por comunidades estrangeiras nas quais eles se apresentaram e as quais, em muitos, se não em todos os casos, eles

\footnotetext{
32 É possível que Anacreonte, partindo de Samos após a morte de Polícrates, tivesse passado algum tempo em Atenas antes de retornar a Abdera, que ajudara a fundar, $c f$. CAMPBELL, vol. 2, fr. 412, 495, 500.

${ }^{33}$ MolyneuX (1992, p. 236), uma data alternativa seria $c$. 466. Nesse caso, Simônides teria morrido após Hierão.

${ }^{34}$ Arist. Ath. 18.

35 CAMPBell, vol. 3, p. 298-9, test. 3.

${ }^{36}$ Guarducci, M. (1929) Poeti vaganti e conferenzieri dell'età ellenistica: ricerche di epigrafia greca nel campo della letteratura e del costume (Atti della R. Accademia nazionale de Lincei. Classe di scienze morali, storiche e filologiche, serie 6: vol. 2,9), Roma, p. 629-65.
} 
celebraram em seus poemas; os privilégios mais comuns conferidos a eles são a proxenia, isenção de impostos e concessões de terra. ${ }^{37}$

Mais importante ainda: é provável que, ao invés de postularmos um certo anacronismo na atribuição dessa realidade ao período arcaico, precisemos, na verdade, rever nossa concepção acerca dos poetas helenísticos, normalmente descritos como eruditos fixados em cortes reais e grandes bibliotecas em Alexandria, Pérgamo e Antióquia.

Posidipo de Pela (c. 310-240), por exemplo, parece ter viajado por diversas cidades e é certo que recebeu honras em Termi (na Calcídia, ao norte da Grécia) e, provavelmente, também em Delfos. Teócrito ( $f$. III séc.), por seu turno, foi, muito provavelmente, um "poeta errante". Podemos deduzir, a partir de sua produção poética, que sua carreira estendeu-se não apenas pela Sicília, onde nasceu, mas por todo o oeste da Grécia, Alexandria e o Egeu oriental (é provável que ele tenha vivido na ilha de Cós durante algum tempo). Mesmo Calímaco, que teoricamente teria feito uma única viagem em sua vida, de Cirene para Alexandria, não parece ter sido tão imóvel como quer dar a parecer e há novas leituras sendo feitas de seus poemas que podem indicar um alto grau de ficcionalismo e convenções literárias que, talvez, não devessem ser tomadas por seu valor de face. ${ }^{38}$

Todos esses fatos, então, podem ser indícios de que a presença física do poeta parecia ser requerida por aquele que comissionava uma ode, sobretudo quando o poeta se tratava de uma estrela do calibre de Simônides e o laudandus um rei ou tirano poderoso ${ }^{39}$. A esse respeito, o testemunho de Cícero $^{40}$, ainda que tardio, é importante, se não porque pode nos informar acerca de uma ocasião de performance típica do período arcaico ${ }^{41}$, então ao menos porque nos revela uma expectativa contemporânea do autor sobre como elas deveriam ter se dado (ou se dar). O relato diz respeito ao desabamento da mansão dos Escopadas em Cránão (atual Cranonas), na Tessália:

Dicunt enim, cum cenaret Crannone in Thessalia Simonides apud Scopam fortunatum hominem et nobilem cecinissetque id carmen, quod in eum scripsisset, in quo multa ornandi causa poetarum more in Castorem scripta et Pollucem fuissent, nimis illum sordide Simonidi dixisse se dimidium eius ei, quod pactus esset, pro illo carmine daturum; reliquum a suis Tyndaridis, quos aeque laudasset, peteret, si ei videretur.

\footnotetext{
${ }^{37}$ HUNTER E RUTHERFORD (2011, p. 3).

${ }^{38} \mathrm{O}$ argumento aqui esboçado é discutido em detalhes por HUNTER e RUTHERFORD (2011, p. 5), $c f$. também a bibliografia ad hoc.

${ }^{39}$ Embora não haja motivos para pensar que a situação pudesse ser normalmente diferente para um cidadão privado, sobretudo quando esses normalmente provinham de famílias riquíssimas, cujas festas "particulares" dificilmente deixavam de ser também um acontecimento público.

${ }^{40}$ De Oratore, 2.352 (= CAMPBELL vol. 3, fr. 510).

${ }^{41}$ Tudo depende das fontes de Cícero, as quais, infelizmente, não conhecemos.
} 
Dizem que Simônides, quando ceava na casa de Escopas, um homem afortunado e nobre, cantara aquela canção que escrevera para o mesmo, na qual, a título de ornato, como é o costume dos poetas, muitas coisas tinham sido escritas para Castor e Pólux; aquele, então, de uma maneira assaz grosseira, dissera-lhe que lhe daria a metade devida pela canção, como fora contratado; quanto ao resto, que ele pedisse, se assim achasse por bem, aos seus Tindaridas, aos quais louvara de igual maneira.

A mesma história, com alguns detalhes adicionais, recorre em Quintiliano ${ }^{42}$, que, embora se revele bastante cético com relação aos acontecimentos fabulosos narrados por Cícero (como o salvamento milagroso de Simônides pela intervenção dos Tindaridas), parece concordar com o mesmo cenário, ocasião e modo de performance do epinício: um grande simpósio para celebrar a vitória do boxeador (grandis convivium in honorem eiusdem uictoriae), na qual o poeta em pessoa teria comparecido (adhibitus ei cenae Simonides) a fim de cantar a canção por uma determinada quantia pré-estabelecida (mercede pacta).

Uma passagem que sugere um mesmo tipo de cenário é aquele da $N$. 1. 18-24:

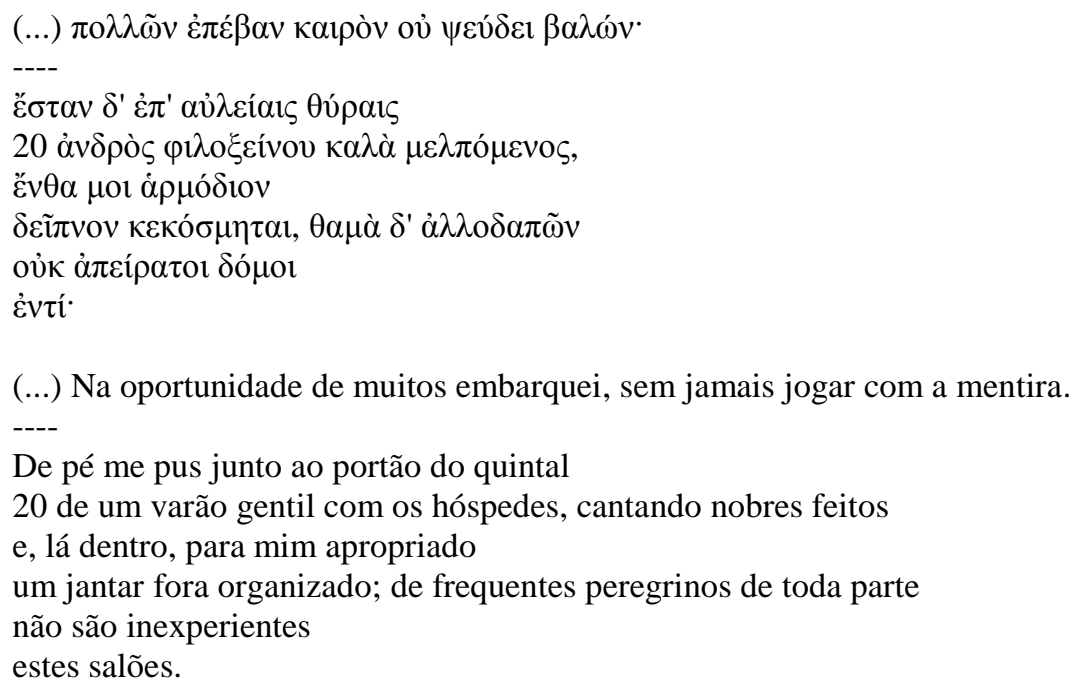

Pouco importa se a persona loquens, um erlebende ich, nesse caso, está relatando uma ocasião real que se refira à própria pessoa do poeta. O discurso é um aĩvo $\mathrm{e}$, portanto, expõe de maneira idealizada uma performance idealizada. O que este trecho nos diz, contudo, é que, mesmo que não possamos (talvez até mesmo não devamos) tomar esses versos em particular como se referindo a um acontecimento pretérito na vida do poeta, tanto ele quanto a sua audiência deveriam ter como certo e líquido que a situação descrita não apenas é verossímil quanto costumeira $(\theta \alpha \mu \alpha ́, 21$, outra vez, como na $O$. 1). Poderíamos pensar, é claro, em uma ficção criada pelo coro, que falaria como um ventríloquo do poeta. Quando comparamos, no entanto, esta passagem com os cenários descritos tanto por Cícero quanto por Quintiliano,

${ }^{42}$ Quint. Inst. 11.2.11 (= CAMPBELL vol. 3, fr. 510, p. 376-7) 
somos obrigados a repensar a questão com mais cuidado. É preciso que nos perguntemos, ainda, se os "peregrinos de toda parte", com os quais a casa de Crômio não está desacostumada, não poderiam ser, justamente, poeti vaganti vindos a celebrar as suas muitas vitórias. Isto, ao menos, seria coerente com a imagem desta estrofe, na qual a persona loquens se vê como um cantor que é recebido pela hospitalidade impecável de Crômio.

O que nos leva a uma outra possibilidade, a saber, a de que a imagem de Píndaro como um escritor que, assaz ocupado com suas encomendas, deva ter permanecido em Tebas, de onde enviava sua obra aos seus mais diversos clientes, parece ser motivada por uma série de pressuposições que refletem apenas, e em última análise, um entendimento da práxis poética derivada, principalmente, da leitura de Píndaro feita em Alexandria, que tende a dar uma grande centralidade ao texto e à escrita. Isso, ademais, não é surpreendente, se pensarmos que os poetas dessa época, havendo já efetuado uma transição talvez completa para uma literacia, compunham a partir de um modelo cognitivo determinado pela escrita e que, portanto, naturalmente deveriam projetar essa experiência para o período arcaico. Uma grande parte da crítica pindárica moderna é herdeira direta dessa leitura alexandrina, que, aliás, se conforma perfeitamente com (algumas) expectativas e preconceitos atuais acerca de como a poesia de alta qualidade deva ser composta ${ }^{43}$ e que fazem dessa última, a priori, uma atividade indissociavelmente dependente da escrita não apenas para ser registrada (i.e., literacia midiática) mas, mais importante, para ser concebida. Assim, se partirmos do pressuposto de que Píndaro era um "escritor” fluente, como sói acontecer, é mais fácil que o imaginemos em um trabalho solitário de composição poética, debruçado sobre rolos de papiro, com cálamo e tinta à mão, contando as sílabas e escandindo os versos de seus epinícios ${ }^{44}$. Uma vez pronta, bastaria despachar a ode ou poema a seu destinatário. Não há nenhuma evidência contundente, no entanto, que aponte para que esse cenário seja o mais provável.

Como já foi apontado por Herington ${ }^{45}$, há, de fato, algumas menções nos epinícios ${ }^{46}$ que poderiam ser interpretadas como se referindo a um envio da canção por meio de algum mensageiro. Em todas essas passagens, figura proeminentemente o uso do verbo $\pi \varepsilon ́ \mu \pi \omega$, "mandar", "enviar", e, ainda que em nenhuma delas haja qualquer menção explícita à mídia de suporte empregada para esse envio, a maior parte das análises pressupõe, sem maiores

\footnotetext{
${ }^{43}$ Acerca dessa discussão, $c f$. o Capítulo 1.

${ }^{4}$ Uma suposição que terá grande implicação no entendimento e na interpretação da colometria pindárica.

${ }^{45}$ HeRington (1985, p. 189 et seq.).

${ }^{46}$ O.6, a I.2, a P.2, a P.3, a N.3, o fr. 124a.b. Ainda em Baquílides, Ep. 5.10-14, fr. 20b, fr. 20c.
} 
considerações, a escrita. No entanto, a meu ver, essa hipótese apega-se a uma interpretação tanto assaz literal quanto, ademais, descontextualizada do verbo $\pi \varepsilon ́ \mu \pi \omega^{47}$.

$\mathrm{Na}$ verdade, tais passagens muitas vezes apenas selecionam frames do modelo cognitivo idealizado para CANÇão na época arcaica. Essa seleção, que ademais é motivada pela economia interna de cada epinício, ao conceitualizar a canção como uma EPÍsTOLA, uma EMBARCAÇÃO, uma MERCADORIA, Uma BEBIDA etc., pode disparar o uso de verbos associados aos domínios semânticos dessas atividades, como $\pi \varepsilon ́ \mu \pi \omega$, sem que isso precise necessariamente implicar de maneira alguma que Píndaro esteja realmente descrevendo o envio real da canção. Por outro lado, interpretações literais do verbo tendem a tomar as informações contidas na ode pelo seu valor de dicionário, ignorando a rica imagética típica da oratura arcaica, bem como a sua tendência natural ao uso de linguagem figurada.

Dois exemplos importantes são a Olímpica 7.1-10 e a N. 3.76-80, onde o verbo pode ser entendido a partir do frame BRINDE. Na primeira, cujo texto já comentamos em certa medida $^{48}$, a metáfora se dá por meio do símile entre a riquíssima taça ofertada ao noivo, repleta de vinho, e a canção que é ofertada ao vencedor, repleta de "mel”, oriundo da mente da poeta. Na segunda, a relação é mais gráfica e mais direta, como podemos ver pela seguinte passagem:

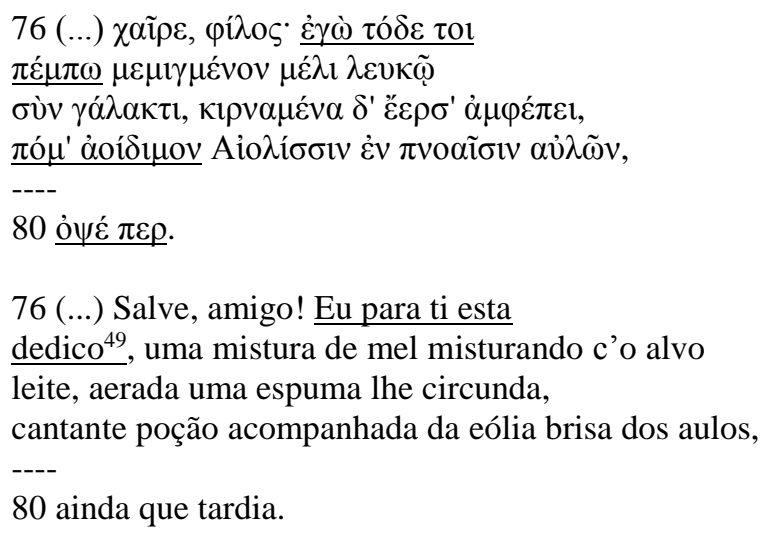

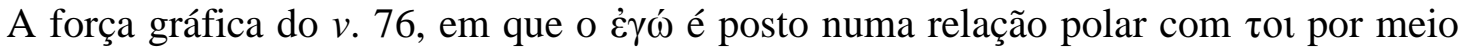
do demonstrativo $\tau o ́ \delta \varepsilon$, pode nos fazer pensar imediatamente no esquema imagético de um BRINDE, com a bebida ( $\tau$ ó $\delta \varepsilon)$ colocada literalmente entre emissor ( $\dot{\varepsilon} \gamma \omega ́)$ e destinatário ( $\tau 01)$. Dessa forma, a unidade [EU ESTA A TI], marcada fortemente pelo fim do período, seria o

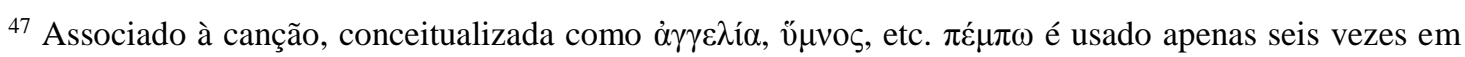
todo o corpus: $O .7 .8,9.25 ;$ P. $2.68 ; N .3 .77 ;$ I. 5.63 e no fr. de encômio $124 \mathrm{a}-\mathrm{b} .2$, onde a canção é conceitualizada como uma SOBREMESA ( $\mu \varepsilon \tau \alpha \delta$ óp $\pi \mathrm{l}$ ) ), provavelmente em virtude de ser cantada em um contexto simpótico.

${ }^{48}$ Para o texto, $c f$. p. 58.

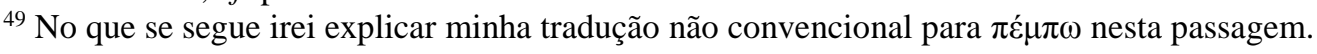


equivalente a um gesto retórico capaz de evocar um determinado frame na audiência, o que ativaria o sentido de $\pi \dot{\varepsilon} \mu \pi \omega$, em acavalamento ademais ${ }^{50}$, como "brindar", ou "erguer um brinde”, ao invés da acepção mais comumente vista nas traduções e comentários, isto é, "enviar"

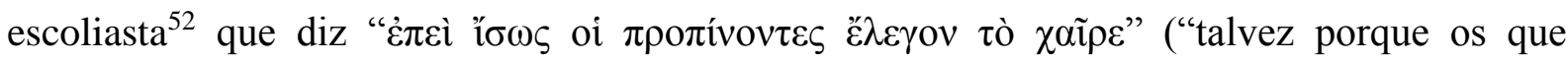
brindavam costumavam dizer o 'Salve"'), citando, a meu ver sem muita relevância para essa passagem, a cena do banquete na tenda de Aquiles (Il. 9.225 et seq.). Se quisermos pensar na ocasião de performance da ode como tendo se dado em um simpósio, como me parece ser o caso, a metáfora faria ainda mais sentido.

Na P. 2.67-8, por outro lado, a canção é, logo no início, conceitualizada como uma

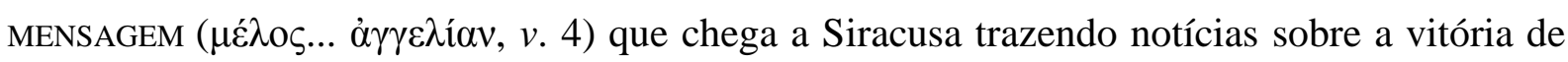
Hierão em Olímpia. É essa seleção do frame inicial que irá motivar as metáforas subsequentes

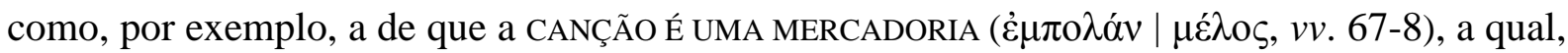
se lida no contexto do que lhe precede, isto é, associada à metáfora de que CANÇÃO É UMA

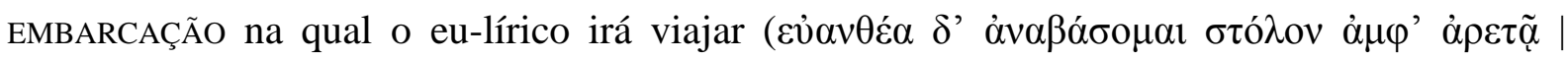
$\kappa \varepsilon \lambda \alpha \delta \varepsilon \dot{\omega} \omega v$, "Embarcarei em um navio coroado $^{53}$ | a fim de cantar sobre tua virtude", vv. 62$3^{54}$ ), parece criar uma ficção sobre o envio do epinício, de um lado, e a sua viagem de outro, dessa forma preservando a sequência imagética iniciada logo no início, que descreve a chegada da ode em Siracusa.

Além disso, a canção pode ser conceitualizada, muitas vezes, como uma MENSAGEM porque ela serve para comunicar a vitória obtida nos jogos à comunidade do laudandus, e, dessa forma, poderia ser entendida como uma versão estendida da $\alpha \dot{v} \alpha \kappa \eta ́ \rho v \xi ı$ do vencedor, que se dava momentos depois da conquista das vitória e na qual se mencionava o seu nome, filiação e a cidade natal ${ }^{55}$. É possível ver esta associação com a canção na $O$. 8. 81-4 em que a

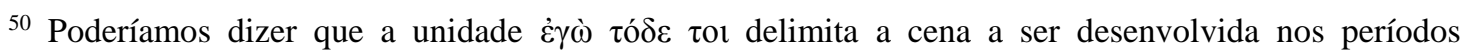
seguintes. Sobre isso, $c f$. BAKKER (1997, p. 87 et seq.).

${ }^{51}$ Algo semelhante acontece em português onde frases do tipo, "Este [brinde] vai para Fulano" são comuns.

${ }^{52} \Sigma N .3 .76,132 \mathrm{a}$ (DRACHMANN, vol. 3, p. 60).

${ }^{53}$ Isto é, coroado em sua popa. Um navio festivo.

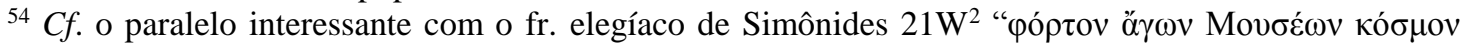
io $\tau \varepsilon \varphi \alpha ́ v \omega v "$, se pudermos confiar na suplementação de M. L. WEST (1993). Para uma discussão desse fragmento, $c f$. MACE (2001), YATROMANOLAKIS (2001) e BROSE (2008) .

${ }^{55}$ Para a cerimônia, $c f$. p. 112. Por si mesmas, três divisões importantes do epinício. Para a menção a

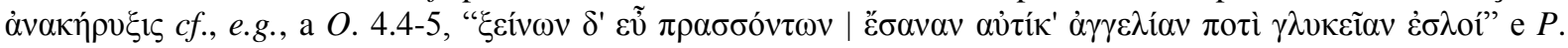

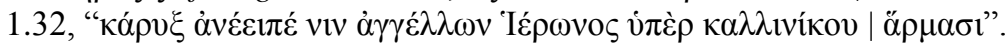


deusa Mensagem, filha de Hermes, deve portar a notícia da vitória de Alcimédão (que é a própria canção) ao seu pai ${ }^{56}$ :

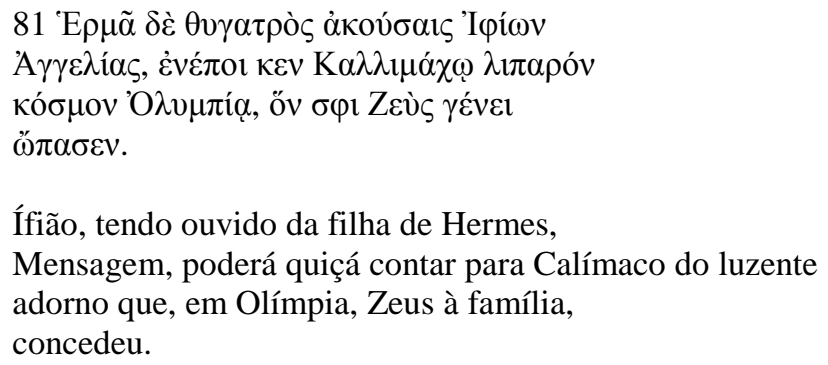

Muitas vezes, o processo de enviar a canção é descrito como simultâneo ao processo de executá-la o que aponta pra uma outra acepção de $\pi \varepsilon ́ \mu \pi \omega$, a saber, a de "popularizar", “enviar para todo lugar", como, por exemplo, nesta passagem da $O .9 .21-8$ :

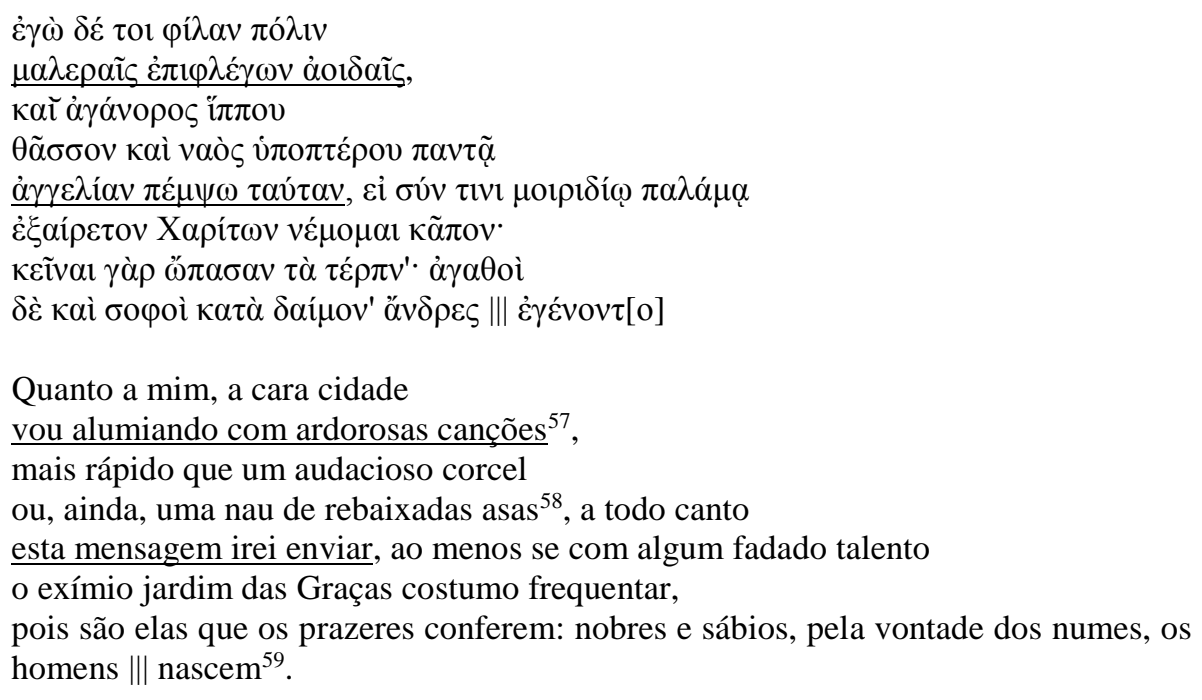

\section{Uma noção expressa claramente no início da N. 5.1-5, em que Píndaro diz que}

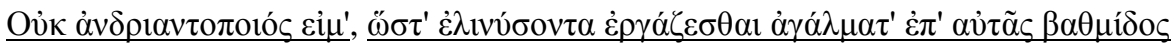

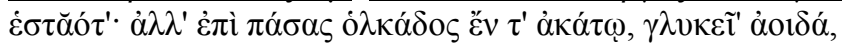

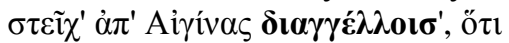

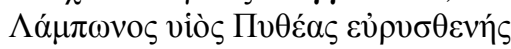

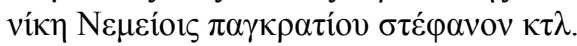

\footnotetext{
${ }^{56} C f$. uma imagética semelhante na $O \cdot 14.20-4$, onde é Eco que deve portar o relato ao falecido pai de Asópico, Cleodamos.

57 A imagem pode tanto fazer referência ao fogo, propriamente dito, isto é, o poeta irá "incendiar" a cidade ao verter suas canções sobre ela, quanto pode ser interpretada como uma metáfora que vê na canção um farol que ilumina a cidade ao mesmo tempo em que anuncia sua glória ao resto do mundo. Acho a segunda hipótese mais provável em vista dos versos seguintes.

${ }^{58}$ Alusão aos remos ou às velas.

${ }^{59} \mathrm{Ou}$, "tornam-se". Optei por "nascer" em virtude do paralelo com a $P$. 1.41-42, onde o verbo " que tem este último sentido, é usado: "pois dos deuses todo tipo de recursos às excelências mortais vêm | e os sábios, e os de mão forte, e os eloquentes nascem (๕̌ $\varphi v v) "$.
} 
Não sou escultor para inertes construir imagens que sobre suas bases restem. Ao contrário, sobre todo cargueiro, dentro de um navio, ó doce canção, parte desde Egina e anuncia que o filho de Lampó, Piteas poderoso, venceu, nas Neméias, do pancrácio uma coroa.

No caso da $P .3$, parece realmente que Píndaro não pode comparecer à execução do epinício e que, portanto, deveria ter enviado a canção por meio de outrem, daí seu tom epistolar. Aliás, desde pelo menos Wilamowitz duvida-se que a ode nada mais seja do que uma epístola poética ${ }^{60}$, embora recentemente essa teoria tenha caído em descrédito. Numa inspeção mais detalhada, no entanto, percebe-se que o tom hipotético com o qual a ode inicia - um desejo impossível (quiçá impertinente) de que os mortos pudessem voltar à vida -, permeia toda uma série de frames irreais que culminam com a famosa passagem em que, argumenta-se, Píndaro lamenta não ter podido vir consolar seu velho amigo:

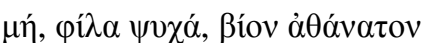

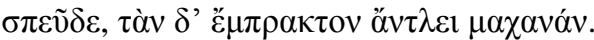

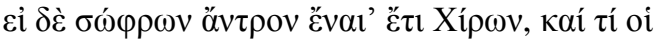

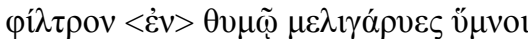

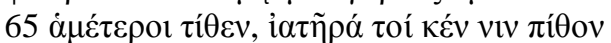

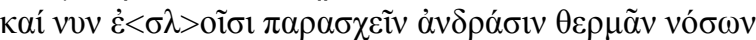

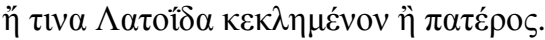

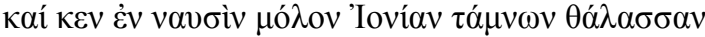

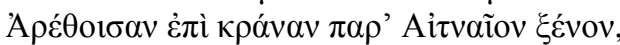

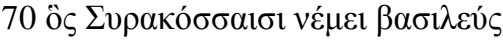

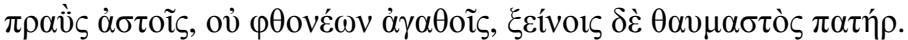

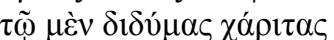

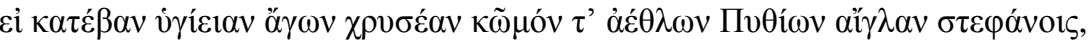

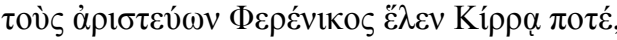

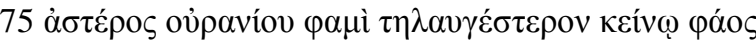

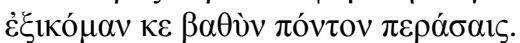 \\ Uma vida imortal, ó Minh 'alma \\ não persigas, mas todo recurso exaure do que te for possível. \\ Se o sábio Quírão ainda habitasse sua cave e se algum \\ tipo de filtro em seu peito melífonos nossos hinos \\ pudessem incutir, um remédio, bem o sabes, tê-lo-ia convencido
}

${ }^{60}$ WILAMOWITZ-MOELLENDORFF (1966, p. 280), "Es ist wirklich nichts als eine poetische Brief; auch über den musikalischen Vortrag fällt kein Wort. Unter die Epinikien ist das Gedicht vielleicht gestellt, weil es V. 74 die alten Siege des Hengstes Pherenikos erwähnt, was freilich ein arger Missgriff sein würde. Sonst hat man nur das Verwandte zusammengestellt, wofür wir dankbar sind", grifo meu. Cf. tambémWILAMOWITZMOELLENDORFF (1900, p. 48) onde o autor ainda pensava em uma possível performance da ode em Siracusa "Freilich, als er dem Hieron poetische Episteln über das Meer schickte und deren Aufführung in Syrakus erwartete, muss er sich nicht nur der einzigen panhellenischen Schrift bedient, sondern auch die Noten für den Gesang so beigeschrieben haben, dass sie die syrakusischen Musiker lesen konnten" , grifo meu. Assim também BURTON (1962, p. 78), "This poem was not written, so far as can be ascertained, for the occasion of any particularly victory, and is therefore not, in the strict sense of the term, an Epinician Ode. (...) The most natural explanation of its origin is that Pindar had received news of Hieron's illness and was moved to write a personal letter of condolence to the king whose hospitality he had recently enjoyed", grifo meu. Cf. ainda BowRA (1964, p. 408). Para uma posição crítica a esse respeito, YounG (1983). 
mesmo agora, a homens retos dar, de febris enfermidades,

a alguém chamado filho de Leto ou do Pai.

E assim teria vindo num navio, o mar singrando,

à fonte de Aretusa, para junto do etnaio amigo,

ele, o rei que governa Siracusa,

gentil aos cidadãos, sem rancor dos nobres e um pai admirável aos estrangeiros.

Para ele uma graça dupla

teria desembarcado, trazendo aúrea saúde e uma comemoração dos jogos píticos,

[lustre a mais aos lauréis

que outrora Ferênico ganhou vencendo em Quira.

Eu garanto que, como o mais longividente astro celeste, uma luz àquele

homem eu teria vindo e singrado o fundo ponto.

Não se trata, como fica claro pelo contexto da passagem, que Píndaro não tenha vindo, pois ele não diz isso em momento algum. É preciso entender a ode dentro da tensão proposital que o poeta magnificamente estabelece entre proposições reais e irreais, entre o que é possível e o que é impossível. Dessa forma, fica claro que o que ele diz é que sua vinda poderia ter se dado sob outras condições se Quíron ainda estivesse vivo, pois então ele poderia tê-lo convencido (ou Apolo), pelo poder de sua música, a lhe dar um remédio capaz de curar a enfermidade de Hierão e, consequentemente, ele poderia ter desembarcado trazendo-lhe um remédio que o restituísse à saúde e uma delegação em festa após outra vitória nos jogos píticos. Nada disso, no entanto, é possível e é preciso conformar-se. Faz-se então o

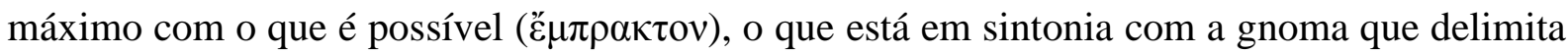
a interpretação dessa passagem. A Píndaro, como mortal, só resta rezar pela recuperação do

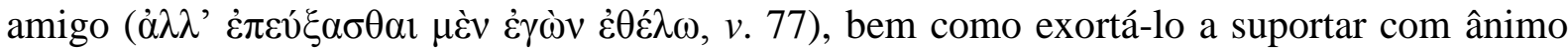
altaneiro as vicissitudes do presente e, para isso, sim, ele poderia ter ido até Hierão ${ }^{61}$.

É possível que a $P .3$ não tenha, de fato, sido sequer um epinício e que, no final das contas Píndaro possa, realmente, tê-la enviado como uma epístola. Não há como provar um ou outro cenário. No entanto, quando a comparamos com a passagem da $O .7 .13-19$ abaixo, não há como não ter dúvidas se, afinal de contas, também aqui devemos estar lidando com uma ficção e, se de fato estivermos, que consequências esta ficção poderia ter para uma audiência confrontada com declarações tão contundentes de uma persona loquens que parece se identificar com o próprio poeta:

${ }^{61}$ Como salienta muito bem Young (1968, pp. 45-6) a respeito dessa passagem, "The entire passage is designed to create a specific mood and to serve as vividly contrasting foil for the antistrophe, where, as in the

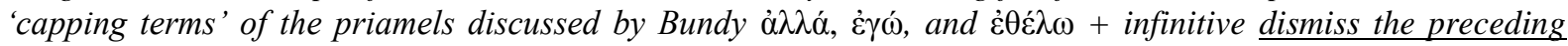
ideas while marking the new subject as climatic", grifo meu. Se pudermos confiar na datação desta ode (c. 474), Píndaro estaria ainda aquém de seus 50 anos, isto é, no auge da carreira. A idade, ao menos neste caso, dificilmente poderia ter sido um empecilho. 


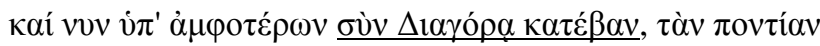

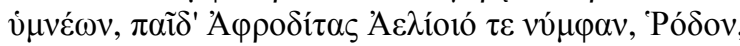

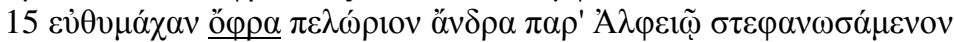

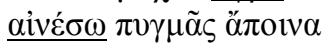

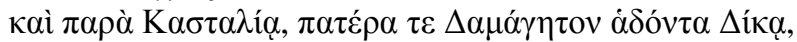

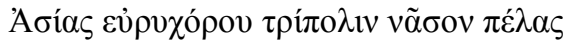

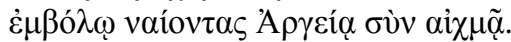

E eis que agora, na companhia de ambos ${ }^{62}$, com Diágoras desembarquei, à marinha filha de Afrodite hineando e, de Hélios, a noiva, Rodes, 15 a fim de um destemido lutador e ingente varão, que junto do Alfeu se fez coroar, louvar em recompensa por seu boxe,

e, junto à fonte da Castália, e também a seu pai, Damageto, propiciado pela Justiça: da vasta Ásia junto ao promontório, trípole ilha habitam na companhia de argivos lanceiros.

Se pudermos admitir, ao menos para esta ode, que Píndaro, de fato, poderia ter viajado até Rodes, esta sim uma ilha quase sem importância na periferia do mundo grego, para a première do epinício, provavelmente partindo de Olímpia junto com o vencedor, onde poderia

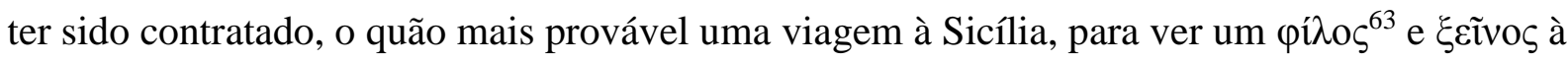
beira da morte, não o seria?

Estas perguntas são difíceis de se responder, talvez até mesmo impossíveis, no entanto, não deveríamos nunca nos deixar de perguntá-las.

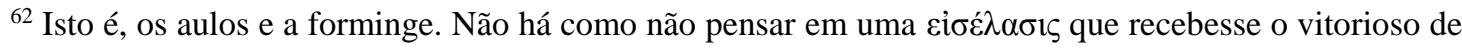

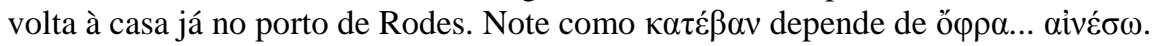

${ }^{63} \mathrm{Na}$ perfeita interpretação de NAGY (1990) dessa palavra como "near and dear". 


\title{
CAPÍTUlO 5
}

\section{O MODO DA PERFORMANCE I: A CONTROVÉRSIA}

\begin{abstract}
Diversity of opinion about a work of art shows that the work is new, complex, and vital.

When critics disagree the artist is in accord with himself.
\end{abstract}

O. Wilde, Prefácio ao The Picture of Dorian Gray.

FALAR de como os epinícios pindáricos poderiam ser executados em sua primeira performance é, inevitavelmente, ter que tocar, ainda que resumidamente, na muito debatida e já célebre celeuma entre "coralistas", que postulam a execução das canções por meio de um coro, e "solistas", que propõem uma execução solo pelo poeta ou, segundo alguns, por um profissional que o substituísse em algumas ocasiões, um sub-rogado (proxy). Embora a tese dos "solistas" esteja sendo relegada, paulatinamente, ao esquecimento, ela está longe de ter sido refutada ou abalada em suas bases principais e, dessa forma, seria inadequado ignorá-la, a despeito da opinião propagada por alguns especialistas ${ }^{1}$.

No que segue, pretendo argumentar que, muito embora a teoria coral tenha se tornado a posição hegemônica da maioria dos especialistas, ela está longe de ter sido provada. $\mathrm{Na}$ verdade, é importante salientar já logo no início deste capítulo que não acredito ser possível provar nenhuma das hipóteses a partir das evidências de que dispomos. Não é a isso que me proponho, muito embora tenha, como qualquer um, minhas convicções pessoais. Na medida em que ambas as hipóteses não são passíveis de serem falseadas, não acho que se possa emitir um juízo de valor acerca de qualquer uma delas, considerando uma como mais ou menos provável, senão de um ponto de vista absolutamente dogmático e, consequentemente, não há e nem pode haver nenhum tipo de "consenso"2 acerca dessa questão simplesmente porque as evidências aduzidas por ambos os lados são inconclusivas na mesma medida em que são convincentes e razoáveis. Dessa forma, se um propalado "consenso" existe, mesmo na

${ }^{1}$ Para uma revisão da bibliografia, as fontes mais importantes são, do lado dos "solistas", HEATH (1988); HeATH e LEFKOWITZ (1991); LEFKOWITZ (1963, 1975, 1977, 1978, 1980, 1984, 1988); reunidos em LEFKOWITZ (1991), a que as referências nesta tese remetem. Do lado dos "coralistas", principalmente CAREY (1989, 1991), BurnetT (1989), D'Alessio (1994) e AGócs (2012). Cf. também DAVIES (1988), Bremer in SLINGS, JARCHO e BREMER (1990), CingANO (2003), J.S. Clay (1999), MorgAN (1993) e ECKERMAN (2010).

${ }^{2}$ Como querem, por exemplo, CurRIE (2004b, p. 49), AGÓCs (2012), MORRISON (2012, pp. 111, n.3 e 12), entre outros. 
ausência de evidências em favor de qualquer uma das duas hipóteses, algo reconhecido por ambos os lados, ele só pode ser prejudicial para o nosso entendimento da questão, por desestimular o debate em favor de uma ortodoxia incapaz de produzir novas ideias.

Num cenário mais pessimista, a aceitação de uma hipótese em detrimento da outra pode nos levar a conclusões baseadas em premissas não comprovadas e, portanto, a criar problemas onde eles talvez não existissem. Como teremos a oportunidade de ver ao longo desse capítulo, o progresso feito por pesquisadores que defendem tanto a hipótese coral quanto a solo avançou apenas no sentido de deixar mais claro tanto nossa total ignorância acerca do modo de performance das odes quanto por nos abrir os olhos para o fato de que essa indeterminação interna dos epinícios pode ser mesmo uma das características tradicionais que veio a assegurar a sua sobrevivência por meio de reperformances posteriores. É extremamente importante, dessa feita, que a discussão acerca do modo de performance da première seja retomada, uma vez que após os intensos debates dos anos noventa o assunto começou a ser tratado por alguns especialistas como tendo sido solucionado. Como tentarei mostrar, isso está muito longe de ser verdade.

No que se segue, irei centrar minha análise em evidências de dois tipos: externas e internas.

As evidências externas são importantes principalmente no que tange ao equacionamento

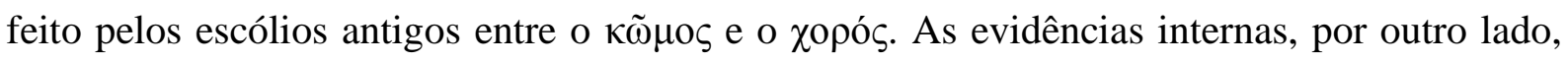
nos permitirão discutir o uso sui-generis que o poeta faz da primeira pessoa e em que medida esse uso difere daquele de outros poemas inquestionavelmente corais. Por fim, irei analisar algumas passagens aduzidas por ambos os lados como evidências de um ou outro modo da performance das canções.

\subsection{Testemunhos antigos e os scholia vetera}

O processo pelo qual o texto das odes foi fixado já foi tratado por Irigoin, em sua Histoire e os diversos modos como ele pode ter sido transmitido após a première nos ocupará no Capítulo 7. Por ora, e a fim de entender melhor as peculiaridades do material ofertado pelos escólios, basta que saibamos que, a partir do momento em que textos das canções de Píndaro começaram a circular, eles devem ter sido paulatinamente modificados por um

trabalho editorial que consistia em correções, edições e comentários por parte de seus receptores, dentre os quais os mais destacados são os bibliotecários de Alexandria. Seus 
textos, lamentavelmente, chegaram até nós apenas na forma de fragmentos devido a um processo de abreviação e seleção que atingiu seu ápice por volta do II d.C. (c. 150-180 d.C.), quando da compilação da "Seleta" ou "Epítome". Com um claro objetivo pedagógico, essa abreviação do cânon legado pelos alexandrinos procurou, como o próprio nome diz, selecionar os autores clássicos adequados ou que eram vistos como importantes para a paideia da aristocracia do período antonino e, dessa maneira, dos nove líricos canônicos foram escolhidos apenas Safo, como representante da lírica monódica, e Píndaro, da $\operatorname{coral}^{3}$. Dos dezessete livros desse último, foram preservados apenas os últimos quatro, justamente os que continham os epinícios ${ }^{4}$, para que servissem de leitura de sala de aula. Uma consequência direta desse fato (e atendendo aos fins práticos de um manual) foi a transferência, por meio de um processo de seleção, abreviação e compressão, do grande comentário de Dídimo (e talvez de outros), em formato de rolos ou volumina, e que até então tinha uma existência em separado dos livros dos epinícios, para um único códex ${ }^{5}$, onde foram preservados como anotações marginais. Nasciam assim os escólios.

Como uma última etapa desse processo, de uma cópia do arquétipo da Seleta que continha os epinícios de Píndaro e os escólios, foram tiradas duas recensões distintas, a Ambrosiana (A - que contém apenas as odes olímpicas), do final do séc. IV ou início do $\mathrm{V}$, e a Vaticana (V), do séc. V. Segundo Irigoin ${ }^{6}$, fica claro, pelo texto dos escólios das duas recensões, que $\mathbf{V}$ sofreu uma perda considerável de material explicativo e, também por causa disso, o seu texto é inferior ao de A, ainda que mais copioso. É comum, por exemplo, encontrar um maior número de autoridades referenciadas nominalmente em $\mathbf{A}$ que não são mencionadas em $\mathbf{V}$. Apesar disso, $\mathbf{A}$ tende a agrupar comentadores que têm a mesma opinião sobre um determinado assunto, o que pode nos levar ao equívoco de supor que esses pertenciam a uma mesma escola, quando, de fato, estão separados tanto no tempo quanto no espaço $^{7}$.

${ }^{3}$ Para uma crítica, a meu ver acertada, dessa divisão, $c f$. DAVIES (1988) e CINGANO (2003).

${ }^{4}$ A partir do terceiro século, nenhum papiro testemunha a sobrevivência de autores que não os da Seleta. Para maiores detalhes, $c f$. Irigoin, Histoire, p. 94, que, baseando-se em WILAMOWITZ-MOELLENDORFF (1907, p. 185 et seq.), crê que a criação da Seleta tenha se dado no contexto da atividade dos novos filólogos ligados à Biblioteca de Adriano, como Apolônio Díscolo, Harpocrácio e Frínico.

${ }^{5} \mathrm{Na}$ verdade, a mudança de formato gráfico dos volumina, que deixavam pouco espaço para anotações marginais, para os códices que, ao contrário, tinham margens largas, deve ter contribuído para o desenvolvimento e a proliferação dos escólios. Assim Irigoin, Histoire, p. 95-8; Pellicia in BUDELMANN (2009, p. 248). Vide também N. G. WiLson (1967) e B. K. Braswell in MatThaios, Montanari e Rengakos (2011, pp. 181-97).

\footnotetext{
${ }^{6}$ Histoire, p. 100 et seq.

${ }^{7}$ LEFKOWITZ (1991, p. 148).
} 
A partir dessas observações preliminares e bastante simples, pode-se deduzir, portanto, que o material transmitido pelos escólios está longe de ser homogêneo ${ }^{8}$. Mais importante ainda: embora eles preservem diversos fragmentos que remetem diretamente aos comentadores alexandrinos ou, em alguns casos, mesmo a fontes mais antigas, na imensa maiorias dos casos, eles não os reproduzem devido ao tortuoso caminho e à natureza de sua transmissão, como já mencionado. Que proporção, portanto, do substrato mais antigo, isto é, anterior ao séc. IV, foi transmitido pela produção helenística e, em última análise, o quanto do trabalho original dos alexandrinos está preservado nos escólios e, mais importante ainda, em que grau de seleção, compressão e abreviação ambos nos foram legados e por meio de que vias de transmissão textual, é difícil precisar ${ }^{9}$. Ainda que as diferenças entre passos idênticos de $\mathbf{A}$ e $\mathbf{V}$, bem como os hábitos de citação helenísticos, verificáveis pelos escólios, porém, não nos permitam ser muito otimistas ${ }^{10}$.

Apesar do exposto, os escólios exegéticos, como são chamados, para distinguí-los dos métricos, continuam a ser usados, não raro na ignorância desses fatos, com o objetivo de sustentar uma série de argumentos, frequentemente sob a premissa (explícita ou não) de que seriam uma fonte altamente confiável e, algo mais grave, fidedigna, de um conhecimento tradicional transmitido ininterruptamente desde o período arcaico, o que não é correto, como irei argumentar. Não se trata, no entanto, e é bom que isso seja ressaltado logo no começo de nossa discussão, de negar o valor importantíssimo que os escólios certamente têm, e o seu papel ainda bastante central em elucidar diversos aspectos e problemas apresentados pelas canções pindáricas. Nem se trata de descartar suas explicações. Por outro lado, isso não significa que as interpretações apresentadas por esses textos devam ter, de algum modo, uma posição privilegiada dentro da crítica pindárica, e, portanto, estejam além de qualquer crítica. Infelizmente, pelo que veremos, apesar de seu alto valor filológico, sobretudo para o nosso entendimento da recepção de Píndaro em Alexandria, os problemas apresentados pelos escólios são bem mais numerosos que as soluções que poderíamos esperar obter a partir deles $^{11}$.

\footnotetext{
${ }^{8}$ Os escólios formam uma editio variorum e, daí, o problema inerente em se falar de um "corpus" escoliástico. Cf. o excelente capítulo de F. Montana in MonTANARI e PAGANi (2011, pp. 105-61) a esse respeito.

${ }^{9}$ DiCKEY (2007, pp. 38-40). Embora eu não compartilhe de seu otimismo quanto à utilidade dos escólios exegéticos.

${ }^{10}$ Cf. LeFKOWITZ (1991, p. 148 et seq.)

${ }^{11}$ Para extensa discussão sobre o tema e que não se restringe apenas aos escólios de Píndaro, $c f$. NüNLIST (2009). Recentemente, Enrico E. Prodi (Christ Church Collegel Oxford) informou-me que está produzindo uma análise específica dos escólios gregos, a qual deve ser publicada em breve.
} 
Seja como for, esse prestígio dos escólios a que nos referimos, começou a mudar a partir do trabalho de Boeckh ${ }^{12}$. Em uma série de investigações, que culminaram com a publicação de sua monumental edição de 1821, aquele erudito rompeu (se para o bem ou para o mal, não teremos a oportunidade de discutir aqui) com a colometria e com a sua interpretação como transmitida pelos escólios ditos "métricos"13. Bundy, por sua vez, em 1962, foi categórico ao afirmar acerca do material fornecido pelo restante dos escólios, “ditos exegéticos", que

\begin{abstract}
No primeiro artigo dessa série, eu argumentei pela necessidade de uma nova abordagem ao estudo de Píndaro e, ao apresentar minha leitura da $O$. 11, tentei indicar que resultados podemos esperar alcançar se descartarmos o que "sabemos" das fontes alexandrinas e das pesquisas modernas baseadas nos métodos daquelas testemunhas antigas, e se deixarmos as odes falar por si mesmas, não separadamente, cada uma em seu vácuo filológico, mas juntas, como o produto de convenções retóricas e poéticas, cujo significado, ainda que atualmente nos seja obscuro, é recuperável a partir de um estudo comparativo. ${ }^{14}$
\end{abstract}

Como nota Most $^{15}$, para Bundy esses métodos eram aqueles dos escólios antigos e “dos modernos, que os aprovam"16. Na década de oitenta, Mary Lefkowitz voltou ao problema em dois artigos ${ }^{17}$ em que fundamenta sua desconfiança na credibilidade dos escólios no que tange a várias questões relacionadas ao texto de Píndaro. Resumidamente, de acordo com Lefkowitz, esse prestígio deve-se a três a priores, nenhum deles falseável, feitos acerca dos escólios: o primeiro é uma premissa ex antiquitate, ou seja, de que, por preservarem o conhecimento produzido em Alexandria e outros centros de saber da Antiguidade, os escólios devam preservar uma opinião mais confiável das odes, sua exegese e problemas. O segundo é o de que os comentadores lá citados estariam mais bem equipados para interpretar Píndaro uma vez que foram falantes nativos do Grego e, o terceiro, de que aqueles acadêmicos teriam tido acesso a obras de outros autores e comentadores contemporâneos (ou quase) do poeta,

12 BOECKH (1809, 1811, 1821).

${ }^{13}$ É preciso que se alerte para o fato de que a colometria transmitida de Píndaro deve remeter, pelo menos, à Aristófanes de Bizâncio. Apenas a sua interpretação, como proposta pelos escólios métricos, é tardia (provavelmente estes se baseiam em um tratado escrito $c$. II séc. d.C.), tendo sido adicionada posteriormente aos escólios exegéticos. $c f$. DiCKEY (2007, p. 38). O veredito de Wilamowitz a esse respeito foi, de certa maneira, decisivo (1966, p. 3): "Nur soviel steht fest, daß die metrischen Scholien ein späterer Zusatz zu der Ausgabe sind; ihr Wert ist fast gleich Null, noch geringer als der des Heliodor im Aristophanes".

${ }^{14}$ P. 47, grifo meu. Ele conclui, ainda (p. 126), com a confiança que se "estiver certo em alguma medida, então os métodos usados no estudo das odes estão errados, e precisamos começar de novo".

${ }^{15}$ Most (1985, p. 26). O leitor irá tirar muito proveito de uma leitura atenta da introdução do referido livro de Most, na qual ele demonstra que há mais semelhanças do que diferenças entre os métodos de interpretação antigos e modernos.

${ }^{16}$ P. 46. Entenda-se, a abordagem, histórico-biográfica inaugurada por Wilamowitz.

${ }^{17}$ LEFKOWITZ (1977); LEFKOWITZ (1985), reunidos em LEFKOWITZ (1991). 
cruciais para a elucidação de muitos problemas das odes, mas que estariam atualmente perdidas, um tipo de auctoritas e phantasmate.

Lefkowitz argumenta que as explicações dadas aos versos iniciais da $P$. 8, que se

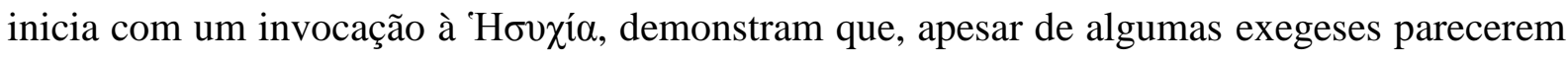
plausíveis, nenhuma delas invoca qualquer outra fonte que não o próprio texto do poeta. $\mathrm{Na}$ impossibilidade de explicar com precisão, por exemplo, por que Píndaro inicia a referida ode com uma invocação àquela deusa, os escoliastas oferecem duas opções: (1a) em virtude de revoltas políticas na época da vitória de Aristomenes (c. 446 a.C.) ou (1b) porque as Guerras Médicas teriam acabado "recentemente" evidentemente, pouco sentido, já que a invasão persa havia sido repelida há mais de trinta anos. Por causa disso, a maioria dos críticos modernos aceita a explicação de (1a) como a mais provável, vendo nela uma alusão à dominação ateniense em Egina. Mas há algum critério objetivo que nos permita fazer tal correlação? Revoltas internas não eram necessariamente raras nas póleis gregas. Na verdade, os escólios apenas aqui e acolá nos fornecem detalhes específicos e, nesse caso em particular, a vaga menção a "revoltas" é motivada, na verdade, pela avaliação estética do próprio verso inicial, através de uma

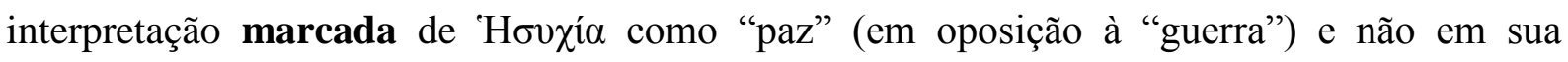
acepção mais esquemática de "tranquilidade" que, hoje sabemos, é um tópos nos epinícios, seja por aludir ao contexto de festa em que a performance se dava, seja ao descanso que sucede à fática atlética ${ }^{19}$.

Como aquela autora chama a atenção, a mesma necessidade de encontrar explicações

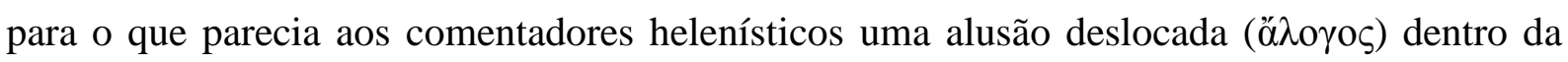
economia da ode irá ocorrer com a invocação à Eileithuia na $N$. 7. Todavia, isso nunca ocorre quando a divindade parece, do ponto de vista dos alexandrinos, bem integrada ao contexto imediato da canção, porque

(...) os escólios aos versos iniciais da $P .8$ nos dizem mais sobre a crítica textual helenística e a educação grega tardia do que sobre a poesia de Píndaro ou o contexto histórico que envolve a performance das odes. Os comentadores não tinham nenhuma dificuldade particular com outras odes onde uma conexão explícita entre as linhas iniciais e a vitória celebrada existe, e.g., $O .1$ (...) ou a P.2 (...). Eles estavam acostumados a ouvir conexões feitas de um modo direto na poesia de seus contemporâneos (...). Mas quando, como no caso dos proêmios à $P$. 8 e à $N$. 7, Píndaro não indica explicitamente a relação da invocação com a vitória, os comentadores voltaram-se para fora das odes em busca de uma explicação. Seguindo a analogia da literatura de seus próprios dias, uma referência mitológica obscura

${ }^{18}$ DrachmanN, vol. 2, p. 206.

${ }^{19} C f$. Bundy (1954) e T. K. HubBard (1985, p. 83 et seq.). 
podia ser interpretada como uma alegoria, como se Píndaro estivesse disfarçando alusões a pessoas e eventos reais por trás de nomes de deuses e heróis. ${ }^{20}$

Outra característica dos escólios salientada por Lefkowitz é sua tendência constante em oferecer variantes explicativas para um mesmo trecho comentado. Ainda que se pudesse argumentar que isso representaria uma certa ansiedade em preservar a tradição filológica (e algumas vezes esse parece ser realmente o caso $^{21}$ ), isto também poderia apontar especialmente no caso de realia e fatos histórico-culturais, mais do que em questões de crítica literária -, para o fato de que, à época da compilação dos comentários, os alexandrinos, tanto quanto nós, já não tinham mais acesso a fontes com autoridade suficiente para decidir algumas questões ${ }^{22}$, caso contrário, não haveria necessidade de se preservar mais do que uma explicação: aquela que pudesse ser comprovada pela fonte mais fidedigna ${ }^{23}$.

É certamente verdade que algumas entradas vêm acompanhadas do nome do autor de onde foram extraídas ${ }^{24}$, o que, no entanto, apenas nos coloca numa situação ainda mais difícil, porque pode indicar que todas as outras que não vêm acompanhadas de tais referências representam, em última análise, apenas a opinião particular de um determinado comentador e devem, consequentemente, ser descartadas ${ }^{25}$. Desta feita, a premissa ex antiquitate, quando aplicada aos escólios, não pode ser tomada como um princípio filológico que tenha qualquer utilidade, mas, ao contrário, deve ser descartada e rechaçada, especialmente quando não assumida explicitamente.

No que diz respeito à segunda premissa citada acima, a de que, por serem falantes nativos do grego, os escoliastas estariam mais aptos a fornecer paráfrases confiáveis das suas partes mais obscuras, a mesma autora, tomando como base os escólios à Ilíada e à Argonáutica, conseguiu mostrar que, enquanto os escólios àqueles poemas são capazes de fornecer explicações e paráfrases na maioria das vezes precisas dos versos comentados, o mesmo não ocorre com os epinícios pindáricos, a despeito da suposta riqueza de livros a que

\footnotetext{
${ }^{20}$ LEFKOWITZ (1991, pp. 78-9).

${ }^{21}$ Quanto, por exemplo, as alusões às $\zeta \eta \tau \dot{\mu} \mu \alpha \tau \alpha$.

${ }^{22} C f$. também a discussão sobre as duas versões dos escólios A e V aos versos da $O .10 .45$ em LEFKOWITZ (1991, p. 147).

${ }^{23}$ LEFKOWITZ (1991, p. 75).

${ }^{24}$ É possível encontrar menções a Heródoto, Hecateu, Éforo, Arístipo, Epicarmo, Teofrasto etc. No entanto, mesmo nesses casos é preciso extremo cuidado, já que o peso dado a cada uma dessas fontes variava de acordo com o viés do comentador. A um poeta como Apolônio de Rodes ou Euforião podia ser dada a mesma (ou maior) credibilidade que a um historiador como Éforo. Não era incomum, ademais, que os escoliastas fizessem uma leitura equivocada dessas fontes, $c f$. LEFKOWITZ (1991, p. 78).

${ }^{25}$ Mesmo que isto possa não ser verdade para todas as entradas não ancoradas em alguma autoridade, o fato permanece de que não temos como escolher quais seriam fidedignas ou não, senão arbitrariamente e, portanto, somos obrigados a descartá-las.
} 
os alexandrinos teriam acesso ${ }^{26}$ e de sua hipotética destreza com o idioma. Além disso, acostumados a uma poética que prezava a alusão e a alegoria, mas que deixava os ligames entre os tropos e figuras, de um lado, e os seus respectivos referenciais, de outro, explícitos, os comentadores alexandrinos frequentemente tentavam transferir essas relações para os epinícios, procurando por alusões e significados ocultos nas passagens mais difíceis e indo buscar essas relações até mesmo fora das próprias odes, o que mormente os levava a incorrer na "falácia biográfica", entre outras.

Um célebre exemplo dessa metodologia são as referências ao par de corvos na $O .2 .86$

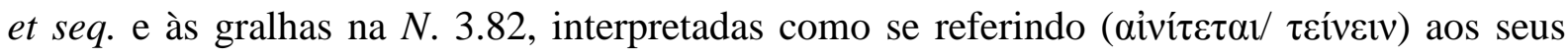
“rivais" Simônides e Baquílides. Na N. 4, onde Píndaro descreve a si mesmo como um atleta em combate, sujeito à inveja ( $\varphi \theta$ óvo $)$ dos oponentes, os escoliastas veem uma alusão a

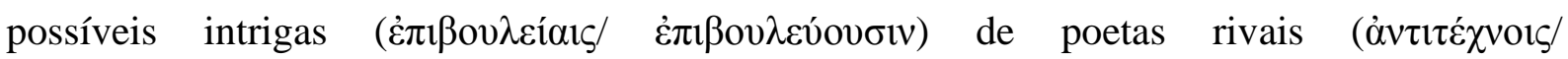
$\dot{\alpha} v \tau \imath \delta 1 \delta \alpha \sigma \kappa \alpha ́ \lambda \omega v)$ que procurariam denegri-lo, presumivelmente face a seus $\operatorname{laudandi}^{27}$. Ainda que essas alusões pudessem ter algum fundo de verdade ${ }^{28}$, elas podem nada mais ser do que uma característica da dicção tradicional dos epinícios que celebram, obviamente, competidores e, dessa forma, tenderiam a usar um vocabulário agonístico que lhes facilitasse o diálogo com o mundo e o linguajar de seus laudandi. Se, contudo, os comentadores antigos chegam ao ponto de fornecer detalhes acerca da identidade de tais opositores, sem, contudo, oferecerem-nos nenhum tipo de evidência externa que nos impeça de descartá-las como mera especulação, então, infelizmente, é precisamente isto que devemos fazer.

Obviamente, muitas das explicações propostas pelos escoliastas são motivadas por características do texto pindárico pouco compreendidas pelos alexandrinos. Uma distorção interessante, notada por $\operatorname{Most}^{29}$, surge quando se comparam as duas recepções de Píndaro, como definidas por esse crítico, na Antiguidade, a saber, a "acadêmica", representada principalmente pelos escólios, e a "literária", composta por vários autores que citam textos do poeta no contexto de suas obras para os mais diversos propósitos. Apenas a tradição

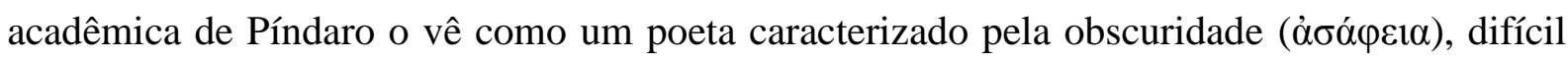
de ser entendido e dado a idiossincrasias (descrita normalmente por palavras como i $\delta$ io $\varsigma /-\omega \varsigma$

${ }^{26}$ LEFKOWITZ (1991, p. 149).

${ }^{27}$ LEFKOWITZ (1991, pp. 149-50). Cf. também FräNKEL (1961) acerca da N. 7.

${ }^{28}$ Num contexto, por exemplo, em que imaginássemos vários poetas sendo comissionados por um único patrono para uma mesma ocasião de performance, o que seria plausível de se esperar de tiranos como Hierão e Arcesilau.

${ }^{29} \operatorname{MosT}(1985$, p. 12 et seq.). 
nos escólios) em termos de estilo, vocabulário e $\operatorname{sintaxe}^{30}$. Para a tradição literária, mesmo aquela dos rhetores antigos, familiarizados com a discussão do tema da "obscuridade" - já nessa época um tópico bem definido -, esse era um problema absolutamente inexistente. A bem da verdade, Píndaro, junto com Tucídides, é citado por Dioniso de Halicarnasso como um exemplo do assim chamado "estilo austero", caracterizado pela grandiloquência

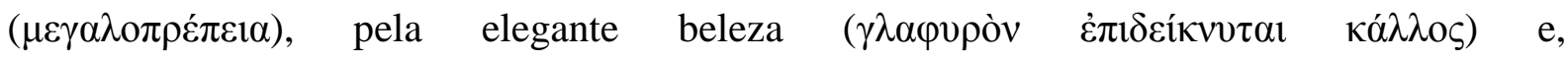

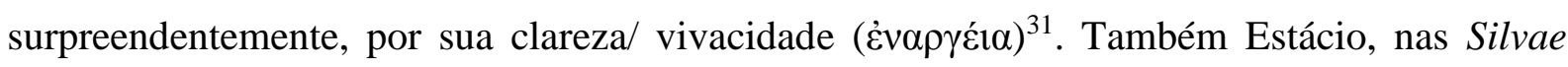
(5.3.147-58), contrapõe Homero, Hesíodo e Píndaro ao estilo labiríntico e obscuro de poetas como Licofronte, Calímaco, Sófrão e Corina. ${ }^{32}$

Most $^{33}$ explica essa divisão na recepção pindárica propondo dois tipos de dificuldade que um ouvinte ou leitor de Píndaro poderia experimentar ao se deparar com as odes: a primeira é de natureza retórica; a segunda, hermenêutica. Ao passo que a dificuldade retórica de Píndaro está ancorada na mensagem e deve-se, em grande parte, à dificuldade que qualquer texto poético impõe ao seu receptor, podendo ser resolvida, dessa forma, de inúmeras maneiras e com o emprego das mais diferentes estratégias, a dificuldade hermenêutica está ancorada no intérprete (e na cultura à qual ele pertence) e reflete o modo como este se relaciona com o texto poético. Ela

(...) reside na possibilidade de que certos tipos de obscuridade poderiam se colocar
não apenas para o intérprete, mas também por causa dele - isto é, que tais
obscuridades não são tanto uma característica intrínseca do texto literário, mas muito
mais um produto de questões específicas e de proposiçõos que um método de
interpretação impõe sobre o texto. Dificuldades podem não apenas ser encontradas,
elas também podem ser criadas, e podem ser, apesar disso, muito angustiantes para o
intérprete. $^{34}$

Essa análise pode contribuir para que entendamos como a recepção de Píndaro pelos alexandrinos pode ter sido marcada por uma abordagem anacronística de sua poesia, absorvida e digerida de acordo com a cultura da época, livresca, fundada sobre o domínio da

${ }^{30}$ A perplexidade dos comentadores antigos fica evidente na incrível frequência de palavras como

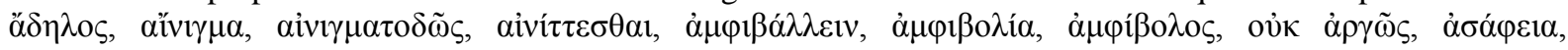

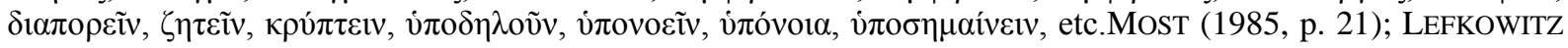
(1991, p. 153 et seq.).

${ }^{31}$ Cf. D.H. 20-22.

${ }^{32} \operatorname{Most}(1985$, p. 14).

${ }^{33}$ Idem, p. 23-4.

${ }^{34}$ MOST (1985, pp. 24-25), grifo meu. Uma posição muito semelhante a de LEFKOWITZ (1991, p. 74), "Comparison [entre os escólios] revels a consistente pattern: the scholarly debates recorded in the scholia focus on matters of particular interest to Aristarchus and his successors at Alexandria. The critical attitudes of these scholars were influenced by the aesthetics of Hellenistic poetry; when applied to a fifth century poet like Pindar, these late aesthetics inevitably let to misapprehension, which in turn compelled the commentators to look outside the poems for solutions to the problems their method of reading made them find", grifo meu. Para uma formulação semelhante do problema, $c f$. MONTANARI (2011, p. 20) . 
palavra escrita e para a qual toda a realidade de uma poesia oral, aí entendidas sua dinâmica, seus hábitos cognitivos, seu estilo característico, não podiam parecer senão completamente irracionais, incompreensíveis ou fora de controle ${ }^{35}$. A incapacidade dos comentadores alexandrinos de conseguir entender Píndaro é, na verdade, apenas o resultado de sua incapacidade de se conectar a uma cultura que já lhes era, então, totalmente estranha; uma barreira que nem livros, nem o seu conhecimento do grego como língua mãe, nem, possivelmente, seu contato com uma tradição que preservasse algum tipo de memória da sociedade arcaica na qual Píndaro operava, poderiam remover.

Não é necessário dizer, contudo, que o pessimismo de M. Lefkowitz foi bastante mal recebido, o que é natural se pensarmos no que os resultados a que chegou implicam. Christopher $\mathrm{Carey}^{36}$, por exemplo, acredita que

\begin{abstract}
A evidência dos escólios não merece nem uma aceitação acrítica, nem uma rejeição automática. Cada evidência deve ser analisada de acordo com seus próprios méritos. Não podemos dizer ao certo que uma referência nos escólios a uma performance coral está fundada sobre uma autoridade real. Mas podemos dizer que elas são consistentes com a evidência interna do texto de Píndaro em sua mais óbvia interpretação daquele texto. E podemos dizer que o interesse nos princípios da poesia coral começou já no quinto século, se pudermos confiar na informação de que Sófocles escreveu um tratado sobre o coro. Assim os eruditos helenísticos, de cujos tratados os escólios derivam suas informações, podem ter se baseado em uma autoridade antiga para sua aparentemente unânime asseveração de que as odes de vitória foram executadas por coros [grifo meu].
\end{abstract}

O problema dessa abordagem dos escólios é que ela, apesar de reconhecer a inexistência de quaisquer fontes externas que corroborem suas exegeses, recai na circularidade ao permitir que princípios altamente subjetivos, quando não idiossincráticos e autoritários - que determinam arbitrariamente qual deve ser "a mais óbvia interpretação daquele texto" -, sirvam para comprovar a sua própria validade, o que, aliás, denuncia um claro viés imposto já no momento da análise das evidências internas, como veremos.

Além disso, argumentos do tipo acima fatalmente precisam recorrer à premissa das "fontes perdidas", a que aludimos anteriormente; neste caso em particular, ao invocado trabalho de Sófocles sobre o coro, acerca do qual basta dizer que, em primeiro lugar, não há nenhuma evidência de que os alexandrinos tenham tido acesso ao referido tratado ou, em caso

35 As digressões de Píndaro e suas apóstrofes tradicionais solicitando que tome o controle da composição do poema eram entendidas pelos escoliastas literalmente, como se Píndaro realmente perdesse momentaneamente o controle. $C f$. LEFKOWITZ (1991, p. 151 et seq.) e p. 181.

36 CAREY (1989, p. 559). Para uma crítica ainda mais veemente, $c f$. ainda BuRNETT (1989), especialmente à p. 285. 
afirmativo, tenham se sentido compelidos a consultá-lo ${ }^{37}$, se não porque essa não era sua prática, como já argumentamos, mas sobretudo porque um tal tratado teria lidado com o coro trágico, como demonstra claramente o contexto da Vita no Suda, que é a única fonte, aliás, a citá-lo ${ }^{38}$. Em segundo lugar, já na época de Aristóteles, o coro da tragédia era tido como ligado geneticamente àquele do ditirambo, e não a outras formas da lírica coral, e, mesmo nesse caso, ele teria passado por transformações em sua evolução (que, aliás, desconhecemos) que tornariam qualquer comparação entre as duas formas, lírica e coral, temerária ${ }^{39}$. De qualquer maneira, uma vez que não há evidências contundentes nos escólios de que os alexandrinos derivam seu conhecimento de fontes antigas, sua opinião seria de pouco valor. Finalmente, a pretensa unanimidade dos mesmos não é corroborada pelas evidências ${ }^{40}$.

Enfim, seria desnecessário e altamente desaconselhável, dada a extensão da discussão, proliferar exemplos acerca das deficiências inerentes ao material dos escólios; o que foi visto até aqui deve bastar para que se tenha uma ideia mais ou menos geral ${ }^{41}$. Dessa forma, essas observações esquemáticas acerca do cuidado necessário ao se lidar com suas análises já devem ser suficientes para que discutamos, a seguir, e em suas devidas proporções, como a questão da maneira de performance dos epinícios é tratada pelos mesmos e em que problemas suas exegeses implicam no que diz respeito ao nosso entendimento das odes pindáricas.

Em um artigo ${ }^{42}$ de 1988 Malcom Heath chegou a conclusões importantes acerca do uso

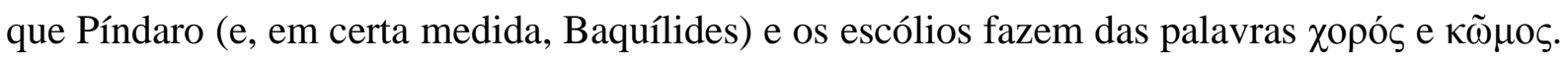

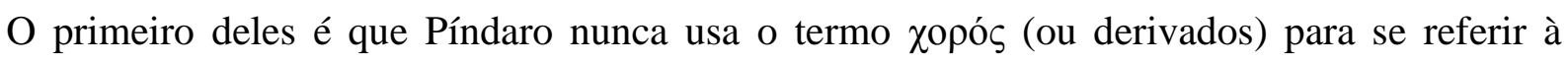
qualquer tipo de atividade envolvida na performance dos epinícios, para o que reserva sempre

${ }^{37}$ A projeção das nossas ideias de rigor científico e método filológico sobre a prática alexandrina é um anacronismo que contribui amiúde para que aceitemos de modo pouco crítico as suas observações, conclusões e interpretações.

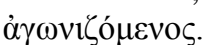

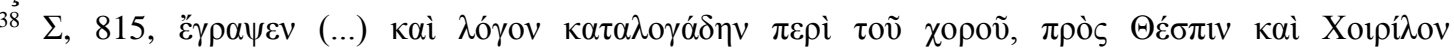

${ }^{39}$ Como faz CAREY (1991, p. 194): "The problem here is that since the chorus is the origin of tragedy the formal features of tragic lyrics originate with the chorus; the presence of these features in some tragic monodies ( $\kappa \tilde{\omega} \mu \mathrm{o} \zeta$ of course is complicated by the involvement of the chorus) may be due simply to assimilation to the song-form already established in tragedy", grifo meu. Cf. ainda Arist., Po. 1449a.10 et seq. e os comentário de LUCAS (1968, p. 80). Sobre isso também, BACON (1994). Para uma crítica da teoria Aristotélica, cf. SCULLION (2002), especialmente, p. 118 et seq.

${ }^{40}$ Uma rápida consulta aos escólios poderá nos informar, por exemplo, que, com referência à N. 1.19 et

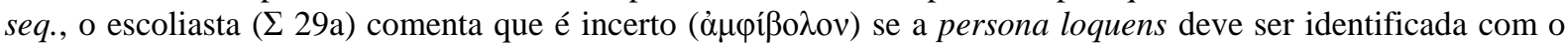
coro ou com o poeta.

${ }^{41}$ Para uma argumentação mais detalhada, vide os trabalhos de Lefkowitz e Heath mencionados à n. 1.

42 HEATH (1988). 


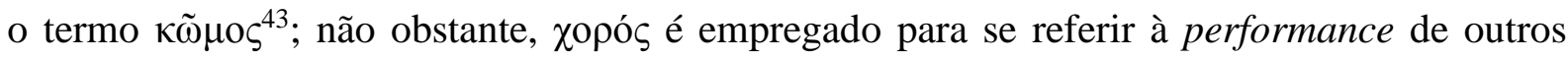
gêneros comprovadamente corais, como o peã, o parteneio e o ditirambo em fragmentos dos respectivos gêneros ${ }^{44}$. Esse uso bastante coerente, a ponto de assumir um caráter praticamente técnico, que Píndaro reserva à palavra $\kappa \tilde{\omega} \mu \mathrm{s}$, é, contudo, ignorado na exegese dos escólios: sempre que esses precisam explicar de maneira não tautológica ${ }^{45}$ passagens em que o termo $\kappa \tilde{\omega} \mu \mathrm{s}$ aparece, assim o fazem por meio de um equacionamento com $\chi 0 \rho \varsigma^{46}$. A dedução a que uma grande parte dos especialistas chega é que eles, portanto, devem estar reproduzindo uma associação usual na Antiguidade, e que, infere-se, a preferência de Píndaro (e Baquílides) por $\kappa \tilde{\omega} \mu$ o deve refletir apenas uma convenção do gênero, que tenderia a evitar a conotação

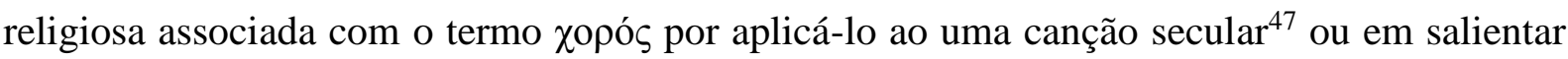
aquelas características do coro epinicial que o distinguiriam de outras formas corais ${ }^{48}$. Essas suposições, contudo, jamais são detalhadas e não há evidências que as suportem.

Uma vez que, ao que tudo indica, epinícios já não eram mais regularmente executados, ou pelo menos já não mais em seu formato "original" desde, pelos menos, a segunda metade do séc. $\mathrm{V}^{49}$, um conhecimento direto do modo da performance a que os escoliastas poderiam ter acesso, e que lhes permitiria emitir uma opinião em primeira mão, pode ser descartado. Restaria, dessa forma, apenas a tradição escrita. Não há, no entanto, e pelo que vimos anteriormente, nenhuma indicação de que os comentadores tenham consultado quaisquer tipos de fontes fidedignas a esse respeito, tivessem eles acesso a elas ou não. Consequentemente, seria mais prudente supormos que os escoliastas, baseando-se apenas nas evidências fornecidas pelo próprio texto das odes, não estivessem em melhores condições para interpretar

${ }^{43}$ Os casos controversos serão discutidos mais adiante. Vocábulos derivados de $\chi 0 \rho$ - com referência à dança são raros nos epinícios e aparecem apenas nas seguintes odes: $O .14 .9 ; P .1 .4,9.114,10.38 ; N .5 .24 ; I$. 1.7. Vocábulos derivados de $\kappa \omega \mu$ - são bem mais frequentes: $\kappa \tilde{\omega} \mu$ o (usualmente com dêictico e/ou adjetivo que

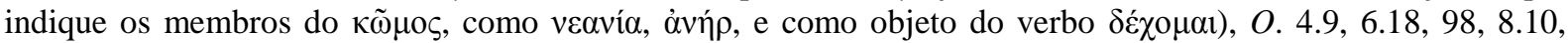

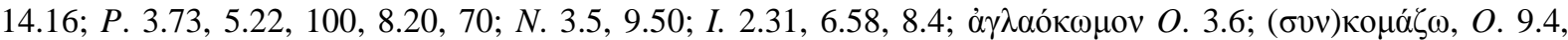

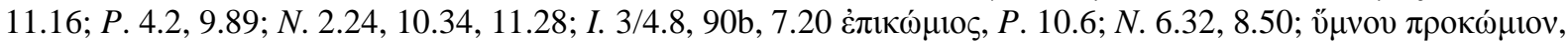

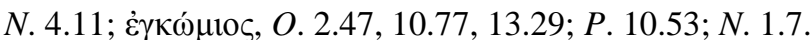

${ }^{44}$ Por exemplo frgs. Peã 52b.99; Ditirambo fr. 75.1, 19; Parteneio fr. 94b.39.HEATH (1988, pp. 184-5). ${ }^{45}$ Isto é, aquelas que não nos dizem nada acerca do sentido em que o termo $\kappa \tilde{\omega} \mu \circ \varsigma$ e derivados são empregados nas

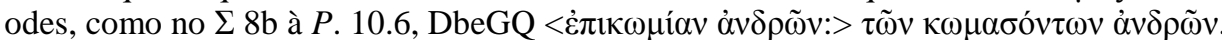

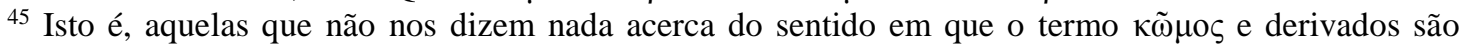

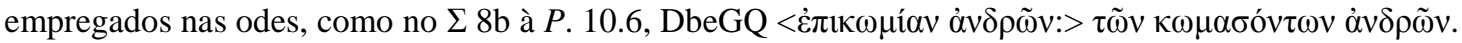

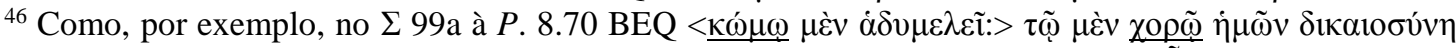

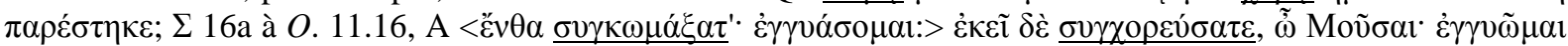

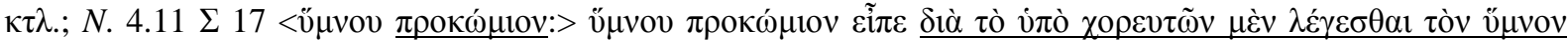

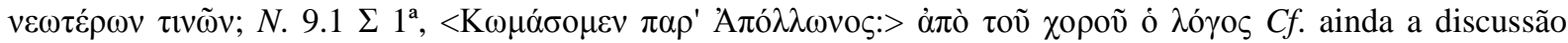
interessante do $\Sigma 25$ a aos versos da N. 1.29 et seq.

${ }^{47} C f$. BREMER (1990, p. 55).

${ }^{48}$ Agócs (2012, pp. 195-6).

${ }^{49}$ Como atesta o fr. 366K de Êupolis (Athe. 1.4.21), $c f$. SWIFT (2010, p. 108). O epinício composto por Eurípides para Alcibíades (755 PMG) deve ser uma rara exceção, mas $c f$. HORNBLOWER (2012). 
o modo de sua performance do que nós atualmente estamos ${ }^{50}$ e que suas explicações demonstram claramente que, a partir do período helenístico, no mais tardar, não apenas o

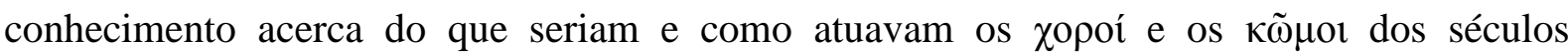
anteriores ao séc. V havia se perdido mas que também, e certamente por causa disso, ambos os termos puderam convergir para um mesmo sentido.

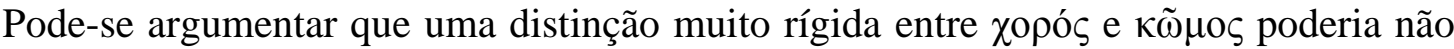
refletir a prática arcaica e que, portanto, os escólios estariam corretos em também não atestála. Mas as evidências externas anteriores aos escólios permitir-nos-iam fazer tal inferência? Aparentemente não. Sobre o significado do termo $\kappa \tilde{\omega} \mu о \varsigma$, já tivemos oportunidade de discorrer anteriormente ${ }^{51}$. Seria apropriado que agora dedicássemos algum tempo para

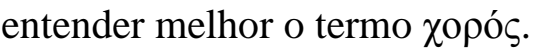

Desde Homero temos evidências de coros que podem apenas dançar, sem, obrigatoriamente, ter que cantar. Talvez o mais célebre deles seja aquele dos jovens feácios que dançam em acompanhamento aos cantos de Demódoco, no Livro 8 da Odisseia. No plano divino, que, de certa forma, serve como modelo ideal das práticas humanas ${ }^{52}$, as Musas, na Teogonia ( $v .7$ et seq.), dançam em volta da Fonte do Cavalo, porém não cantam. O canto, que toma a forma de um hino processional a Zeus e aos outros deuses, inicia-se apenas quando elas se dirigem ao Olimpo $^{53}$. Mais do que uma interpretação assaz esquemática do texto poético, como poderia ser argumentado, acredito que ele, na verdade, nos apresenta de forma espontânea uma realidade idealizada das práticas corais gregas que, aliás, podem ser encontradas em várias sociedades ainda hoje. Dentro da metodologia que temos utilizado, o que vemos nas práticas corais e festivas divinas é, portanto, um Modelo Cognitivo Idealizado ao qual a realidade das práticas humanas deveria corresponder em maior ou menor grau, assumindo formas mais ou menos prototípicas.

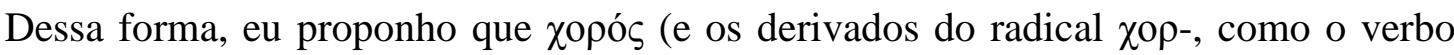
$\chi о \rho \varepsilon v ́()$ deva ser entendido a partir de uma categoria que inclui "dança" e "canto", mas que, dentro desta categoria, a acepção "dança" seja a mais prototípica ou marcada ${ }^{54}$. Que essa

${ }^{50}$ Assim HERINGTON (1985, p. 27), para uma revisão das fontes, consulte, naquela obra, o Apêndice IV à p. 181 et seq.

${ }^{51} C f$. p. 74

${ }^{52}$ Y. Zarifi in MCDONALD e WALTON (2007, p. 227 et seq.) e LONSDALE (1994), especialmente p.29 et seq. $C$. também MULLEN (1982).

${ }^{53}$ WEBSTER (1970, p. 48)

${ }^{54}$ RICHARDSON (2011, p. 16), "One should also bear in mind that, whereas we use 'choir' and 'choral'

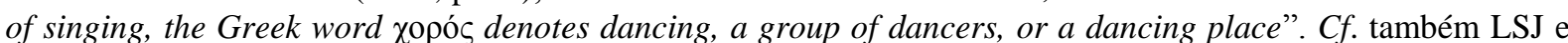

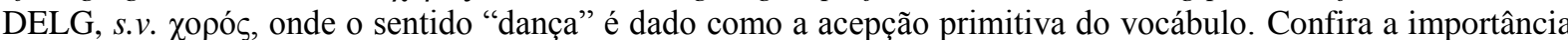
do espaço ( $\tau$ ó $\pi \mathrm{o} \varsigma)$, onde naturalmente se dá a dança, para a definição do Suda $(\chi, 410)$. Informações importantes sobre a etimologia também apontam para essa acepção primitiva da palavra, $c f$. CALAME (2001, pp. 19, n.3). 
hierarquia semântica determine o uso que a palavra tem em grego, isso fica mais claro quando

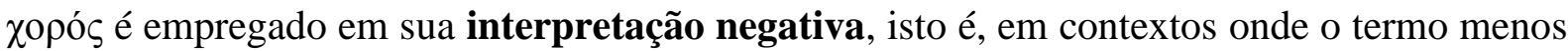
prototípico ("canto") é posto em saliência por meio de uma instanciação explícita, como por exemplo, na fala de Alcínoo, em Od. 8.248 em que o conceito FESTA é evocado através do merismo "comida-música-dança":

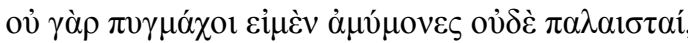

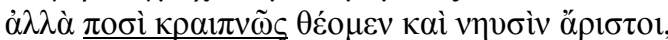

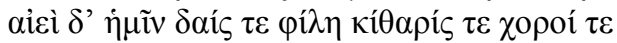

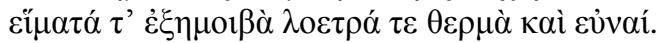

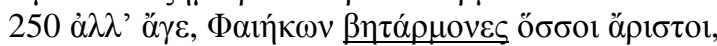

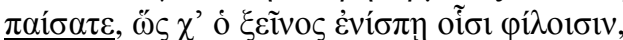

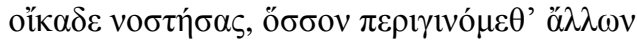

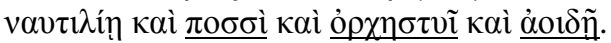

\begin{abstract}
Pois não somos boxeadores invencíveis, nem lutadores, mas corremos rápido com os pés e, com os navios, somos os melhores, e entre nós há sempre o banquete amável e a cítara e as danças (khoroî), troca de roupas e banhos quentes e camas.

250 Mas anda, vai, vós que sois os melhores dançarinos feácios, dançai (paísate) ${ }^{55}$, a fim de que o estrangeiro conte aos seus camaradas, no retorno à casa, o quanto superamos todos com a navegação e com os pés e com a dança e a canção!
\end{abstract}

O contexto da passagem permite que identifiquemos com precisão o valor conferido à

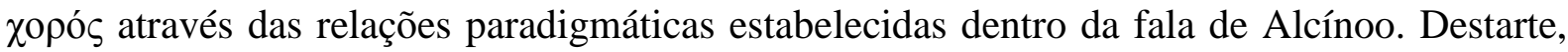

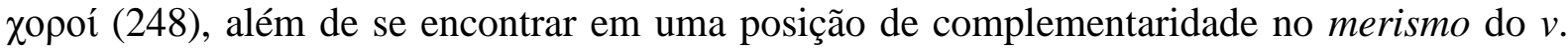

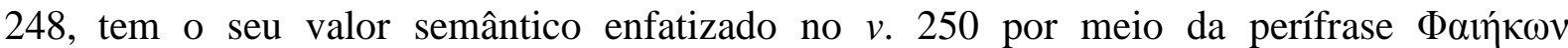

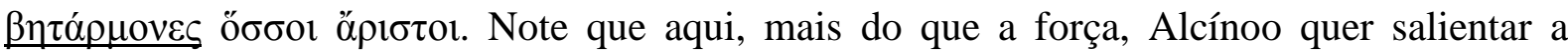

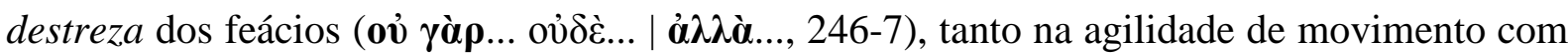
os pés, na corrida, quanto na perícia exigida para se controlar um navio ou para tomar parte na dança $^{56}$. Nesse sentido o uso de $\beta \eta \tau \alpha ́ \rho \mu \omega v$ é motivado tanto pela intenção de salientar tais qualidades por meio de um forte contraste com a força física e a aparência alquebrada de Odisseu, quanto por uma figura etymologica que parece ouvir no adjetivo um composto de

Essa é uma definição um pouco mais formal que a dada por GREGORY NAGY (1994): "I understand the fundamental meaning of khoros (...) as 'song-and-dance ensemble', with emphasis on both song and dance, although I also understand that either the song may dominate the dance or the dance may dominate the song in different choral traditions", grifo meu. Obviamente, a definição de Nagy, que se aproxima mais daquela de $\mu о \lambda \pi \eta$, é suficiente para os objetivos que ele tem em mente; para nós, no entanto, um maior grau de formalização é necessário.

${ }^{55} C f$. minha interpretação que faço de $\pi \alpha i \zeta \zeta \omega$ neste tipo de contexto à p. 86.

${ }^{56}$ Se tivéssemos mais do fr. $1 \mathrm{~W}^{2}$ de Arquíloco, eu não me surpreenderia de encontrar o poeta falando de dança, mais do que de poesia ou música. Guerra e dança estão amiúde intimamente ligados, ademais. 


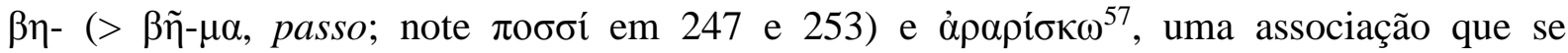
aproxima das propostas de Tölle e por Froehde para $\chi 0 \rho{ } \varsigma^{58}$. Enquanto a primeira o conecta a

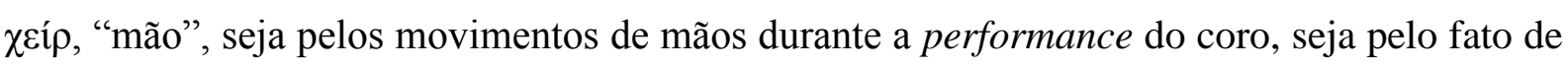
que na dança circular a mão de um dançarino apoia-se no pulso de outro; este, doutra feita, propõe uma etimologia aparentada com o lit. záras, "linha”, “ordem". Em ambos os casos estão implicadas as noções de "junção", “ordem" e "coordenação", presentes também em

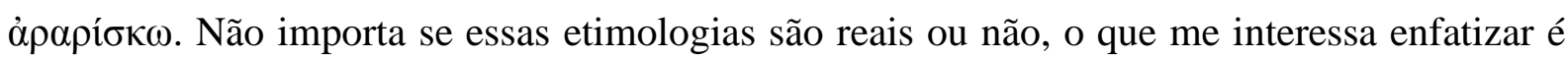
que do ponto de vista do poeta e de sua audiência elas poderiam ser significativas.

A fim de ilustrar essas observações, eu gostaria de chamar a atenção para um trecho do Hino Homérico a Apolo, onde temos uma descrição do coro divino composto pelas Musas, tendo Apolo como citaredo ${ }^{59}$ :

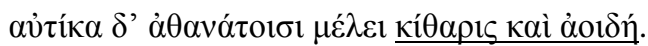

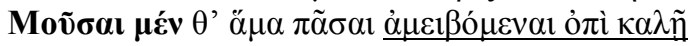

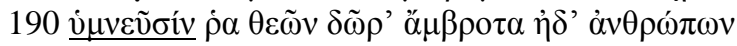

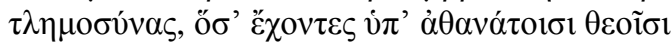

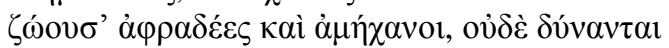

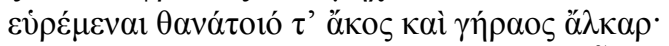

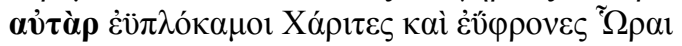

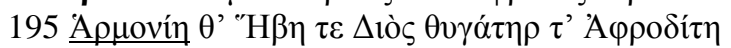

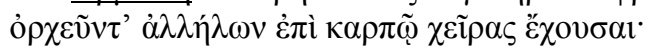

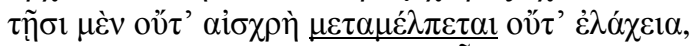

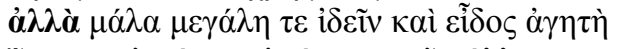

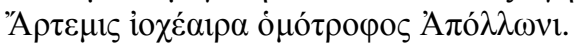

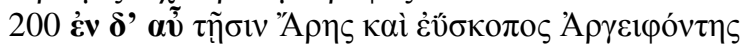

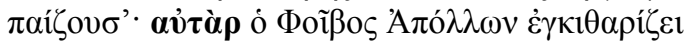

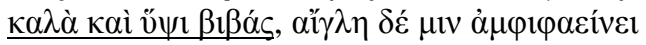

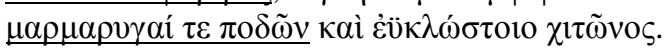

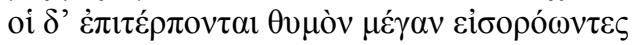

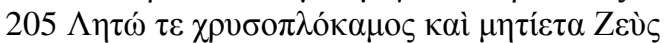

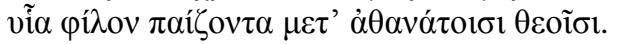

De pronto anseiam os deuses pela cítara e pela canção As Musas então, em conjunto, alternam com bela voz 190 hineando os imperecíveis dons dos deuses, mas, dos homens, a resiliência, o tanto que suportam sob os deuses imortais: vivem sem entendimento, impotentes, e não são capazes de descobrir, da morte, da dor e da velhice, proteção.

Mas as Graças de belas tranças e as despreocupadas Estações,

195 Harmonia, Hebe e Afrodite, a filha de Zeus dançam tendo as mãos umas sobre o pulso das outras. Compartilha do canto-dança, àquelas em nada inferior, nem menor, mas muito mais alta de se ver e de compleição admirável, Ártemis verte-flechas, irmã de Apolo.

57 Apenas aqui e em 8.383. Cf. DELG, s.v. $\beta \eta \tau \alpha ́ \rho \mu \omega v$, a respeito da etimologia. A etimologia "verdadeira" do composto, de qualquer maneira, é irrelevante, dado que seu uso pressupunha esse entendimento, que, em última análise, deve ter motivado o seu emprego nesta passagem, $c f$., p. ex., o $\Sigma \mathrm{V}$ a essa passassem:

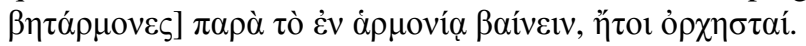

58 Apud Calame (2001, pp. 19, n.3).

${ }^{59}$ Sobre essa aparente divisão entre canto e dança, $c f$. também PAGLIARO (1953, p. 10 et seq.). 


\begin{abstract}
200 E bem no meio delas Ares e o Argifonte vista-boa
dançam. Por seu turno, Apolo acompanha na lira com belas e altas passadas, um fulgor o envolve e faíscas saltam de seus pés e de sua bem tecida túnica. [205] Leto de douradas tranças e o doloso Zeus [204] no peito muito folgam enquanto assistem, os filhos festejando entre os deuses imortais.
\end{abstract}

Neste trecho, temos várias cenas ou quadros que se alternam a fim de fornecer ao ouvinte uma descrição que lhe permita visualizar em $360^{\circ}$ o que está acontecendo no coro. Podemos distinguir quatro grupos distintos que executam tarefas igualmente distintas. Em

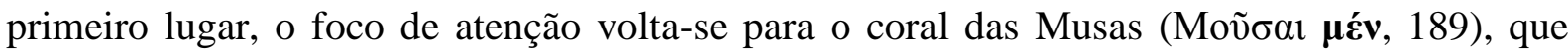
cantam (mas não dançam) em antifonia. Uma mudança de foco ( $\alpha$ $\tau \grave{\alpha} \rho, 194)$ e eis a dança

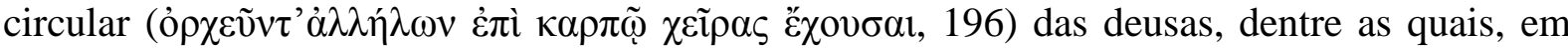

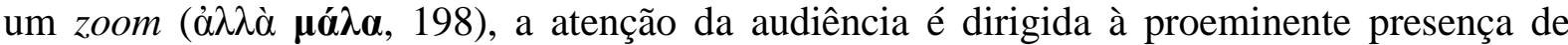
Ártemis como líder-do-coro, que canta $e$ dança ( $\mu \varepsilon \tau \alpha \mu \varepsilon ́ \lambda \pi \varepsilon \tau \alpha 1,197)$. Outra mudança de perspectiva ( $(\dot{\varepsilon} \vee \boldsymbol{\delta}$ ' $\boldsymbol{\alpha} \tilde{v} \tau \tilde{n} \sigma ı, 200)$ e vemos Ares e Hermes executando uma espécie de dança cujos passos são descritos de uma maneira que alude aos movimentos de $\kappa \omega \mu \alpha \sigma \tau \alpha i ́$ vistos em vasos do séc. V. Finalmente, de outro ângulo ( $\alpha$ v̇ò̀, 201), temos, de um lado, Apolo, como

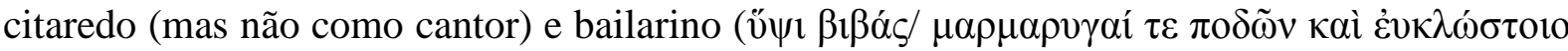

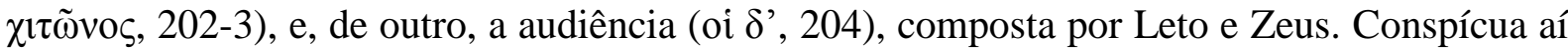

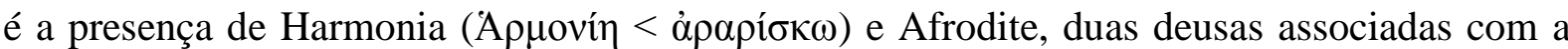
ordem e a coesão ${ }^{60}$.

Em duas outras passagens, o valor de $\chi \mathbf{0 \rho \rho o ́} \varsigma=\sim$ canto parece mais claro em virtude do uso de termos especializados construídos sobre o radical $\mu \varepsilon \lambda \pi-$, que denota, em sua interpretação mais esquemática, "canto-dança"61. Na seguinte passagem Hino Homérico a Hermes ( $v v .450-3)$, que eu segmentei em quatro unidades, (a), (b), (c) e (d), para tornar a análise mais clara, Apolo diz

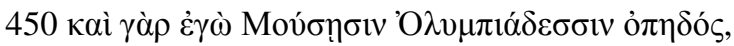

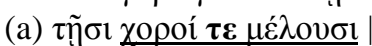

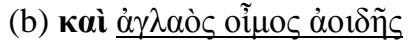

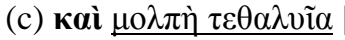

${ }^{60}$ RiCHARDSON (2010, pp. 112-14). Compare com Il. 1.603, onde Apolo acompanha as Musas que cantam, mas não dançam. $C f$. ainda com as cenas de dança e canto na écfrase do escudo de Aquiles em $I l .18 .567$ et seq. e 590 et seq, mais abaixo. Para uma revisão da imagética de Harmonia e sua relação com Afrodite, $c f$. CORRÊA (2008, p. 23 et seq.).

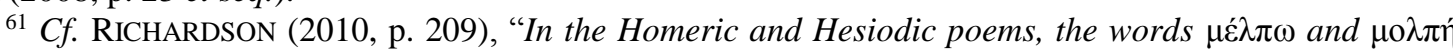

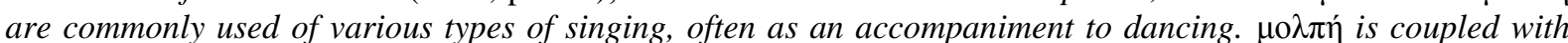
ó $\propto \chi \theta \mu$ ó $\varsigma$ at Il. 13.637, Od. 1.152, 23.145. Elsewhere it is not always clear whether it refers to song, or song and dance combined, or simply 'play': cf. Il. 1.472, 474, 18.606, Od. 4.19, 6.101, etc. The Alexandrian scholars debated about the range of meaning", grifo meu. $C f$. o LSJ e, principalmente, DELG, s.v. $\mu \varepsilon \dot{\lambda} \pi \omega$. 


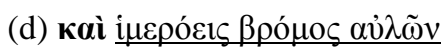

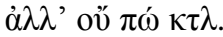

E ainda que eu seja das Musas do Olimpo o companheiro,

(a) às quais danças importam

(b) e a clara via da canção

(c) e o canto-dança virente

(d) e o sedutor rugido dos aulos,

mas nunca antes $(. .$.

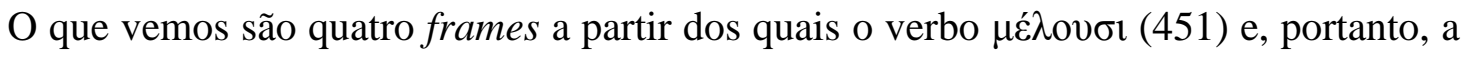
atividade nas quais as Musas tomam parte, é detalhado por meio de diversas frases

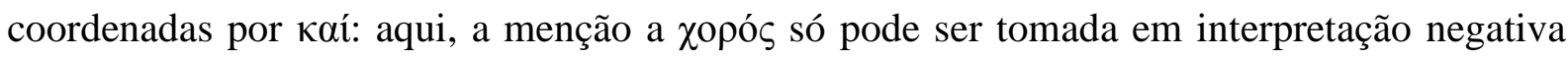
segundo a qual dança $=$ canto, isto porque a unidade (b) acrescenta, justamente, essa dimensão à noção mais esquemática de (a), isto é, as Musas não só dançam, elas também

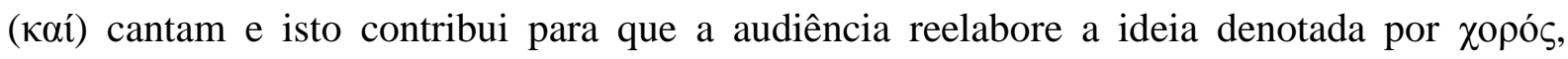
apenas ouvida no verso anterior e ainda ativa na memória de curto prazo. A unidade seguinte, (c), reintegra (a) e (b) por meio do substantivo $\mu$ o $\lambda \pi \eta ́$, que denota uma atividade na qual o canto $e$ a dança são concomitantes, ainda que em Homero o termo possa designar um outro tipo de dança além daquela dos coros cíclicos ${ }^{62}$. Finalmente, (c) acrescenta uma outra dimensão, aquela da musica aulética, acerca da qual só poderíamos especular. O importante aqui, no entanto, é notar como a fraseologia da passagem, por meio de uma série de cenas sobrepostas, é capaz de projetar as Musas em diferentes atividades como se elas acontecessem ao mesmo tempo. Sobre isso é interessante notar o que Bakker nos diz acerca da aditiva kaí:

(...) notamos que kaí pode ser usada para introduzir uma unidade na qual uma dada ideia é reformulada de maneira a salientar um aspecto diferente dela, marcando não tanto que algo novo está sendo focado, mas que aquela ideia que já estava em foco continua a estar e vai sendo expandida neste momento [grifo meu]. ${ }^{63}$

O que eu pretendo enfatizar com esses exemplos e essa brevíssima análise é que,

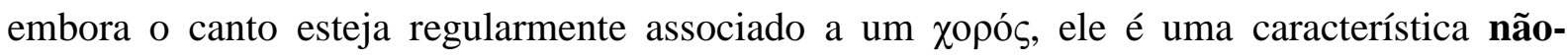
prototípica do mesmo, e que, portanto, qualquer tipo de inferência baseada em uma generalização do sentido e da função com os quais o termo é usado em diferentes períodos da literatura grega e em diferentes contextos pode ser conducente a uma série de equívocos.

De certa maneira, nosso entendimento do coro arcaico é imensamente influenciado pela desproporcional familiaridade que temos com o coro trágico, que parece conferir, em virtude mesmo da natureza da nossa recepção do drama, uma maior centralidade para o canto.

${ }^{62} C f$. sobre isso, a importantíssimo discussão de Pagliaro (1953, p. 19 et seq.).

${ }^{63}$ BAKKER (1997, p. 72). 
Obviamente, essa distorção advém do sabermos muito pouco sobre a natureza da dança do coro dramático, exceto que ela também deve ter sido uma parte extremamente importante da mimese trágica. Não se trata, portanto, sequer de uma transformação histórica pela qual o coro dramático tenha passado; trata-se, isto sim, de uma fatalidade na transmissão dos textos da tragédia, que preservou as canções do coro, mas não a sua coreografia.

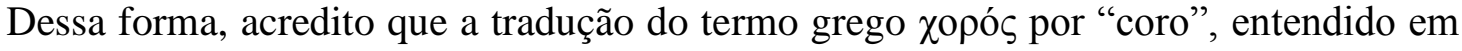
português como "coral", isto é, como "conjunto de pessoas que cantam trecho musical em uníssono ou em várias vozes" ${ }^{64}$, pode levar a mal-entendidos, já que seu sentido mais esquemático é, na verdade, o de um "corpo de baile" que eventualmente, mas nem sempre, canta. Consoante a isso, irei reservar o uso do termo "coro" para traduzir a performance de um grupo de indivíduos na qual a dança é o elemento obrigatório, ao passo que reservarei o termo "coral” quando for necessário especificar que o coro, além de dançar, também canta.

${ }^{64}$ Houaiss, s.v. "coro". 


\section{CAPÍtulo 6}

O MODO DA PERFORMANCE II: OS EPINÍCIOS

Hostility to theory usually means an opposition to other people's theories and an oblivion of one's own.

Terry Eagleton, Literary Theory: an introduction, p. xv.

NO QUE SE SEGUE, pretendo discutir algumas passagens mais relevantes para a controvérsia solo $x$ coral. Muito embora toda a minha argumentação reflita a bibliografia já citada sobre o assunto, sobretudo os trabalhos de Malcolm Heath, Mary Lefkowitz e Cris Carey, não pretendo detalhar seus argumentos, exceto naqueles casos que me pareçam importantes para minhas próprias considerações. Dessa forma, muito do que se segue reflete, além do meu diálogo com os participantes da controvérsia, também a minha leitura de Píndaro e o modo como entendo o seu fazer poético, tópicos de que tratei no primeiro capítulo dessa tese.

\section{O.1.1-23}

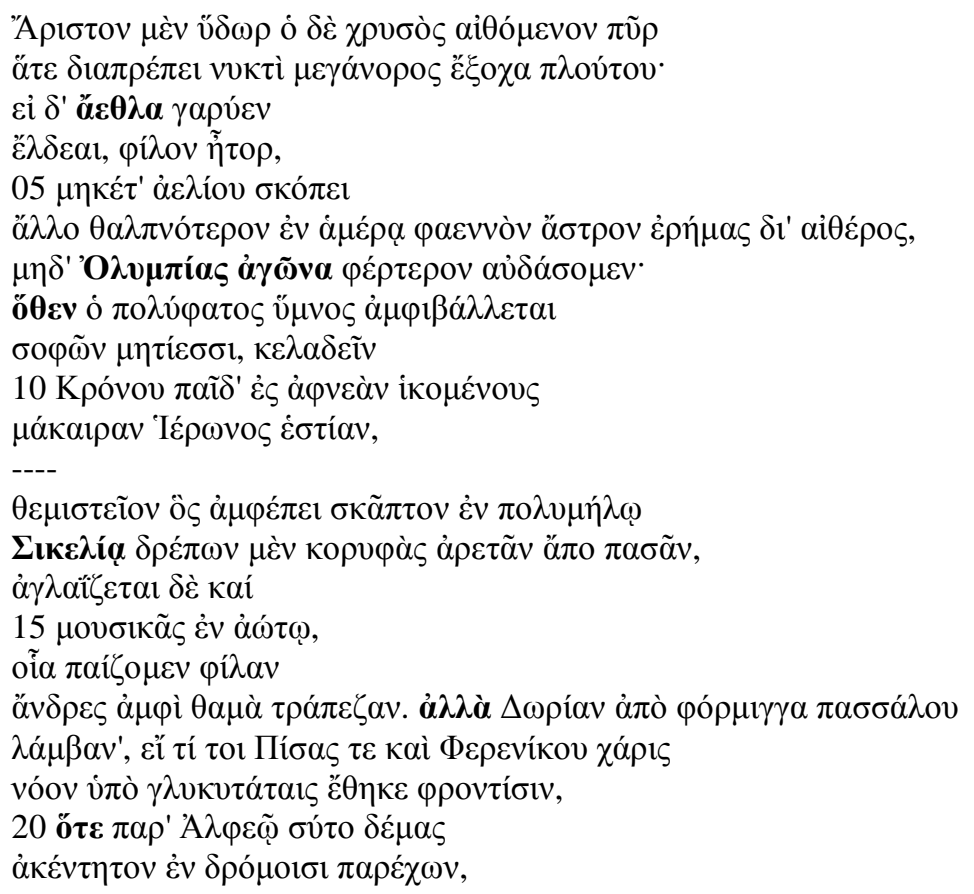




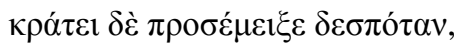

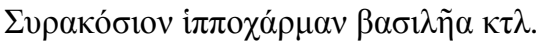

Excelente é a água; e este, o ouro, um fogo ardente, assim a noite vara, acume de magnânima fortuna.

E se as disputas garrir desejas, coração meu, já não mais busques do que o sol outro mais cálido, luzente astro, em pleno dia, através do ermo celeste; tampouco nós jogos superiores aos de Olímpia anunciaremos, donde o multiafamado hino é lançado sobre a mente dos sábios, vindos a cantar o filho de Crono, junto ao opimo e beatífico lar de Hierão,

que da lei detém o cajado na armentosíssima Sicília, e vai colhendo o sumo de todas virtudes, brilhando ainda em meio

à fina-flor da música a qual amiúde tocamos, barões em volta de uma mesa hospitaleira. Mas anda, a dórica forminge do gancho vai tirando, se acaso a ti de Pisa e de Ferênico alguma graça ao pensamento dulcíssimos cuidados inspirou, quando ao longo do Alfeu disparou um corpo nunca fustigado, nas raias exibindo-o, e com a vitória casou o seu senhor

que se alegra nos cavalos, o siracúsio rei etc.

Algo interessante acerca dessa passagem é que nenhum dos críticos que a evoca como evidência de uma performance solo ou coral leva em consideração que o comando dado à

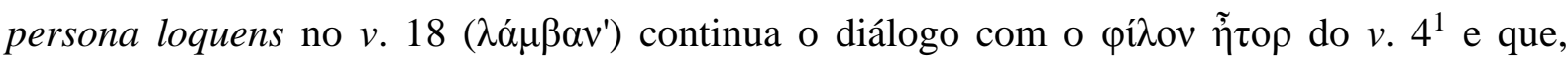
portanto, o imperativo poderia ser lido a partir do contexto mais geral da deliberação, lá expressa, acerca do que se deve cantar. Ao menos pelo que pude averiguar, essa interpretação nunca foi proposta. Por meio dela, porém, o comando do verso 18 poderia ser entendido como uma admoestação mais geral que diz respeito à uma ficção acerca da composição poética. Esse tipo de ficção, batizado por Carey de "subterfúgio oral" 2, é uma das principais marcas do estilo pindárico e serve, entre outras coisas, para salientar as dificuldades envolvidas na composição do louvor poético bem como para evitar que a transição de um tópico para outro se configure em uma espécie de lista que o poeta, à medida em que progride na trajetória do canto, vai marcando como concluída.

De fato, a ordem é dada como uma apódose à condicional do $v$. 18-19 e deve ser contextualizada a partir do enquadramento dado pelo advérbio ö $\tau \varepsilon$, que invoca o frame de um

\footnotetext{
${ }^{1}$ Assim GiLDERSLEEVE (1886, p. 131).

${ }^{2}$ CAREY (1981, p. 4 et seq.) e CAREY (1989, pp. 551-3).
} 
evento passado ( $v v .20-22)$, no qual a persona loquens se projeta $\left(\tau 0 \mathrm{l}^{3}\right)$ no momento da corrida, ativando na consciência da audiência a vitória olímpica obtida na raia em Pisa, o que serve para, ao mesmo tempo, esclarecer para o público as condições nas quais a mesma foi obtida, mas sobretudo como um artifício etiológico que explica a realidade da ode ora cantada, ligando o hic et nunc da performance ao momento de glória que ela pretende imortalizar. O frame dos vv. 19-22 fornece, além do mais, uma ponte para que se retorne ao louvor de Hierão, por meio da ativação promovida por $\delta \varepsilon \sigma \pi$ ó $\alpha \alpha$, bem como prepara a passagem para a primeira versão do mito, nos $v v$. 25-27, através de uma apositiva relativa (

A meu ver, isso implica necessariamente em que o poeta não está ordenando ao seu coração para que tome a lira do cravo para cantar o epinício em questão, mas para compô-lo. Em outras palavras, o imperativo não diz respeito ao momento da performance, mas ao da

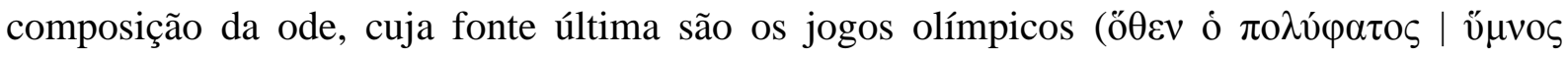
$\dot{\alpha} \mu \varphi 1 \beta \alpha ́ \lambda \lambda \varepsilon \tau \tau \alpha 1,8)$. Obviamente não se trata de uma composição extemporânea e sim de uma ficção, como já salientamos. No entanto, ela não causaria um impacto menor em uma audiência, que, por meio desta ficção, poderia se projetar, junto com o poeta, para o momento de criação da canção, cujo momento de inspiração coincide com a espetacular vitória celebrada pelo poeta. Uma ideia semelhante é expressa por Baquílides em seu encômio a Alexandre, filho de Amintas (fr. 20b):

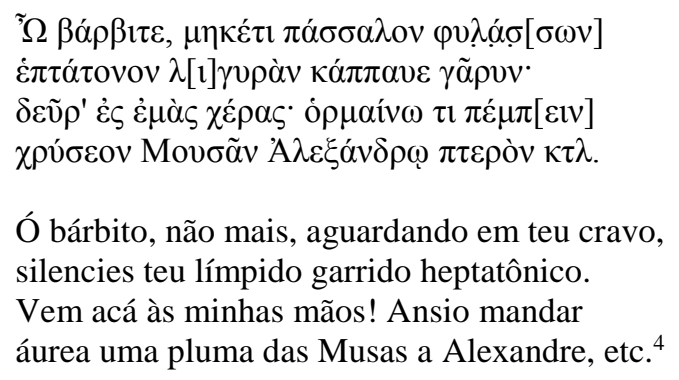

Píndaro, nas duas primeiras estrofes, elabora uma estrutura quiástica, por meio da qual admoesta seu coração a que (1) não componha louvores a outros jogos que não aos de

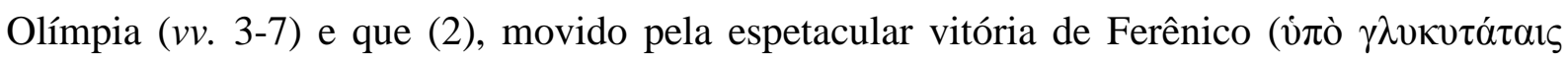

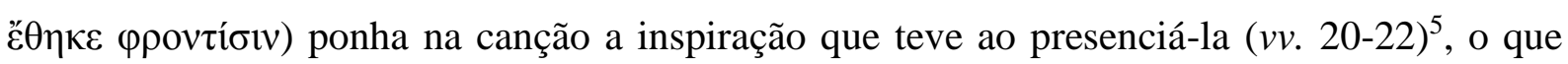

${ }^{3}$ Cf. D.E. GERBER (1982, p. 44), "here the pronoun, not the particle".

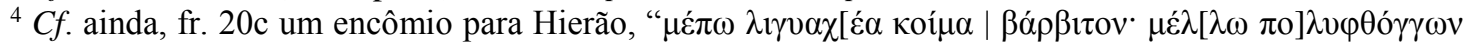

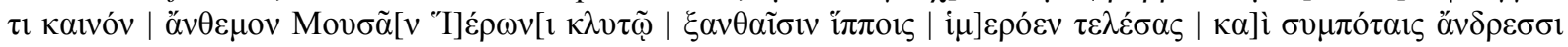
$\pi\left[\varepsilon^{\prime} \mu \pi \varepsilon v \kappa \tau \lambda ”\right.$.

${ }^{5}$ Sobre a possibilidade de o próprio Píndaro ter sido não apenas o executante da ode, como de ter estado presente na vitória, em Olímpia, $c f$. o Capítulo 4. 
faz por meio do imperativo $\lambda \alpha ́ \mu \beta \alpha v \varepsilon$ (18). Há um processo de alternância de frames ao longo da trajetória da canção ${ }^{6}$ que dirige, passo a passo, o foco da audiência do esplendor dos jogos olímpicos, para o esplendor da corte de Hierão (via hino) e, de lá, de volta para o momento da vitória, até retornar, novamente, ao laudandus (v. 23). De qualquer maneira, seria improvável que Píndaro (ou, na verdade, quem quer que se postule como executante da ode) estivesse exortando a si mesmo a tomar a forminge para fazer o acompanhamento musical de uma ode que ele já está cantando, a menos que, como notam Lefkowitz e Heath, devamos supor que o poeta "construía suas fícções sem qualquer respeito à verossimilhança"7 . Gerber percebeu uma parte dessa estratégia narrativa ao notar, em seu comentário a essa passagem, que

Está claro que Píndaro deliberadamente construiu os $v v .17$ et seq. de maneira que eles formem um quiasmo com os vv. 3 et seq. A primeira passagem começa com uma condicional e se conclui com imperativos de auto-apóstrofe, ao passo que a segunda começa com o mesmo tipo de imperativo e conclui-se com uma condicional. Ademais, ambas apódoses contêm referências à canção ( $\alpha$ v̉ó́ $\sigma 0 \mu \varepsilon v$ e $\underline{\varphi} \rho \mu(\gamma \gamma \alpha)$ e à Olímpia. O propósito dessa simetria é dirigir a atenção da audiência para o fato de que Píndaro está voltando aqui ao ponto de onde ele tinha se desviado, ao final do priamel de abertura, isto é, que ele concluiu a seção sobre o louvor mais geral a Hierão. Do louvor dos jogos olímpicos, Píndaro se prepara para louvar a vitória de Hierão naqueles jogos ${ }^{8}$.

Cenas nas quais a persona loquens se descreve em pleno ato de compor a ode que, de fato, está cantando não são raras nos epinícios ${ }^{9}$ e, se pudermos equacionar essa persona ao próprio poeta, precisaremos inclusive reavaliar a função do assim chamado futuro encomiástico $^{10}$, explicando-o por meio de estratégias narrativas como essa da $O$. 1 . Tomemos, por exemplo, esta passagem da N. 9.1-5, para Crômio do Etna, um dos generais de Hierão, estruturalmente muito semelhante aos $v v .12-20$ da $O .1$ :

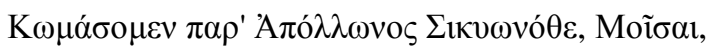

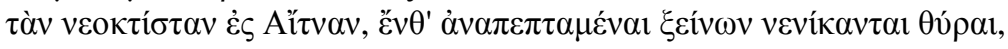

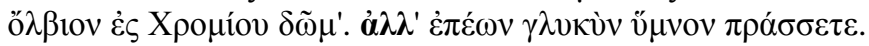

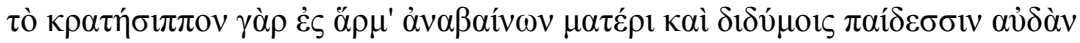
$[\mu \alpha v v ́ \varepsilon 1$

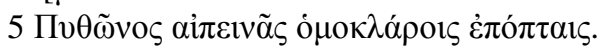

${ }^{6}$ Um termo usado na épica para se referir à técnica narrativa do aedo homérico. A ideia de que o poeta percorre um caminho ao compor/ cantar a canção faz parte, contudo, da conceitualização arcaica segundo a qual a CANÇÃO É UM CAMINHO. Cf. BAKKER (1997, p. 61), "What I think should be stressed, however, is that epic notions of path and space envolve more than just a poetic metaphor. Path and space are realities in terms of which the presentation of the epic tale is viewed by the performers and their audiences, grifo meu."

${ }^{7}$ HEATH e LEFKOWITZ (1991, p. 181)

${ }^{8}$ D.E. GERBER (1982, pp. 43-4), grifo meu. 20b.1-3.

${ }^{9} C f$. por exemplo, a estrutura praticamente idêntica da $N .9, N .3 .10-11, I$. 1 etc. ainda, Baquílides, fr.

${ }^{10}$ Assim também, mas por um raciocínio diverso, HeATH e LEFKOWITZ (1991, p. 174). 
Celebremos na casa de Apolo em Sicião, Musas,

rumo à recém fundada Etna, onde escancaradas estão as vitoriosas portas aos

[hóspedes,

de Crômio rumo à abençoada casa. Eia vamos, preparai um doce hino de

[palavras

5 Pois montando na carruagem de cavalos vitoriosos, ele solicita a voz à mãe e aos

filhos,

partícipes protetores da íngreme Pítia.

Note que aqui também há dois frames, ou, mais precisamente, um frame e um sub-frame, relacionados por meio da partícula $\alpha \lambda \lambda \alpha$ : um que projeta a persona loquens no futuro por meio do jussivo $\kappa \omega \mu \alpha ́ \sigma o \mu \varepsilon v^{11}$, mas que se refere, pragmaticamente (porque a ode já está em execução), a uma cena passada, e outro que, também por meio de um imperativo, solicita às Musas que componham a canção. Ao passo que o primeiro frame é situacional, ou seja, ele estabelece o pano-de-fundo da ode ao apresentar seus elementos principais (onde? para onde? quem?), o segundo, ao elaborar sobre o processo criativo, orienta a atenção do público para o que virá ${ }^{12}$. Em certa medida, ele também cria a ilusão de uma composição extemporânea, ao se referir ao momento de criação da ode como um processo quando ela já está, de fato, pronta. É uma estratégia idêntica à empregada nos $v v \cdot 12-20$ da $O$. 1, exceto que lá a figura empregada, o quiasma, torna a passagem entre frames mais complicada. No entanto, enquanto aqui é o contexto da festa que motiva o pedido pela canção, lá é o da cena festiva que urge a persona loquens a contribuir também com o seu ư $\mu v o \varsigma$ e, dessa forma, integrar-se aos "barões à volta da mesa hospitaleira de Hierão".

Chris Carey, entre outros ${ }^{13}$, ao falhar em perceber uma estratégia comunicativa que é típica da poesia oral, o quiasmo, usado para organizar e fazer a audiência avançar na trajetória narrativa, ao mesmo tempo em que seleciona o objetivo a ser alcançado ${ }^{14}$, equivoca-se ao ver o comando de Píndaro no v. 18 como simultâneo à performance e, portanto, argumenta de

${ }^{11}$ Aqui o contexto praticamente garante um subjuntivo em vogal curta, como na épica. Entretanto um futuro seria igualmente cabível. Outros futuros em vogal curta aparecem na $O .6 .3$ e $24,7.3 ; P .11 .10 ; N .11 .13$ etc. $C f$. HUMMEL (1993, p. 265).

12 BAKKER (1997, p. 88) descreve o processo da seguinte maneira: “ A unit verbalized after an orienting statement may be said to be added to it. (...) In terms that are less metaphorical than they may seem, we might speak of a close-up: the speaker stands still for a moment on the path of speech to look more closely on a scene, or the speaker focuses on how the scene came about, explaining it and thus providing a basis for what is next in the story.", grifo meu.

${ }^{13}$ Note que o uso do imperativo presente, ao invés do aoristo, indica o início de um processo que liga a ordem dada à atividade denotada pelo verso, que virá a seguir, assim HUMMEL (1993, pp. 259-60). Uma vez que o canto já começou, a única explicação para o uso do imperativo presente seria supor, como faz BOECKH (1821, p. 106), CAREY (1989, p. 560) e HEATH e LEFKOWITZ (1991, p. 181), que é apenas nesse ponto que a lira começa ser tocada, o que me parece altamente implausível, até mesmo em virtude das evidências dos versos iniciais da $P .1$, onde as $\dot{\alpha} v \alpha \beta$ o $\lambda \alpha i$ da lira sinalizam o início da canção e a precedem.

${ }^{14}$ Cf. BAKKER (1997, pp. 100-1), “(..) figures as chiasmus (...) and hysteron proteron (...) are not by themselves a matter of style in the sense of literary embellishment used by philologists; they are quite normal in living speech, where they result from a natural sequence in the flow of ideas and their verbalizations". 
maneira errônea por uma ficção retórica (um "ato performativo", v. mais abaixo) promovida por um coro. Para tanto ele aduz como exemplos as $P$. 10.1 e $N .3 .26-32^{15}$, que, segundo ele, seriam "comprovadamente" corais, e nas quais, no entanto, o mesmo tipo de "auto-apóstrofe" é empregado, daí concluindo que

esta não é uma evidência confiável quanto à performance. Deveríamos, além do mais, notar que Píndaro descreve a si mesmo como um participante físico na celebração, mesmo quando ele nos dá bons motivos para acreditar que não estava presente na performance, como também o faz Baquílides. Deveríamos, portanto, ter cuidado em tomar este comando de uma maneira excessivamente literal. ${ }^{16}$

$\mathrm{O}$ argumento de que Píndaro não estava presente no momento da performance dos seus epinícios já foi discutido anteriormente ${ }^{17}$ e, como vimos, ele não se baseia em evidências contundentes, embora não possa ser descartado. Por ora, basta salientarmos que, se a hipótese aventada aqui, ou seja, de que a exortação do $v$. 18 deve ser tomada como se referindo ao momento da composição da ode, ao invés do de sua performance, seria pouco plausível que um coral pudesse enunciá-la. Ainda, mesmo que se argumente contra essa hipótese, não vejo como um coral pudesse deliberar acerca da composição poética usando o homérico "meu

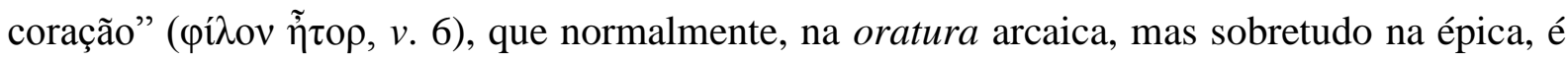
empregado em momentos em que uma decisão ou uma escolha importante se apresenta ao personagem, como no paradigmático exemplo da $I l .1 .188$-90, em que Aquiles pondera com o

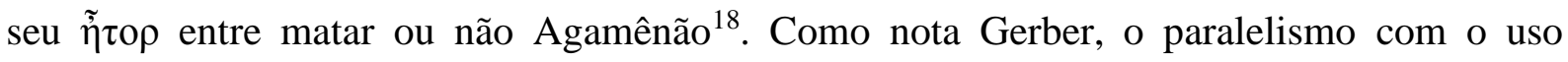
homérico e a proximidade com o $\tilde{\varepsilon} \lambda \delta \varepsilon \alpha 1$, no mesmo verso, praticamente asseguram uma leitura de pínov em seu valor épico como possessivo e, assim, a expressão seria o equivalente de Пív $\delta \alpha \rho \varepsilon^{19}$.

Mesmo se quiséssemos descartar a hipótese levantada acima, ainda precisaríamos explicar o banquete musical que o poeta imagina ou recorda e no qual se inclui ( $\pi \alpha i \zeta \zeta \mu \mu \varepsilon v-\mathrm{e}$ também uma audiência de colegas?) na cena dos $v v .14-17^{20}$. Krummen ${ }^{21}$ já argumentou por um cenário no qual essa ode seria executada em um banquete e essa hipótese parece-me bastante plausível se considerarmos toda a imagética da $O$. 1 , suas referências à música, à

${ }^{15} C f$. minha discussão dessa odes mais abaixo, pp. 213 e 217.

${ }^{16}$ CAREY (1989, p. 560).

${ }^{17}$ Cf. Capítulo 4.

${ }^{18}$ cf. S.D. Sullivan (1995); S. D. Sullivan (2010)) para estatísticas; ela, ao contrário de D.E. GERBER (1982, pp. 16-17), inclina-se mais por um significado não possessivo de pírov.

19 D.E. GERBER (1982, pp. 16-17), que nota, ainda, que o uso da expressão no vocativo é o único exemplo em toda a literatura grega.

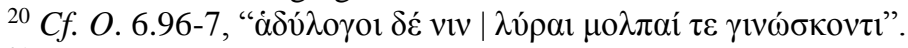

${ }^{21}$ KRUMMEN (1990, p. 155 et seq.). 
comida, à bebida, aos comportamentos recomendáveis ou execráveis durante o banquete e às suas respectivas consequências. Além disso, a voz da persona loquens, fortemente marcada na

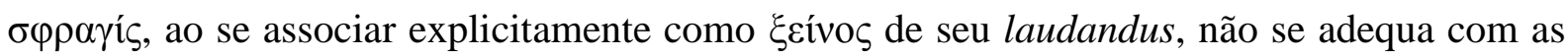
convenções dedutíveis a partir de poemas claramente corais ${ }^{22}$.

\section{O. 6.87-92}

A próxima ode em que, aparentemente, estaria implicada não só uma performance coral mas também uma referência ao mestre-do-coro ou ao proxy encarregado de executar a ode no lugar de Píndaro é a $O .6$, da qual citam-se mormente apenas o trecho a partir do $v .87$, quando o contexto no qual ele está inserido (vv. 82-100) é extremamente importante:

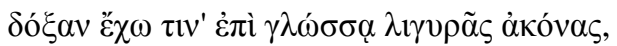

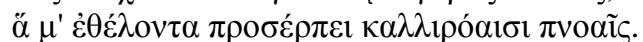

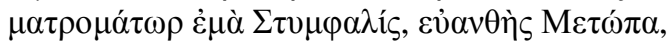

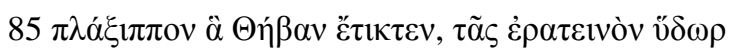

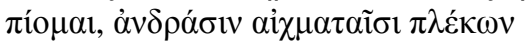

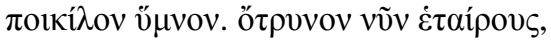

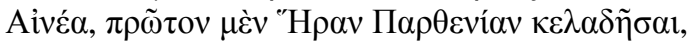

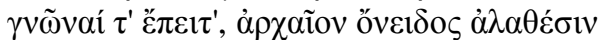

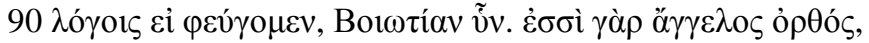

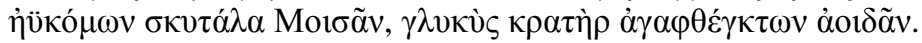

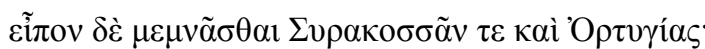

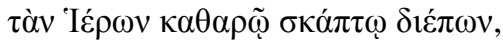

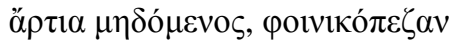

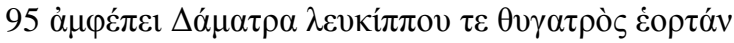

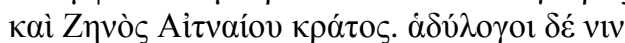

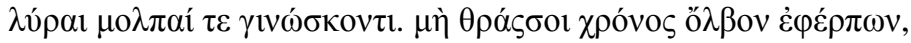

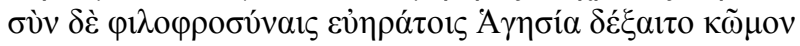

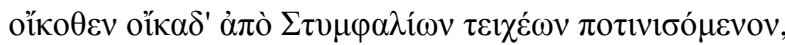

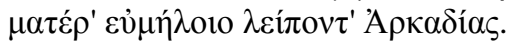

Tenho a impressão de uma estrídula pedra de amolar sobre minha língua a qual me arrasta, se eu quiser, nas belas ondulações dos meus trinados. A mãe de minha mãe era estinfália, formosa Metopa,

85 que gerou Tebas cavaleira, de cuja amável água beberei, tecendo para varões lanceiros hinos multivariegados. Incita agora os camaradas, ó Enéias, primeiro a Hera Juvenil anunciar em canto, e em seguida a descobrir se do antigo insulto, por meio de veras 90 palavras, escaparemos, o tal "porco beócio". És, pois, reto um mensageiro, o cetro das belícomas Musas e doce cratera de retumbantes canções.

Eu disse que lembraria de Siracusa e de Ortígia, que Hierão, administrando com imaculado cetro,

${ }^{22} C f$. Capítulo 3. 
cioso das coisas justas, à roxipedália

Demáter reverencia e à festa da filha cavaleira d'alvo potro

e ao poder de Zeus do Etna. Dulcíloquas

conhecem-lhe as liras e as cantilenas. Vindouro o tempo a ventura não lhe

[turbe

e que com amável generosidade receba a celebração de Hagésias

de uma casa a outra casa, desde os muros do Estínfalo se achegando, deixando a mãe da Arcádia de belos rebanhos

Há muitas incertezas e enigmas nessa passagem, muitos deles já discutidos à exaustão por outros comentadores, inclusive no âmbito da controvérsia solo x coral. Não irei explorar todos os argumentos e contra-argumentos em detalhes. Uma coisa, no entanto, parece-me clara: o comando de Píndaro para que Eneias (quem quer que ele seja) "incite os camaradas" a cantar Hera Parthenia não pode se referir à própria canção que está sendo executada simplesmente porque este hino nunca se materializa nesta ode ${ }^{23}$.

Chris Carey, face a essa dificuldade, por meio de uma análise retórica excessivamente convoluta, que, aliás, trai o seu próprio "princípio de economia" 24 , vê no comando de Píndaro um "ato performativo", com o que quer dizer que o hino a ser cantado a Hera cumpre-se no momento em que é mencionado e que, portanto, esse louvor é, de fato, a própria ode ${ }^{25}$. Isso implicaria assumir, no entanto, que o epinício estaria sendo executado pelos é $\tau \alpha$ ípor de Eneias ao quais se alude no $v$. 87, e que esses, incorporando a persona de Píndaro, estariam, por sua vez, exortando Eneias para que, por sua vez, os exortasse a cantar a ode que eles já estão

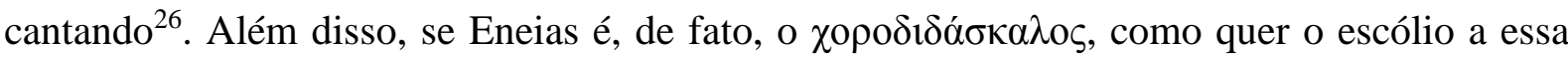
passagem, por que o coral, na voz de Píndaro, dirigir-se-ia a Eneias para que ele fizesse algo que, de fato, ele já teria feito, i.e., treiná-los para a execução da ode? Ou, ao invés de um

${ }^{23}$ A opinião do $\Sigma$ 148a de que Eneias seria o mestre-do-coro não pode ser verificada, além de ser inverossímil (nenhuma fonte é apresentada que a corrobore), claramente ficcional (baseada numa anedota semelhante acerca da voz de Sófocles, na Vita, 4) e provavelmente anacronística (os epinícios são vistos do ponto de vista das práticas empregadas no treinamento de coros trágicos). Não cabe detalhar o argumento aqui porque ele já foi devidamente desenvolvido por LEFKOWITZ (1991, pp. 195-7).

24 CAREY (1989, p. 545), "that in reconstructing a situation described or adumbrated by Pindar or Bakchylides an economical interpretation (by which is meant one which does not require the reader to supply facts not mentioned in the text) is to be preferred, grifo meu.". Crítica já feita por HEATH e LEFKOWITZ (1991, p. 182) na resposta ao seu artigo.

${ }^{25}$ Carey segue aqui a influente opinião de SLATER (1969a, p. 89), "the praise of Hera, and the recognition of the falsity of the ancient taunt have been accomplished in the same moment as the desire for them was expressed, as, e.g., P. 3. 78, Bacch. 5. $179 f$.".

26 Esse problema já havia sido notado pelos escoliastas e causou perplexidade inclusive nos comentadores modernos, $c f$. SLATER (1969a, p. 88 et seq.). 


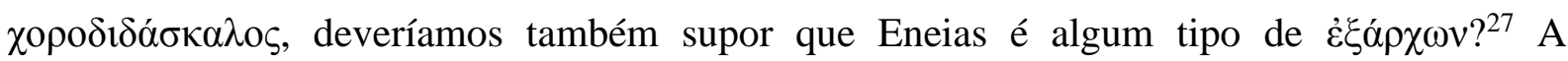
despeito do quer Carey, não há nada de "simples" ou "econômico" em sua explicação 28 .

Há um problema mais grave, contudo, na tentativa de Carey em tentar explicar as ordens dadas por Píndaro a Enéias como um "ato performativo", algo que foi ignorado pelos seus principais críticos. O uso que Carey faz do termo "ato performativo" - sem, aliás, explicar o que entende por ele - repercute uma opinião de W. J. Slater em seu influente artigo de 1969 sobre o futuro em Píndaro ${ }^{29}$, no qual este último, em certa medida acertadamente, identifica o valor ilocucionário que o poeta faz desse tempo verbal em seus epinícios. $\mathrm{O}$ próprio Slater foi, por sua vez, provavelmente influenciado pela conferência de J. L. Austin sobre os atos da fala (speech atcs) proferida em Harvard em 1952 e, posteriormente, publicada pela OUP, um pouco antes da publicação do artigo de Slater, em $1962^{30}$. Entretanto, nos trinta anos que separam o trabalho pioneiro de Austin do artigo de Carey, as observações do eminente filósofo sobre os atos da fala foram bastante modificadas e reformuladas por uma série de pesquisadores, chegando-se a abolir, por exemplo, a dicotomia entre enunciados constativos e performativos em favor de uma análise mais sofisticada dos atos ilocucionários, como aquela vista no trabalho desenvolvido por Vanderveken e Searle ${ }^{31}$.

Assim, de acordo com a definição de Searle ${ }^{32}$, que atualmente goza de um certo consenso, um ato ilocucionário só pode ser caracterizado como performativo se ele contém uma expressão que nomeia o tipo de ato da fala, o que, no caso em questão seria, "eu te ordeno (ordenarei) a incentivar (dar por incentivado) os camaradas, Eneias". No trecho acima, contudo, temos um imperativo na segunda pessoa, o que viola a própria definição de ato ilocucionário performativo, já que não se pode fazer com que alguém faça alguma coisa simplesmente por ordenar que esta pessoa a faça.

Assim, se considerarmos orações do tipo,

(a) Incentiva os camaradas!

(b) Eu ordeno que incentives os camaradas!

(c) Eu incentivo/incentivarei os camaradas.

${ }^{27} C f$. a hipótese de Rutherford à p. 154.

${ }^{28}$ CAREY (1989, p. 195), "The simplest explanation of Olympian 6. 87-92 is that Aeneas' "companions" perform Olympian 6."

${ }^{29}$ SLATER (1969a).

30 J. L. AUSTIN e URMSON (1975).

${ }^{31}$ VANDERVEKEN E KUBO (2002).

${ }^{32}$ SEARLE (2002, pp. 86-7), "These utterances, and only these, are correctly described as performative utterances. On my usage, the only performatives are what Austin called 'explicit performatives.' Thus, though every utterance is indeed a performance, only a very restricted class are performatives, grifo meu". 
(d) Por meio disto eu ordeno que incentives os camaradas.

ficará evidente que o ato da fala descrito ou expresso só pode ser levado a cabo pela própria enunciação em (b), (c) e (d), e, neste último caso, apenas para o ato descrito pela oração principal, não para a ação da subordinada. Em (a), porém, não podemos postular um ato ilocucionário da fala com força performativa porque o locutor não é capaz de garantir a realização do que foi requisitado a outrem. Em outras palavras, (b), (c) e (d) tem "autogarantia" no que tange à sua força ilocucionária, ao passo que (a) não. Por meio disso, vemos que, colocado de uma maneira mais simples, um ato performativo da fala é aquele em que o dizer é fazer. Quando, no entanto, o fazer independe daquele que enuncia o comando, como poderíamos ter um ato performativo $?^{33}$ Esse é o caso, na verdade, com os imperativos, já que dar uma ordem a outrem não é realizar a ação implicada pela ordem.

Não há, no trecho em questão, que Carey e Slater veem como um "ato performativo", nada que indique que a proposição implicada pela sentença "incentiva os camaradas" esteja sujeita a algum tipo de força ilocucionária capaz de transformar a realidade a fim de fazê-la

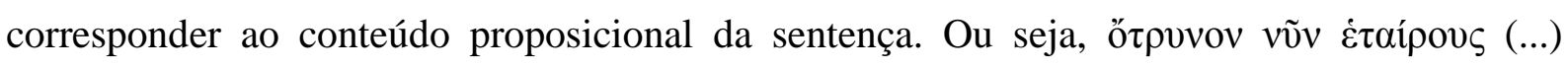
$\kappa \varepsilon \lambda \alpha \delta \tilde{\eta} \sigma \alpha \iota$ (...) $\gamma v \tilde{\omega} v \alpha \iota$ não é uma “declaração" no sentido searleano do termo ${ }^{34}$.

Por fim, mesmo no trabalho original de Austin, esse chamava a atenção para o fato de que todas as sentenças performativas têm, como uma de suas características principais, verbos na primeira pessoa do singular do presente do indicativo ativo. Esse não é o caso, contudo, para o trecho da ode sob análise. Além do mais, em todos os paralelos citados por Carey e Slater $^{35}$ como atos ilocucionários performativos que comprovariam sua interpretação da passagem, a primeira pessoa (sing. ou pl.), um pronome dativo, a voz passiva ou um modo impessoal do verbo é usado, em consonância com a opinião de Austin, mas sem qualquer relação com os $v v$. 87-93. Evidentemente, pode-se argumentar que essa aplicação tão rígida da teoria não faça justiça à essência dos argumentos de Carey e Slater, a saber, de que o comando de Píndaro é meramente retórico. No entanto, parece-me que, se o uso de um determinado conceito não está embasado em uma definição científica do mesmo, mas é, por outro lado,

33 cf.SEARLE (2002, p. 88).

${ }^{34}$ Sobre o conceito de "força ilocucionária”, cf. SEARLE (2002, pp. 90-1), "Declarations (...) are speech acts (...) where the illocutionary point of the speech act is to change the world in such a way that the propositional content matches the world, because the world has been changed to match the propositional content. In a declaration of the form $F(p)$ the successful performance of the speech act changes the world to make it the case that p.". F é a "força ilocucionária".

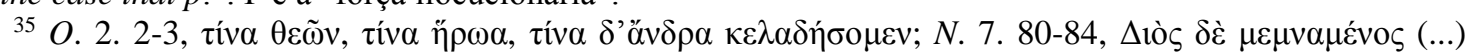

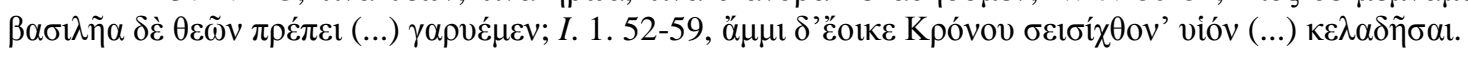


apresentado sob esta forma, ele serve apenas para dar ares de credibilidade a uma afirmação que é, em última análise, apenas uma opinião pessoal e, além do mais, arbitrária.

É preciso concluir, portanto, que, muito embora não haja nenhuma evidência explícita em favor de uma performance solo, esta passagem também não pode ser evocada como "prova" de uma performance coral, uma vez que os imperativos enunciados pela persona loquens poderiam, de fato, estar se referindo a elementos ou circunstâncias externas à ode. De qualquer maneira, eles não são atos da fala com força ilocucionária performativa.

\section{O. 14.13-18}

Sobre essa ode, que citamos na íntegra no capítulo anterior ${ }^{36}$ e que, portanto, eu me escusarei de reproduzir aqui novamente, Heath diz que "o $\kappa \tilde{\omega} \mu \varsigma_{\varsigma}$ é visto, mas o que é ouvido é o canto, que é o que 'eu' faço, não o que 'este $\kappa \tilde{\omega} \mu \varsigma_{\varsigma}$ faz",37. Carey, em sua primeira resposta, argumenta que o yó $\rho$ do $v .17$ refere-se a toda a sentença precedente, incluindo

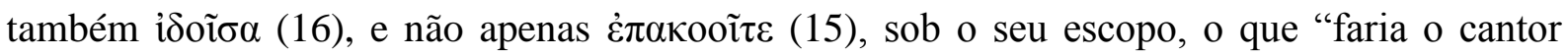

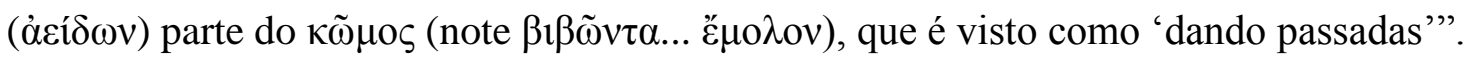

Apesar disso, eu não vejo porque o cantor, em uma ode claramente processional, não poderia se ver como parte do $\kappa \tilde{\omega} \mu$ os. Na verdade, muitas das análises dos que postulam uma

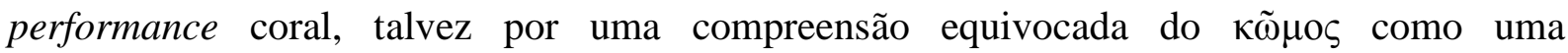
"comissatio" ou como um "revel", e não, simplesmente, como uma festa, móvel ou estacionária, demonstram uma incapacidade em perceber que, sob a hipótese solo, o cantor $\mathrm{faz}$ parte do $\kappa \tilde{\omega} \mu \mathrm{s}$; é isso, ademais, que a persona loquens deixa transparecer quando usa formas

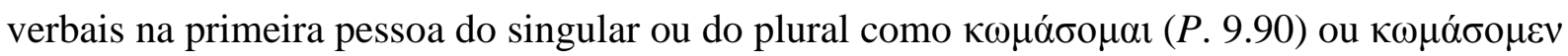

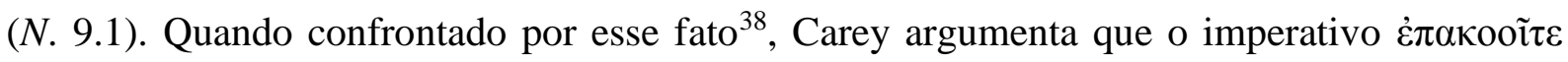

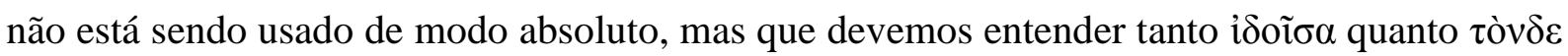

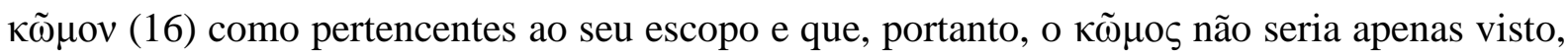
mas também ouvido.

De um ponto de vista local, numa análise atomística da ode, esse argumento poderia fazer algum sentido, muito embora eu duvide de que, fosse o contexto outro que não o de se decidir, ou não, por um ou outro tipo de performance, uma tal interpretação da sintaxe nesses

\footnotetext{
${ }^{36}$ Cf. pp. 113 et seq.

${ }^{37}$ HEATH (1988, p. 187).

${ }^{38} \mathrm{Na}$ resposta de HEATH e LEFKOWITZ (1991, p. 183 e n. 33).
} 
termos pudesse ter sido proposta ${ }^{39}$. Seja como for, uma consideração adequada dos versos da primeira estrofe pode nos assegurar de que a leitura de Carey não se apresenta tão satisfatória como ele nos quer fazer parecer.

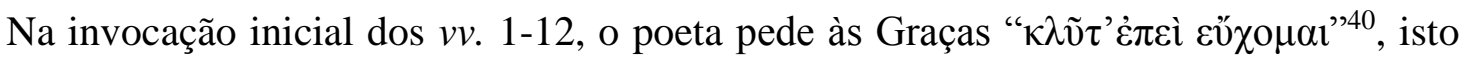
é, "ouvi, posto que eu rezo", e o que ele pede é justamente que estas confiram "graça" à canção, apelando justamente às deusas tutelares do canto e da dança, como deduzimos dos versos imediatamente subsequentes, subordinados a yóp, e que dão o motivo da prece: "pois com o vosso auxílio [бúv comitativo] tudo de aprazível e doce vem aos mortais" $(5-6)^{41}$. Não há um motivo plausível, portanto, para postular uma mudança de sujeito quando a persona loquens diz, na segunda estrofe, $v v$. 15-18, “mas agora ouvi, e especialmente tu, Festa, que

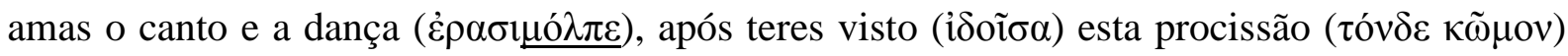
numa auspiciosa ocasião, com graça a avançar. Pois numa lídia harmonia a Esópico, em bem

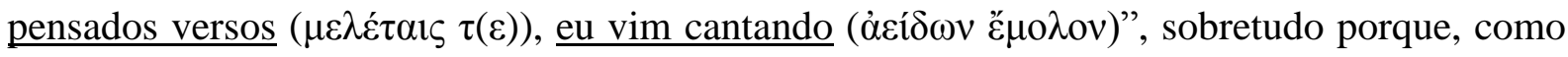
vimos anteriormente, não é usual que a persona loquens dos poemas corais discorra sobre a composição das canções ${ }^{42}$.

\title{
P. 1
}

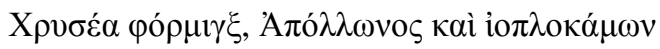

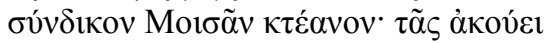

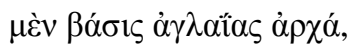

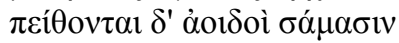

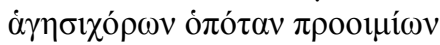

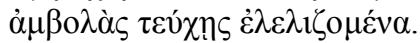

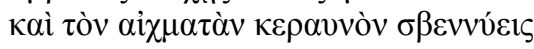

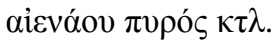

Áurea forminge, de Apolo e das negrícomas

${ }^{39}$ Como de fato não o foi por Carey em seu primeiro artigo. Apenas após ver seu argumento rebatido por Heath e Lefkowitz é que ele recorreu a esta leitura do verso, ademais não chancelada por qualquer outro comentarista ou tradutor.

40 VERDENIUS (1987, p. 89), citando a $O .12 .1$, em que a persona loquens utiliza o verbo $\lambda i ́ \sigma \sigma o \mu \alpha 1$, chama a atenção para os resultados obtidos por A. Corlu (Recherches sur les mots relatifs à l'idée de prière

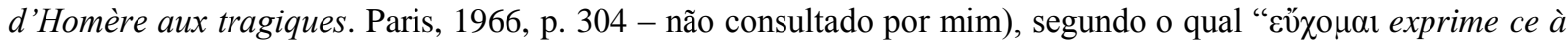
quoi l'on s'engage par un voeu ou ce qu'on demande par un voeu, en parlant de soi (...)”, grifo meu. A esse respeito, $c f$. também ADKINS (1969).

${ }^{41}$ Assim também VERDENIUS (1987, p. 109), "That the first person refers to the poet, not the chorus, has been shown by M. Lefkowitz, HSCP 64 (1963), 195 ff. [= LEFKOWITZ (1991, p. 25 et seq.)], espec. $202-03$ [= 33-4]. What the poet is praying for has to be deduced from the next sentence, where yó motivates the contents of

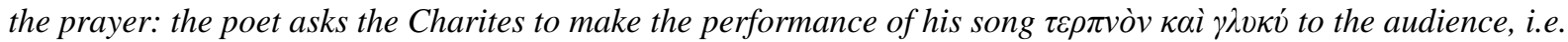
successful".

${ }^{42}$ Sobre o sentido de $\mu \varepsilon \lambda \varepsilon \dot{\tau} \tau \alpha 1 \varsigma, c f$. VerdeniUs (1987, p. 122). $C f$., além dos exemplos aí listados o vĩò

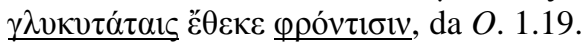




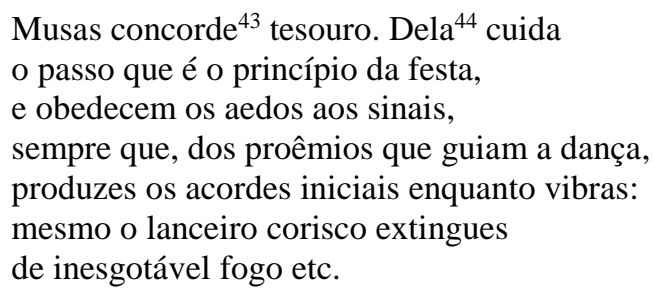

É difícil entender como esta passagem possa ser usada como evidência de uma performance coral dos epinícios. A despeito da certeza de $\mathrm{Carey}^{45}$, não há nenhuma menção explícita a algum tipo de canto coral nesses versos, muito embora uma dança coral possa estar

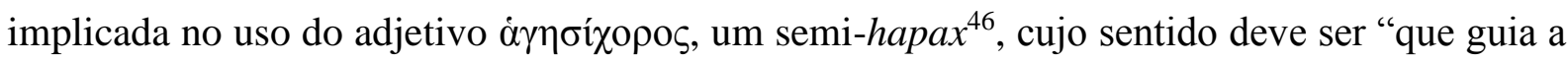

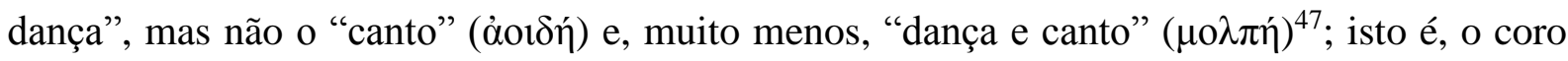
não é um coral pois, como já vimos, em seu sentido mais esquemático, isto é, na ausência de

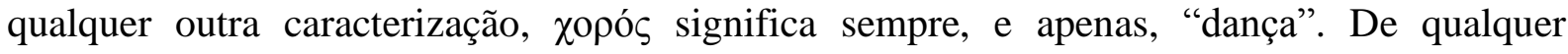
maneira, além desse proêmio ser apenas uma generalização acerca da forminge ${ }^{48}$ e de seu uso, ele descreve uma cena idealizada no Olimpo, o que reforça, na verdade, uma interpretação solo da performance dos epinícios, por se associar paradigmaticamente com outras passagens em que o aedo, como sub-rogado terreno de Apolo, é perfilado como um cantor solo contra o pano-de-fundo de um coro que dança, porém, até onde podemos inferir dos textos, pode, em alguns casos, não cantar.

${ }^{43}$ As Musas nunca são, até onde sei, descritas com a forminge de Apolo em mãos, por isso não é de se

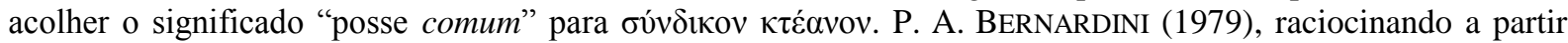

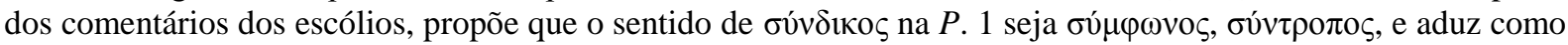

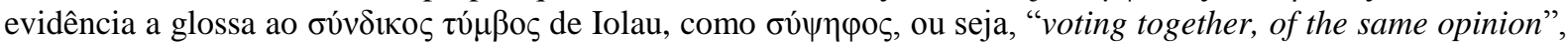

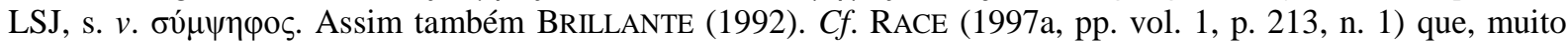
embora seguindo a tradução comum, observa "or perhaps possession that speaks on their behalf. The normal

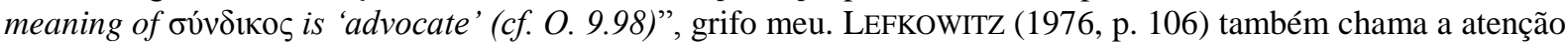
para o epíteto pouco usual aqui e salienta a conotação legal do termo.

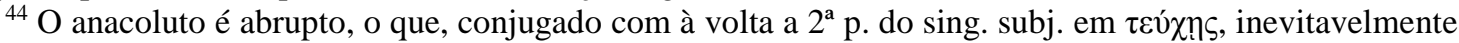
nos faz suspeitar de que o texto tenha se corrompido nesse trecho; se isto ocorreu, no entanto, deve ter sido em uma fase muito incipiente da transmissão, uma vez que todos os manuscritos apresentam a mesma lição. $\tau \tilde{\alpha} \varsigma$ poderia ter sido introduzida pela sinizese de $\tau \varepsilon \tilde{\alpha} \varsigma$. De fato, RACE (1997a, p. 213) e outros traduzem como se $\tau \varepsilon \tilde{\alpha} \varsigma$

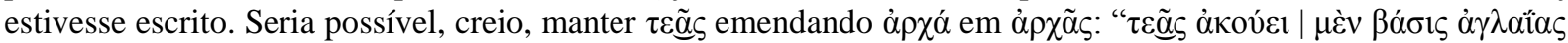

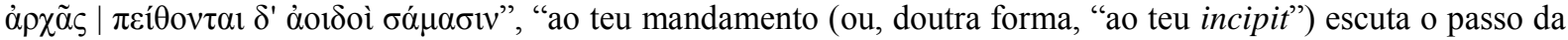

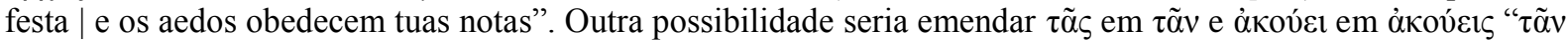

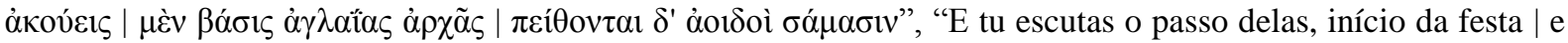
as cantoras obedecem teus sinais". Essa última leitura, ademais, faria sentido se $\sigma u ́ v \delta i \kappa o \varsigma$ significar, realmente, "concorde". $C f$. no trecho citado da $O d$. 8.25667, abaixo, como os dançarinos batem o pé antes de Demódoco começar a cantar. $\mathrm{Na}$ falta de testemunhos porém, e tendo em vista a lição unânime dos manuscritos, essas emendas devem permanecer apenas possibilidades.

${ }^{45}$ CAREY (1991, pp. 199-200).

PMG.

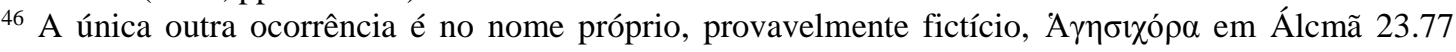

${ }^{47}$ CAREY (1991, p. 200), "It appears therefore that we have here a reference to a performance of song and dance by a single chorus to the accompaniment of the phorminx, grifo meu".

${ }^{48}$ HEATH (1988, p. 185). 
É exatamente esse tipo de performance que vimos descrita no Hino Homérico a

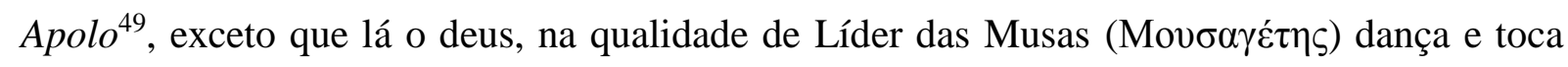
sua forminge, porém, aparentemente ${ }^{50}$, não canta, como também não o faz o grande coro, formado pelas Horas, Graças, Harmonia, Hebe e Afrodite e liderado por Ártemis ${ }^{51}$, descrito à

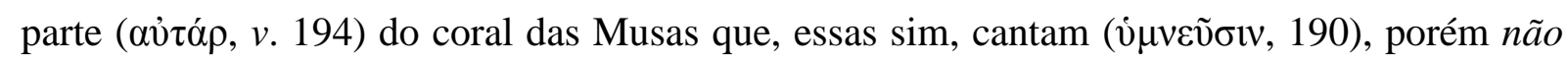
são descritas como dançando.

Esta mesma cena do hino a Apolo vemos, no plano terreno, porém não menos idealizado, na performance do aedo divino dos Feácios, Demódoco, na Od. 8.256 et seq. ${ }^{52}$ :

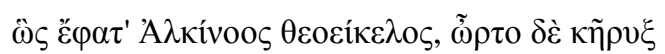

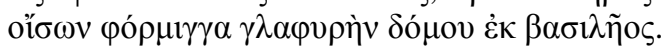

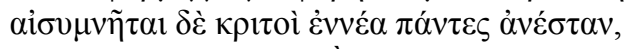

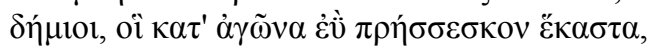

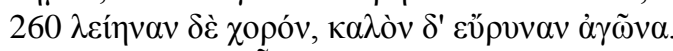

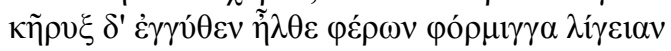

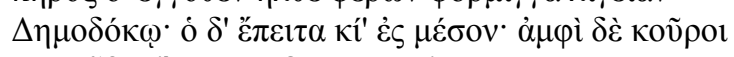
$\pi \rho \omega \theta \tilde{\eta} \beta \alpha$ i

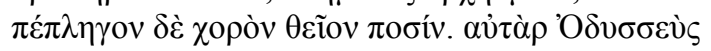

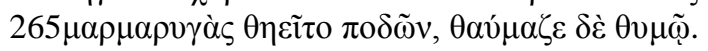

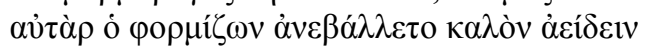

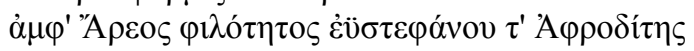
$\kappa \tau \lambda$.
\end{abstract}

Assim disse o divino Alcínoo e levantou-se o arauto para trazer a oca forminge da morada do rei.

E todos os nove juízes oficiais ficaram de pé, homens do povo, que nas congregações tudo administravam: 260 aplainaram o chão e bom espaço abriram entre todos. $\mathrm{O}$ arauto aproximou-se trazendo a estrídula forminge a Demódoco, que ao meio foi e, à sua volta, rapazes pré-adolescentes puseram-se, exímios na arte da dança: com os pés golpearam a divina arena. Odisseu, por sua vez, 265o clarão de seus pés contemplava com ânimo admirado. E eis que tocando a cítara principiou a cantar belamente sobre a paixão entre Ares e a bel-coroada Afrodite, etc.

Observe como Demódoco põe-se no meio do círculo de dançarinos, da mesma forma que Apolo, no hino homérico. Também é digno de nota que, mais adiante (8.370-80), os bailarinos Hálio e Laodamas executem, em meio ao coro, uma dança que nos faz pensar naquela de Ares e Hermes, naquele mesmo hino a Apolo. Com base nessa passagem da

\footnotetext{
${ }^{49}$ Cf. h. Hom. Apol. vv. 182 et seq.

${ }^{50}$ Aparentemente porque o particípio $\dot{\alpha} \mu \varepsilon i ́ \beta o \mu \varepsilon v \alpha \iota$ pode indicar uma antifonia não somente entre as Musas, mas entre estas e Apolo.

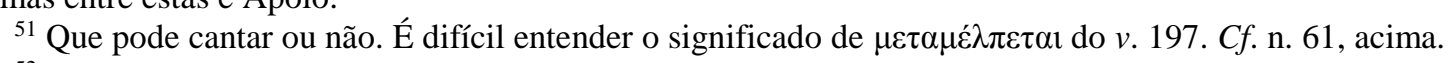

${ }^{52} C f$. também a descrição da performance de Fêmio, Od. 1.155. CAREY (1991, p. 200), citando essa passagem como um paralelo, não parece se dar conta de que, para uma audiência de Píndaro, fosse a conexão entre um texto e outro feita, o frame evocado seria justamente, a partir dessas passagens da Odisseia, um de canto solo e não coral.
} 
Odisseia e dos exemplos já aludidos anteriormente dos hinos homéricos, parece-me que Píndaro tem em mente uma performance solo nesses termos. Não acredito, no entanto, que esta passagem aluda à presente performance, se não justamente neste nível: o de evocar, na audiência, a noção de um aedo inspirado que é um representante de Apolo e das Musas.

Carey $^{53}$ acredita que $\pi \varepsilon i ́ \theta$ ov $\tau \alpha$ não pode se referir ao próprio aedo, uma vez que este não recebe ordens da forminge, mas a controla. No entanto, a apóstrofe à forminge em questão não é àquela que o aedo teria em mãos no momento da performance, mas sim à forminge divina de Apolo, a que todos os poetas, na medida em que são inspirados pelo deus e pelas Musas, precisam, sim, obedecer, afinal de contas, a música do aedo é apenas a manifestação terrena da música divina ${ }^{54}$. Não é verdade, também, que Píndaro deixe implícita a identidade do instrumentalista. É a música desta lira de ouro, invocada no v. 1, que causa todos os efeitos sobre os deuses descritos na antístrofe e epodo seguintes, e quem seria capaz de extinguir o raio de Zeus, fazer dormir sua águia sobre o cetro, aplacar a fúria de Ares etc. com sua música senão Apolo e as Musas? Não me parece haver nenhum mistério sobre quem empunha a forminge de ouro.

Há ainda a possiblidade de que "ảoı́óci” possa, no $v$. 3, referir-se não a cantores humanos, mas às próprias Musas que, como no hino a Apolo, cantariam uma canção sob o acompanhamento da forminge ${ }^{55}$, o que colocaria toda a festa no plano divino, sem a brusca intermitência dos $v v$. 3-4 (uma generalização sobre a performance musical humana) entre a apóstrofe inicial e toda a antístrofe e o epodo, que descrevem uma cena divina. A meu ver, essa transição do Olimpo para a terra inicia-se apenas na segunda estrofe, motivada pela menção a Tufão e à sua prisão, o monte Etna, o que permite que, no v. 29 da segunda antístrofe, a passagem para a cidade do Etna e à presente ocasião seja finalizada com a nomeação do vencedor, de sua cidade e da prova em que tivera êxito (30-33).

${ }^{53} \operatorname{CAREY}(1991$, p. 200).

${ }^{54} \mathrm{O}$ que pode nos levar a considerar que $\sigma 0 ́ v \delta ı \kappa o \varsigma$, como a forminge é caracterizada nesta ode, também pode ter o sentido de "representante", a que já aludimos, precisamente nestes termos: de que a lira divina de Apolo, instanciada em cada uma das liras terrenas, representa e presentifica o poder do deus e das Musas e por eles "fala".

${ }^{55} C f$. à n. 44 uma hipótese de emenda que, se confirmada, fortaleceria essa leitura, a qual, no entanto, independe daquela. 


\title{
P. 5.22;103ff
}

A $P .5$ inicia-se com o seguinte elogio à Riqueza que, na minha opinião, é essencial

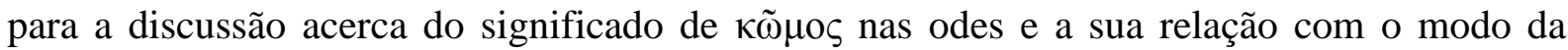
performance:

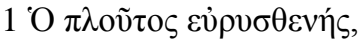

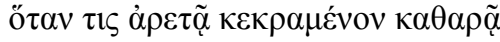

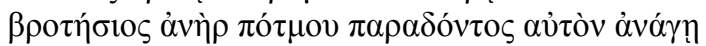

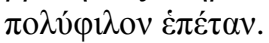 \\ 1 A Riqueza é vastipotente \\ sempre que, misturada a uma pura virtude, \\ um homem mortal, tendo-a recebido do destino, a celebra \\ como companha de muitos amigos.
}

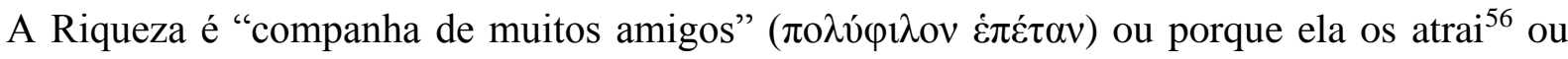
porque, por meio dela, é possível auxiliar-se os pí pensamento arcaico. Ambos os sentidos seriam usuais para o pensamento pindárico. O que é importante aqui é justamente relacionar essa capacidade da riqueza em obter não apenas a fama tão perseguida, e finalmente obtida, por Arcesilau (6-8) em uma prova aristocrática como a da quadriga, mas também a de poder propagá-la e compartilhá-la com os seus concidadãos. Portanto, de acordo com os versos da segunda estrofe, o laudandus é duas vezes um bem-aventurado, primeiro por ter nascido rei de uma grande cidade, Cirene (15-16), depois por ser capaz de, com a sua fortuna, organizar uma festa, possivelmente na forma de

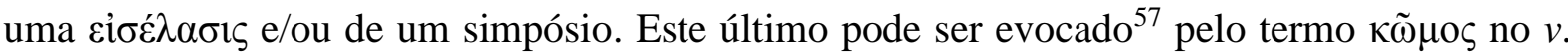
22 do seguinte trecho:

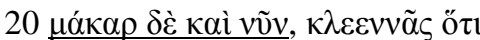

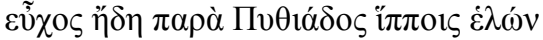

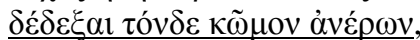

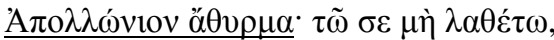

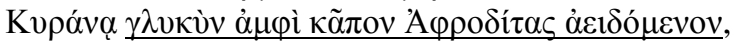

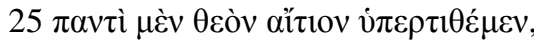

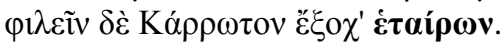

(..)

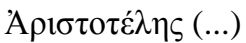

(...)

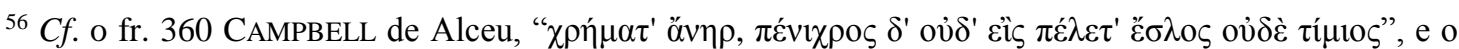
adágio atribuído a Aristodemos de Esparta e citado por Píndaro na I. 2.9-11: “ $\chi \rho \eta ́ \mu \alpha \tau \alpha \chi \rho \eta ́ \mu \alpha \tau$ ' $\alpha v \eta ́ \rho$ ' òs $\varphi \tilde{\alpha}$

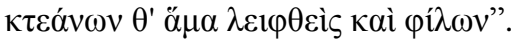

${ }^{57}$ E assim também a LEFKOWITZ (1991, p. 170). 


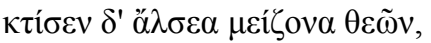

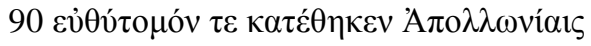

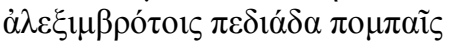

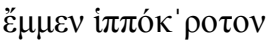

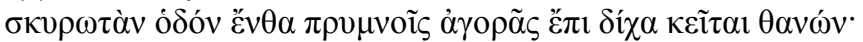

$\mu \alpha \alpha_{\kappa} \alpha \rho \mu \grave{\varepsilon} v \dot{\alpha} v \delta \rho \tilde{\omega} \nu \mu \varepsilon \tau^{\prime} \alpha$

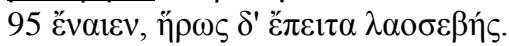

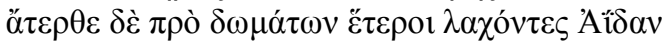

$\beta \alpha \sigma \imath \lambda \varepsilon ́ \varepsilon \zeta$ i $\varepsilon \rho o i ́$

$\dot{\varepsilon} v \tau i^{\prime} \mu \varepsilon \gamma \alpha \dot{\lambda} \alpha \nu \delta^{\prime} \alpha \dot{\alpha} \rho \tau \tau^{\prime} \nu$

$\delta \rho o ́ \sigma \omega \mu \alpha \lambda \theta \alpha \kappa \tilde{\alpha}$

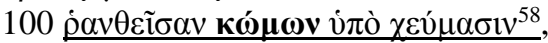

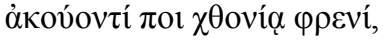

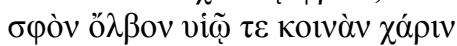

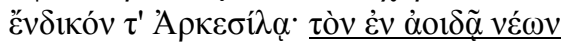

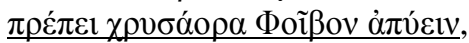

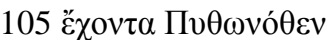

$\tau$ ò $\kappa \alpha \lambda \lambda i ́ v 1 \kappa o v ~ \lambda v \tau \eta ́ p l o v ~ \delta \alpha \pi \alpha v \alpha \tilde{\alpha}$

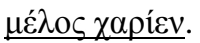

Bem-aventurado também nesta ocasião, pois da ínclita

Pítia já um motivo de orgulho com os cavalos havendo colhido, recebeste este kōmos de homens,

apolônio brinquedo: não te olvides portanto,

enquanto és cantado em Cirene por todo o doce jardim de Afrodite,

de dares tanto crédito ao deus por tudo,

quanto de amares Carroto acima de todos os camaradas.

(...)

87 Aristóteles (...)

(...)

fundou grandes bosques dos deuses,

90 e boa de transitar assentou para ser, nas procissões

de Apolo Protetor dos Mortais, plana

e pavimentada uma estrada

que ecoasse o trote dos cavalos, e lá, sobre a popa da ágora, morto, à parte jaz.

Bem-aventurado enquanto entre homens

95 viveu, e depois um herói de culto popular.

Em separado, à frente das casas, outros partícipes no Hades,

reis sagrados,

há: e as ingentes qualidades,

aspergidas com delicado orvalho

100 pelas libações dos $\boldsymbol{k} \overline{\boldsymbol{o}} \boldsymbol{m o \boldsymbol { i }}$,

eles, d'algum modo, ouvem com suas mentes infernais,

sua aventurança e comum ao filho

Arcesilau a justa graça, a quem, na canção dos rapazes,

cabe evocar o Lúcio da cítara dourada ${ }^{59}$,

105 tendo da Pítia obtido,

em recompensa por seus gastos, a graciosa

canção de vitória.

${ }^{58}$ Leio com GeNTILI et al. (1995), vide o apparatus criticus, p. 178. S-M lê com o codd. B (vat. graec. 1312, que propõe $\dot{\alpha} \rho \varepsilon \tau \tilde{\omega} v), \mu \varepsilon \gamma \alpha \lambda \tilde{\alpha} v \delta^{\prime} \dot{\alpha} \rho \varepsilon \tau \tilde{\alpha} v(..) \dot{\rho} \alpha v \theta \varepsilon \iota \sigma \tilde{\alpha} v$ como objeto de $\dot{\alpha} \kappa o v ́ o v \tau i ́$, entretanto isso faz pouco

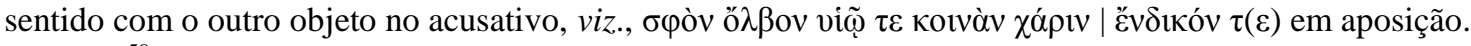

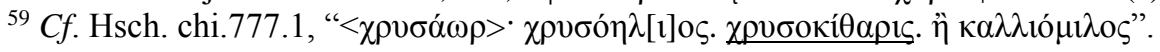


Há um belíssimo e intricado paralelismo nesse hino a Arcesilau. Em primeiro lugar, a sua bem-aventurança congênita é partilhada mesmo pelos seus ancestrais já falecidos em seus túmulos fora dos muros da cidade ( $v v .20$ e 95). Da mesma forma que Arcesilau é bem-

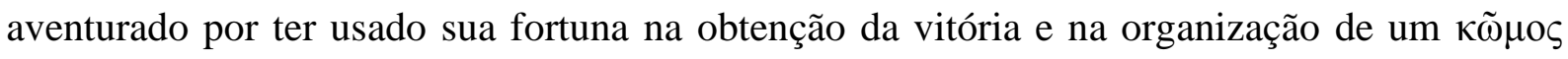
que a celebrasse $(1-4 ; 106-7)$, também o é Batos (o Aristóteles do v. 87), o fundador de Cirene, bem como seus descendentes, ancestrais de Arcesilau, que partilham de sua fortuna

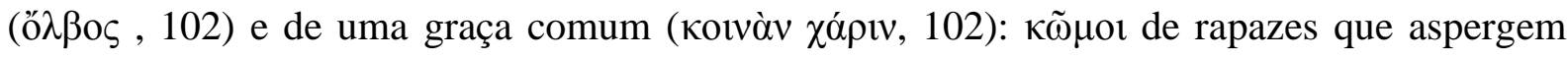
seus túmulos com canções, entre os quais o próprio Arcesilau, que deve cantar um hino a Apolo. Este, sendo exterior à ode, poderia se referir a um peã ou algum outro tipo de procissão que passasse pela Via Sacra, partindo do templo de Apolo até a ágora e, dali, para fora dos muros da cidade, à nordeste, na necrópole recentemente descoberta sob a acrópole ${ }^{60}$.

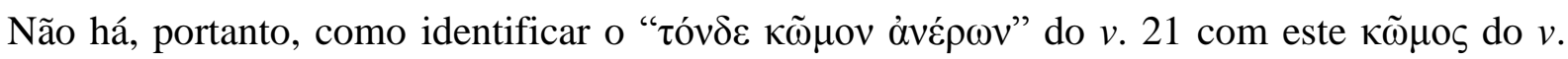
100 porque as locações da performance em que ambos se situam são diferentes: a $P$. 5 situa a sua própria performance no Jardim de Afrodite, na parte norte da cidade, perto da fonte de Cira, longe, portanto, das sepulturas dos Batíadas e mesmo do túmulo de Batos, na ágora de

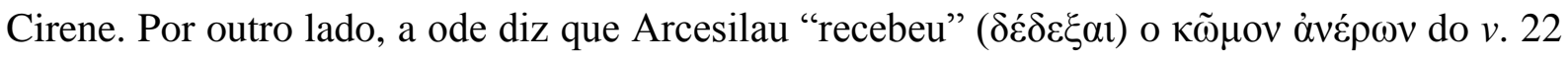
o que exclui a possibilidade de uma procissão ritual durante a execução da ode, embora não se possa afirmar que o $\kappa \tilde{\omega} \mu$ o não pudesse ter aí chegado na forma de uma procissão ou que daí assim não partiria após a cerimônia, o que me parece mais provável em vista dos $v v$. 98104.

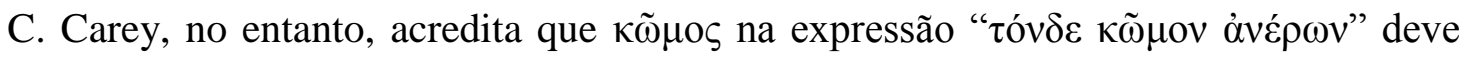
significar "canção". Essa é a única forma, na verdade, de embasar definitivamente a hipótese de uma performance coral em uma evidência concreta, já que, por meio dessa leitura, a persona loquens estaria dizendo "tendo aceito esta canção de varões". Entretanto, como já

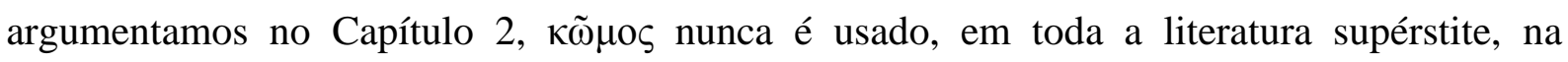

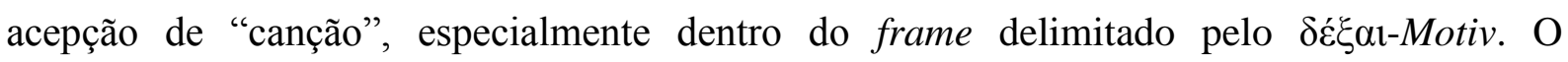
“exemplo garantido" aduzido por Carey, o da $O .4 .9$, baseia-se em um a leitura equivocada do poema que já discutimos. Tampouco suportam essa leitura os outros exemplos que fornece ${ }^{61}$.

${ }^{60}$ Cf. F. FERRARI (2012, pp. 170-72).

${ }^{61}$ CAREY (1989, p. 549) N. 4.6, 7.11 et seq.; I. 4.40-5. Como "altamente prováveis" ele cita P. 3.73,

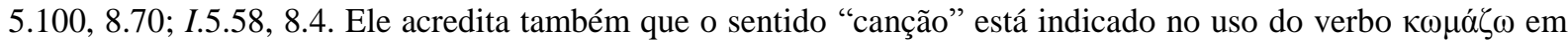
P. 9.89; I. 4.72, 7.20. Cf. também CAREY (1991), onde sua hipótese de que na N. 4.11 "the use of ṽ $\mu$ vov

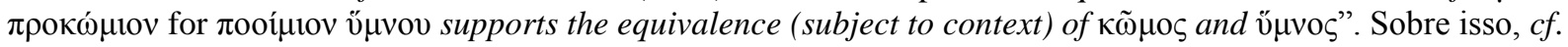
minha discussão no Capítulo 2. O leitor interessado pode, no entanto, comparar os resultados de Carey e os seus exemplos, listados na n. 61 com HEATH e LEFKOWITZ (1991), "all of the instances that Carey cites as 'highly probable' (...) can be referred to the celebration as a whole without difficulty". Cf. também ECKERMAN (2010, $\mathrm{p}$. 310). 
Essa leitura de Carey, aliás, baseia-se na já vista, porém equivocada, interpretação

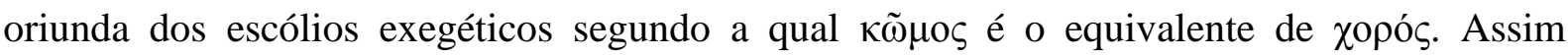
Gentili et $a l^{62}$, que dá grande importância à exegese daqueles textos, sente-se à vontade para traduzir o v. 22 como "e ora accogli questo festoso coro d'uomini, | delizia d'Apollo", aparentemente tentando conciliar a conotação festiva de $\kappa \tilde{\omega} \mu$ o com a ideia de que o mesmo é um coro, muito embora deixe sem tradução, no v. 103, o ablativo $\kappa \omega ́ \mu \omega v$, que lá não pode, evidentemente, ser um coro, uma vez que nessa passagem quem deve cantar a canção a Apolo é Arcesilau, o que nos faz pensar em algum outro tipo de composição que não o epinício em que se constitui a presente ode.

Uma outra passagem que, segundo Carey, só poderia se referir ao coro são os $v v$. 7281, na qual, no entanto, é perfeitamente possível que Píndaro esteja fazendo uma alusão aos seus próprios descendentes, os Egidas de Esparta ${ }^{63}$, que teriam imigrado para Tera e, de lá, para a colônia fundada por Batos na Líbia, o que o ligaria por $\sigma 0 \gamma \gamma \varepsilon ́ v \varepsilon i \alpha$ à aristocracia cirenaica:

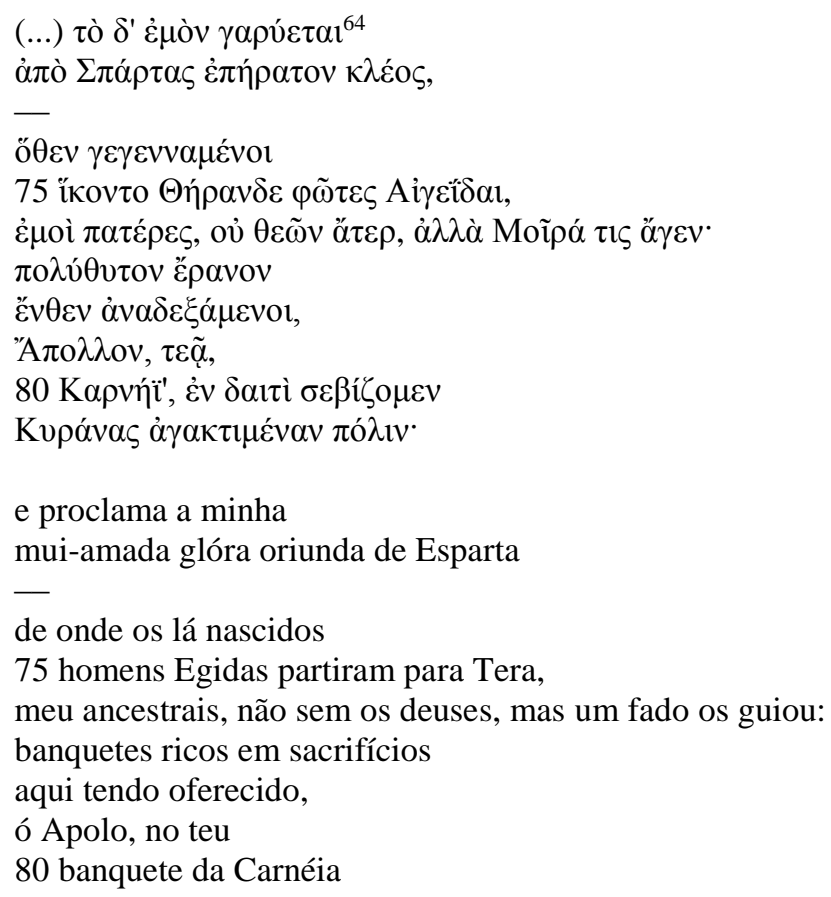

62 GENTILI et al. (1995, p. 173), note que no comentário $\kappa \tilde{\omega} \mu \mathrm{s} \varsigma$ é assim explicado "indica il coro di giovani (crf. v. 103) che esegue l'ode; il coro è detto di 'uomini' (...) in contrapposizione ai cori femminili (Christ)".

${ }^{63}$ Para uma revisão do mito, $c f$. p. ex., GENTILI et al. (1995, p. 532) e WILAMOWITZ-MoELLENDORFF (1966, p. 477).

${ }^{64}$ Ao invés do $\gamma \alpha \rho v ́ \varepsilon \tau$ ' dos códices (um lapso oriundo, provavelmente, de uma simplificação de $\alpha \imath>\varepsilon$ comum na língua posterior e moderna), que poria este verso em sinafia com o próximo, arruinando o metro. Essa

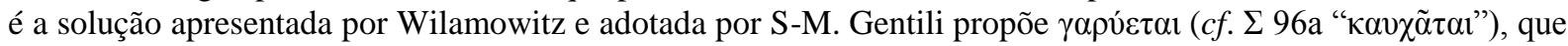

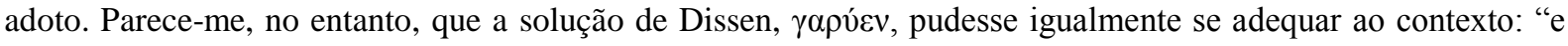
pertence a mim o proclamar a mui-amada glória vinda de Esparta". 
veneramos a firme cidade de Cirene.

Os próprios escólios admitem que esse trecho pode ter sido dito pelo poeta ou pelo "coro" ${ }^{65}$, uma vez que a tradição reporta dois grupos de Egidas oriundos de Esparta: um seria uma fratria originária de Tebas que, segundo Éforo ${ }^{66}$, conquistara aquela cidade duas vezes ${ }^{67}$ e, algum tempo depois, retornando, fixaram-se em Tera. A outra seria uma tribo ( $\varphi \nu \lambda \eta ́)$ que tiraria seu nome de Egeu, sobrinho de Tera, colonizador da ilha homônima de onde a expedição para Cirene partiu ${ }^{68}$. Gentili et al. ${ }^{69}$ acredita que a tradição pode ter transmitido um mesmo povo sob o nome de dois grupos diferentes, mas que aqui deve ser o coro, em nome dos Egidas filhos de Tera, que está falando e não Píndaro.

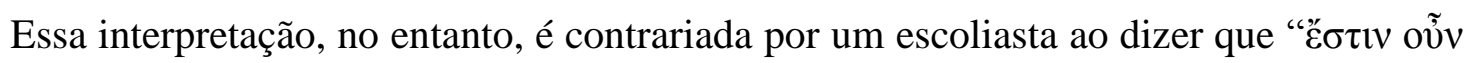

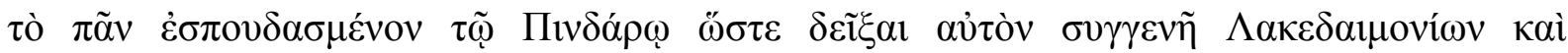

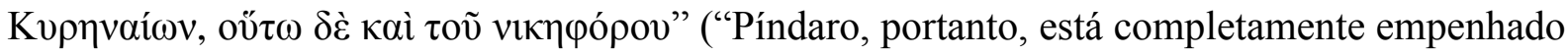
em mostrar a si mesmo como um descendente dos Lacedemônios e dos Cireneus, e, dessa forma, também do vencedor”), o que faz sentido à luz do fato de que o poeta, ainda que valorize em muitas odes, e em graus diferentes de afeição, sua $\xi \varepsilon v i ́ \alpha$ para com o laudandus, traz especialmente à tona a sua $\sigma v \gamma \gamma \varepsilon ́ v \varepsilon ı \alpha$ quando ela é relevante para a história familiar desse último, como por exemplo na $I .7 .10-12$, na $I .8-16-18$, na $N .7 .84-5$ e na $P$. 8.98, onde ele se dirige a Egina como " $\varphi \hat{i} \lambda \alpha \mu \tilde{\alpha} \tau \varepsilon \rho " 70$. Não há portanto, a meu ver, porque pensarmos que aqui pudesse ser diferente, o que faz da ideia de um "coro" uma adição desnecessária e externa à ode.

É de se notar que o uso de ěpavos pode significar que a ode tenha sido executada cerca de um ano depois da vitória pítica de Aristomenes, isto é, em 461 ${ }^{71}$, uma vez que o termo designa, como na $O .1 .38$, um banquete retributivo, nesse caso como ação de graças pela vitória, como aliás explicita a injunção dos $v v$. 24-5.

\section{P. 10.4-6;55-9}

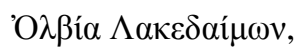

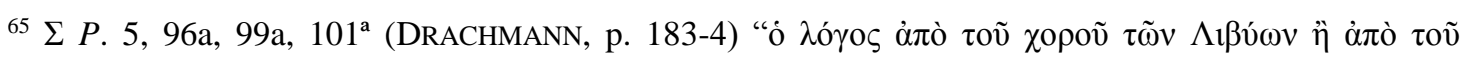

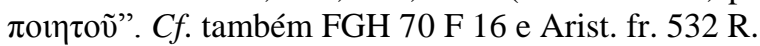

${ }^{66}$ FGE I, p. 235.

${ }^{67} \mathrm{Cf}, \mathrm{I} .7 .10-12$.

${ }^{68}$ Hdt. 4..147.2.

${ }^{69} C f$. a explicação do $v v$. 75-6 em GENTILI et al. (1995, p. 532).

${ }^{70}$ LEFKOWITZ (1991, p. 180).

${ }^{71}$ Uma execução no mesmo ano da vitória não seria possível porque os Jogos Píticos, realizados na lua

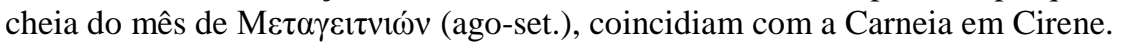




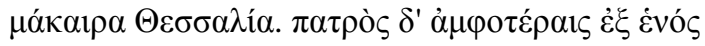

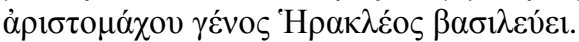

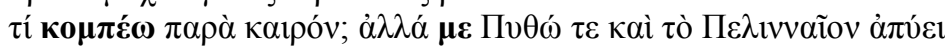

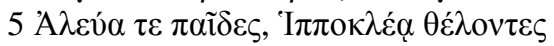

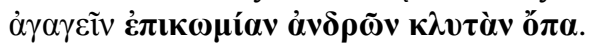

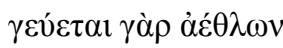

(...)

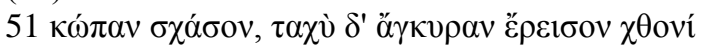

$\pi \rho \omega ́ \rho \alpha \theta \varepsilon, \chi 01 \rho \alpha ́ \delta$ o $\alpha^{\alpha} \lambda \kappa \alpha \rho \pi \varepsilon \dot{\tau} \tau \alpha \varsigma$.

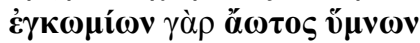

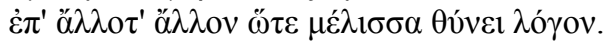

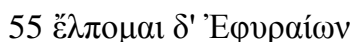

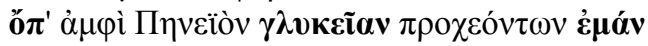

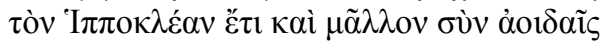

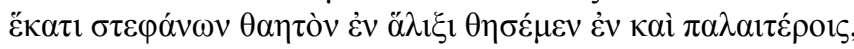

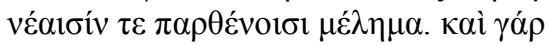

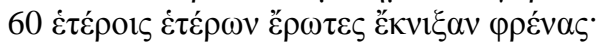

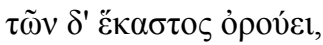

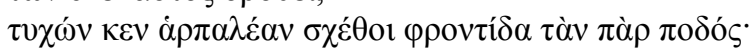

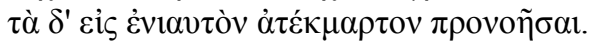

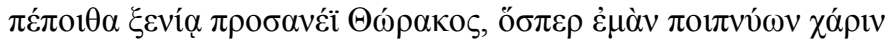

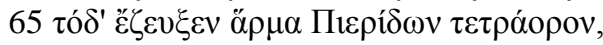

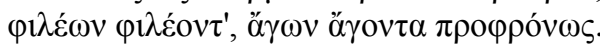

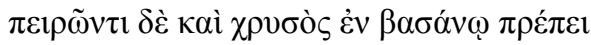

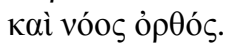

Afortunada Lacedemônia,

Bem-aventurada Tessália, sobre ambas de um único pai,

Hércules, invencível em batalha, reina uma raça.

Que jactância é essa fora de hora? Mas é que a Pítia e Pelina me chamam

e os filhos de Alevas, querendo à Hipoclés

levar a ínclita e festiva voz dos homens,

pois ele provou dos jogos.

(...)

55 e eu espero que quando os Efireus

tiverem vertido a minha doce voz em todo o Peneu,

a Hipoclés ainda mais, entre as canções

devidas às coroas, esplêndido entre coetâneos irei fazê-lo e entre os seniores,

e um cuidado para as jovens solteiras. Ainda que, de fato,

60 desejos por diversas coisas diversos corações excitem:

que cada um que por algo se lance,

alcançando-o, possa manter a sua ardente e imediata ambição.

Obscuras veem-se as coisas um ano adentro.

Confio na gentil hospitalidade de Tórax, este que, trabalhando em meu favor,

65 a quadriga das Filhas de Piéria junjiu,

amigo a um amigo e um guia a quem se alegra em guiá-lo.

e tanto brilha o ouro na pedra de toque,

quanto justo um coração.

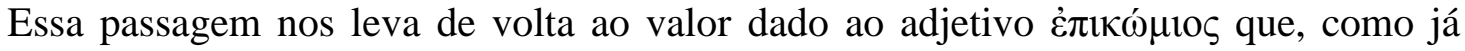
discutimos no capítulo anterior, significa apenas "que pertence ao $\kappa \tilde{\omega} \mu \varsigma$ ". Dessa forma, a 
“epikōmía e ínclita voz dos homens", a que se faz alusão no $v$. 6, é apenas uma perífrase para

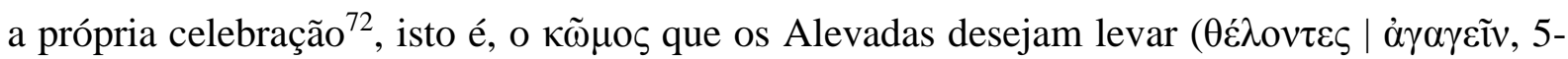
6), "como uma noiva ao noivo"73, a Hipoclés por ocasião de sua vitória na corrida do diaulos. Trata-se de um uso nada surpreendente desta forma épica de ö $\gamma \omega$ se considerarmos, por exemplo, o fr. 410 PMG de Anacreonte, que sugere, ademais, uma ambientação simpótica como a que parece também ser o caso para esta ode:

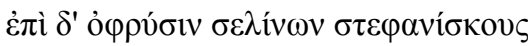

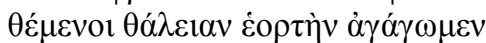

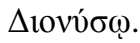 \\ sobre as frontes coroazinhas de salsão \\ havendo posto, a farta festa celebremos \\ à Dioniso.
}

Carey $^{74}$, em sua crítica a Lefkowitz ${ }^{75}$, não consegue acreditar que se pudesse comissionar um poeta como Píndaro para uma performance solo que fosse menos elaborada que a celebração informal por parte dos companheiros de Hipoclés. Ele certamente vê as duas ocasiões como mutuamente excludentes. No entanto, não há nenhuma razão para separar a performance solo da celebração do $\kappa \tilde{\omega} \mu \mathrm{o}$ e não acho que foi isso que Lefkowitz quis dizer em sua análise, mas sim que a performance solo $e$ o $\kappa \tilde{\omega} \mu \mathrm{o} \varsigma$ dizem respeito à mesma ocasião, porém em momentos diferentes. Carey nos alerta que uma leitura "imparcial" deve reconhecer que o $v .6$ refere-se explicitamente a um canto coletivo por parte dos homens, com o que concordamos, afinal de contas, ao que me parece, ninguém jamais propôs que o $\kappa \tilde{\omega} \mu$ o fosse um agrupamento de pessoas mudas. Ao contrário, em uma festa - que aqui provavelmente deve tomar a forma de um simpósio -, há canto e há dança e há barulho, ao menos se formos crer na descrição de Platão e Xenofonte, em seus respectivos “banquetes”. O que não há neste

72 HeAth e LeFKOWITZ (1991, p. 185). Não sei como comentar as palavras de CAREY (1991), em

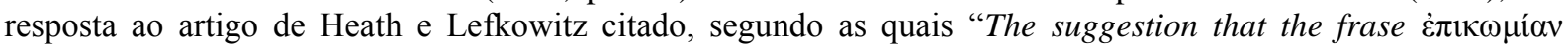

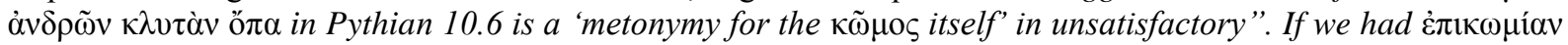
$\dot{\alpha} v \delta \rho \tilde{\omega} v \dot{\alpha} \gamma \tilde{\omega} v \alpha(. .$.$) there would be no problem. But Pindar is made to say here on the solo hypothesis: "the$

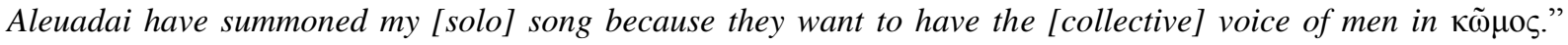
This is not a natural way to take Pindar's words", grifo meu. Aparentemente deve haver uma forma "mais natural" e uma "menos natural" de interpretar as palavras de Píndaro, como também deve haver uma noção "correta" e outra "incorreta" sobre como Píndaro deveria escrever. Tudo, obviamente, a partir do ponto de vista de cada um. Note que em nenhum momento, na ode, Píndaro diz que os Alevadas invocaram a sua canção, mas apenas que eles $o$ invocaram, presumivelmente para que a festa pudesse estar completa na presença de um cantor profissional. "Solo song" e "colective voice" são informações que Carey põe no texto com o mero objetivo de desqualificar o argumento de Heath e Lefkowitz.

${ }^{73}$ Como nota sensivelmente GiLdersleEve (1886, p. 352). Cf., de fato, Il. 18.87, S. Tr. 858.

${ }^{74}$ CAREY (1989, p. 547). Assim também GENTILI et al. (1995, pp. 623-4).

75 LEFKOWITZ (1991, p. 195), "Earlier in the ode (5-6) he speaks of bringing for the victor 'the sounding voice of men in a komos (...). But this komos, too, need have been involved not in the performance of his ode, but in some more informal celebration of the victory singing in unison as well as dancing". 
verso, e que uma leitura "imparcial” dos mesmos também deve reconhecer é evidência “explícita" de que são os homens, e não o $\mu \varepsilon$ (4), que cantam a ode em particular.

Quando, portanto, Carey diz que "'the Aleuadai prompt my ode because they want collective singing for Hippokleas' makes little sense if Pindar's song is a solo performance" [grifo meu $]^{76}$, ele parte, na verdade, de uma petição de princípio, já que a informação de que os Alevadas querem "um canto coletivo para Hipoclés" não pode ser deduzida da ode, onde não há nenhuma menção "explícita" desse desejo. Presumir, portanto, que este é o caso literalmente "begs the question". No máximo, uma leitura totalmente "imparcial", se é que isto existe, nos levaria a concluir que esta passagem é, afinal de contas, inconclusiva no que diz respeito à forma da performance.

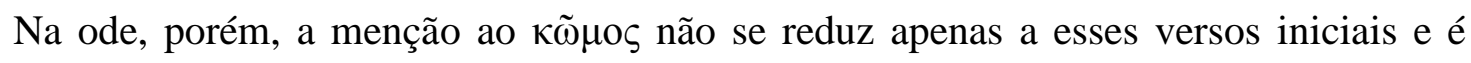
importante estar atento às relações intratextuais do epinício. Píndaro, de fato, retorna a uma descrição de sua própria canção no v. 53, que não é citado nem por Carey nem por Lefkowitz,

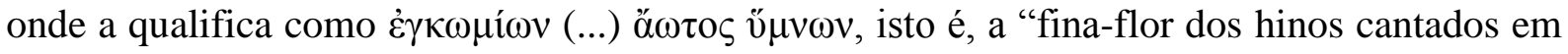

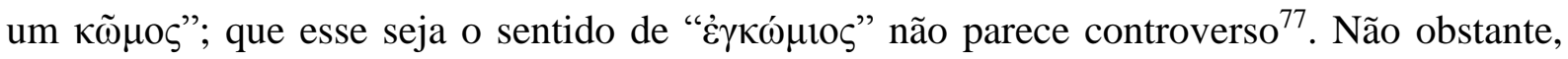
poder-se-ia argumentar, com razão, que o significado do adjetivo apenas prova que o hino “pertence ao $\kappa \tilde{\omega} \mu о \varsigma$ ” porque é cantado por ele. Contrário a isto, vemos que, logo em seguida,

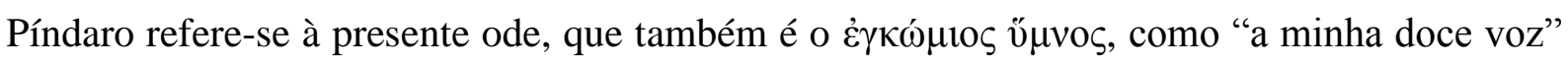

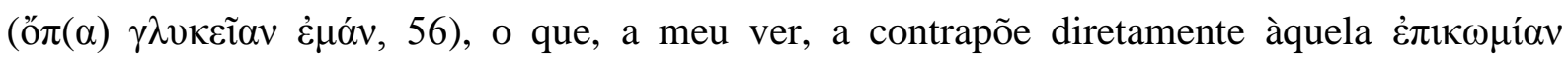

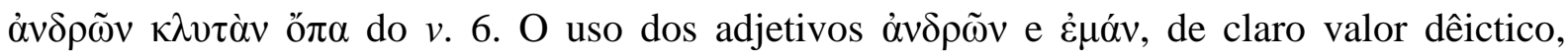
apontam para momentos diferentes da performance: de um lado há os cantos do $\kappa \tilde{\omega} \mu \mathrm{s}$, de outro, a performance do profissional.

Nesta mesma estrofe, vista, aliás, como uma menção explícita ao "coro" de efireus

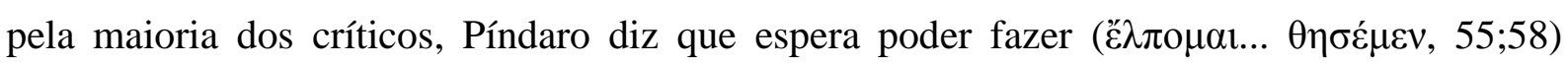
Hipoclés distinto tanto entre os jovens quanto entre os mais velhos quando aqueles "verterem" por todo o Peneu a sua "doce voz", isto é, a voz que eles agora ouvem e irão guardar na memória, e não a "voz" que eles supostamente estariam cantando. Que tipo de esquizofrenia poética faria com que o "coro" primeiro se referisse a si mesmo como " $\boldsymbol{\mu \varepsilon}$ ", um verso depois

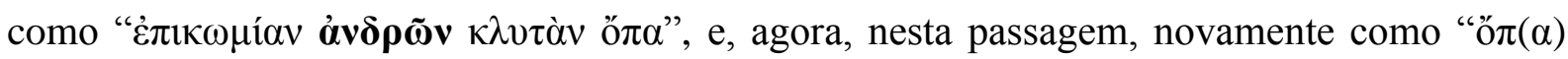

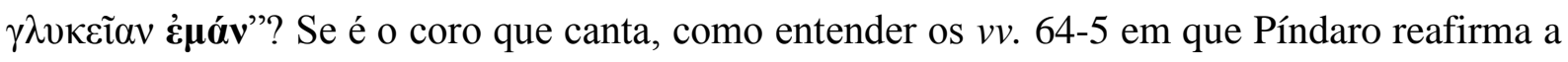

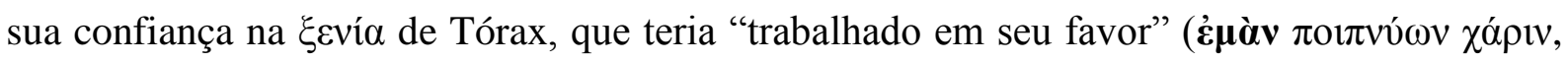

\footnotetext{
${ }^{76}$ CAREY (1989, p. 547), “"Os Alevadas pedem por minha ode porque eles querem um canto coletivo a Hipoclés' faz pouco sentido se a canção de Píndaro for uma performance solo."

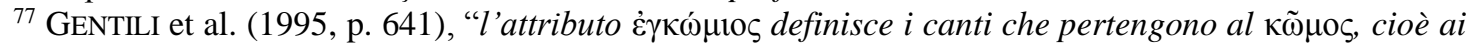
festeggiamente in onore del vincitori negli agone (...)".
} 
64)? Gentili et al. ${ }^{78}$ insistem que um coro poderia expressar a voz do poeta, enquanto outros ${ }^{79}$ explicam essas mudanças de referencial dêictico dentro da ode por meio de uma "polifonia" de vozes que serviria para multiplicar o louvor do laudandus. Parece-me porém que possa haver uma explicação mais simples.

Como vimos no Capítulo 2, Píndaro, na N. 4.9-15 pode estar se referindo a ocasiões

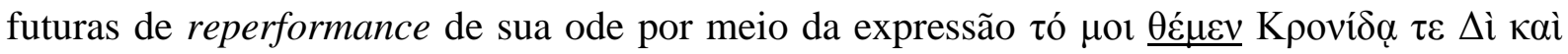

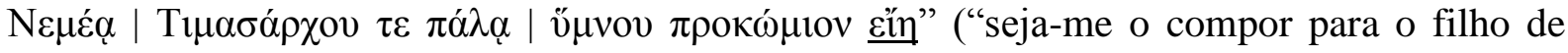
Crono, Zeus, para Nemeia e a luta de Timasarco | o prokốmios de um hino"), onde v̋ $\mu v o v$

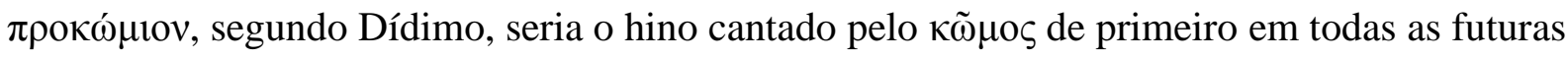
vitórias de Timasarco. Aqui também, o ع̌ $\lambda \pi$ o $\mu \alpha 1 . . . \theta \eta \sigma \varepsilon ́ \mu \varepsilon v ~(55 ; 58$ - note o paralelismo da construção com $\theta \varepsilon \dot{\varepsilon} \mu \varepsilon v .$. Eli efireus sempre que outras canções e $\kappa \tilde{\omega} \mu o \imath$ de vitória viessem a ser executados. Píndaro parece projetar a sua própria canção em um frame futuro no qual os efireus irão "verter" a sua

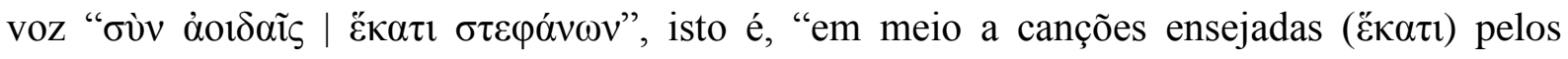
lauréis", o que equivale a dizer, canções de vitória ou "epinícios". É apenas nesse último

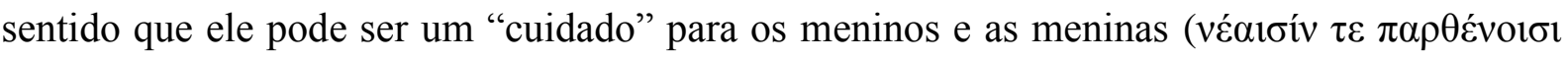
$\mu \varepsilon ́ \lambda \eta \mu \alpha, 59)$, na medida em que viva através da canção.

Nos versos seguintes, Píndaro contrapõe o seu desejo à realidade: é impossível saber o que acontecerá daqui a um ano (63) e, além disso, os gostos das pessoas são variados (60); de sorte que o melhor é se contentar com o presente sucesso (62). Apesar de todas essas variáveis, ele demonstra confiança $(\pi \dot{\pi} \pi 01 \theta \alpha, 64)$ na hospitalidade de Tórax que se esforçou por favorecê-lo, ao comissionar a presente canção ${ }^{80}$, metaforicamente descrita como "a quadriga das Filhas da Piéria”. Enfim, conclui, só o tempo dirá. O tempo - que revela um caráter justo como a pedra-de-toque, o ouro -, revelará, da mesma forma, se a sua canção irá vingar entre os efireus e se, numa futura vitória, ele terá ainda a graça dos Alevadas que lhe permitirá, mais uma vez, celebrá-la.

\section{N. 3.1-12;65 et seq.}

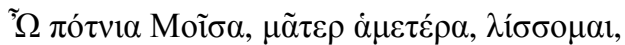

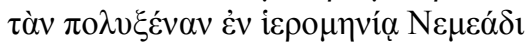

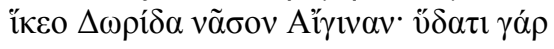

${ }^{78}$ GENTILI et al. (1995, p. 644).

${ }^{79} C f$., por exemplo, CALAME (2011).

${ }^{80}$ O sentido de $\chi \alpha$ ópı é difícil de determinar aqui. Pode ser interpretado tanto como "favor", isto é, ter preferido Píndaro a outros poetas, como "ode", por fornecer os meios e as condições para a sua execução. 


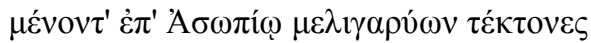

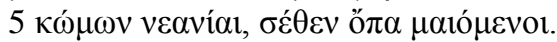

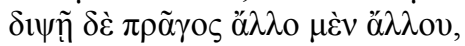

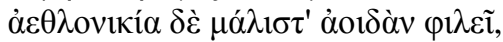

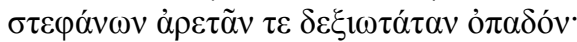

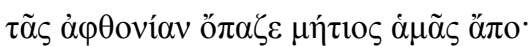

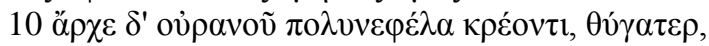

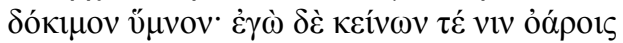

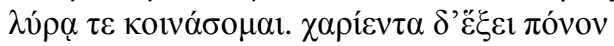

$\chi \omega ́ \rho \alpha \varsigma \alpha ̋ \gamma \alpha \lambda \mu \alpha$.

Ó Musa Rainha, nossa mãe, eu suplico, no mês sagrado da Nemeia, à mui-visitada dórica ilha de Egina vai, pois junto à água do Esopo ${ }^{81}$ esperam jovens artífices de melíssonas celebrações (kómōn), procurando por tua voz. Diferentes feitos têm sedes de diferentes coisas, mas a vitória atlética, mais que tudo, ama a canção, a mais adequada companha de lauréis e habilidades.

Farta dispensa-a, nascida de nossa arte.

Principia, filha, para o Senhor do multinebuloso céu, conceituado hino, eu às vozes daqueloutros e à lira irei popularizá-10 ${ }^{82}$, e uma graça exibirá o adorno da terra ${ }^{83}$.

Esta, juntamente com a $O .6$, que já vimos, é uma das odes mais importantes no que diz respeito a referências metapoéticas da performance e, por esse motivo, meu tratamento dela será mais detalhado.

Não há nenhuma evidência explícita nesses versos iniciais da $N .3$ que indique que a mesma tenha sido executada por meio de um coral, o que requereria que supuséssemos um complemento no infinitivo para o particípio $\mu \alpha \imath$ ó $\mu \varepsilon v o r$ quando o próprio poeta não sentiu a necessidade de explicitá-lo, mesmo se na $O$. 8.4-6 o tenha feito ${ }^{84}$, quando fala dos profetas que tentam saber de Zeus se teria algum sinal acerca dos homens "que procuram angariar

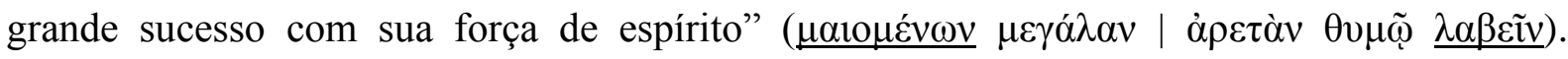

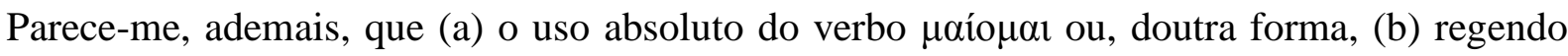
um acusativo, seja a norma a partir da qual construções com um infinitivo epexegético seriam as exceções. Tanto em (a) quanto em (b), o sentido mais prototípico de $\mu \alpha i ́ o \mu \alpha \iota$ é o de

${ }^{81}$ Uma fonte em Egina, não o rio na Beócia. $C f$. PrIVITERA (1988) e PFEIJFFER (1999b, p. 247).

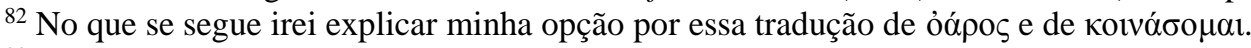

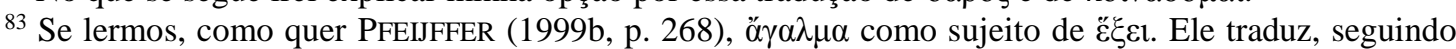

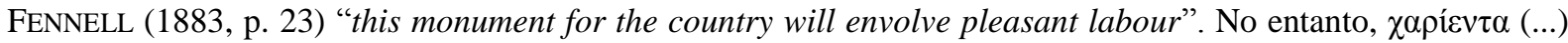

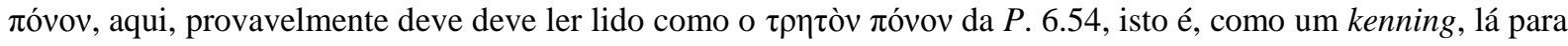

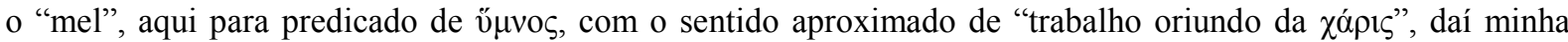

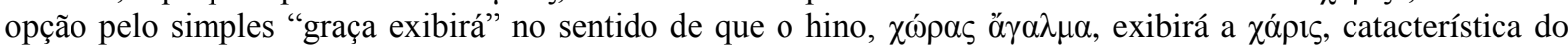
produto final (para $\pi$ óvoৎ nesse sentido, $c f$. LSJ, s.v.), que a vitória atlética enseja no poeta e que, ulteriormente, dentro da economia do epinício, é sempre conceitualizada como a causa do louvor.

${ }^{84} C f$. também, Peã , 52d.36-7. 
"procurar por", "perseguir" 85 . Em Píndaro apenas, essa é a acepção de três entre cinco ocorrências atestadas: aqui, na $O .1 .46$ e na $P$. 11.51. No restante da lírica, com o mesmo sentido, é digno de nota o fr. $36 \mathrm{~V}$ de Safo e o $141 \mathrm{~V}$ de Alceu ${ }^{86}$. Na épica o verbo nunca é empregado regendo infinitivo.

Dessa forma, se quiséssemos suprir um infinitivo, a colocação de $\mu \alpha$ ío $\mu \alpha$ ı com o acusativo singular de ő $\psi$ nos levaria normalmente à escolha de verba sentiendi, ao invés de verba dicendi, haja vista que um dos verbos mais comuns a reger ő $\pi \alpha$ é, precisamente,

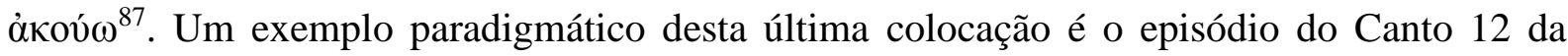
Odisseia em que Odisseu deseja ouvir a voz (ő $\psi$ ) das Sirenas pelo simples deleite que o canto

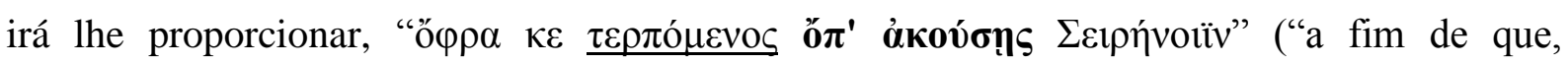
deleitando-se, ouças a voz das duas Sirenas", 52) ${ }^{88}$. Doutra feita, quando ő $\psi$ é empregado como instrumento através do qual se canta, vai, obviamente, para o dativo. Um exemplo interessante desse emprego, também em virtude do paralelo com a $N$. 3, aparece em Baquílides, Ditirambo 17.126-7, em que, para comemorar a vitória de Teseu, jovens solteiros (’’î́t

Note que nesse último caso, onde a performance é certamente coral, temos a descrição de um $\kappa \tilde{\omega} \mu$ os extemporâneo de jovens que reage à imediata saída de Teseu do mar e que, portanto, no nível da narrativa, não é coral. Assim, e até onde pude verificar, sempre que ó $\psi$ é

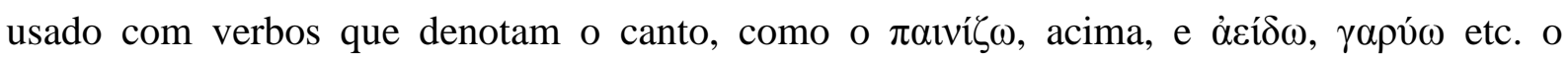
substantivo aparece no dativo-instrumental com o infinitivo expresso, se for o caso ${ }^{89}$.

Parece-me temerário, dessa feita, afirmar, acerca dos versos iniciais da N. 3.4-5, que “a óbvia explicação para o seu desejo [i.e. dos jovens] pela canção de Píndaro é que eles desejam cantá-la" 90 , já que isto, a um só tempo, seria suprir algo que não está no texto e admitir uma construção incomum do particípio tanto com relação ao estilo de Píndaro quanto ao uso verificado por outras fontes, donde se deduz que " $\sigma \varepsilon \dot{\theta \varepsilon v}$ ő $\pi \alpha \mu \alpha \imath$ ó $\mu \varepsilon v o \imath$ " deveria ser lido, ao menos num primeiro momento, apenas como "ansiosos por tua voz" e, consoante a

${ }^{85}$ Assim PfeijfFer (1999b, p. 250), que, no entanto, traduz o particípio por "in desire of your voice". Cf. também DELG, p. 658 s.v. $\mu \alpha$ ío $\mu \alpha 1$.

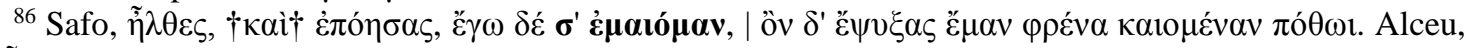

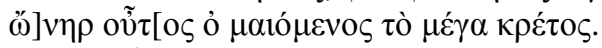

${ }^{87}$ Das 22 ocorrências de ö $\alpha \alpha$ em Homero e Hesíodo, por exemplo, 11 são objeto de $\dot{\alpha} \kappa o v ́ \omega, 6$ de ï $\mu$ 1, 2

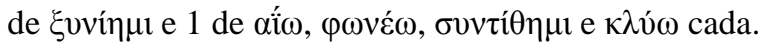

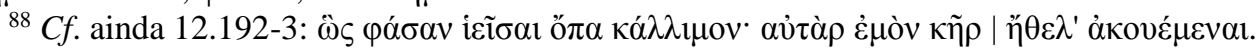

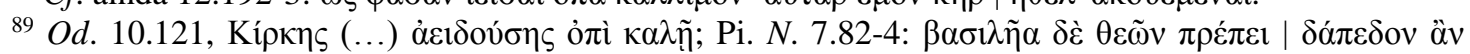

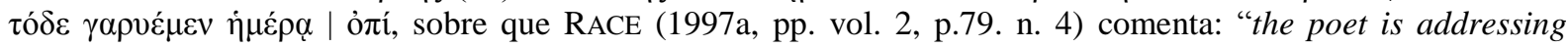
himself (or the chorus leader)". No restante do corpus, ơ $\psi$ é empregado três vezes, sendo uma na passagem da Nemeia ora sob análise e as outras duas na $P .10 .6$ e 56, que já discutimos.

${ }^{90}$ CAREY (1989, p. 553). 
isso, verificar se esta leitura mais econômica não se encontraria justificada dentro da própria economia da ode. Suprir qualquer complemento para o particípio é, no mínimo, ler no texto da canção uma informação não dedutível de sua sintaxe ou de seu contexto. No máximo, face à evidência de que ö $\pi \alpha$ é frequentemente regido por $\alpha$ $\kappa o v ́ \omega$, isso é fazer uma leitura forçada da passagem a partir de uma suposição sobre o seu modo de performance, o que, parece-me, configura-se em um exemplo clássico de petição de princípio ${ }^{91}$.

A favor de uma performance coral, pode-se dizer, por outro lado, que a caracterização do $\kappa \tilde{\omega} \mu о \varsigma$ como $\mu \varepsilon \lambda i ́ \gamma \eta \rho v \varsigma$ implicaria em salientar essa característica a fim de conceitualizar o

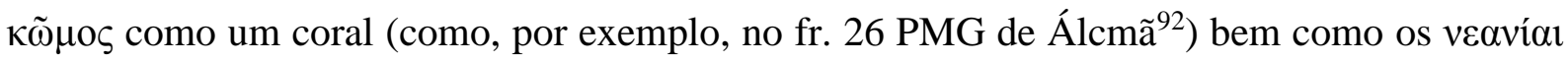

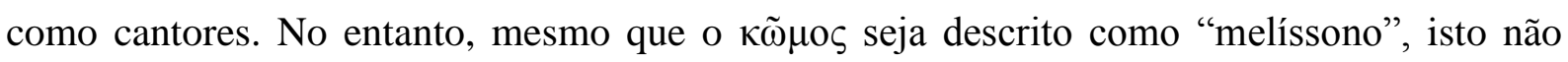
implica, necessariamente, em uma performance da $N .3$ por um coro, isto é, de uma maneira coreografada, previamente ensaiada e em uníssono. Como vimos pelos exemplos aduzidos no Capítulo 2, e pelo recém-citado ditirambo de Baquílides, não existem $\kappa \tilde{\omega} \mu o r$ mudos. Ao contrário, é de se esperar que os mesmos cantem, ao longo de uma celebração, diversas canções ${ }^{93}$.

$\mathrm{Na}$ verdade, essa característica do $\kappa \tilde{\omega} \mu \mathrm{o}$, de um lado, e a sua associação com o simpósio, de outro, são elementos-chave para que possamos entender que tipo de cenário Píndaro poderia ter em mente ao dizer que irá fazer seu hino koıvó artesões dos melífonos $\kappa \tilde{\omega} \mu$ or quanto à lira, já que, se entendermos o $\kappa \tilde{\omega} \mu \mathrm{o}$ nesta ode como conceitualizado a partir do frame SIMPÓSIO, o epíteto não soaria mais tão surpreendente, afinal

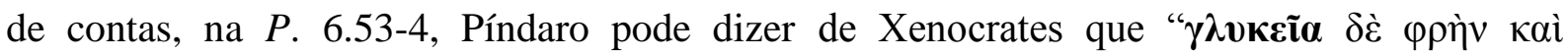

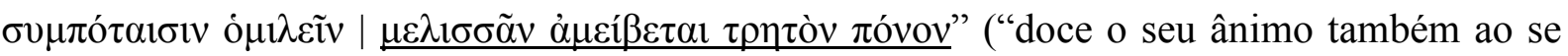

${ }^{91}$ Nesse sentido, a injunção de CAREY (1989, p. 555) segundo a qual "we should be wary of any interpretation which requires us to supply data on which the text is silent, unless the data is necessary for an understanding of the text" poderia ser aplicada à sua própria metodologia com relação a essa passagem, já que

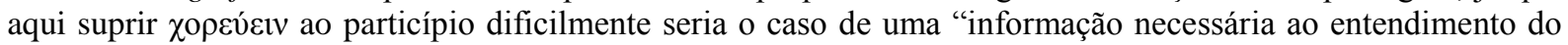
texto".

92 Mas $c f$. n.95, abaixo.

${ }^{93}$ Cf. HeAth e LeFKOwitz (1991, p. 187), "Carey [CAREY (1989)] comments that the passage "is perfectly intelligible without any supplement as a statement that Pindar is to supply the singers with the song they desire" (p. 555); but that is how we too understand it. We disagree only about whether to specify "desire to sing" or "desire to hear"; the text is not explicit in this respect, and here again both hypotheses supplement it. Further, the objection that "Pindar says nothing of any song which has already been sung by the young men," thus stated, begs the question; on our hypothesis "sweet-voiced" and "voices" allude precisely to such songs. If the point is that Pindar does not state explicitly that they sing other songs, then the objection works both ways: neither does he state explicitly that they sing Pindar's song; that is at most implied. The implication that the young men are singing the victory ode, however, cannot be substantiated. The inference that the young men must desire to sing the song because they are described as singers is unsound; for the young men (being komasts) are singers on any interpretation (the phrase which describes their singing is a generalizing one, without specific reference to this song: 'builders of sweet-voiced $\kappa \tilde{\omega} \mu \mathrm{ol}$ ')". 
reunir com os simposiastas | o qual, das abelhas, ultrapassa o perfurado labor ${ }^{94 ") . ~ D a ~ m e s m a ~}$ forma, na $P$. 4.128, que comentarei mais abaixo, as palavras de Jasão a seus parentes, igualmente enquadradas pelo frame do simpósio, são caracterizadas como $\mu \varepsilon \imath \lambda \imath \chi i ́ o ı \iota ~ \lambda o ́ \gamma o เ \varsigma$, o que não implica, certamente, que Jasão as tenha cantado ou que, nesta passagem, devamos vê-lo com imbuído das qualidades de um cantor: $\mu \varepsilon \imath \lambda$ í $\chi$ los aqui, eu proponho, tem um sentido equivalente de $\mu \varepsilon \lambda i ́ \gamma \eta \rho \varsigma_{\varsigma}$ na $N .3$, isto é, "agradável”. De fato, algo normalmente minimizado pelos comentadores, é que, muito embora compostos com $\mu \varepsilon \lambda t_{-}$em Píndaro estejam normalmente associados à canção, $\mu \varepsilon \lambda i ́ \gamma \eta \rho \vartheta \varsigma$ pode ser dito de qualquer som melodioso,

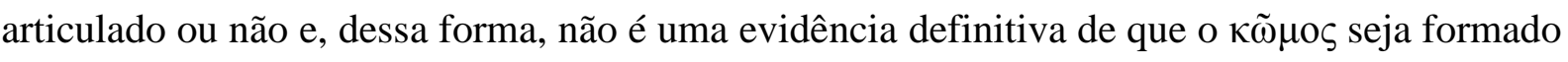
por cantores, como seria requerido de um coro, mas apenas que o som coletivo de suas vozes, que, por sinédoque, é a própria festa, é doce como toda a festa o é àquele que é festejado ${ }^{95}$.

Voltando outra vez ao himeneu de Alceste $^{96}$, e na medida em que muito da imagética

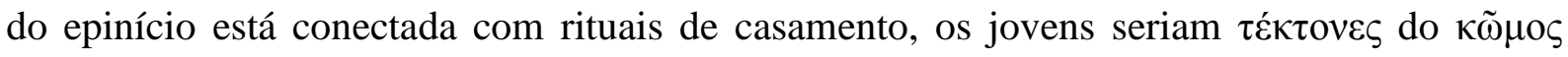
inclusive porque sem eles não há festa, não há celebração e, novamente, as canções desses

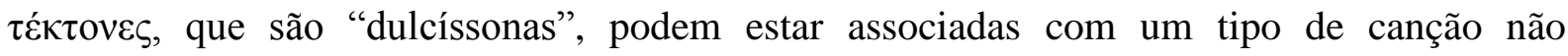
profissional, improvisada, a que se alude na $O .9 .1-4$, na cena mencionada de Alceste, ou, ainda, no himeneu (fr. 111 CAMPBELL) de Safo, cuja fraseologia revela um certo paralelismo com a N. 3.4-5 no que tange à metáfora conceitual segundo a qual CANTORES SÃO ARTESÃOS:

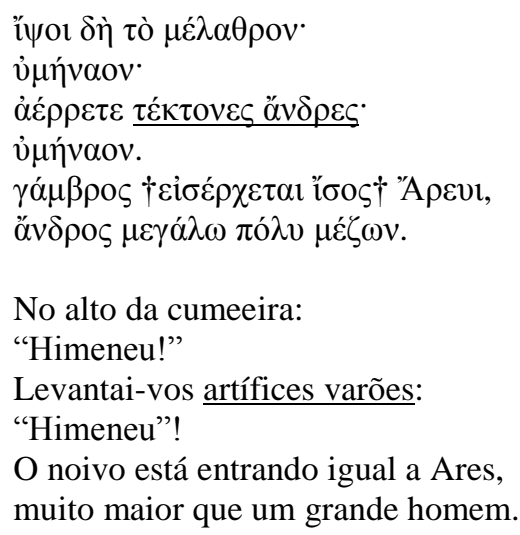

Normalmente traduzido por "varões carpinteiros", esse homens poderiam muito bem ser os celebrantes que acompanham a noiva ou o noivo durante o $\kappa \tilde{\omega} \mu о \varsigma$ nupcial, já vistos tanto na passagem citada de Eurípides quanto naquela do Escudo. Deduz-se daí que eles

${ }^{94}$ Um kenning para "mel".

${ }^{95}$ Como do canto do pássaro no $h$. Hom. Pan, 17-18, no caso específico de Teócrito, 9.437, do rouxinol. É possível que as meninas do Parteneio de Álcmã, citado acima, sejam descritas como $\mu \varepsilon \lambda \imath \gamma \alpha \dot{\alpha} \rho \varepsilon \varepsilon \varsigma$ em virtude de sua associação, no poema, com as alcíones. Para a ancestralidade indo-europeia dos compostos de $\mu \varepsilon \lambda_{1}-$ associados a canção, $c f$. M.L. WEST (2007, p. et set.).

${ }^{96} \mathrm{Cf}$. p. 94 . 
poderiam ser, nessa canção de Safo, equivalentes dos $\tau \varepsilon ́ \kappa \tau o v \varepsilon \varsigma \kappa \omega ́ \mu \omega v ~ v \varepsilon \alpha v i ́ \alpha l$ em Píndaro. Assim como lá não se está falando de coreutas, tampouco precisaríamos supor este sentido aqui.

Consequentemente, acho que seria possível fazer uma leitura da ode que incorporasse os resultados a que chegamos no Capítulo 2, em que tentamos demonstrar, por meio do

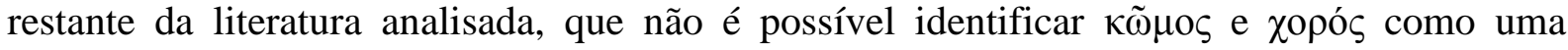
mesma forma de performance e que $\kappa \tilde{\omega} \mu \mathrm{s} \zeta$, ademais, refere-se sempre ao frame mais inclusivo no qual a celebração de vitória está enquadrada e não ao simples modo de execução da ode.

Um outro aspecto digno de nota é que todas as análises desta passagem tendem a se centrar em uma interpretação excessivamente atomística e literal dos vv. 1-12, quando me parece que uma abordagem mais holística, que leve em consideração a possibilidade de que Píndaro, ao invés de estar se referindo a jovens reais que estivessem literalmente esperando pela canção ao redor de uma fonte (ou mesmo em algum outro lugar) a fim de cantá-la, esteja, na verdade, construindo uma cena de alto cunho metafórico, que pode ser entendida tanto a partir do espaço discursivo corrente partilhado com a audiência quanto do seu conhecimento de pano-de-fundo.

No que se segue, portanto, tentarei explorar essas conexões.

Foquemos, por ora, na metáfora dos versos 3-7, que surge da interação entre três frames principais: (a) o dos jovens esperando em torno de uma fonte de água ${ }^{97}$ procurando pela voz da Musa, (b) o da gnoma generalizante segundo a qual diferentes sucessos têm sede

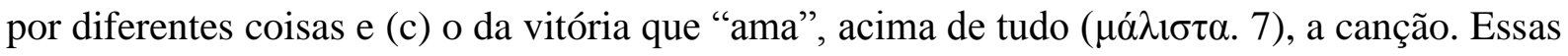
relações tomam a forma de um priamel de transição ${ }^{98}$ que, esquematicamente, poderíamos dispor da seguinte forma:

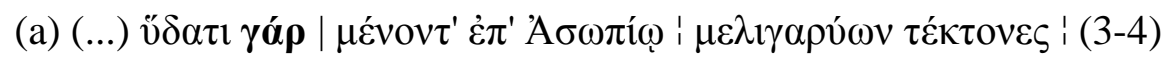

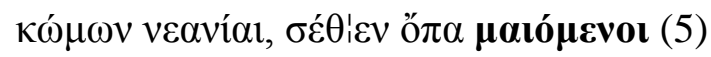

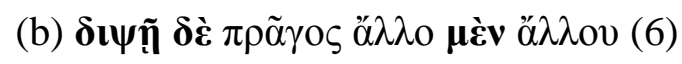

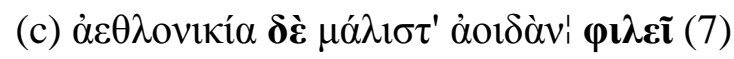

${ }^{97}$ Se a teoria de PRIVITERA (1988) estiver correta, como parece ser o caso. Cf. também CAREY (1989, pp. 552, n.17) e o $\Sigma$ N.3.1c (DRACHMANN, vol. 3, p. 42).

${ }^{98}$ Cf. RACE (1982, p. 13 et seq. e 73 et seq.). BUNDY (1962) classificaria este priamel como sumariante. 
Como nota Pfeijffer ${ }^{99}$, o $\delta \dot{\varepsilon}$ de (6) conecta-se com o verso anterior, criando uma

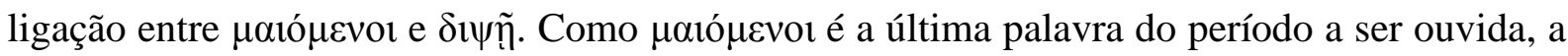
forte pausa que se segue deveria pô-la em grande saliência, sobretudo pelo rápido movimento

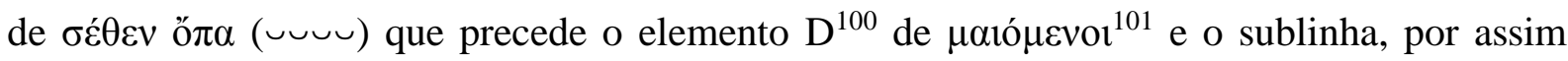
dizer, sonoramente. Parece-me apenas plausível supor que uma audiência que ouvisse $\delta \imath \psi \tilde{n} \delta \dot{\varepsilon}$ ("e tem sede") no início do $v .6$ poderia estabelecer uma associação com $\mu \alpha i o ́ \mu \varepsilon v o$, ainda vívido na memória de curto prazo $^{102}$. Ao menos pragmaticamente, se o $\delta \varepsilon ́$ do $v .6$ aponta para o verso anterior (isto é, é mais um passo na narrativa que, por parataxe, acrescenta uma informação adicional ao particípio ${ }^{103}$ ) e o $\mu \varepsilon ́ v$, vindo logo em seguida, sinaliza ao ouvinte que a ideia expressa por $\alpha \partial \lambda \lambda o v$ deverá ser expandida na sequência, isso então faz de $\pi \rho \tilde{\alpha} \gamma o \varsigma$ $\alpha \lambda \lambda \lambda_{0}$ $\mu \varepsilon \grave{v} \alpha_{\alpha} \lambda \lambda$ ov o núcleo ${ }^{104}$ a partir do qual o ouvinte pode construir a relação entre (5) e (7),

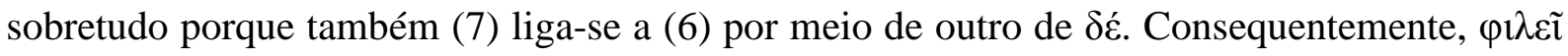

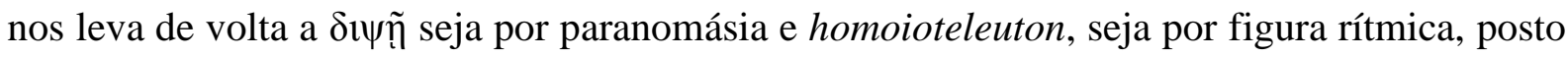
que ambos apresentam o contorno $\cup-{ }^{105}$, seja, ainda, por pura associação aural, o que evoca uma relação do tipo $\varphi \imath \lambda \varepsilon \tilde{\imath} \approx \delta i \psi \tilde{n}^{106}$. Finalmente, é notável que o movimento $\mathrm{e}^{2} \mathrm{~d}$ do segundo colon do $v .5$ ecoe tanto em 6 quanto em 7.

No esquema abaixo tentei mostrar essas relações de uma forma mais gráfica:
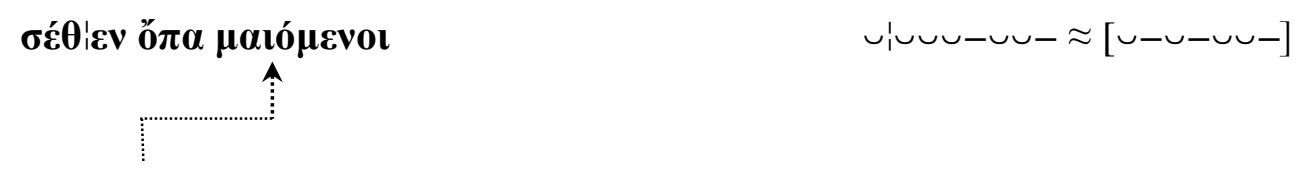

99 PFEIJFFER (1999b, p. 252).

${ }^{100}$ A colometria de Píndaro, como sempre difícil de interpretar, é, nesta ode, indecifrável e não tive a felicidade de ler qualquer análise que dela fizesse qualquer sentido. Todas se resumem a observações ad hoc acerca de cada período sem estabelecer nenhuma relação etiológica entre metro e o significado do mesmo para a ode. Para uma discussão detalhada da colometria dessa ode, $c f$., contudo, ITSUMi (2009, p. 281 et seq.) e PFEIJFFER (1999b, pp. 235-40).

101 Não é certo, contudo, que possamos interpretar $\mu \alpha \imath$ $\mu \varepsilon v o \imath$ como um d devido ao frequente fim de palavra após a primeira longa, como, e.g., no $v .13$ ǐva $\pi \rho$ ó $\varepsilon \rho \rho o$, equivalente a $\checkmark-\vdots \smile \smile-$. Daí porque, para a colometria dos escólios, que dividem o verso depois de $\sigma \varepsilon \dot{\varepsilon} \theta-$, “- $\varepsilon v$ ö $\pi \alpha \mu \alpha$ ió $\mu \varepsilon v o$ ” seria um monômetro trocaico

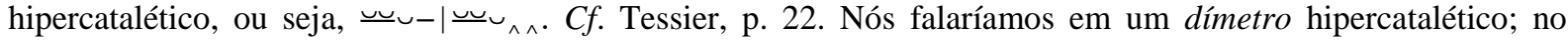
entanto, segundo a teoria de Heféstião (17.15), que os escólios seguem, o troqueu nunca aparece em sua forma simples - , razão pela qual chamam o "dímetro" de "monômetro". Talvez ITSUMI $(2009$, p. 288) esteja certo ao reduzir o movimento desse verso a uma cadência do tipo $e^{n} d$, isto é, $(-\cup-)^{\mathrm{n}}-\cup \cup-$. Na verdade, parece-me que esta é a cadência de toda a ode, muito embora seja difícil interpretar a relevância desse movimento.

102 Para uma discussão interessante nesse sentido, $c f$. WILLETT (2002).

${ }^{103}$ Mesmo que não esteja relacionado sintaticamente com ele. Há também uma sintaxe da audição e ela não depende tanto das relações sequenciais e lógicas do texto escrito como o temos.

${ }^{104}$ Mesmo metricamente, note o tema - $-\backsim \cup--$ neste grupo.

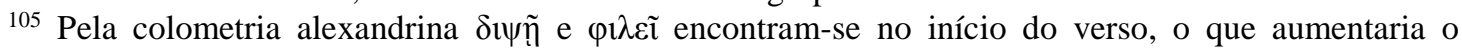

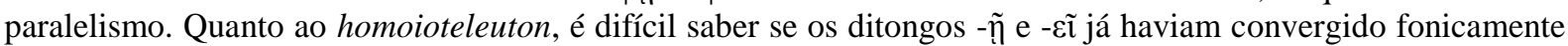
nessa época. Certamente ambos teriam sido transmitidos como $-\varepsilon 1$ nos primeiros manuscritos.

106 Assim também PFEIJFFer (1999b, p. 251) que, no entanto, não dá centralidade à metáfora na explicação dos versos seguintes. 

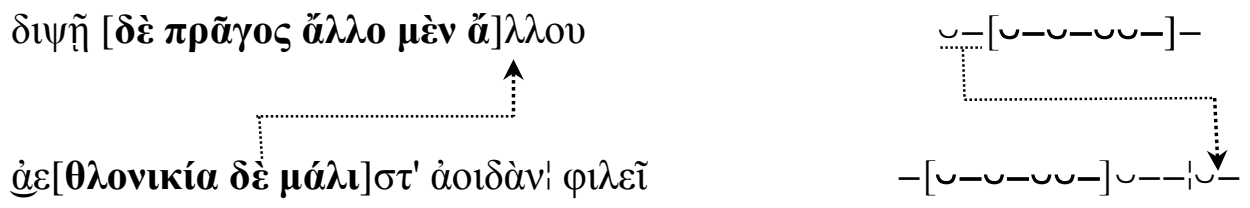

Há, portanto, mesmo no nível da forma, uma relação muito bem trabalhada entre as imagens de (a), (b) e (c) e, como acredito, essa sofisticação é vista também transladada para o plano do conteúdo.

Semelhantemente à água que flui constantemente de uma fonte, neste caso a fonte Asópica em Egina ${ }^{107}$, também a canção irá fluir, querendo a Musa (ő $\pi \alpha \zeta \varepsilon, 9$ ), fartamente

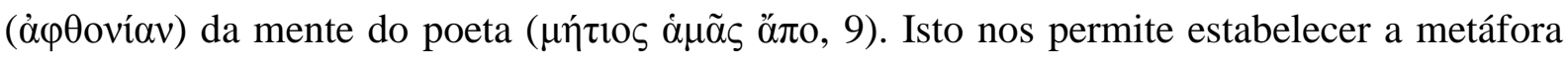
conceitual segundo a qual o POETA É UMA FONTE. Por meio dela, vemos que, da mesma maneira que os jovens se agrupam em volta de uma fonte, teoricamente para beber de sua água, assim o fariam em volta do poeta para "beber" de sua poesia, o que vale dizer, "ouvila".

Muito embora essa seja apenas uma outra interpretação da canção, ela utiliza apenas os elementos internos da ode e a imagética tradicional da literatura grega para fazer uma leitura metafórica que, ainda que não possa ser tomada como definitiva, é coerente com o que sabemos acerca da conceitualização dos papéis do poeta e da canção na práxis poética arcaica. Não são poucas as passagens nos epinícios em que o cantor é descrito como a fonte da poesia, esta última frequentemente comparada com algum líquido valioso (orvalho, mel, vinho etc.) que é aspergido sobre o público, a cidade ou o vencedor. Parece-me muito significativo, ademais, que apenas aqui e no Peã $6.55^{108}$, em que uma fonte também está envolvida (vide abaixo) Píndaro caracterize a Musa como "filha do Senhor do céu multinebuloso"109, a qual deve dar início ao hino. Uma afiliação tão idiossincrática dificilmente deveria se tomada como fortuita ${ }^{110}$.

Como foi muito bem argumentado por Pfeijffer ${ }^{111}$, o uso de óp $\chi \omega$ na voz ativa e regendo um acusativo implica que o sujeito tem importância no início do processo, o qual

107 PRIVITERA (1988).

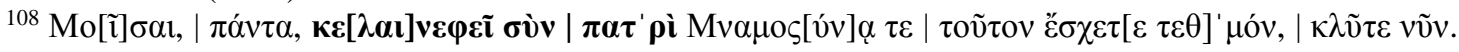
$C f$. a tradução de partes desse peão à pp. 149 et seq.

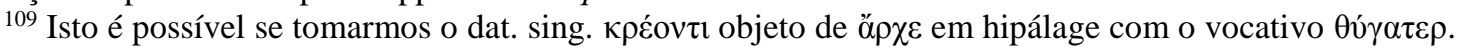
É notável que Pausânias (29.4.5-6) fale, sob a autoridade de Estesícoro, de uma tradição, provavelmente mais antiga, segunda a qual as Musas, originalmente três ao invés de nove, seriam filhas da Memória com o Céu

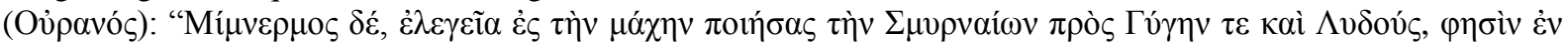

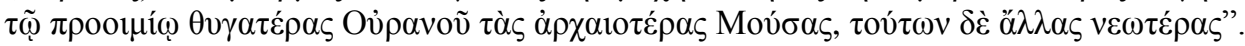

${ }^{110}$ Explico no que se segue.

111 PFEIJFFER (1999b, pp. 259-60). 
deverá ser, no entanto, continuado ou completado por outros; nesse caso, o próprio poeta, de cujo engenho $(\mu \tilde{\eta} \tau \iota \varsigma)$ a canção irá brotar. De acordo com Privitera ${ }^{112}$, as águas da fonte Esópica eram trazidas por meio de aquedutos subterrâneos desde as montanhas, na parte interna da ilha, onde se originavam pela precipitação da chuva. Dessa forma, a relação estabelecida entre o domínio-fonte, a saber "NUVENS-ÁGUA-FONTE-JOVENS" mapeia, termo a termo, a relação “MUSA-CANÇÃO-POETA-PÚBLICO" dentro do domínio-alvo, tornando toda a metáfora dos $v v$. 1-8 compreensível a partir da mesclagem desses dois domínios ${ }^{113}$.

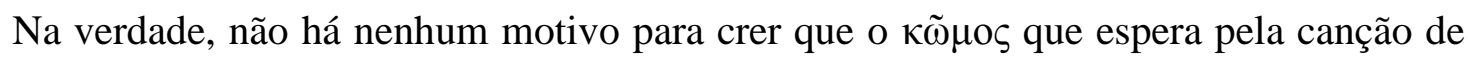
Píndaro em torno a uma fonte possa ser mais do que uma sinédoque que represente toda a comunidade do vencedor, ansiosa por uma celebração de vitória. Isso fica mais claro se compararmos os versos iniciais da $N .3$ com aqueles do Peã $6^{114}$, em que a ausência de jovens em festa em torno da fonte da Castália é o motivo dado pela persona loquens para vir em socorro dos habitantes de Delfos, ou, numa outra leitura, dos eginenses responsáveis pela execução do peã em Delfos ${ }^{115}$ :

Assim como a água é capaz de conferir vida, a canção também o é, imortalizando o feito; talvez por isso ela seja descrita ao final do epinício de uma maneira exuberante como uma "poção cantante"116, dada pela persona loquens para o seu pí̉oç. Agora, no entanto, interessa-me mais o $v$. 80, "ỏ $\psi \varepsilon \varepsilon \pi \varepsilon \rho$ ", "ainda que tardia", que situa, por meio de uma deixis temporal, a performance da canção em um momento (fictício ou não, isso seria de pouca importância) muito posterior à ocasião ideal imaginada para a mesma, o que nos remete para o início da ode, onde se fala da "sede" da vitória pela ode e onde vemos os jovens ansiosos ao lado de uma fonte de água, enquanto esperam pela voz (ő $\pi \alpha, 5)$ da Musa. Agora, no epílogo, vemos a canção materializar-se como uma "poção cantante" que, por tardia, chega em um momento em que a "sede" por ela deveria ter atingido o ápice. O que a persona loquens oferece, no entanto, não é meramente água, é algo muito mais elaborado: uma "poção cantante de mel misturado com alvo leite e recoberta de uma espuma". Isto, dentro da

112 PRIVITERA (1988).

113 Para uma relação implícita entre as diferentes necessidades ( sedes) dos homens e a canção de vitória, $c f . O$. 11.1-6 em que as águas divinas são ditas ỏ $\mu \beta \rho i ́ \omega v ~ \pi \alpha i ́ \delta \omega v v \varepsilon \varphi \varepsilon ́ \lambda \alpha \varsigma$, de uma maneira alusiva a ascêndencia da Musa expressa nessa ode.

${ }^{114} C f$. tradução da passagem relevante à p. 149 et seq.

${ }^{115}$ Para uma discussão dos problemas apresentados por esse peã, bastante atípico pelo que sabemos das regras formais do gênero, $c f$. a excelente discussão de RUTHERFORD (2001, p. 306 et seq.) e também aquelas de STEHLE (1997, p. 138 et seq.) e KURKE (2005).

116 Já discutimos a imagética do brinde no Capítulo 4, p. 58. Cf. N. 4.4-8, onde a canção é comparada,

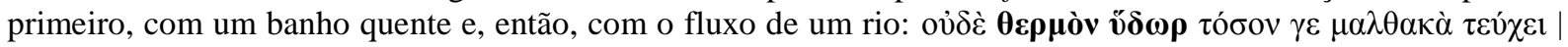

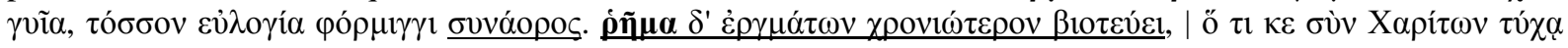

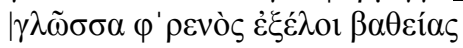




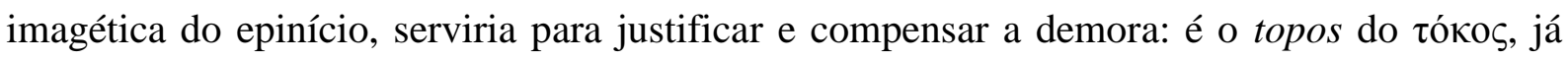
empregado por Píndaro na $O .10 .7-9$, por exemplo ${ }^{117}$.

Essas observações, contudo, não esgotam todas as ressonâncias da metáfora, nem a

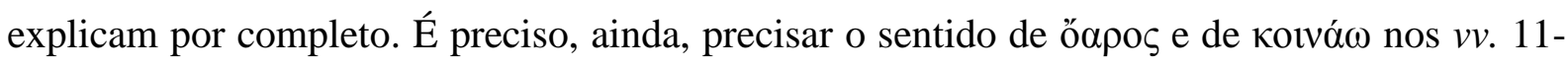
12, tomados como referências explícitas a uma performance coral. Os comentadores parecem estar de acordo quanto ao sentido "primitivo" que se deve ler em ambos, isto é, respectivamente, "conversa", "bate-papo descontraído", "lábia" (sobretudo amorosa) ${ }^{118}$ e, para o verbo, “tornar comum”, “popularizar”. Apesar disso, quase todos ${ }^{119}$ optam por uma interpretação metafórica tanto de um quanto do outro, a fim de que se adequem à suposição de

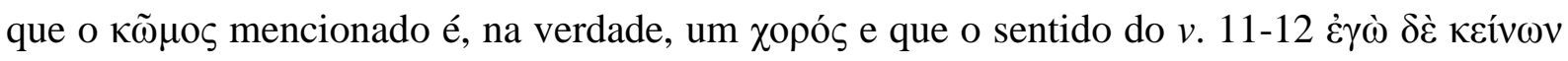

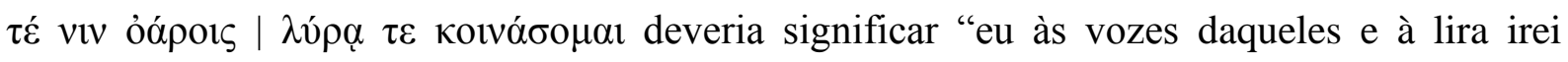

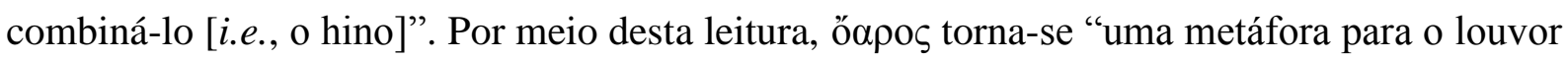
cantado pelo coro de meninos" ${ }^{120}$ [grifo meu], apesar de Píndaro falar aqui de veqvíaı e não de

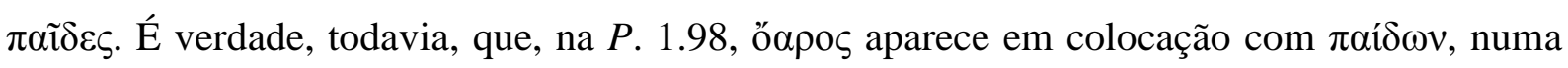
passagem que teremos a oportunidade de comentar em seguida.

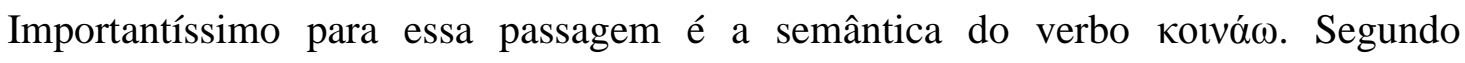

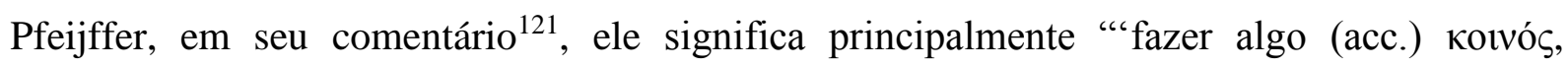
comum, para alguém (dat.)', i.e., 'dividir com', 'combinar com”" e, em nota, "especialmente na voz média ('fazer algo comum para alguém visando um interesse próprio')"122. SLATER, no

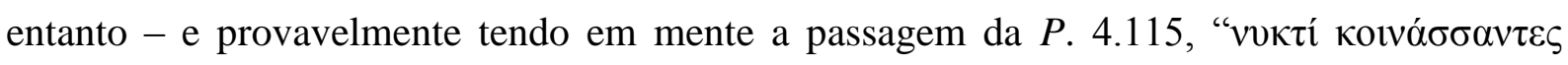

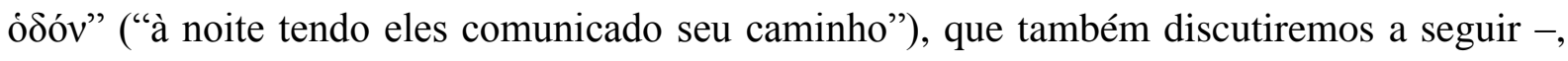
opta por dar maior centralidade à acepção metafórica de "confidenciar a", "confiar a"123. Isto, no entanto, é conferir ao verbo um sentido exatamente oposto ao de "fazer algo (acc.) кoıvó $\varsigma$ ". Seja como for, RUMPEL, nesse sentido, parece-me ter ido mais sucintamente ao ponto com a glossa “communico".

Hubbard, em um artigo em que propõe uma leitura dos dativos ỏóporৎ e $\lambda u ́ \rho \alpha^{124}$ na qualidade de instrumentais, ao invés de objetos indiretos de кoıvó $\omega$, chama a atenção para o

117 VeRdENIUS (1988a, p. 59), "Does not refer to O. 11 (...), but to the extra beautiful quality of the

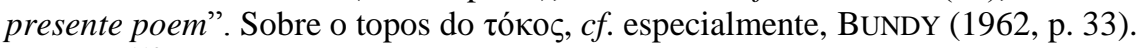

$118>$ ǒ $\alpha \rho, c f$. DELG e DEG, s.v. No sentido de "conversa mole", "sedutora", provavelmente na $P$. 4.136-8, $c f$. discussão mais abaixo.

${ }_{119}$ Para uma relação dos comentadores e tradutores, $c f$. T. HUBBARD (1987, p. n.1).

${ }^{120}$ PFEIJFFER (1999b, p. 263).

${ }^{121}$ PFEIJFFER (1999b).

122 PfeijfFer (1999b, p. 266 e n. 57). Assim também BOECKH (1821)

123 Ambos s.v. Kotvá $\omega$.

124 T. HUBBARD (1987, p. 3). 
fato de que esse verbo não é atestado na geração anterior a Píndaro, Ésquilo e Baquílides e que, portanto, o seu valor semântico deveria estar ainda sujeito a uma certa instabilidade ${ }^{125}$. É

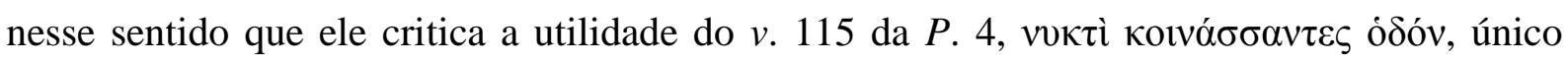
outro exemplo em Píndaro, como evidência de um emprego normativo do verbo no sentido de "confidenciar a", já que vê aí uma acepção claramente metafórica em que "comunicar à noite" seria equivalente a "sair em segredo" 126 . Hummel também desaprova a interpretação dada pela maior parte dos críticos ao verbo, vendo nos dativos que o acompanham exemplos claríssimos de instrumentais:

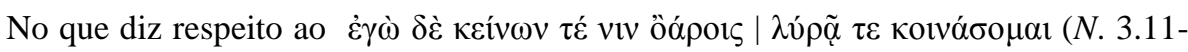
12), a maior parte dos comentadores e dos tradutores interpretam os dativos como

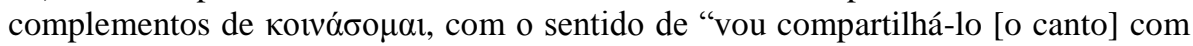
as vozes do coro e a lira"; raros são os que analisam os dativos como instrumentais, "vou fazê-lo público com a ajuda das vozes do coro e da lira". A segunda opinião parece preferível e oferece um sentido mais interessante. ${ }^{127}$
\end{abstract}

Embora a leitura metafórica de Hubbard esteja, em linhas gerais, correta, acredito, contudo, que não se trate de um uso metafórico do verbo, mas, isto sim, que o verso deva ser lido como enquadrado pela metáfora conceitual de que A NOITE PERCORRE UM CAMINHO NO CÉU ${ }^{128}$ e que, portanto, os responsáveis por levar Jasão ao exílio teriam fugido percorrendo esse caminho, ou, doutra forma, fazendo-o coincidir com a sua fuga, o que é uma forma altamente estilizada e poética de dizer que teriam "saído à noite", isto é, quando a noite já começara o seu caminho pelo céu. Consequentemente, não é que o uso de kovvá $\omega$ na $P .4 .115$ seja metafórico (ele é, de fato, bastante literal), apenas assim nos parece porque ele é usado dentro do frame delimitado por uma metáfora conceitual que já não nos é tão evidente, mas que provavelmente poderia soar bastante clara a uma audiência arcaica.

Uma outra passagem relevante, apontada por Boeckh ${ }^{129}$, e que aparece também na $P$. 4, precisa ser citada em um contexto mais amplo para que depois possamos entender sua relevância para a discussão. A cena descreve a volta de Jasão a Iolco e o reencontro com seus parentes em um contexto simpótico:

${ }^{125}$ Curtius, apud BRASWELL (1988, p. 204), vê no uso do verbo um arcaísmo.

126 Assim também BRASWELL (1988, p. 204): "In Greek the exclusivity of a secret is sometimes emphasized by saying that it is shared only with a personified object or abstraction. cf., e.g., E. Ion 956-57 (...) e AP 5.8.1-2". Nenhum dos exemplos que cita, no entanto, usam o verbo kotvó $\omega$, o que enfraquece seu argumento. Uma posição semelhante é a de GENTILI et al. (1995, p. 461), muito embora aí se reconheça o valor literal da expressão como "avendo comunicato la strada alla notte"

127 HUMMEL (1993, p. 126).

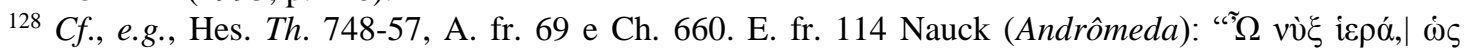

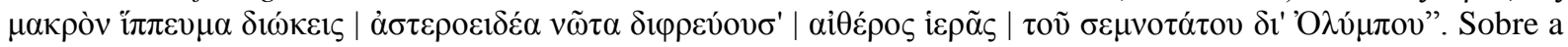
origem indo-europeia da imagem, $c f$. M.L. WeST (2007, p. 220 et set.).

${ }^{129}$ BOECKH (1821, p. 365). 


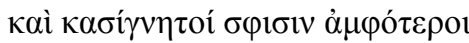

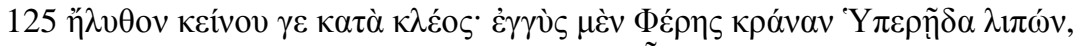

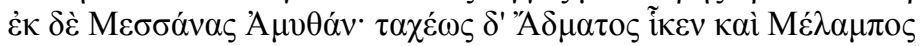

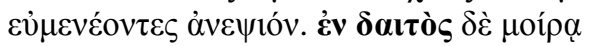

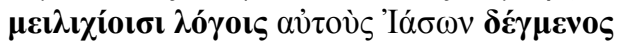

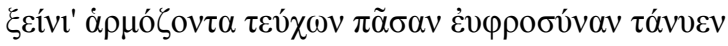

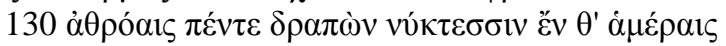

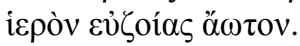

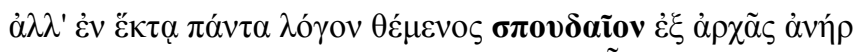

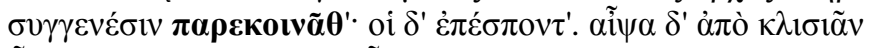

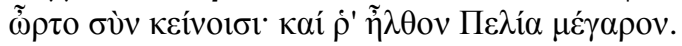

e ambos os irmãos de seu pai

125 vieram seguindo-lhe o boato. De perto veio Feres, deixando a Hipéria fonte,

e, de Messana, Amitão. Rapidamente vieram também Admeto e Melampo,

benquerendo ao sobrinho. Na ocasião do banquete,

tendo-os recebido com doces palavras, Jasão,

preparando-lhes a hospitalidade adequada, toda a festa estendeu

130 por cinco noites e dias ininterruptos, colhendo

a fina-flor do bem-viver.

mas no sexto, um assunto sério abordando, desde o princípio, o varão,

com os parentes, compartilhou. E eles o apoiaram ${ }^{130}$. De pronto dos reclinatórios

levantou-se na companhia daqueles, e foram ao palácio de Pélias.

Essa passagem é crucial por vários motivos. Em primeiro lugar, o verbo

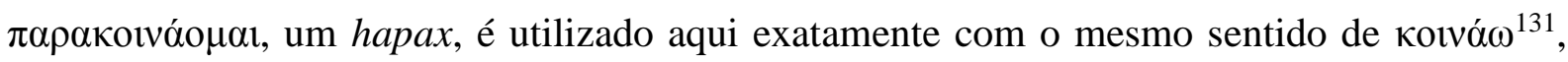
ou seja, "comunicar para", "fazer do conhecimento de", com objeto direto e o indireto explícitos, respectivamente, $\lambda$ ó ${ }^{\circ} \varsigma_{\text {e }}$ e

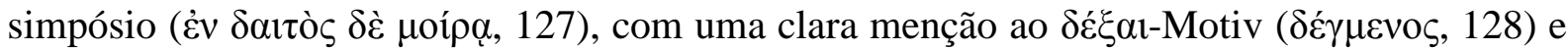
uma separação entre as duas fases do banquete: uma de diversão, que dura "cinco dias e cinco noites" (130) e outra, que marca o fim do simpósio, para que se possa tratar de "um assunto

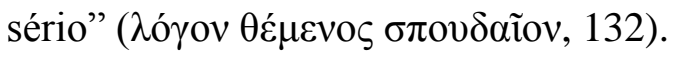

A partir desse exemplo, parece-me bastante plausível que a acepção "combinar com"132 atribuída ao verbo kotvów na $N .3 .12$ não deveria ser lida quando o sentido “comunicar a" é o único possível na passagem acima, e, além disso, poderia ser lido sem maiores problemas também naquela Nemeia, mesmo levando-se em consideração uma forma ligeiramente diferente do verbo aqui, isto é, $\pi \alpha \rho \alpha \kappa o t v o ́ o \mu \alpha r^{133}$. Consoante a isso, talvez a acepção “combinar com” faria sentido se (e apenas se), novamente, partirmos do princípio de

${ }^{130}$ Para essa interpretação de oi $\delta^{\prime} \dot{\varepsilon} \pi \varepsilon ́ \sigma \pi o v \tau^{\prime}, c f$. BRASWELL (1988, p. 219). Jasão não conta apenas a sua história, mas também o plano de recuperar o trono, o que fica subentendido.

${ }^{131}$ Assim Braswell (1988, p. 218) e GenTILI et al. (1995, p. 465), “col senso del semplici кowvó $\omega ”$.

132 CAREY (1989, pp. 553, n. 18), "This is made clear in vv. 11-12, where Pindar promises to blend his song with their voices". A acepção "combinar com” parece ser melhor denotada, em Píndaro, por $\sigma 0 \mu \mu \varepsilon i ́ \gamma v \bar{u} \mu 1$,

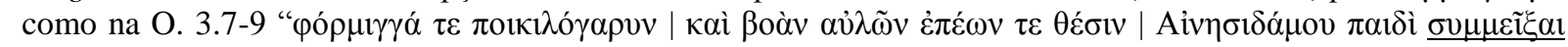

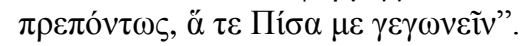

${ }^{133} C f$. n. 131, acima. 


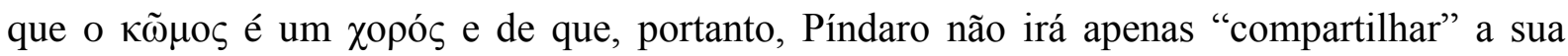
canção com as vozes dos jovens a que irá se juntar, mas que irá “combinar" sua canção às suas vozes para que esses a cantem. No entanto, para que essa hipótese faça sentido, precisaríamos supor um emprego também não convencional para ő $\alpha \rho \varsigma$ que nunca é usado como sinônimo de "canto"134 ou, ainda, de "voz como instrumento do canto"135, algo evidente a partir das acepções listadas na entrada do LSJ para essa palavra, na qual o sentido "canto" aparece ilustrado apenas por passagens tiradas dos epinícios, onde o sentido "conversa", "bate-papo" ou "boato" poderia ser facilmente lido. Uma dessas passagens é a N. 3. As outras são a $P .4 .137$, a $N .7 .69$ e a $P .198$.

Na P. 4.136-8 o sentido de "conversa mole" é facilmente dedutível do contexto, que descreve como Jasão tenta ganhar a graça de Pélias por uma divisão pacífica do poder em

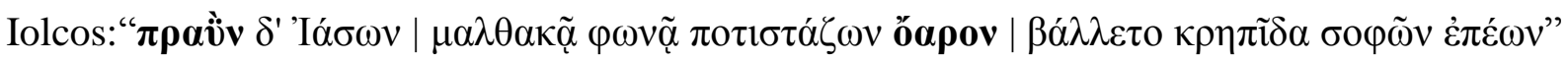
("e Jasão, destilando | com voz suave uma conversa mole, | lançou a base de palavras sagazes"136). Na N. 7.69, Píndaro tenta se livrar da acusação de que algum dia teria ofendido

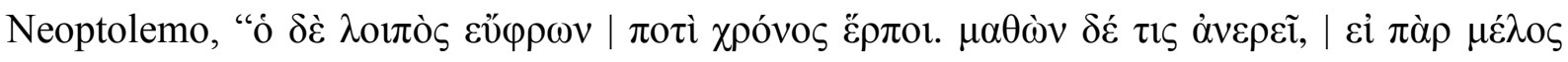

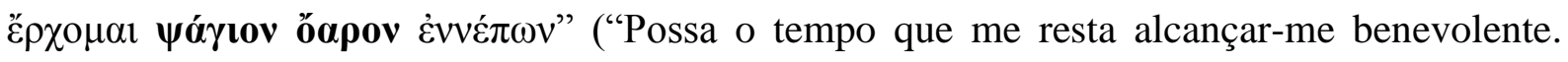
Alguém que o saiba dirá | se costumo, abusando da canção ${ }^{137}$, pôr, em versos oblíquos, ${ }^{138}$ boatos"). Muito embora se possa discutir qual seria a melhor solução para traduzir ő $\alpha \rho \varsigma^{139}$, parece que todos os tradutores concordam que o sentido "canto" aqui seria inadmissível. $\mathrm{Na}$

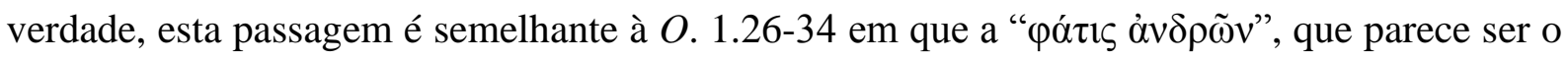

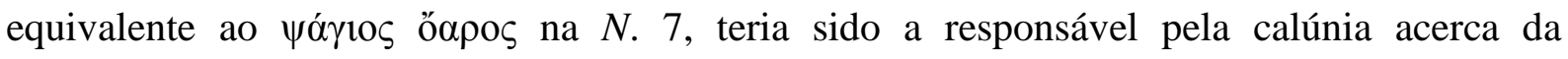
“glutoneria dos deuses". Utilizando uma imagem semelhante, também lá o poeta demonstra

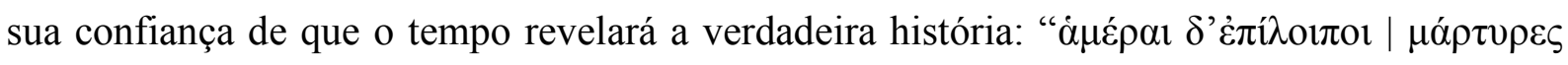

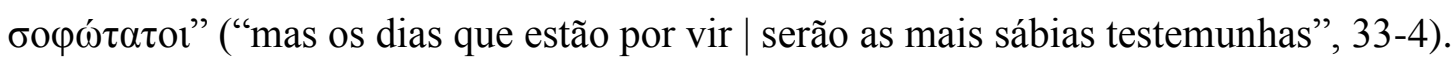

A passagem da $P$. 1.98, merece ser comentada em maiores detalhes. $\mathrm{O}$ trecho relevante é o seguinte (92-100):

${ }^{134}$ BRASWELL (1988, pp. 222-3), “originally a) 'intimate coversation with one's wife (ő $\left.\alpha \rho\right)($ Il. 6, 516), then b) 'familar talk' more generally (so already at its first attested occurrence, Hes. Th. 205 (...), and finally c) 'discourse', 'words (spoken or sung)' in a neutral sense (Empedocles 31 B 21.1 and always in Pindar)".

135 Como ö $\pi \alpha$ o é, como vimos no início dessa seção, e como será usado na N. 3 . 65 et seq. que comentaremos em seguida.

${ }^{136}$ Assim RACE (1997a, pp. vol 1. p. 278-9), “In a soft voice | Jason distilled soothing speech | and laid the foundation of wise words". Cf. também, PINDAR (2007, p. 58). GENTILI et al. (1995, p. 466), "parole benevole".

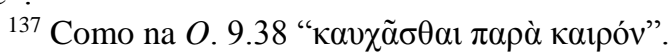

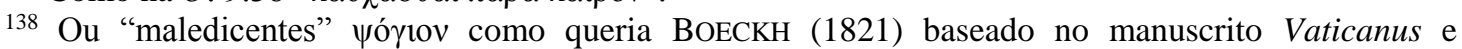
suportado por Hesíquio, a variante não aparece, contudo, no apparatus criticus de S-M, como já era de se esperar.

${ }^{139}$ RACE (1997a, p. 79), “crooked utterance”. PINDAR (2007, p. 107), “lies”. 


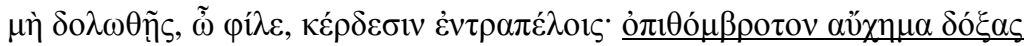

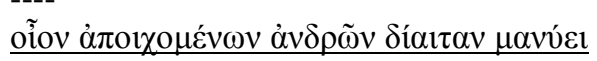

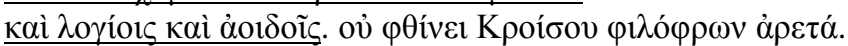

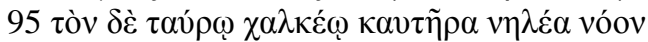

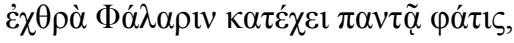

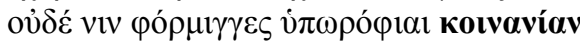

$\boldsymbol{\mu \alpha \lambda \theta \alpha \kappa a ̀ v ~ \pi \alpha i ́ \delta \omega v ~ o ̉ \alpha ́ \rho o เ \sigma ı ~ \delta \varepsilon ́ \kappa o v \tau \alpha l . ~}$

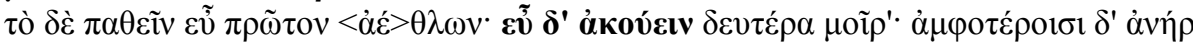

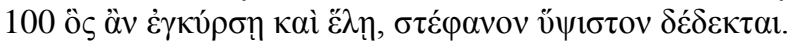

Não sejas enganado, ó amigo, por infames lucros: a glória póstuma de uma reputação

é a única capaz de revelar a saga dos varões que já se foram

tanto aos cronistas quanto aos cantores. Não perece a gentil virtude de Creso,

95 mas com seu touro de bronze o incendiário de ímpia mente,

Faláris, odiosa tem sua fama silenciada em todo lugar,

nem as forminges dos salões na gentil

comunhão com a conversa dos meninos o recebem.

Ser bem sucedido é o primeiro prêmio. Ouvir de outrem a boa fama, o segundo. $\mathrm{O}$

[varão que ambos

encontra e colhe, com o mais supino laurel é agraciado.

Nesta ode há uma clara alusão ao poder imortalizador da canção (92-4) que se manifesta, aparentemente, em dois níveis: naquele que a liga à capacidade dos aedos (94) e

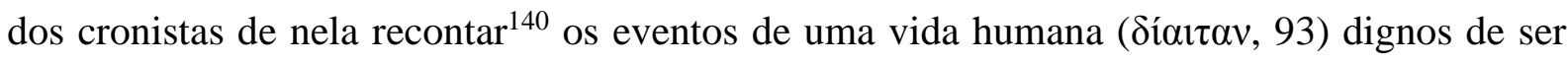
cantados e num outro, que me parece implicado pelos $v v$. 94-100, que vincula a sobrevivência da canção e, portanto, da saga nelas preservada, a uma contínua sucessão de reperformances.

É provável, além disso, que o cenário de reperformance visualizado seja aquele do simpósio, para o que aponta fortemente a caracterização das forminges como "de salão"

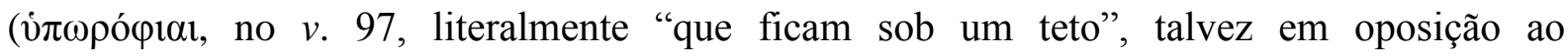
instrumento dos poeti vaganti de que falamos anteriormente no Capítulo 4), a $\mu \alpha \lambda \theta \alpha \kappa \eta ́$

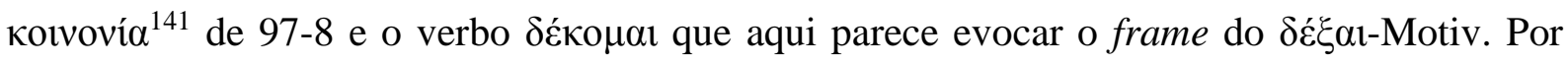
meio da metáfora que vê nas forminges as anfitriãs de um simpósio, a "gentil virtude" de Creso seria recebida e faria companhia às vozes dos meninos como se fosse um comasta aceito em um simpósio. A infâmia de Faláris, no entanto, teria um destino contrário e a sua admissão no simpósio, como no caso de Tântalo, na $O$. 1, estaria interditada. Muito embora o próprio Faláris seja, de fato, lembrado na canção pindárica, o que se ouve dele não é a fama, e sim a infâmia, daí o sentido limitador ao sucesso dado pela gnoma ao final da ode: não basta ter sucesso, é preciso que o sucesso venha acompanhado de uma história digna de ser ouvida e

\footnotetext{
${ }^{140}$ Provavelmente Píndaro não deveria ter em mente cronistas que difundissem histórias em prosa, isto é, numa forma não metrificada.

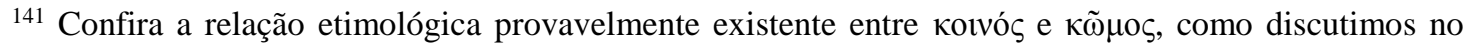
Capítulo 2, p. 78.
} 


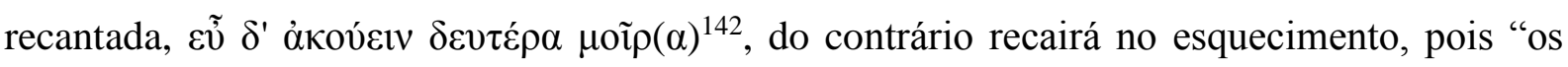

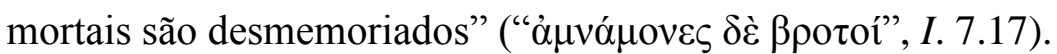

Admitidamente, esse verso da P. 1.98 é onde őapoৎ mais se aproxima do sentido proposto de "canto" e poderia estar, de fato, empregado nesta acepção. No entanto, parece-me que haja uma solução mais simples para entender o verso e que leve em conta a dinâmica do simpósio, ao qual se alude na cena imaginada para uma possível performance de canções que falassem de Creso ou de Faláris. Ao passo que uma canção que tratasse da "gentil virtude" de Creso seria um tema adequado para um momento de descontração e alegria como aquele do simpósio, uma história horrenda (e, ademais, baseada em fatos reais relativamente recentes) como as atrocidades cometidas por Faláris não seria uma companhia adequada à "delicada conversa dos meninos" e, portanto, como um hóspede ou comasta indesejado, seria impedida de adentrar o simpósio na forma de uma canção ou de ser mencionada nas conversas. $\mathrm{O}$

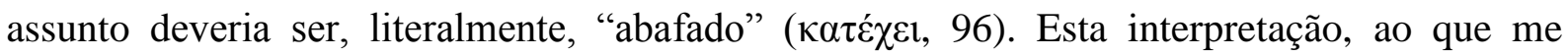
parece, adequa-se bem à etiqueta do simpósio como vista na passagem da $P$. 4.123-34, mais acima, em que Jasão deixa os assuntos "sérios" apenas para o final do simpósio com os parentes. A mesma ideia aparece expressa no seguinte fragmento elegíaco anônimo ${ }^{143}$ :

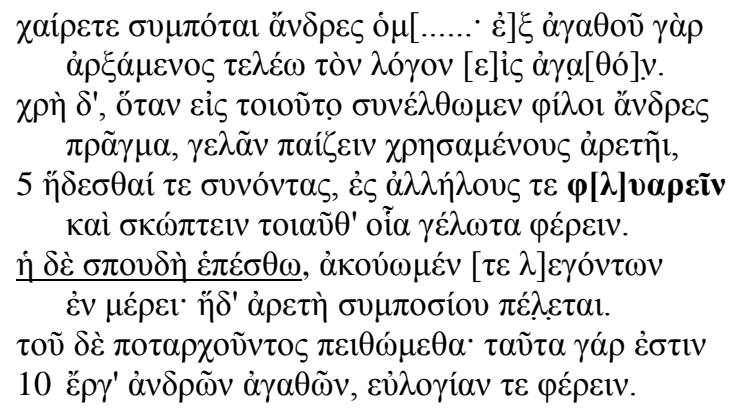

Salve camaradas de bebedeira [...] pois com algo bom tendo começado, finalizo também com algo voltado ao bem.

É mister, meus amigos, que, sempre que nos reunamos em tal negócio, saibamos rir e divertirmo-nos como cavalheiros, saber agradar e, uns com os outros, jogar conversa fora, fazendo também piadas do tipo que o riso induzem.

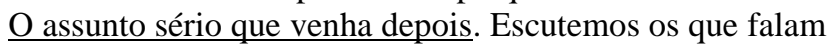
cada um em sua vez: essa vem a ser a virtude do simpósio. Obedeçamos ao simposiarca, pois essas coisas são comportamento de nobres varões e comportam elogio.

\footnotetext{
${ }^{142} C f$. RuMPEL s.v. àkoṽ $\omega$, que glossa dicor. Isto é, o verbo é empregado com um sentido passivo. Para

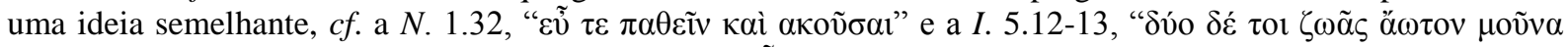

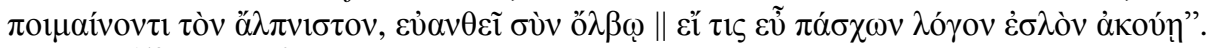

$14327 \mathrm{IEG}^{2}$. Para fotos e bibliografia desse interessantíssimo fragmento do III séc. d.C., cf. o Berliner Papyrusdatenbank neste link: $\underline{\text { P. Berol. } 13270 .}$
} 


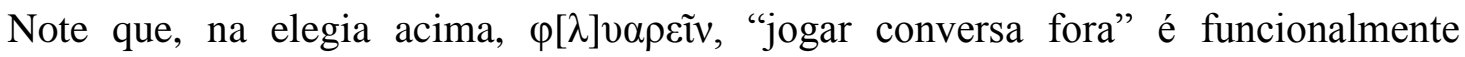
equivalente a ỏ $\alpha \hat{\zeta} \zeta \omega$, o que me parece, ademais, confirmado por este outro epigrama anônimo

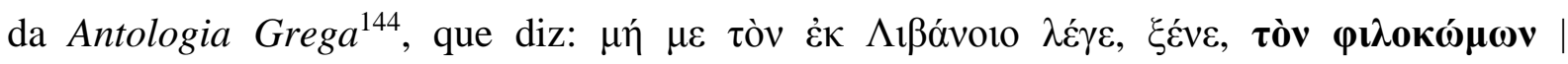

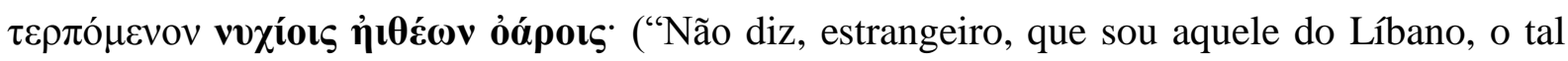
que se deleita no bate-papo noturno dos jovens amantes dos kōmoi"). Ainda que a fonte seja possivelmente tardia, não deixa de ser digno de nota que óópo $\varsigma$ aparece explicitamente associado ao bate-papo do simpósio.

O que nos leva a uma segunda questão. Do ponto de vista da teoria coral, é necessário

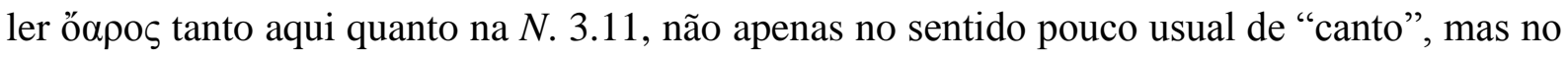
não menos usual sentido de "canto coral". Carey, por exemplo, cita o $\pi \alpha i ́ \delta \omega v$ óópoı́ı da $P$.

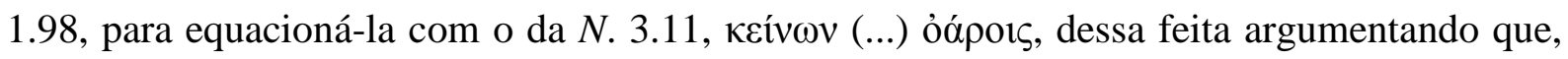

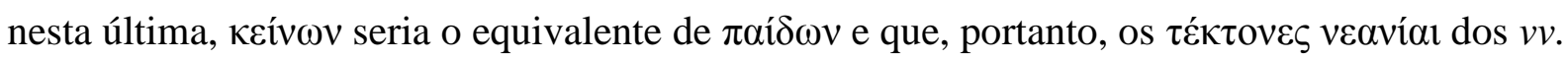
4-5 da N. 3 seriam, na verdade, os meninos do coro responsáveis pela performance da ode. Esses estariam esperando ansiosos pela ode do poeta para que pudessem cantá-la. Seu raciocínio parte do princípio que, de acordo com a etiqueta do simpósio, não deveríamos esperar encontrar $\pi \alpha \tilde{i} \delta \varepsilon \varsigma$ desacompanhados de seus tutores em tais ocasiões, ao menos no caso de pudicos jovens de família, embora reconheça que outros, não tão pudicos ${ }^{145}$, pudessem frequentar esse ambiente, segundo ele, tipicamente associado com o mundo adulto. Como exemplos, ele cita uma passagem do Banquete de Xenofonte (1.8) e uma das cenas finais da Paz de Aristófanes (1256-1301) que me parecem, na verdade, contradizer seu argumento ${ }^{146}$.

Com relação à passagem de Xenofonte, é preciso que se atente para o fato de que o próprio simpósio é, na verdade, uma festa de celebração pela vitória de Autólico na luta do

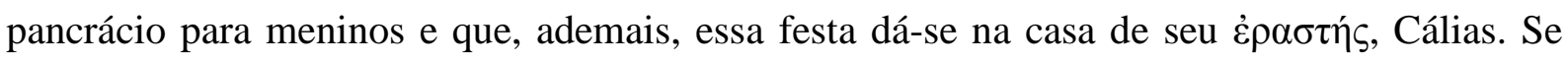
esse tipo de celebração era comum - algo do que, de fato, não temos razões para duvidar -, torna-se difícil entender em que sentido Carey vê o simpósio como um evento eminentemente adulto. Muito embora o comportamento de Autólico seja irreprochável, na medida em que ele passe todo o tempo sentado ${ }^{147}$ ao lado de seu pai, não são poucos os olhares e os elogios que

${ }^{144}$ Mais precisamente da Antologia de Planudes, relegada ao livro XVI da Antologia Grega, 16.202.

145 Como Alcibíades, acusado por Lísias, 14.25. Não vejo esta evidência como convicente porque me parece que a ênfase dada é mais sobre (a) a associação de Alcibíades com Arquedemos, um corrupto e demagogo ateniense acusado de receber propina enquanto em serviço público, (b) sobre o possível relacionamento sexual entre os dois e (c) o consumo excessivo de vinho e a convivência com prostitutas em uma idade ainda tida como inapropriada a tais práticas. Extrapolar esta passagem em uma "lei" que proibia ou via com maus olhos a presença de menores nos simpósios é um exagero.

${ }^{146}$ Como esse argumento de Carey e as respectivas passagens são normalmente repetidas, muitas vezes acriticamente, por outros autores, me pareceu necessário análisá-las em maiores detalhes.

${ }^{147}$ Ao contrários dos homens, que se reclinavam nas $\kappa \lambda i ́ v \alpha \mathbf{l}$, os meninos deveriam se sentar ao lado de seus tutores; neste caso, o pai de Autólico. 
recebe dos convivas; além disso, mesmo que brevemente e sempre de uma maneira muito recatada, ele participa do diálogo. A despeito de seu comportamento exemplar, não deveríamos supor que os banquetes fossem frequentados apenas por jovens pudicos da aristocracia como ele ${ }^{148}$. É possível, inclusive, utilizar evidências do mesmo diálogo para argumentar o contrário, já que, no segundo capítulo, somos apresentados a um outro $\pi \alpha i ̄ \varsigma, ~ o$

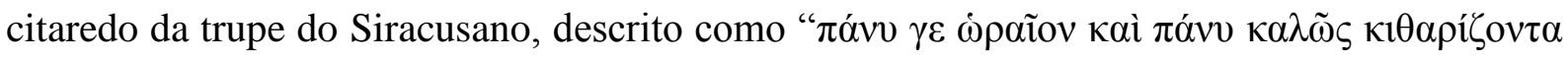

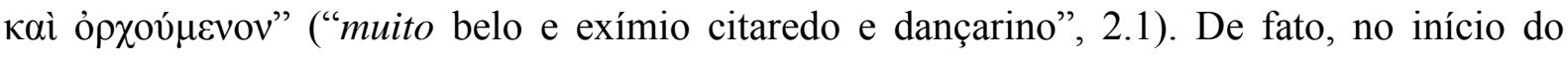
capítulo três, podemos vê-lo cantando solo:

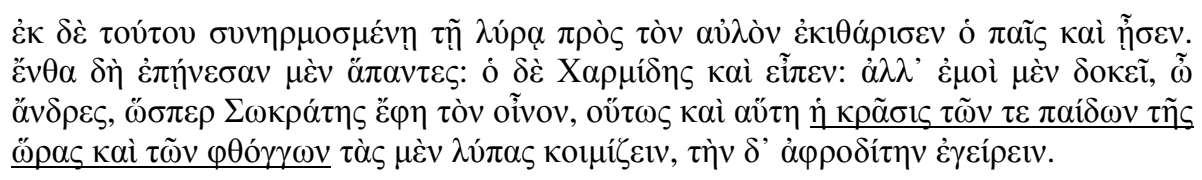

Em seguida, afinando sua lira com o aulos [da auletriz], o menino a tocou e cantou. Todos então o cumprimentaram. Cármides, inclusive, disse "Parece-me, meus caros, que o que Sócrates disse sobre o vinho vale também para essa mistura da beleza dos meninos e de suas vozes: ela leva embora as preocupações e acorda o desejo". ${ }^{149}$

Se atentarmos à fala de Cármides, veremos que tanto a comparação com o vinho como o uso do plural ( $\pi \alpha i ́ \delta \omega v / \varphi \theta o ́ \gamma \gamma \omega v)$ assumem um tom generalizante que talvez indique que a performance musical de meninos, como a recém descrita, era tão usual quanto a própria presença do vinho nos simpósios. Uma performance solo, no entanto, e não coral.

De fato, é exatamente isso que vemos na cena de $\mathrm{Paz}$ (1265-1301), em que dois meninos saem da casa de Trigeu (onde estaria acontecendo um baquete de núpcias) para

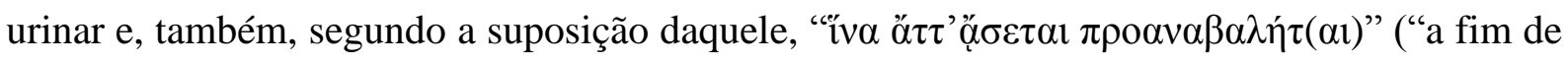
ensaiarem o que irão cantar"). Quando, no entanto, Trigeu pede que lhe deem uma amostra do que pretendem cantar, o versos que produzem não são aqueles associados com metros da "lírica coral", mas sim hexâmetros e trímetros jâmbicos ${ }^{150}$, ademais, de cunho bélico, mais pertinentes a uma performance solo, o que faz com que essa cena de Paz seja, de fato, uma evidência em favor de um costume no qual $\pi \alpha \tilde{i} \delta \varepsilon \varsigma$ não apenas poderiam frequentar banquetes mas que, inclusive, poderiam executar peças musicais como solistas. Há de se convir, ademais, que dois meninos dificilmente poderiam ser vistos como um "coro", que deveria ter,

${ }^{148}$ Sobre isso, parece-me suficiente citar apenas os trabalhos de Dover (1989) e T. K. HUBBARD (2003).

${ }^{149}$ X. Smp. 3.1.

${ }^{150}$ Epigonoi, fr.1, fr. dub. 6; Il. 3.15, 5.14, 8.61, Od. 19.32; Archil. fr. 5.1-2 etc. Para uma lista completa cf. OLSON (2003, p. 308 et seq.). 
no mínimo ${ }^{151}$, entre 9 e 11 participantes, se pudermos usar como comparação a autodescrição do fr. 1 PMG de Álcmã, ainda que aquele tenha sido composto para um coro de moças ${ }^{152}$. De fato, nem no nível da dramaturgia eles fazem parte do coro desta comédia, mas se configuram como "papeis extras"153.

Um outro exemplo que Carey cita como paralelo à hipotética canção coral da $N$. 3 é a elegia atribuída a Teógnis (237-246 W²). Parece-me, entretanto, que o que poeta está prometendo ao seu destinatário seja imortalidade através da canção que os jovens,

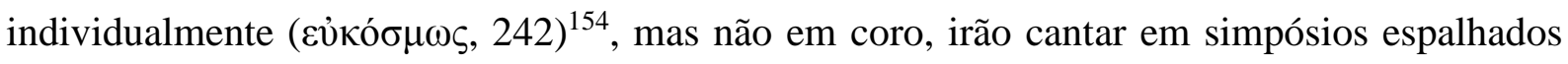
por diversas partes do mundo grego ${ }^{155}$, exatamente como Píndaro promete a Hierão através do exemplo positivo de Creso e do negativo de Faláris.

Consequentemente, não há porque não ler o plural $\pi \alpha i \delta \omega v$ ỏópoıøı na $P$. 1.98 como uma generalização acerca da infâmia póstuma de Faláris, que não será lembrado nas conversas (ou nas canções), óópoıøı, que os meninos (se pudicos ou não, pouco importa) com suas vozes e suas liras irão cantar nos simpósios. É possível que isto esteja implicado, ademais, pela generalização da fala de Cármides, no Banquete. Poder-se-ia argumentar que lá o $\pi \alpha \tilde{i} \varsigma$ citaredo da trupe do Siracusano deveria ser, na verdade, um escravo. Ainda que isso seja bem possível, esse fato tem, no entanto, pouca relevância, uma vez que é menos o cantor, e mais a canção, que confere fama. Além do mais, não temos igualmente nenhuma informação sobre o status social dos $\pi \alpha i ́ \delta \omega v$ da $P .1$ e, portanto, o mesmo argumento aplicarse-ia para essa passagem.

Em se abrindo mão, portanto, de que ő $\alpha \rho$ s em Píndaro signifique sempre "canto" e que кoıvó $\omega$ signifique "combinar", dois sentidos, como vimos, parcamente atestados, nada

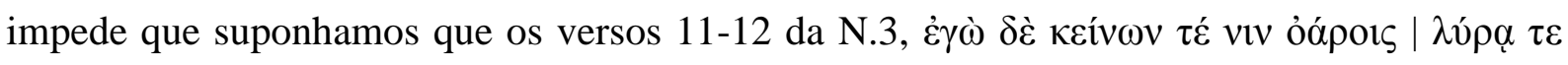

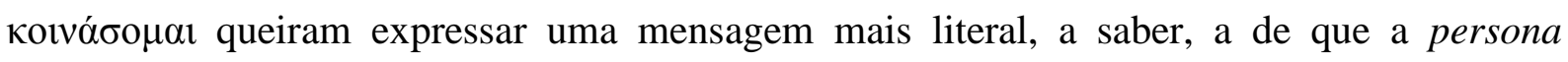
loquens deseja compartilhar com os jovens que formam o $\kappa \tilde{\omega} \mu о \varsigma$ de Aristocleides e com a lira (já que esta fará o acompanhamento musical) aquilo que a Musa lhe inspirou no ânimo e que

${ }^{151}$ Heródoto, 6.27, nos informa da tragédia que acometera um coro de cem rapazes que os habitantes de Quios haviam enviado a Delos, dos quais apenas dois retornaram, todos os outros tendo sido acometidos por uma peste mortal. Em Atenas, o número padrão de dançarinos em ditirambo era cinquenta. Escudo.

${ }^{152} C f$., no Capítulo 2, a estreita relação entre o coro de moças e o de meninos na passagem discutida do 193-5).

${ }^{153}$ Para um comentário de toda essa passagem, $c f$. OLSON (2003, p. 306) e SOMMERSTEIN (1985, pp.

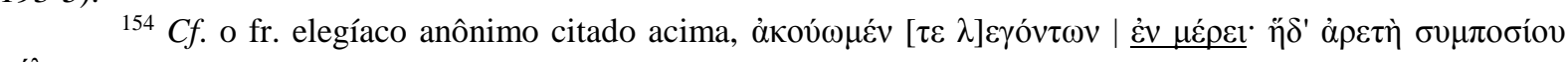
$\pi \varepsilon \dot{\ell} \ell \varepsilon \tau \alpha 1$.

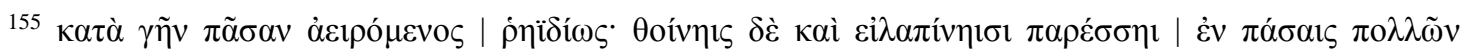

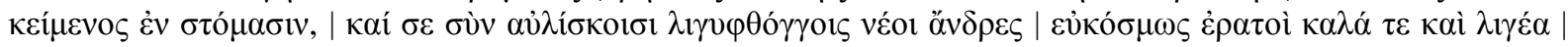

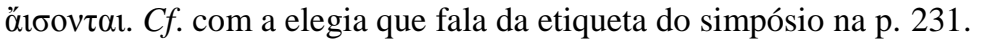


deverá fluir de sua mente abundantemente, como a água de uma fonte, em meio àqueles que esperam em Egina com tanta ansiedade pela canção que é devida à vitória obtida por um de

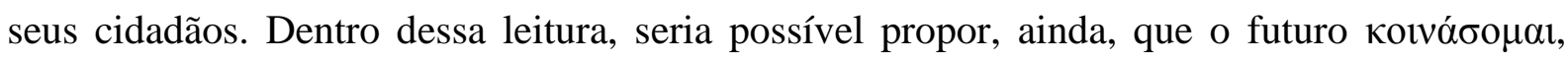
mesmo que encomiástico, também possa aludir obliquamente, sobretudo num contexto diferente da première, a futuras ocasiões de reperformance e, assim, seu significado de “tornar אoเvó $\varsigma$ " adquira uma outra dimensão, aquela de "popularizar" a canção tanto por meio de reperformances nos simpósios quanto porque o laudandus estará sempre "na boca"156 dos jovens que dele participam, através de suas conversas (ỏóporৎ).

Ao contrário das estrofes iniciais dessa Nemeia, nos $v .65$ et seq. temos o que parece uma menção explícita à execução do epinício pelas "vozes dos moços", o que poderia, de fato, apontar para uma performance coral.

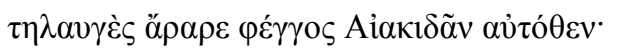

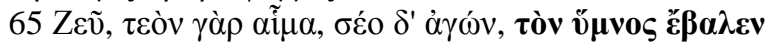

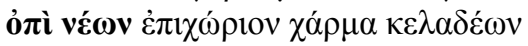

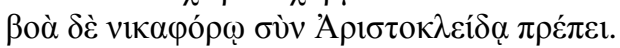

A luz do filhos de Eáco, que daqui ao longe brilha, está fixada firmemente.

Ó Zeus, pois teu é o sangue; tua, a contenda, que o hino coroou ${ }^{157}$

com a voz dos jovens, celebrando a alegria local ${ }^{158}$,

e o clamor é adequado na companhia do vitorioso Aristocles.

A proposta de Lefkowitz e Heath de que o aoristo $\check{\varepsilon} \beta \alpha \lambda \varepsilon v$ poderia se referir a um hino cantado anteriormente, durante a festa de celebração da vitória, embora não seja impossível, é muito improvável. Sobretudo porque Píndaro parece retornar, aqui, à injunção feita à Musa anteriormente para que trouxesse sua voz à Egina e que desse início ao hino, que agora ele parece dizer que está concluído. Como Carey e Pfeijffer observam, uma menção abrupta a uma outra canção, sem qualquer outro tipo de referência adicional que permitisse à audiência identificá-la, seria improvável, muito embora, é preciso que se ressalte, essa informação pudesse fazer parte do EDC da performance. Além disso, o v. $65 \mathrm{com}$ a sua menção à descendência de Éaco, cuja fama acaba de ser lembrada ao longo dos vv. 33-64, e aos jogos nemeios do qual Zeus era o guardião, tornam a hipótese de uma outra canção muito pouco atraente. Capítulo 7.

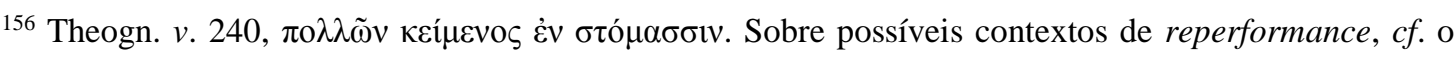

${ }^{157} C f$. SLATER, s.v. $\beta \alpha ́ \lambda \lambda \omega$ e NÜNLIST (1998, p. 153)

${ }^{158}$ Minha tradução acima é propositadamente ambígua e eu a explicarei no que se segue. 
Seja como for, parece haver sérios problemas para o entendimento dos $v v$. 65-6, crucial para nos decidirmos quanto ao modo de performance dessa passagem e que, a meu ver e até onde pude averiguar, não foram considerados com propriedade dentro da controvérsia "monódica x coral".

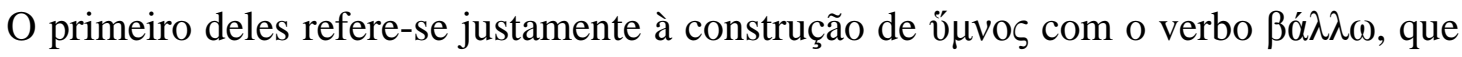
Pfeijffer acredita estar empregado em sua acepção metafórica de "atingir" um alvo ${ }^{159}$, um sentido que seria comum em Píndaro a partir da metáfora conceitual segundo a qual DICTA SÃO MísSEIS ${ }^{160}$. Entretanto, em todos os casos em que Píndaro usa o verbo $\beta \alpha ́ \lambda \lambda \omega$ metaforicamente, sempre na voz ativa, o mapeamento dos elementos do domínio-fonte no domínio-alvo é ATIRADOR $\rightarrow$ LAUDATOR/ MUSAS; MÍSSEIS $\rightarrow$ DICTA; ALVO $\rightarrow$ LAUDANDUM, como aliás comprovam todos os exemplos que ele cita ${ }^{161}$. Na $N$. 3, contudo, a partir da metáfora do $v$. 65, teríamos ATIRADOR $\rightarrow$ DICTA e MísSEL $\rightarrow$ LAUDANDUM, isto é, "o hino lançou a competição com a voz", o que produz um sentido insatisfatório e, ademais, não atestado em Píndaro. Na verdade, além dessa passagem, v̋ $\mu$ vo só aparece como sujeito de um

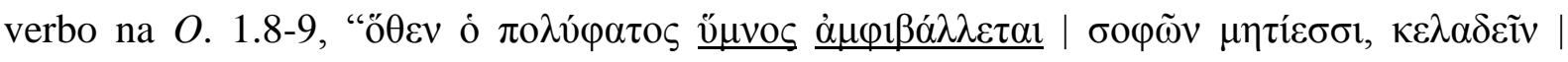

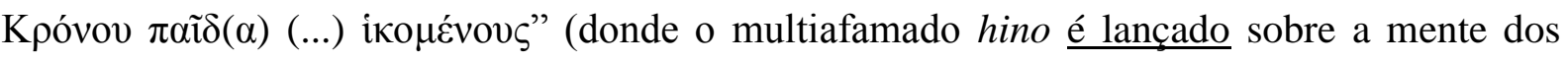
artistas, vindos a cantar o filho de Crono), no entanto, aqui também o sentido de $\grave{\alpha} \mu \varphi \imath \beta \alpha ́ \lambda \lambda{ }_{0} \mu \alpha \imath$ é muito disputado ${ }^{162}$.

Uma outra acepção poderia ser "atingir", atestada, por exemplo, na elaborada metáfora

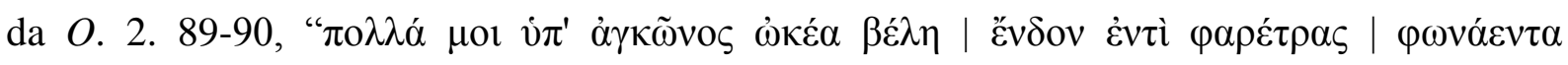

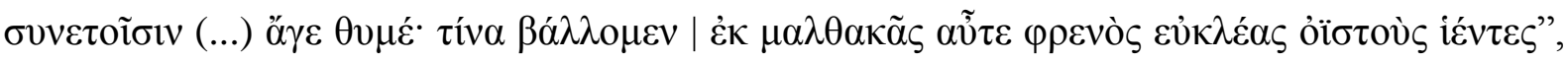
(“São me muitos os rápidos mísseis sob o braço | dentro da aljava | vozeantes aos entendidos (...) | Eia, meu coração! Sobre quem verteremos | de nossa mente gentil, outra vez, lançando [uma saraivada de] ínclitas flechas?") ${ }^{163}$. No entanto, aqui, o flecheiro é o poeta e os mísseis são as flechas, as quais, subentende-se, são suas palavras de louvor e, portanto, qualquer paralelo com a N. 3 pode ser descartado, onde precisaríamos supor algo do tipo "o hino

159 PFEIJFFER (1999b, p. 374), “The verb ع̈ $\beta \alpha \lambda \varepsilon v$, borrowed from 'ballistic' terminology, is used metaphorically in a poetical contexto. Similar metaphors are not uncommon in the work of Pindar" [grifo meu].

${ }^{160}$ Irei empregar a palavra latina DICTA para cobrir todos as $\beta \varepsilon \dot{\lambda} \eta$ conceitualizadas como MísSEIS por

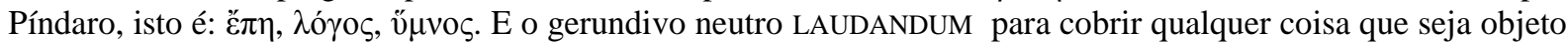
do louvor, o laudandus, a sua cidade, a vitória, etc. Dentro desta mesma metáfora, muitas vezes encontramos o mapeamento ARCO $\rightarrow$ LIRA e DARDO/ LANÇA $\rightarrow$ LÍNGUA.

${ }^{161}$ O. 1.111/2, O. 2.83, O. 9.5, O. 13.93-5, P. 1.43-5, N. 1.18, N. 6.26, N. 7.66, N. 9.55, I. 2.35 I. 5.46-8, I. 2.1-5. E, em outros autores, B. 10.43, A. Ag. 241, Eu. 676, Suppl. 446, Pl. Tht. 180a, Hor. C. 2.16.17.

162 Sobre isso, principalmenteD.E. GERBER (1982, p. 27), que ainda acrescenta "The litteral idea of 'throwing' or 'striking' is so often absent in "

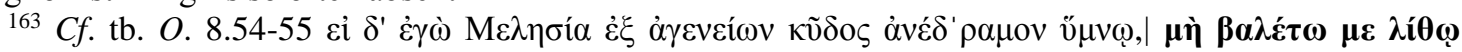

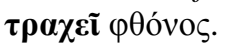


atingiu a competição com a voz"164, com um sentido aproximado de "o hino tocou na contenda", isto é, "falou dela", mas o sentido de $\beta \alpha ́ \lambda \lambda \omega$ na acepção de "tocar em um determinado assunto" é pouco usual ${ }^{165} \mathrm{e}$, ademais, o v̋ $\mu v o \varsigma$ nunca aparece em Píndaro nem, ao menos até onde pude verificar, em qualquer outro autor, como sujeito desse verbo. Como nota Nünlist, "ao contrário dos exemplos [i.e., do poeta como um atirador] citados até aqui, este [N. 3.65-66] se descata por dois motivos: Primeiramente é dito de maneira explícita que a canção "atingiu" não uma pessoa, e sim uma temática (...). Além disso, já não é mais o poetaatirador o sujeito, mas o hino como canção-flecha (ou -lança) que atinge o objeto" 166

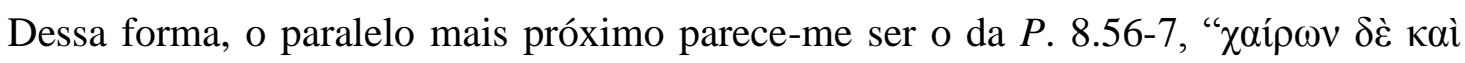

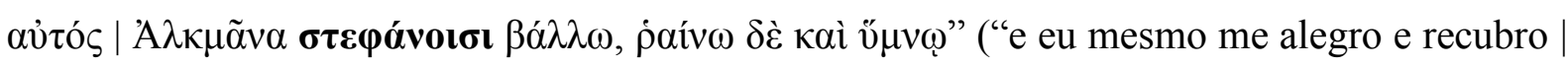
Álcmã com coroas, e também o aspirjo com um hino"), onde o acusativo A $\lambda \kappa \mu \tilde{\alpha} v \alpha$ e o plural

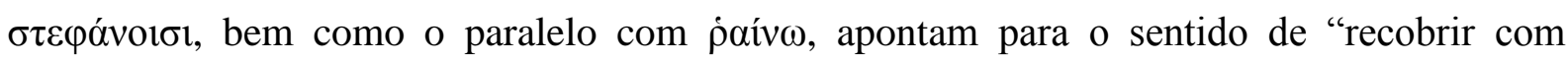
coroas", mais do que simplesmente "alvejar com", sobretudo porque a cena alude à conhecida prática da $\varphi v \lambda \lambda \circ \beta o \lambda i ́ \alpha$, na qual o vencedor era recebido sob uma chuva de pétalas de flores, coras e frutos secos. Além do mais a contrução $\beta \alpha ́ \lambda \lambda \omega \omega+$ ACC. + DAT. INST. é idêntica em ambas as passagens. Minha proposta, consequentemente, é que na $N$. 3.65, leiamos $\beta \alpha ́ \lambda \lambda \omega$

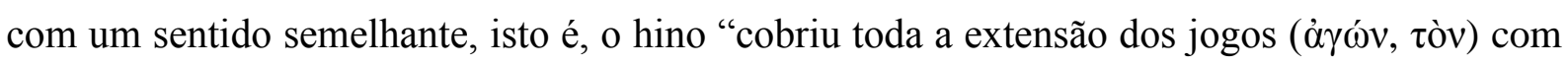
a voz (ỏ ì), ou seja, coroou-o ${ }^{167}$. Em primeiro lugar, essa é uma acepção metafórica atestada em Píndaro e, além disso, produz um sentido razoavelmente bom, quando se pensa que a canção "coroa" os jogos não só porque nele o laudandus se sagrou como vitorioso mas também porque o epinício, vindo ao final das competições (nesse caso, algum tempo depois,

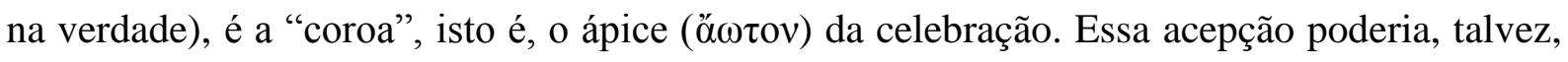
estar implicada também na metáfora da $O$. 1.8-9, mencionada acima ${ }^{168}$.

Seria possível, consequentemente, pontuar após ỏ $i$ í, lendo vé $\omega v$ como complemento do objeto de $\kappa \varepsilon \lambda \alpha \delta \varepsilon \dot{\varepsilon} \omega v$, o que alteraria completamente o sentido do verso: "coroei o hino com a voz, cantando a alegria local dos jovens". Essa leitura, contudo, talvez não seja

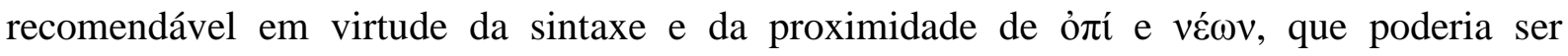

${ }^{164}$ A solução idiomática de RACE (1997a, p. 29), "this hymn has struck/ with young men's voices" e PINDAR (2007) "which my hymn strikes upon" não deveria nos levar a supor que a expressão "to strike a subject", natural em inglês, soe tão natural em grego.

${ }^{165}$ Rumpel glossa tango como um dos sentidos de $\beta \alpha ́ \lambda \lambda \omega$, mas é capaz de fornecer apenas este exemplo da $N$. 3.65. Eu não fui capaz de encontrar nenhum exemplo em que $\beta \alpha ́ \lambda \lambda \omega$ é empregado no sentido de "tocar"

${ }^{166}$ NÜNLIST (1998, p. 153)

${ }^{167}$ De fato, Slater, citando tanto a $P .8$ quanto a $N .3$, glossa um dos sentidos de $\beta \alpha ́ \lambda \lambda \omega$ nessa passagens como "to crown".

${ }^{168} C f$. NiSETICH (1975). 
imediatamente interpretado por uma audiência como “com a voz dos jovens", mas ela não é, apesar disso, absurda.

Em primeiro lugar porque a colocação ỏ $\pi \grave{~ v \varepsilon ́ \omega v ~ n a ̃ o ~ a p a r e c e ~ e m ~ n e n h u m a ~ d a s ~} 66$ ocorrências de ỏ $\pi$ ì no corpus do $\mathrm{TLG}^{169}$. Além disso, normalmente ỏ $\pi \grave{i ̀ ~ v e m ~ q u a l i f i c a d o ~ p o r ~}$ um adjetivo no mesmo caso, como por exemplo na fórmula homérica VERBA CANTANDI +

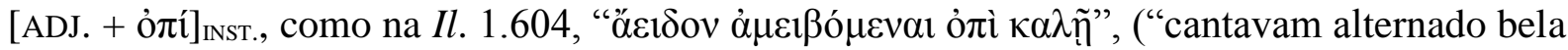
voz") e similares. Em segundo lugar porque, na N. 7.83-4, a persona loquens, numa autoinjunção ${ }^{170}$, utiliza-se precisamente dessa fórmula épica, em um verso ritmicamente semelhante àquele da N. 3.66:

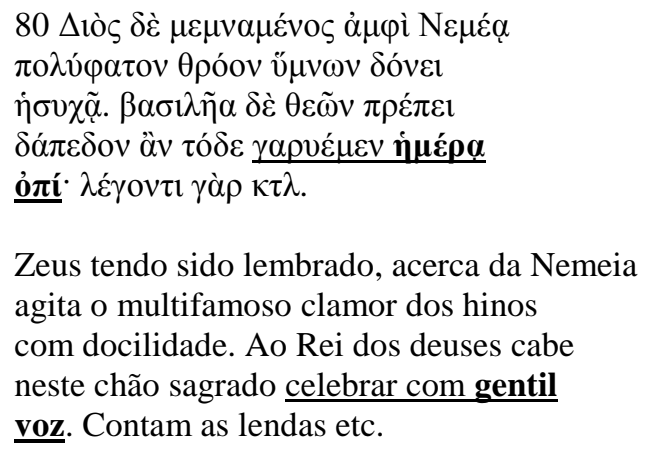

Um outro argumento favorável a pontuar após ỏ í é a coerência interna da ode. Como vimos, na estrofe inicial, Píndaro pede pela voz da Musa ( $\underline{\sigma \varepsilon \varepsilon \varepsilon v}$ ő $\pi \alpha$ ) e diz que os jovens anseiam por ela ( $\mu \alpha$ ió $\mu \varepsilon v o \imath)$. É no mínimo estranho que, ao final da canção, a voz já não seja mais da Musa e sim dos jovens. Entretanto, se a voz fosse ainda a do cantor, e não a de um coro, não soaria estranho dizer que aquele cantara "a alegria local dos jovens", já que essa alegria seria, obviamente, Aristocleides. Como coloca Bremer ${ }^{171}$ de uma maneira bastante precisa, "a vitória pertencia à pólis, e a sua pólis estava orgulhosa dele [i.e., o vencedor]; a celebração poética da gloria unius civis era, ao mesmo tempo, a celebração da gloria totius civitatis". Apesar disso, dentro da teoria do "subterfúgio oral" de Carey, seria perfeitamente possível argumentar que nos vv. 80 et seq. Píndaro estaria apenas finalizando a ficção que começara no início da ode, ou seja, a de que iria "combinar a voz da Musa com as vozes dos

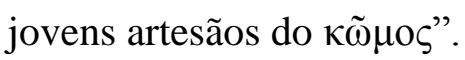

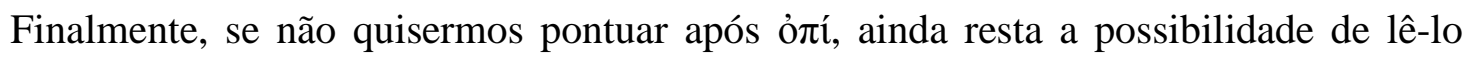
como um dativo de acompanhamento ou associação, isto é, que "o hino coroou na companhia

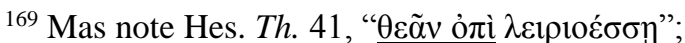

${ }^{170}$ RACE (1997a, p. 79), "The poet is addressing himself or the chorus leader".

${ }^{171}$ BREMER (1990, p. 43).
} 
da voz dos jovens". É preciso pensar que na $O .9$, Efarmosto é descrito como sendo festejado

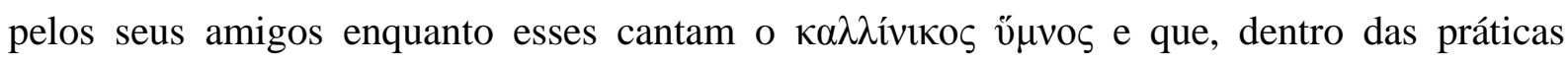
aludidas no Capítulo 2, isto provavelmente teria acontecido sob um chuva de coroas e folhas, lançadas sobre o vencedor. Na medida em que a própria canção pode ser conceitualizada como uma $\mathrm{COROA}^{172}$, o ato do poeta de metaforicamente lançá-la sobre a cabeça do vencedor

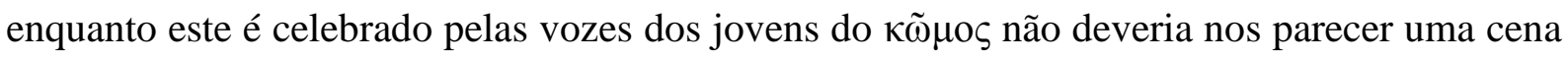
tão implausível.

\section{1.10}

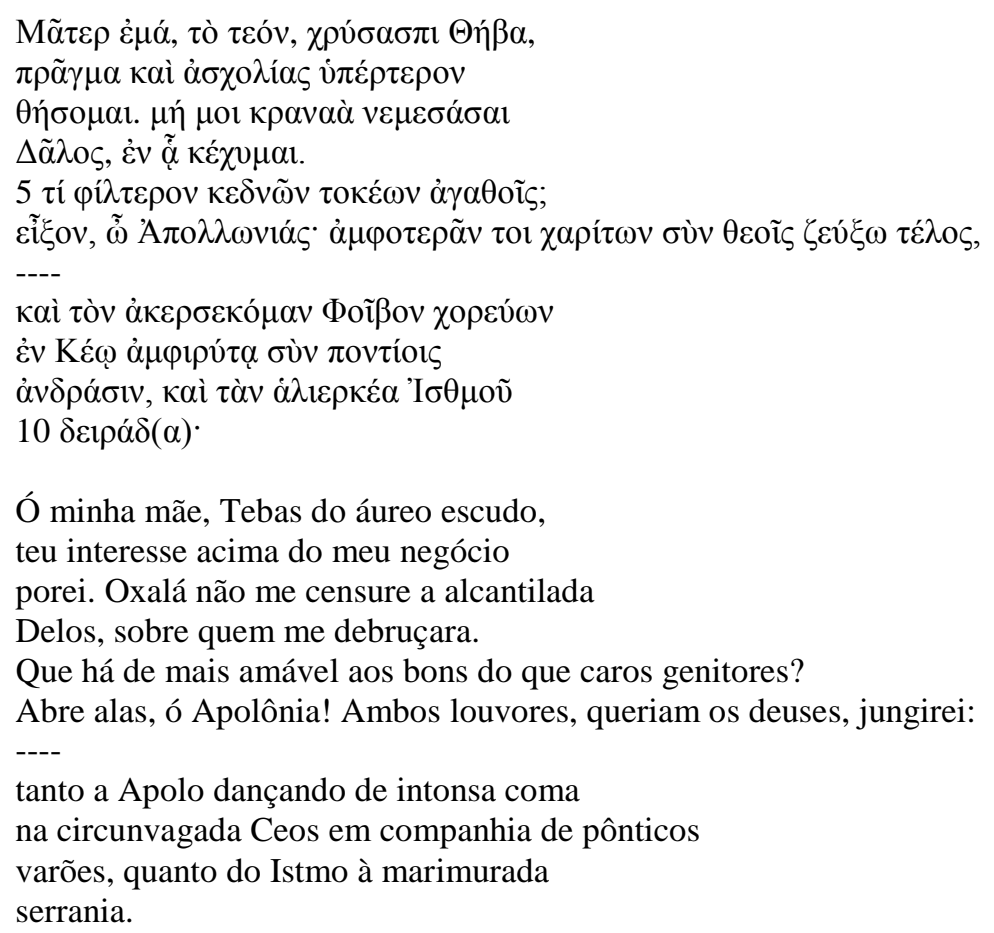

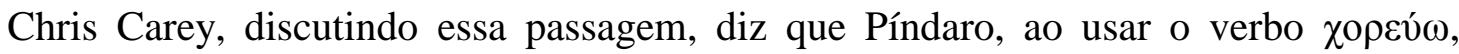
"claramente" tem em mente uma "performance formal por meio de canto e dança grupais" 173.

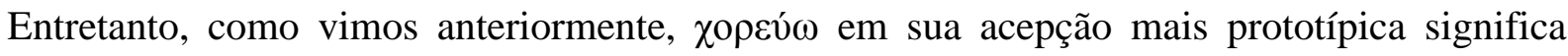
sempre "dançar", não "cantar" e, muito menos, "cantar $e$ dançar", para o que o grego reservava uma outra palavra, $\mu \varepsilon ́ \lambda \pi \omega$. Ainda segundo ele, uma performance coral é "obviamente" o que Píndaro está prometendo à Delos ao usar, aqui, o complemento oùv

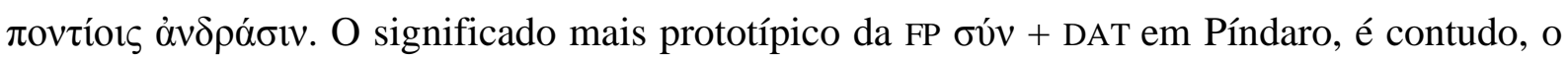

172 Sobre isso, $c f$. especialmente NISETICH (1975).

${ }^{173}$ CAREY (1989, p. 546). 
comitativo, nunca o instrumental ${ }^{174}$. Disso, aliás, temos um exemplo nesta mesma ode, no

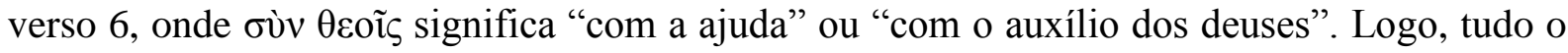
que Píndaro está dizendo é que ele irá dançar entre os homens de Delos e também entre aqueles do Istmo, por ocasião do $\kappa \tilde{\omega} \mu о \varsigma$ de Heródoto, para quem a Ístmica I foi escrita.

Um detalhe que Carey prefere minimizar é que, se ele estiver correto, esta é a única

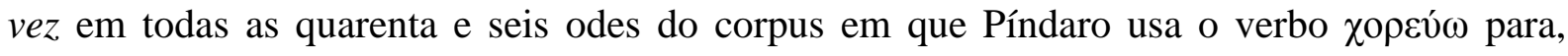
possivelmente, se referir à performance de um epinício. Não é a exceção, então, que provaria a regra? $\mathrm{Na}$ verdade, é exatamente por isso que ele precisa recorrer a exemplos do mesmo verbo em outros poemas do corpus pindárico - esses sim, indiscutivelmente corais -, para

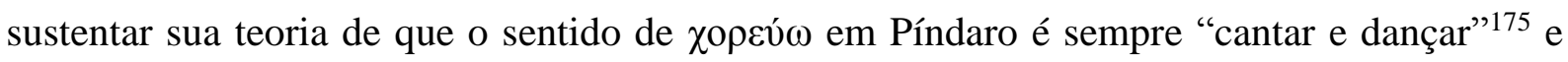
que, deduzir-se-ia daí, a sua escolha deste verbo em detrimento de muitos outros que seriam "neutros" com relação ao modo da performance indicaria "inevitavelmente" o modo como ambos os poemas seriam executados.

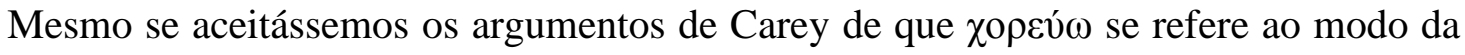
performance e que, além disso, esse modo implica dança e canto corais, uma explicação muito mais simples poderia ser dada, que leva em conta menos a letra morta do texto, e mais o estilo, não só de Píndaro, mas de toda a lírica arcaica ${ }^{176}$ : a de que o verbo é usado àmò

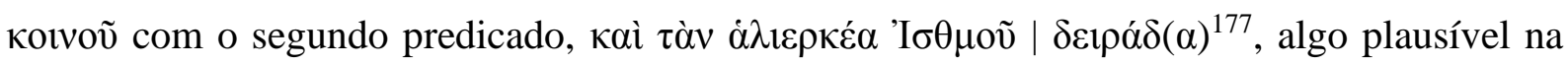
medida que o frame de toda a estrofe está dentro do escopo da menção a uma obra coral, o peã para Delos.

\title{
I. 8.62
}

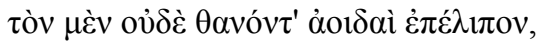

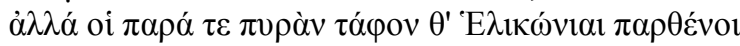

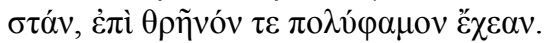

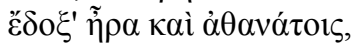

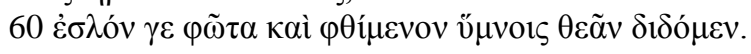

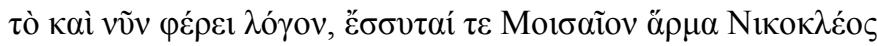

\footnotetext{
174 BOSSLER (1862, p. 26), "Praepositio oúv ubique notionem societatis et conjunctionis vel hominum vel rerum tenet. (...) Tum eodem modo, quo غ̇v, etiam haec praepositio nonunquam instrumentalem significationem asciscere videtur, sed manifestum est, his quoque locis aliam rationem inesse quam quae nobis placet; nam quod nobis id esse videtur, cuius ope aliquid efficitur, a Pindaro tanquam id cogitatur, quocum conjunctus et sociatus aliquis agit", grifo meu. Cf. também a excelente discussão de LURAGHI (2003, p. 146 et seq.).

175 Mais especificamente, o Peã 6.9, fr. 75.1, Partenéio 2.39, e o fr. 94c.1.

$176 C f$., especialmente, DORNSEIFF (1921, p. 102 et seq.) e D.E. GERBER (1982, pp. 136-7), sobre a $O$. 1.88 , onde ele aduz outros exemplos de zeugma na literatura arcaica.

177 Assim também HeATH e LEFKOwitz (1991, p. 189 e n. 45) e BrEMER (1990, pp. 51-2). Para paralelos em Píndaro, $c f . O .1 .88 ;$ N. 10.25-6; P. 1.40, 4.104, 8.19.
} 


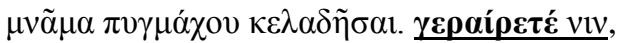

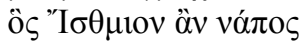

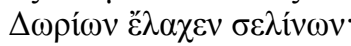

Nem mesmo morto abandonaram-lhe ${ }^{178}$ as canções, mas em volta de sua empírea sepultura as Musas do Hélicão prostaram-se e verteram o multíssono treno.

Pois pareceu por bem também ao imortais

aceder um nobre varão, mesmo finado, aos hinos das deusas.

Isto também se aplica a este momento, e o carro musical avança a celebrar a lembrança do boxe de Nicoclés. $\underline{\text { Honrai-o }}$

ele que no vale do Istmo

ganhou uma coroa de dório salsão.

Acerca dessa passagem, Carey diz que:

Teoricamente, o comando $\gamma \varepsilon \rho \alpha i ́ \rho \varepsilon \tau \varepsilon 62$ poderia ser dirigido ou àqueles presentes ou à comunidade como um todo. Nesse caso, poderia se argumentar que ele se refere a outras canções ou a formas não-musicais de louvor e seria, antes de mais nada, uma maneira intensa de salientar que Nicoclés é digno de louvor. Não há qualquer razão óbvia para que entendamos o comando além do escopo da ode e ao menos um bom motivo para que não o façamos. O comando $\gamma \varepsilon \rho \alpha i ́ \rho \varepsilon \tau \varepsilon$ é seguido pelo louvor a Nicoclés (63-65), que é anunciado nos $v v$. 61-62 (...). O exemplo de outras passagens em Píndaro no qual um imperativo exigindo o louvor é seguido pelo louvor exigido e no qual uma referência além da ode parece estar fora de questão pelo uso do singular (O. 9.108-12, N. 3.26-32, N. 5-50-54, N. 10.21 et seq.) sugere fortemente que o louvor de Nicoclés nos $v v$. 63-65 é o cumprimento do comando

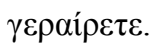

É digno de nota que todos os exemplos aduzidos por Carey dizem respeito a imperativos da $2^{\mathrm{a}} \mathrm{p}$. do singular ${ }^{179}$ em que é possível deduzir que a persona loquens está, na verdade, dando uma ordem a si mesma ${ }^{180}$. No exemplo acima, contudo, temos um imperativo na 2.p do plural. Para fazer sentido, a hipótese de Carey deveria explicar por que, se a ode é de fato cantada por um coro, há essa alternância entre as pessoas verbais, isto é, por que o suposto coro algumas vezes dá ordens a si mesmo na $2^{\mathrm{a}}$ (ou, em alguns casos, na $3^{\mathrm{a}}$ ) pessoa do singular, ao passo que, em outros, o faz na $2^{\text {a }}$ pessoa do plural. Na ausência dessa explicação, não temos porque não supor que as pessoas verbais estejam sendo empregadas de modo

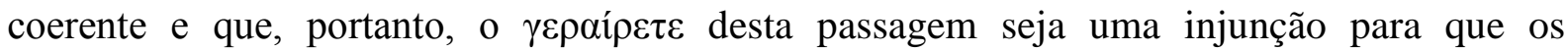

${ }^{178}$ Aquiles, de quem trata a parte mítica.

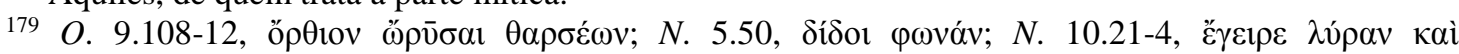

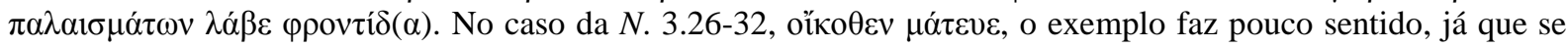
trata de uma Abbruchsformel que efetua a passagem do mito à ocasião. mencionado.

${ }^{180}$ Compare com o caso discutido da $O .6 .87-92$, acima, em que o destinatário é explicitamente 


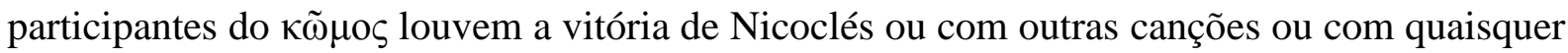
outros meios que, podemos apenas supor, seriam apropriados ${ }^{181}$.

Em segundo lugar, não há nenhuma "lei dos epinícios" que determine que o canto de louvor deva excluir qualquer referência a práticas laudatórias externas à canção ${ }^{182}$, sobretudo se estivermos dispostos a aceitar que a performance da ode deveria se dar em um contexto celebrativo que não se restringia apenas à execução da ode, mas que provavelmente incluía uma série de outras formas de louvor, musicais ou não, subentendidas a partir do EDC partilhado pelo cantor e sua audiência a que possíveis referências diriam respeito. Nós, no entanto, não partilhamos desse EDC, o que não é razão suficiente para negá-lo ou para, na ignorância do mesmo, criar uma "lei" que nos obrigue a ler todas as referências que não entendemos apenas a partir do escopo interno da ode. Nesse sentido, e levando em

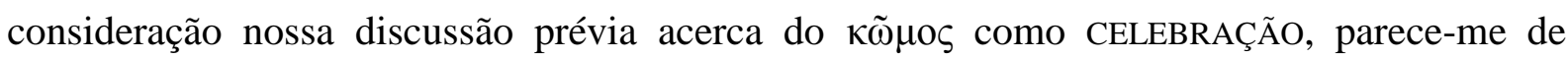
extrema relevância a observação de Heath e Lefkowitz de que

\begin{abstract}
Ainda estaríamos inclinados a atribuir a este comando (bem como a muitos outros) uma referência externa, mesmo se adotássemos a hipótese coral. Se o epinício for interpretado como uma canção própria do $\kappa \tilde{\omega} \mu \mathrm{s}$, então ele foi criado não para permanecer isolado, mas para funcionar como uma parte específica da festa comunal. Deveríamos esperar, portanto, que o epinício fizesse conexões de muitas e mais variadas formas dentro do contexto da performance; e o horizonte restrito de referências admitido pela doutrina corrente, com sua limitação radical dos fenômenos ligados aos futuros e imperativos apenas às referências internas, é, consequentemente, questionável.[grifo meu] ${ }^{183}$
\end{abstract}

\title{
Conclusões
}

Acredito que a análise das fontes externas parece apontar, desde o período arcaico,

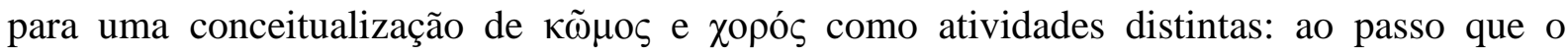

${ }^{181} \mathrm{O}$ mesmo aplica-se à outra passagem aduzida por Carey e com a mesma estrutura, o epinício 13.190 et seq. de Baquílides.

182 Propor qualquer regra unicamente a partir do texto das odes e então aplicar essa regra para explicar problemas para os quais a mesma foi inicialmente proposta é um patente exemplo de circulus in probando. Como notam HEATH e LEFKOWITZ (1991, p. 190), "the paralels only constitute reason to reject a reference beyond the ode if the choral hypothesis is correct, which is the point at issue". CAREY (1991, p. 198) concorda com o pouco valor desta ode como evidência que suporte tanto uma quanto outra hipótese, "to appeal to either model in support of an interpretation is to beg the question we are trying to settle. Of course the audience knew how each ode was performed. We do not. We only have Pindar's words; we must make what sense we can of them and seek to objectify judgements on ambiguous cases by drawing on more straightforward passages", grifo meu. Carey parece tentar argumentar em favor de uma análise textual, o que pode significar uma concepção das odes como texto e não como canção. Abordar a forma entextualizada da canção por meio das regras da crítica literária tradicional não significa em uma obrigação da canção em obedecer a essas regras. As distorções, segundo me parece, resultam inevitáveis.

${ }^{183}$ HEATH e LEFKOWITZ (1991, p. 190). 
elemento principal, mais prototípico, para que uma atividade seja conceitualizada como

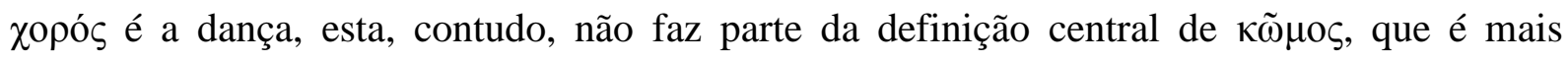
inclusiva e que se organiza a partir do conceito CELEBRAÇÃO, em torno do qual outras características (dança, chiste, bebedeira, pantomima, simpósio, procissão etc.) podem orbitar, sem que nenhuma delas tenha, por si só, centralidade suficiente para invocar o uso do termo.

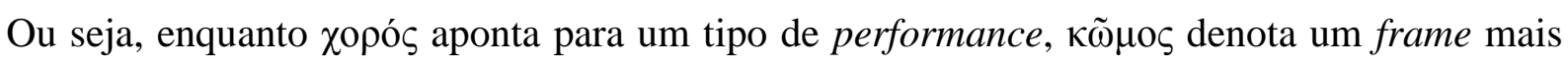

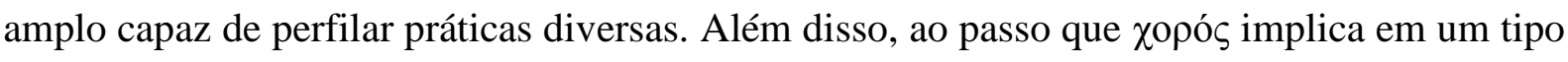
de dança especial, isto é, marcada, que pressupõe organização em vários níveis (na forma, no ritmo, no acompanhamento do canto etc.) e que, portanto exigiria ou profissionais ou um certo nível de treinamento, isso jamais acontece com $\kappa \tilde{\omega} \mu \circ \varsigma$, no qual a dança, quando presente, é necessariamente de um tipo espontâneo, não ensaiado, isto é, não-marcado ${ }^{184}$,

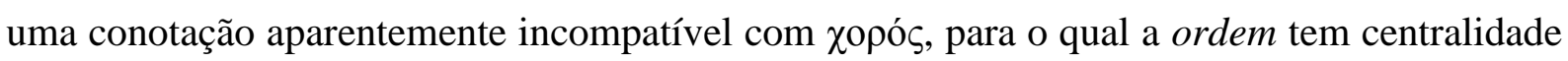
absoluta.

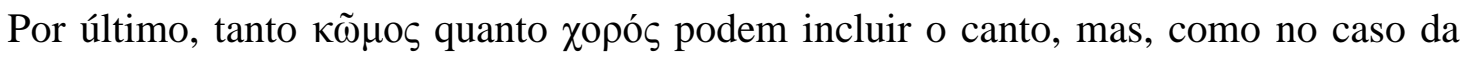
dança, as condições nas quais o canto é conceitualizado dentro de cada um desses frames são completamente diferentes: naquele, o canto, como a dança, é espontâneo, não-ensaiado, nãoresponsivo e não está associado, até onde sabemos, com nenhum tipo de dança como acompanhamento; neste, porém, dá-se exatamente o contrário. Nas palavras de Bremer:

\begin{abstract}
Agora, no emprego normal da língua grega, há uma considerável diferença entre

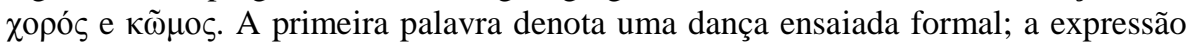

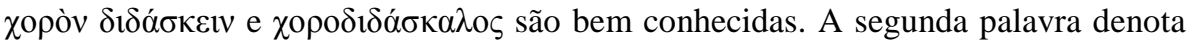
uma celebração móvel (ocasionalmente bêbada e, em todo caso, normalmente pouco séria), uma procissão alegre; a palavra $\kappa \omega \mu$ o $\delta \delta \alpha ́ \sigma \kappa \alpha \lambda o \varsigma$ não existe e seria quase uma contradictio in adiecto. Pode-se questionar com toda a razão porque Píndaro usava precisamente essa palavra de um modo tão persistente. ${ }^{185}$
\end{abstract}

É exatamente isto que tentamos fazer ao longo desses dois capítulos. Como vimos, Píndaro sempre faz referência ao tipo de atividade da qual participa através do frame

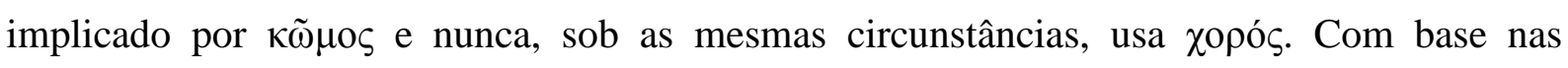
evidências fornecidas pelos textos da oratura arcaica examinados precedentemente, que não sugerem uma identificação entre os dois termos, seria no mínimo plausível supor que Píndaro deva usar $\kappa \tilde{\omega} \mu$ os porque tinha um mente um tipo de atividade totalmente diferente daquela

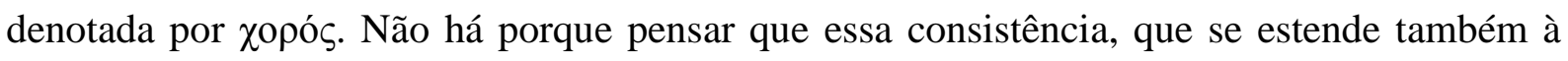

184 Isso demonstra, aliás, que a afirmação de AGÓCS (2012, p. 196) segundo a qual "[choros] is

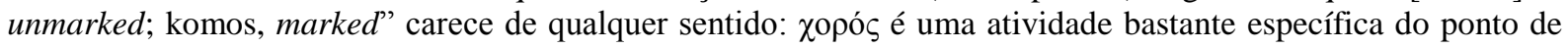
vista da conceitualização grega dedutível a partir do que vimos dos textos citados e não "only a notion of a group performance and dance".

${ }^{185}$ BREMER (1990, p. 51). 
Baquílides, pudesse ser motivada por qualquer outro fator que não uma referência explícita ao tipo de atividade aludida por meio do conceito invocado pelo uso de um ou outro termo. Uma vez, portanto, que a performance das odes está ligada (muitas vezes explicitamente, por meio

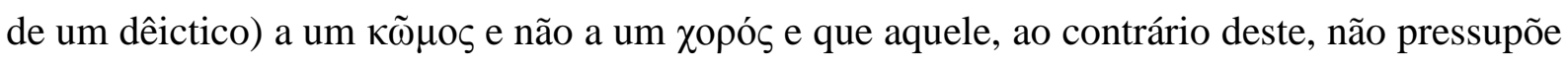
nem a dança nem o canto ensaiados, parece-me plausível pressupor que a probabilidade de

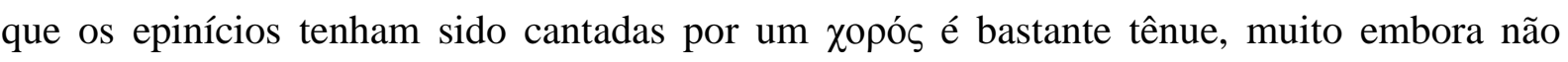
possa ser descartada. É preciso ainda insistir no fato que muitos dos "epinícios" do corpus podem, na verdade, pertencer a outras formas poéticas e que, deduz-se daí, alguns deles

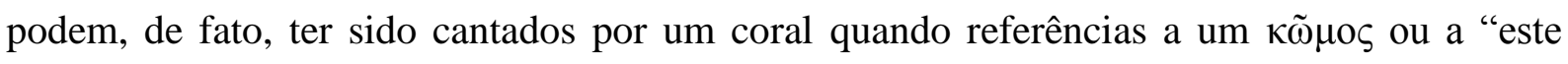
$\kappa \tilde{\omega} \mu \circ \varsigma^{\prime \prime}$ apontarem nesse sentido. Não há porque adotar uma atitude extremamente dogmática a esse respeito.

Na verdade, um dos argumentos mais importantes - e que permitiu que, até hoje, a hipótese coral tivesse uma maior centralidade na interpretação do modo de performance das odes (muitas vezes, como vimos, de modo tácito e acrítico) - é o testemunho dos escólios,

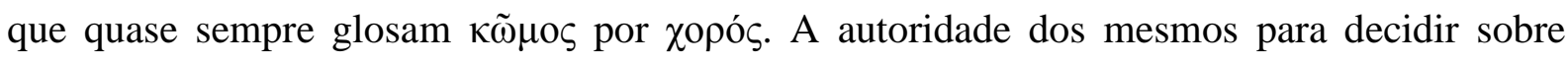
essas questões foi, no entanto, consistentemente questionada e, até hoje, nenhuma resposta satisfatória foi dada a esse respeito que pudesse reestabelecer a autoridade dos escólios sobre esta questão ${ }^{186}$. O problema torna-se ainda mais relevante quando percebemos que a própria

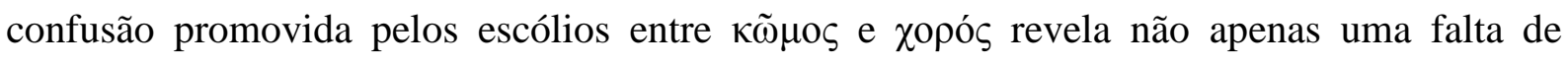
familiaridade com práticas antigas de celebração epinicial (o que seria natural depois do séc. IV, dado o aparente ocaso do gênero) mas, de uma maneira ainda mais preocupante, uma falta de diálogo ou incapacidade demonstrada pelos mesmos de estabelecer uma leitura intertextual entre a forma entextualizada das canções e o restante da literatura grega, que aponta fortemente para uma diferenciação entre os conceitos KŌMOS e KHOROS. Isto, no entanto, como demonstrou M. Lefkowitz é um tipo de equívoco em que a metodologia da filologia helenística, baseada na atomização, no monofuncionalismo e na predileção restritiva, como mais tarde iria definir Most ${ }^{187}$, estava fadada a incorrer.

Por outro lado, é preciso que se diga que julgar o trabalho filológico dos alexandrinos por meio daquilo que os escólios nos apresentam também traz seu perigos e é, de certa forma, perverso. Ao mesmo tempo, abraçar seu testemunho como o legítimo herdeiro de uma

${ }^{186} c f$. HEATH e LEFKOWITZ (1991, p. 175 et seq.).

187 cf. MOST (1985, p. 36 et seq.). A atomização fragmenta o texto nas menores unidades possíveis de sentido; o monofuncionalismo confere a cada uma das unidades atômicas uma, e apenas uma, função; a predileção restritiva assegura que um átomo não apenas tenha um significado único fora do texto, ele também fornece as leis para todos os outros elementos e, por causa disso, é por si só capaz de garantir a sua unidade. 
tradição que remeta à antiguidade, sem levar em consideração as distorções e as deformações sofridas durante o seu processo de recepção, é igualmente inadmissível e incrivelmente ingênuo $^{188}$. Ainda que os escólios possam conter informações valiosas e fidedignas (como, de fato, eles devem) não há uma maneira segura de usarmos essas informações simplesmente porque não temos, na esmagadora maioria dos casos e na ausência de um terceiro comparativo, critérios que nos permitam avaliar as informações aí contidas e, dessa forma, separar o que é fidedigno do que é espúrio, o que diminui em muito a utilidade desses textos. Cautela, então, deveria ser a palavra de ordem ao lidar com eles, que devem servir como evidências acessórias e jamais definitivas.

Se, no entanto, as evidências da oratura arcaica desabonam, ou pelo menos colocam em dúvida, a hipótese de uma performance coral dos epinícios, devemos nos voltar para o que os próprios textos nos dizem sobre a sua performance a fim de que possamos avaliar se há algum tipo de interpretação "mais óbvia"189 que aponte sem sombra de dúvidas (afinal esse é o sentido da palavra óbvio) para a hipótese coral. Temo, no entanto, que nada haja de "óbvio" no que tange a qualquer aspecto da performance epinicial ou à análise do próprio texto das odes. O único caminho que me parece possível é tentar definir para onde um maior número de evidências aponta. Infelizmente (ou não), a decisão sobre o que conta como evidências, bem como sobre a maneira como se deve interpretá-las, é uma atitude subjetiva, no sentido bastante literal de que diz respeito ao sujeito como centro da atividade hermenêutica. Procurar, dessa forma, por uma "regra" ou por uma chave que seja capaz de explicar com rigor topológico todos os aspectos do epinício é tirar dessas canções, que são uma resposta a ocasiões muito mais complexas e ricas do que podemos imaginar, aquilo que, até hoje, nos manteve interessados nelas e contribuiu para que sobrevivessem: sua capacidade de nos intrigar e nos maravilhar a cada releitura.

${ }^{188}$ CAREY (1989, p. 559).

${ }^{189} C f$. a citação de Carey à p. 185. 


\title{
CAPÍtulo 7
}

AO INFINITO E ALÉM:

CENÁRIOS DE TRANSMISSÃO E REPERFORMANCE

\begin{abstract}
As long as Pindar's medium of song making depended on the prestige of public performance, we cannot assume that a written record could have maintained, of and by itself, such prestige. Rather we should be asking the question the other way around: what was it about the public prestige of Pindar's lyric poetry, as it was once performed, that made it possible in the first place for a written record to evolve and to be preserved for later generations?
\end{abstract}

G. Nagy, Pindar's Homer, p. 383.

EM UM TRABALHO que se propôs a discutir a performance dos epinícios de Píndaro, qual a importância de se investigar a sua transmissão escrita? Essa pergunta, embora legítima, parece-me que já tenha sido respondida por Finglass ${ }^{1}$ (mas com relação ao texto sofocliano), i.e., de que ninguém deveria começar ou, neste caso, terminar um estudo de Píndaro sem colocar em suas devidas proporções o quão obscura e desconhecida é a história de sua transmissão, sobretudo em seus primeiros estágios. Essa compressão pode nos ajudar, além do mais, a entender melhor diversos aspectos das canções e o processo pelo qual ela tomou a forma com que chegou até nós, bem como promover uma reflexão sobre a maneira como puderam sobreviver como registro entextualizado da performance. Num outro nível, pode nos servir de ponto de partida para avaliar como esse registro veio a sofrer, na qualidade de texto, uma pressão para se conformar a um novo paradigma cognitivo: aquele da disseminação cada vez maior, a partir do séc. IV, da literacia. Uma das premissas centrais do meu entendimento do texto pindárico e, de um modo geral da oratura da Grécia arcaica, é que nesse desencontro de realidades cognitivas diversas deva estar muito da dificuldade que, como intérpretes, encontramos ao lidar com os epinícios.

Uma forma, portanto, de começar essa investigação é lembrar da distinção, já tratada na Introdução, entre oralidade conceitual e midiática. Uma vez que a minha abordagem dos poemas pindáricos leva em consideração que o texto que temos representa uma transcrição das palavras da performance e que é, por isso mesmo, do ponto de vista de sua concepção,

\footnotetext{
${ }^{1}$ FingLaSs (2012, p. 9 et seq.).
} 
oral, entender como essas palavras chegaram até nós é de enorme importância. Além disso, há evidências suficientes para se crer que a forma entextualizada dos epinícios possa ter sofrido alterações desde muito cedo durante sua transmissão, algo natural dado um cenário de uma sociedade ainda no limiar entre a oracia e a literacia ${ }^{2}$. No entanto, é preciso que se ressalte que as alterações do texto pindárico não são nem tão grandes, nem tão extensas. Claramente, em algum momento a letra das canções foi fixada ${ }^{3}$, o quão cedo ou tarde é difícil de precisar, muito embora eu parta do princípio, em si mesmo indemonstrável, de que essa fixação possa ter sido bem mais tardia do que podemos ser levados a crer.

Minha atitude pessoal com relação ao processo de fixação é, em primeiro lugar, o de que embora ele provavelmente possa ter acontecido em um período imediatamente posterior à performance por meio da escrita, essa não é a única possibilidade, nem há motivos para se crer que ela seja necessária. Descartar um processo mais longo, no qual os poemas seriam transmitidos oralmente, baseando-se unicamente na alegada sofisticação e/ou dificuldade da estrutura dos epinícios simplesmente porque eles assim nos parecem na página ${ }^{4}$, daí implicando que, por causa disso, a única forma de transmissão plausível seria a escrita é projetar nossas práticas, angústias e limitações como membros de uma literacia sobre aquelas dos integrantes de uma oracia e, além disso (e algo mais grave) é ignorar a riqueza de material etnográfico que prova, sem sombra de dúvida, que canções tão ou mais complicadas e tão ou mais longas que os epinícios pindáricos foram e são memorizadas por indivíduos, profissional ou amadoristicamente, em diversas sociedades ao longo da história e da geografia humanas 5 .

Em segundo lugar, não há razão para se reduzir o processo de transmissão a uma única mídia ou a um único modelo, quando é muito mais provável que ele tenha sido multiforme e tenha se desenvolvido através de uma confluência de caminhos no qual a transmissão oral e a escrita devem ter se alternado, coincidido e se influenciado até o último momento em que um texto definitivo foi fixado no séc. III a. C em Alexandria, do qual descendem nossas edições

${ }^{2}$ Sobre isso, $c f$. THOMAS (1992).

${ }^{3}$ Nada sabemos sobre o destino da melodia, nem se havia uma melodia específica que acompanhasse a letra a partir de sua concepção.

${ }^{4}$ Cf. T. K. HubBARD (2004, p. 85), por exemplo: "Almost all theories have relied on some measure of written circulation, since the length, the dialectal variety, and metrical complexity of the odes, make oral tradition an unreliable instrument of preservation.", grifo meu. Para uma opinião semelhante, mas que envolve também o processo de composição, $c f$. Knox in EASTERLING e KNOX (1989, p. 3). Obviamente as práticas de transmissão oral de canções entre outros povos como documentadas por diversos especialistas, muitos dos quais citados ao longo desse texto, tornariam a Grécia do período arcaico uma exceção, caso o cenário e as razões dadas por Hubbard sejam, de fato, verdadeiras: as mesmas características (grifadas) que ele aponta como empecilhos para uma difusão oral são, na verdade, o que garantem uma transmissão fidedigna do texto entre vários povos. Sobre isso, e especialmente relevante para o caso de Píndaro, $c f$. THOMAS (2012).

${ }^{5}$ Sobre isso THOMAS (2012) e FINNEGAN (1980). 
modernas. Uma divisão radical entre transmissão oral e escrita, além de já ter sido ultrapassada, não é nem desejável, nem proveitosa.

Felizmente, uma grande parte do trabalho concernente à transmissão textual de Píndaro já foi feita por Jean Irigoin, em seu tour de force sobre a história do texto pindárico ${ }^{6}$, a que toda esta tese deve muito. Seu detalhado trabalho permitir-me-á, além disso, ser mais conciso e me dedicar apenas a alguns pontos onde divergimos ou onde me pareceu necessário, por alguma razão, complementá-lo. Procedendo dessa forma, ser-me-á possível, ainda, direcionar o sentido da discussão para atender os propósitos que me interessam mais nessa monografia, que são os cenários de transmissão imediata, pré-alexandrina das odes, e os possíveis cenários de suas reperformances que, como argumentarei, creio terem sido decisivos na entextualização das canções.

\subsection{Promessas de imortalidade}

O poeta, enquanto sacerdote das Musas, filhas da Memória, é um dos poucos indivíduos $^{7}$ que, em uma sociedade oral, detém o acesso ao conhecimento do passado e pode garantir a passagem deste ou daquele indivíduo ao futuro por meio de sua habilidade em transformar o conhecimento da comunidade de uma forma (e em uma forma) que torne a sua disseminação mais efetiva. Nesta seção, portanto, eu gostaria de explorar brevemente as alusões que os epinícios fazem à sua capacidade de entextualizar a canção e as estratégias que usam para garantir a fama de seus laudandi.

Uma das funções precípuas de um epinício é imortalizar tanto o laudandus quanto o seu feito. A expressão da capacidade do poeta em conferir fama inextinguível, $\kappa \lambda \dot{\varepsilon}$ o $\alpha_{\alpha} \varphi \theta \imath \tau o v$, aos seus laudandi é, por isso mesmo, parte da dicção tradicional da poesia laudatória e deita suas raízes na terra comum da cultura dos povos indo-europeus ${ }^{8}$. Entre os gregos, expressões de louvor aparecem mencionadas já na Ilíada e na Odisseia, muito embora esses próprios poemas jamais tomem a forma de um louvor". Dentro da categoria mais geral de "poesia de louvor", que pode incluir outras formas de canções, o exemplo mais antigo que temos daquilo

\footnotetext{
${ }^{6}$ Histoire. Para um bom resumo em português, $c f$. a Introdução de ARAÚJO (2005).

${ }^{7} \mathrm{O}$ outro seria o profeta ou o adivinho, sacerdote de Apolo, com o qual ele, muitas vezes, se confunde Sobre isso NAGY (1990, p. 164 et seq.) e SVENBRo (1976).

${ }^{8}$ Essa consciência de pertencer a uma tradição tão antiga é aparente na epígrafe que abre esta tese.

${ }^{9}$ NAGY (1990, p. 149), "In contrast with the praise poetry of Pindar, the epic poetry of the Homeric Iliad and Odyssey makes no claims to exclusiveness and does not qualify as a form of ainos. Whereas both the poetry of Homer and the poetry of Pindar qualify as kleos, only praise poetry qualify as ainos".
} 
com que associamos os epinícios pindáricos pode ser o fr. 282 CAMPBELL de Íbico (segunda metade do séc. VI) ${ }^{10}$ :

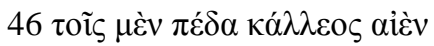

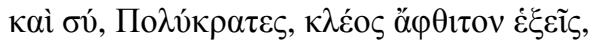

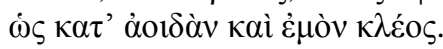
46 entre aqueles, de uma beleza, sempre,
tu também, Polícrates, imperecível fama terás,
proporcional à canção e à minha fama ${ }^{11}$.

Nesta canção, da qual eu cito apenas as últimas linhas, Íbico por meio de um

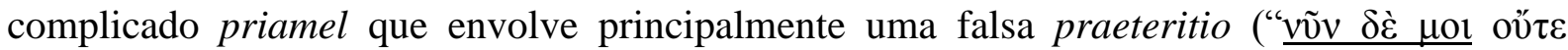

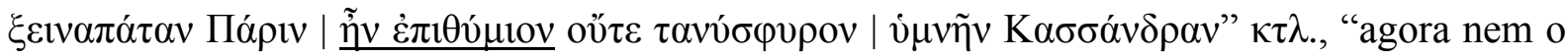
engana-hóspede Páris | era minha vontade cantar | nem Cassandra de fina cintura” etc., 10-12) e catálogo (Aquiles, Ájax, Ciânipo, Troilo) ${ }^{12}$, coloca em relação o mundo do passado épico com o hic et nunc da performance epinicial e os personagens daquele mundo com o seu presente objeto de louvor, ao mesmo tempo em que reafirma seu status de portador daquele conhecimento através do seu acesso privilegiado à memória coletiva e oral, personificada pelas Musas ( $v v$. 23-26). Já temos aí, portanto, completamente desenvolvidos todos os elementos básicos que veremos de muitas e diversas formas na poesia de Píndaro e Baquílides.

Mesmo que as últimas linhas do poema apresentem uma crux na sua interpretação ${ }^{13}$, podemos deduzir que, no fragmento de Íbico, a fama do patrono, qualificada de imperecível,

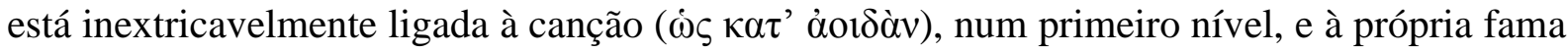

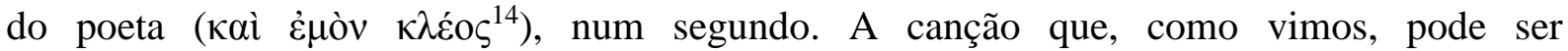
conceitualizada como um OBJETO, frequentemente como algo tecido, depende da fama do poeta precisamente como um objeto de arte depende da do artesão que o fez e, portanto, do

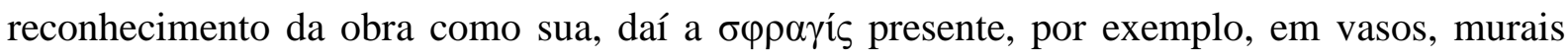

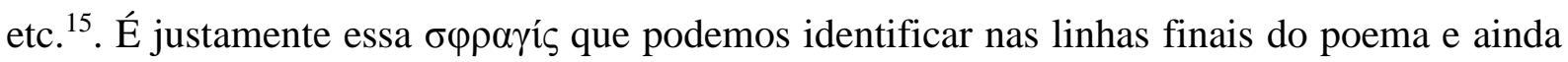
que aí esteja faltando o nome do poeta (ele poderia ter aparecido em outra parte da canção), o

\footnotetext{
${ }^{10}$ Sobre a pré-história do epinício, $c f$. RAWLES (2012).

${ }^{11}$ Minha tradução segue a leitura e os comentários de HutCHINSON (2001, p. 253 et seq.).

12 Acerca disso RACE $(1982,1992)$.

${ }^{13}$ Será a fama do patrono imortal na mesma medida em que (ou enquanto) a canção e a fama do poeta o

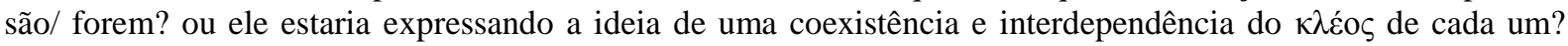
Não é minha intenção discutir esses problemas aqui. $C f$. GOLDHILL (1991, p. 118).

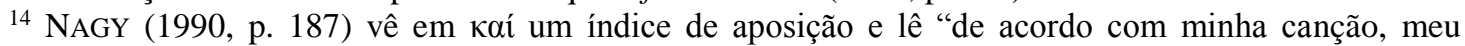

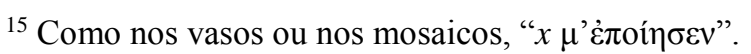

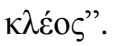


pronome possessivo já serviria para preencher essa função. Essa mesma relação de interdependência entre laudator e laudandus, no sentido de que o nome dos dois seja difundido pela canção, aparece de um modo mais equilibrado na $O \cdot 1.115-17^{16}$ :

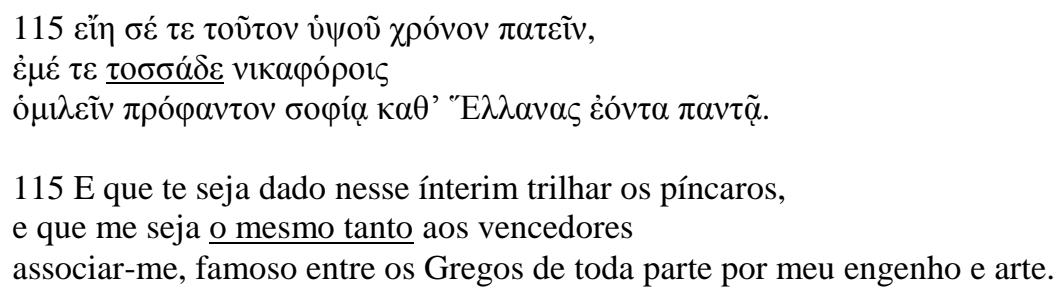

A canção de louvor, ao contrário da épica, que se refere a um outro tempo e a outros homens, enfrenta o problema premente de conseguir, a um só tempo, destacar aquele que louva não só de seus contornos triviais, cotidianos, como projetá-lo em um futuro, que é idealizado do ponto de vista de audiências também futuras, da mesma forma que a audiência presente se relaciona com o passado épico.

Essa operação, realizada a partir dos frames PASSADO, PRESENTE e FUTURO, parece se concretizar de uma maneira muito explícita no fragmento de Íbico citado acima: no pano-defundo destacam-se os heróis da geração de Tróia (PASSADO) que o poeta é capaz de acessar através das Musas e por meio da canção. Esta não é sobre aqueles homens, mas sobre este homem (Polícrates). A falsa preaeteritio dos vv. 11 e 15, no entanto, é usada para evocar o quadro mítico dentro do frame PRESENTE, no qual se desenrola a performance ( $v \tilde{v} v \delta \grave{\varepsilon} \mu \mathrm{o} . . .$, 10), para, em seguida, efetuar a mesclagem entre os dois, PASSADO e PRESENTE, através da

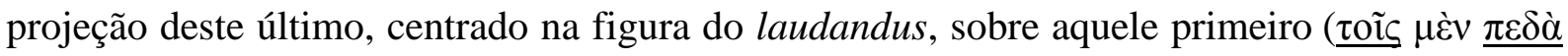

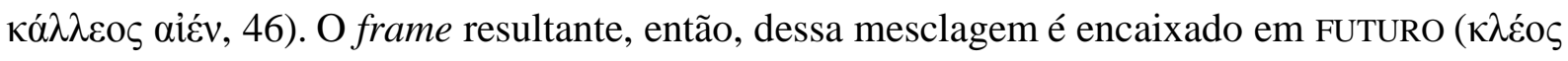

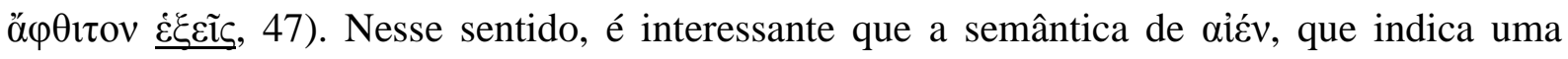
sucessão contínua, ininterrupta, sirva justamente para pôr em evidência o colapso entre esses

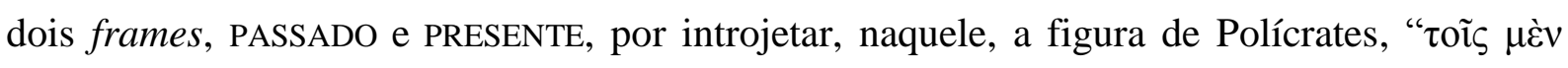

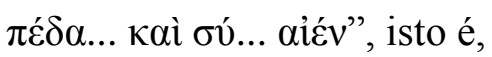

$$
\{[\text { ENTRE AQUELES/ PASSADO }] \leftarrow[\text { TU/ PRESENTE }]\}_{\text {SEMPRE. }}
$$

Por sua vez, esse frame composto, mostrado acima, pode ser visto como a própria canção que, assim, efetua uma espécie de bricolagem ${ }^{17}$, onde jazem sobrepostas a figura

16 Cf. D.E. Gerber (1982, pp. 168, vv. 11-14) e, especialmente, KuRKE (1991, p. 140), “The parallelism of language and syntax here is iconic for the reciprocal relationship of poet and patron, emphasized by the central $\tau 0 \sigma \sigma \alpha \dot{\delta \varepsilon}$, which equalizes the gifts and responsibilities of the two. Indeed, these last lines make clear what each partner brings to the relationship - Hieron his success and the poet his sophia - as matching 'gifts"'. 
contemporânea do laudandus contra o pano-de-fundo dos heróis, ao mesmo tempo em que se descreve o roteiro para uma reativação futura de tudo o que jaz encapsulado na ode, nos mesmos moldes em que o conteúdo da épica é, por ela mesma, reativado no contexto do presente louvor. Dessa forma, utilizando a nomenclatura da escola de Praga, poderíamos dizer que o frame implicado pela canção é o eixo sintagmático sobre o qual os eixos paradigmáticos do PRESENTE, PASSADO e FUTURO se projetam.

Parece-me que haja por trás da relação entre esses dois eixos, tão importantes para o epinício, e através dos quais o hic et nunc da performance se orienta, a noção generalizada de um tempo que é sentido como involutivo, na mesma medida que cíclico, isto é, assim como os semideuses e heróis do passado tiveram a fama de seus feitos preservada pela poesia épica, também o poeta do epinício irá trabalhar para preservar a fama do feito atlético obtido por aquele que ele louva ${ }^{18}$. Entretanto, como os próprios homens do passado eram muito superiores aos homens do presente, também suas gestas o eram. Por meio do epinício, no entanto, ambos, ainda que sejam contrapostos, não se opõem, justamente porque o tempo serve como fator de proporcionalidade entre os feitos da idade heroica e os de agora. É apenas por meio dessa relação de proporcionalidade que passado, presente e futuro entram em homeostase: o laudandus, por meio de sua ascendência, que o liga aos heróis, e o feito, por meio de seu caráter excepcional para os padrões dos homens atuais. A partir disso, o pano-de-

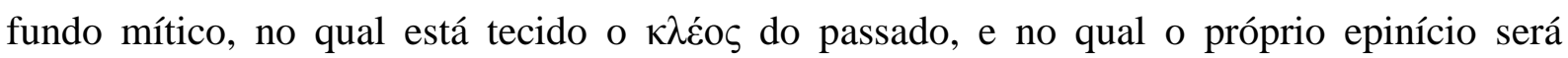
entretecido, é capaz de operar funcionalmente dentro do presente, não para diminuir o louvor do laudandus, mas para aumentá-lo, tanto em função de sua relação proporcional com os homens de outrora, quanto de sua superioridade equivalente com relação ao homens do presente.

As duas formas de canção têm como objeto os primi inter pares de suas épocas que, embora distintas, se relacionam por proporcionalidade em um tempo que opera para diminuir constantemente o valor das gerações futuras. A função do epinício, então, é também mostrar essa relação entre os eixos temporais, o que Píndaro expressa muito bem por meio da gnoma

${ }^{17}$ O termo já foi usado por LEVI-STRAUSS (1962, p. 30et seq.) com um sentido similar para expressar as operações típicas do pensamento mítico: “Or, le propre de la pensée mythique est de s'exprimer à l'aide d'un répertoire dont la composition est hétéroclite et qui, bien qu'étendue, reste tout de même limité; pourtant, il faut qu'elle s'en serve, quelle que soit la tâche qu'elle s'assigne, car elle n'a rien d'autre sur la main. Elle apparaît ainsi comme une sorte de bricolage intellectuel, ce qui explique les relations qu'on observe entre les deux."

${ }^{18}$ Cf. J-P. Vernant, Aspectes mythiques de la mémoire, in J. P. VERNANT (2007, p. 344), especialmente sua n.1: “R. Scherer (...) a bien vu que, dans la Théogonie, si le temps des dieux va dans les sens de l'ordre et aboutit à la stabilité, celui des hommes est orienté em sens inverse et tend finalement à basculer du côté de la mort. Cette disparité contitue un des enseignements du poème." 


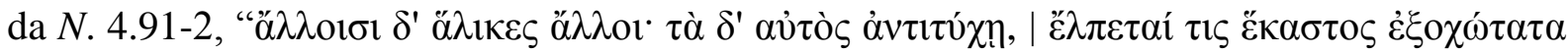

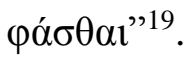

Uma outra passagem interessante, que atesta para essa temática tradicional na qual a fama do patrono é relacionada à do poeta e vice-versa, é aquela de Baquílides, 3.85-90:

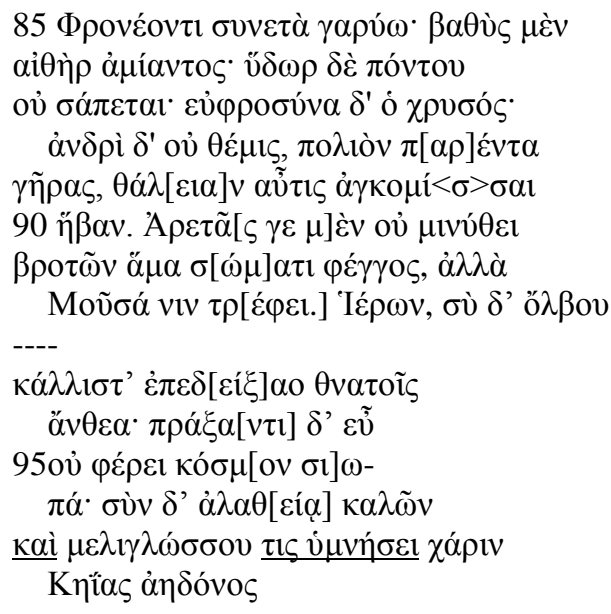

85 Aos sensatos o óbvio anuncio: que o alto firmamento é incorruptível, que a água do mar nunca apodrece, que o ouro é pura alegria, e que a um varão não é lícito, chegada a gris velhice, virente outra vez recuperar 90 a juventude. Da virtude, porém, a luz não míngua junto com o corpo dos mortais, mas a Musa a nutre. Hierão, tu, da prosperidade,

as mais belas flores mostraste aos mortais. Àquele que obtém sucesso, o silêncio não traz qualquer adorno, e, com o auxílio de Aletheia, teus belos feitos

97 alguém também irá cantar graças ao melífluo rouxinol de $\operatorname{Ceos}^{20}$.

O que nos interessa nesse trecho é a menção explícita às futuras reperformances da ode ( $\tau 1 \varsigma$ v $\mu v \eta ́ \sigma \varepsilon ı, 97)$, que novamente a vincula à habilidade do artesão, aqui identificado como o "melífluo rouxinol de Ceos" (97-8). Isto me parece apontar fortemente para a conceitualização arcaica da canção como OBJETO ARTESANAL, como falávamos acima, na

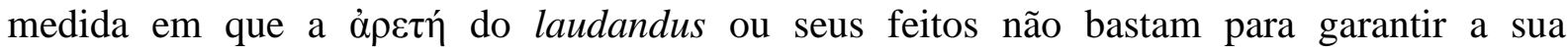
imortalidade. Esta está intimamente ligada apenas à capacidade do artista em entextualizar a canção por meio de sua arte, pois nisso reside o seu valor enquanto OBJETO passível de ser

${ }^{19}$ Para uma tradução do texto, $c f$. mais abaixo p. 266.

${ }^{20} \mathrm{Ou}$ : "and along with the true telling of your fine achievements, men will praise also the grace of the honey-tongued Cean nightingale" ou "men will also sing the friendship-gift", assim CAMPBELL, ambas. Aqui, de novo, minha tradução segue a leitura de HUTCHINSON (2001, p. 365). Preferi manter "Aletheia" (e personificada) ao invés de "Verdade" em virtude do paralelo (que me parece existir) com $0.10 .3-6$. Sobre $\dot{\alpha} \lambda \eta \theta \varepsilon i ́ \alpha$ como meio de preservação da poesia, $c f$. NAGY (1990, p. 17 et seq.) e SVEMBro (1976, pp. 46-60 e 139 et seq.). 
entesourado, guardado, possuído ou alvo de desejo. Em outras palavras, é o trabalho despendido pelo poeta na entextualização da canção, que, por sua vez, reconta a fama ( $\kappa \lambda \dot{\varepsilon} \circ \zeta)$ dos homens, que a transforma em um $\kappa \tau \tilde{\eta} \mu \alpha$. Píndaro não poderia ser mais claro em formular essa concepção, ao dizer, na $P .1 .92-100$, que

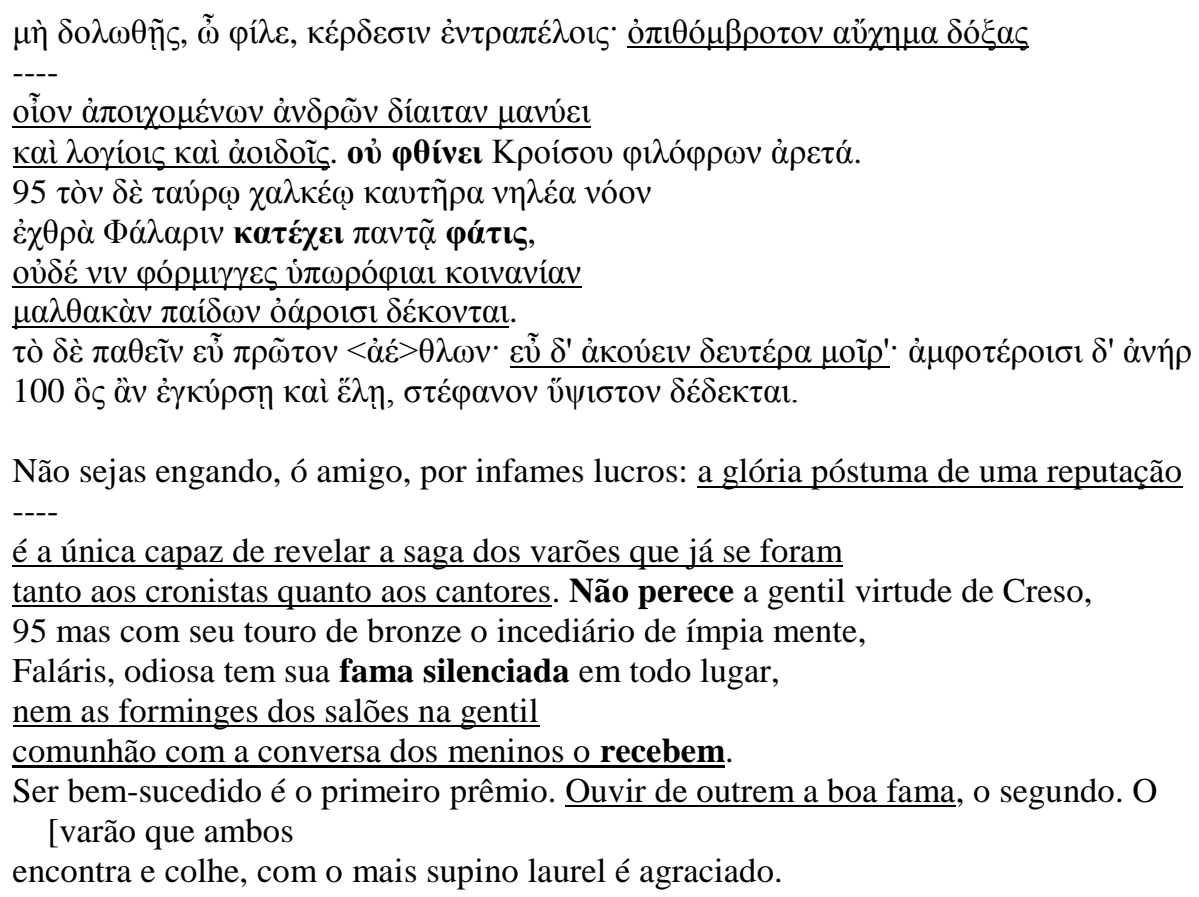

A fama póstuma dos homens (92) é importante na medida em que ela revela aos poetas ( $\mu \alpha v v ́ \omega$ + DAT., 93) o material bruto que eles poderão trabalhar; por si só, porém, ela não é imperecível, já que, em uma oracia ela está fadada a cair no esquecimento $(\lambda \eta \dot{\theta} \eta)$. É a seleção operada pela Memória em seu aspecto positivo, como 'A $\lambda \eta \varepsilon \dot{c} \alpha$, e negativo, como $\Lambda \eta ́ \theta \eta$, entre aquilo que precisa entrar e o que precisa sair do arcabouço de conhecimento coletivo partilhado pela comunidade (o qual, ainda que enorme, não é infinito) que determina o que é digno de ser preservado ou não ${ }^{21}$. Daí a importância da conceitualização de $\alpha \dot{\lambda} \eta \theta \varepsilon^{\prime i} \alpha^{22}$ como "não-ocultação" no pensamento arcaico. Não é à toa que, no epinício de Baquílides, o nome de 'A $\lambda \eta \theta \varepsilon i ́ \alpha$, isto é, "Não-ocultação", apareça empregado em seu valor instrumentalcomitativo com $\sigma u ́ v$. A arte do poeta ao transformar a canção em um objeto de valor auxilia em que esta não seja "encoberta" pelas camadas do superestrato de conhecimento que irão, inexoravelmente, se acumular na memória coletiva da comunidade a que o laudandus

${ }^{21}$ NAGY (1990, p. 52 et seq.), mas numa formulação mais relevante à nossa discussão, na p. 226, "In this sense the memory of oral tradition is at the same time a forgeting of the ordinary as well as remembering of the extraordinary (but exemplary)", grifo meu. Cf. também toda a rica discussão em SvEMBRo (1976, p. 146 et seq.). literária.

2 Não me refiro à etimologia da palavra, mas à funcionalidade do conceito na Grécia arcaica, pré- 
pertence. No entanto, o próprio poeta, ainda que prometa essa imortalidade, que se traduz em eterna presença, eterna reiteração por meio da memória, não pode, como indivíduo, garantir que, de fato e ao cabo, o objeto, que é a canção, vindo a perder o seu valor, não caia no

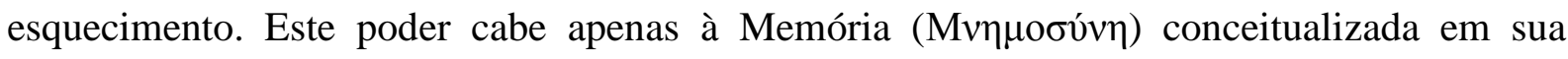
interpretação positiva de "Não-esquecimento", isto é, AA- $\lambda \eta \theta \varepsilon i ́ \alpha$, e é, portanto, nesta capacidade que eu a interpreto aí e em outras passagens dos epinícios ${ }^{23}$, como por exemplo, no proêmio da $O .10$ :

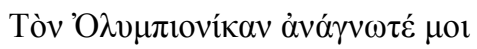

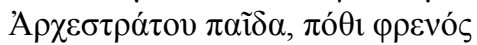

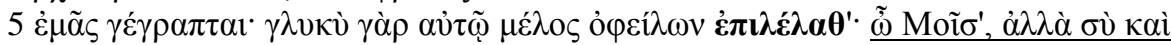
$[\theta$ ovó́

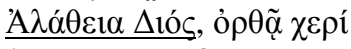

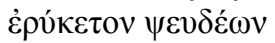

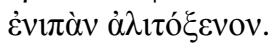

Lede para mim a vitória olímpica

do filho de Arquestrato, lá onde em meu peito

5 ela está gravada. Olvidei-me ${ }^{24}$ que lhe devia uma doce canção. $\underline{\mathrm{Tu}}$, porém,

[Ó Musa,junto com a filha

de Zeus, a Verdade,

com uma mão corretiva

afastai de mim a censura

por inóspitas mentiras.

A sobrevivência da fama do laudandus está, dessa maneira, indissociavelmente ligada à fama do poeta, sem dúvida. No entanto, a fama do poeta, como a de qualquer outro artista, reside na sua habilidade ( бoфía) em transformar o material bruto de seu métier em algo que se torne o objeto de cuidado ( $\mu \varepsilon ́ \lambda \eta \mu \alpha^{25}$ ) de todos. É o seu sucesso ou fracasso nessa empresa que irá determinar se as promessas feitas ao laudandus nos epinícios irão se concretizar ou não. Isto porque a tradição não é controlada pelo poeta, que nela opera. Ao contrário, a tradição é que opera através do poeta por reiterar de diferentes formas e arranjos aquilo que a memória coletiva julgou apropriado não ocultar em seu processo de autofagia. Logo, esta mesma

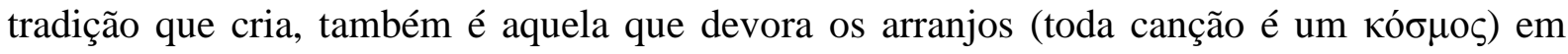
forma de bricolagem que, por inúmeras razões - mas sobretudo porque a tradição é algo de vivo, que também muda e evolui -, não julga à altura de permanecer sob o olhar da Memória.

${ }^{23}$ Esse argumento poderia ser desenvolvido com muito mais riqueza de detalhes, o que não convém ao espaço limitado desta seção. Note ainda, contudo, a capacidade alusiva ao esquecimento ou à lembrança, nas

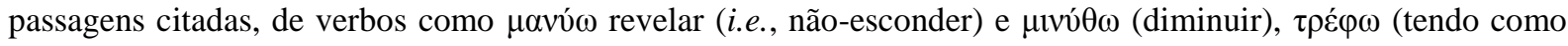
sujeito a Musa).

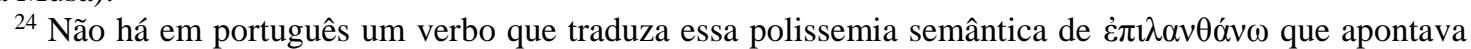

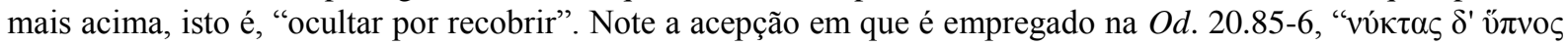

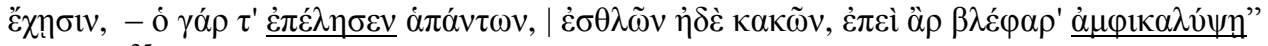

${ }^{25}$ Cf. P. 10. 55-9; Part. 95.3-4. 


\subsection{Cenários de transmissão e reperformance}

Uma das características mais conspícuas do epinício é o de ser uma "canção de ocasião". Embora essa constatação ressalte uma característica importantíssima das canções de que tratamos nessa tese, ela não chega, por si só, a ser um traço definidor, isto porque toda canção grega do período arcaico, até onde sabemos, era concebida com vistas à performance, fosse ela pública ou privada. Em grande medida, era em relação ao EDC delimitado pela performance que uma canção era conceitualizada por aquele que a criava, por aquele que a comissionava, no caso dos epinícios, e pelo público que a assistia. Essa conceitualização era então capaz de perfilar um tipo específico de canção face a um universo de muitas outras, com quais se relacionava por semelhança ou diferença. Esse é um dos sentidos de "ocasião" que gostaria de ressaltar.

No caso dos epinícios, essa característica não é apenas de fundamental importância na conceitualização do gênero em sua dimensão sincrônica por seu público-alvo, mas, sobretudo, no entendimento de suas transformações diacrônicas, quando ela deveria estar naturalmente sujeita a incertezas quanto à sua classificação genérica em virtude da desestabilização de sua mensagem promovida pelo desaparecimento do contexto de sua primeira instanciação. Ao mesmo tempo, o seu reenquadramento em outros cenários (reperformance, citações, transmissão literária, catalogação por bibliotecários etc.) deveria certamente levar a uma reformulação de sua afiliação genérica, bem como motivar uma reinterpretação de seu conteúdo quanto mais distantes os receptores da canção estivessem removidos de sua primeira performance e quanto menos informações tivessem sobre ela . Isto é, a partir da primeira performance, e o quanto mais nos afastamos dela, deve ter ficado cada vez mais difícil avaliar a prototipicidade de qualquer canção com relação ao modelo cognitivo idealizado de seu gênero ${ }^{26}$.

Com relação a essa problemática, porém, o epinício é bastante transparente ao menos no que diz respeito à ocasião mais ampla para a qual a sua performance deve ter sido pensada, isto é, o próprio nome da canção nos auxilia a ter uma ideia, mesmo que muito genérica, a partir da qual poderíamos ser capazes de conceitualizá-la: غ̇đt-víkı ś suficiente para evocar, em virtude de seu próprio nome, o frame OCASIÃO DE UMA VITÓRIA e, portanto, غ̇ंıvíkıৎ

${ }^{26}$ Cf. PFEIJFFER (1999b, p. 10), "What we have, [sic] is a poet whose primary concern is to compose odes that fulfill their encomiastic aims in the context of their first performance, writing from the perspective of his first audience, while at the same time fully realizing the Panhellenic potential of his art. The impact of a Pindaric ode on subsequent audiences can be compared to a pebble that is thrown into a pond, causing concentric circles of rippling water, the intensity of which decreases the further away one gets from the center", grifo meu. 
ג̇oı $\delta$, como na $N .4 .78$, a categoria CANÇÃO POR OCASIÃO DE UMA VITÓRIA . Da mesma

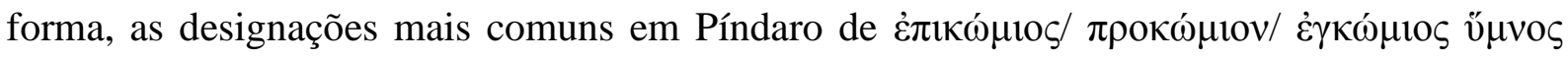
disparam o frame KŌMOS e perfilam também o sentido HINO PARA UM KŌMOS, cujo significado já tivemos oportunidade de discutir ${ }^{27}$.

Essa aparente vantagem da nomenclatura do epinício face a outras formas, como o ditirambo, por exemplo, tem, no entanto, consequências paradoxais quando pensamos em outros cenários que não o da première e isto porque, ainda que os jogos atléticos celebrados por esse tipo de canção fizessem parte de um calendário cíclico, cada epinício instancia uma competição, um atleta e uma vitória específicos e não reiteráveis, o que dá um sentido mais estrito ao termo "ocasional" do que quando aplicado, por exemplo, a outras formas poéticas, suscetíveis de ser reexecutadas dentro de um contexto cujo frame poderia permanecer essencialmente o mesmo, como no caso de um peã, de um hino (sctricto sensu), ou até mesmo de uma elegia, e, dessa maneira, esses gêneros seriam mais propensos à "reciclagem" e, consequentemente, à preservação via uma tradição de reperformances mais frequentes ${ }^{28}$. No caso dos epinícios, como ficará imediatamente evidente, isso implica em algumas complicações, uma vez que novas edições dos jogos, com seus novos vencedores, demandavam novas canções e, portanto, relegavam as canções antigas para um outro contexto, possivelmente de reperformance ${ }^{29}$. Este é o outro sentido de "ocasional".

Num cenário em que a reiteração de uma dada canção acontecia dentro zona de influência do laudandus ou de sua família, um ou outro podia controlar a interpretação da canção e minimizar as incongruências oriundas de um reenquadramento da mesma. No entanto, diacronicamente, é provável que as distorções entre a canção e esse reenquadramento em novos contextos de performance só aumentassem, tornando, no limite e ao menos hipoteticamente, uma grande parte de sua mensagem incompreensível ou irrelevante do ponto de vista de um público ignorante das condições da performance original e das referências que lhe eram feitas, o que poderia ameaçar sua existência. E não é exagerado supor que esse tipo de distorção possa ter sido o responsável pelo desaparecimento de inúmeras canções antes, e até mesmo depois, que elas tivessem sido fixadas pela escrita. É legítimo e absolutamente

\footnotetext{
${ }^{27}$ Sobre isso, e as possíveis interpretações dos adjetivos, $c f$. o Capítulo 2. Aqui eu cito apenas o sentido mais esquemático denotado pelo frame.

${ }^{28}$ Apesar disso, a situação que se apresenta é completamente diversa. No caso de Píndaro, por exemplo, os epinícios foram os únicos textos a serem transmitidos via uma linha ininterrupta desde a Antiguidade. No entanto, isto tem mais a ver com a organização da Seleta, no período Antonino. Sobre isso, cf. Histoire, p. 93 et seq.

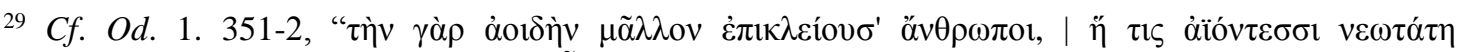

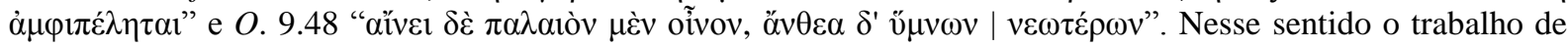
KURKE (1991) é tanto inovador quanto instigante.
} 
necessário, portanto, que nos perguntemos porque os epinícios pindáricos não tiveram o mesmo fim da maior parte da lírica grega e, de fato, de outros tipos de canções pindáricas, em sua grande maioria reduzidas aos "purpurei panni" ao longo de inúmeras coleções de gramáticos e antologistas ${ }^{30}$.

$\mathrm{Nagy}^{31}$ responde a essa pergunta por meio de um raciocínio sofisticado que leva em conta a pan-helenização progressiva da canção. Esta, segundo ele, deve ter sido capaz de falar e de se manter relevante para uma aristocracia cuja paideia centrava-se principalmente no aprendizado da poesia dos "clássicos" do passado, isto é, da geração áurea dos

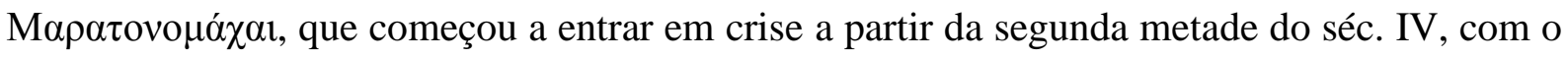

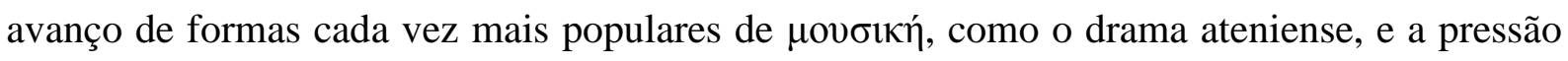
cada vez maior sobre (e contra) formas associadas com a velha aristocracia. A partir daí, a lírica de um modo geral, e não apenas os epinícios, deve ter sido transmitida apenas através da instrução escolar, mas ainda de forma oral, na qual os textos utilizados em classe deveriam servir apenas como registro de uma performance em potencial. As crianças da elite aprendiam principalmente por imitação de seus professores e não há motivos para se crer que a alfabetização tivesse o objetivo de ensiná-las a ler livros ou a ler silenciosamente a poesia lírica do passado. Quando isto finalmente ocorreu, a "cultura da canção" já havia morrido na Grécia, a música dos epinícios - transmitida oralmente de professor para aluno - deixara de circular e uma enorme carga de conhecimento tradicional, não escrito, sobre vários aspectos da canção se perdera. Indícios dessa decadência podem ser encontrados em toda a obra de Platão, mas especialmente nas Leis (2.664b-667a), onde vemos Sócrates traçando uma diferenciação esquematizada entre as formas musicais, como existentes no passado, e a realidade de seus próprios dias, em que as fronteiras entre essas formas começavam a se confundir. Posteriormente, a criação de uma ideia de "gênero", já incipiente nesta passagem das Leis, irá se desenvolver e atingir seu ápice em Alexandria.

Dentro desse cenário de transmissão escolar, é possível também que a sobrevivência dos epinícios pindáricos teria se dado, num período mais tardio, sobretudo em virtude de sua riqueza enciclopédica mais do que necessariamente por algum tipo de apreciação estética de que gozaria na Antiguidade ${ }^{32}$ tardia, isso, ademais, explicaria tanto a raridade de citações diferentes nos autores clássicos ${ }^{33}$ quanto a razão pela qual apenas alguns fragmentos

${ }^{30} C f$. Hubbard in MACKIE (2004, pp. 71-93).

${ }^{31}$ NAGY (1990, p. 382 et seq.).

${ }^{32}$ Histoire, p. 20.

${ }^{33}$ Com a exceção evidente de Aristófanes (3 citações explícitas) e Platão (várias vezes), mas mesmo nesses autores, embora haja quantidade, não há variedade, a seleção sendo sempre feita entre os poemas mais 
sobreviveram de seus outros poemas, bem como da produção de outros poetas que se dedicaram ao mesmo gênero, como Íbico e Simônides. Baquílides é uma exceção apenas parcial, uma vez que, até a descoberta do papiro de Londres $^{34}$, quase nada de sua poesia havia sido transmitido via tradição bizantina e medieval.

A partir dessas considerações iniciais, eu gostaria de detalhar alguns cenários propostos para a transmissão dos epinícios ainda na Antiguidade e, sobretudo, quando as canções ainda não haviam adquirido o status de texto.

\subsection{1. (c) by Pindar}

Um dos primeiros cenários que vem à cabeça de qualquer um que já tenha se debruçado sobre a questão da transmissão do texto pindárico é aquele em que o próprio poeta escreve ou manda escrever suas canções à medida em que as vai compondo, seja com o objetivo de preservá-las para a posteridade, seja para formar um "catálogo" de vendas para possíveis compradores ${ }^{35}$ ou, ainda, a fim de obter algum lucro, não necessariamente financeiro, com a circulação de seus $\operatorname{livros}^{36}$. No caso de Píndaro, mesmo que uma tal coleção, catálogo ou "programa de marketing pessoal" tenha existido e que, de alguma forma, uma protoedição da cuvre do poeta tenha sido organizada pelo mesmo, ela deve ter se perdido, uma vez que a metodologia editorial dedutível a partir da vulgata que chegou até nós reflete claramente práticas alexandrinas ${ }^{37}$. Some-se a isso o fato de que os próprios escólios antigos repercutem um trabalho de editoração e de classificação de um corpus até então amorfo de odes em edições realizadas por diferentes bibliotecários e comentadores do Museu. Isso me parece ser um forte argumento contra a hipótese de uma protoedição. Além do mais, há um certo consenso entre os especialistas de que, durante os séculos V e IV a. C., a produção de livros e o comércio livreiro ainda estavam em uma fase bastante incipiente ${ }^{38}$, o que seria um pré-requisito importante para o desenvolvimento de uma cultura de publicação.

célebres, como o Ditirambo de Atenas, o Hiporquema a Hierão, o prosódio a um destinatário desconhecido, o fr. 169 a e a $O .1$ (sobretudo o primeiro verso), $c f$. Histoire, p. 9 et seq. para mais detalhes.

${ }^{34}$ P. Lond. 733.

${ }^{35}$ Como o modelo construído por David Sider para a origem da Sylloge Simonidea, in BING e BRUSS (2007, p. 118 et seq.).

${ }^{36}$ Essa teoria assemelha-se com a ideia, proposta por alguns pesquisadores, de que a escrita teria sido introduzida na Grécia justamente para preservar, ou ajudar a compor, os épicos homéricos, $c f$. J.-P. WILSON (2009, p. 548).

37 T. K. HubBARD (2004). Cf. também NEGRi (2004).

38 T. K. Hubbard (2004) e PFeIfFer (1976, p. 27 et seq). Contra, Knox KnOX (1989, p. 4 et seq.) in $\mathrm{CAH}$. 
Há uma outra possibilidade, porém, a de que Píndaro tenha produzido algum tipo de

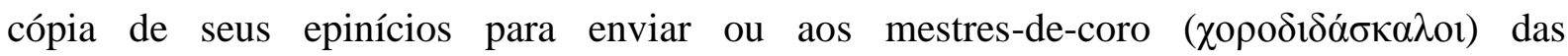
comunidades cujos patronos comissionavam suas canções, a fim de que aqueles pudessem ensiná-las aos integrantes do coro e/ou, então, a aedos profissionais responsáveis por executá$\operatorname{las}^{39}$. Por trás dessa hipótese está a suposição de que, por algum motivo, o próprio poeta não podia ou não queria viajar até esses locais a fim de executar suas próprias composições ou treinar o coro pessoalmente, o que lhe permitiria, entre outras coisas, controlar a execução adequada, tanto em termos musicais quanto coreográficos, de suas canções ${ }^{40}$.

\subsubsection{Transmissão Oral}

A ideia, muitas vezes e em diferentes graus, esposada de que a escrita seria o único meio de preservar uma canção tão logo ela fosse executada minimiza tanto uma tradição oral ainda vigorosa no séc. V e IV, quanto a cultura altamente musical em que as póleis gregas estavam imersas $^{41}$, a qual propiciava, de um modo para nós atualmente difícil de imaginar, a memorização e a rápida disseminação do conteúdo das canções ${ }^{42}$. Ignora, ainda, o papel importante que tanto a estrutura formal do epinício, i.e., a melodia que o acompanhava, seu metro/ ritmo, sua estrutura estrófica, sua linguagem e tropos poéticos, bem como seu caráter sociocultural, a saber, sua importância cívica, etiológica, seu caráter autoreferencial e integrador, etc., tinham na preservação, ou não, de seu conteúdo. É uma posição que, além do mais, revela um certo anacronismo responsável por projetar nossa experiência e as nossas expectativas sobre a forma literária do epinício, ademais (e do nosso ponto de vista) muito

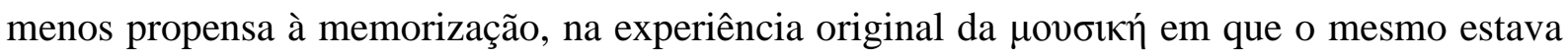
então inserido. A posição de Morrison, nesse sentido, é exemplar de uma filologia totalmente

${ }^{39}$ Aqui se pressupõe dois cenários distintos (e não mutuamente excludentes) de execução: a coral e a monódica. Para uma sinopse acerca desse celeuma, $c f$. o Capítulo 5. Sobre esse cenário, $c f$. também a descrição (talvez por demais fantasiosa) de Histoire, p. 5 et seq.

${ }^{40} C f$. o Capítulo 4; também HeringTON (1985, p. 26 et seq.) e Histoire, p. 5 e 8. Este último tende a exagerar nas possibilidades de um manuscrito das odes ser capaz de fornecer tantas informações sobre as partes mais técnicas da performance. Quanto à notação musical, é possível que Píndaro já a conhecesse e, talvez, a usasse, no entanto, indícios materiais a esse respeito aparecem apenas a partir do séc. III a.C, sobre isso $c f$. HAGEL (2009, p. 1 et seq.) e M.L. West (1992, p. 254 et set.). Quanto à possível existência de uma notação coreográfica, não há qualquer evidência que indique ou mesmo sugira que ela tenha existido.

${ }^{41}$ Cr. SWIFT (2010, pp. 1-2). Toda a discussão de Svenbro 1976, p. 173 et seq.) é bastente relevante para a discussão desenvolvida até aqui, mas especialmente a conclusão do autor ao dizer que "Si le poème assume ce caractère matériel à ses yeux, cela ne doit pourtant pas être confondu avec la simple matérialisation écrite de la parole sur les papyrus ou sur le marbre, comme dans le cas de la VII ${ }^{e}$ Olympique, gravée sur le temple d'Athéne à Lindos. La parole 'objectivée' des poètes choraux, c'est cette parole même, par rapport à celui qui la prononce."

${ }^{42} C f$. THOMAS (2012). 
desconectada dos estudos etnográficos que têm sido conduzidos desde, pelo menos, os anos sessenta que praticamente invalidam toda a sua argumentação acerca da improbabilidade de uma transmissão oral do texto pindárico. Em sua crítica ao modelo desenvolvido por $\mathrm{Nagy}^{43}$, ele diz:

Contudo, no modelo de difusão oral de Nagy de reperformances pan-helênicas, algumas mudanças nas odes teriam sido, muito provavelmente, inevitáveis, particularmente devido à natureza informal dos contextos de reperformance do simpósio privado. Canções oralmente transmitidas são muito propensas à mudança, mesmo onde os executantes esforçam-se por um reprodução [das mesmas], mais do que por uma recomposição. (...) A difusão oral de uma ode por meio de uma cadeia de reperformances independentes de um texto escrito é um modelo plausível para uma primeira difusão do texto das odes de vitória de Píndaro, mas ela não forma um estágio na história do nosso texto. Não há, acredito, boas evidências de que reperformances orais independentes de um texto escrito tenham deixado algum traço em nosso texto na forma de variantes que tenham surgido de performances diferentes, nem que, de fato, uma tal variante sequer tenha entrado na tradição textual, mesmo em um estágio preliminar. $O$ texto de Píndaro não foi textualizado por uma difusão pan-helênica nem por reperformances, mas sim por ter sido escrito por Píndaro, daí a falta de um grau de corrupção que esperaríamos encontrar em uma canção oralmente difundida [grifo meu] $]^{44}$.

Em um artigo bastante recente, em que trata também da disseminação do texto pindárico, Rosalind Thomas chama a atenção para características que seriam capazes de entextualizar uma canção, isto é, de transformá-la em um obra de arte vocal estável que compensaria a fluidez inerente a uma transmissão oral. Entre essas características estão algumas normalmente aduzidas justamente como "prova" de que uma disseminação oral dos epinícios seria impossível: a sintaxe complicada, a dificuldade da linguagem, o uso de alusões muitas vezes crípticas, o metro intricado etc. Como paralelo ela aduz (sem ignorar o fato de que tais comparações podem parecer, ou de fato são, sacrílegas para uma grande parte da crítica pindárica) a poesia de louvor ioruba conhecida como oriki, famosa por sua dificuldade e compactação. Nisso ela retoma a tradição comparatista que tem em R. Finnegan o maior, ainda que também bastante controverso, expoente. Um dos argumentos de Morrison, na obra citada acima, é a de que seria impossível para uma audiência decorar a $P$. 4 de Píndaro, que conta com mais de 295 versos. Essa impossibilidade, no entanto, é uma realidade entre os somalis, cujos poemas apresentam um alto grau de estabilidade que se deve, justamente, às caraterísticas formais do seu canto. Nesse caso a aliteração:

Um poema passa de boca em boca. Entre um jovem somali que escuta um poema hoje, composto há cinquenta anos atrás, a oitocentos quilômetros de distância, e sua

\footnotetext{
${ }^{43}$ NAGY (1990, p. 382 et seq.), do qual a epígrafe deste capítulo é um citação.

${ }^{44}$ MORRISON (2007, p. 117).
} 
primeira audiência há uma longa cadeia de recitadores que o passaram de um para o outro. É natural que nesse processo de transmissão algumas distorções ocorram, mas comparações de diferentes versões do mesmo poema normalmente mostram um surpreendente grau de fidelidade ao original. Isso se deve em grande medida à rigidez formal da poesia somali: se uma palavra for substituída por outra, por exemplo, ela ainda deve obedecer às regras de aliteração, limitando consideravelmente, dessa forma, o número possível de alterações. O sentido geral do poema, além do mais, inibe a omissão ou a transposição das linhas. ${ }^{45}$

Da mesma forma, o tamanho de uma canção, normalmente medida em número de palavras, de versos, de linhas, de cola, não tem qualquer importância para aquele que a memoriza ou quem a aprende de cor, isto é, de coração, já que a motivação psicológica ou emocional não podem ser minimizadas no aprendizado e na memorização de canções. Um caso interessante relatado por Finnegan, é o dos panegíricos de Ruanda e do Sul da África, conhecidos como izibongo:

\begin{abstract}
Os longos poemas panegíricos de Ruanda e da África do Sul são frequentemente citados como exemplos incríveis de poesia oral. Eles normalmente se estendem por centenas de linhas e apresentam um elemento narrativo, ainda que o foco principal seja o elogio. Contudo, em Ruanda, havia memorização de versões herdadas dos poemas de louvor, com uma variação mínima na performance e os compositores originais eram lembrados pelo nome (Kagame, 1951). Entre os Zulus, um estudo recente nos informa categoricamente que os cantores especializados em louvor adidos às cortes preocupavam-se mais com a 'performance' do que com a 'composição': o cantor 'tem que memorizar [os louvores dos chefes e dos ancestrais] tão perfeitamente que, em ocasiões importantes para a tribo, eles os proferem em uma torrente contínua. Ainda que ele possa variar a ordem e as seções ou estança do poema de louvor, ele não pode variar o próprio texto dos louvores. Ele os memoriza como os ouviu, mesmo se eles lhe são incompreensíveis' (Cope, 1968, pp. $28-8) .{ }^{46}$
\end{abstract}

Descrições que se assemelham bastante com a própria natureza da práxis poética grega, em que, se por um lado o ritmo e a melodia deveriam ser conducentes à memorização, por outro lado a rigidez das regras de resposta estrófica poderia auxiliar na identificação de intrusões ou acréscimos que desestabilizariam o texto da canção. $\mathrm{Na}$ verdade parece haver uma prova desse efeito estabilizador de uma dicção tradicional no comentário de um escoliasta à $2^{\mathrm{a}}$ Pítica, por meio do qual ficamos sabendo como Aristófanes de Bizâncio (c. 260-180) foi capaz de identificar facilmente o verso 27a da segunda estrofe da $2^{a}$ Olímpica,

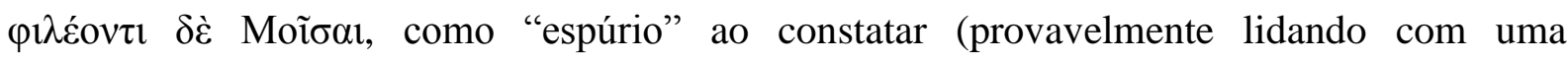
transcrição que poderia apresentar um desvio do "texto" canônico) que todas as outras estrofes (e antístrofes) contariam 14 cola, apenas aquela apresentando $15^{47}$. Essa única e

${ }^{45}$ FINNEGAN (1980, p. 74). Compare esta passagem com o relato de Plutarco, citado à p. 271.

${ }^{46}$ Idem, p. 79.

${ }^{47} \Sigma$ à $2^{\mathrm{a}} O$. (DRACHMANN, p. $73 \mathrm{O}$. II, 48c, e) é baseando-se nesse fato que Irigoin salta à conclusão de que teria sido Aristófanes o inventor da colometria pindárica. 
pequena história de uma intrusão no texto "canônico" ainda que não prove que, de fato, versões alternativas das odes poderiam existir, também não permite que descartemos essa possibilidade como um absurdo.

Não é difícil imaginar, por outro lado, que grupos de pessoas que tenham ouvido a mesma canção, tenham-na memorizado de diferentes maneiras; também não é difícil imaginar que, por um processo de retroalimentação, esses primeiros participantes tivessem podido corrigir uns aos outros ou que os receptores dessas diferentes versões, ao longo do processo de transmissão oral, tivessem podido, por seu turno, também corrigir uns aos outros, gerando, por fim uma versão (ou versões) estável(eis) da canção original, que não precisaria, e de fato não deveria, ser exatamente igual àquela primeira cantada pelo aedo. Essa canção, no entanto, por atingir uma forma estável e consensual em uma determinada comunidade teria adquirido um caráter canônico. Ao convergirem, contudo, para um mesmo centro de edição como Alexandria, teria havido inevitavelmente um processo de normalização do texto pindárico que poderia ter apagado qualquer marca vista como desviante de um determinado modelo ${ }^{48}$. Ao menos no que tange ao texto das odes, sabemos que houve, de fato, uma normalização, conhecida como $\mu \varepsilon \tau \alpha \gamma \rho \alpha \mu \mu \alpha \tau \iota \mu$ ós, em que os alfabetos locais em que as canções teriam sido transmitidas foram substituídos pelo alfabeto jônico, primeiro em Atenas, no arcontado de Euclides (403-2) e, depois, no restante da Grécia. Uma séria consequência dessa escolha foi a necessidade de desambiguar formas como OYPANO (N. 3.16) em oủ $\rho \alpha v \tilde{\varphi}$ ou oủ $\rho \alpha v o \tilde{~ e ~ e m ~}$ não se poder decidir entre um futuro ou um subjuntivo épico na $O .9 .1$, por exemplo, em que a lição de um manuscrito ocidental teria trazido apenas KOMA $\Sigma O M E N^{49}$.

Isso não significa, evidentemente, que a escrita não deva ter tido um papel crucial na preservação do texto pindárico, sobretudo quando a canonização do poeta torna sua "leitura" obrigatória nos meios escolares. Ou que, já na segunda metade do IV séc. a. C., ela não tenha sido, provavelmente, a única forma de difusão dos poemas. Daí não se deduz, por outro lado, que a transmissão escrita tenha tido um papel indispensável num primeiro momento da transmissão textual, principalmente naquele que se segue imediatamente à performance. Essa ressalva é necessária, em primeiro lugar, para nos alertar de que nada impede, e não há nenhuma evidência contundente em contrário, que a fixação do texto pindárico tenha se dado não antes da performance, para servir como "partitura" aos executantes (Píndaro poderia, e.g., ter treinado oralmente um aedo local, ou o próprio coro responsável pela performance), nem

\footnotetext{
${ }^{48}$ Cf. mais abaixo, pp. 278 et seq.

${ }^{49}$ Sobre isso, Histoire, p. 22 et seq.
} 
após a mesma (num esforço desesperado de evitar que a ode caísse no esquecimento), mas talvez algum, ou muito, tempo depois.

$\mathrm{Na}$ verdade, a necessidade que sentimos de que haja um documento, seja como ponto de partida (às vezes tomado como indispensável ao processo criativo), seja como mídia de suporte que preserve esse texto do esquecimento, apenas põe em evidência nossa própria angústia com relação à preservação da palavra, tida como impossível sem o auxílio da escrita, o que reflete os modelos cognitivos por meio dos quais conceitualizamos, em nossa própria cultura, a relação que nela se estabelece entre o que é dito e o que é escrito (verba volant, scripta manent). Não é possível, como já discutimos ao longo dessa tese, projetar a nossa experiência, expectativas e ansiedades sobre aquelas da cultura grega arcaica, em que a garantia da preservação de qualquer conhecimento residia na disseminação oral do relato como mediado pela voz por meio de diferentes formas de oratura, entre as quais a música e a dança eram proeminentes.

Uma outra angústia que dificilmente era partilhada pelos gregos e que, de certa forma, jaz por trás de inúmeras descrições de Píndaro como um escritor de poemas, é aquela da fidelidade, afinal de contas como poemas tão intricados como as odes de vitória de Píndaro poderiam ter sido transmitidas tão fidedignamente, senão por meio do uso da escrita? Por ora, seria importante que refletíssemos sobre o que entendemos por "fidelidade" e se esse conceito poderia fazer algum sentido para uma cultura oral, como aquela em que Píndaro vivia. É impossível falarmos de "fidelidade" sem pensarmos na existência de um original com o qual cópias possam ser comparadas, mas o que significa uma canção original para um poeta oral? Significa apenas a canção em sua primeira performance que, como Lord e outros estudiosos já demonstraram, será, para o cantor de contos, sempre a mesma, imutável, ainda que qualquer um que a grave ou transcreva possa apontar desvios significativos ao compará-la, posteriormente, com suas reperformances subsequentes. Para fazer isso, no entanto, será preciso fixar o texto. Assim fica claro que "fidelidade", "originalidade" apenas fazem sentido quando há um texto escrito, ou seja, quando esses conceitos são enquadrados dentro dos paradigmas de uma literacia que concede mais centralidade e valor à palavra escrita do que à falada, uma situação diametralmente oposta àquela na Grécia em que o documento escrito estava abaixo, em termos de confiabilidade, do testemunho oral ${ }^{50}$.

\footnotetext{
${ }^{50}$ Sobre isso, $c f$. especialmente THOMAS $(1989,1992)$.
} 


\subsubsection{Um tesouro de canções}

Deixando então de lado a possibilidade de que o próprio Píndaro possa ter sido responsável por uma "protoedição" de seus poemas, se não por sua improbabilidade, sobretudo em virtude da total ausência de fontes e/ou evidências sobre o período, é possível supor, como faz Irigoin $^{51}$, que pelo menos em dois outros momentos distintos suas canções pudessem ter sido transferidas para um suporte físico: (a) logo após sua composição, para ser enviadas aos laudandi, ou ao professor do coro, ou, ainda, como cópia mestre a partir da qual se poderia acrescentar a melodia ${ }^{52}$; ou, então, (b) após sua execução, como lembrança física da performance. No caso específico de (b), somos informados, através de um escoliasta ${ }^{53}$ que, de acordo com o historiador Górgão ${ }^{54}$, a $7^{\text {a }}$ Olímpica, escrita para Diágoras de Rodes, fora inscrita em letras de ouro no templo de Atena, em Lindos. Pausânias (9.16.1.6), por outro lado, nos relata que o Hino a Ámon fora enviado por Píndaro ao templo do deus na Líbia, onde fora gravado em uma estela triangular.

Essas são evidências importantes que demonstram de modo inequívoco que, na época de Píndaro, já se sentia a necessidade de que a letra das canções fosse preservada. Não, porém, como poderíamos ser levados a imaginar, como "documento" da performance, mas sim como "monumento", ou seja, como marca física que a traria de volta à vida ${ }^{55}$, o que pode ter sido feito através da tecnologia que, à época, pareceria ser a mais apropriada a esse propósito: a escrita. Pelo menos para um período mais tardio, a dedicação de canções em templos, inclusive com notação musical e provavelmente como oferta religiosa, ou na qualidade de ex-votos, não era algo incomum, o que prova o peã da autoria de Limênio, o hino a Asclépio e o epitáfio de Seikilos, os dois primeiros encontrados, respectivamente, em Delfos e no santuário de Asclépio em Epidauro, o que pesa em favor da tese desenvolvida por alguns pesquisadores ${ }^{56}$ de que essas canções poderiam ser objeto de reperformances cíclicas durante os festivais para os quais teriam sido primordialmente compostas. O mesmo pode ser postulado para algumas canções de Píndaro, como as dos testemunhos mencionados acima, e embora seja improvável que canções mais longas, como a Pítica 4, por exemplo, possam ter

${ }^{51}$ Histoire, p 71-93.

52 Outra questão espinhosa. Píndaro escrevia a própria música de seus poemas? Se sim, em que momento. Se não, por que e a quem cabia fazer isso? Não teríamos tempo para discutir essas questões interessantíssimas e as evidências são menos que escassas.

${ }_{53}^{53}$ DRACHMANN, p. $195 O$. VII.

${ }^{54}$ FGH IV, 410.

${ }^{55}$ Para uma definição e distinção entre "documento" e "monumento", cf. ZUMTHOR (2010, p. 39 et seq.).

${ }^{56} C f$. T. K. HUBbard (2004), CURRIE (2004a) e MORRISON (2007, 2012). 
sido preservadas da mesma forma que o peã de Limênio, a $O$. VII ou o Hino a Ámon, elas poderiam ter sido dedicadas de outra forma, escritas em chumbo, por exemplo, como os Trabalhos e Dias vistos por Pausânias ${ }^{57}$, ou na forma de livro, como Heráclito fizera com o seu livro de aforismos no tempo de Ártemis. Este é um cenário de transmissão que, a meu ver, poderia ter assegurado uma transcrição inicial bastante fiel às palavras originais da canção.

Uma outra forma em que a cação poderia ser entesourada seria através de uma transcrição da ode dada à família pelo próprio Píndaro ou transcrita durante a performance por alguém designado para esse trabalho. Não há como sabermos dos detalhes e essa hipótese não pressupõe, a priori, que o próprio Píndaro pudesse escrever o texto da canção. Entretanto, não há nenhum motivo para pensar que Píndaro pudesse saber escrever e alguma evidência de que ele, de fato, não sabia ${ }^{58}$. Seja como for, as próprias odes são um bom testemunho de que Píndaro previa este tipo de cenário futuro para as suas canções ${ }^{59}$. Por exemplo, na I. 2.43-6, provavelmente composta para a vitória de Xenócrates na quadriga, ele diz:

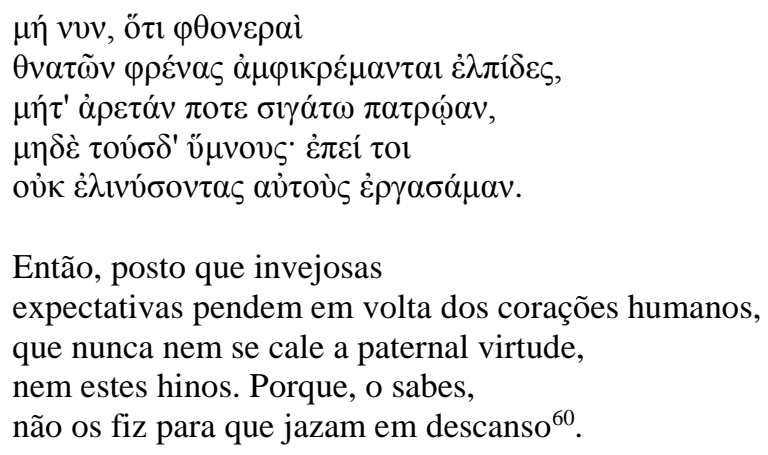

O outro exemplo que Currie ${ }^{61}$ cita, propondo uma nova, e a meu ver, melhor interpretação, refere-se às duas passagens da $N .4 .13-19^{62}$ (a) e 89-92 (b):

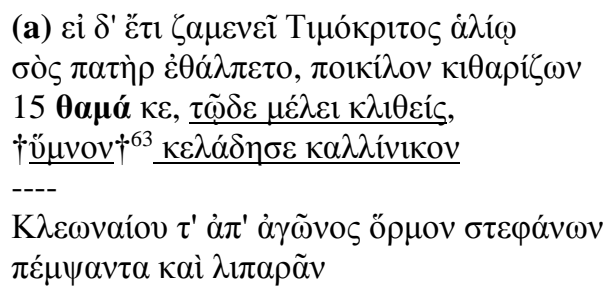

57 9.31.4-5.

${ }^{58}$ Confira a escassez do verbo $\gamma \rho \alpha ́(\varphi \omega$ e similares, bem como observações sobre sua semântica, na p. 54 et seq.

${ }^{59}$ Devo toda a minha argumentação nesta parte às excelentes observações feitas por CURRIE (2004a, p. 56 et set.

${ }^{60}$ Cf. a N. 5. 5-1, p. 172.

${ }^{61}$ CURrIE (2004a, pp. 56-70).

62 Discutida brevemente à p. 128.

${ }^{63}$ As cruces são minhas. S-M, a meu ver equivocadamente, as dispensa. 


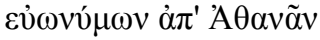

se ainda abrasante com o sol, Timócrito

o teu pai, se aquecesse, tocando a cítara

15 frequentemente, i inclinado? nesta melodia,

variegado o hino cantaria de vitória,
\end{abstract}

um ¿porto seguro? de guirlandas na competição em Cleonas

obtido e na rica

e bem afamada Atenas.

(...)

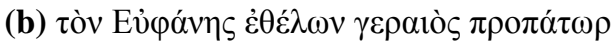

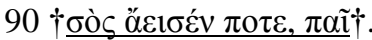

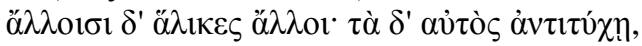

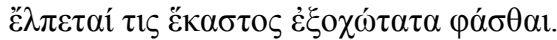

a quem ${ }^{64}$ Eufânes, teu velho avô, de bom grado

90 ¿um dia já cantou, menino?

Idades diferentes a tempos diferentes: mas, do que se vive pessoalmente,

cada um espera contar o mais sublime.

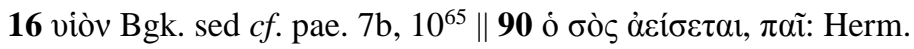

A passagem (a) implica em um cenário (imaginado) de reperformances frequentes

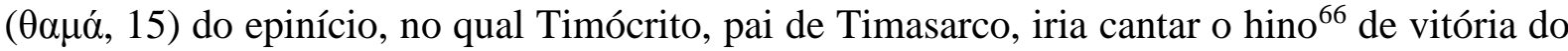

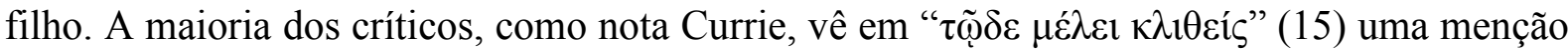
ao contexto de um simpósio, o que seria ativado pelo uso do verbo $\kappa \lambda$ ívo $\mu \alpha \imath+$ DAT, como na

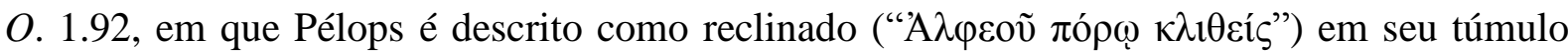
junto ao banco do Alfeu. Entretanto, Currie propõe uma leitura metafórica do verbo, para a qual o sentido "dedicado a" seria mais pertinente e aduz como paralelo a frase em Pausânias

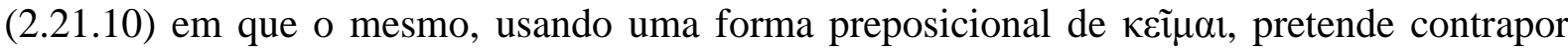

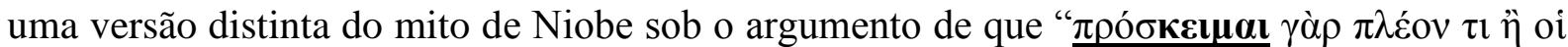

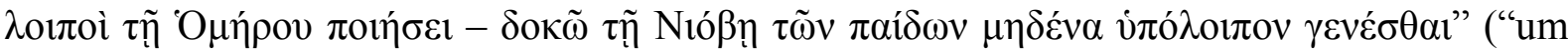
pouco mais dedicado que os outros à poesia de Homero, parece-me que nenhum dos filhos de Niobe tenha sobrevivido.") ${ }^{67}$. Aceitando-se, portanto, essa leitura, teríamos que alterar a tradução do verso para "frequentemente, ¿dedicado? a esta melodia, variegado o hino cantaria

${ }^{64}$ Cálicles, avô materno de Timasarco.

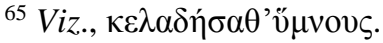

${ }^{66}$ Muito embora Curie prefira a sugestão de Bergk, citada no apparatus criticus a esse verso logo abaixo da citação, não me parece que seja necessária qualquer emenda ao texto de $\mathrm{S}-\mathrm{M}$, sobretudo em face da evidência do $P$. 7b, $10, c f$. n. 65 , acima. Isto também motiva a minha leitura de ö $\rho \mu$ o $\varsigma$ como "porto seguro" $(C f$. LSJ, II.2) das guirlandas, uma metáfora para o hino: ao contrário das guirlandas ganhas nos jogos, que inevitavelmente murcharão ou secarão, o hino permanecerá sempre um repositório contra o avanço do tempo.

${ }^{67} C f$. CURRIE (2004a, p. 57) para maiores evidências que apontariam para essa leitura. 
de vitória", que parece fazer mais sentido, sobretudo porque nos permite reter o ư $\mu$ vov dos manuscritos, ao invés da emenda de Bergk, vióv.

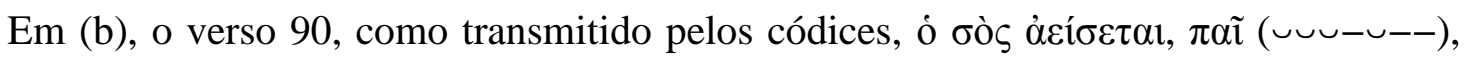
não cabe no metro, que requereria $x-x-\underline{-}-$. Com base nisso, Hermann ${ }^{68}$ propôs a emenda

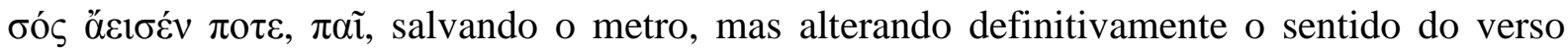
como transmitido. Sua emenda foi aceita pela maioria dos editores até Snell-Maehler. Mommsen, entretanto, sem alterar o sentido transmitido pela vulgata e recuperando o metro, propôs a transposição de ó $\sigma o ̀ \varsigma$ para o fim do colon, produzindo uma solução muito superior a de Hermann: $\alpha \varepsilon i ́ \sigma \varepsilon \tau \alpha 1, \pi \alpha \tilde{\imath}$, ó $\sigma o ̀ \varsigma ~(\smile-\cup---)$, que foi adotada por Race em sua edição mais

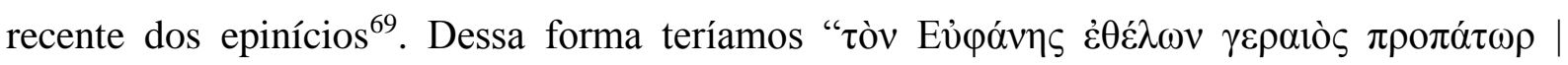

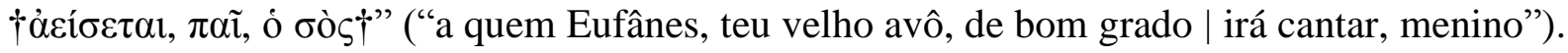
Um fato importante em se restaurar essa leitura é que, além de fazer mais sentido, ela nos fornece um cenário de reperformance na qual o avô de Timasarco, descrito como velho, porém ainda vivo ${ }^{70}$, irá provavelmente cantar, talvez após a performance deste epinício, um outro, composto para Cálicles, avô materno do laudandus. Mais importante ainda, este cenário em que epinícios passados seriam reexecutados por membros da família do vencedor informa-nos tanto de uma tradição nesse sentido, quanto projeta um futuro semelhante para a própria canção de Píndaro.

\subsubsection{Transmissão Escolar}

Um outro ponto importante diz respeito às referências à poesia lírica feitas por Aristófanes nas comédias, em especial dos epinícios de Píndaro e Simônides, o que deve indicar uma grande familiaridade da audiência com as odes desses poetas, doutro modo o efeito cômico desejado simplesmente não se produziria $^{71}$. Isso, no entanto, parece estar em contradição com o fato de que nas próprias comédias a poesia de louvor é vista como uma prática do passado e da aristocracia. De fato, de acordo com o testemunho de Ateneu ${ }^{72}$, pouco

\footnotetext{
${ }^{68}$ Para uma lista completa (e extensa) das emendas propostas para esse verso, $c f$. D. GERBER (1976, p. 107), com bibliografia ad hoc.

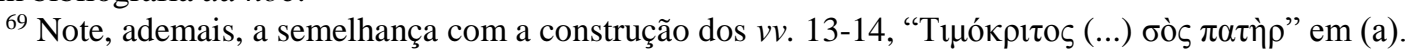

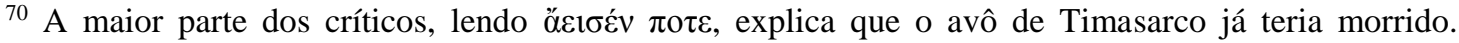

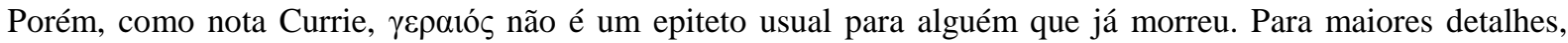
CURRIE (2004a, p. 58 et set.).

${ }^{71}$ SWIFT (2010, p. 112 et seq.); CAREY (2007).

${ }^{72}$ Deipnosophistaei, 1.4.21, onde nos relata como um dos personagens de Êupolis (366K/ 398K-A) queixava-se de que os poemas de Píndaro já não eram mais cantados ( $\alpha \alpha \tau \alpha \sigma \varepsilon \sigma \gamma \alpha \sigma \mu \varepsilon ́ v \alpha)$ em sua época devido à

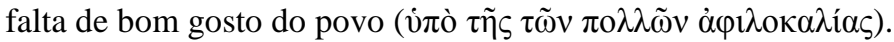


depois da morte de Píndaro, a composição e a performance de epinícios entrou em decadência, uma situação que parece se confirmar diante do fato de que nada mais nos chegou dessa época, com exceção do epinício a Alcibíades, da autoria de Eurípides ${ }^{73}$. $\operatorname{Irigoin}^{74}$, no entanto, destaca que, na ausência de uma demanda por novos epinícios ou mesmo quando a reperformance pública desses parece ter sido abandonada, a transmissão escolar poderia ter tido um papel capital em garantir a sobrevivência não só das odes pindáricas, mas de uma grande parte de lírica grega arcaica, uma vez que os alunos que frequentavam a escola eram obrigados a decorar esses autores como parte essencial de sua paideia.

Somente a educação escolar, entretanto, não seria capaz de justificar a familiaridade do público com a poesia do passado, sobretudo no grau sugerido pelas cenas aristofânicas: não é plausível supor-se que, ao menos em Atenas, onde não havia qualquer tipo de educação pública para as massas, uma educação de tal qualidade existisse, fosse tão disseminada ou tão específica a ponto de toda uma audiência teatral ser capaz de identificar trechos de canções compostas para aristocratas de terras distantes, como a Sicília, inclusive por meio de alusões veladas a acontecimentos bastante paroquiais, como a celebração da fundação de Etna por Hierão, em 476/5, como parodiada em Aves, 924-30. Além disso, a passagem das Nuvens ${ }^{75}$ citada por Irigoin para dar credibilidade à ideia de que a transmissão escolar seria um dos principais meios de preservação dos epinícios parece, na verdade, estar em franca contradição com o seu argumento, que implica em uma crise no sistema educacional ateniense ${ }^{76}$ em que a paideia do passado, aquela na qual o próprio Estrepesíades fora criado, já não era mais vista pela nova geração, representada pelo seu filho, Fidípides, como adequada aos novos tempos ${ }^{77}$.

Pelo que se deduz do discurso entre os Lógoi, ao menos à época de encenação das Nuvens ${ }^{78}$, essa crise parecia ameaçar os valores tradicionais da sociedade grega. Toda uma tensão entre "os bons e velhos tempos" e a "decadência da modernidade" começa a ficar evidente a partir dos $v v$. 934-8, quando o Coro de Nuvens pede aos Discursos que parem de se

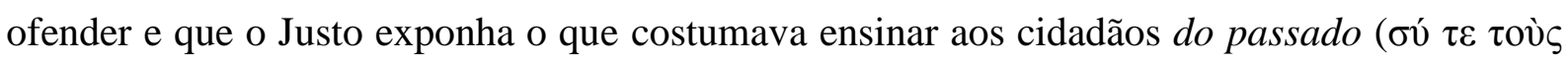

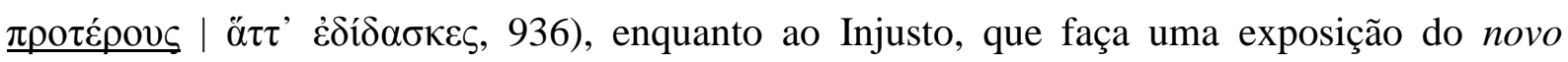

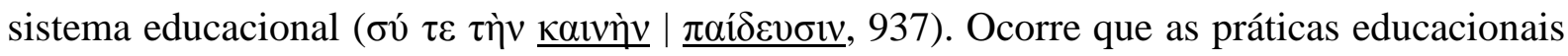
descritas pelo Discurso Justo são aquelas de uma geração passada, valores nutridos pelos

\footnotetext{
73 PMG 755.

${ }^{74}$ IRIGOIN (1952, p. 9 et seq.).

${ }^{75}$ V. 966 et seq.

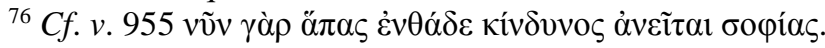

${ }^{77}$ Sobre essa crise, NAGY (1990, p. 408 et seq.) e NAGY (1996, p. 6 et seq.).

${ }^{78}$ Nuvens é datada de aproximadamente 423.
} 
"homens que lutaram em Maratona"79 e que, portanto, não teriam mais lugar no novo paradigma delineado pela paideia sofística. Na verdade, aos olhos dos sofistas, como se deduz da opinião do Discurso Injusto, as práticas da antiga paideia estão "totalmente ultrapassadas"

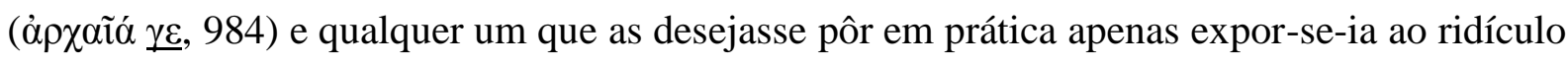

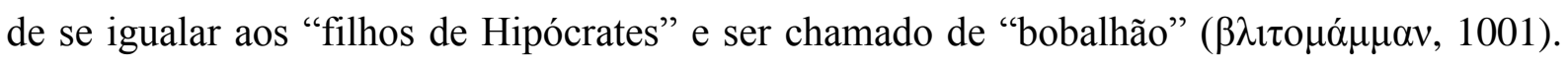
Mesmo o Coro, ao louvar a sabedoria do Discurso Justo, o faz de um modo nostálgico, como se referindo a uma época de ouro, agora já de todo perdida. ${ }^{80}$ De fato, ao final da diatribe entre os Discursos, é o Injusto que sai vencedor e é a ele, portanto, que a educação do jovem Fidípides é confiada, com resultados desastrosos para o seu pai e, deduz-se, o futuro da sociedade ateniense.

Ainda que seja preciso descontar o abuso cômico do motivo "velho x novo", que tende a exagerar uma diferença de ideologias entre gerações, é inegável que Aristófanes confia em que seus espectadores irão se reconhecer nas cenas por ele descritas entre o "pai antiquado" e o "filho afeito às modas do presente" (uma situação universal, aliás) e essa "simpatia" entre a situação vivida pelos personagens e aquela possivelmente experimentada pela audiência na vida cotidiana muitas vezes pode ter um efeito cômico mais efetivo que o uso de paródias mais explícitas. Aliás, talvez aqui seria importante salientar justamente a questão da "moda". Não é possível que pensemos que a crise educacional descrita por Aristófanes, ainda que esquematicamente fiel a uma realidade da época em Atenas, possa ter sido um fenômeno homogêneo.

É preciso lembrar que Estrepesíades e Fidípides representam a classe média ateniense, uma que, justamente, busca a ascensão social prometida pelos sofistas e que, portanto, não está tão apegada aos valores aristocráticos de uma paideia tradicional, senão de uma maneira muito pragmática ou pedante. O próprio Estrepesíades faz menção apenas ao que parece ser um trecho mais famoso de um epinício de Simônides e a algumas passagens de Ésquilo, dois heróis, aliás, da geração de Maratona e que, portanto, condensam em si os valores que se poderia esperar que um pai defendesse face a uma "juventude transviada", seduzida pela cultura de massas representada por Eurípides e os novos músicos. Daí não se deduz, contudo, que os estratos realmente aristocráticos dessa sociedade, os "filhos de Hipócrates" mencionados no v.1001, não persistissem em uma educação mais tradicional, voltada para a leitura oral e a disseminação dos clássicos e que essa aristocracia tenha continuado a consumir

\footnotetext{
है $\theta \rho \varepsilon \psi \varepsilon v "$.

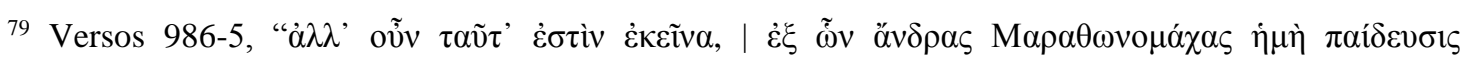

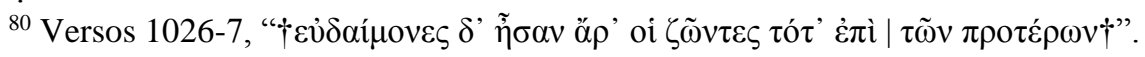


e, portanto, a demandar, cópias dos grandes poetas do passado, em um escala que, no entanto, é difícil de se precisar.

\subsubsection{Outros cenários}

Um cenário de transmissão que possivelmente teve um papel essencial na transmissão das canções é o do simpósio. Como já vimos anteriormente, e como sugerem alguns especialistas, algumas das próprias odes de Píndaro podem ter sido pensadas para serem executadas em sua première em um simpósio ${ }^{81}$. O próprio Píndaro parece prever cenários, que poderiam ser descritos como simpóticos, nos quais seus epinícios seriam cantados após a première, como por exemplo nas já mencionadas $I .2$ e N. $4^{82}$. Ao menos em um contexto familiar, esta possibilidade parece ser aparentemente aludida na famosa cena do jantar (Aves, 1355 et seq.) em que, após o pai de Estrepesíades lhe pedir que cantasse o epinício de Simônides para um boxeador de Egina - canção esta que, à época, já era célebre o suficiente para ser conhecida pelo nome de sua "ária" mais famosa, "Como Carneiro foi Tosado"83) -,

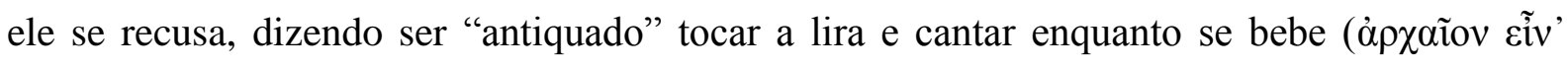

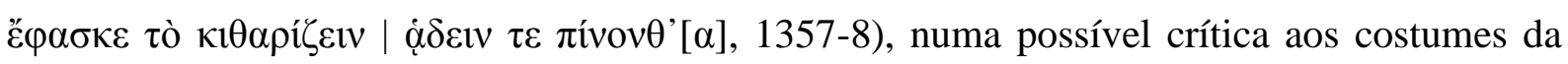
aristocracia, sempre saudosa dos "tempos melhores".

Outro indício interessante neste sentido, é o da fala de Sócrates no Protágoras. Logo após a discussão hermenêutica entre esse e a personagem-título sobre o fragmento 542 PMG, ele propõe que se abandone o uso da poesia - uma típica forma de argumentação sofística, baseada justamente em uma paideia aristocrática que prezava pela utilização dos "clássicos" na construção do argumento -, comparando essa prática aos banquetes dos homens “ordinários e dos comerciantes da ágora" que, por não poderem, devido à sua própria falta de

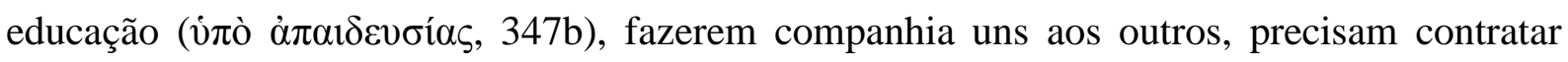
auletriz para que se entretenham com uma voz alheia à sua própria, ao passo que os homens educados são capazes de conversar sem a necessidade desses inconvenientes, "falando e

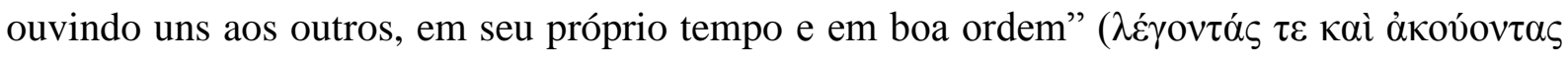
$\dot{\varepsilon} v \mu \varepsilon \dot{\rho} \varepsilon \varepsilon \dot{\varepsilon} \alpha u \tau \tilde{\omega} v \kappa o \sigma \mu i ́ \omega \varsigma, 347 \mathrm{~d})^{84}$. Como Nagy observa muito bem,

${ }^{81} C f$. sobretudo KrUMmen (1990), JenNy StRauss Clay (1999)e, mais recentemente, BudeLMANN

\footnotetext{
${ }^{82}$ Cf. p. 265. Ainda, O. 7.1-10; P. 5. 55-9.

${ }^{83}$ Fr. 507 PMG.

${ }^{84} \mathrm{Cf}$. com o fragmento elegíaco anônimo citado à p. 231 e a elegia de Teógnis, vv. 237 et seq.
} 
Platão poderia ter feito Sócrates dizer, como na poesia de Aristófanes, que os participantes educados, em um simpósio, também podem se entreter executando e interpretando composições líricas, ao contrário dos participantes mal-educados, que contratam flautistas para tocar por eles. Platão, porém, é o campeão da nova educação, onde os diálogos suplantam a primazia da poesia e, de fato, Sócrates chega a comparar "os poetas" com algo ruim como as tocadoras de flauta. ${ }^{85}$

A prática de se cantar composições líricas extraídas dos poetas, já então canonizados pela instrução escolar, é bem atestada no simpósio do V séc. A tais canções os simposiastas referiam-se como "escólio" ( $\sigma \kappa o ́ \lambda ı v^{86}$ ), como, por exemplo, no fr. 223 dos Banqueteadores

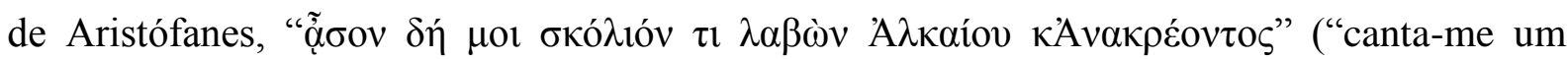
escólio qualquer, tirando-o de Alceu e Anacreonte”). Embora Currie ${ }^{87}$ restrinja esse modelo apenas à poesia não epinicial, a prática atestada para o epinício de Simônides, citada acima no contexto das Aves, deveria servir para nos pôr em dúvida, diante de um ceticismo exagerado. Apesar disso, ele parece ter razão ao chamar atenção para o fato de que, neste tipo de cenário, as odes provavelmente sofreriam alterações e reduções, para que se adequassem a um contexto mais limitado e completamente diferente daquele da première. Como exemplo concreto, ele cita as diferenças consideráveis enre o fr. $249 \mathrm{~V}$ de Alceu e a sua readaptação como carmina convivialia na forma do fr. 891.8 PMG através da citação nos Sábios ao Jantar de Ateneu $(15.695 \mathrm{a})^{88}$.

Dois outros cenários importantes, segundo Currie. Um deles seria a difusão da canção por meio de viajantes, que poderiam ter aprendido as odes de cor na primeira performance ou em reperformances imediatamente subsequentes. Se quisermos postular uma execução coral das odes, é plausível, ainda, presumir que cada integrante do coro poderia ser uma fonte fidedigna do texto (uma $\sigma \kappa v \tau \alpha ́ \lambda \eta ~ M o ı \sigma \tilde{\nu}$, como Eneias, na $O$. 6) da ode. As regras da progressão geométrica poderiam, então, nos dar uma dimensão de quão longe uma determinada canção poderia, passando de boca em boca, viajar. Este seria, também, um cenário de transmissão oral, de que já tratamos. Currie o vê com certo pessimismo, ainda que cite o caso, contado por Plutarco, dos prisioneiros atenienses em Siracusa que teriam ganho a sua liberdade, por cantarem partes (das odes corais?) de Eurípides ${ }^{89}$. A passagem merece ser citada na íntegra:

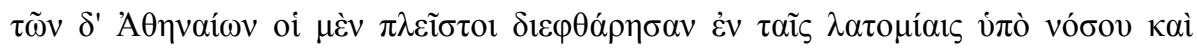

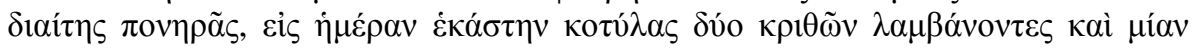

\footnotetext{
${ }^{85}$ NAGY (1990, p. 409).

${ }^{86}$ Sobre o termo, cf. a discussão em Ateneu, Sábios ao Jantar, 15.693f-694a.

${ }^{87}$ CURRIE (2004a, pp. 52-3).

88 Tratadas especialmente por FABBRO (1992).

${ }^{89}$ Plu. Nic. 29.2-3.
} 


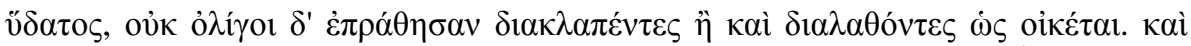

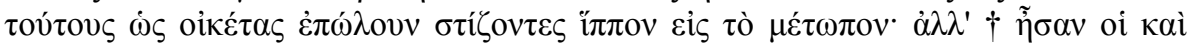

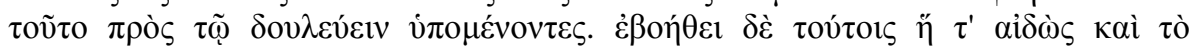

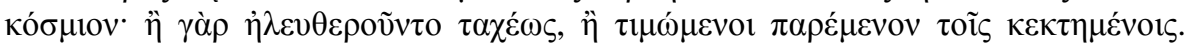

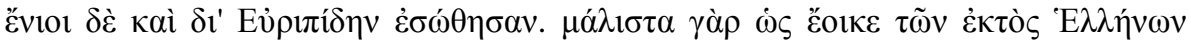

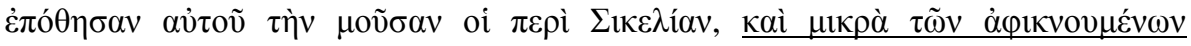

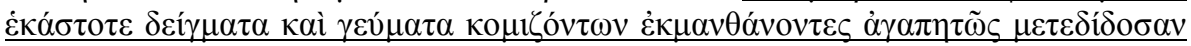

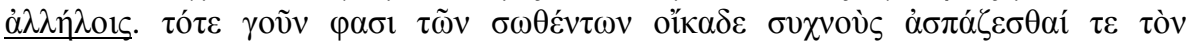

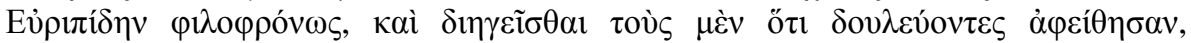

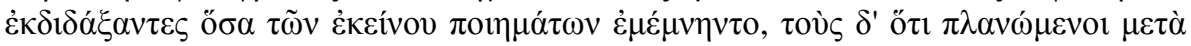

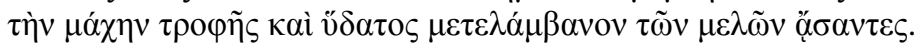

A maioria dos atenienses morreu nas pedreiras de doença ou da dura rotina. Para cada dia, recebiam apenas duas medidas de pão de centeio e uma de água. Não foram poucos os que, pegos roubando ou furtando, foram vendidos como escravos; tatuados na testa como os cavalos, assim eram vendidos. Mas houve alguns que permaneceram trabalhando como escravos. Ajudou-os a decência e o bom comportamento, pelos quais alguns obtiveram a liberdade rapidamente ou, sendo honrados por seus senhores, permaneceram. Alguns salvaram-se graças a Eurípides. Pois parece que os gregos na Sicília, mais do que todos os outros gregos no exterior, sentiam muita falta da música de Eurípides e cada pequena amostra ou migalha que obtinham dos que chegavam trazendo-as, aprendiam de cor com muito prazer e compartilhavam entre si. Diz-se que muitos dos que se salvaram, ao voltarem para casa, abraçavam Eurípides com muita afeição e lhe contavam, uns, como, enquanto escravos, haviam ganhado a liberdade ao ensinar [aos seus mestres] tudo o que lembravam de seus poemas; outros, que, perdidos depois da batalha, haviam trocado comida e bebida pelos versos que cantavam.

Não há porque se pensar que possa ter havido um zelo diferente para com as canções de Píndaro e essa vontade (que é quase uma ansiedade) em aprender uma canção nova é típica das oraturas $^{90}$ não só arcaicas mas também modernas, como já vimos, ao longo dessa tese, a partir de vários exemplos citados de outras culturas.

O outro cenário seria a execução das odes em festivais tanto por meio de coros patrocinados pelas famílias dos laudandi, quanto pela pólis. Currie admite que a distinção entre público e privado no período arcaico era bem menos marcada do que podemos ser levados a imaginar e, dessa forma, ainda que deva permanecer um cenário puramente especulativo, não é impossível que famílias da alta aristocracia de uma determinada cidade pudessem oferecer uma espécie de "simpósio coletivo" no aniversário da vitória do

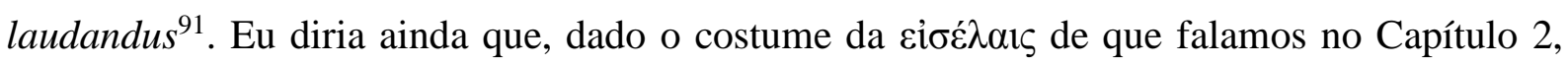

${ }^{90}$ É preciso lembrar ainda, duas anedotas: uma contada por Amm. Marc. Res Gestae, 27.3.15, segundo a qual Sócrates, já na prisão e condenado à morte, tendo ouvido um homem cantar um poema de Estesícoro, pedira que o mesmo lhe fosse ensinado, ao que o homem teria lhe perguntado de que lhe serviria aprender uma canção, se estava prestes a morrer, e sua resposta teria sido, "ut aliquid sciens amplius e vita discedam". Uma história semelhante é contada por Élio (fr. 190 D-F, apud YATROMANOLAKIS (2007, p. 86), mas dessa vez envolvendo Sólon, que, já em idade avançada, teria ouvido seu sobrinho cantar uma canção de Safo em um simpósio ( $\pi \alpha \rho \grave{\alpha} \pi$ ó $\tau$ ov) e pedido para que ele lha ensinasse, confrontado com a mesma questão, teria respondido

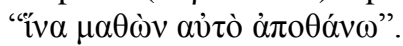

${ }^{91}$ Assim também Jenny Strauss Clay (1999) e CARey (2007, p. 201), com o importante caveat de que "(...) we have no reason to suppose that public resourcing of the celebration was the norm, just as we have no reason to suppose that the victor statues at Panhellenic sites were normally civic dedications". 
não seria surpreendente que, em alguns casos, a própria cidade pudesse financiar essa comemoração. A vitória atlética, afinal de contas, é sentida como algo obtido por toda comunidade, e não pertence apenas ao indivíduo ${ }^{92}$. Currie chama a atenção, então, para a

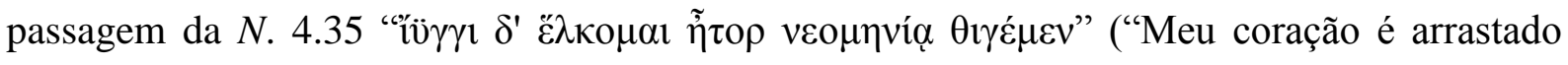

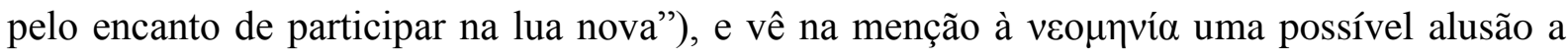
um festival local de Egina no qual a ode poderia ter tido sua première e no qual Eufanes poderia recantar o epinício de Calicles, mencionado anteriormente.

O caso para uma reperformance pública nos festivais da pólis parece ser fortalecido quando pensamos que, teoricamente, os mesmos se incluem em um calendário cíclico perpetuável in aeternitate e, portanto, seriam o contexto (e o alvo) ideal para qualquer poeta que almejasse conferir imortalidade ao seu patrono ${ }^{93}$. A esse respeito, Currie cita os casos muito sugestivos da $I$. 4.37-44, em que Píndaro compara a capacidade da sua poesia em conferir imortalidade aos épicos homéricos, traçando uma relação entre o passado e o presente que já tivemos oportunidade de analisar na seção anterior. A comparação torna-se relevante na medida em que a poesia de Homero é descrita como um "brinquedo" ( $\alpha \theta v \rho \mu \alpha$ ) com o qual

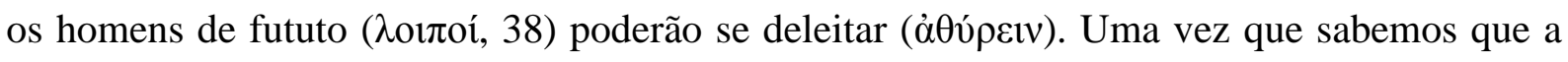
poesia de Homero era recitada em difetentes festivais, como nas Panatenéias, em Atenas, podemos presumir que Píndaro previa um futuro semelhante para suas canções ${ }^{94}$. Outro exemplo que apontaria nesse sentido seria a passagem da $P$. 2.13-20 que poderia estar comparando o culto de Ciniras pelos cíprios com o próprio culto das moças da Lócrida a Hierão, seu salvador. Presumivelmente, durante a festa desse culto, os epinícios àquele tirano poderiam ser reexecutados.

Finalmente, o costume de se mandar inscrever textos de determinados poemas em templos - muitas vezes com notação musical, como o peã de Limênios, em Delfos -, e outros locais públicos poderia ser uma forma de promover tanto a dispersão do conteúdo dessas canções quanto o de tornar acessível um texto para reperformances nesses locais. Como nota $\mathrm{Nagy}^{95}$, porém, mais do que demonstrar uma ansiedade cultural em preservar a canção por meio da escrita, o ato de inscrever a letra de um poema constitui-se em uma $\alpha \dot{\pi} \delta$ $\delta \varepsilon 1 \xi 1 \varsigma$ que tem em vista a reiteração da performance enquanto ato da fala. Dessa forma, segundo ele, é importante estar atento à semântica do verbo normalmente utilizado para denotar o ato da

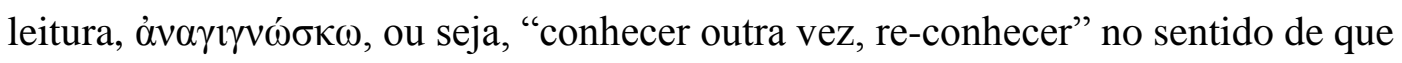

\footnotetext{
${ }^{92}$ Cf. Herington (1985, p. 56 et seq.).

${ }^{93}$ CURRIE (2004a, p. 64).

${ }^{94}$ CURRIE (2004a, pp. 65-6).

${ }^{95}$ NAGY (1990, p. 217 et seq.).
} 
Esse significado de ana-gignōskō é uma extensão metafórica da noção de performance pública, como vemos na $O .10 .1$ de Píndaro, onde a noção correspondente de uma composição real por parte do poeta mantém-se distinta por meio da metáfora de uma inscrição dentro do phrēn, 'mente' (10.2-3)

Ou seja, todo aquele que lê a inscrição (e o faz em voz alta, como era comum na antiguidade) promove a reiteração da performance.

\subsubsection{Fixação e Transmissão na Antiguidade}

Quaisquer cenários de transmissão que queiramos propor para os epinícios no período imediatamente posterior à première, permanece o fato de que, em algum momento, um texto (ou textos) contendo a obra poética de Píndaro, deve ter sido fixado, já que por volta de 295 85 a.C. uma ou mais cópias dos poemas deve ter chegado até o Egito, onde pôde ser editada pelos gramáticos alexandrinos.

É, de fato, à tradição filológica e editorial cultivada pelos bibliotecários do Museu em Alexandria que devemos todo nosso conhecimento da obra pindárica, que nos foi legada por meio de uma transmissão tão complicada que, não fosse pela própria materialidade de sua existência, seria difícil de se tomar por crível. Nihil ex nihilo fit, porém, e, para que esses textos tivessem chegado em Alexandria seria preciso postular uma cultura e um comércio livreiros mais ou menos sofisticados já por volta do final da primeira metade do séc. V, bem como a existência de coleções, bibliotecas, editores, revisores etc. o que é visto como problemático por muitos especialistas, como já apontamos. Não obstante, ao traçarmos a transmissão de Píndaro na Antiguidade vemos que todos os indícios apontam para o fato de que os bibliotecários, em Alexandria deveriam ter tido acesso a uma coleção de obras do poeta que lá chegaram por terem sido adquiridas de alguma maneira, já que não é plausível supor que os próprios bibliotecários ou mesmo pessoas empregadas por eles, pudessem rodar o mundo grego em busca de odes espalhadas em templos, arquivos de família, gravados em cidades, ou apenas na memória de alguns. Não há, além disso, nenhuma evidência de que a Biblioteca adquirisse seu acervo por tais métodos.

O que eu proponho, então, no que se segue, é que dediquemos um pouco de nossa atenção a investigar um período imediatamente posterior àquele da difusão das odes, para entretermos a possibilidade de que uma coleção dos textos de Píndaro, bem como de outros poetas, pudesse ter sido reunida algum tempo antes da fundação da Biblioteca de Alexandria e que seria a esta coleção, a que a maioria dos exemplares das odes a que os bibliotecários 
tinham acesso, remetesse. Obviamente, isso apenas transfere o problema de saber como e quando os poemas foram fixados e reunidos a um período anterior, sem, contudo, resolvê-lo. Entretanto - a parte de o problema ser, de fato, irresolvível -, se pudermos supor que os poemas poderiam ter sido recolhidos e editados antes de Alexandria e ainda na Grécia, onde uma collatio das fontes poderia ter sido levada a cabo com mais eficiência e, sobretudo, se pudermos ancorar essa reunião e "proto-edição" dos poemas a uma figura com competência e autoridade para tanto, então poderíamos avaliar melhor a qualidade do texto com o qual estamos lidando, o que teria implicações importantes para a sua crítica textual.

Muito embora isto vá sem dizer, é importante salientar que uma tal investigação é admitidamente especulativa. Acredito, no entanto, que ela pode fornecer um cenário plausível em face das evidências que apresentarei. Este cenário, portanto, como tentarei reconstruí-lo a partir daqui, coloca Aristóteles e a sua imensa coleção de livros como ponto focal a partir do qual as odes poderiam ter chegado ao Egito.

Segundo uma passagem importante de Estrabão ${ }^{96}$ Aristóteles teria sido o primeiro a reunir ( $\sigma v v \alpha \gamma \alpha \gamma \omega ́ v)$ um acervo de $\operatorname{livros}^{97}$ e, mais importante ainda, teria sido aquele que ensinara $(\delta 1 \delta \alpha ́ \xi \alpha \varsigma)$ aos reis do Egito a sistemática de organização de uma biblioteca

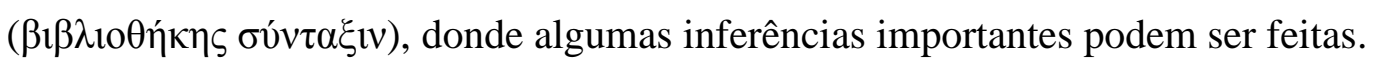

A primeira é a de que o tamanho da coleção de Aristóteles deve ter sido significativo para que ele tivesse necessidade de desenvolver um sistema de catalogação e/ou organização ( $\sigma 0 ́ v \tau \alpha \xi ı \varsigma)$ para a mesma. Uma outra é que esse sistema deve ter sido não só bastante eficiente mas também famoso, a ponto de ser requisitado pelos reis egípcios, que, infelizmente, não são nomeados, mas que só podem ser os ptolomeus, já que, até então, o Egito estava sob o comando dos persas, o que teria inviabilizado relações amigáveis com o ex-tutor do rei macedônio. É improvável, no entanto, que Estrabão pudesse usar o termo $\beta \alpha \sigma \imath \lambda \varepsilon v ́ \varsigma$ para se referir aos sátrapas deixados por Alexandre após sua conquista do Egito em 332, aí incluído Ptolomeu I, que deteve esse posto até 305. Se a isso somarmos o fato de que Aristóteles morre em 322, apenas um ano depois de seu discípulo, torna-se ainda mais difícil entender o que

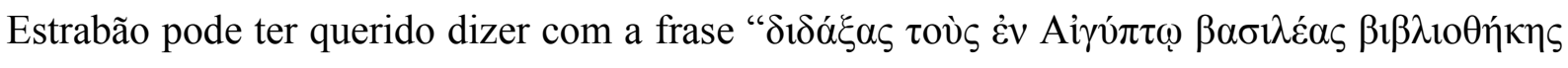
$\sigma u ́ v \tau \alpha \xi ı v "$ ("tendo ensinado aos reis do Egito a organização de uma biblioteca"). O mais seguro é admitirmos que ele deve estar reproduzindo, de uma maneira descuidada, uma

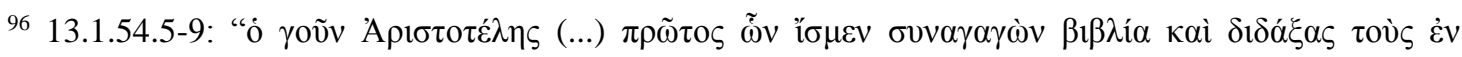

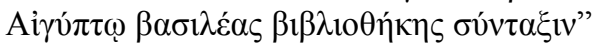

${ }^{97}$ Presumivelmente entre os gregos e, mais importante, de maneira sistemática, já que outros antes dele foram famosos por possuir coleções também não desprezíveis, como, por exemplo, Eurípides. $C f$. adiante a discussão sobre a passagem dos Sábios ao Jantar.
} 
tradição, possivelmente ainda vigente em seu tempo, que ligava a criação da Biblioteca a Aristóteles, o que não seria algo absurdo, como veremos.

De fato, se a filologia nasce face à necessidade de se vencer as dificuldades $(\dot{\alpha} \pi о \rho \eta ́(\mu \alpha \tau \alpha)$ apresentadas pelos poemas homéricos, nesse sentido ao menos, ela antecede em muito aos gramáticos alexandrinos, já que o primeiro crítico de Homero de que temos conhecimento surge por volta da primeira metade do séc. VI, um certo Xenófanes de Cólofão, que se rebelara contra a impiedade com que os deuses eram descritos nos poemas. A reação vem uma geração depois, na figura de Teágenes de Régio, que propõe uma interpretação alegórica às passagens mais ofensivas, de um modo que deve ter sido peculiar a muitos rapsodos, se tomarmos o Íon, de Platão, como paradigmático, como parecer ser o caso. Mais tarde, com o advento dos sofistas, as discussões sobre os problemas homéricos (uma atividade

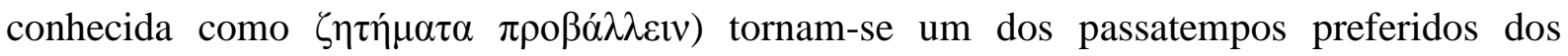
filósofos e dos cidadãos eruditos em todas as cidades gregas ${ }^{98}$. Como ressalta Blum ${ }^{99}$, apesar da ausência de rigor metodológico nessas discussões e de seu caráter por vezes pueril, elas não deixavam de ser indagações legítimas às dificuldades apresentadas pelo texto de Homero e, obrigatoriamente, engendravam tentativas de respostas e (re)interpretações que se traduziam em um diálogo com o poeta e com seus leitores, algo que, dogmatismos à parte, é de um caráter eminentemente filológico.

Com uma maior difusão da escrita, sobretudo a partir do séc. IV, foi possível que se produzisse cada vez mais cópias de textos do cânone de poetas gregos, sobretudo para uso escolar, o que facilitou a comparação entre diferentes versões desses autores, mas também criou um novo problema: a necessidade de se lidar com as variantes e de se separar o espúrio do legítimo. Que a qualidade das cópias deveria variar significativamente é atestado não somente pelas diferentes leituras preservadas ainda hoje em papiros supérstites, quando comparadas, por exemplo, com nosso texto da Ilíada ou da Odisseia, mas também pela linguagem técnica usual nos escólios, que deixa transparecer uma classificação dos diferentes manuscritos segundo seus variáveis graus de qualidade: haveria cópias mais "comuns"

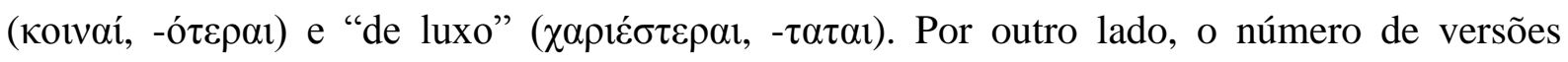
também deveria ser considerável, o que é sugerido pelas diferentes designações aplicadas aos textos, que eram agrupados de acordo com o seu "editor" ( $\left.\kappa \alpha \tau^{\top} \not \alpha \nu \delta \rho \alpha\right)$ ou com seu local (mas

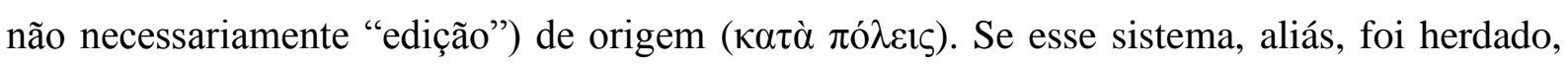

\footnotetext{
98 PFEIFFER (1976, p. 69).

${ }^{99}$ BLUM (2011, p. 14).
} 
como me parece ser o caso, da biblioteconomia aristotélica mencionada acima, podemos apenas especular.

A quantidade imensa de textos que chegaram a Alexandria ao longo de seus primeiros anos testemunha, por seu turno, uma atividade filológica considerável e constante desde, pelo menos, o início do período clássico. É preciso lembrar, afinal de contas, que Alexandria não se tornou uma grande biblioteca da noite para o dia, mas que se insere dentro do processo de valorização da cultura e dos valores helênicos que se dará após a divisão do império de Alexandre pelos seus diádocos. Assim, seja na Macedônia, sob o reinado de Antígono II "Gônatas", ou no Império Selêucida, a partir de Antíoco II, ou ainda, mais tarde, em Pérgamo, após a vitória de Átalo I "Sóter" sobre os gauleses, o processo de helenização dessas populações passava, necessariamente, pela absorção da cultura grega clássica, o que, por sua vez, gerava uma demanda cada vez maior por cópias de seus principais autores. Dessa forma, uma dinâmica de compra, troca, empréstimos (e, em alguns casos, até mesmo roubo ${ }^{100}$ ) de livros deve ter se estabelecido em todo o mundo mediterrâneo, o que, em última instância, significará um afluxo de fontes dos mais diferentes cantos do mundo grego convergindo em Alexandria ${ }^{101}$, que nessa época já era um importante entreposto comercial e, portanto, estava na rota do comércio livreiro do Mediterrâneo. Na verdade, sabemos, por meio de Galeno ${ }^{102}$, que muitos livros da Biblioteca chegaram trazidos por navios que aportavam em Alexandria e

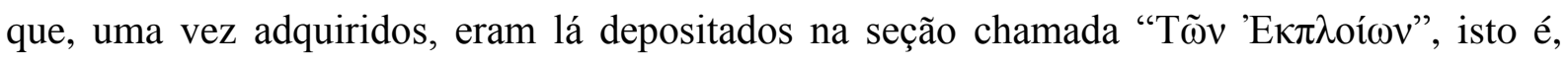
"dos navios".

É claro que a qualidade dessa produção pré-alexandrina não era nem uniforme, nem comparável ao nível de excelência que se atingiria no Egito, sobretudo porque os predecessores dos alexandrinos, salvo raras exceções, não dispunham da mesma riqueza de material bibliográfico, nem de igual facilidade de acesso que uma coleção concentrada em um único local proporcionaria, o que, em última análise, facilitaria e promoveria uma crítica textual mais metódica e rigorosa. Isso, contudo, e no caso específico de Homero, não desqualifica a atividade de "editores" como Antímaco de Colofão (final do séc. V) e de Eurípides (séc. V, mas não o tragediógrafo ${ }^{103}$ ), nem as "edições" de diversas cidades como Massília, Sínope, Quios, Chipre, Creta ou das regiões da Argólida e da Eólida; ao contrário,

${ }^{100} \mathrm{Cf}$. mais abaixo o caso das cópias licurgianas.

${ }^{101} C f$. SUSEMIHL (1891, p. 1).

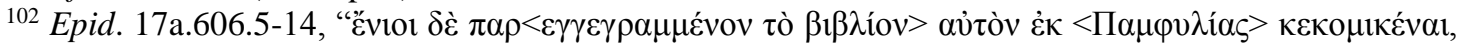

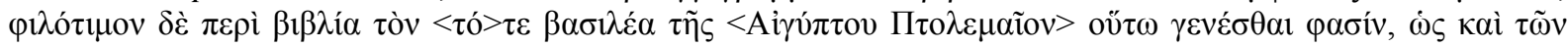

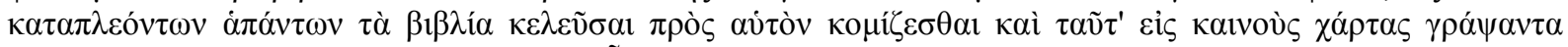

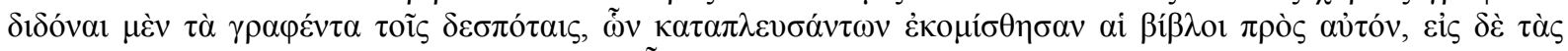

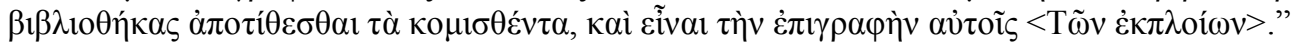

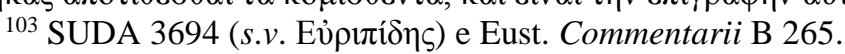


isso mostra como, a partir de um determinado momento, os gregos começaram a responder à tensão que se estabelecia entre diferentes versões epicóricas de textos que, por exibir um apelo pan-helênico, eram tomados até então como uniformes, embora não o fossem: suas discrepâncias apenas se diluíam na imaterialidade de sua transmissão, que era, até então, bastante independente da escrita.

Com o intercâmbio de cópias de textos entre cidades e indivíduos, no entanto, as diferenças começaram a se tornar aparentes e, consequentemente, pode ter havido uma reação contra aquilo que era percebido como um fator desagregador do "texto original" do poeta. Essa reação deu-se através de uma tentativa de se preservar uma determinada versão regional (que ademais seria tomada como "original") do aporte de material trazido por cópias provenientes de outras regiões, o que foi feito tanto corrigindo-se essas cópias, para adequálas ao cânon, quanto eliminando-se desvios aí percebidos como intrusões, mas que nada mais seriam que flutuações comuns a uma tradição oral diversa, texturizada e multifocal. É importante ressaltar, no entanto, que esse processo, por se dar num âmbito regional, provavelmente mantinha o status canônico da versão epicórica, à qual as possíveis versões alienígenas tinham que se adequar ao entrarem em sua zona de influência, o que seria suficiente para preservar diferentes tradições locais intactas.

Em Alexandria, ao contrário, todas essas vertentes convergiram sob a influência de um único centro gravitacional que, para o bem ou para o mal, as fez desaparecer. Sob o olhar crítico e uniformizador dos alexandrinos, foi-se produzindo, através de um longo processo de $\delta 10 \rho \theta \omega ́ \sigma \varepsilon ı \varsigma$ (lit. "retificações") sucessivas, uma vulgata que incorporou as "melhores leituras" de diferentes vertentes, mas que, por isso mesmo, já não mais representava nenhuma.

Uma exceção a essa atividade livreira descentralizada, comum na era que antecede a formação da Biblioteca, poderia ocorrer apenas sob condições propícias ao cotejamento e comparação de textos, ou seja, somente na presença de uma grande coleção de livros, pública ou particular ${ }^{104}$. É exatamente isso que encontramos em Atenas por volta do ano 335/4 a.C., quando Aristóteles volta para a cidade acompanhado de Teofrasto, após passar cerca de oito anos em Mieza, como tutor de Alexandre ${ }^{105}$. Naquela cidade ele funda o Liceu e dá continuidade às suas pesquisas filológicas, provavelmente ajudado por seus alunos, que deveriam auxiliá-lo no cotejamento, coleta e cópia das fontes. É preciso ressaltar que, embora sua atividade filológica tenha sido eclipsada pela sua reputação como filósofo, ela nem por

\footnotetext{
104 É importante lembrar que havia centros de comércio livreiro e bibliotecas importantes antes de Alexandria, como, por exemplo, em Rodes, Cos, Samos e Pela.

${ }^{105}$ Que nessa época já tinha cerca de 15 anos, D. L. 5.9.5 et seq. Onde é citado (5.9.11), seu testamento.
} 
isso deixou de ter um papel central na construção de suas teorias, na medida em que assegurava textos confiáveis em que sua argumentação pudesse se basear ${ }^{106}$, o que fica evidente se lembrarmos, por exemplo, que por trás de sua teoria política está um acervo de cerca de $158 \pi \mathrm{o} \lambda \iota \tau \varepsilon i ́ \alpha \varsigma$, ou "constituições" das mais diversas regiões do mundo antigo, das quais nos restaram apenas fragmentos da Constituição dos Atenienses.

Da mesma forma que seus antecessores, Aristóteles também se dedicou aos problemas apresentados pelos textos homéricos, dos quais provavelmente deveria possuir outras cópias, além da versão ática ${ }^{107}$, afinal sua fama de leitor voraz ${ }^{108}$ e de um grande colecionador de livros, como vimos pela passagem de Estrabão aludida acima, já se tornara proverbial. É possivelmente baseado nesse acervo que escreve os seis livros dos 'А que não foram preservados, exceto de modo indireto, pela influência que exerceu em outros

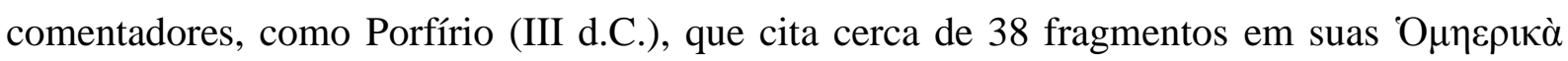
$\mathrm{Z \eta \tau} \tilde{\mu} \alpha \tau \alpha^{110}$.

Sabemos ainda que sua produção teórica no campo da filologia homérica foi posta em prática a serviço de seu pupilo, Alexandre, célebre por ser um obcecado pela leitura

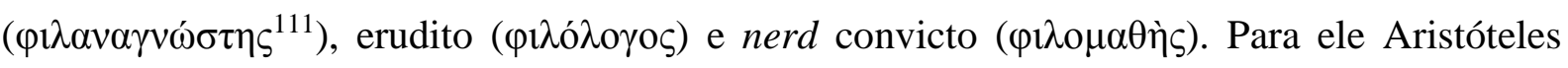

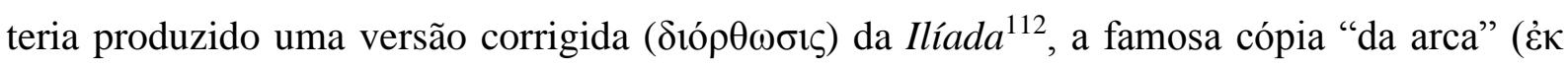

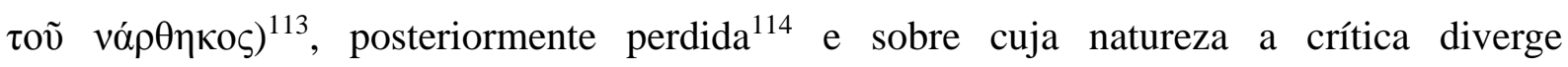

\footnotetext{
${ }^{106}$ PFEIFFER (1976, p. 67), "Aristotle and his followers could not have achieved their immensely learned compilations if they had not accumulated as many writings of the past as they could get hold of".

${ }^{107}$ BLUM (2011, p. 22).

${ }^{108} \mathrm{Na}$ Vita Marciana 7 (Düring) ficamos sabendo, por meio de uma anedota, que Aristóteles, durante seu noviciado junto à Platão, recebera a alcunha de $\dot{\alpha} v \alpha \gamma v \omega ́ \sigma \tau \eta$, i.e., "escravo leitor". Platão costumava dizer,

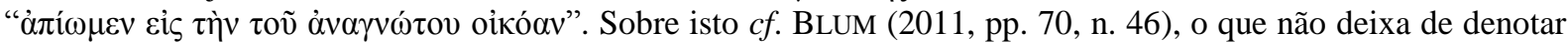
um certo preconceito ainda vigente contra a cultura do livro (algo, talvez, equivalente ao nosso "rato de biblioteca") entre os acadêmicos.

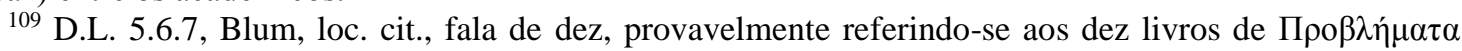

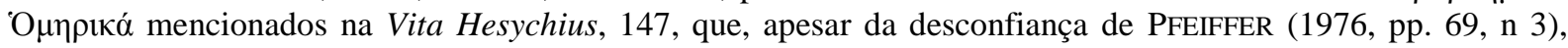
pode ser, na verdade, uma outra obra perdido.

${ }^{110}$ PFEIFFER (1976, pp. 69, n 4). $C f$. ERBSE (1960)

${ }^{111} C f$. n. 108 .

${ }^{112}$ Era comum, ao que tudo indica, que os professores entregassem cópias corrigida para seus alunos, $c f$.
} Plu. Alc. 7.1-3.

${ }^{113}$ Pois fora depositada na arca em que Dário guardava seus unguentos. Plu. Alex. 8 "ĩ $\delta \dot{\varepsilon}$ [sc.

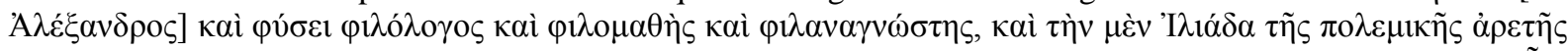

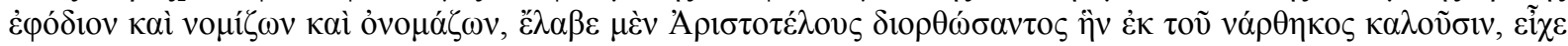

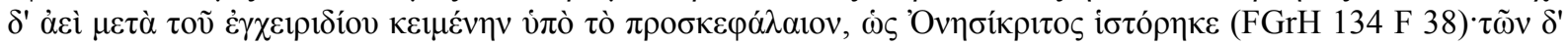

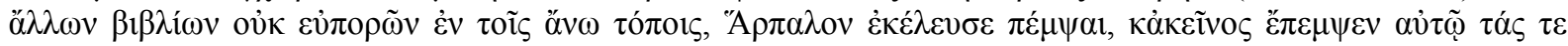

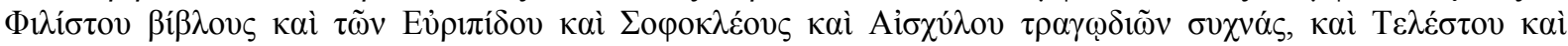

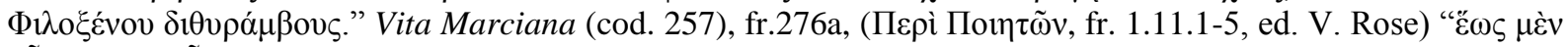

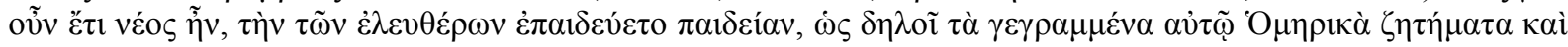

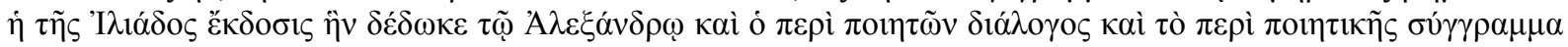

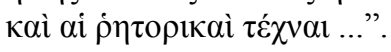


grandemente. Não há, porém, argumentos contundentes que nos impeçam de ver nessa

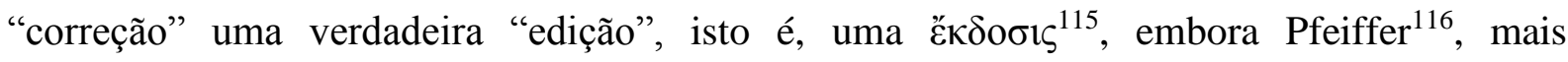
recentemente, negue essa possibilidade, constrangido por uma definição apriorística de "filologia", que não caberia discutir aqui ${ }^{117}$. O que nos interessa de seu argumento, por outro lado, é que ele, mesmo admitindo a razoabilidade da história narrada por Plutarco, descarta a

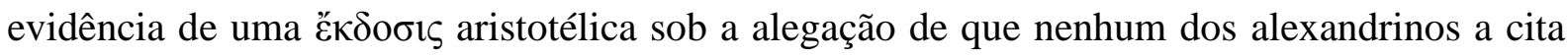
nos escólios à Ilíada e que, além disso (o que considera mais sério), essa edição não aparece nas listas das obras daquele filósofo, o que, a meu ver, constitui um argumento ex silentio que dificilmente pode se sustentar. Basta que consideremos, por exemplo, que nem todas as obras do período anterior à Biblioteca puderam ser salvas da obliteração pelos alexandrinos e que, portanto, esse terrível destino da única edição corrigida por Aristóteles para o uso privado de Alexandre não pode ser tido como singular ${ }^{118} \mathrm{e}$, portanto, não deveria causar espécie que a Ilíada "aristotélica" possa ter desaparecido tão logo o rei tenha morrido em Susa. Da mesma forma, sua ausência das listas canônicas do filósofo poderia ser explicada pelo fato de que esta não pertencia a Aristóteles, mas a Alexandre, que a carregava para todo o lado, até que ela se perdeu e, dessa forma, tornou impossível que cópias da mesma fossem produzidas. Finalmente, o julgamento de Pfeiffer ${ }^{119}$ de que o trabalho de crítica textual realizado por Aristóteles restringir-se-ia a responder, de modo quase frívolo, a uma série de ataques de

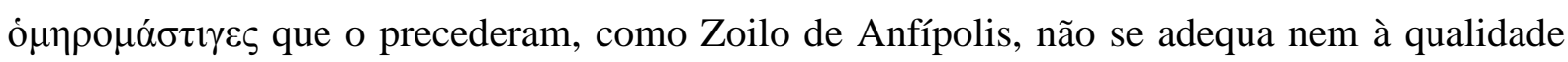
das obras supérstites do filósofo, nem à seriedade que lhe é característica no tratamento de questões importantes para a interpretação e o estabelecimento da fidedignidade do texto.

Foi Aristóteles, por exemplo, rebatendo a censura de Platão ( $R$. 319b) de que não se deveria responsabilizar Homero pela barbaridade cometida contra o corpo de Heitor (I. 22), que pôde provar, no uso provavelmente de sua imensa coleção de material bibliográfico ${ }^{120}$, que o costume de se arrastar o corpo do assassino três vezes em volta do túmulo da vítima

${ }^{114} \mathrm{E}$ muito provavelmente por isso jamais mencionada nos escólios à Ilíada, embora os A Aopí $\mu \alpha \tau \alpha$ tenham sido usados frequentemente pelos alexandrinos, $c f$. Fragmenta, 149-9(Fragmenta Varia no TLG, que é a ed. de V. Rose, 1886).

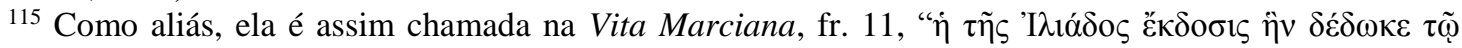
'A $\lambda \varepsilon \xi \alpha \dot{\alpha} \nu \rho \omega "$ ".

${ }^{116}$ PFEIFFER (1976, p. 69).

${ }^{117}$ Para uma análise mais equilibrada, e uma resposta ao dogmatismo de Pfeiffer, $c f$. Blum 2011, pp. 14; $20-4 ; 65$, n.10; 69, n. 45).

${ }^{118}$ Como aconteceu, de fato, com outra edição famosa dos poemas, a de Eurípides ( $c f . \mathrm{n} 103$ ), que, ao contrário da de Aristóteles, deveria ter sido copiada mais de uma vez. BLUM (2011, pp. 69, n.6), "it is deplorable that we know so little about the Homer edition of Euripides, because the Athenian version of the Homeric epics was apparently of great importance for their textual history".

${ }^{119}$ PFEIFFER (1976, p. 72).

${ }^{120}$ PFEIFFER (1976, p. 70). 
ainda era em seus dias praticado entre os Tessálios ${ }^{121}$. No campo da análise linguística, por outro lado, ele oferece uma explicação (à época) plausível para a difícil série de eventos desencadeada pela ira de Apolo, quando este, surpreendentemente, golpeia primeiro as mulas (ỏpcús) do acampamento grego, propondo que, neste passo, talvez o poeta estivesse usando a

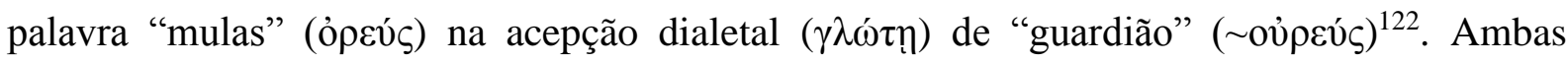
análises que não deixam nada devendo à pratica alexandrina, quando não lhe são superiores e, talvez, justamente por isso, Dio Crisóstomo (séc. I/II d.C.) tenha louvado Aristóteles, em seu

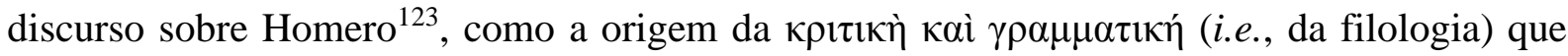
posteriormente se desenvolveria em Alexandria, posição, aliás, defendida também por outros teóricos modernos ${ }^{124}$.

Além de Homero, Aristóteles pode ter comentado também outros poetas, como Hesíodo, Arquíloco, Eurípides e, provavelmente, Píndaro. Temos fragmentos de um tratado

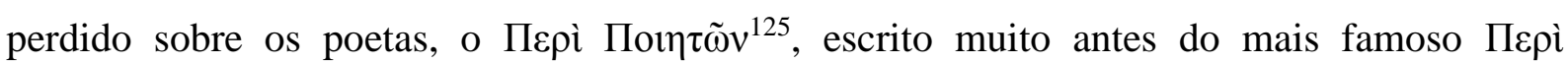

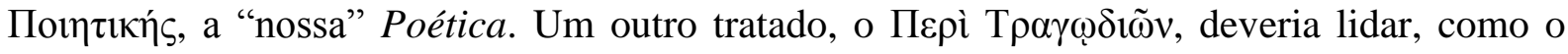
próprio nome indica, com as tragédias dos dramaturgos atenienses, embora provavelmente incluísse, da mesma forma, uma história do gênero (como se deduz da pequena introdução na Poética), da vida de alguns dos principais poetas, uma cronologia e, possivelmente, comentários a algumas peças. Junte-se a isso uma série de compilações ( $\dot{\alpha} v \alpha \gamma \rho \alpha \varphi \alpha i ́)$, entre as quais as mais relevantes para a nossa investigação seriam as 'O $\lambda v \mu \pi ı$ víka1 $^{126}$, as

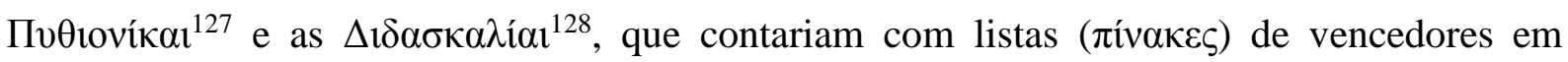

${ }^{121} \Theta \varepsilon \sigma \sigma \alpha \lambda \tilde{\omega} \nu \pi \mathrm{o} \iota \tau \varepsilon \dot{\alpha} \alpha$, fr. 495-500.

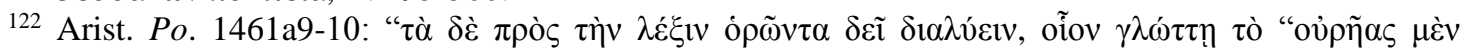

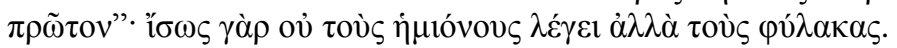

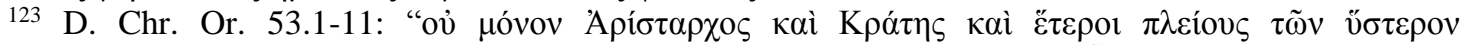

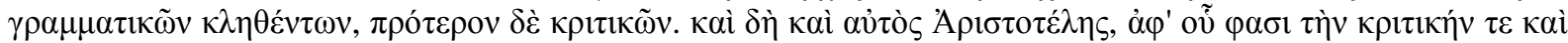

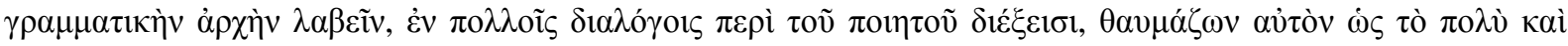

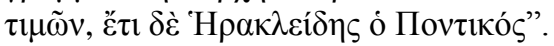

${ }^{124}$ Como, e.g., L. Ulrichs, W. Jaeger, F. Mehmel etc. apud Pfeiffer, PFEIFFER (1976, p. 67).

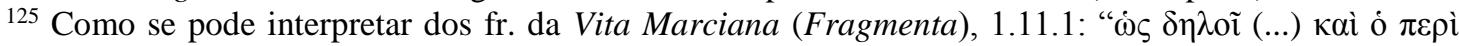

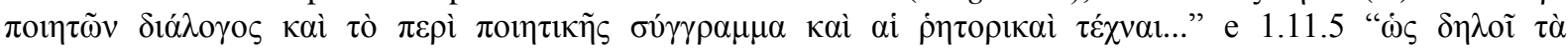

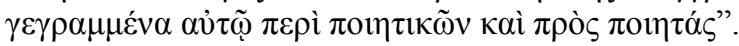

${ }^{126}$ Das quais existem seis fragmentos, segundo CHRISTENSEN (2007) p. 165 et seq: IG II ${ }^{2} 2326 ; \Sigma$ Pi. $N$. 3 27a. 3-4 (FGH F261); $\Sigma$ Theoc. 4.6 (FGH F262); D.L. 8.51-2 (FGH F263); $\Sigma$ Pi. O. 7 (FGH F264); Arist. Pol. 1339a 1-5 (FHG F264); $\Sigma$ Pi. O. 9 86e (FGH F118) e, talvez, EM 426.10.

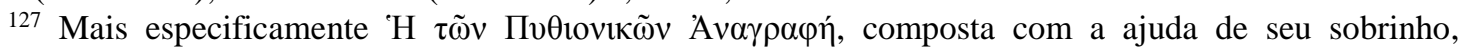
Calístenes e, de fato, mais do que uma mera lista, já que contava com quatro livros, dos quais o primeiro

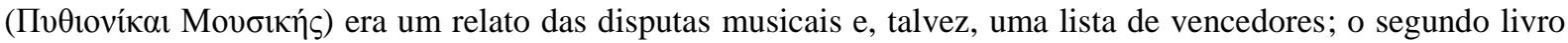

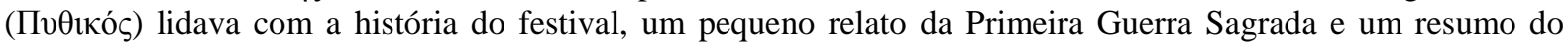

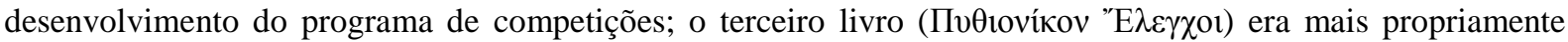
uma tabela que continha o catálogo dos vencedores nos jogos hípicos e na ginástica, começando com a reorganização dos Jogos Píticos em 586 até o ano de 330. As fontes, que são diversas, foram reunidas em CHRISTENSEN (2007, pp. 374-81), que apresenta, além disso, muitas outras informações relevantes sobre o tema. 
ordem cronológica a partir de 776 a.C. nos principais jogos homônimos e nas competições teatrais das Grandes Dionísias, no caso das $\Delta 1 \delta \alpha \sigma \kappa \alpha \lambda i ́ \alpha 1$.

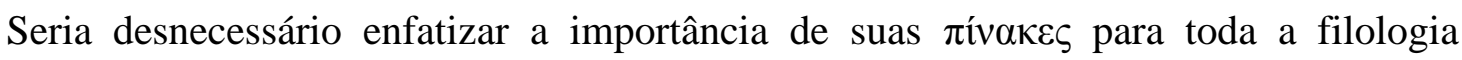
posterior, uma vez que tanto os escólios pindáricos como diversas outras obras importantes da Antiguidade basearam-se extensivamente nesses tratados e foi em grande medida por causa deles que uma cronologia exata e confiável nos pôde ser transmitida, já que foi Aristóteles, por exemplo, que numerou as séries olímpicas da maneira como as contamos atualmente ${ }^{129}$. Devido à importância de seu trabalho, os Anfictiões, na segunda metade do séc. IV a.C., emitiram um decreto ${ }^{130}$ premiando-o com uma coroa e uma quantia em dinheiro por seu trabalho com as ПvӨıvíkal, além de providenciarem para que estas fossem cortadas na pedra e anexadas ao santuário, donde, mais tarde, foram copiadas para papiros e puderam chegar em Alexandria.

Ainda, no que tange às $\Delta 1 \delta \alpha \sigma \kappa \alpha \lambda i ́ \alpha$, vemos que seu trabalho foi crucial tanto para a filologia de sua época quanto para a alexandrina, já que, como ressalta Blum ${ }^{131}$, não só essa compilação reunia uma quantidade imensa de informações sobre a história literária das competições trágicas em Atenas mas principalmente porque permitia aos estudiosos tirar conclusões importantes sobre as obras e as vidas dos poetas bem como separar aquelas espúrias das legítimas: quando uma determinada peça não constava na lista de obras de um autor como compiladas na lista aristotélica, podiam-se levantar sérias dúvidas sobre a autenticidade da mesma. Seu trabalho provavelmente deve ter servido a Licurgo, seu colega na Academia, quando este, ascendendo ao cargo de administrador ( $\tau \alpha \mu$ ía $)$ das finanças públicas de Atenas em 338-26, decide levar adiante uma série de reformas que tinham por objetivo restaurar o Teatro de Dioniso à sua antiga glória. Uma parte dessas reformas passava pelo estabelecimento de uma cópia oficial das tragédias de Sófocles, Ésquilo e Eurípides (cujas estátuas em bronze ele, aliás, mandou erigir) a ser depositado em um arquivo público ${ }^{132}$ em Atenas, visto que o texto de algumas já se tornara, em muitos casos, irreconhecível devido

${ }^{128}$ BLUM (2011, p. 27 et set.) trata detalhadamente da questão e apresenta uma bibliografia seleta sobre o tema.

${ }^{129}$ Como é possível supor-se por meio da evidência de que ele teria feito o mesmo para os jogos píticos, segundo a argumentação de CHRISTENSEN (2007, pp. 172-3), que me parece convincente, cf. também a nota 28. Mais tarde Eratóstenes (c. 285 a.C.) irá refinar o sistema por dividir cada $\pi \varepsilon v \tau \alpha \eta \tau \varepsilon \rho i ́ \varsigma$ em quatro anos consecutivos.

${ }^{130}$ Recuperado em 1895 em uma escavação em Delfos, SIG ${ }^{3}$ 275. Também CHRISTENSEN (2007, pp. 181-2), com uma tradução.

${ }^{131}$ BLUM (2011, pp. 41-2).

${ }^{132}$ A interpretação mais aceita para o $\dot{\varepsilon} v$ kovṽ̃, do texto plutarquiano, $c f$. PRAUSCELlo (2006, p. 70 n. 21). 
às inúmeras modificações pontuais introduzidas pelos atores a cada reperformance, bem como a cópias de péssima qualidade em circulação.

A partir de então os atores ficaram proibidos de usar ou interpretar textos corruptos ${ }^{133}$. É plausível se supor que, se uma cópia oficial era necessária, isso poderia significar que não havia nenhuma depositada pelos próprios poetas nos arquivos de Atenas e que, dessa forma, seria preciso, em primeiro lugar, estabelecer um texto aceitável, algo para o que Aristóteles, tendo conduzido estudos literários sobre os tragediógrafos, era a pessoa mais indicada para fazer. Ao que tudo indica, aliás, o prestígio dessas cópias era tamanho que um dos ptolomeus (não se tem certeza se Ptolomeu II "Filadelfo" ou III "Euergetes") após ter solicitado o empréstimo das mesmas mediante um seguro de 15 talentos $(\sim 395 \mathrm{~kg})^{134}$ de prata, a fim de que se realizassem cópias em Alexandria, preferiu abrir mão do prêmio, permanecendo assim com os originais e devolvendo as cópias aos atenienses ${ }^{135}$.

Aristóteles morre em 322, ano em que Ptolomeu I "Soter" (c. 354/48-283 a.C.), tornase sátrapa (322 a.C.) e, posteriormente (305 a.C.), rei do Egito. Este, tendo sido amigo de infância de Alexandre e, talvez, seu colega de instrução sob a tutela de Aristóteles ${ }^{136}$, provavelmente partilhava de igual bibliofilia. Dessa forma, provavelmente logo após se tornar rei, tenta assegurar para seu filho, o futuro rei Ptolomeu II "Filadelfo" (309-246 a.C.), uma educação semelhante, ao convidar Teofrasto, herdeiro de Aristóteles, para a corte do Egito ${ }^{137}$, porém sem sucesso. Consegue, no entanto, trazer, entre outros eruditos importantes de sua época, o historiador Hecateu de Abdera (ou de Teos), Teodoro de Cirene, o poeta e filólogo Fileta de Cós e Estratão de Abdera, discípulo de Teofrasto. Sob a responsabilidade desses dois últimos, coloca a educação de seu sucessor. Finalmente, em 295 a.C. chega em sua corte, em busca de asilo político, o recém destituído general de Atenas, Demétrio de Faleros, o principal discípulo de Teofrasto e um dos mais prolíficos peripatéticos ${ }^{138}$. Será a ele e a Ptolomeu I que

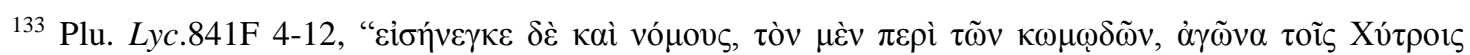

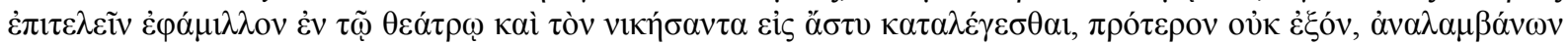

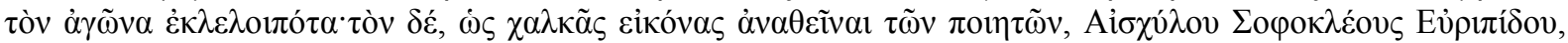

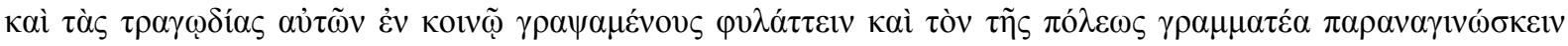

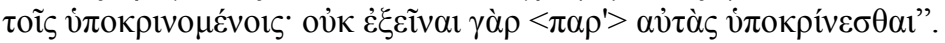

${ }^{134}$ Algo em torno de R \$ 600.000,00 a 700.000,00, em valores atuais. A “cotação" da prata, na época, deveria ser muito mais alta, devido à dificuldade de extração e logística. Provavelmente estaríamos falando de valores na casa dos milhõe de reais.

${ }^{135}$ Gal. Epid. III 17a.607.5-13.

${ }^{136}$ É controversa a questão de se saber

137 D. L. 5:37. Além de Estilpão de Mégara e o poeta cômico Menandro, $c f$. SuSEMIHL (1891, p. 6), SANDYS (1903, p. 105 et. seq.).

${ }^{138}$ General em Atenas de 317-307, como procurador de Cassandro. Sobre sua produção literária, $c f$. D. L. 5.80. Foi por meio de sua influência que Teofrasto pode comprar o terreno em Atenas onde se construiria o "templo das Musas" (já que nem ele, nem Aristóteles eram cidadãos atenienses BLuM (2011, p. 21)). É possível que seus escritos estivessem ancorados em uma coleção pessoal de livros diretamente proporcional. Não 
se atribuirá, tradicionalmente, a iniciativa de se criar uma coleção de livros em Alexandria ${ }^{139}$ e, embora essa atribuição nos pareça plausível, é preciso acautelarmo-nos contra qualquer certeza, já que se sabe muito pouco sobre esse período de formação da Biblioteca e as fontes são mormente confusas e contraditórias no que diz respeito aos seus possíveis idealizadores.

O protagonismo de Demétrio de Faleros, por exemplo, é mencionado explicitamente apenas em duas fontes importantes, a famosa "Carta de Aristeas", datada do séc. II, claramente pseudoepigráfica $^{140}$, e o prólogo de Tzetzes às comédias de Aristófanes ${ }^{141}$. Em ambos os casos, no entanto, fica evidente, por meio do contexto, que o rei a que aquela faz referência é, na verdade, Ptolomeu II "Filadelfo"142, enquanto que o desta é Ptolomeu III "Euergetes"; contradições irreconciliáveis, já que sabemos que, por um lado, à época de Ptolomeu II, Demétrio teria sido exilado de Alexandria, ao passo que já estaria morto por ocasião do reinado de "Euergetes"143. De qualquer maneira, é possível supor que, quando Ptolomeu I funda o Museu, já houvesse algum tipo de acervo bibliográfico em Alexandria ${ }^{144}$ ou mesmo planos para se construir uma biblioteca, que, ademais, seria necessária para a própria atividade dos eruditos congregados no Egito, muitos deles discípulos de Aristóteles, para quem a atividade filosófica estava intimamente ligada à sua, já proverbial, coleção de livros.

sabemos, no entanto, se ele teria tido tempo de transportar seus livros para o Egito durante a fuga (presumivelmente) apressada de Atenas, onde aliás, foi condenado à morte in absentia. Em Alexandria, no

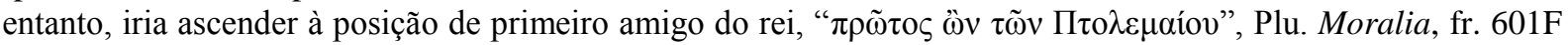
(De Exilio), até ser expulso novamente por seu filho, Ptolomeu II "Filadelfo", c. 283 a.C., por ter aconselhado seu pai a preteri-lo em favor do filho de Eurídice, sua terceira esposa. Morre algum tempo depois vitimado acidentalmente pela picada de uma víbora (D.L. 5.78).

139 Os dois testemunhos invocados por Pfeiffer PFEIFFER (1976, p. 96 et seq.), são a passagem em Plu.

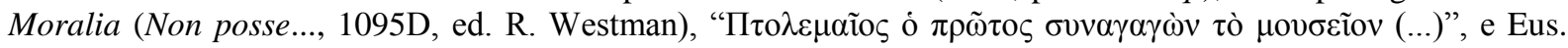
Hist. Ecc. 5.8.11, sobre a história da tradução da Septuaginta. Com relação ao primeiro, é preciso notar que a identidade estabelecida entre Ptolomeu I e o Ptolomeu da passagem não é automática (como ele mesmo dá a entender na p. 99) e deve ser tomada com cautela. A data da obra de Eusébio, por outro lado, é tardia (IV séc. d.C.), o que o coloca sob suspeita de contaminação por, viz., "Carta de Aristeas" (mais abaixo). Cf., ainda, a opinião de SUSEMIHL (1891, pp. 135, n. 18), sobre o assunto.

${ }^{140}$ A versão da "carta" está em Eus. PE 8:2.1.1-3, mas é parafraseada, ainda, por Flávio Josefo em suas Antiquitates Judaicae, 12:12-13. Sobre os problemas de autenticidade da carta, cf., e.g., GoODING (1963) e PFEIFFER (1976, pp. 135 e 99-02).

${ }^{141}$ Prooimium II, 2.1 et seq. (Koster). A importância de Demétrio de Faleros parece ter sido favorecida, entre os modernos, pela autoridade de Wilamowitz WILAMOWITZ-MOELLENDORFF (1965, p. 291): “es muss aber doch mit einem worte darauf hingewiesen werden, dass Demetrius von Phaleron wie das peripatetische Museion in Athen so das universale in Alexandria gestiftet hat (...). Ptolomaios und Demetrios bewiesen eben auch hier, ihr ganz bewunderungswürdiges organisatorisches talent: aber der weltüberschattende baum der alexandrinischen gelehrsamkeit ist doch nur ein reis von dem heiligen ölbaume am Rosshügel zu Athen". Opinião ecoada por Susemihl SUSEMIHL (1891, p. 16 et set. e 135) e criticada por PFEIFFER (1976, pp. 99, n 4).

142 Para uma discussão relativamente recente da "carta de Aristeas" e da referida passagem em Tzetzes, $c f$. PFEIFFER (1976, pp. 99-102).

${ }^{143}$ Detalhes em PFEIFFER, loc. cit. n. 140

${ }^{144}$ Assim, R. Barns in MACLEOD (2000, p. 63). 
A influência peripatética em Alexandria, consequentemente, salta aos olhos, e está presente não apenas no desenho do edifício do Museu (que contava, inclusive, com um $\pi \varepsilon \rho i ́ \pi \alpha \tau o \varsigma^{145}$ ), mas também na sua concepção logística e, até mesmo, em seu nome, que faz lembrar imediatamente o templo das Musas, em Atenas, a que Teofrasto alude em seu testamento $^{146}$. Talvez aí esteja uma explicação razoável para o papel proeminente que a figura de Demétrio de Faleros tomou em todas as histórias sobre a Biblioteca: sua ligação com Aristóteles e com Ptolomeu II.

A bibliofilia deste último, como vimos, era proverbial. É, no entanto, o autor da epítome $^{147}$ dos Sábios ao Jantar quem nos fornece a primeira pista de uma ligação entre o acervo da Biblioteca e a coleção de livros do filósofo. Ao louvar a erudição de Larensio, um dos convivas do "jantar", ele a compara com a de outros famosos colecionadores de livros como Polícrates, Pisístrato, Euclides, Nicocrates de Chipre, os reis de Pérgamo, Eurípides, Aristóteles e, finalmente, Ptolomeu II. Agora, segundo ele, este último teria comprado toda a famosa coleção de Aristóteles, já aumentada pelos livros de Teofrasto, do fiel depositário e sucessor deste último no Liceu, Neleu de Cépis, transportando-os para Alexandria junto com um carregamento de livros obtidos em Atenas e Rodes. No entanto, um pouco mais adiante somos surpreendidos pela informação contraditória de que Apelicão de Teos (séc. I a.C., capacho do então tirano de Atenas, Atenião), além de roubar diversos arquivos originais do

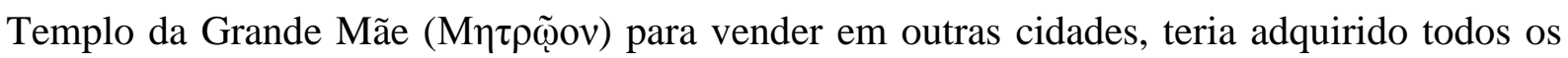
escritos dos peripatéticos para sua biblioteca pessoal ${ }^{148}$.

É preciso, no entanto, complementar essa informação com a passagem em Estrabão (13.1.54) que nos diz que Neleu levou os livros de Aristóteles para sua cidade natal, Cépis,

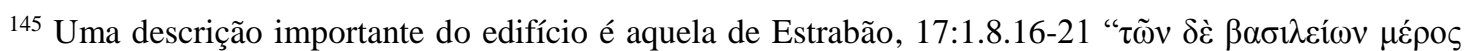

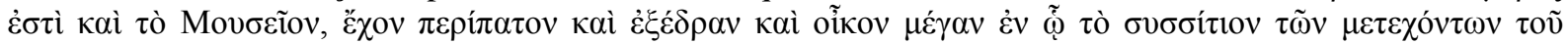

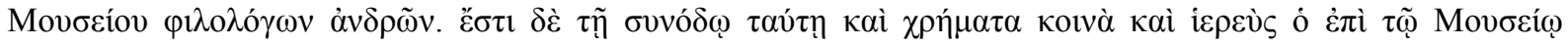

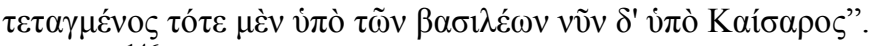

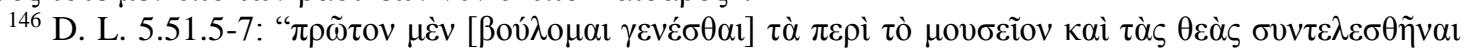

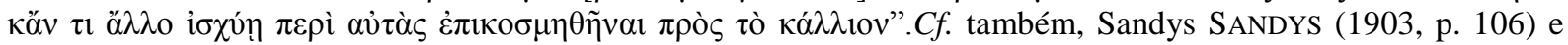
PFEIFFER (1976, p. 97).

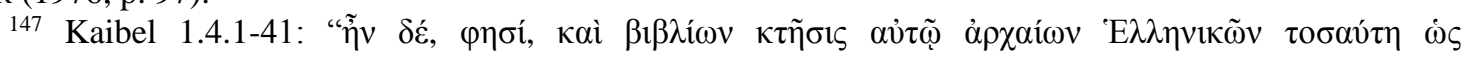

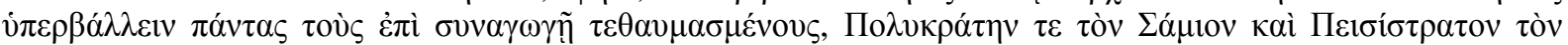

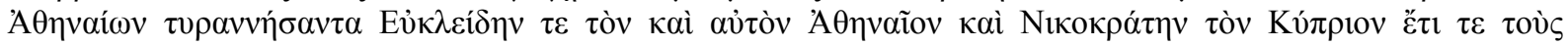

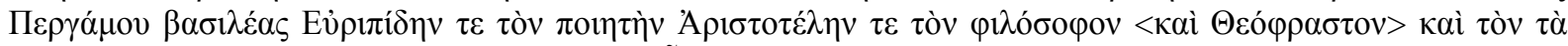

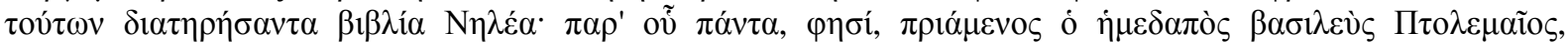

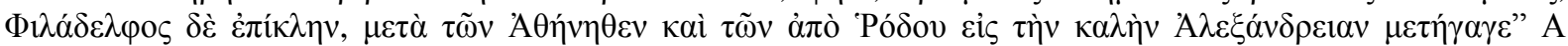
epítome é falsamente atribuída a Estácio (séc. 12 d.C.) cf. DICKEY (2007, p. 23). "Teofrasto" é um suppl. de Wilamowitz, como se faz necessário em virtude da passagem em Estrabão 13.1.54.1-5, v. sub.

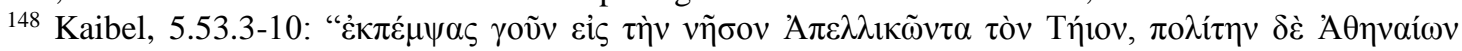

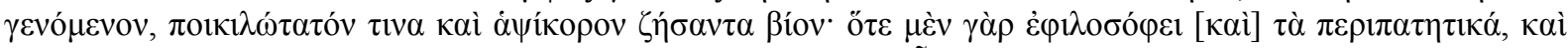

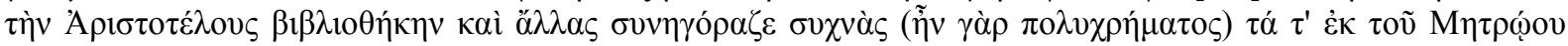

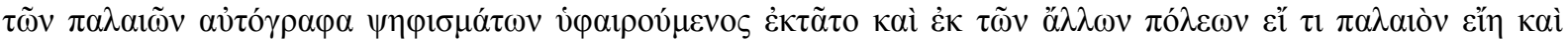

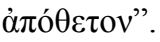


onde eles teriam sido passados como herança para seus descendentes que, por serem pessoas

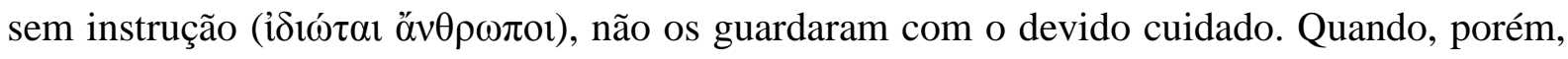
os reis da dinastia dos Atalidas, a quem Cépis estava subjugada, tentaram se apoderar do legado para o acervo da biblioteca de Pérgamo, a família de Neleu enterrou os manuscritos a fim de escondê-los, mas, devido ao clima úmido da Mísia e das péssimas condições de armazenamento, os papiros acabaram sendo terrivelmente consumidos pelo mofo, danificando áreas extensas do texto. Foi somente várias gerações mais tarde que os descendentes de Neleu teriam concordado em vender os originais para Apelicão que, sendo mais um bibliófilo do que um filólogo, teria produzido cópias dos mesmos, inserindo emendas de sua autoria a fim de recuperar as partes perdidas, com um resultado, porém, catastrófico. Foi da biblioteca deste último, então, que Sula, por sua vez, ao invadir e saquear a cidade no ano 83 a.C. os teria levado embora para Roma ${ }^{149}$. Pelo que se deduz que aqueles livros comprados por Ptolomeu II a que o autor da epítome de Ateneu faz alusão só poderiam ter sido cópias dos originais, que acabaram tendo, apesar disso, um destino mais feliz que seus autógrafos.

É possível, portanto, que os livros de Píndaro, numa forma já previamente editada por Aristóteles, que muito provavelmente deveria ter tido uma coleção das obras do poeta, poderiam ter chegado em Alexandria junto com o espólio do filósofo. Certamente seu mais famoso pupilo, Alexandre o Grande, deve ter entrado em contato com as obras do poeta através de Aristóteles e, a julgar pela sua reação, ao arrasar Tebas, mas deixar intacta apenas a casa do poeta ${ }^{150}$, sua admiração pelo mesmo e a sua intimidade com a sua obra deveriam ser enormes.

Não há, obviamente, como provar nada disso, mas, tivessem as coisas acontecido dessa maneira, algo que, como pudemos ver também não é totalmente implausível, teria sido, de fato, uma bela história e belas histórias sempre são, de alguma maneira, verdadeiras. 
APÊNDICES 


\section{Apêndice 1}

\section{TABELA SiNÓPTICA dOS EPINÍ́CIOS PINDÁRICOS}

O asterisco (*) ao lado do número da ode indica que a mesma é monóstrofa.

\begin{tabular}{|c|c|c|c|c|c|c|}
\hline ODES & \# & DATA & $\begin{array}{c}\text { Posição } \\
\text { CRONOLÓGICA }{ }^{1}\end{array}$ & VENCEDOR & Cidade & Prova \\
\hline \multirow{13}{*}{$\sum_{0}^{\infty}$} & 1 & 476 & $12^{\mathrm{a}}$ & Hierão & Siracusa & cavalo \\
\hline & 2 & 476 & $13^{\mathrm{a}}$ & Terão & Ácragas & quadriga \\
\hline & 3 & 476 & $13^{\mathrm{a}}$ & Terão & Ácragas & idem \\
\hline & 4 e 5 & 460 ou 456 & $37^{\mathrm{a}}$ & Psaumias & Camarina & carroça de mulas \\
\hline & 6 & 468 & $27^{a}$ & Agésias & Siracusa & idem \\
\hline & 7 & 464 & $31^{\mathrm{a}}$ & Diágoras & Rodes & boxe \\
\hline & 8 & 460 & $34^{\mathrm{a}}$ & Alcmédão & Egina & luta \\
\hline & 9 & 466 & $28^{\mathrm{a}}$ & Efarmosto & Opúntia & idem \\
\hline & 10 & $474 ?$ & $18^{\mathrm{a}}$ & Agesídamo & $\begin{array}{c}\text { Lócria } \\
\text { Ocidental }\end{array}$ & pugilismo infantil \\
\hline & 11 & 476 & $14^{\mathrm{a}}$ & Agesídamo & idem & idem \\
\hline & 12 & 466 & $29^{a}$ & Ergoteles & Himera & dólichos \\
\hline & 13 & 464 & $32^{\mathrm{a}}$ & Xenofonte & Corinto & pentatlo e estádio \\
\hline & $14 *$ & $488 ?$ & $4^{a}$ & Asópico & Orcomeno & estádio \\
\hline \multirow{11}{*}{$\sum_{=}^{\infty}$} & 1 & 470 & $25^{\mathrm{a}}$ & Hierão & Etna & carruagem \\
\hline & 2 & 475 & $16^{\mathrm{a}}$ & Hierão & Siracusa & idem \\
\hline & 3 & $474 ?$ & $19^{a}$ & Hierão & Siracusa & idem \\
\hline & 4 & 462 & $33^{\mathrm{a}}$ & Arcesilau & Cirene & idem \\
\hline & 5 & $462 / 1$ & $3^{a}$ & Arcesilau & Cirene & idem \\
\hline & $6^{*}$ & 490 & $2^{a}$ & Xenócrates & Ágragas & idem \\
\hline & 7 & 486 & $5^{\mathrm{a}}$ & Megaclés & Atenas & triga \\
\hline & 8 & 446 & $39^{a}$ & Aristomenes & Egina & luta \\
\hline & 9 & 474 & $20^{\mathrm{a}}$ & Telesícrates & Cirene & corrida de hoplitas \\
\hline & 10 & 498 & $1^{\mathrm{a}}$ & Hipocleide & Tessália & $\begin{array}{c}\text { corrida de diaulo } \\
\text { juvenil }\end{array}$ \\
\hline & 11 & 474 & $21^{a}$ & Trasidaio & Tebas & Estádio juvenil \\
\hline
\end{tabular}

1 et se $^{1}$ A posição cronológica é apenas uma aproximação. 


\begin{tabular}{|c|c|c|c|c|c|c|}
\hline & $12 *$ & 490 & $3^{\mathrm{a}}$ & Midas & Ácragas & aulética \\
\hline \multirow{11}{*}{ 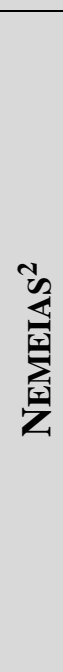 } & 1 & 476 & $15^{\mathrm{a}}$ & Crômio & Siracusa/Etna & corrida de cavalos \\
\hline & $2 *$ & 485 & $6^{\mathrm{a}}$ & Timodemo & Acárnia & pancrácio \\
\hline & 3 & 475 & $17^{\mathrm{a}}$ & Aristocleide & Egina & idem \\
\hline & $4^{*}$ & 473 & $24^{\mathrm{a}}$ & Timasarco & Egina & luta \\
\hline & 5 & 483 & $8^{\mathrm{a}}$ & Piteas & Egina & pancrácio juvenil \\
\hline & 6 & 465 & $30^{\mathrm{a}}$ & Alcimidas & Egina & pancrácio infantil \\
\hline & 7 & 485 & $7^{\mathrm{a}}$ & Sógenes & Egina & pentatlo infantil \\
\hline & 8 & 459 & $35^{\mathrm{a}}$ & Dêinias & Egina & corrida de diaulo \\
\hline & 9* & 474 & $22^{\mathrm{a}}$ & Crômio & Etna & quadriga \\
\hline & 10 & 444 & $41^{\mathrm{a}}$ & Teaio & Argos & luta \\
\hline & $11^{3}$ & 446 & $40^{\mathrm{a}}$ & Aristágoras & Tênedos & pritania \\
\hline \multirow{9}{*}{$\sum_{\substack{\infty \\
\infty}}^{\infty}$} & 1 & 458 & $36^{\mathrm{a}}$ & Heródoto & Tebas & quadriga \\
\hline & 2 & 470 & $26^{\mathrm{a}}$ & Xenócrates & Ácragas & quadriga \\
\hline & \multirow{2}{*}{3 e 4} & \multirow{2}{*}{$474 / 3$} & $23^{\mathrm{a}}$ & \multirow{2}{*}{ Melisso } & \multirow{2}{*}{ Tebas } & corrida de cavalos e \\
\hline & & & & & & pancrácio \\
\hline & 5 & 478 & $10^{\mathrm{a}}$ & Filacida & Egina & pancrácio \\
\hline & 6 & 480 & $9^{a}$ & Filácida & Egina & pancrácio infantil \\
\hline & 7 & 454 & $38^{\mathrm{a}}$ & Estrpesíades & Tebas & pancrácio \\
\hline & $8^{*}$ & 478 & $11^{\mathrm{a}}$ & Cleandro & Egina & pancrácio infantil \\
\hline & 9 & - & & vacuit & Egina & vacuit \\
\hline
\end{tabular}

2 Todas as datas das Nemeias são incertas.

${ }^{3}$ Não se trata de um epinício, mas de um hino de inauguração do laudandus em sua inauguração como pritaneu.

${ }^{4}$ Todas as datas das Ístmicas são incertas, com exceção das odes 6 e 8. Da Ístmica 9 nem a data nem o vencedor ou a prova são conhecidos. 


\section{Apêndice 2}

\section{TABELA SINÓPTICA DAS OCORRÊNCIAS DE PALAVRAS EM -KRM- EM PÍNDARO E BAQUÍLIDES}

\begin{tabular}{|c|c|c|c|c|}
\hline AUTOR & $\begin{array}{c}\text { REF. } \\
\text { \# }\end{array}$ & LOCAL & CONTEXTO & OBSERVAÇÕES \\
\hline \multirow{12}{*}{ 을 } & \multicolumn{4}{|c|}{$\kappa \tilde{\omega} \mu \mathrm{s}$} \\
\hline & 1 & O. $4.8-10$ & 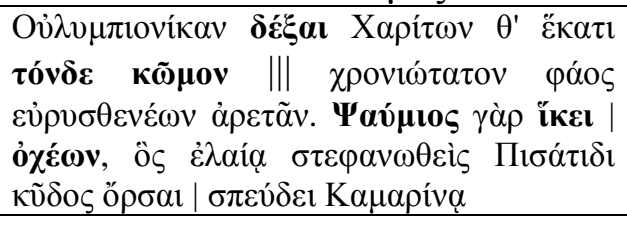 & dêictico+ $\delta \varepsilon ́ \xi \alpha l-M o t i v$ \\
\hline & 2 & O. $6.16-8$ & 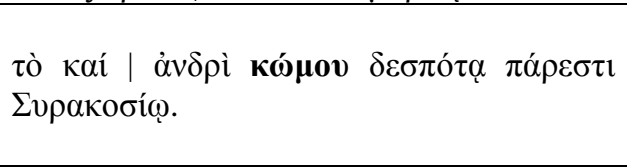 & 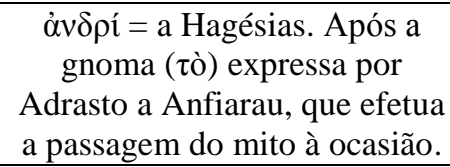 \\
\hline & 3 & O. $6.98-100$ & 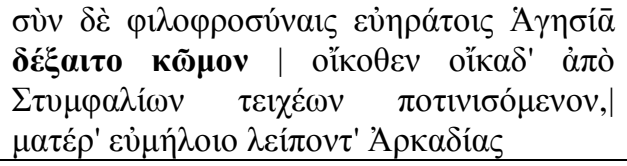 & 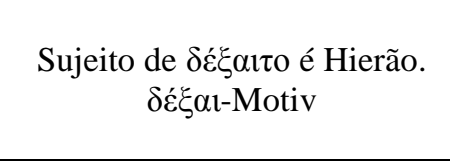 \\
\hline & 4 & O. $8.8-10$ & 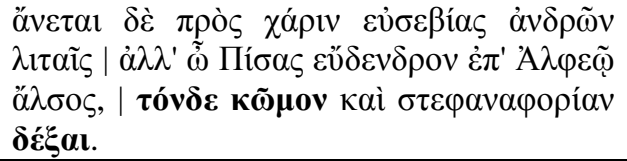 & 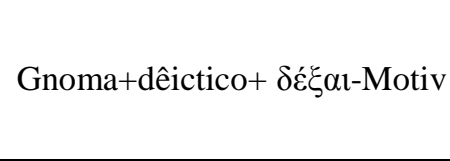 \\
\hline & 5 & O. $14.13-20$ & 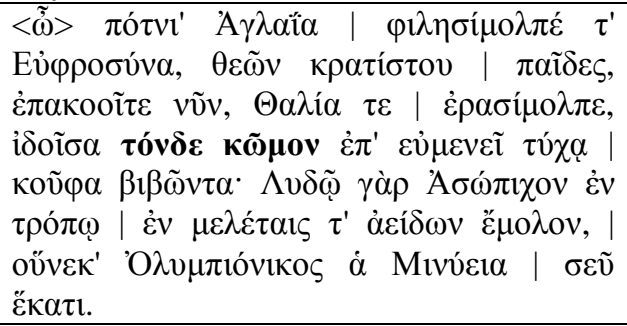 & dêictico+ $\delta \varepsilon ́ \xi \alpha l-M o t i v$ \\
\hline & 6 & P. 3.73-4 & 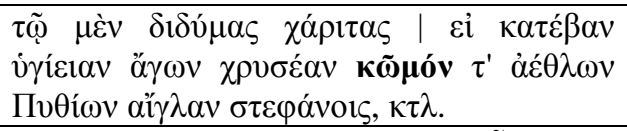 & $\tau \tilde{\varphi}=$ Hierão \\
\hline & 7 & P. 5.20-23 & 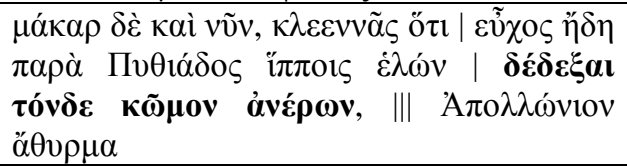 & 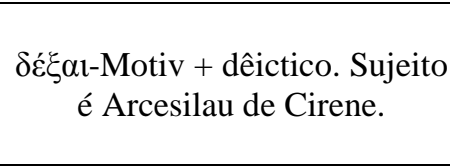 \\
\hline & 8 & P. 5.98-103 & 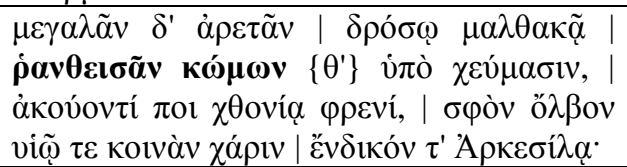 & 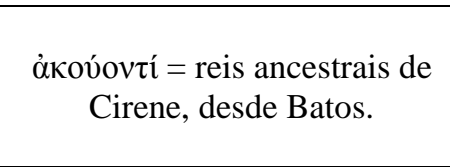 \\
\hline & 9 & P. $8.18-20$ & 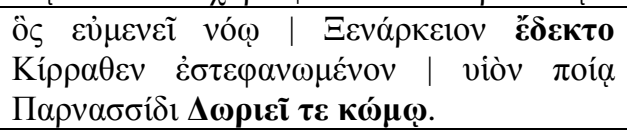 & 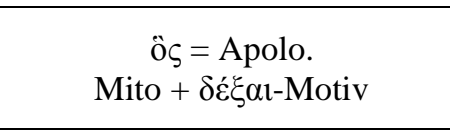 \\
\hline & 10 & P. 8.67-71 & 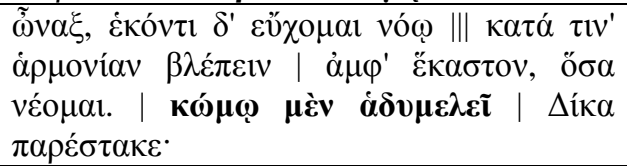 & $\tilde{\omega} v \alpha \xi=$ Apolo. \\
\hline & 11 & N. 3.1-5 & 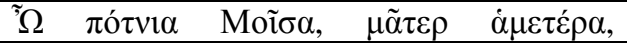 & \\
\hline
\end{tabular}




\begin{tabular}{|c|c|c|c|c|}
\hline & & & 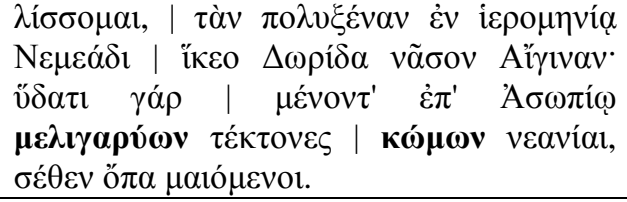 & \\
\hline & 12 & N. 9.48-53 & 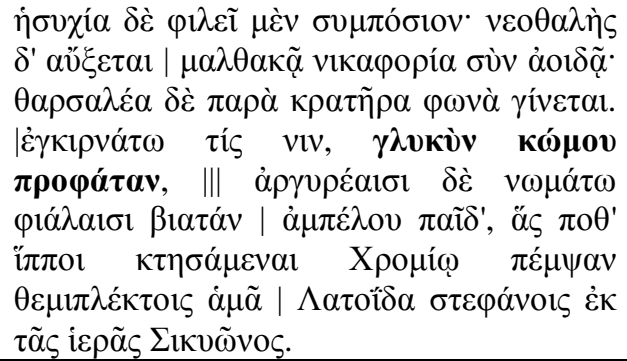 & $\begin{array}{c}\text { Após relatar os feitos de } \\
\text { Crômio e os comparar aos de } \\
\text { Heitor. }\end{array}$ \\
\hline & 13 & I. $2.25-32$ & 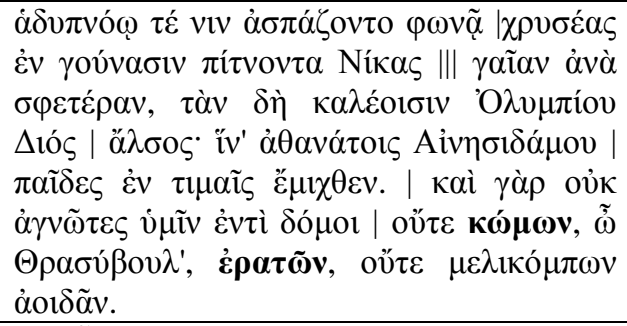 & $\begin{array}{c}v i v=\text { Nicômacos, auriga de } \\
\text { Xenócrates. Trasíbulo seria seu } \\
\text { filho. }\end{array}$ \\
\hline & 14 & I. $6.55-59$ & 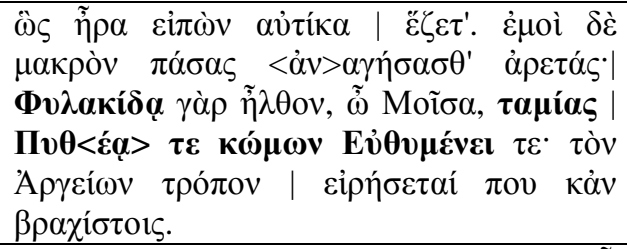 & 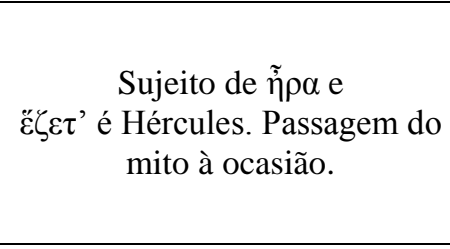 \\
\hline & 15 & I. $8.1-8$ & 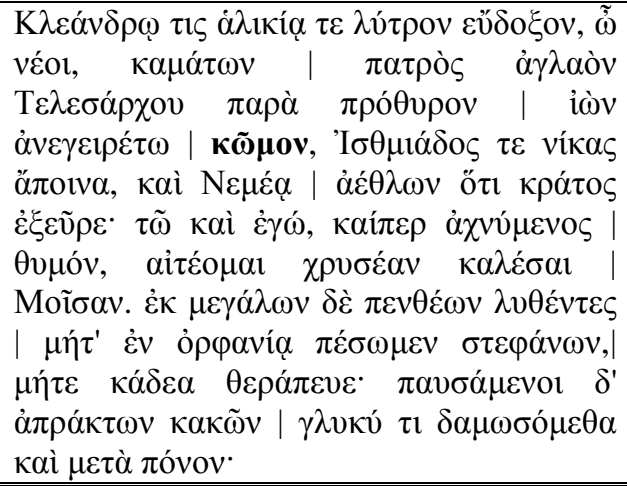 & \\
\hline \multirow{4}{*}{ 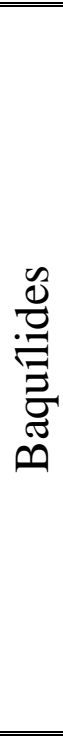 } & 1 & $9.102-4$ & 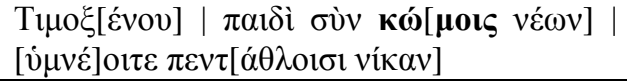 & \\
\hline & 2 & $11.9-12$ & 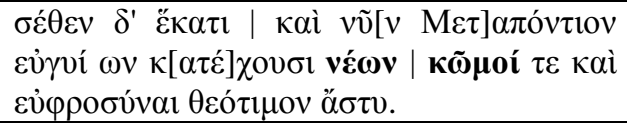 & $\begin{array}{c}\text { Passagem da gnome para a } \\
\text { ocasiçao. }\end{array}$ \\
\hline & 3 & $13.33-43$ & 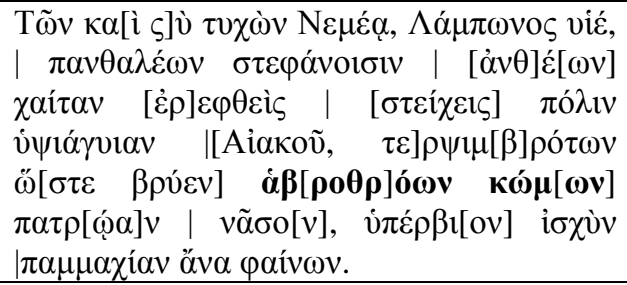 & Passagem do mito à ocasião. \\
\hline & 4 & Peã 1.64-8 & 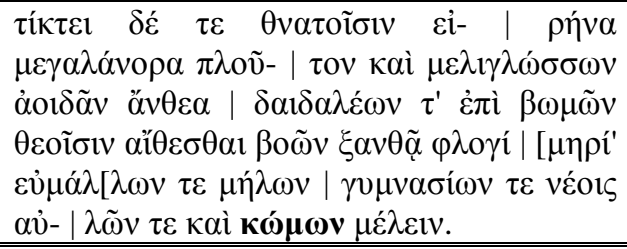 & 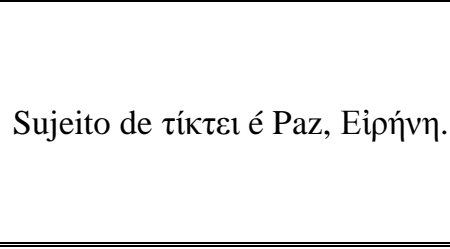 \\
\hline \multicolumn{4}{|r|}{ 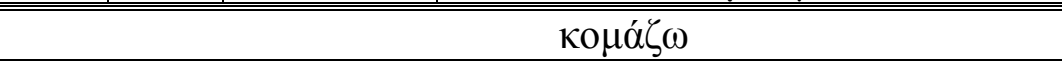 } & \\
\hline
\end{tabular}




\begin{tabular}{|c|c|c|c|c|}
\hline \multirow{9}{*}{ 을 } & 1 & O. $9.1-5$ & 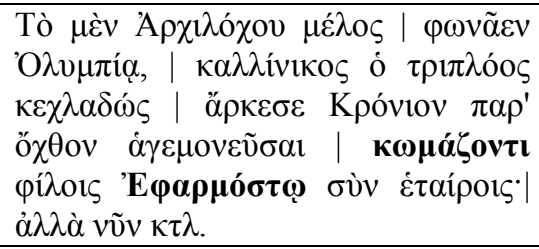 & \\
\hline & 2 & O. 11.11-19 & 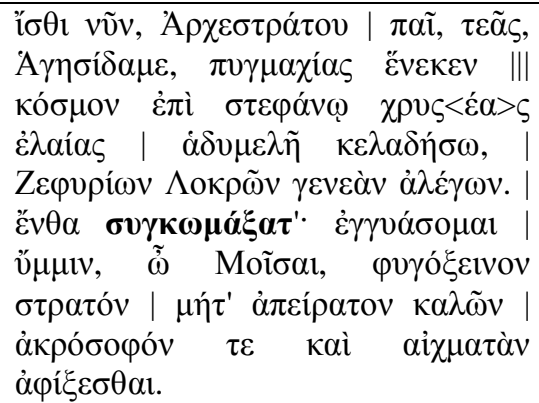 & Transição da gnoma para a ocasião \\
\hline & 3 & P. 4.1-4 & 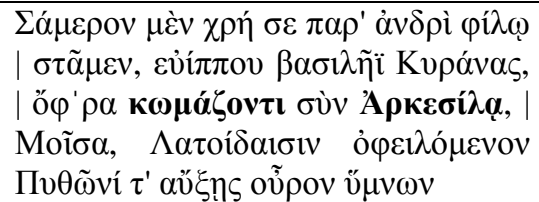 & \\
\hline & 4 & P. 9.87-90 & 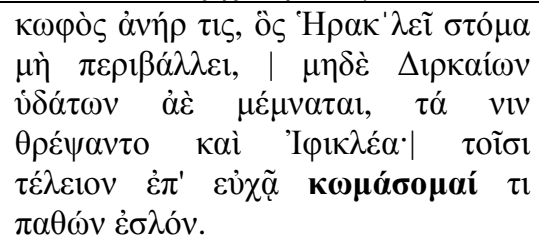 & Passagem do mito à ocasião. \\
\hline & 5 & N. 2. 23-4 & 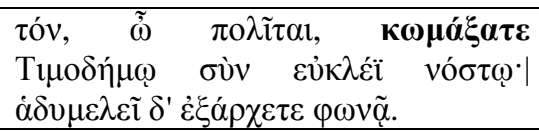 & $\tau o ́ v=$ Zeus. \\
\hline & 6 & N. 9. 1-5 & 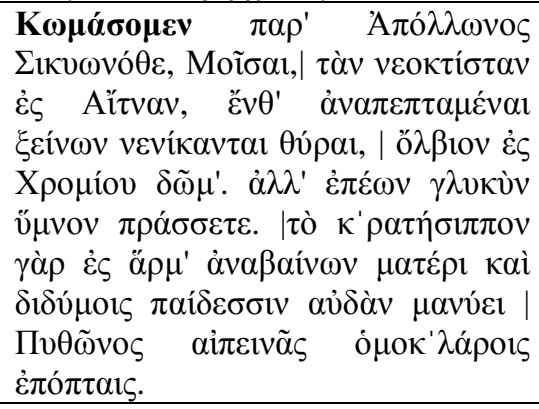 & \\
\hline & 7 & N. $10.31-6$ & 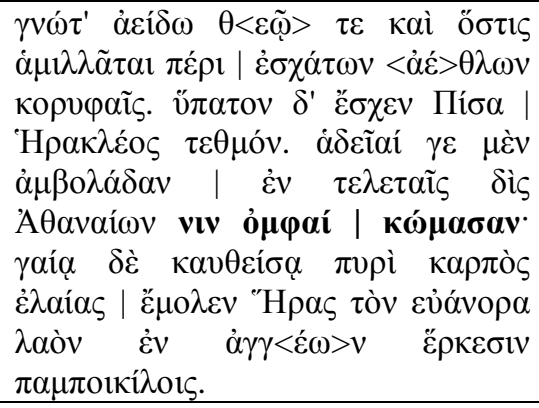 & $v \imath v=$ Teaio \\
\hline & 8 & N. 11-24-9 & 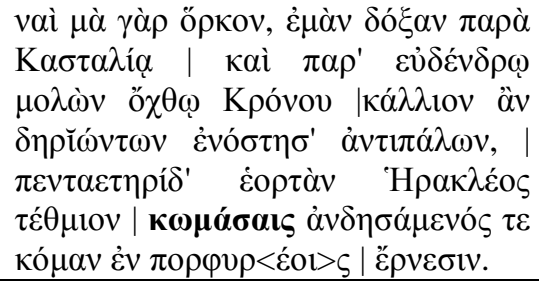 & Precedendo a gnome e o mito. \\
\hline & 9 & I. $3.7-8$ & 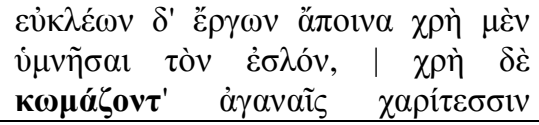 & Gnoma introdutória à ocasião. \\
\hline
\end{tabular}




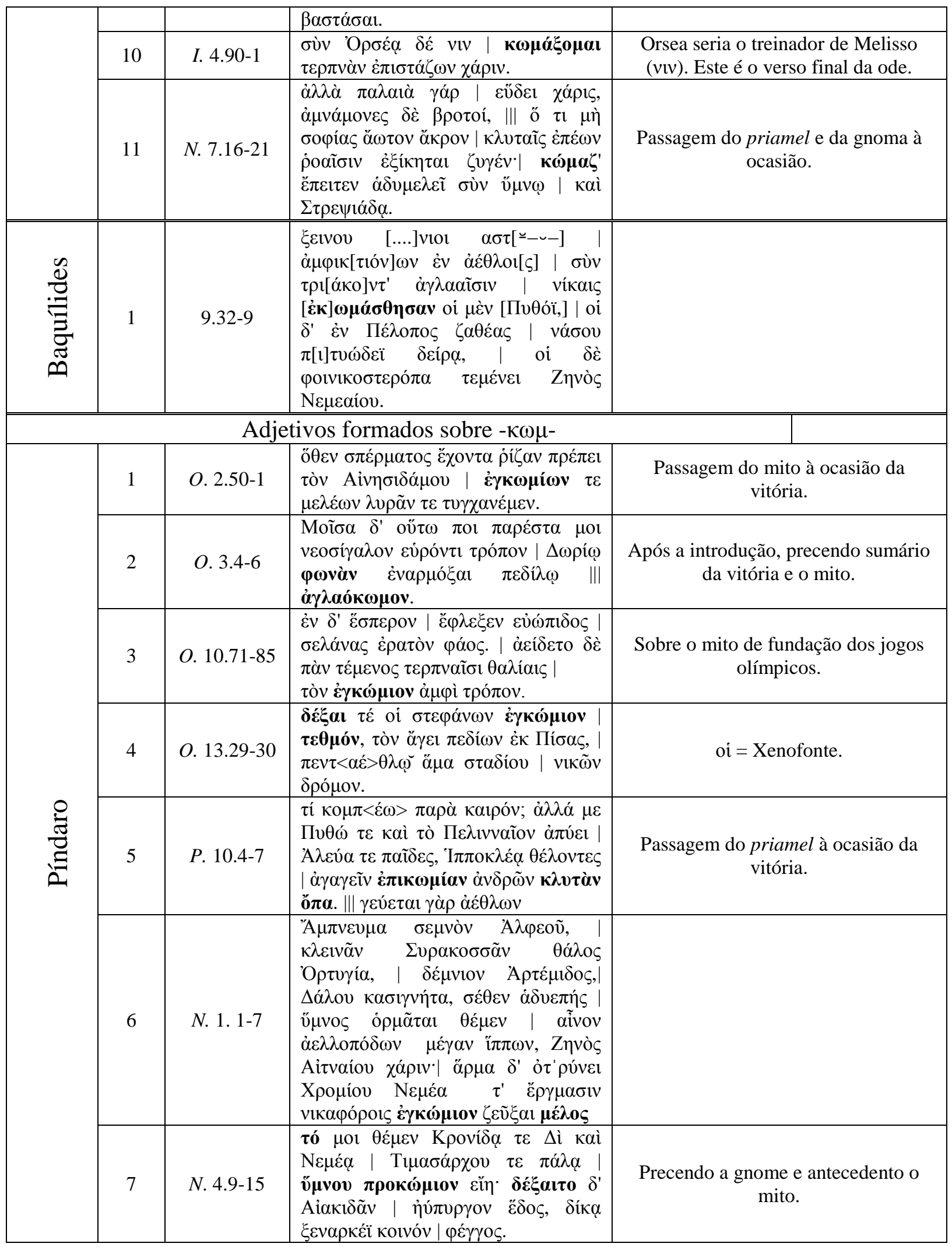




\begin{tabular}{|c|c|c|c|c|}
\hline & 8 & N. 6. 28-34 & 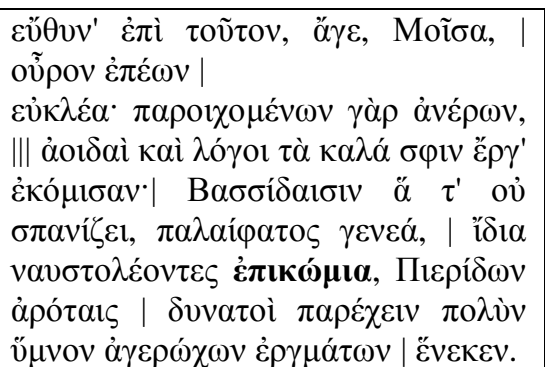 & \\
\hline & 9 & N. 8. & 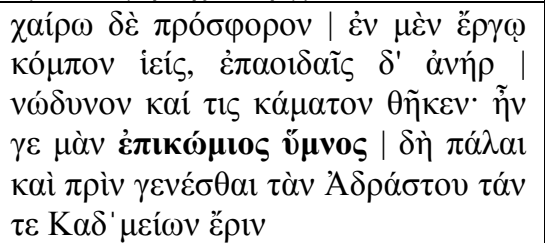 & \\
\hline
\end{tabular}




\section{Apêndice 3}

\section{GLOSSÁRIO DE TERMOS TÉCNICOS}

ENTRINCHEIRAMENTO: É processo de formação de unidades linguísticas complexas por meio de outras mais simples. A princípio, as duas unidades podem ser sentidas como independentes, mas, devido à colocação constante entre ambas pode haver uma associação definitiva. Um exemplo clássico seria a formação dos advérbios no português a partir do abaltivo latino mentē: assim a colocação constante no latim tardio e vulgar de adjetivos no abaltivo singular qualificando mentē, como em placidā mentēe, "com uma mente tranquila", logo iria levar ao entrincheiramente das suas unidades lexicais [PLACIDA/placida] e [MENTE/mente] em [PLACIDA/placida]- [MENTE/mente $]^{1}$, de tal forma que se pode chegar a uma esquematização por meio da qual novos advérbios podem ser formados em português de acordo com o esquema [X/ADJETIVO]-[DE FORMA/mente].

ESPAÇO DISCURSIVO CORRENTE: na definição de LANGACKER (2008, p. 281) é o construto definido como tudo aquilo que se presume ser compartilhado pelo falante e o ouvinte como base para um discurso em um determinado momento. O EDC é estável e pressupõe um imenso conhecimento como pano-de-fundo, mas à medida que o discurso prossegue, ele é continuamente atualizado. Em qualquer momento, o EDC fornece a base para interpretar a próxima sentença, que modifica tanto o seu conteúdo quanto o foco.

ESQUEMATIZAÇÃo: A esquematização é o processo de extrair tudo que é comum ou inerente em múltiplas experiências a fim de se chegar a um conceito com um alto nível de abstração LANGACKER (2008, p. 17). A esquematização implica na formação de categorias. Por exemplo, "veículo" é mais esquemático que "automóvel”, que, por sua vez, é mais esquemático que "sedã preto", que, novamente, é mais esquemático do que "Corola preto".

ESQUEMA IMAGÉTICO (EI): Esquemas imagéticos são conceitualizações abstratas construídas a partir de nossa experiência corporal com o mundo. Eles podem ser muito simples, mas, por

\footnotetext{
${ }^{1}$ Como já explicado na Introdução, os nomes em versalete denotam o conceito associado ao item lexial, do qual são separados por uma barra.
} 
meio do processo de entrincheiramento, tornarem-se bastante complexos. Um exemplo relativamente fácil de entender é o EI “CIMA-BAIXO”, a partir do qual tendemos a associar tudo é BOM com CIMA e tudo o que é RUIM com BAIXO: "Hoje ela está se sentindo para cima", "Pare de deixa-la para baixo".

INTERPRETAÇÃO NEGATIVA (minus interpretation): a interpretação negativa do termo nãomarcado é aquela que exclui o termo marcado. Dado o par "homem-mulher", um exemplo de interpretação negativa do termo não-marcado "homem" (i.e. "homem" = “ mulher") seria como empregado na frase "os homens, não as mulheres, são seres racionais", onde o par é contextualizado em um frame que salienta o sexo como característica distintiva. Ver marcação.

INTERPRETAÇÃO POSITIVA (plus interpretation): a interpretação negativa ocorre quando a figura é trazida à frente do pano-de-fundo (o termo não-marcado) por meio do perfilhamento de uma característica específica. No par "homem-mulher" a interpretação positiva de homem (= ser humano do sexo feminino) fica evidente na frase: “o aborto é um direito essencial garantido a todos os homens".

INTERPRETAÇÃO ZERO (zero interpretation): a interpretação zero do termo não-marcado é aquela em que estão implícitos tanto o pano-de-fundo quanto a figura, por meio da abstração de características salientes. É a interpretação mais esquemática e inclusiva. No par "homemmulher", a interpretação zero do termo não-marcado, "homem", na acepção de "ser humano", inclui automaticamente o termo marcado "mulher", como, por exemplo, na frase “os homens são seres racionais”. Ver marcação.

MARCAÇão: A ideia de que a marcação seria uma superestrutura avaliativa, de natureza binária e comum à linguagem humana, foi proposta por Nikolai Trubtzkoy e Roman Jakobson na década de 70. Basicamente ela postula a existência de uma hierarquização implícita entre conceitos linguísticos, de modo a criar uma polarização aparente entre eles que se estrutura em uma hierarquia. "Marcação" então refere-se ao relacionamento entre os dois polos de uma oposição aparente, dado um determinado ponto de vantagem. A designação termo marcado e não-marcado refere-se à avaliação dos polos dessa oposição com base na presença ou ausência de uma característica definidora $x$ : o termo não-marcado é sempre sentido como uma supercategoria e, portanto, mais inclusiva e esquemática (o pano-de-fundo 
ou o conjunto), ao passo que o termo marcado toma a forma de uma subcategoria (ou, ainda, a saliência, figura, ponto focal ou subconjunto do termo não-marcado). Um exemplo prático é dado pelos termos "homem" e "mulher" em português, no qual "homem" é o termo nãomarcado e, portanto, mais inclusivo, enquanto "mulher" é o termo marcado, mais saliente. Por isso podemos dizer, de uma maneira geral, esquemática, que "os homens estão destruindo o meio-ambiente", sem implicar com isso que apenas os seres humanos do sexo masculino sejam os responsáveis pelo crime, o que não aconteceria caso substituíssemos aquele substantivo por "mulheres". O termo "homem", não-marcado, inclui o termo "mulher" marcado, quando se abstrai a característica sexo. Do ponto de vista da linguística cognitiva, relevante para a discussão dessa tese, a marcação pode ser melhor entendida como o resultado de efeitos prototípico que surgem a partir do processo de categorização típico da linguagem humana, que distribui elementos de uma mesma categoria a partir de uma organização radial na qual os termos mais prototípicos tendem a se concentrar no centro, ao passo que os menos prototípicos são relegados à periferia. A partir dessa consideração (e por razões de ordem extralinguística) a categoria "ser humano" tem como o seu representante mais prototípico aquele do sexo masculino, ou seja, "homem" e menos prototípico, aquele do sexo feminino, ou seja, "mulher". Pode-se dizer que "homem", na categoria "ser humano", ocupa o nível básico de especificidade L. FERRARI (2011, p. 39). Para mais detalhes, cf. Battistella BATTISTELla (1990, 1996), Janda JANDA (1995), Waugh WAUGH (1982)

modelo cognitivo idealizado (MCI): modelos cognitivos idealizados são gestalts que usam quatro tipos de princípios estruturantes: estrutura proposicional, esquemas imagéticos, mapeamentos metafóricos e metonímicos. Um exemplo de MCI é aquele de semana, entendido como um todo organizado em sete partes distintas, chamados dias. Esse é um modelo idealizado porque não corresponde a nenhum fenômeno natural objetivo e pode variar de uma cultura para outra. Mais detalhes em Lakoff LAKOFF e JOHNSON (1987, p. 68 et seq.). termo marcado e não marcado: ver marcação.

MeSCLAGEM: também conhecido como "integração conceitual”, é o processo por meio do qual dois espaços mentais podem ser mesclados por meio de uma rede interativa, dando origem a um espaço mesclado. A mesclagem é um dos principais processos por trás da emergência de conceitualizações metafóricas. Por exemplo, a expressão "vírus de computador" origina-se da mesclagem de dois espaços mentais distintos, o BIOLÓGICO, no qual vírus invadem organismos e injetam seu DNA ou RNA nas células a fim de se reproduzirem, e o da INFORMÁTICA, onde programas ou pedaços de programa podem invadir 
um determinado sistema para adicionar suas informações a esse sistema e , assim, tomar conta dele, gerando cópias de si mesmo. Há um mapeamento entre as características do espaço BIOLÓGICO e do espaço INFORMÁTICA em um espaço mesclado que torna inteligível a expressão "vírus de computador" a partir daqueles dois domínios. 


\section{REFERÊNCIAS BIBLIOGRÁFICAS}

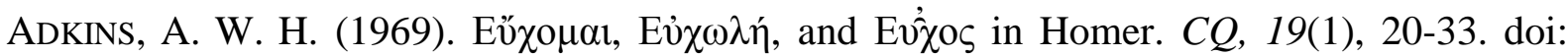
$10.2307 / 637483$

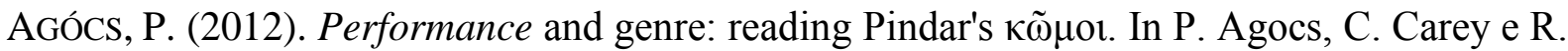
Rawles (Eds.), Reading the Victory Ode (pp. 191-223). Cambridge: Cambridge University Press.

Agócs, P., Carey, C., e Rawles, R. (Eds.). (2012). Reading the Victory Ode. Cambridge: Cambridge University Press.

Araúuo, A. A. D. (2005). $7^{a}$ Ode Olímpica de Píndaro: Tradução e Notas. (Mestrado em Letras Clássicas), Universidade de São Paulo, São Paulo. Disponível em http://www.teses.usp.br/teses/disponiveis/8/8143/tde-23082007-121817/es.php

Assunção, T. R. (1999). XIV Olímpica de Píndaro: tradução e comentário. In A. O. D. Lopes, C. F. Lage e O. Flores (Eds.), Scripta Classica - História, Literatura e Filosofia na Antiguidade (pp. 47-54). Belo Horizonte: UFMG.

Athanasaki, L. (2009). Narratology, Deixis, and the Performance of Choral Lyric. On Pindar's First Pythian Ode. In J. Grethlein e A. Rengakos (Eds.), Narratology and Interpretation: The Content of Narrative Form in Ancient Literature. Berlin/New York: Walter de Gruyter GmbH \& Company.

Athanassaki, L. (2004). Deixis, Performance, and Poetics in Pindar's First Olympian Ode. Arethusa, 37, 317-41.

Austin, C., e Olson, S. D. (Eds.). (2004). Aristophanes Thesmophoriazusae. Oxford: Oxford University Press.

Austin, J. L., e Urmson, J. O. (1975). How to Do Things With Words. [s.1.]: Harvard University Press.

BACON, H. H. (1994). The Chorus in Greek Life and Drama. Arion, 3(1), 6-24. doi: $10.2307 / 20163562$

BAKKer, E. J. (1997). Poetry in Speech: Orality and Homeric Discourse. Ithaca/ London: Cornell University Press.

--------. (2010). A Companion to the Ancient Greek Language. London: Wiley-Blackwell.

Bara, B. G. (2010). Cognitive Pragmatics: The Mental Processes of Communication. Massachusetts: MIT Press. 
Battistella, E. L. (1990). Markedness: The Evaluative Superstructure of Language. New York: State University of New York Press.

(1996). The Logic of Markedness. Oxford: Oxford University Press.

Bauman, R., e BRiggs, C. L. (1990). Poetics and performance as critical perspectives on language and social life. Annu. Rev. Antropol., 19, 59-88. doi: 00846570

Bernardini, P. (1997). Olimpia e i giochi olimpici: le fonti letterarie tra lode e critica. Nikephoros, 10, 179-90.

Bernardini, P. A. (1979). La dike della lira e la dike dell'atleta (Pindaro, "P." 1, 1-2; O. 9, 98). QUCC, 2, 79-85.

BING, P., e BRUSS, J. S. (Eds.). (2007). Brill's companion to Hellenistic epigram. Leiden: Brill.

Blum, R. (2011). Kallimachos: The Alexandrian Library and the Origins of Bibliography. Wisconsin: University of Wisconsin Press.

BoeckH, A. (1809). Ueber die Versmasse des Pindaros. Berlin: Realschulbuchhandlung. (1811). De Metris Pindari Libri Tres. Leipzig: Ionn. Aug. Gottlob Weigel.

(Ed.). (1821). Pindari epiniciorum interpretatio latina cum commentario perpetuo, fragmenta et indices (Vol. 2). Hildesheim: Georg Olms.

BoedeKer, S., e Sider, D. (Eds.). (2001). The New Simonides : Contexts of Praise and Desire: Contexts of Praise and Desire. Oxford/ New York: Oxford University Press.

Bossler, C. (1862). De Preaepositionum Usu apud Pindarum. Giessen, Darmstadt.

BowIE, A. M. (1997). Thinking with Drinking: Wine and the Symposium in Aristophanes. JHS, 117, 1-21. doi: 10.2307/632547

Bowra, C. M. (1964). Pindar. Oxford: Oxford University Press.

Braswell, B. K. (1988). A Commentary on the Fourth Pythian Ode of Pindar. Berlin; New York: De Gruyter.

Bremer, J. M. (1990). Pindar's Paradoxical غ̇ $\gamma \omega ́$ and a recent controversy about the performance of his epinicia. In S. R. Slings (Ed.), The poet's I in archaic Greek lyrics (pp. 41-57). Amsterdam: VU University Press.

Brillante, C. (1992). La musica e il canto nella "Pitica" I di Pindaro. Quaderni Urbinati di Cultura Classica, 41(2), 7-21. doi: 10.2307/20547140

Brose, R. D. (2007). Os fragmentos atenienses de Simônides: um estudo das fontes epigráficas anteriores a 480 a.C. (Mestrado em Letras Clássicas /Dissertação), 
Universidade de São Paulo, São Paulo. Disponível em http://www.teses.usp.br/teses/disponiveis/8/8143/tde-19052008-114517/

(2008). Simônides 22W²: Lamento ou utopia? Calíope, 18(Julho), 84-104.

Brose, R. D., Araújo, A. A. D., e Pompeu, A. M. C. (Eds.). (2013). Oralidade, Escrita e Performance na Antiguidade. Fortaleza: Expressão Gráfica.

BudelmanN, F. (2012). Epinician and the symposium: a comparison with the enkomia. In P. Agocs, C. Carey e R. Rawles (Eds.), Reading the Victory Ode (pp. 173-90). Cambridge: Cambridge University Press.

(Ed.). (2009). The Cambridge Companion to Greek Lyric. New York: Cambridge University Press.

Bundy, E. L. (1954). Hesychia in Pindar. Berkeley.

--------. (1962). Studia Pindarica. Berkeley: University of California, Department of Classics.

BuRnetT, A. (1989). Performing Pindar's Odes. CP, 84(4), 283-93.

Burton, R. W. (1962). Pindar's Pythian Odes. Oxford: Oxford University Press.

Calame, C. (1999). The Poetics of Eros in Ancient Greece (J. Lloyd, Trans.). Princeton: Princeton University Press.

(2001). Choruses of Young Women in Ancient Greece: Their Morphology, Religious Role, and Social Functions (D. Collins e J. Orion, Trans.). Boston: Rowman \& Littlefield Pub Incorporated.

(2011). Enunciative fiction and poetic performance. Choral voices in Bacchylides' Epinicians. In L. Athanasaki e E. Bowie (Eds.), Archaic and Classical Choral Song: Performance, Politics and Dissemination (pp. 115-38). Berlin/ Bostin: De Gruyter.

CAMPBell, D. A. (Ed.). (1988). Greek lyric: Anacreon, Anacreontea, choral lyric from Olympus to Alcman. Massachusetts: Harvard University Press.

CARey, C. (1981). A commentary on five odes of Pindar: Pythian 2, Pythian 9, Nemean 1, Nemean 7, Isthmian 8. [s.1.]: Arno Press. (1989). The Performance of the Victory Ode. AJP, 110(4), 545-65.

(1991). The Victory Ode in Performance: The Case for the Chorus. CP, 86(3), 192200.

(2007). Pindar, Place and Performance. In S. Hornblower e C. Morgan (Eds.), Pindar's Poetry, Patrons and Festivals: From Archaic Greece to the Roman Empire (pp. 199-210). Oxford: Oxford University Press. 
CÀssola, F. (Ed.). (2006). Inni Omerici. Italy: Fondazione Lorenzo Valla e Arnaldo Mondadori.

Chomsky, N. (2002). Syntactic Structures. Berlin: Walter De Gruyter Incorporated.

Christensen, P. (2007). Olympic victor lists and ancient Greek history. Cambridge: Cambridge University Press.

Cingano, E. (2003). Entre skolion et enkomion: réflexions sur le "genre" et la performance de la lyrique chorale grecque. In J. J. J. Lechant (Ed.), Colloque: La Poésie grecque antique (pp. 17-45). Paris.

Clarke, M. (2010). Semantics and Vocabulary. In E. J. Bakker (Ed.), A Companion to the Ancient Greek Language (pp. 120-33). London: Wiley-Blackwell.

Clay, J. S. (1999). Pindar's Sympotic "Epinicia". QUCC, 62(2), 25-34. doi: $10.2307 / 20546585$

Clay, J. S. (1999). Pindar's Sympotic "Epinicia". Quaderni Urbinati di Cultura Classica, 62(2), 25-34.

CorrêA, P. D. C. (2008). Hamonia: mito e música na Grécia antiga (2 ${ }^{\mathrm{a}}$ ed.). São Paulo: Humanitas.

Croft, W., e Cruse, D. A. (2004). Cognitive Linguistics. Cambridge: Cambridge University Press.

CrotTy, K. (1982). Song and Action: The Victory Odes of Pindar. Baçtimore and London: Johns Hopkins University Press.

CURRIE, B. (2004a). Reperformance Scenarios for Pindar's Odes. In C. J. Mackie (Ed.), Oral Performance and Its Context (pp. 49-70). Leiden: Brill.

--------. (2004b). Reperformance Scenarios for Pindar's Odes. In C. J. Mackie (Ed.), Oral Performance and Its Context (Vol. 248, pp. 49-69): Brill.

(2005). Pindar and the Cult of Heroes. Oxford and New York: Oxford University Press.

. (2011). Epinician choregia: funding a Pindaric chorus. In L. Athanasakē e E. L. Bowie (Eds.), Archaic and Classical Choral Song: Performance, Politics and Dissemination (pp. 269-310). Oxford: Walter de Gruyter.

D'Alessio, G. B. (1994). First-person Problems in Pindar. BICS, 39, 117-39.

(2004). Past Future and Present Past: Temporal Deixis in Greek Archaic Lyric. Arethusa, 37, 267-94.

DAviES, M. (1988). Monody, Choral Lyric, and the Tyranny of the Hand-Book. CQ, 38(1), $52-64$. 
DE Jong, I. J. F. (2001). A Narratological Commentary on the Odyssey. Cambridge: Cambridge University Press.

DicKey, E. (2007). Ancient Greek Scholarship. Oxford: Oxford University Press.

DoRnseIFF. (1921). Pindars Stil. Berlin: Stefan Geibel \& Co.

Dover, K. J. (1989). Greek Homosexuality. Massachusetts: Harvard University Press.

DuARTE, A. D. S. (2005). Aristófanes - Duas Comedias: Lisistrata E as Tesmoforiantes (A. d. S. Duarte, Trans.). São Paulo: Martins Fontes.

DuCHEMIN, J. (1956). Pindare: poète et prophète. Paris: Les Belles Lettres.

DURANTE, M. (1976). Sulla prehistoria della tradizione poetica greca: Risultanze della comparazione indoeuropea. [s.l.]: Edizioni dell'Ateneo.

Easterling, P. E., e Knox, B. M. W. (Eds.). (1989). The Cambridge History of Classical Literature: Volume 1, Greek Literature, Part 1, Early Greek Poetry (Vol. 1). Cambridge: Cambridge University Press.

ECKERMAN, C. (2010). The K $\Omega M O \Sigma$ of Pindar and Bacchyides and the semantics of Celebration. CQ (New Series), 60(02), 302-12. doi: 10.1017/S0009838810000054

ERBSE, H. (1960). Beiträge zur Überlieferung der Iliasscholien. Zetemata(24), 17-77.

Evans, V. (2007). A Glossary of Cognitive Linguistics. Edinburgh: Edinburgh University Press.

FABBro, E. (1992). Sul riuso di carmi d'autore nei simposi attici ("Carm. conv." 8 P. e Alc. fr. 249 V.). QUCC, 41(2), 29-38. doi: 10.2307/20547142

FARNell, L. R. (1961). Critical Commentary to the Works of Pindar. Amsterdam: Hakkert.

Fennell, C. A. M. (Ed.). (1883). Pindar: the nemean and isthmian odes. Cambridge: Cambridge University Press.

------- (Ed.). (1893). Pindar: the olympian and pythian odes. Cambridge: Cambridge University Press.

FERRARI, F. (2012). Representations of cult in epinician poetry. In P. Agócs, C. Carey e R. Rawles (Eds.), Reading the Victory Ode (pp. 158-72). Cambridge: Cambridge University Press.

FERrARI, L. (2011). Introdução à Linguística Cognitiva. São Paulo: Contexto.

Fillmore, C. J. (2006). Frame Semantics. In D. Geeraerts (Ed.), Cognitive Linguistics: basic readings (Vol. 34, pp. 373-97). Berlin: W. de Gruyter. 
Finglass, J. P. (2012). The textual transmission of Sophocles' Dramas. In K. Ormand (Ed.), A Companion to Sophocles (pp. 9-24). England: Wiley-Blackwell.

Finkelberg, M. (1987). Homer's View of the Epic Narrative: Some Formulaic Evidence. CP, 82(2), 135-38. doi: 10.2307/270103

FinkelberG, M. (2011). The Homer Encyclopedia, Three Volume Set. Sussex: WileyBlackwell.

Finnegan, R. (1980). Oral Poetry. Cambridge: Cambridge University Press.

(2008). O que veio primeiro: o texto, a música ou a performance? In C. Matos, E. Travassos e F. T. de Medeiros (Eds.), Palavra cantada: ensaios sobre poesia, música e voz (pp. 15-43). Rio de Janeiro: 7Letras.

Fleming, T. J., e KopfF, E. C. (1992). Colometry of Greek Lyric Verses in Tragic Texts. SIFC 3rd series, 10, 758-70.

Fogelmark, S. (1972). Studies in Pindar: With Particular Reference to Paean VI and Nemean VII. Lund: Glocrup.

FracCARoli, G. (1894). Le Odi di Pindaro. Verona: G. Franchini.

FRÄNKEL, H. (1961). Schrullen in den Scholien zu Pindars Nemeen 7 und Olympien 3. Hermes, 89(4), 385-97. doi: 10.2307/4475179

(1993). Dichtung und Philosophie des frühen Griechentums: eine Geschichte der griechischen Epik, Lyrik und Prosa bis zur Mitte des fünften Jahrhunderts. München: Beck.

Gamkrelidze, T. V., e IVAnov, V. V. (1995). Indo-Eurpean and the Indo-Europeans: A reconstruction and Historical Analysis of a Proto-Language and a Proto-Culture (W. Winter Ed.). Berlin, New York: Mouton de Gruyter.

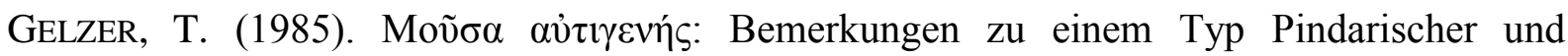
Baccylideischer Epinikien. MH, 42(2), 95-120.

Gentili, B. (1990). Poetry and Its Public in Ancient Greece: From Homer to the Fifth Century (A. T. Cole, Trans.). Baltimore and London: Johns Hopkins University Press.

GEnTILI, B., et al. (Eds.). (1995). Le Pitiche. Roma: Fondazione Lorenzo Valla.

GERBER, D. (1976). Emmendations in Pindar 1513-1972. Amsterdam: A. M. Hakkert.

GERBER, D. E. (1969). A Bibliography of Pindar 1513-1966. Cleveland, Ohio. (1982). Pindar's Olympian One. Toronto: University of Toronto Press.

--------. (1987). Pindar's "Olympian" Four: A Commentary. QUCC, 25(1), 7-24. 
GERBER, D. E. (1991). Pindar and Festive Performance. Resenha de Pyrsos Hymnon: festliche Gegenwart und mythisch-rituelle Tradition als Voraussetzung einer Pindarinterpretation (Isthmie 4, Pythie 5, Olympie 1 und 3) by Eveline Krummen. $C R$, 41(2), 295-97. doi: 10.2307/711367

Geus, K., e ThIERING, M. (Eds.). (2012). Common Sense Geography and Mental Modelling. Berlin: Max Planck Institute für Wissenschaftsgeschichte.

Gildersleeve, B. L. (1886). Pindar: Olympian and Pythian Odes. Cambridge: Cambridge University Press.

GoldhILL, S. (1991). The Poet's Voice: Essays on Poetics and Greek Literature. Cambridge.

Gooding, D. W. (1963). Aristeas and Septuagint Origins: A Review of Recent Studies. Vetus Testamentum, 13(4), 357-79.

Hagel, S. (2009). Ancient Greek Music: A New Technical History. Cambridge: Cambridge University Press.

Hamilton, J. T. (2003). Soliciting Darkness: Pindar, Obscurity, and the Classical Tradition. Massachusetts: Harvard University Press.

Hamilton, R. (1979). Euripides' Cyclopean Symposium. Phoenix, 33(4), 287-92. doi: $10.2307 / 1087186$

HARDER, A. (Ed.). (1985). Euripides' Kresphontes and Archelaos: Introduction, Text, and Commentary. Leiden: E.J. Brill.

HARRIS, W. V. (1991). Ancient Literacy. Massachusetts: Harvard University Press.

Heath, M. (1986). The Origins of Modern Pindaric Criticism. JHS, 106, 85-98.

(1988). Receiving the $\kappa \tilde{\omega} \mu \mathrm{o}$ : The Context and Performance of Epinician. AJP, 109(2), 180-95.

HeAth, M., e LefKowitz, M. (1991). Epinician Performance. CP, 86(3), 173-91.

Herington, J. (1985). Poetry Into Drama: Early Tragedy and the Greek Poetic Tradition. Berkeley/ Los Angeles/ London: University of California Press.

Heubeck, A., West, S., e Hainsworth, J. B. (1998). A Commentary on Homer's Odyssey. Oxford: Clarendon Press.

Heyne, C. G. (Ed.). (1817). Pindari Carmina cum lectionis varietate et adnotationibus (Vol. 1-3). Leipzig: Vogelii.

Hornblower, S. (2012). What happened later to the families of Pindaric patrons - and to epinician poetry? In P. Agócs, C. Carey e R. Rawles (Eds.), Reading the Victory Ode (pp. 93-110). Cambridge: Cambridge University Press. 
Hornblower, S., e Morgan, C. (Eds.). (2007). Pindar's Poetry, Patrons and Festivals: From Archaic Greece to the Roman Empire. Oxford: Oxford University Press.

Hubbard, T. (1987). Pindar and the Aeginetan Chorus: "Nemean" 3.9-13. Phoenix, 41(1), 19. doi: $10.2307 / 1088598$

Hubbard, T. K. (1985). The Pindaric Mind: A Study of Logical Structure in Early Greek Poetry. Leiden: Brill.

. (2003). Homosexuality in Greece and Rome: A Sourcebook of Basic Documents. Berkeley/ Los Angeles: University of California Press.

(2004). The dissemination of Epinician lyric: pan-hellenism, reperformance, written texts. In C. J. Mackie (Ed.), Oral Performance and Its Context (pp. 71-94). Leiden: Brill.

Hummel, P. (1993). La syntaxe de Pindare. Paris: Peeters.

Hunter, R., e Rutherford, I. (Eds.). (2011). Wandering Poets in Ancient Greek Culture: Travel, Locality and Pan-Hellenism. Cambridge: Cambridge University Press.

Hutchinson, G. O. (2001). Greek Lyric Poetry: A Commentary on Selected Larger Pieces : Alcman, Stesichorus, Sappho, Alceaus, Ibycus, Anacreon, Simonides, Bacchylides, Pindar, Sophocles, Euripides. Oxford: Oxford University Press.

Instone, S. (1993). Review: Pyrsos Hymnon. Festliche Gegenwart und mythisch-rituelle Tradition als Voraussetzung einer Pindarinterpretation (Isthmie 4, Pythie 5, Olympie 1 und 3) by Eveline Krummen. Gnomon, 65(6), 483-86. doi: 10.2307/27691424

IRIGOIN, J. (1952). Histoire du Texte de Pindare. Paris: Klincksieck.

ITsumi, K. (2009). Pindaric Metre: The 'Other Half'. Oxford: Oxford UNiversity Press.

JaKOBSOn, R. (1987). Linguistics and Poetics. In K. Pomorska e S. Rudy (Eds.), Language in Literature (pp. 62-94). Michigan: Belknap Press.

JANDA, L. A. (1995). Unpacking Markedness. In E. H. Casad (Ed.), Cognitive Linguistics in the Redwoods: The Expansion of a New Paradigm in Linguistics (pp. 207-30). Berlin: Mouton de Gruyter.

JARCHO, V. N. (1990). Das poetische 'Ich' als Gesellschaftlich-Kommunicatives Symbol in der frühgriechieschen Lyrics. In S. R. Slings (Ed.), The Poet's I in Archaic Greek lyrics (pp. 31-39). Amsterdam: VU University.

Kefalidou, E. (1999). Ceremonies of Athletic Victory in Ancient Greece. Nikephoros, 12, 95-119.

KIRK, G. S., et al. (Eds.). (1993). The Iliad: A Commentary (Vol. v. 3). Cambridge: Cambridge University Press. 
KIRKWOOD, G. M. (1974). Early Greek Monody. Ithaca and London: Cornell University Press.

KIVILO, M. (2010). Early Greek Poets' Lives: The Shaping of the Tradition. Leiden: Brill Academic Pub.

KnOX, B. M. W. (1989). Books and readers in the Greek world The Cambridge History of Classical Literature: Volume 1, Greek Literature, Part 1, Early Greek Poetry (pp. 115). Cambridge: Cambridge University Press. (Reimpressão da: 2003).

KomornickA, A. H. (1976). La Notion du Temps chex Pindare. Eos, 64, 5-15.

KÖVECSES, Z. (2005). Metaphor in Culture: Universality and Variation. Cambridge: Cambridge University Press.

Kratzer, E. (2013). A Hero's Welcome: Homecoming and Transition in the Trachiniae. APA, 143(1), 23-64.

Krummen, E. (1990). Pyrsos Hymnon. Berlin.

Kurke, L. (1991). The Traffic in Praise: Pindar and the Poetics of Social Economy. Nova York e Londres: Ithaca.

--------. (1998). The Economy of kudos. In C. Dougherty e L. Kurke (Eds.), Cultural Poetics in Archaic Greece : Cult, Performance, Politics (pp. 131-63). Oxford: Oxford University Press.

(2005). Choral Lyric as "Ritualization": Poetic Sacrifice and Poetic Ego in Pindar's Sixth Paian. Classical Antiquity, 24(1), 81-130.

LaKoff, G., e Johnson, M. (1980). Metaphors we Live By. Chicago: The University of Chicago Press.

(1987). Women, fire, and dangerous things: what categories reveal about the mind. Chicago: University of Chicago Press.

. (1999). Philosophy In The Flesh. New York: Basic Books.

LANGACKER, R. W. (2008). Cognitive Grammar: a basic introduction. Oxford: Oxford University Press.

LECKIE, R. (2005). The Bluffer's Guide to Classics: Oval Books.

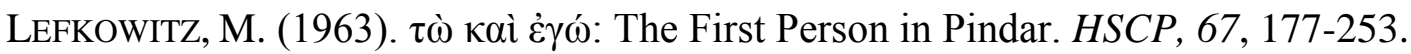

(1975). The Pindar Scholia. AJP, 106(3), 269-82.

(1976). The Victory ode: an introduction. New Jersey: Noyes Press.

-------. (1977). The Influential Fictions in the Scholia to Pindar's Pythian 8. CP, 70(3), $173-$ 85. 
(1978). The Poet as Hero: Fifth-Century Autobiography and Subsequent Biographical Fiction. CQ, 28(2), 459-69.

(1980). Autobiographical Fiction in Pindar. HSCP, 84, 29-49.

-------. (1984). The Poet as Athlete. JSH, 11(2), 18-24.

--------. (1985). The Pindar Scholia. AJP, 106(3), 269-82.

(1988). Who Sang Pindar's Victory Odes? AJP, 109(1), 1-11.

(1991). First-person fictions - Pindar's poetic 'I'. Oxford: Clarendon Press.

(2012). The Lives of the Greek Poets. Baltimore: Johns Hopkins University Press.

LeVi-Strauss, C. (1962). La Pensée Sauvage. Paris: Agora.

LonsDale, S. H. (1994). "Homeric Hymn to Apollo": Prototype and Paradigm of Choral Performance. Arion, 3(1), 25-40. doi: 10.2307/20163563

LORD, A. B. (2000). The Singer of Tales. Massachusetts: Harvard University Press.

LuCAs, D. W. (Ed.). (1968). Poetics. Cambridge: Clarendon Press.

LURAGHI, S. (2003). On the meaning of prepositions and cases: the expression of semantic roles in ancient Greek. Amsterdam/ Philadelphia: J. Benjamins Pub. Co.

MACE, S. (2001). Utopian and erotic fusion in a new elegy by Simonides. In S. Boedeker e D. Sider (Eds.), The New Simonides : Contexts of Praise and Desire: Contexts of Praise and Desire (pp. 185-207). Oxford/ New York: Oxford University Press.

MACKIE, C. J. (Ed.). (2004). Oral Performance and Its Context. Leiden: Brill.

MACLEOD, R. M. (2000). The Library of Alexandria: centre of learning in the ancient world. London: I.B. Tauris.

MalloRY, J. P., e ADAMs, D. Q. (2006). The Oxford Introduction to Proto-Indo-European and the Proto-Indo-European World. Oxford: Oxford University Press.

Malta, A. (2013). A poesia homérica e a demonstração de M. Parry: uma leitura crítica. In R. d. Brose, A. A. d. Araújo e A. M. C. Pompeu (Eds.), Oralidade, Escrita e Performance na Antiguidade (pp. 11-25). Fortaleza: Expressão Gráfica.

Maltby, R. (1991). A Lexicon of Ancient Latin Etymologies (Vol. 25). Leeds: Francis Cairns (Publications).

Mathiesen, T. J. (1999) Apollos's Lyre: Greek Music Theory in Antiquity and the Middle Ages. Publication of the Center for the History of Music Theory and Literature (2 ed.). London: University of Nebrasca Press. 
Matthaios, S., Montanari, F., e Rengakos, A. (Eds.). (2011). Ancient scholarship and grammar: archetypes, concepts and contexts. Berlin: Gruyter, Walter de GmbH.

McDonald, M., e Walton, M. (Eds.). (2007). The Cambridge Companion to Greek and Roman Theatre. Cambridge: Cambridge University Press.

MeZger, F. (1880). Pindars Siegeslieder. Berlin: B. G. Teubner.

Miller, A. M. (1993). Inventa Componere: Rhetorical Process and Poetic Composition in Pindar's Ninth Olympian Ode. TAPA, 123, 109-47. doi: 10.2307/284325

MiLler, S. G. (2006). Ancient Greek Athletics. [s.1.]: Yale University Press.

- (2012). Arete: Greek Sports from Ancient Sources (3rd ed.). London: University of California Press.

MolyneuX, J. H. (1992). Simonides: A Historical Study. Illinois: Bolchazy-Carducci Publishers.

Montanari, F. (2011). Ancient Scholarship and Classical Studies. In S. Matthaios, F. Montanari e A. Rengakos (Eds.), Ancient Scholarship and Grammar: Archetypes, concepts and contexts (Vol. 8, pp. 11-24). Berlin/ New York: Walter de Gruyter.

Montanari, F., e Pagani, L. (Eds.). (2011). From Scholars to Scholia: Chapters in the History of Ancient Greek Scholarship. Berlin: De Gruyter.

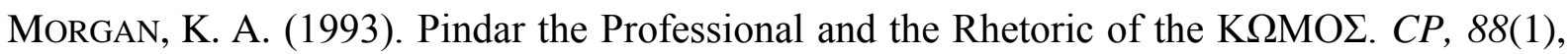
1-15. doi: $10.2307 / 270007$

Morrison, A. D. (2007). Performances and Audiences in Pindar's Sicilian Victory Odes. London.

(2012). Performance, re-performance and Pindar's audiences. In P. Agocs, C. Carey e R. Rawles (Eds.), Reading the Victory Ode (pp. 111-33). Cambridge: Cambridge University Press.

Most, G. W. (1985). The Measures of Praise: structure and function in Pindar's Second Pythian and Seventh Nemean Odes, (Hypomnemata, Vol. 83). Göttingen.

Mullen, W. (1982). Choreia: Pindar and Dance. Princeton: Princeton University Press.

NAGY, G. (1990). Pindar's Homer. Baltimore: The Johns Hopkins University Press. . (1994). Genre and Occasion. Mètis, 9-10. doi: 10.3406/metis.1994.1008

NAGY, G. (1994). Transformations of Choral Lyric Traditions in the Context of Athenian State Theater. Arion, 3(1), 41-55. doi: 10.2307/20163564

NAGY, G. (1996). Homeric Questions. Austin: University of Texas Press. 
Negri, M. (2004). Pindaro ad Alessandria (Vol. 34). Brescia: Paidea Editrice.

NiSETICH, F. J. (1975). Olimpian 1.8-11: An Epinician Metaphor. HSCPh, 79, 55-78.

NÜNLIST, R. (1998). Poetologische Bildersprache in der frühgriechischen Dichtung. Leipzig: De Gruyter. (2009). The Ancient Critic at Work: Terms and Concepts of Literary Criticism in Greek Scholia. Cambridge: Cambridge University Press.

Olson, S. D. (Ed.). (2003). Aristophanes' Peace. Oxford: Oxford University Press.

Ormand, K. (Ed.). (2012). A Companion to Sophocles. England: Wiley-Blackwell.

Pagliaro, A. (1953). Aedi e Rapsodi Saggi di Critica Semantica (pp. 3-62). Messina, Florença.

PARry, A. (1987). The Making of Homeric Verse: The Collected Papers of Milman Parry. Oxford: Oxford University Press, USA.

PFEIFFER, R. (1976). History of classical scholarship from 1300 to 1850. Cambridge: Clarendon Press.

PfEIJFFER, I. L. (1999a). First Person Futures in Pindar: Franz Steiner.

--------. (1999b). Three Aeginetan Odes of Pindar: A Commentary on Nemean V, Nemean III, \& Pythian VIII. Leiden; Boston; Köln: Brill.

PINDAR. (1990). Odes. Pindar D. A. Svarlien (Ed.) Disponível em http://data.perseus.org/citations/urn:cts:greekLit:tlg0033.tlg001.perseus-eng 1:1

--------. (2006). Poesia Grega - de Álcman a Teócrito (F. Lourenço, Trans.). Lisboa: Cotovia. (2007). Pindar: the complete odes (A. Verity, Trans.). Oxford: Oxford University Press.

PISHwA, H. (2009). Language and Social Cognition: Expression of the Social Mind. Berlin: Mouton de Gruyter.

PoDleckI, A. J. (2011). The Early Greek Poets and Their Times. British Columbia: UBC Press.

Prauscello, L. (2006). Singing Alexandria: music between practice and textual transmission. Leiden: Brill.

Privitera, G. A. (1988). Pindaro, Nem. iii, 1-5, e l'acqua di Egina. QUCC, 58, 63-70.

-------- (Ed.). (1998). Istmiche. Italia: Fondazione Lorenzo Valla. 
PÜTZ, B. (2007). Symposium And Komos in Aristophanes. Oxford: Aris \& Phillips.

RaAflaub, K. A., e van WeEs, H. (Eds.). (2009). A Companion to Archaic Greece. Oxford: Wiley-Blackwell.

RACE, W. H. (1982). The Classical Priamel from Homer to Boethius. Leiden: Brill.

--------. (1992). How Greek Poems Begin. YCS, 29, 13-38.

(1997a) Pindar. 2 vol: I Olympian Odes, Pythian Odes. II Nemean Odes, Isthmian Odes, Fragments. Loeb Classical Lybrary: Vol. vol I: 85; vol. 2: 485. Massachusetts e Londres.

(1997b). Pindar: Olympian odes, Pythian odes. Massachusetts: Harvard University Press.

Rawles, R. (2012). Early epinician: Ibycus and Simonides. In P. Agócs, C. Carey e R. Rawles (Eds.), Reading the Victory Ode (pp. 3-27). Reading the Victory Ode: Reading the Victory Ode.

RICHARDSON, N. (2011). Reflections of choral song in early hexameter poetry. In L. Athanasakē e E. L. Bowie (Eds.), Archaic and Classical Choral Song: Performance, Politics and Dissemination (pp. 15-31). Berlin/ Boston: Walter de Gruyter.

(Ed.). (2010). Three Homeric Hymns: To Apollo, Hermes, and Aphorodite. Cambridge: Cambridge University Press.

RiscH, E. (1973). Wortbildung der homerischen Sprache. Berlin: De Gruyter.

Rocha JR., R. A. D. (2007). O Peri Mousikēs, de Plutarco: Tradução, Comentários e Notas. (Doutorado), Universidade Estadual de Campinas, Campinas. Disponível em http://www.bibliotecadigital.unicamp.br/document/?code=vtls000431822\&fd=y

RÖSLER, W. (1980). Dichter und Gruppe (Vol. 50). München: Wilhelm Fink.

Russo, C. F. (Ed.). (1950). Hesiodi Scutum. Firenzi.

RUTHERFORD, I. C. (Ed.). (2001). Pindar's Paeans: a reading of the Fragments with a survey of the genre. Oxford: Oxford University Press.

SANDYS, J. E. (1903). A history of Classical Scholarship. Oxford: Oxford University Press.

SchadewaldT, W. (1928). Der Aufbau des pindarischen Epinikion: Max Niemeyer Verlag.

. (1966). Der Aufbau Des Pindarischen Epinikion. 2. Unveränderte Auflage. Darmstadt: Wissenchaftliche Buchgesellschaft.

Scharfe, H. (2002). Handbook of Oriental Studies (Vol. 2: India). Leiden/ Boston/ Koln: Brill. 
SchmidT, L. V. (1862). Pindar's Leben und Dichtung. Bonn: Adolph Marcus.

SCUldion, S. (2002). 'Nothing to Do with Dionysus': Tragedy Misconceived as Ritual. CQ, 52(1), 102-37. doi: $10.2307 / 3556447$

SEARLE. (2002). How performative works. In D. Vanderveken e S. Kubo (Eds.), Essays in Speech Act Theory (pp. 85-108). Amsterdam/ Philadelphia: John Benjamins.

Slater, W. J. (1969a). Futures in Pindar. CQ, 19(1), 86-94.

(Ed.). (1969b). Lexicon to Pindar. Berlin.

SLINGS, S. R. (1990). The I in personal archaic lyric: an introduction. In S. R. Slings (Ed.), (pp. 1). Amsterdam: VU University Press.

Slings, S. R., Jarcho, V., e Bremer, J. M. (Eds.). (1990). The Poet's I in Archaic Greek Lyric: Proceedings of a Symposium Held at the Vrije Universiteit Amsterdam. Amsterdam: VU Boekhandel/Uitgeverij.

Smyth, H. W., e Messing, G. M. (1956). Greek Grammar. Massachusetts: Harvard University Press.

SNELl, B. (1946). Die Entdeckung des Geistes. Hamburg: Claaszen und Govert.

SNYDER, J. M. (1981). The Web of Song: Weaving Imagery in Homer and the Lyric Poets. The Classical Journal, 76(3), 193-96.

SommersteIn, A. H. (Ed.). (1985). Peace. Wiltshire: Aris \& Phillips Ltd.

SteHLe, E. (1997). Performance and Gender in Ancient Greece: Nondramatic Poetry in its Setting. Princeton.

STEINRUECK, M. (2012). L'accent musical secondaire des properispomènes et thes proparoxytons dans la VIIle Nèméenne. Classica, 25(1), 79-100.

SuARez DE LA Torre, E. (1990). Parole de Poète, parole de prophète: le oracles et la mantique chez Pindare. Kernos, 3, 347-58.

Sullivan, S. D. (1995). Psychological and Ethical Ideas: What Early Greeks Say. Leiden: Brill Academic Pub.

Sullivan, S. D. (2010). Etor in Pindar, Olympian 4, 25. Leiden: Brill.

SUSEMIHL, F. (1891). Geschichte der griechischen litteratur in der Alexandrinerzeit (Vol. v. 1). Berlin: B. G. Teubner.

Svembro, J. (1976). La Parole et le Marbre. Aux Origines de la Poétique Grecque. Lund.

Svenbro, J. (1976). La Parole et le marbre: aux origines de la poétique grecque. [s.1.]: Studentlitteratur. 
(1993). Phrasikleia: An Anthropology of Reading in Ancient Greece. Ithaca/ New York: Cornell University Press.

SwIFT, L. A. (2010). The Hidden Chorus. Oxford e New York: Oxford University Press.

Thiong'o, N. (1998). Penpoints, Gunpoints, and Dreams: Towards a Critical Theory of the Arts and the State in Africa: Oxford University Press, USA.

Thomas, R. (1989). Oral Tradition and Written Record in Classical Athens. Cambridge: Cambridge University Press.

(1992). Literacy and Orality in Ancient Greece. Cambridge Cambridge University Press.

(2012). Pindar's 'difficulty' and the performance of epinician poetry. In P. Agócs, C. Carey e R. Rawles (Eds.), Reading the Victory Ode (pp. 224-45). Cambridge: Cambridge University Press.

Thummer, E. (1968/1969). Pindar - Die Isthmichen Gedichte (Vol. 2 vols.). Heiderberg.

Toporov, V. N. (1981). Die indoeuropäische Poetik und ihre Ursprünge. Poetica, 13, 189251.

VAN GRONINGEN, B. A. (1960). Pindare au banquet: les fragments des scolies édités avec un commentaire critique et explicatif. Leiden: A. W. Sythoff.

VAn Groningen, B. A. (Ed.). (1966). Théognis. Le premier livre, édité avec un commentarire. Amsterdam.

VAnderveken, D., e Kubo, S. (2002). Essays in Speech Act Theory. Amsterdam/ Philadelphia: John Benjamins Publishing Company.

Verdenius, W. J. (1987) Commentaries on Pindar. Vol. 1, Olympian Odes 3, 7, 12 e 14. In A. D. Leeman, H. W. Pleket e C. J. Ruijgh (Series Ed.), Mnemosyne Supplementum: Vol. 14. Leiden: Brill.

(1988a). Commentaries on Pindar. Vol. 2, Olympian odes 1, 10, 11, Nemean 11, Isthmian 2. Leiden: Brill.

--------. (1988b). Review: [untitled]. Mnemosyne, 41(1/2), 136-40.

Vergados, A. (2012). The "Homeric Hymn to Hermes": Introduction, Text and Commentary. Berlin: De Gruyter.

Vernant, J.-P. (1990). Myth and Society in Ancient Greece (J. Lloyd, Trans.). New York: Zone Books.

Vernant, J. P. (2007). Oeuvres: Religions, rationalités, politique. Paris: Éditions du Seuil. 
WatKIns, C. (1995). How to Kill a Dragon : Aspects of Indo-European Poetics: Aspects of Indo-European Poetics. Oxford/ New York: Oxford University Press, USA.

(2002). Pindar's Rigveda. JAOS, 122(2), 432-35.

WAUGH, L. E. (1982). Marked and Unmarked: a choice between unequals in semiotic structure. Semiotica(38), 299-318.

WEBSTER, T. B. L. (1970). The Greek chorus. [s.1.]: Methuen.

Wells, J. B. (2009). Pindar's Verbal Art: An Ethnographic Study of Epinician Style (Vol. 40). Washington: CHS/ Harvard University.

WeST, M. L. (1966). Theogony: edited with prolegomena and commentary by M.L. West. Oxford: Clarendon Press.

--------. (1974). Studies in Greek Elegy and Iambus. Berlin: de Gruyter.

--------. (1992). Ancient Greek Music. Oxford: Oxford University Press.

West, M. L. (1993). Simonides Redivivus. Zeitschrift für Papyrologie und Epigraphik, 98, 114. doi: $10.2307 / 20188914$

WEST, M. L. (2007). Indo-european poetry and myth. Oxford: Oxford University Press.

(Ed.). (2003). Homeric hymns: Homeric apocrypha. Massachusetts: Harvard University Press.

WILAMOWITZ-MOELLENDORFF, U. (1900). Textgeschichte der griechischen Lyriker. Berlin: Weidmannsche Buchhandlung.

--------. (1907). Einleitung in die Griechische Tragödie (unveränderter Abdruck aus der ersten Auflage von Euripides Herakles I Kapitel I-IV). Berlin: Weidmannsche Buchhandlung.

(1965). Antigonos von Karystos. Berlin: Weidmann.

--------. (1966). Pindaros (1 ${ }^{\mathrm{a}}$ (2 ${ }^{\mathrm{a}}$ reimpressão) ed.). Berlin/Zurique/Dublin: Weidmann.

Wilamowitz-MöllendorfF, U. V. (1880). Excurse zu Euripides Medeia. Hermes, 15(4), 481-523. doi: 10.2307/4471725

WiLletT, S. J. (2002). Working Memory and Its Constraints on Colometry. QUCC, 71(2), 719.

Wilson, J.-P. (2009). Literacy. In K. A. Raaflaub e H. van Wees (Eds.), A Companion to Archaic Greece (pp. 542-63). Oxford: Wiley-Blackwell.

WILSON, N. G. (1967). A Chapter in the History of Scholia. CQ, 17(2), 244-56. doi: $10.2307 / 637998$ 
Wollock, J. L. (1997). The Noblest Animate Motion: Speech, Physiology and Medicine in Pre-Cartesian Linguistic Thought. Amsterdam/ Philadelphia: J. Benjamins Pub.

YATROMANOLAKIS, D. (2001). To sing or to mourn? A reappraisal of Simonides $22 W^{2}$. In S. Boedeker e D. Sider (Eds.), The New Simonides : Contexts of Praise and Desire: Contexts of Praise and Desire (pp. 208-25). Oxford/ New York: Oxford University Press.

. (2007). Sappho in the making: the early reception. Washington: Center for Hellenic Studies, Trustees for Harvard University.

Young, D. C. (1968). Three Odes of Pindar (Vol. 9). Leiden: Brill.

. (1970). Pindaric Criticism. In W. M. Calder III e J. Stern (Eds.), Pindaros und Bakchylides (Vol. 2, pp. 1-95). Darmstadt: Wissenschaftliche Buchgeselchaft.

-------. (1983). Pindar Pythians 2 and 3: instriptional $\pi$ o $\varepsilon \dot{\varepsilon}$ and the "poetic epistle". HSCP, $87,31-48$.

ZuMThor, P. (2010). Introdução à Poesia Oral. Belo Horizonte: UFMG. 